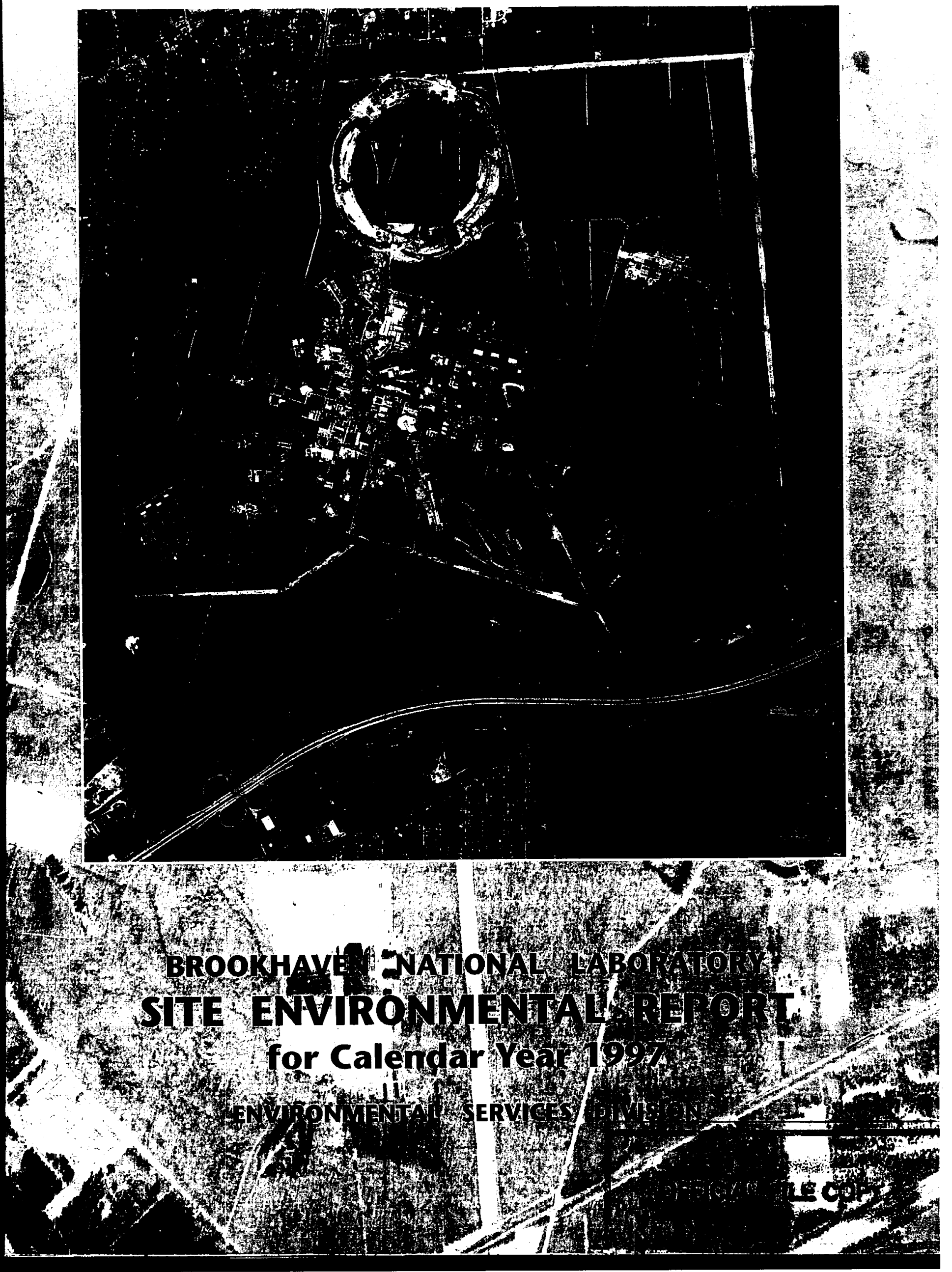




\section{On The Cover}

Looking out over the Brookhaven National Laboratory site, it is easy to focus only on the buildings and roads. But the 2,130-hectare campus contains much more than scientific machines, research laboratories and the infrastructure that supports them. The natural environment is an integral part of BNL.

To trace the natural history of the BNL site, one must begin eons ago, when glaciers formed Long Island during their slow trek southward. The glaciers deposited layers of sand, clay and gravel. Within these layers the aquifers of Long Island's groundwater formed. Above the earth's surface, forests and grasslands grew upon the sandy soil.

After European settlers arrived, the area that is now BNL's site became part of a large farm, owned by the Smith family. When World War I arrived, and the nation needed to train new soldiers, the government acquired much of the site, cleared the land and dubbed it Camp Upton. After the war, the site lay dormant, except for reforestation efforts by the Civilian Conservation Corps during the Great Depression. But with the start of American involvement in World War II, Camp Upton was once again mustered into use, from 1941 to 1945.

In 1947, nine Northeastern universities joined forces to found Brookhaven, and since then, the site has bustled with scientific activity. Funded by the federal government for the good of humankind, BNL has built particle accelerators, laboratories, research reactors and more. In all, more than 300 buildings stand today, among them some of the world's most advanced technical facilities. Dominating the aerial view of the Laboratory is a large ring, 2.4 miles around. This is the underground tunnel of Brookhaven's next cutting-edge research machine: the Relativistic Heavy Ion Collider. Scheduled to begin operation in 1999, RHIC will bring BNL into the $21^{\text {st }}$ century with sophisticated physics research.

BNL is actively addressing historical environmental problems at the site, including groundwater contamination and historical disposal sites being cleaned up under the federal Superfund program. The Lab is also striving to operate today in harmony with the environment.

The protection of BNL's ecological resources is a considerable responsibility for the Laboratory, one that Brookhaven takes seriously. So is the protection of the neighboring public, and compliance with environmental laws at the local, state and federal levels.

Toward those ends, BNL has installed over hundreds of groundwater monitoring wells, as well as numerous air monitoring stations, river water checkpoints, soil and groundwater cleanup systems, and emission-point monitors. Even though these are not visible from high above the Laboratory site, their presence is a sign of BNL's commitment to the environment - and to the future. 


\section{Brookhaven National Laboratory Environmental Stewardship Policy}

These environmental commitments provide the framework within which $B N L$ employees, contractors, guests, and visitors will conduct their job-related activities.

Policy: It is Brookhaven National Laboratory's (BNL) policy to integrate environmental stewardship into all facets of the Laboratory's missions. We will manage our programs in a manner that protects the ecosystem and public health.

In support of this policy, BNL makes the following commitments:

- We are committed to achieving compliance with applicable environmental requirements.

- In consideration of the potential impacts of our activities on the environment, we will integrate pollution prevention/waste minimization, resource conservation, and compliance into all of our planning and decision-making. We will adopt cost-effective practices that eliminate, minimize or mitigate environmental impacts.

- We will define, prioritize, and aggressively correct and clean up existing environmental problems.

- We will work to continually improve our environmental management system and performance. We will establish appropriate environmental objectives and performance indicators to guide these efforts and measure our progress.

- We will maintain a positive, proactive, and constructive relationship with our neighbors in the community, regulators, DOE, and our other stakeholders. We will openly communicate with stakeholders on our progress and performance.

In addition to my annual review of BNL's progress on environmental goals and adherence to this policy, I invite all interested parties to provide me with input on our performance relative to this policy, and the policy itself.

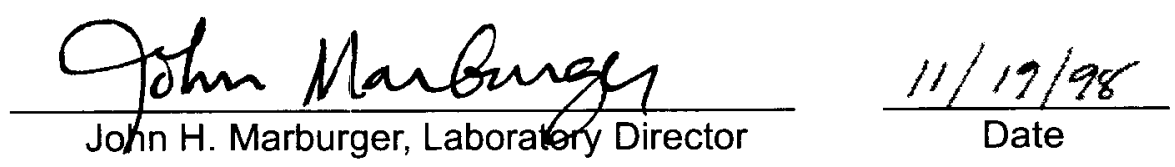




\title{
BROOKHAVEN NATIONAL LABORATORY SITE ENVIRONMENTAL REPORT for Calendar Year 1997
}

\author{
R.J. LEE, J.R. NAIDU, G.L. SCHROEDER, D.E. PAQUETTE, S. SCARPITTA \\ R. HOWE, W. DORSCH, A. BOU and W. GUNTHER
}

\section{February, 1999}

Environment, Safety and Health Services Division and Environmental Restoration Division

Brookhaven National Laboratory

Brookhaven Science Associates

Upton, Long Island, New York 11973 


\section{DISCLAIMER}

This report was prepared as an account of work sponsored by an agency of the United States Government. Neither the United States Government nor any agency thereof, nor any of their employees, nor any of their contractors, subcontractors, or their employees, makes any warranty, express or implied, or assumes any legal liability or responsibility for the accuracy, completeness, or usefulness of any information apparatus, product, or process disclosed, or represents that its use would not infringe privately owned rights. Reference herein to any specific commercial product, process, or service by trade name, trademark, manufacturer, or otherwise, does not necessarily constitute or imply its endorsement, recommendation, or favoring by the United States Government or any agency, contractor or subcontractor thereof. The views and opinions of authors expressed herein do not necessarily state or reflect those of the United States Covernment or any agency, contractor or subcontractor thereof. 


\section{PREFACE}

The U.S. Department of Energy Order 5400.1, "General Environmental Protection Program", establishes the requirement for environmental protection programs. These programs ensure that the Department of Energy's operations comply with applicable federal, state, and local environmental laws and regulations, executive orders, and departmental policies. Brookhaven National Laboratory established a plan for implementing this Order, which is described in the Environmental Monitoring Plan. This plan is updated annually.

The Brookhaven National Laboratory's Site Environmental Report is prepared annually pursuant to Department of Energy Order 5400.1 to summarize environmental data, characterize the Brookhaven National Laboratory Site, demonstrate compliance status, assess the impact of Brookhaven National Laboratory's operations on the environment, and document the efforts made by Brookhaven $\mathrm{Na}$ tional Laboratory's Management to mitigate environmental impacts. More detailed environmental compliance, monitoring, surveillance, and study reports may be of value; therefore, to the extent practical, these additional reports are referred to in the text.

This report is prepared for the Department of Energy by the Environment, Safety and Health Services Division at Brookhaven National Laboratory; the document is the responsibility of the Environmental Protection Office of the Division. This Office is responsible for preparing the sampling plan, collecting environmental and facility samples, interpreting the results, performing impact analysis of the emissions and effluents from Brookhaven National Laboratory, and compiling the information presented here.

Although this report is written to meet Department of Energy requirements and guidelines, it is also intended to meet the needs of the public. The Executive Summary was written with a minimum of technical jargon, and a condensed version of this Site Environmental Report, titled the Summary Report, also has been prepared for public distribution. The Appendices give a list of acronyms, abbreviations, and other useful information.

Inquiries about this report and the Summary Report may be sent to the Public Affairs Office, Brookhaven National Laboratory, Upton, New York 11973 (516 344-2345). 


\begin{abstract}
This report documents the results of the Environmental Monitoring Program at Brookhaven National Laboratory and summarizes information about environmental compliance for 1997. To evaluate the effect of Brookhaven National Laboratory's operations on the local environment, measurements of direct radiation, and of a variety of radionuclides and chemical compounds in the ambient air, soil, sewage effluent, surface water, groundwater, fauna, and vegetation were made at the Brookhaven National Laboratory site and at adjacent sites. The report also evaluates the Laboratory's compliance with all applicable guides, standards, and limits for radiological and non-radiological emissions and effluents to the environment.

Areas of known contamination are subject to Remedial Investigation/Feasibility Studies under the Inter Agency Agreement established by the Department of Energy, Environmental Protection Agency and the New York Department of Environmental Conservation. Except for identified areas of soil and groundwater contamination, the environmental monitoring data have continued to demonstrate that compliance was achieved with the applicable environmental laws and regulations governing emission and discharge of materials to the environment. Also, these data show that the environmental impacts at Brookhaven National Laboratory are minimal, and do not pose a threat to the public or to the environment.
\end{abstract}

This report meets the requirements of Department of Energy Order 5400.1, General Environmental Protection Programs. 


\section{ACKNOWLEDGMENTS}

Many individuals assisted in collecting data, and preparing this report. The editors express their gratitude to all these individuals. However, the following individual efforts require special acknowledgment.

Monitoring and surveillance data were obtained through the combined efforts of the Environmental Protection Office and the Analytical Services Laboratory. Special recognition is reserved for the dedication and professionalism of the Sampling Staff: M. Bero, R. Lagattolla, and L. Lettieri and W. Rizzitello; and the Analytical Services Laboratory Staff: C. Decker, R. Gaschott, P. Hayde, E. Klug, A. Meier, L. Muench, J. Odin-McCabe, and R. Wang.

The editors further extend their appreciation to the following additional contributors of the main sections of this report, which included review of data and preparation of text. These individuals are:

\section{Environment, Safety and Health Services Division}

G. Goode, Waste Minimization and Pollution Prevention Program

T. Sperry, Compliance - National Environmental Policy Act

\section{Other ES\&HS Contributors:}

R. Selvey, Asbestos

J. Pearsall, Data Base and Data Reports

R. Thompson, Thermoluminescent Dosimeter Assays

A. Caplan, Summer Student - Fish Radiological Analysis

\section{Contributors from other Departments:}

J. Meersman and Staff of the Environmental Restoration Division; in particular M. Daum, T. Burke, V. Racaniello, M. Hauptmann, and W. Medeiros; M. Clancy and T. Grieve of the Waste Management Division; P. Yalden and M. Kahanda of Graphic Arts and V. Cassella of the Meteorology Group, Department of Applied Science.

\section{Contributions from other Agencies}

The Laboratory acknowledges the continued support of the: New York State Department of Environmental Conservation, Fisheries Bureau, in the collection of fish samples from the Peconic River and adjacent fresh water bodies; and the Suffolk County Department of Health Services for the collection of potable water samples for adjoining communities, collection of vegetation and fruit samples from local farms.

Finally, the authors would like to extend a special thanks to Rosemary Taylor for her infinite patience and quality of work in typing, reviewing, and finalizing this report. 


\section{EXECUTIVE SUMMARY}

Brookhaven National Laboratory's (BNL) Environmental Monitoring Program is designed to determine whether BNL facility operations have met the requirements of applicable environmental and effluent control standards. The program is also used to assess the impact of past and present BNL operations on the environment. This report summarizes the data generated by that program.

The mission of the Environmental Restoration Program is to identify, characterize, mitigate, and eliminate, as appropriate, areas of soil and groundwater contamination that resulted from past chemical and radiological spills, discharges, and waste handling activities. This report also summarizes the data collected during Environmental Restoration activities in 1997 including those related to soil, groundwater, surface water, and private potable water quality.

\section{Radiological Monitoring and Surveillance}

Airborne emissions of radioactive material from BNL facilities were monitored in 1997. Radioactive airborne effluents originated primarily with the Brookhaven LINAC Isotope Producer (BLIP), the Brookhaven Medical Research Reactor (BMRR), and the High Flux Beam Reactor (HFBR). Argon-41, oxygen-15 and tritium were the predominant radionuclides released. A member of the public residing at the site boundary is projected to have received a radiation dose of 0.07 mrem $(0.7 \mu \mathrm{Sv})$ from all 1997 airborne emissions. The typical annual dose from natural background radiation sources to an individual living in the U.S. is approximately $300 \mathrm{mrem}(3 \mathrm{mSv})$.

Air sampling was performed throughout the year to monitor airborne radionuclide concentrations. All annual average airborne tritium concentrations were below detectable levels. Gross alpha and gross beta activity levels were consistent with expected background levels; no site related elevations were observed. All measured values were comparable to those measured in Albany, NY (a location used as a control area by the NY State Department of Health in their statewide environmental radiation monitoring program).

An array of thermoluminescent dosimeters was used to monitor gamma radiation levels at 24 on-site and 25 off-site locations. The average annual on-site integrated dose for 1997 was $70 \pm 6$ mrem (0.70 $\pm 0.06 \mathrm{mSv})$, while the off-site integrated dose was $67 \pm 5 \mathrm{mrem}(0.67 \pm 0.05 \mathrm{mSv})$. These levels are typical of those measured throughout the northeastern part of the United States and verify that airborne emissions from the Laboratory had no impact on the external radiation levels of the surrounding area.

All liquid discharges to the Peconic River and on-site recharge basins met the radiological limits specified by the DOE in Order 5400.5, "Radiation Protection of the Public and the Environment." The principal radionuclide detected at the Peconic River Outfall was tritium. The annual average tritium concentration was equal to $7 \%$ of the limit specified by the Safe Drinking Water Act. Other radionuclides were detected on an infrequent basis throughout the year at concentrations that were less than $2 \%$ of the applicable limits.

Due to past tritium discharges from the Sewage Treatment Plant, potable wells in a few homes near the Laboratory's eastern boundary continue to show the presence of tritium. Concentrations ranged from $2 \%$ to $11 \%$ of the Safe Drinking Water Act standard. The maximum individual dose resulting from the consumption of this drinking water is equal to $0.1 \mathrm{mrem}(1 \mu \mathrm{Sv})$. The typical annual dose to an individual from the ingestion of naturally-occurring radionuclides is 39 mrem $(0.39 \mathrm{mSv})$.

Samples of regional soils, river sediments, vegetation, fish and deer were collected. Important conclusions drawn from the analysis of these samples are:

- Deer inhabiting BNL property contain Cesium-137 concentrations at levels that are above those in off-site deer. A committed effective dose equivalent of $9 \mathrm{mrem}(0.09 \mathrm{mSv})$ would be received by an individual consuming deer meat from on-site animals at the highest observed concentration and an annual consumption rate of $67 \mathrm{lbs}$. per year. 
- All radionuclides detected in soil and vegetation samples were either of natural origin, were deposited from the application of fertilizers, or were fallout-related. No radionuclides attributable to BNL operations were detected.

- Man-made radionuclides detected beyond the site boundary in the sediments of the Peconic River, the Carmans River, Peconic Bay, Flanders Bay, and Lloyd Harbor are consistent with global fallout patterns; no BNL contribution was indicated. No man-made radionuclides were observed in shellfish collected from local water bodies.

- Present day Cesium-137 concentrations in fish from the Peconic appear to be within the range of variability seen in fish from local waters which have never received discharges from BNL.

Potential radiological doses were less than specified limits for each exposure pathway and equal to a fraction of the dose received annually from natural background sources (approximately $300 \mathrm{mrem}$ [ 3 $\mathrm{mSv}]$ ). All measurements and dose calculations demonstrate that in 1997, BNL's radiological effluents had no impact on the health of the public or environment in the surrounding area.

\section{Non-Radiological Monitoring}

Liquid discharge limits for non-radiological parameters are subject to conditions listed in BNL's State Pollutant Discharge Elimination System (SPDES) Permit (No. NY-0005835), issued by the New York State Department of Environmental Conservation (NYSDEC). Administrative controls are used to maintain all liquid discharges at or below concentrations prescribed by the Safe Drinking Water Act (SDWA) and DOE Orders. The compliance rate for Sewage Treatment Plant effluents exceeded $99 \%$ for the year. The SPDES permit also requires monthly and quarterly monitoring of discharges to the BNL recharge basins. Except for a single pH excursion at one recharge basin (Outfall 003), all discharges complied with the SPDES limitations.

For collected surface water samples, all water quality parameters were consistent with off-site control locations and with historical data. Except for iron, analytical data for metals showed all parameters to be consistent with historical data. All concentrations were below the NY State Drinking Water Standard (NYS DWS). Except for zinc and iron, all analytical data for metals were consistent with the New York State Ambient Water Quality Standards (NYS AWQS). The presence of iron and zinc is due to the natural sediment.

\section{Groundwater Surveillance}

During 1997, over 400 groundwater surveillance wells were monitored by the ERD and ES\&HS Division. Groundwater samples were collected for non-radiological and radiological analyses, with greater than 1,500 individual sampling events taking place. Groundwater surveillance data are compared to New York State Ambient Water Quality Standards (NYS AWQS), NYS DWS and DOE Derived Concentration Guides (DCGs) (for radionuclides). Comparison of surveillance well data to Environmental Protection Agency (EPA), NYSDEC, and NYSDOH reference levels provides a mechanism to evaluate the radiological and non-radiological levels of contamination relative to current standards.

Water-quality analyses conducted on groundwater samples collected site wide show that the $\mathrm{pH}$ of groundwater typically ranges from 5.5 to 7.2, which is below the lower limit of the NYS AWQS of 6.5 to 8.5. Chloride, sulfate, and nitrate concentrations in most areas of the site were typically below the NYS AWQS. However, metals and VOCs in groundwater exceed NYS AWQS in several locations onsite.

Several areas of known surface radiological contamination have introduced man-made radionuclides into the groundwater underlying the Laboratory. The most common radionuclides which have been introduced include tritium, Cesium-137, Strontium-90, and Sodium-22. Often these radionuclides are below applicable drinking water standards, but concentrations have been found above these standards downgradient of the HWMF (Strontium-90 and Tritium), "Current" and "Former" Landfills (Strontium-90), HFBR (Tritium), WCF (Strontium-90), and Building 650 sump outfall (Strontium-90).

During 1997, Well Nos. 10, 11, and 12 were used to supply drinking water at BNL. Water samples collected from these wells were analyzed for radioactivity, metals, organic material, and water quality 
parameters. In 1997, the BNL potable water system was found to be in full compliance with the requirements of the SDWA and NY State DWS.

\section{Environmental Restoration}

During 1997, the BNL Environmental Restoration Program made significant progress in its ongoing efforts to characterize and remediate contaminated soil and groundwater resulting from past spills, releases and disposal practices. The highlights of accomplishments in 1997 include:

- Completion of the free public water hookups to approximately 1,500 homes in North Shirley and East Yaphank;

- Characterization of the HFBR tritium plume and the construction of an interim pump and recharge system;

- Construction and operation of a groundwater cleanup system at the BNL southern boundary that pumps and treats groundwater contaminated with chemical solvents;

- Construction and operation of an air sparging/soil vapor extraction treatment system that treats soil and groundwater contamination at the Central Steam Facility;

- Excavation, characterization, and back filling of fifty-five unlined chemical/animal/glass holes at the Former Landfill area; and

- Capping of the Interim Landfill. 


\section{TABLE OF CONTENTS}

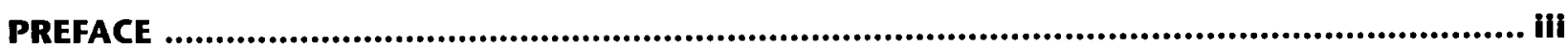

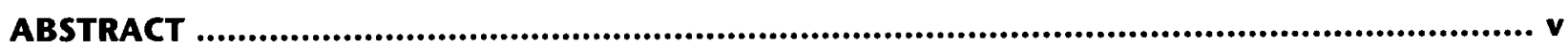

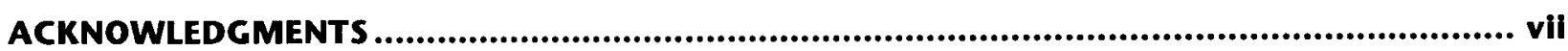

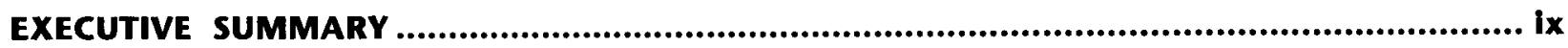

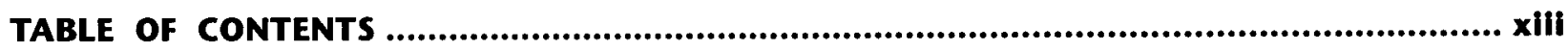

Chapter 1 INTRODUCTION ................................................................................ 1-1

1.1 Brookhaven National Laboratory's Mission ................................................................ 1-1

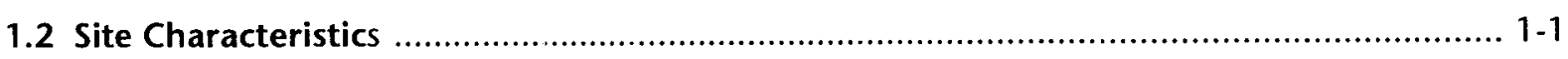

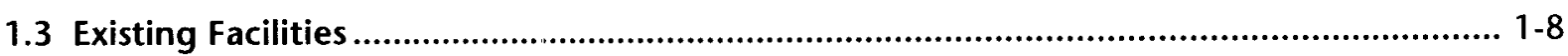

Chapter 2 COMPLIANCE SUMMARY ..................................................................... 2-1

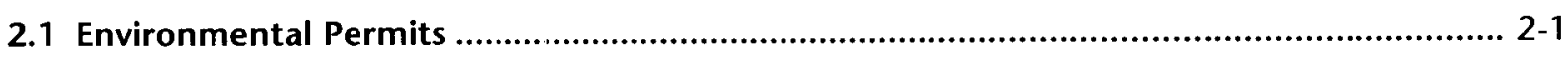

2.2 Groundwater Compliance Monitoring ................................................................... 2-1

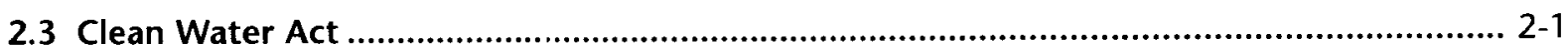

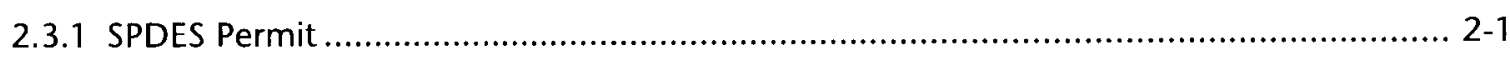

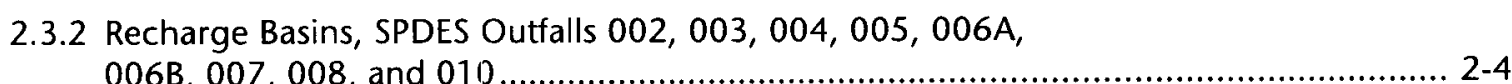

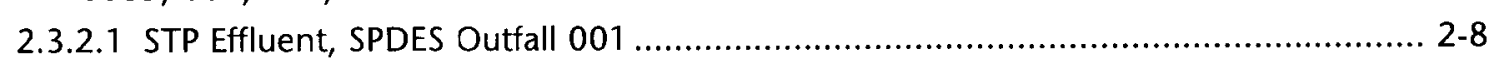

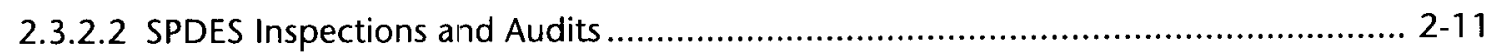

2.3.2.3 National Pollution Discharges Elimination System (NPDES)

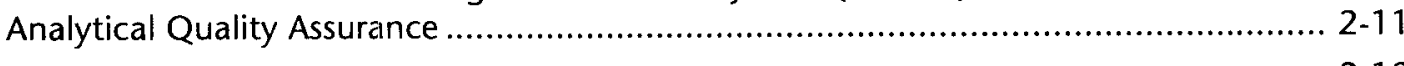

2.3.3 Major Petroleum Facility (MPF) ............................................................... 2-12

2.3.3.1 Spill Prevention, Control, and Countermeasures Plan
and Facility Response Plans ........................................................................ 2-13

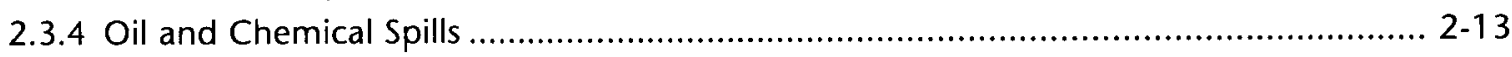

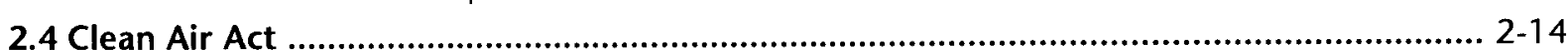

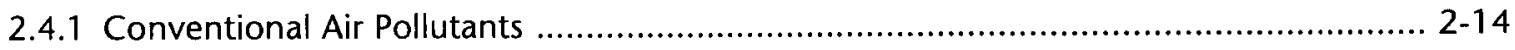

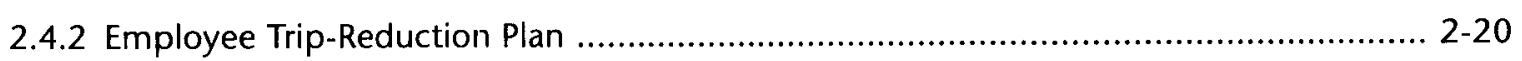

2.4.3 Reasonable Available Control Technology (RACT) Requirements .......................... 2-20

2.4.4 Phaseout of Halon Fire-Suppression Systems .................................................... 2-20

2.4.5 Ozone Depleting Refrigerants ......................................................................... 2-20

2.4.6 National Emission Standards for Hazardous Air Pollutants (NESHAPS) ...................... 2-21

2.4.6.1 Radioactive Airborne Effluent Emissions Governed by NESHAPs .......................... 2-21

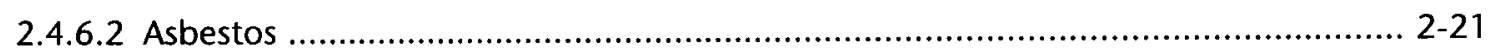

2.4.6.3 Maximum Available Control Technology (MACT) Requirements........................ 2-22

2.4.7 Facility Audits .......................................................................................... 2-22 


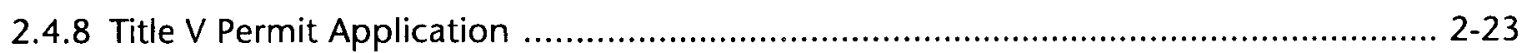

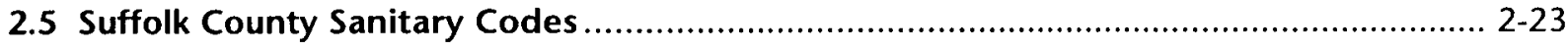

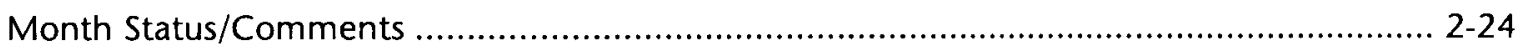

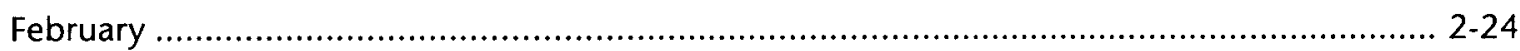

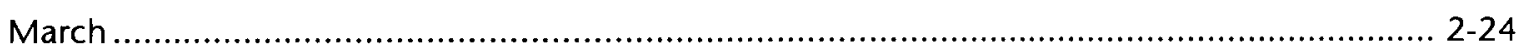

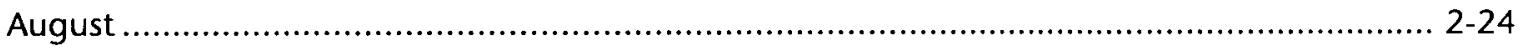

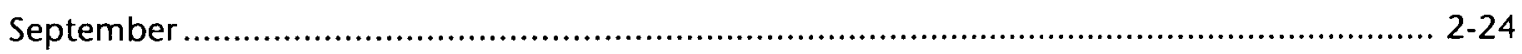

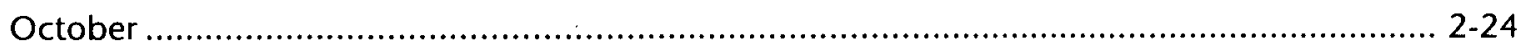

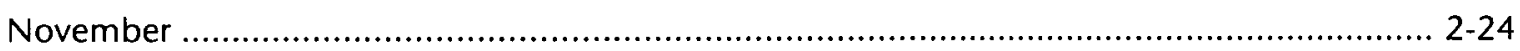

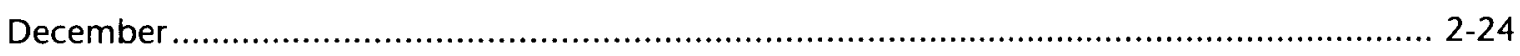

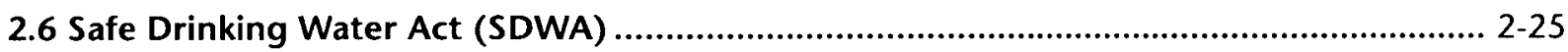

2.6.1 Applicability to Brookhaven National Laboratory ......................................... 2-25

2.6.2 Potable Water Monitoring Requirements ...........................................................25

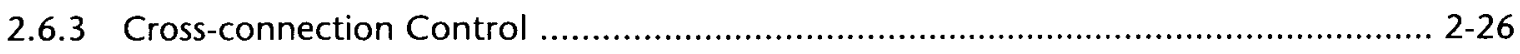

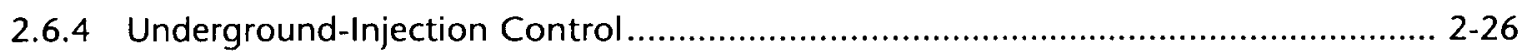

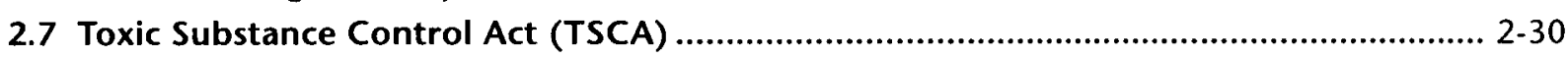

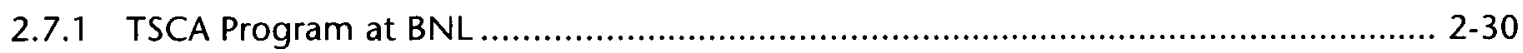

2.8 NYSDEC Bulk Chemical Storage Registration ........................................................... 2-30

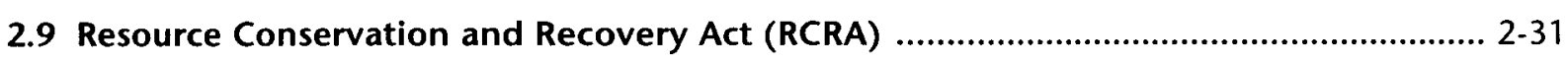

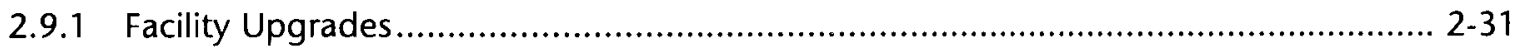

2.9.2 RCRA Part B Permit (6 NYCRR Part 373 Permit) and RCRA Closure ....................... 2-31

2.9.3 90-Day Accumulation Areas and Satellite Areas................................................ 2-31

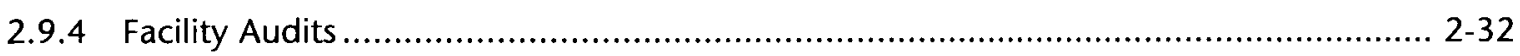

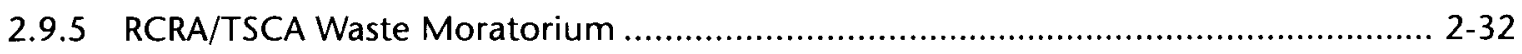

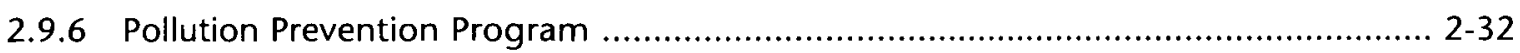

2.9.7 Liquid Waste Management .......................................................................... 2-32

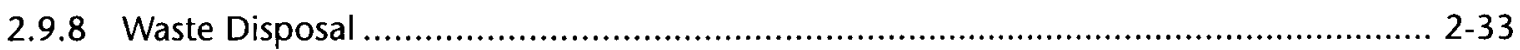

2.9.9 Federal Facilities Compliance Act (FFCA) Mixed Waste Site Treatment Plan ............ 2-33

2.9.10 Mixed-Waste Inventory Report ...................................................................... 2-33

2.9.11 Comprehensive Environmental Response, Compensation

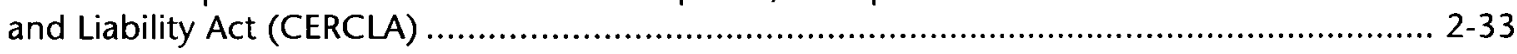

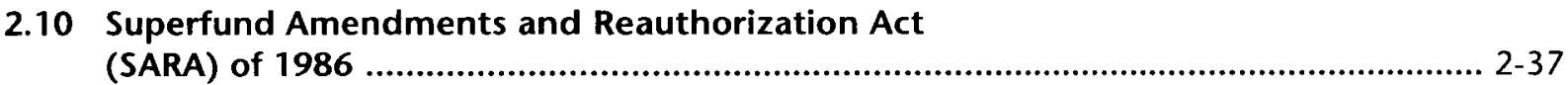

2.11 National Environmental Policy Act (NEPA) ....................................................... 2-38

2.12 Federal Insecticide, Fungicide, and Rodenticide Act ................................................ 2-38

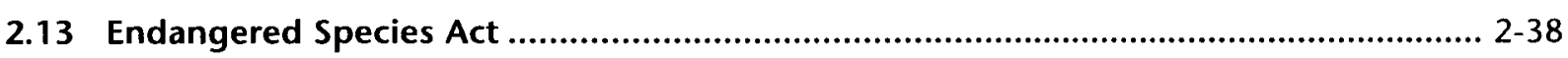

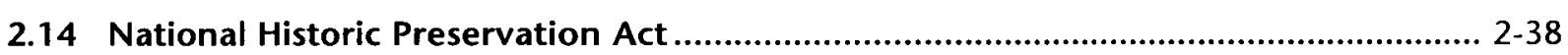

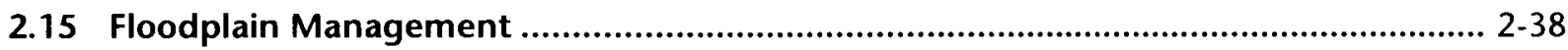

2.16 New York Wild, Scenic, and Recreational River Systems Act .................................... 2-38

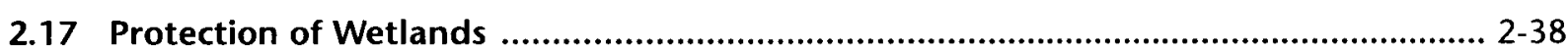

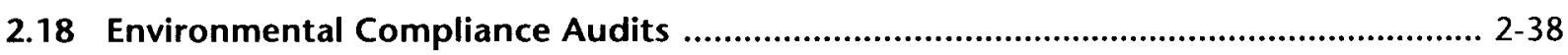

2.18.1 Integrated Safety Management Evaluation (ISME) ...................................... 2-38 
2.18.3 Gilbert Hill Associates Audit of the Analytical Laboratory.

Chapter 3 ENVIRONMENTAL PROGRAM INFORMATION ........................................... 3-1

3.1 Environmental Program Elements ........................................................................ 3-1

3.1.1 Environmental Regulations ....................................................................... 3-1

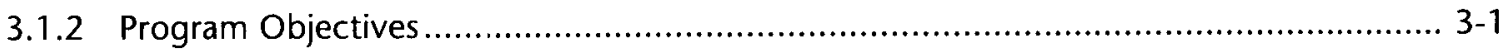

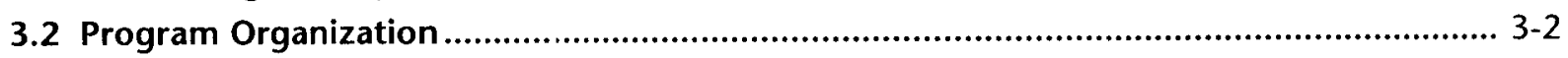

3.2.1 Environmental Restoration Division .......................................................... 3-2

Environment, Safety and Health Services Division -
Environmental Protection Office .................................................................... 3-2

3.2.3 Waste Management Division ......................................................................... 3-3

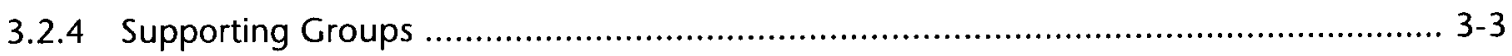

3.3 Regulatory Agency Monitoring Program ............................................................... 3-3

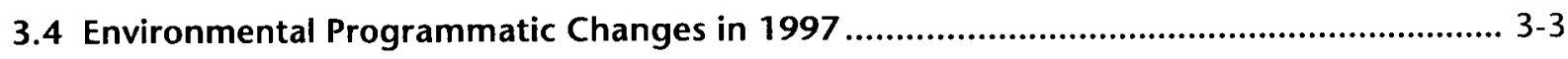

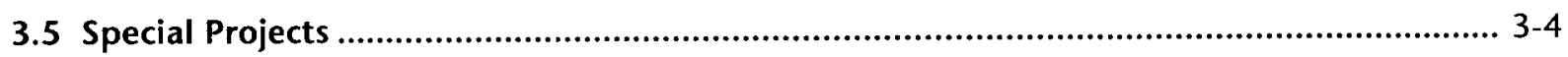

3.5.1 High Flux Beam Reactor Tritium Investigation ................................................ 3-4

3.5.2 Facility Review Project ........................................................................... $3-4$

3.6 Waste Minimization and Pollution Prevention Programs ............................................. 3-5

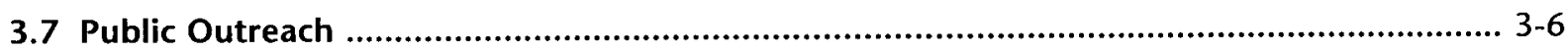

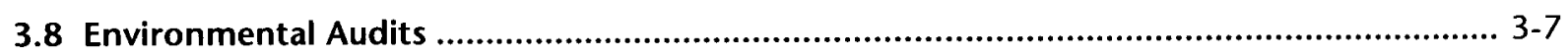

3.9 Site Environmental Performance Measures Program ................................................... 3-8

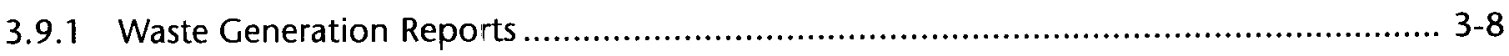

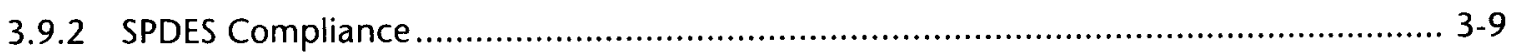

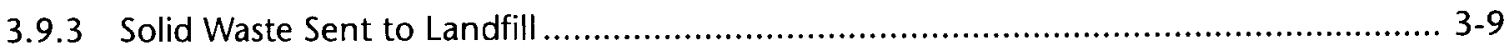

Chapter 4 RADIOACTIVITY .............................................................................. 4-1

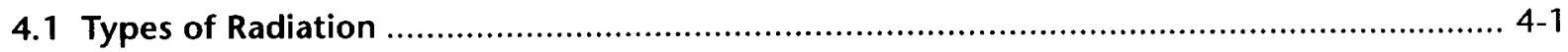

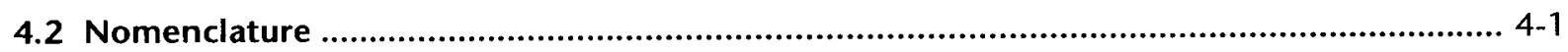

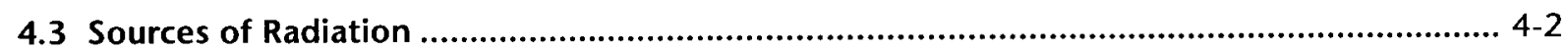

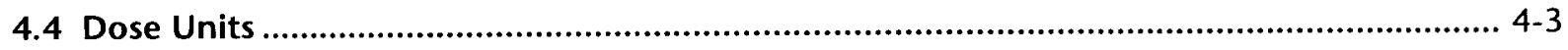

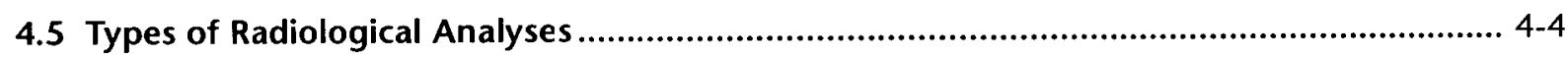

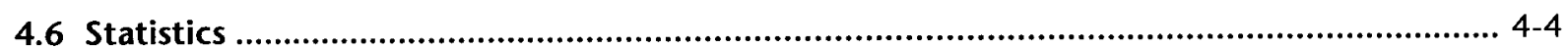

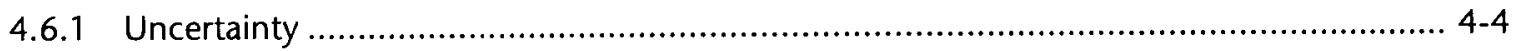

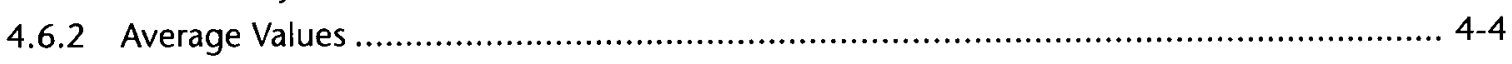

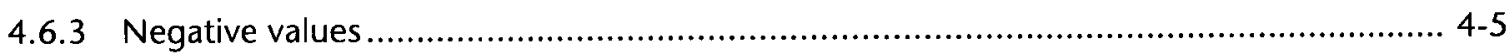

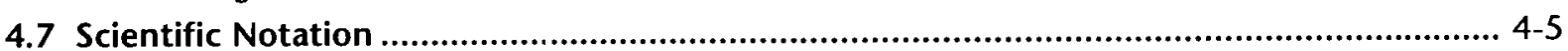

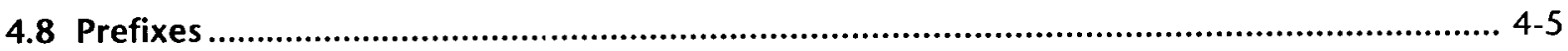

4.9 Radionuclides of Environmental Interest .................................................................... 4-6

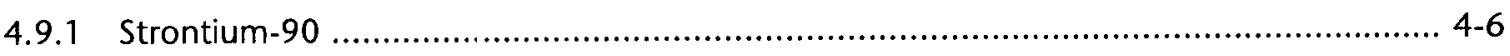

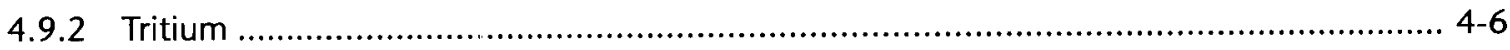




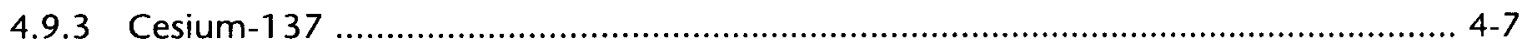

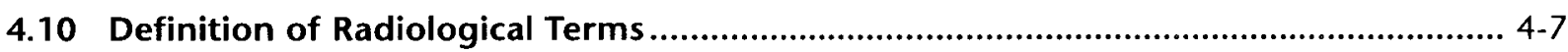

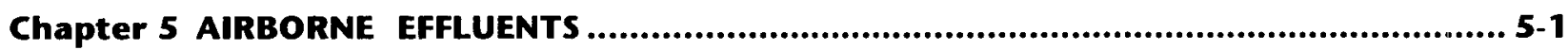

5.1 Airborne Effluent Emissions - Radioactive …............................................................... 5-1

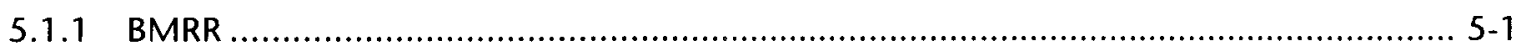

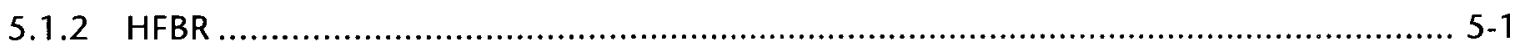

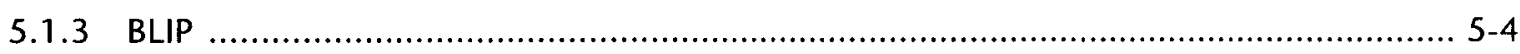

5.1.4 Tritium Evaporator Facility .......................................................................... 5-5

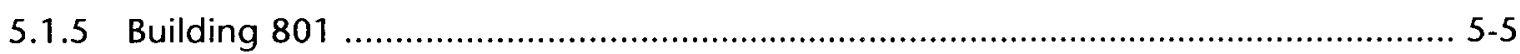

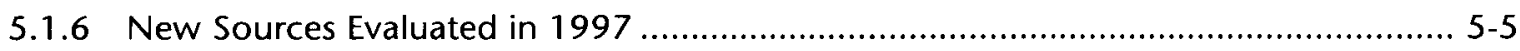

5.1.6.1 Removal Action V Recharge Basin ............................................................... $5-5$

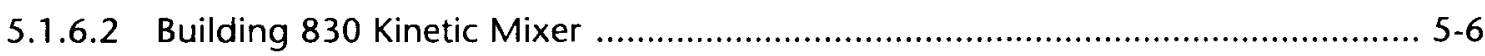

5.1.6.3 HFBR Spent Fuel Pool Dewatering Operation ................................................. 5-6

5.1.6.4 BGRR Deep Drain Sump Pumping Operation ................................................... 5-6

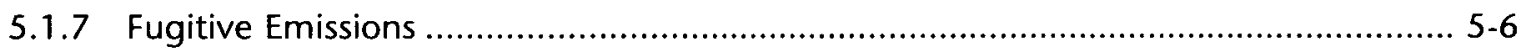

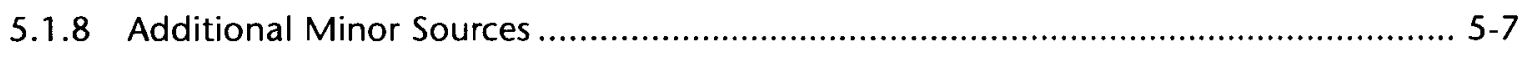

5.2 Airborne Effluent Emissions - Nonradioactive ............................................................... 5-7

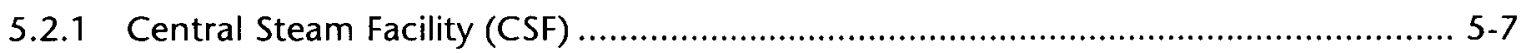

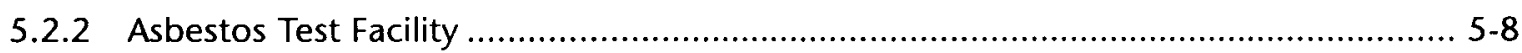

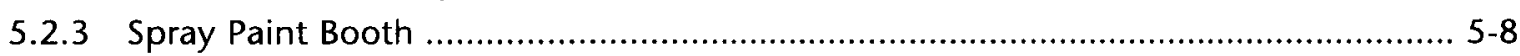

5.2.4 Gasoline Refueling Facilities ................................................................... 5

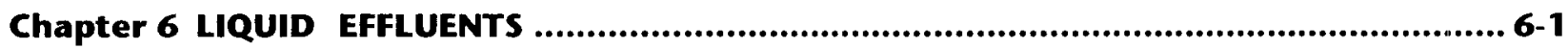

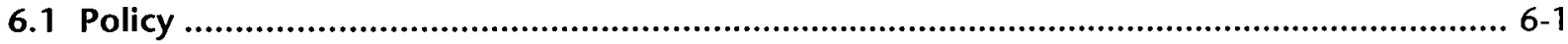

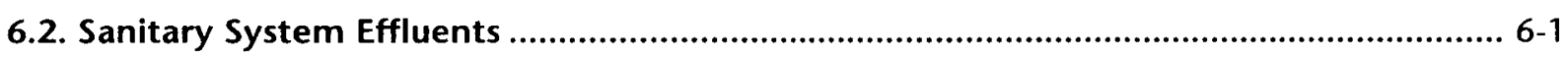

6.2.1 Sanitary System Effluent - Radiological ............................................................. 6-2

6.2.2 Tritium Concentration Increase in July, 1997 .................................................. 6-7

6.2.3 Sanitary System Effluent - Non-radiological .......................................................... 6-8

6.2.4 Assessments of Process-Specific Waste Water ................................................. 6-12

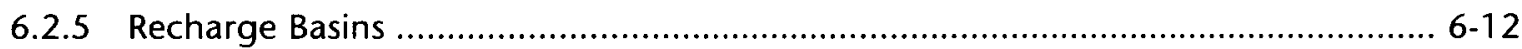

6.2.5.1 Recharge Basins - Radiological Analyses .................................................. 6-13

6.2.5.2 Recharge Basins - Non-radiological Analyses .............................................. 6-13

Chapter 7 ENVIRONMENTAL SURVEILLANCE .............................................................. 7-1

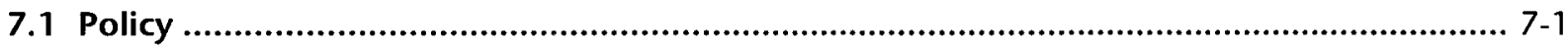

7.2 External Radiation Monitoring ...................................................................................... $7-1$

7.2.1 Building 650 Sump Outfall Monitoring ....................................................... 7-1

7.3 Atmospheric Radiological Monitoring ........................................................................... 7-6

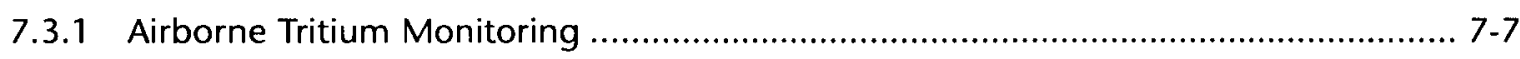

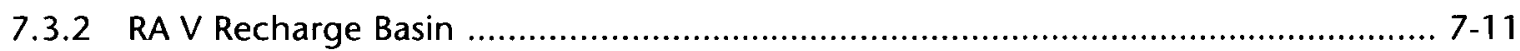


7.5 Terrestrial and Ecological Radioactivity Studies ....................................................... 7-13

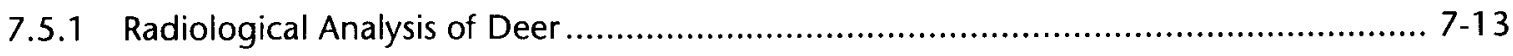

7.5.2 Radiological Analysis of Vegetation .............................................................. 7-13

7.5.3 Radiological Analysis of Soils and Sediments ................................................... 7-15

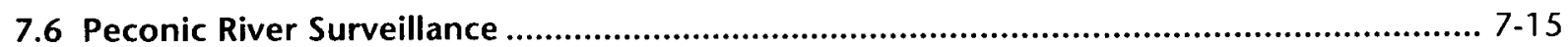

7.6.1 Peconic River Surveillance - Non-radiological Analyses ...................................... 7-15

7.6.2 Peconic River Surveillance - Radiological Analyses ........................................ 7-17

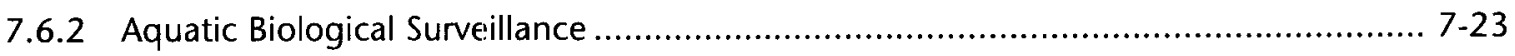

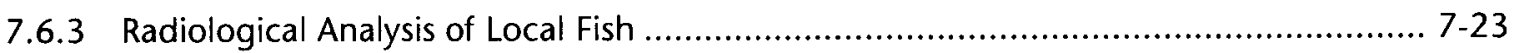

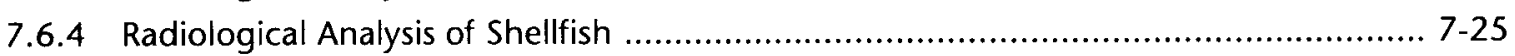

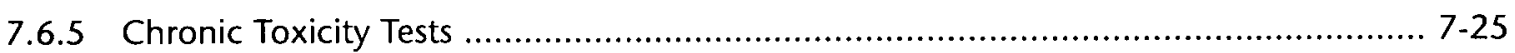

7.6.6 OU V Remedial Investigation Bioaccumulation Study ...................................... 7-26

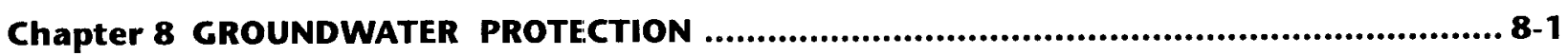

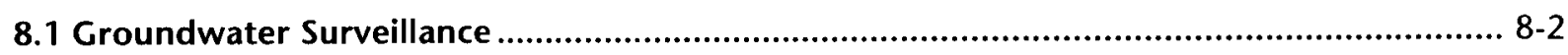

8.1.1 Potable Water and Process Supply Wells ..................................................... 8-2

8.1.1.1 Non-radiological Analyses ...................................................................... 8-2

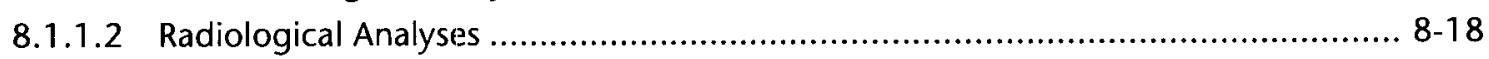

8.1.2 Environmental Restoration (CERCLA) Groundwater Monitoring .......................... 8-21

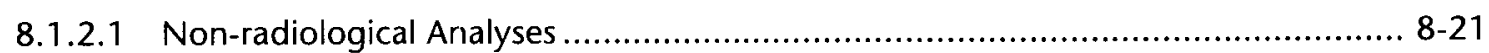

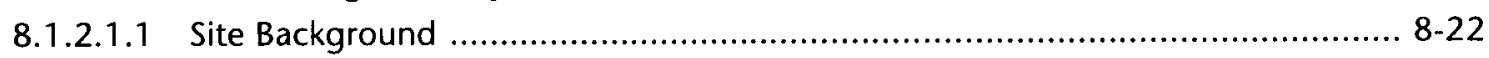

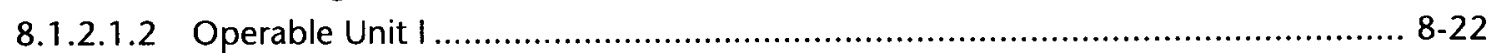

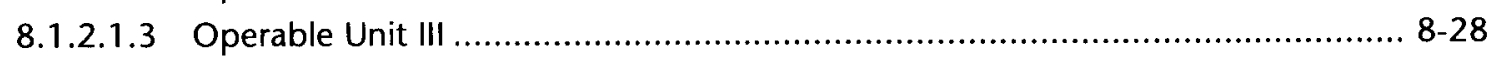

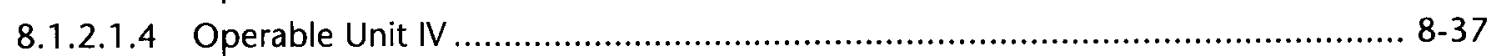

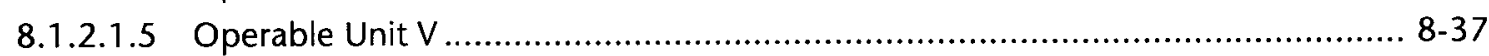

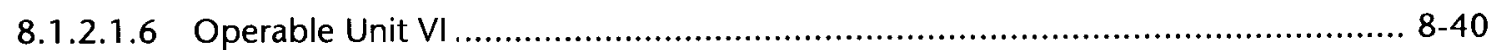

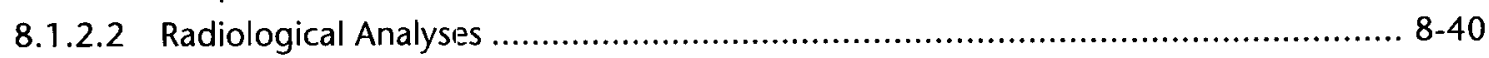

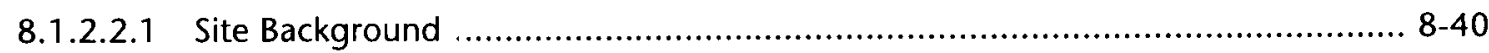

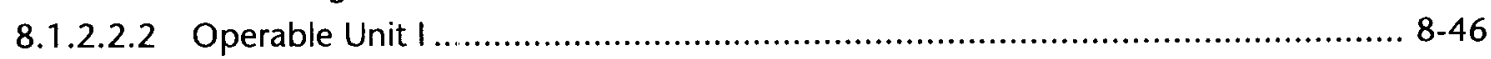

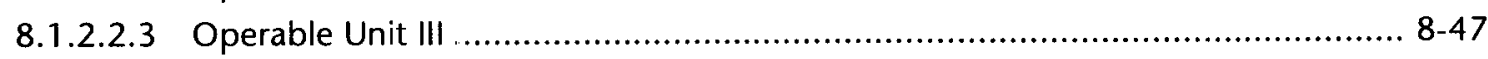

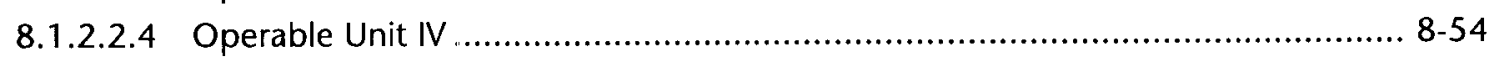

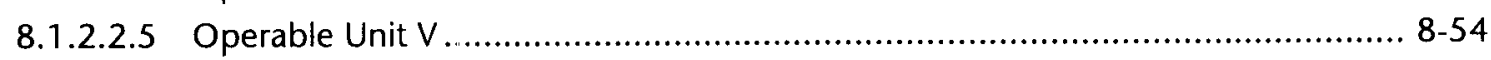

8.1.2.3 CERCLA Groundwater Treatment Systems Operational in 1997 ....................... 8-54

8.1.3 Facility Surveillance (NON-CERCLA) Groundwater Monitoring ............................. 8-61

8.1.3.1 Non-Radiological Analyses ................................................................ 8-61

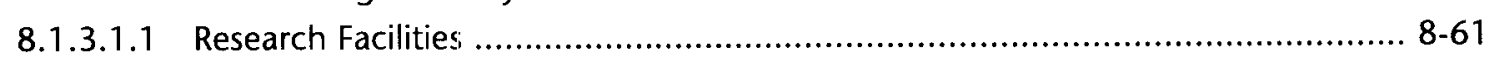

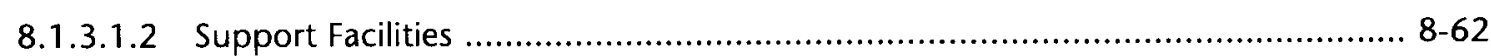

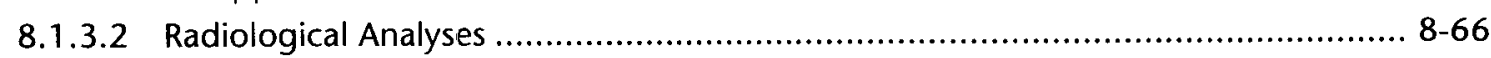

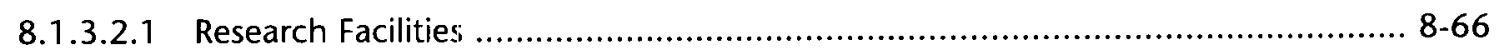

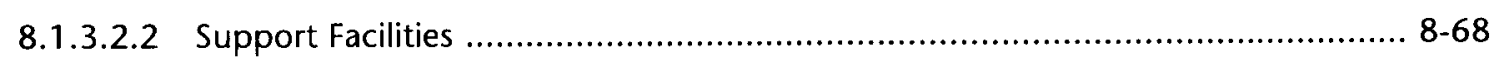

8.1.4 Surveillance of Private Supply Wells ............................................................ 8-68

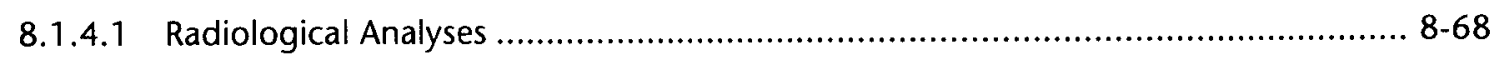


8.1.5 Surveillance of SCWA Municipal Supply Wells ............................................ 8-72

Chapter 9 RADIOLOGICAL DOSE ASSESSMENT ...................................................... 9-1

9.1 Effective Dose Equivalent Calculations - Airborne Pathway ......................................... 9-1

9.1.1 Air Dispersion Model ................................................................................ 9-1

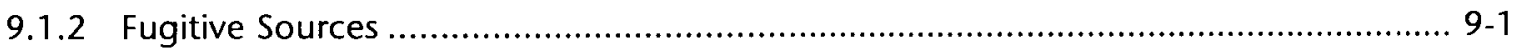

9.1.3 Total Dose from the Airborne Pathway ........................................................... 9-2

9.2 Effective Dose Equivalent Calculations - Water Pathway ................................................ 9-2

9.3 Effective Dose Equivalent Calculations - Fish Consumption .......................................... 9-3

9.4 Effective Dose Equivalent Calculations - Meat Consumption ......................................... 9-4

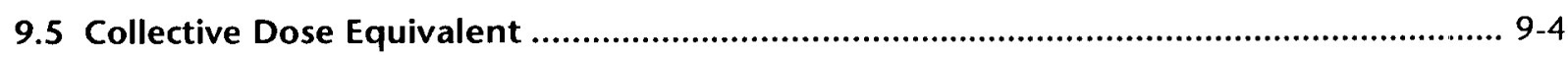

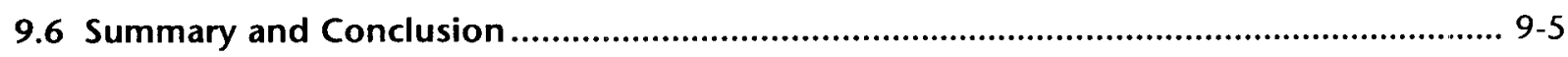

Chapter 10 QUALITY ASSURANCE PROGRAM ....................................................... 10-1

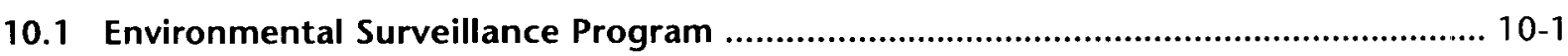

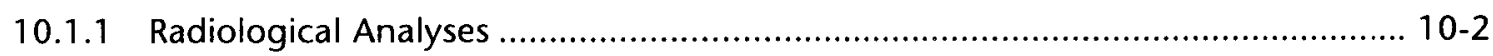

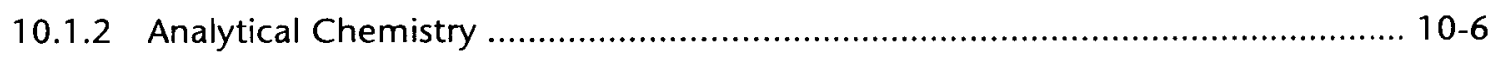

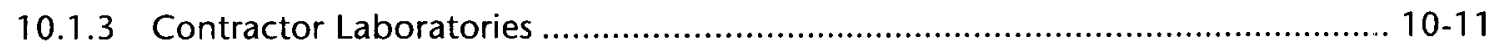

10.2 The HFBR Tritium Plume Characterization Project ........................................... 10-14

Contractor Lab Tritium Analysis Accuracy ................................................................. 10-16

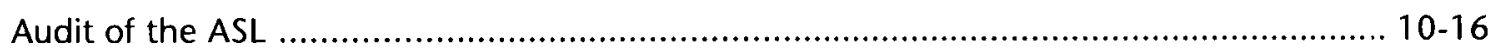

Gross Alpha/Beta Analyses ............................................................................... 10-19

10.3 Quality Assurance Program for CERCLA Groundwater Monitoring Activities .......... 10-19

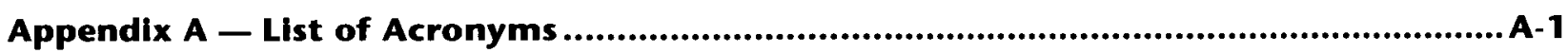

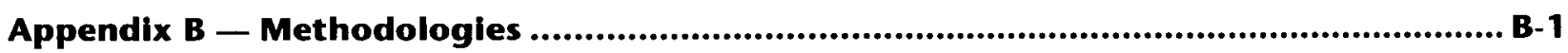

Appendix C - Instrumentation and Analytical Methods ............................................. C-1

Appendix D - CY 1997 SER- Groundwater Monitoring Wells List .................................D-1

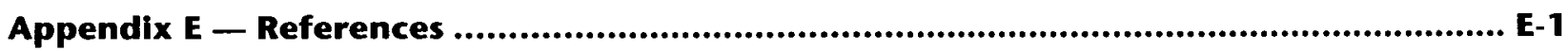

\section{Distribution}




\section{LIST OF FIGURES}

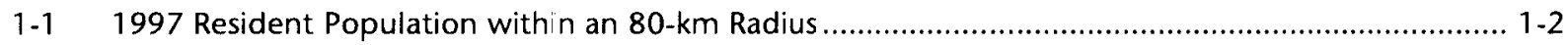

1-2 Brookhaven National Laboratory 1997 Local and On-Site Population Distribution .......................... 1-3

1-3 Brookhaven National Laboratory - Surrounding Communities .................................................... 1-4

1-4 Brookhaven National Laboratory — Major Facilities .................................................................... 1-5

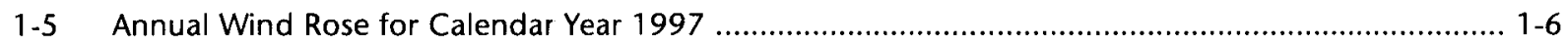

1-6 Monthly Mean Temperature Trend ......................................................................................... 1 1-7

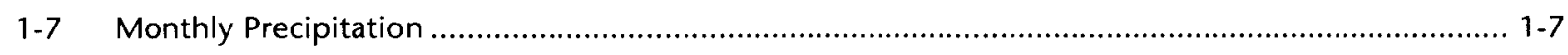

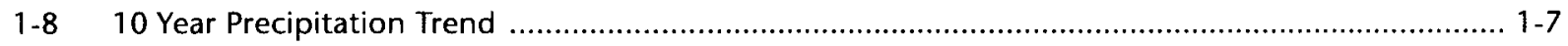

1-9 Groundwater Elevation at BNL March, 1997 (ft AMSL) ............................................................. 1-9

1-10 Groundwater Elevation at BNL. August, 1997 (ft AMSL) ....................................................... 1-10

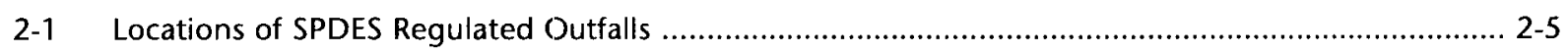

2-2 Effluent Concentration of Iron and Suspended Solids Discharge from BNL STP 1997 ................... 2-10

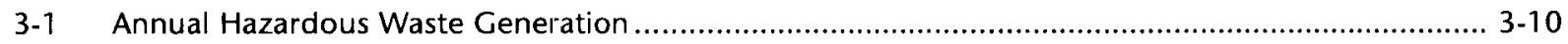

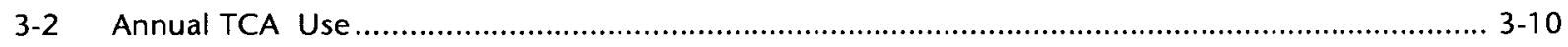

3-3 Annual Radioactive Waste Generation ..................................................................................... 3-10

3-4 Annual Mixed Waste Generation ........................................................................................... 3-10

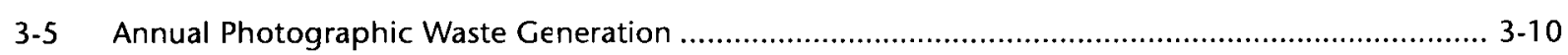

4-1 Typical Annual Dose Due To Natural Sources (mrem) ................................................................. 4-3

5-1 Brookhaven National Laboratory Effluent Release Points and

On-site Environmental Monitoring Stations ................................................................................... 5-2

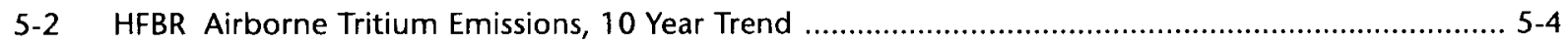

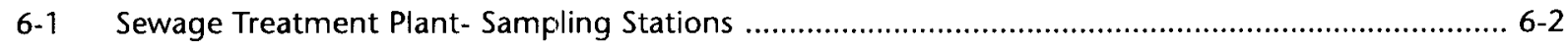

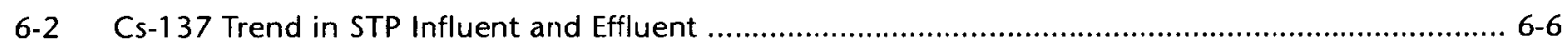

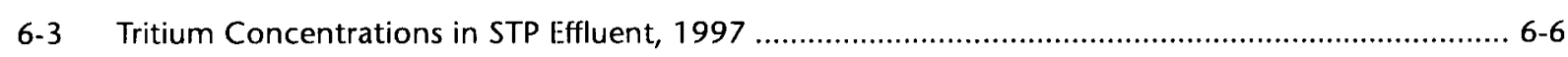

6-4 Tritium Released to Peconic River, 15 Year Trend .......................................................................... 6-7

6-5 STP/Peconic River Annual Average Tritium Concentrations, 10 Year Trend ....................................... 6-7

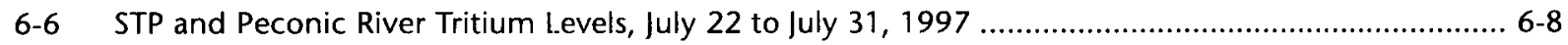

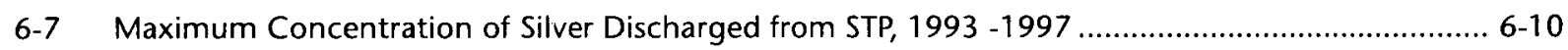

6-8 Maximum Concentration of Copper Discharged from STP, 1993 - 1997 ..................................... 6-10

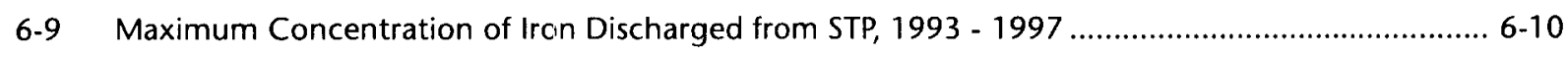

6-10 Maximum Concentration of Nickel Discharged fro STP, 1993 - 1997 .......................................... 6-11

6-11 Maximum Concentration of Lead Discharged from STP, 1993 - 1997 .......................................... 6-11

6-12 Maximum Concentration of Zinc Discharged from STP, 1993 - 1997 .......................................... 6-11

6-13 On-Site: Potable and supply wells and recharge sumps ............................................................... 6-14

6-14 Brookhaven National Laboratory Schematic of Water Use and Flow for 1997 ................................ 6-15 


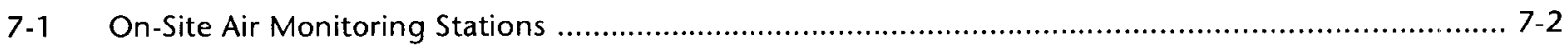

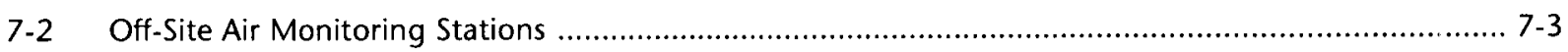

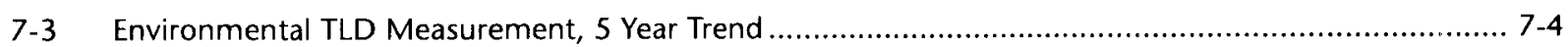

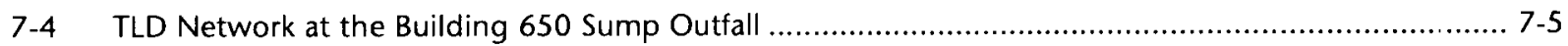

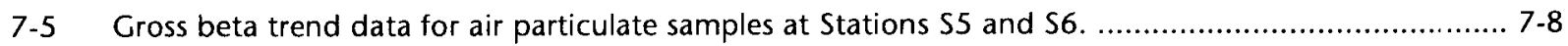

7-6 Gross beta trend data for air particulate samples at Stations P2 and P4 ..................................... 7-9

7-7 Gross beta trend data for air particulate samples at Stations P7 and P9. .................................... 7-10

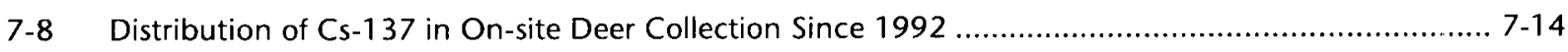

7-9 River Sampling Stations - Peconic River, Peconic Bay, and Carmans River .................................... 7-20

7-10 Cesium-137 Concentrations in Fish Collected From Peconic River, Bluegill Species ........................ 7-25

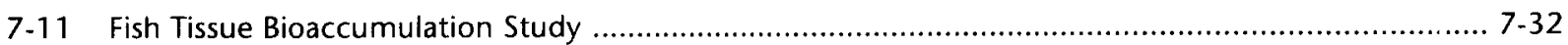

7-12 Fish Tissue Bioaccumulation Study ....................................................................................... 7-33

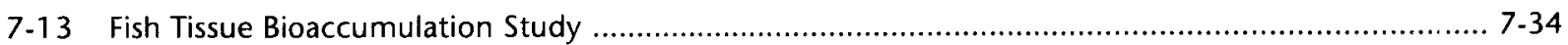

8-1 Contaminant Plumes and Reference Grid to Wells Maps ........................................................... 8-3

8-2 Wells located along the North Boundary - Upgradient/ Background Wells for BNL Site .................... 8-4

8-3 North Boundary - Upgradient/ Background Wells for BNL Site and

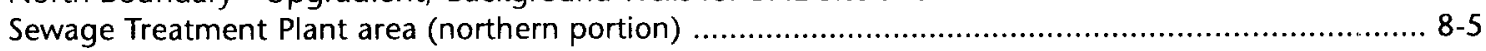

8-4 Western Supply Well Area (northern portion), AGS Experimental Areas,

Waste Concentration Facility, Recharge Basin HT, Water Treatment Plant,

Eastern Supply Well Area (western portion)

8-5 Sewage Treatment Plant and Peconic River Area, Eastern Supply Well Area,

Building 830 Spill Site, Recharge Basin HO, Building 650 Outfall,

Upland Recharge Experimental area

8-6 Peconic River Area, Upland Recharge Experimental Area

8-7 Western Supply Well (southern portion), Water Treatment Plant,

Building T-111, Supply and Materiel Area (northern portion), Building 479,

Recharge Basin HP, Ash Repository Area ....

8-8 Building 650 Area, Central Steam Facility/Major Petroleum Facility Area,

Biology Fields, Meadow Marsh Area, Hazardous Waste Management Facility,

Current Landfill, Former Landfill Area including Interim Landfill and

Chemical/Animal Disposal Areas, Supply and Material Area (southern portion)

8-9 Biology Fields, Meadow Marsh Area,

Hazardous Waste Management Facility (downgradient areas).

8-10 Southwestern Boundary Area

8-11 Southeast boundary - Downgradient of Former Landfill and Current Landfill .............................. 8-13

8-12 Wells located north of Brookhaven National Laboratory ........................................................... 8-14

8-13 Wells located east of Brookhaven National Laboratory ............................................................. 8-15

8-14 Wells located south of Brookhaven National Laboratory ............................................................. 8-16

8-15 Former Landfill, Animal/Chemical Pits, and Glass Holes areas -

TVOC Plume Cross Section C-C(ug/L)

8-16 Former Landfill, Animal/Chemical Pits, and Glass Holes areas

TVOC Plume Cross Section C-C (ug/L) 
8-17 Time-vs.-VOC concentration trend plots for selected off-site wells in the Former Landfill Plume: well 000-108 located on North Street approximately $900 \mathrm{~m}$ south of Long Island Expressway; and well 000-154 located on Sleepy Hollow Drive approximately $900 \mathrm{~m}$ south of the Long Island Expressway

8-18 Hazardous Waste Management Facility and Current Landfill (RA V) (TVOCs, ppb) ....................... 8-29

8-19 Current Landfill/HWMF-TVOC Plume Cross Section D-D (ug/L) .......................................... 8-30

8-20 Time-vs. VOC concentration trend plots for selected wells in the Current Landfill/ HWMF TVOC plume: well 88-109 located directly downgradient of landfill; well 88-22 located 120m downgradient of landfill; well 115-36 located approximately $900 \mathrm{~m}$ downgradient of landfill near the southern boundary; and well 000-124 located off-site approximately $\$ 00 \mathrm{~m}$ south of the Long Island Expressway

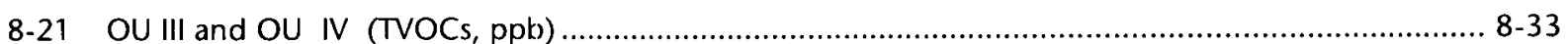

8-22 OU III TVOC Plume Cross Section A-A (ug/L) ............................................................... 8-34

8-23 Time-vs.-VOC concentration trend plots for selected wells in the OU III Plume (Central Area): well 64-03 located within the AGS area; well 65-03 located downgradient of the AGS area; well 96-07 located downgradient of Supply and Materiel Building 208; and well 105-23 located near East Princeton Avenue

8-24 Time-vs.-VOC concentration trend plots for selected wells in the OU III Plume (south boundary and off-site): wells 121-10 and 121-14 located near the southern boundary; off-site well 000-112 located $400 \mathrm{~m}$ south of the Long Island Expressway in the Brookhaven Industrial Complex; and off-site well 000-108 located on Carleton Drive

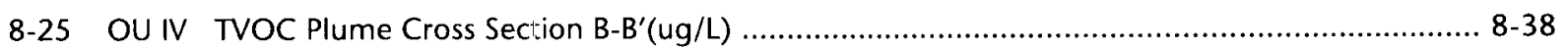

8-26 Time-vs.-VOC concentration trend plots for selected OU IV South Boundary Monitoring Wells.

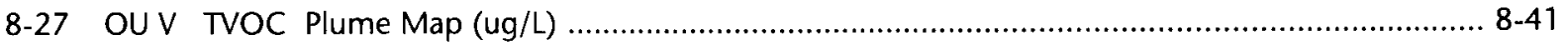

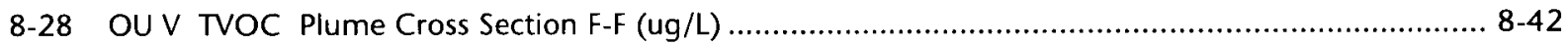

8-29 Time-vs.-VOC concentration trend plots for selected wells in the OU V Plume: Wells 50-01 and 61-05 located near the eastern boundary; and off-site well 000-122 located just north of the Long Island Expressway ............................................... 8-43

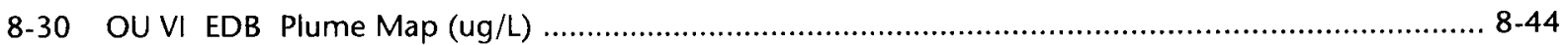

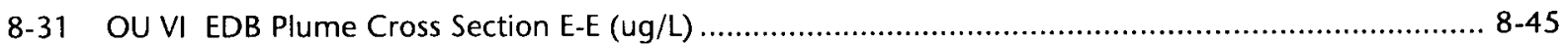

8-32 Time-vs.-EDB concentration trend plots for selected wells in the OU VI EDB Plume: Well 89-14 located immediately downgradient of the Biology Fields; well cluster 100-13/100-14 located at the southeastern boundary; and off-site well 000-110 located on South Street

8-33 Map showing tritium concentrations in wells located

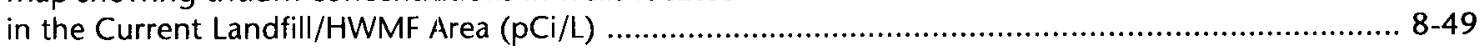

8-34 Time-vs.-tritium concentration trend plots for well 88-26 located in the HWMF area .................... 8-50

8-35 Time-vs.-strontium-90 concentration trend plots for well 106-16 located

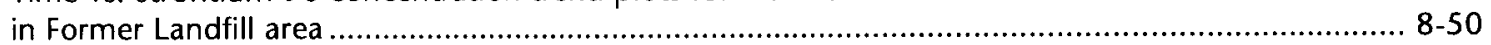

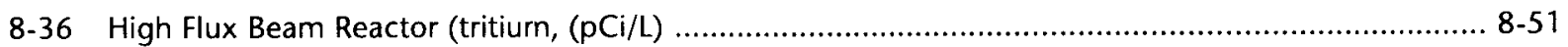

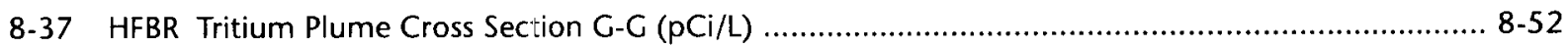

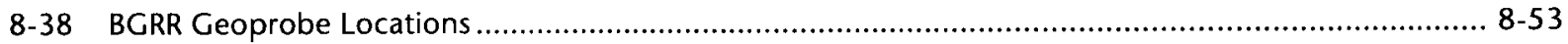

8-39 OU IV AOC 6 Radionuclide Results Results are reported in $p C i / L M C A=$ Minimum Detectable Activity ............................................ 8-55

8-40 Sewage Treatment Plant (OU V) Tritium Sampling Results ................................................... 8-56 
8-41 Time-vs.- tritium concentration trend plots for well cluster 50-01/50-02 located

in the OU V Plume near the eastern site boundary

8-42 Groundwater Elevation at BNL, June, 1997 ( $\mathrm{ft}$ AMSL)

8-43 Annual average tritium concentration trend plots for selected wells located in the STP Filter Bed area ...................................................................................... 8 -70

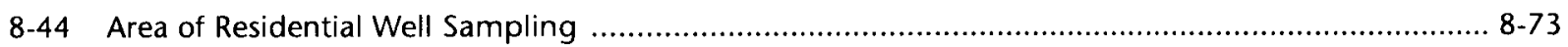

8-45 Private supply well sampling program for CY 1995 and CY 1996 - Tritium Data ......................... 8-74

8-46 Private supply well sampling program for CY 1995 and CY 1996 - Strontium-90, Gross Alpha and Gross Beta Data

8-47 Gross activity in private wells sampled in 1997 (number of homes vs. concentrations).

8-48 Tritium in private wells sampled in 1997

(number of homes vs. concentrations)

8-49 Private supply well sampling program for CY 1995 and CY 1996 - VOC Data ............................. 8-76

8-50 Private supply well sampling program for CY 1997 - VOC Data ............................................... 8-76

8-51 Suffolk County Water Authority Public Supply Wells .......................................................... 8-77

9-1 Dose Summary, Maximum BNL Contribution and Federal Limits ............................................. $9-4$

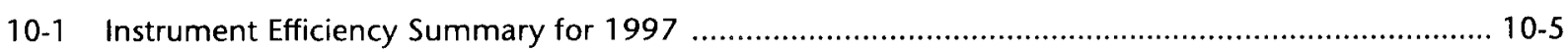

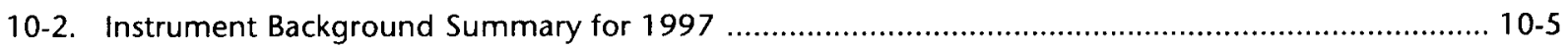

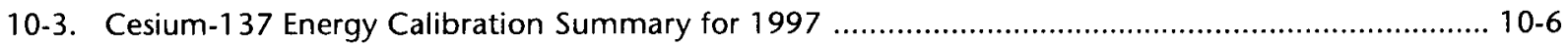

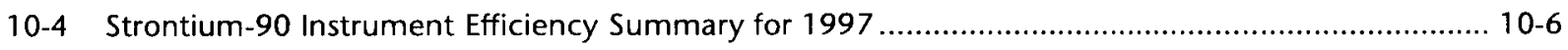

10-5 Reference Check Summary for 1997 Inorganic Analyses ................................................. 10-11

10-6 Summary of Spike Recoveries for 1997 Inorganic Analyses ............................................... 10-11

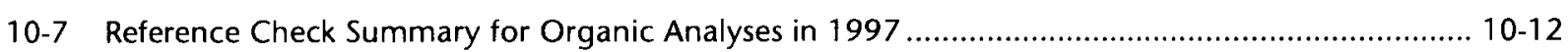

10-8 Surrogate and Spike Recovery Summaries for 1997 Organic Analyses ....................................... 10-12

10-9 Matrix Spike Duplicate Summary for Organic Analyses in 1997 ........................................... 10-12

10-10 Comparison of BNL vs. U.S. EPA Tritium Results

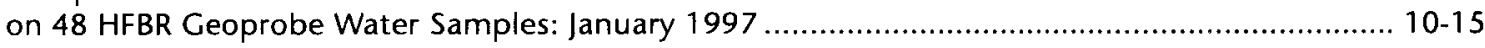

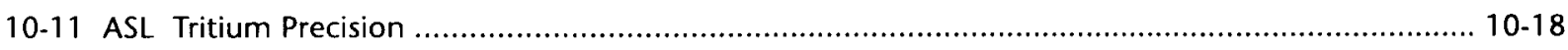

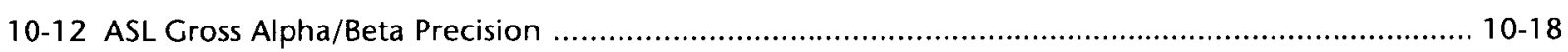




\section{LIST OF TABLES}

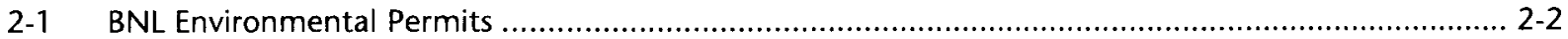

2-2 Summary of Analytical Results for Waste Water Discharges to Outfalls 002-010 ........................... 2-6

2-3 Summary of Analytical Results for Waste Water Discharges to Outfall 001 ...................................... 2-8

2-4 Summary of Chemical and Oil Spill Reporting Record ........................................................... 2-15

2-5 Potable Water Wells and Potable Distribution System, Bacteriological, Inorganic Chemical, and Radiological Analytical Data ${ }^{(1)}$.

2-6 Potable Water Wells, Analytical Data for Principal Organic Compounds, Synthetic Organic Compounds, Pesticides \& Micro-Extractables .................................................... 2-28

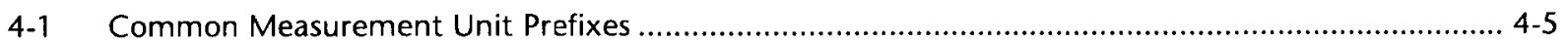

5-1 Airborne Radionuclide Releases from Monitored Facilities ............................................................... 5-3

6-1 Gross Activity and Tritium Results at STP Clarifier Influent ........................................................... 6-3

6-2 Gross Activity and Tritium Results at STP at Peconic River Outfall .................................................. 6-4

6-3 Gamma-Emitting Radionuclides and Srontium-90 Detected

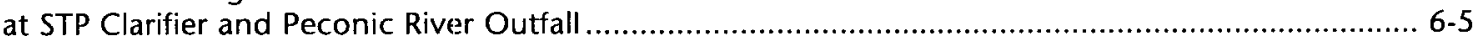

6-4 Sewage Treatment Plant (STP) ${ }^{(\mathrm{a})}$ Average Water Quality and Metals Data ...................................... 6-9

6-5 Gross Activity and Tritium in Recharge Basin Water ................................................................... 6-16

6-6 Gross Activity and Tritium in Recharge Basin Water ..................................................................... 6-17

6-7 Recharge Basin Gamma-Emitting Radionuclide Analysis ........................................................... 6-18

6-8 Water Quality Data for On-Site Recharge Basins ...................................................................... 6-19

6-9 Metals Data for On-Site Recharge Basins …............................................................................... 6-20

7-1 On-Site Annual Exposure Measurements .................................................................................... 7-4

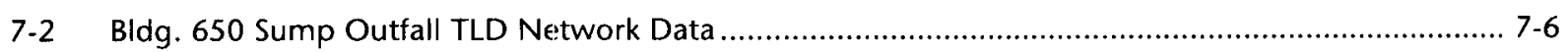

7-3 Gross Activity Detected in Air Particulates Filters .......................................................................... 7-7

7-4 Ambient Airborne Tritium Measurements ................................................................................. 7-11

7-5 Ambient Tritium Monitoring Results at RA V Recharge Basin ...................................................... 7-12

7-6 Radiological Analysis of Precipitation ……................................................................................ 7-12

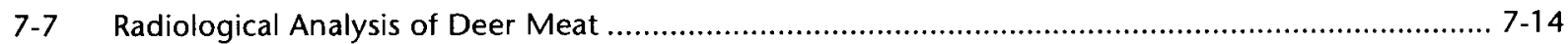

7-8 Radiological Analysis of Vegetation Samples ............................................................................. 7-15

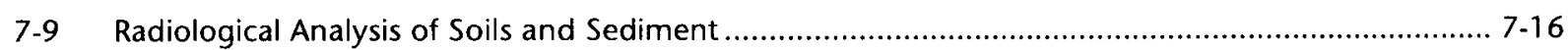

7-10 Water Quality Data for Surface 'Water Samples Collected Along the Peconic and Carmans Rivers.

7-11 Metals Concentration Data for Surface Water Samples Collected Along the Peconic and Carmans Rivers

7-12 Gross Activity and Tritium Analysis of the Peconic River .............................................................. 7.21

7-13 Gamma-Emitting Radionuclides and Sr-90 Analysis of Peconic River ........................................... 7-22

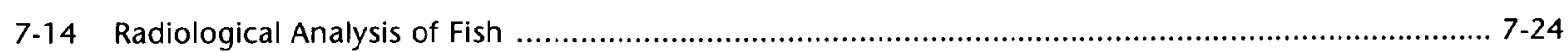

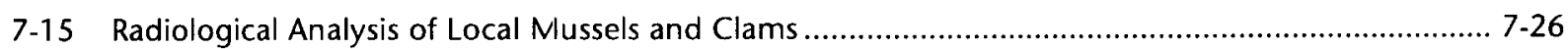


7-16 OU V Fish Tissue Bioaccumulation Data, Metals

7-17 OU V Fish Bioaccumulation Data, Pestcides and PCBs

$7-30$

7-18 OU V Fish Tissue Bioaccumulation Data, Radionuclides

7-31

8-1 Potable and Process Supply Wells Volatile Organic Compound Data

8-2 Potable Water and Process Supply Wells Water Quality Data .............................................. 8-19

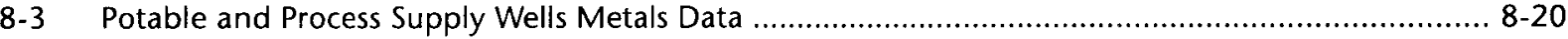

8-4 Potable Water and Process Well Gross Activity and Tritium Results ........................................ 8-21

8-5 OU III South Boundary Groundwater Remediation System Comparison of Monthly Average Influent and Effluent VOC Concentrations...

8-6 Removal Action V Groundwater Remediation System Comparisons of Monthly Average Influent and Effluent VOC Concentrations $\stackrel{(a)}{.}$

8-7 Sewage Treatment Plant/Peconic River Area

Groundwater Surveillance Wells, Water Quality Data

8-8 Sewage Treatment Plant/Peconic River Area Groundwater Surveillance Wells, Metals Data

8-9 Radiological Data for Groundwater Wells near AGS, BLIP and LINAC Areas

8-10 Gross Activity and Tritium Results at STP and Peconic River Area ....................................... 8-69

8-11 Gross Activity and Tritium Results at New Waste Management Facility .................................... 8-71

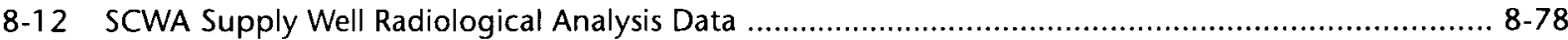

9.1 Radiological Dose due to Airborne Effluents as Calculated by CAP88-PC ..................................... 9-3

9-2 Summary of Dose from all Environmental Pathways ...................................................................

10-1 BNL Quality Assessment Program Results Environmental Measurements Laboratory

10-2 BNL Quality Assessment Program Results National Exposure Research Laboratory (NERL-LV)

10-3 BNL Potable Water Radiochemistry Proficiency Test Results Environmental Laboratory Approval Program...

10-4 BNL Non-Potable Water Chemistry Proficiency Test Results Environmental Laboratory Approval Program....

10-5 BNL Potable Water Chemistry Proficiency Test Results Environmental Laboratory Approval Program ....

10-6 BNL Water Pollution Performance Evaluation Studies - WP037 USEPA Environmental Monitoring System Laboratory - Cincinnati

10-7 BNL Water Supply Performance Evaluation Studies - WSO38 and WS039

USEPA Environmental Monitoring System Laboratory - Cincinnati

10-8 BNL Contractor Laboratory Performance Evaluation Study

BNL National Pollution Discharge Elimination System (NPDES) - DMR QA 17

10-9 BNL Contractor Laboratory (H2M) Water Pollution Performance Evaluation Studies USEPA Environmental Monitoring System Laboratory - Cincinnati

10-10 Results of BNL Prepared Blind QA Water Samples* Analyzed by U.S. EPA Methods May 1997

10-11 Accuracy of Contractor Labs Performing Distilled Tritium Analyses in Water during Phase II of HFBR Plume Project 


\section{Chapter 1}

\section{INTRODUCTION}

\subsection{Brookhaven National Laboratory's Mission}

Brookhaven National laboratory is a multi-program national laboratory operated by Brookhaven Science Associates for the U.S. Department of Energy. The Laboratory's broad mission is to produce excellent science in a safe, environmentally benign manner with the cooperation, support and appropriate involvement of our many communities. Specifically, the mission of BNL, which supports the U.S. Department of Energy's strategic missions, is to:

- Conceive, design, construct and operate complex, leading-edge, user-oriented facilities in a safe and environmentally benign manner that is responsive not only to the DOE, but also to the needs of the users.

- Carry out basic and applied research in long-term programs at the frontier of science that supports DOE missions and the needs of the Laboratory's user community.

- Develop advanced technologies that address national needs and initiates their transfer to other organizations and to the commercial sector.

- Disseminate technical knowledge to educate new generations of scientists and engineers, to maintain technical currency in the nation's workforce, and to encourage scientific awareness in the general public.

In 1997 Brookhaven National Laboratory (BNL) was managed by Associated Universities Inc. (AUI) under DOE Contract No. DE-AC02-76CH00016. AUI was formed in 1946 by a group of nine universities whose purpose was to create and manage a Laboratory in the Northeast to advance scientific research of interest to universities, industry, and government. On January 31, 1947, the contract for BNL was approved by the Manhattan District of the Army Corps of Engineers, and the Laboratory was established on the former Camp Upton Army site.

The Laboratory carries out basic and applied research in the following fields: high-energy, nuclear and solid-state physics; fundamental material and structural properties and the interactions of matter; nuclear medicine, biomedical and environmental sciences; and selected energy technologies. In undertaking research, it is the Laboratory's policy to protect the health and safety of employees and the public, and to minimize the impact of BNL's operations on the environment.

\subsection{Site Characteristics}

Brookhaven National Laboratory is located near the geographical center of Suffolk County, Long Island, about $97 \mathrm{~km}$ east of New York City. About 1.35 million persons reside in Suffolk County (LILCO, 1997), and about 0.43 million in Brookhaven Township, where the Laboratory is situated. Approximately eight thousand people live within a half-km of the Laboratory's boundaries. Figure 1-1 shows the distribution of the resident population within $80 \mathrm{~km}$ of the BNL site and Figure $1-2$ shows that within $0.5 \mathrm{~km}$. Although much of the land area within a $16 \mathrm{~km}$ radius is either forested or cultivated, there has been an increase in residential housing in the rural areas surrounding BNL. There have been no major construction projects since 1978, but detailed plans are proposed for two shopping centers, a corporate park, and several thousand single- and multiple-family dwellings within a $1.5-\mathrm{km}$ area of BNL, predominately on the north, south, and west boundaries. Figure 1-3 shows the rural areas surrounding BNL.

Figure 1-4 shows the Laboratory's site, consisting of 21.3 square kilometers $(2,130$ hectares [ha]), with most principal facilities located near the center. The developed area is approximately 6.7 


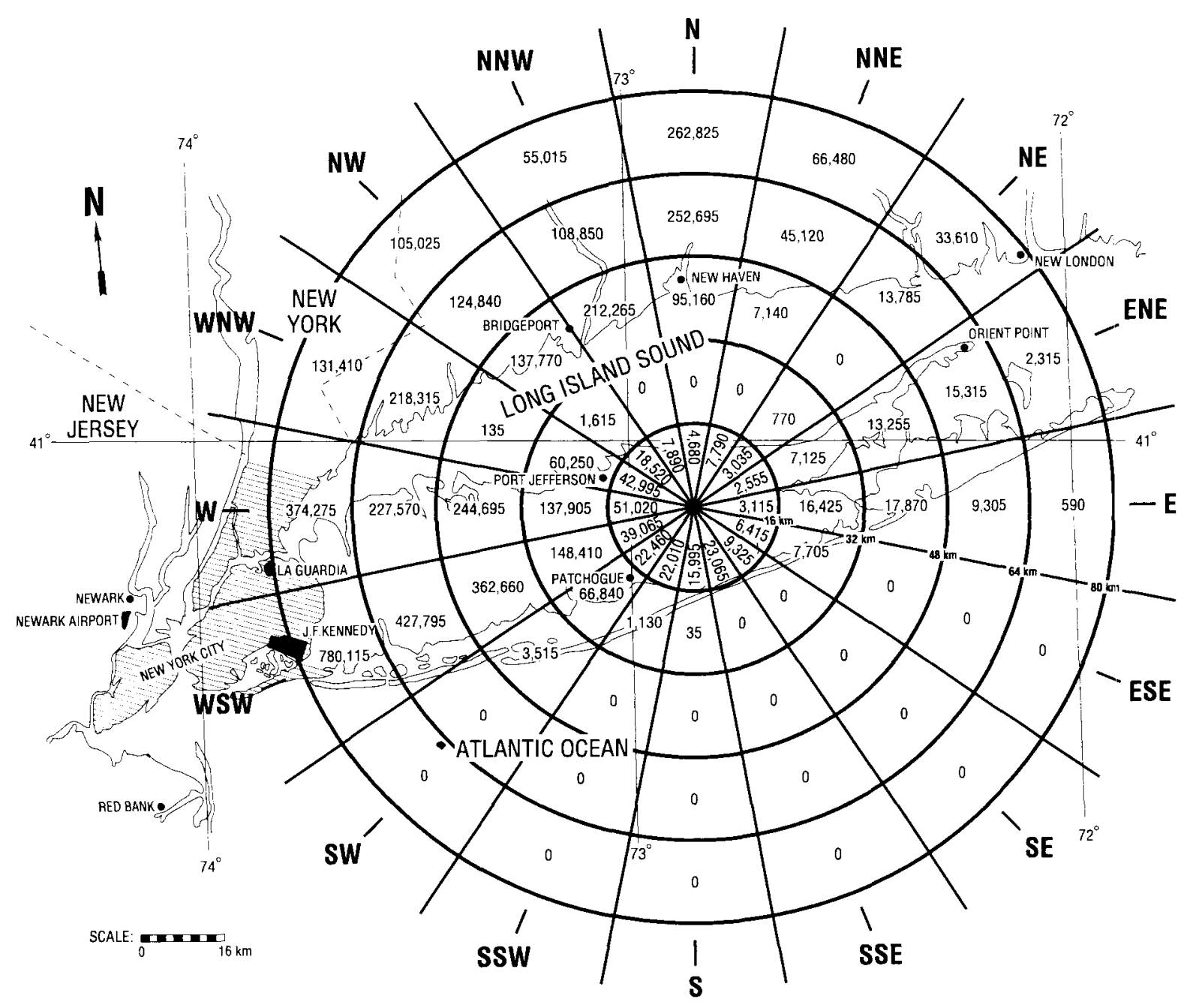

Figure 1-1.

1997 Resident Population within an 80 km Radius

square kilometers ( $670 \mathrm{ha}$ ), of which about 2.02 square kilometers ( $202 \mathrm{ha}$ ) were originally developed by the Army, and about 0.81 square kilometers ( $81 \mathrm{ha}$ ) are occupied by various large, specialized research facilities. Outlying facilities occupy about 2.22 square kilometers ( $222 \mathrm{ha}$ ); these include the Sewage Treatment Plant (STP), research agricultural fields, housing, and fire breaks. The balance of the site is largely wooded.

The Laboratory can be characterized as a well-ventilated site, like most of the eastern seaboard. The prevailing ground level winds are from the southwest during the summer, from the northwest during the winter, and about equal from these two directions during the spring and fall (Nagle, 1975; 1978). Figure $1-5$ shows the 1997 annual wind rose for BNL, measured at a height of $88 \mathrm{~m}(288 \mathrm{ft}$.). Figure $1-6$ shows the monthly average temperatures. 


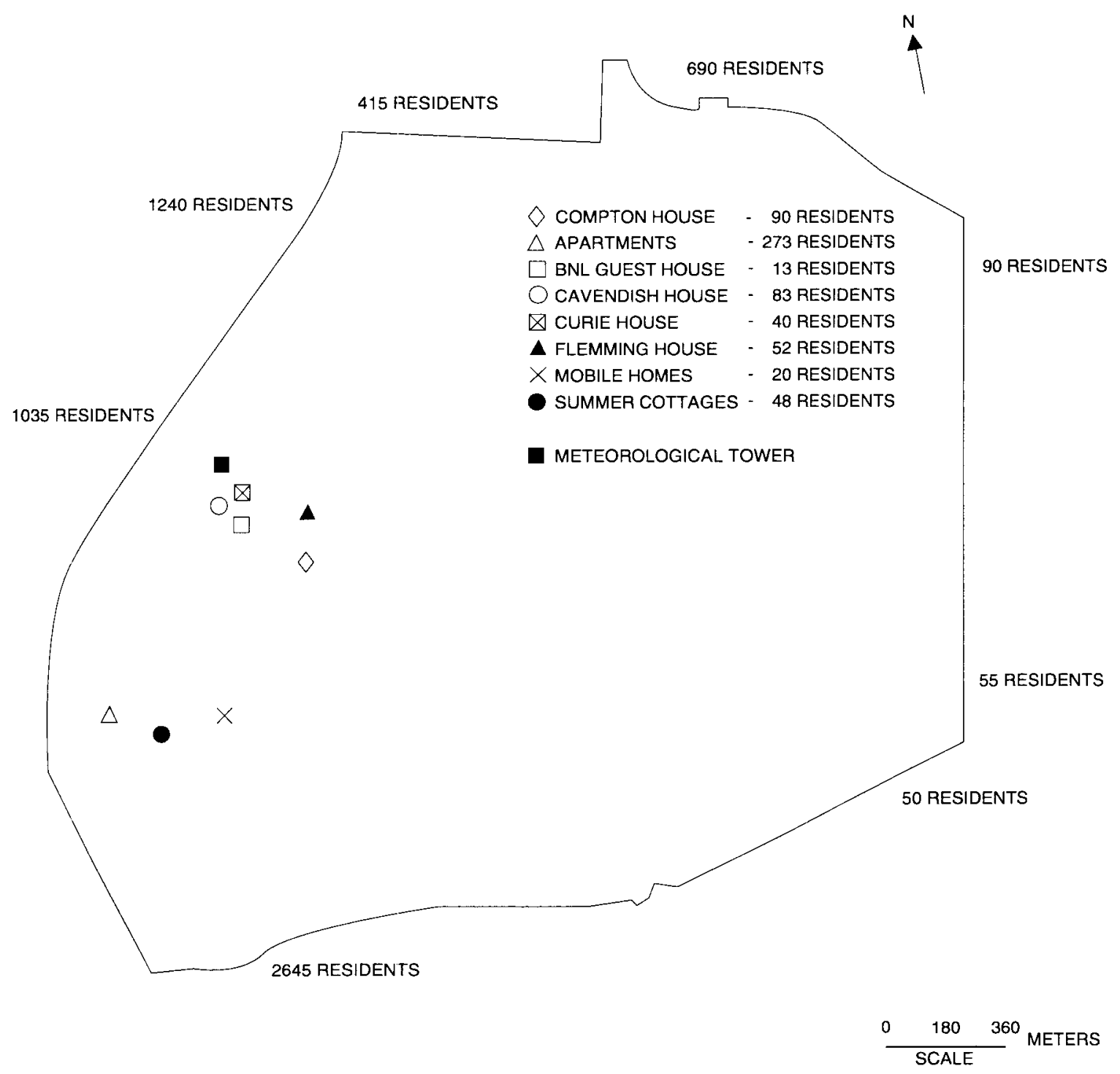

Figure 1-2.

Brookhaven National Laboratory 1997 Local and On-site Population Distribution

The terrain of the site is gently rolling, with elevations varying between $36.6 \mathrm{~m}$ and $13.3 \mathrm{~m}$ above sea level. The land lies on the western rim of the shallow Peconic River watershed. The marshy areas in the north and eastern sections of the site are a part of the Peconic River headwaters. The Peconic River both recharges to, and receives water from, the groundwater aquifer depending on the hydrological potential. In times of drought, the river water typically recharges to groundwater (i.e., a losing stream) while with normal to above-normal precipitation, the river receives water from the aquifer (i.e., a gaining stream). Thus, the river on-site is classified as an intermittent river. In 1997, the Peconic River bed on-site was in a discharge mode from January to June and in a recharge mode from July to December. During this latter period, no flow was observed to leave the site. 


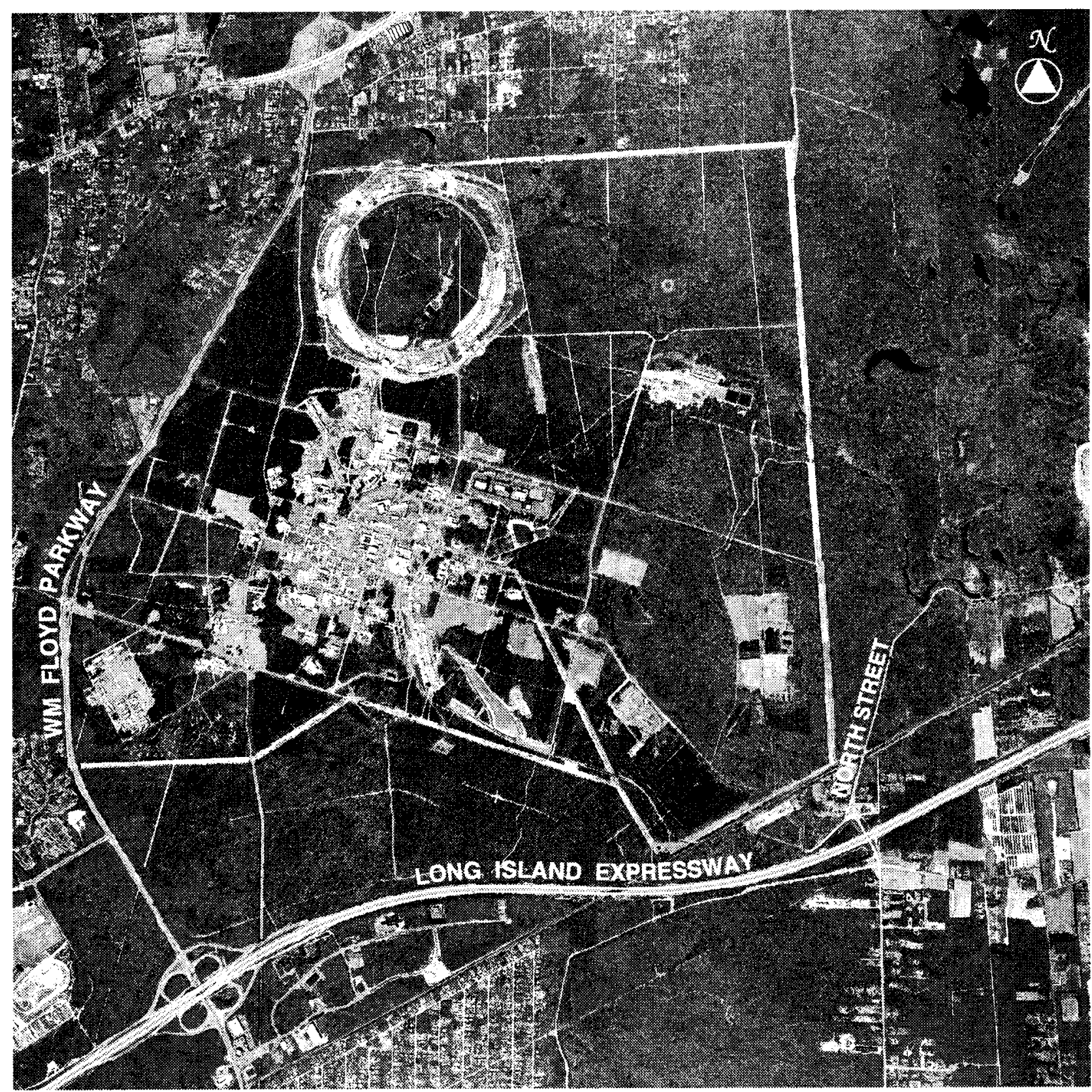

Figure 1-3. Brookhaven National Laboratory Surrounding Communities

The Laboratory uses approximately 10 million liters of groundwater per day (MLD) to meet potable water needs plus heating and cooling requirements. Approximately $74 \%$ of the total pumpage is returned to the aquifer through on-site recharge basins. About 19\% is discharged into the Peconic River. Human consumption, evaporation (cooling-tower and wind-losses) and sewer line losses account for the remaining seven percent. An additional 2.13 MLD of groundwater is pumped from remediation wells for treatment, and then returned to the aquifer by the use of recharge basins.

Studies of hydrology and geology in the vicinity of the Laboratory indicate that the uppermost Pleistocene deposits (referred as the Upper Glacial Aquifer) are between 31-61 m thick, and are generally composed of highly permeable glacial sands and gravel (Warren et al., 1968). Water 


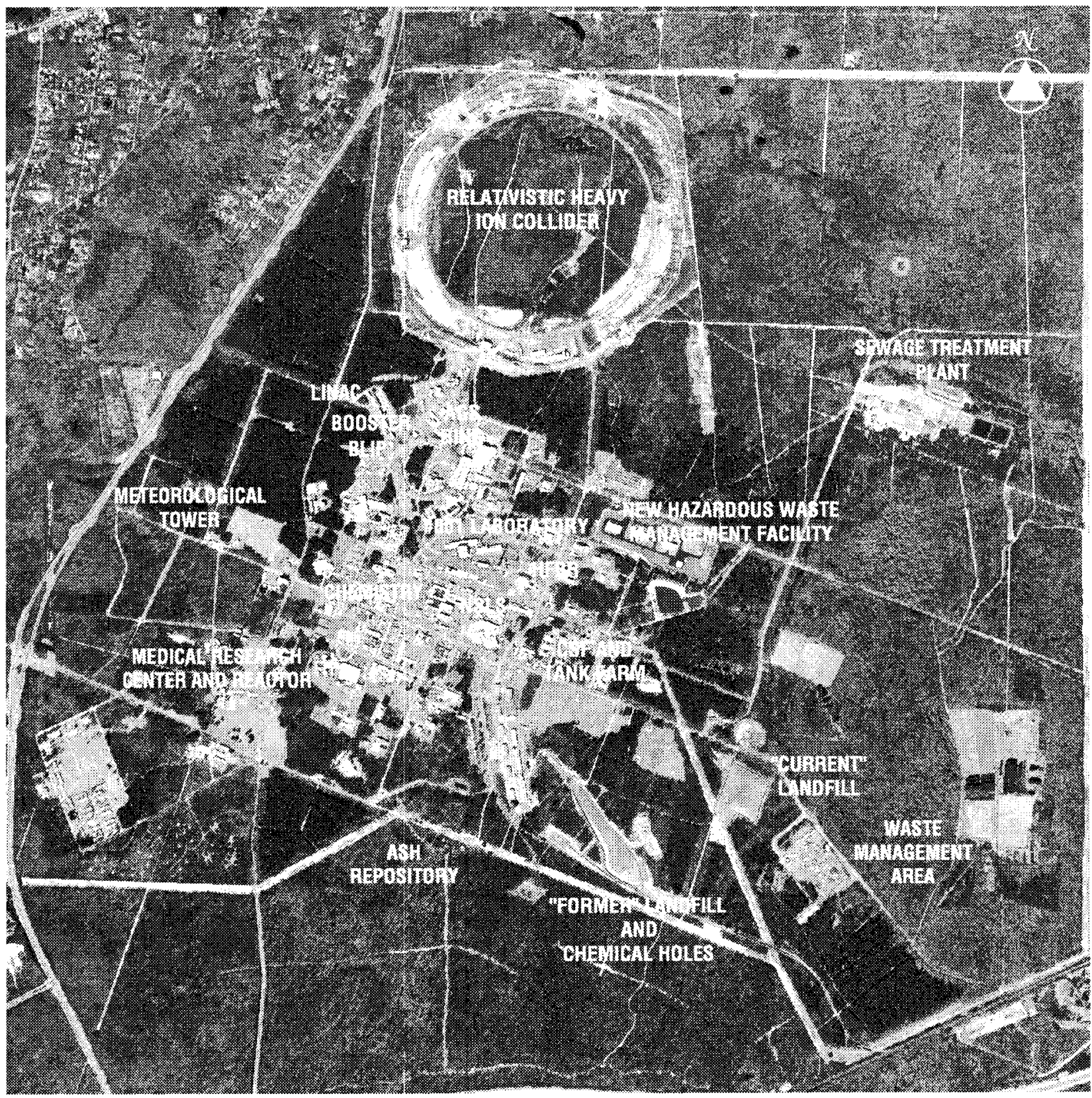

Figure 1.4. Brookhaven National Laboratory Major Facilities

penetrates these deposits readily and there is little direct runoff into surface streams unless precipitation is intense. The total precipitation for 1997 was $101.7 \mathrm{~cm}$, which is about $20 \mathrm{~cm}$ below the 40-year annual average. Figures 1-7 and 1-8, respectively, present the 1997 monthly and historic precipitation data. On average, about half of the annual precipitation is lost to the atmosphere through evapotranspiration, and the other half percolates through the soil to recharge groundwater (Koppelman, 1978).

Many factors affect groundwater flow around BNL. The main groundwater divide lies approximately $2-3 \mathrm{~km}$ north of BNL, and runs parallel to the Long Island Sound. The secondary groundwater divide that defines the southern boundary of the area contributing groundwater to the Peconic River lies to the east. South of these divides, the groundwater moves southward to the 


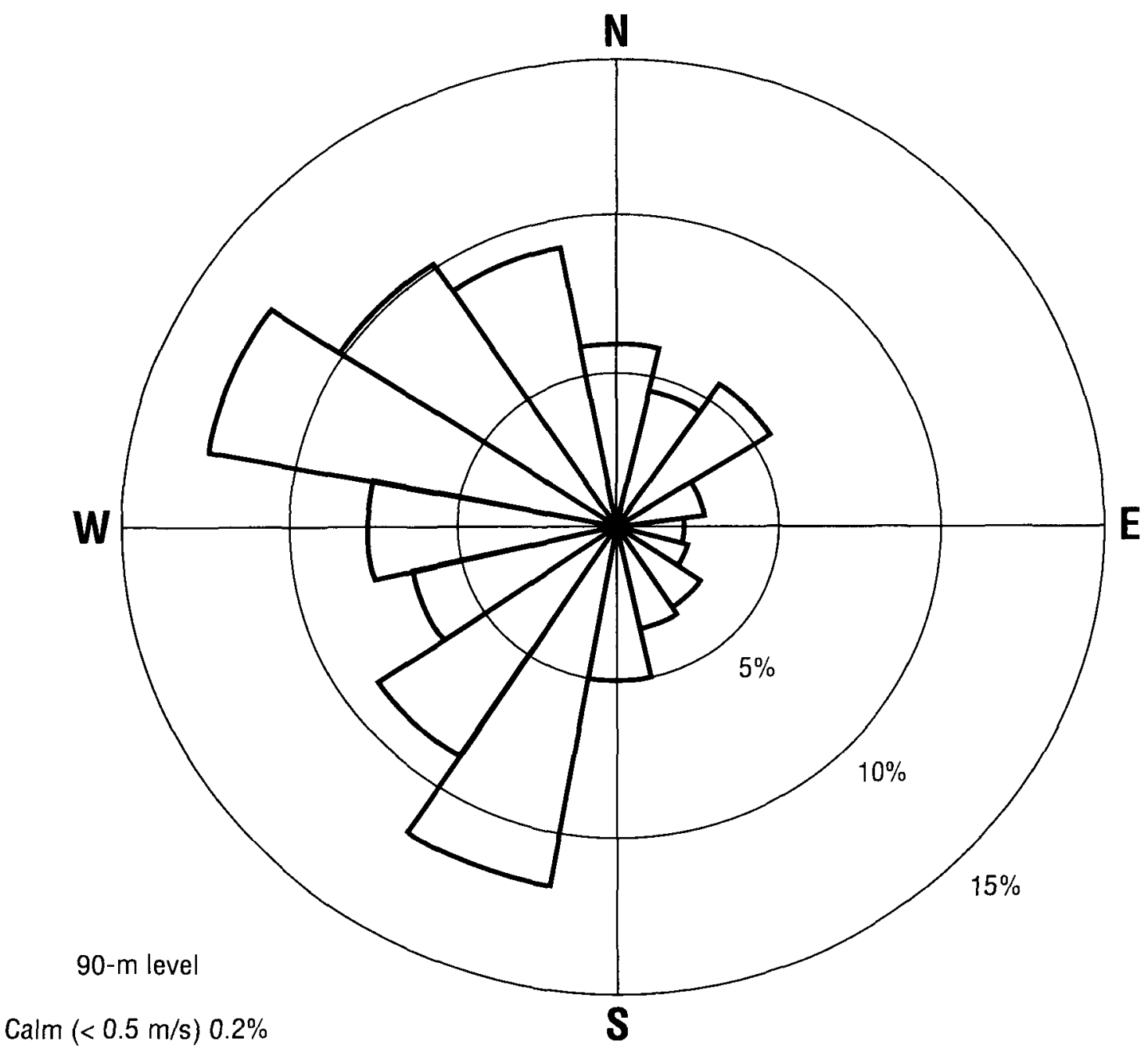

Figure 1-5

Annual Wind Rose for Calendar Year 1997

Great South Bay, Carmans River and Moriches streams. In general, the groundwater from the area between the two branches of the divide moves eastward to the Peconic River. North of the divide, groundwater moves northward to the Long Island Sound. The pressure of a higher water table to the west of the BNL area generally inhibits westward movement. Variability in the direction of flow on the BNL site is a function of the hydraulic potential and is further complicated by the presence of near-surface clay deposits that accumulate perched water at several places within the site, and also by the pumping and recharge of groundwater during BNL's daily operations. In general, groundwater in the northeast and northwest sections of the site flows towards the Peconic River. On the western portion of the site, groundwater flow tends to be towards the south, while along the southern and southeastern sections of the site the flow tends to be towards the 


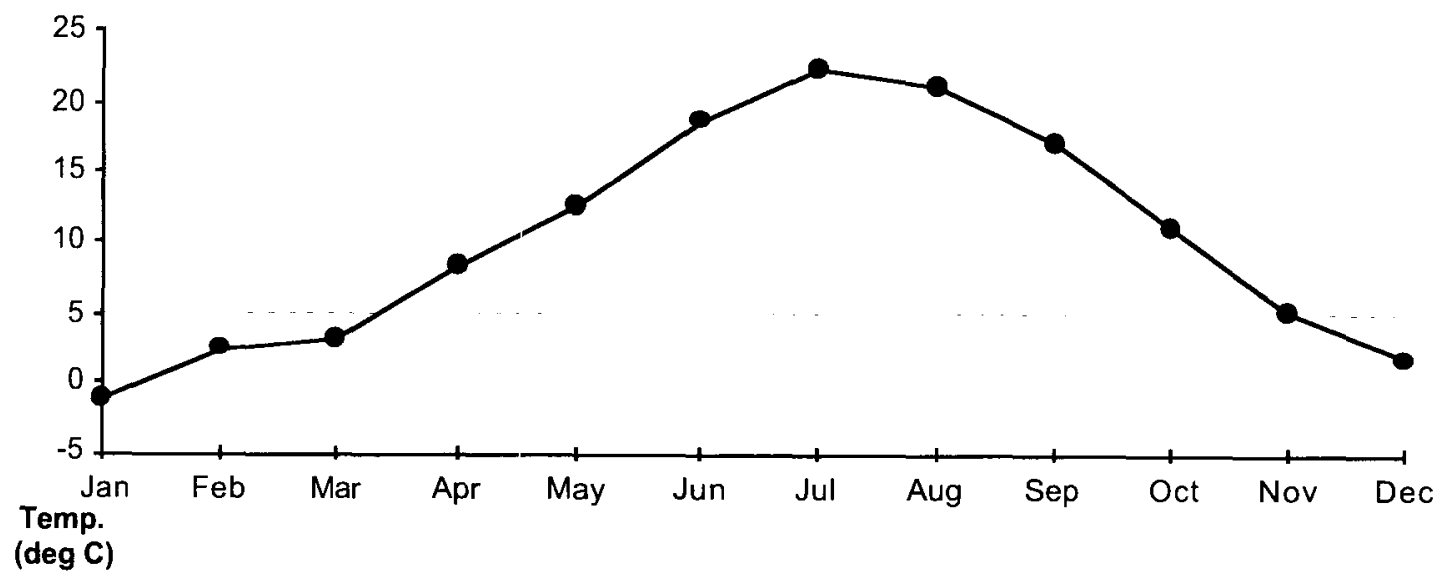

Figure 1-6. Monthly Mean Temperature Trend

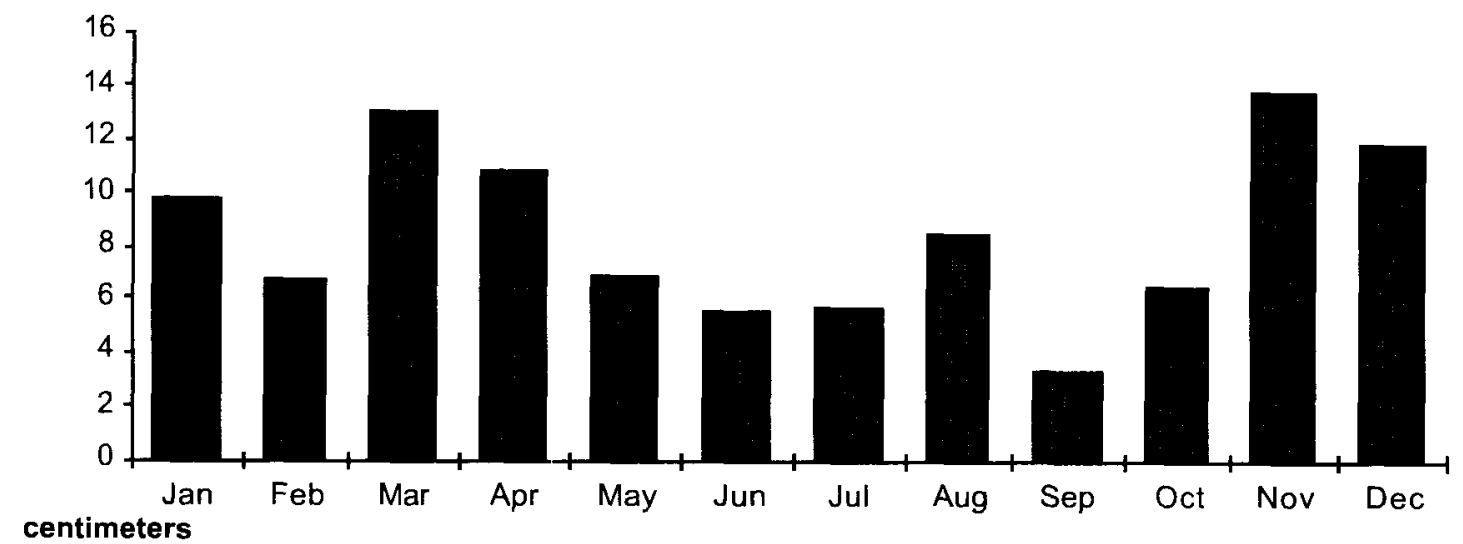

Figure 1-7. Monthly Precipitation

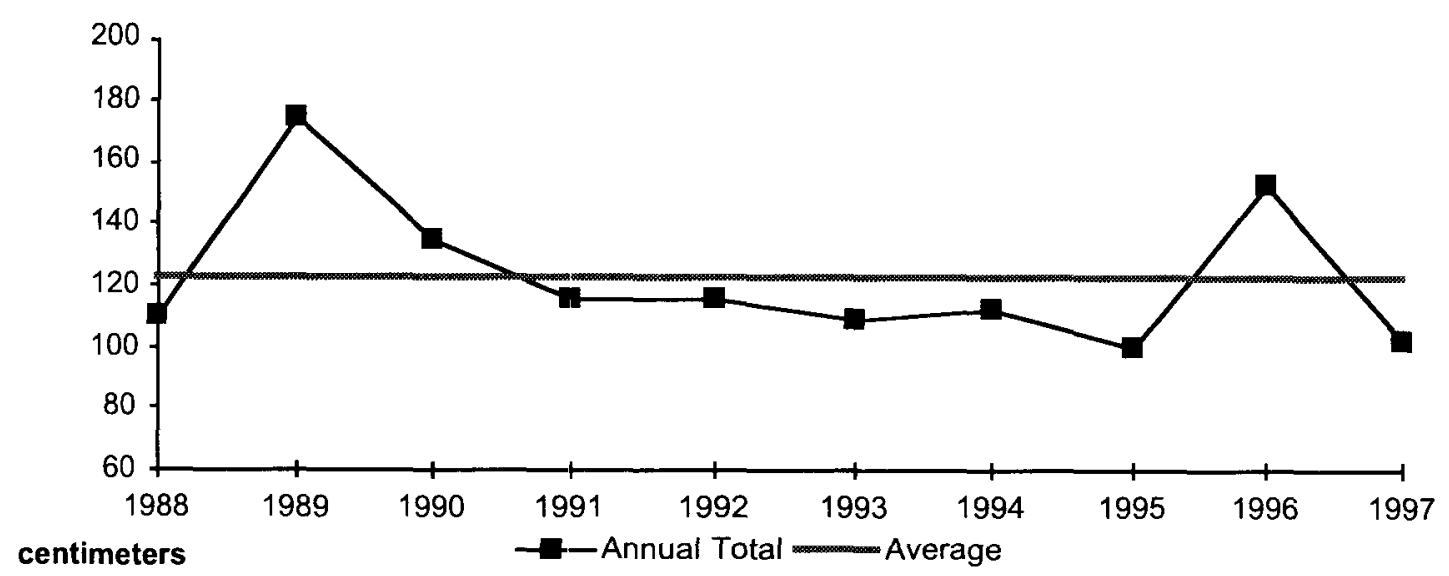

Figure 1-8. 10 Year Precipitation Trend 
south to southeast. Figures 1-9 and 1-10 depict the configuration of the groundwater table at the BNL site during March, and August 1997, respectively. The horizontal velocity of groundwater ranges from 22 to $30 \mathrm{~cm} / \mathrm{d}$ (Warren et al., 1968). BNL's site was identified by the Long Island Regional Planning Board and Suffolk County as being over a deep-flow recharge zone for Long Island (Koppelman, 1978). This finding implies that precipitation and surface water which recharge within this zone have the potential to replenish the lower aquifer systems (Magothy and Lloyd) lying below the Upper Glacial Aquifer. It is estimated that up to two-fifths of the recharge from rainfall moves into the deeper aquifers. The extent to which the BNL site contributes to deep flow recharge was evaluated by Geraghty and Miller (1996b). In coastal areas, these aquifers discharge to the Atlantic Ocean or to the Long Island Sound.

The Laboratory is located in a section of the Oak/Chestnut forest region of the Coastal Plain. Because of the general topography and porous soil, there is little surface runoff or open water. Upland soils tend to be drained excessively, while depressions form small pocket wetlands. Hence, a mosaic of wet and dry areas on the site are correlated with variations in topography and depth to the water table. Without fires or other disturbances, the vegetation normally follows the moisture gradient closely. In actuality, vegetation on-site is in various stages of succession reflecting the history of disturbances to the area, the most important having been land clearing, fire, local flooding, and draining.

Mammals endemic to the site include species common to mixed hardwood forests and open grassland habitats. At least 180 species of birds have been observed at BNL, a result of its location within the Atlantic Flyway, and the scrub/shrub habitats which offer food and rest to migratory songbirds. Open fields bordered by hardwood forests at the recreation complex are excellent hunting areas for hawks. Pocket wetlands with seasonal standing-water provide breeding areas for amphibians. Permanently flooded recharge basins and other watercourses support aquatic reptiles. Recent ecological studies at the BNL site indicated that the NYS-endangered eastern tiger salamander (Ambystoma tigrinum) uses BNL's vernal ponds and some recharge basins as breeding areas. The banded sunfish (Eanneacanthus obesus) is one NYS species of "special concern", as it occurs solely within the Peconic River system: it has been confirmed as inhabiting the Peconic River on-site (Scheibel, 1990; Corin, 1990). Part of the Peconic River running through BNL's property was designated "scenic" in accordance with the NYS's Wild, Scenic, and Recreational River Systems Act (WSRRSA). The wide variety of wildlife resources at BNL attest to the Laboratory's planning practices which have clustered development to minimize fragmenting habitats, particularly in environmentally sensitive areas such as the Peconic River corridor.

\subsection{Existing Facilities}

A wide variety of scientific programs are conducted at Brookhaven, including research and development in the following areas:

1. The fundamental structure and properties of matter;

2. The interactions of radiation, particles, and atoms with other atoms and molecules;

3. The physical, chemical, and biological effects of ionizing radiation;

4. The production of special radionuclides and their medical applications;

5. Energy-and nuclear-related technologies; and

6. The assessment of energy sources, transmission, and uses, including their environmental and health effects. 


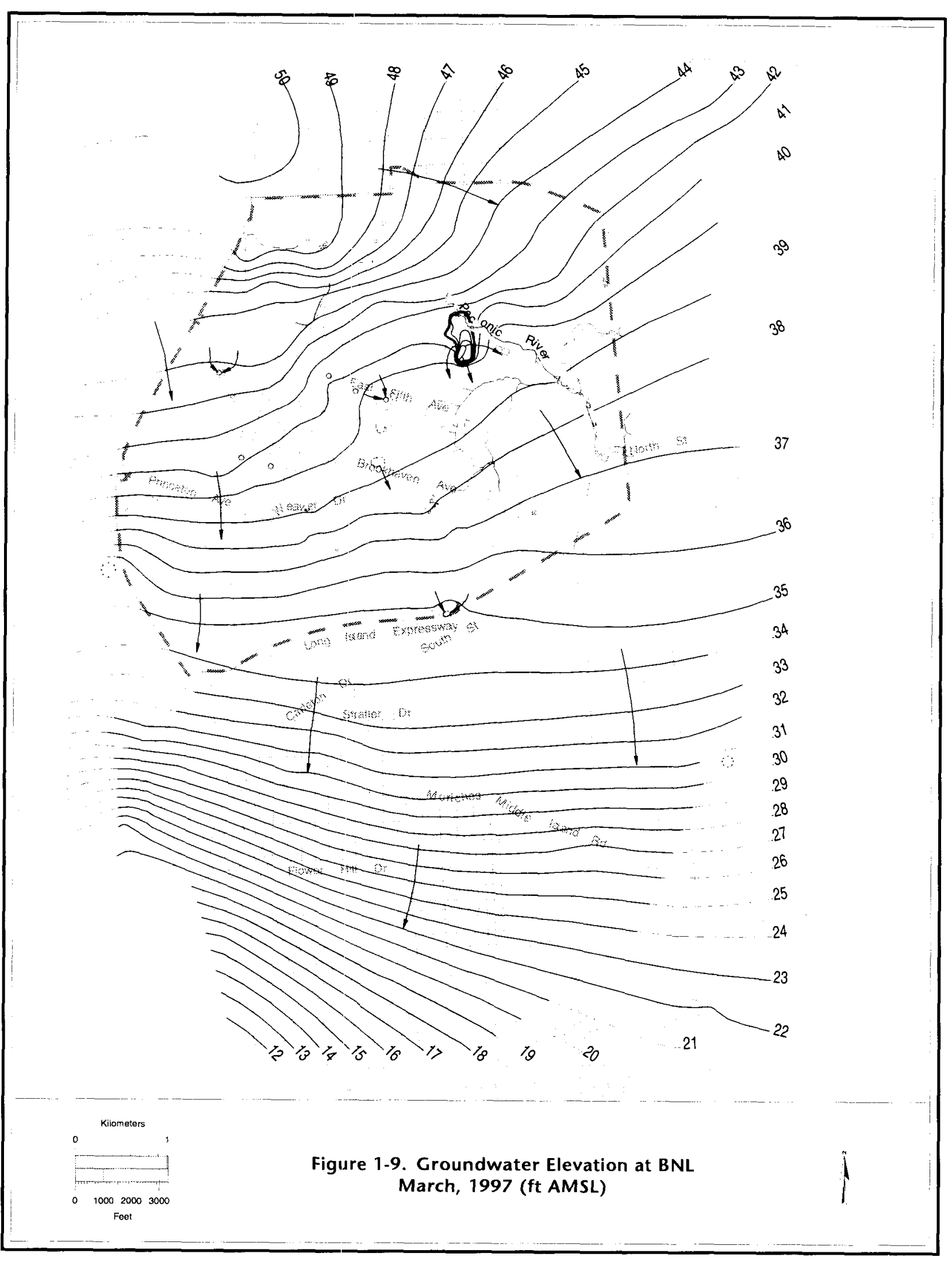




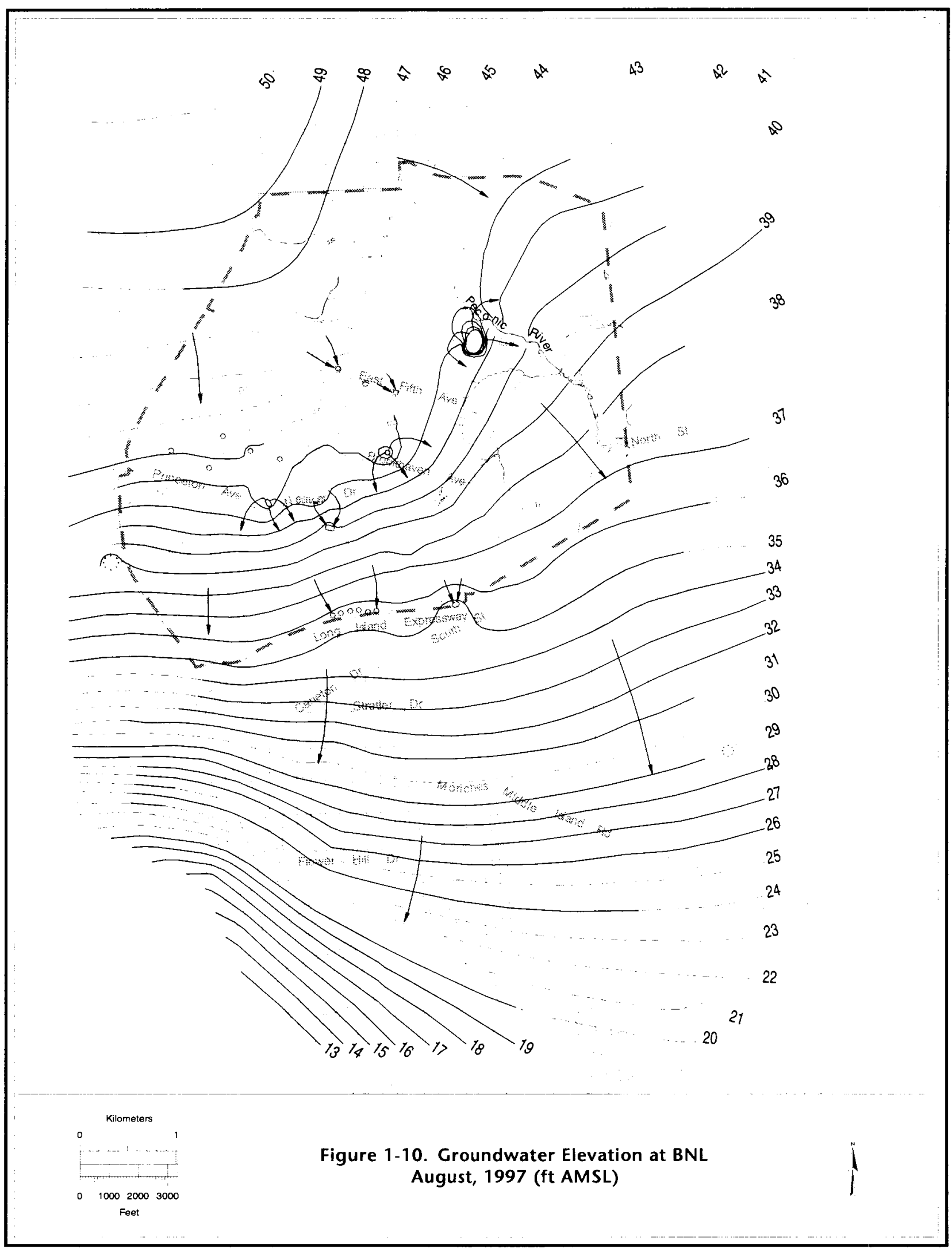


The following are the major scientific facilities operated at the Laboratory:

1. The National Synchrotron Light Source (NSLS) utilizes a linear accelerator and booster synchrotron as an injection system for two electron storage rings which provide intense ultraviolet (UV) and $\mathrm{x}$-ray photon sources. There are 83 beam lines for research in Materials Science, Biology, Chemistry, and industrial applications. There are over 2300 users.

2. The Brookhaven Medical Research Reactor (BMRR), an integral part of the Medical Research Center (MRC), is fueled with enriched uranium, moderated and cooled by light water, and is operated intermittently at power levels up to $3 \mathrm{MW}$ (thermal). The BMRR is used for Neutron Capture Cancer Therapy Research.

3. The Alternating Gradient Synchrotron (AGS) is used for research in Particle and Nuclear Physics. It accelerates protons to energies up to $30 \mathrm{GeV}$, and heavy-ion beams to 15 $\mathrm{GeV} / \mathrm{amu}$. It has over 900 uisers.

4. The $200 \mathrm{MeV}$ Linear Accelerator serves as a proton injector for the AGS and also supplies a continuous beam of protons for radionuclide production by spallation reactions in the Brookhaven Linac Isotope Producer (BLIP) facility.

5. The Tandem Van de Graaff Facility can inject heavy ions into the AGS. It contains a microchip radiation testing area and has 250 industrial users from 45 Institutions.

6. The High Flux Beam Reactor (HFBR) contains 16 instruments for research in Physics, Biology, Chemistry, and Applied Science. In the past, this facility operated at a routine power level from 40 to $60 \mathrm{MW}$ thermal. Since May 1991, it has operated at $30 \mathrm{MW}$. In 1997, it did not operate.

7. The AGS Booster is a circular accelerator of 200 meters in circumference that receives either a proton beam from the Linac, or heavy ions from the Tandem Van de Graaff. The Booster accelerates proton particles and heavy ions before injecting them into the AGS ring. This facility became operational in 1992.

8. The Radiation Therapy Facility, operated jointly by BNL's Medical Department and State University of New York at Stony Brook, is a high-energy dual x-ray mode linear accelerator for radiation therapy of cancer patients. This accelerator delivers therapeutically useful beams of $x$-rays and electrons for conventional and advanced radiotherapy techniques. Approximately, 250 patients are treated annually.

9. The Accelerator Test Facility is operated jointly by the National Synchrotron Light Source and the Center for Accelerator Physics. The ATF attracts users from BNL and other institutions for advanced work that has implications for both physics research and future medical uses of accelerators.

10. The Center for Imaging and Neurosciences is a joint effort of BNL's Chemistry and Medical Departments. It comprises three imaging facilities that provide a window into the workings of the brain. Two positron emission tomography cameras, a 4-Tesla magnetic resonance imaging machine and a single-photon-emission computed tomography camera are all used to explore addiction, aging, mental disorders and normal brain function.

11. The Scanning Transmission Electron Microscope (STEM), operated by BNL's Biology Department, allow scientists to see the intricate details of living things, from bacteria to human tissue.

Additional programs involving irradiations and radionuclides for scientific investigations are carried out at other Laboratory facilities including those at the MRC, the Biology Department, the Chemistry Department, and the Department of Advanced Technology (DAT). Special purpose 
radionuclides are developed and processed for general use under the joint auspices of the Department of Applied Science (DAS) and the Medical Department.

In addition to the scientific facilities, there are numerous major facilities, which provide support to the science and technology mission of the Laboratory. These facilities include:

1. The Sewage Treatment Plant (STP) (Bldg. 575 and ancillary structures) has a design capacity of 3.0 million gallons per day. The STP receives sanitary and process waste waters from all facilities and treats these wastes before to their discharge to the Peconic River. The STP employs a tertiary treatment sequence and includes primary clarification for removing settleable solids and floatable materials, aerobic oxidation for the removal of biological matter, sand filtration to remove suspended particulate, and UV disinfection for bacterial control. The STP effluent is permitted by the New York State Department of Environmental Conservation.

2. The Water Treatment Plant (WTP) (Bldg. 624) is a 5 million-gallon per day potable water treatment facility. The treatment is a lime-softening process for the removal of iron from potable water obtained from the three wells located along the western boundary of the developed site. The WTP also has dual air-stripping towers for controlling volatile organic compounds in the potable-water supply.

3. The Central Steam Facility (CSF) (Bldg. 610) provides high-pressure steam, which is used for both facility and process heating. The CSF has a design capacity of 480,000 pounds of steam per hour at 125 pounds per square inch. Steam is conveyed to the users through a series of underground piping. Condensate is collected and returned to the CSF for reuse.

4. The Major Petroleum Facility (MPF) provides the petroleum reserves for operating the CSF. In total, 2.3 million gallons of fuel oil, predominantly residual fuel (No. 6) are stored at this facility. The installation of a natural gas line has reduced the Laboratory's reliance on oil as the main source of fuel.

5. The Central Chilled Water Plant (Bldg. 600) provides chilled water for ventilation and process cooling. The plant has a refrigeration capacity of 4830 tons ( 58 million BTU) and reduces the necessity for local refrigeration plants, and once through cooling. A network of underground supply and return piping supplies chilled water.

6. In December 1997 a new state-of-the art Waste Management Facility was opened. This complex consists of four buildings in which wastes can be handled with the utmost consideration for the environment. These facilities were constructed with advanced environmental protection systems and features including, but not limited to permanent secondarily contained storage bays for the safe storage of drummed wastes, flammable liquid storage and handling rooms with overpressure relief venting, double walled underground storage tanks and enclosed shielded storage cells. These facilities will improve BNL's management of the chemical and radioactive wastes generated during scientific research and other support operations. 


\section{Chapter 2}

\section{COMPLIANCE SUMMARY}

It is the policy of BNL to operate and maintain the site in compliance with applicable federal, state, and local regulations and DOE Orders. This section briefly summarizes the compliance status for existing facilities and operations during CY 1997.

\subsection{Environmental Permits}

A variety of processes and facilities at BNL are subject to regulatory permits. They include one SPDES permit, a Major Petroleum Facility (MPF) license, two Resource Conservation Recovery Act (RCRA) permits (one for the existing Hazardous Waste Management Facility (HWMF); one for the new Waste Management Facility), a certificate from the NYSDEC registering tanks storing bulk quantities of hazardous substances, eight authorizations for the National Emission Standards for Hazardous Air Pollutants (NESHAPs), and 62 Certificates to Operate (CO) air emission sources from NYSDEC. Fifteen applications are pending with NYSDEC either for renewing or canceling existing COs, or obtaining COs for new air-emission sources. Table 2-1 gives information on the type and status of all environmental permits issued to the DOE through December 31, 1997.

In May 1996, NYSDEC renewed the permits for 25 sources. This action was taken to facilitate the Title V permit process. The remaining permitted sources are being evaluated by NYSDEC to determine whether they need to be included in the Laboratory's Title V permit either as exempt or trivial sources.

\subsection{Groundwater Compliance Monitoring}

Groundwater monitoring at the MPF and the Current Landfill is required by NYSDEC permit and Inter Agency Agreement (IAG)-approved monitoring plans, respectively. The results of the monitoring are provided in Chapter 8. The MPF currently operates under NYSDEC License No. 01-1700, and is monitored in accordance with the requirements listed in the License. Section 2.3.4 describes the results of CY 1997 compliance monitoring for the MPF.

Until December 1990, the Current Landfill was operated under NYSDEC Permit No. 52-S-20. Although the Current Landfill ceased operation in accordance with the Long Island Landfill Law, BNL continued to monitor the groundwater under the requirements specified in the permit until December 1995, when the extent of groundwater contamination in that area had been fully investigated and the landfill was capped. Since January 1996, groundwater has been monitored as part of a post-closure monitoring program specified in 6 NYCRR Part 360, Solid Waste Management Facilities (December 31, 1988). As required under the Current Landfill Operation and Maintenance Plan (CDM, 1996), BNL submitted the first annual Environmental Monitoring Report to the NYSDEC in 1997 (BNL, 1997). The second annual report (for CY 1997) will be submitted by July 1998. These groundwater data are summarized in Chapter 8, Groundwater Protection.

\subsection{Clean Water Act}

\subsubsection{SPDES Permit}

Sanitary waters, process-waste waters, and non-contact cooling waters discharged from BNL's operations are regulated by an SPDES permit issued by the NYSDEC. Specifically, effluents discharged to seven recharge basins, the Peconic River, and storm water emanating from the CSF are currently governed by the monitoring requirements and effluent limitations of the 
Table 2-1

BNL Site Environmental Report for Calendar Year 1997

BNL Environmental Permíts

\section{Bldg./Facility \\ Designation}

134

197

197

197

197

197

197

206

207

208

208

208

208

244

$42 \underline{2}$

422

423

423

444

458

462

462

473

479

490

490

490

490

510

510

526

526

5358

$535 \mathrm{~B}$

$535 \mathrm{~B}$

$535 \mathrm{~B}$

555

555

610

610

610

610

630

650

650

703

705
Process

Description

blueprint machine

degreaser tank

acid metal cleaning

welding shop

cleaning room hoods

cleaning room hoods

epoxy coating/curing exhaust

cyclone $\mathrm{G}-10$

belt sander

lead melting

vapor degreaser

sandblasting

sandblasting

cyclone collector

cyclone collector

cyclone collector

stage II vapor recovery

welding hood

incinerator

paint spray booth

machining, grinding exhaust

machining, grinding exhaust

vapor degreaser

cyclone G-10

Inhalation

Toxicology Facility

Inhalation

Toxicology Facility

lead alloy melting

milling machine/

block cutter

metal cutting exhaust

calorimeter enclosure

polymer mix booth

plating tank

etching machine

PC board process

welding hood

scrubber (1)

scrubber (2)

combustioñin unit

combustion unit - ALF

combustion unit

combustion unit

stage II vapor recovery

scrap lead recycling

shot blasting

machining exhaust

building ventilation
Permitting Agency

and Division

NYSDEC-Air Quality

NYSDEC-Air Quality

NYSDEC-Air Quality

NYSDEC-Air Quality

NYSDEC-Air Quality

NYSDEC-Air Quality

NYSDEC-Air Quality

NYSDEC-Air Quality

NYSDEC-Air Quality

NYSDEC-Air Quality

NYSDEC-Air Quality

NYSDEC-Air Quality

NYSDEC-Air Quality

NYSDEC-Air Quality

NYSDEC-Air Quality

NYSDEC-Air Quality

NYSDEC-Air Quality

NYSDEC-Air Quality

NYSDEC-Air Quality

NYSDEC-Air Quaiity

NYSDEC-Air Quality

NYSDEC-Air Quality

NYSDEC-Air Quality

NYSDEC-Air Quality

NYSDEC-NESHAPS

NYSDEC-Air Quality

NYSDEEC-Air Quality

NYSDEC-Air Quality

NYSDEC-Air Quality

U.S. EPA - NESHAPS

NYSDEC-Air Quality

NYSDEC-Air Quality NYSDEC-Air Quality NYSDEC-Air Quality NYSDEC-Air Quality NYSDEC-Air Quality NYSDEC-Air Quality NYSDEC-Air Qualitity NYSDEC-Air Quality NYSOEC-Air Quality NYSDEC-Air Quality NYSDEC-Air Quality NYSDEC-Air Quality NYSDEC-Air Quality NYSDEC-Air Quality U.S. EPA - NESHAPS
Permit Number

472200349113401

472200349119702

472200349119703

472200349119704

472200349119706

472200349119707

472200349119708

472200349120601

472200349120701

472200349120801

472200349120802

472200349120803

472200349120804

472200349124401

472200349142202

472200349142203

472200 D365 WG

472200349142305

472200349144401

472200349145801

472200349146201

472200349146202

472200349147301

472200349147905

472200349149001

472200349149002

$4 \overline{72200} 349149003$

472200349149004

472200349151002

BNL-689-01

472200349152601

472200349153501

472200349153502

472200349153503

472200349153504

472200349155501

472200349155502

$47220034916101 A$

472200349161005

472200349161006

472200349161007

472200 D366 WG

472200349165001

472200349165002

472200349170301

BNL-288-01

\section{Expiration \\ Date}

$11-29-97(5)$

02-01-98(5)

03-22-96(5)

04-01-00

01-07-98(5)

01-07-98(5)

06-08-98(6)

04-01-00

04-01-00

11-29-97(5)

$11-29-96(5)$

11-29-96(5)

11-29-96(5)

01-28-99(6)

11-29-96(3)

11-29-96(3)

09-27-95(1)

05-15-01

05-15-01(5)

04-23-97(6)

11-29-96(3)

11-29-96(3)

03-22-96(4)

04-01-00

05-15-01

05-15-01(2)

05-15-01

05-15-01

$09-30-9(6)$

None

04-01-00

04-01-00

04-01-00

05-15-01

09-30-98(6)

04-01-00

04-01-00

05-15-01

05-15-01

05-15-0

12-18-02

09-27-95(1)

11-29-96(5)

$11-29-96(5)$

05-15-01

None 


\begin{tabular}{|c|c|c|c|c|}
\hline $\begin{array}{l}\text { Bldg./Facility } \\
\text { Designation }\end{array}$ & $\begin{array}{l}\text { Process } \\
\text { Description }\end{array}$ & $\begin{array}{l}\text { Permitting Agency } \\
\text { and Division }\end{array}$ & Permit Number & $\begin{array}{l}\text { Expiration } \\
\text { Date }\end{array}$ \\
\hline 820 & accelerator test facility & U.S. EPA - NESHAPS & BNL-589-01 & None \\
\hline 865 & lead melting pot & NYSDEC Air Quality & 472200349186501 & status pending \\
\hline 901 & tin lead solder & NYSDEC-Air Quality & 472200349190101 & $04-01-00(5)$ \\
\hline 902 & spray booth exhaust & NYSDEC-Air Quality & 472200349190201 & $09-30-98(6)$ \\
\hline 902 & belt sander & NYSDEC-Air Quality & 472200349190202 & $05-15-01$ \\
\hline 902 & $\begin{array}{l}\text { sanding, cutting, } \\
\text { drilling }\end{array}$ & NYSDEC-Air Quality & 472200349190203 & $05-15-01$ \\
\hline 902 & $\begin{array}{l}\text { brazing/ } \\
\text { solder exhaust }\end{array}$ & NYSDEC-Air Quality & 472200349190204 & $05-15-01$ \\
\hline 902 & $\begin{array}{l}\text { painting/ } \\
\text { soldering exhaust }\end{array}$ & NYSDEC-Air Quality & 472200349190205 & $05-15-01$ \\
\hline 903 & blueprint machine & NYSDEC-Air Quality & 472200349190301 & $11-29-96(5)$ \\
\hline 903 & cyclone G-10 & NYSDEC-Air Quality & 472200349190302 & $04-01-00$ \\
\hline 903 & $\begin{array}{l}\text { brazing } \\
\text { process exhaust }\end{array}$ & NYSDEC-Air Quality & 472200349190303 & $09-30-98(6)$ \\
\hline 905 & vapor degreaser & NYSDEC-Air Quality & 472200349190501 & $03-22-96(5)$ \\
\hline 905 & belt sander & NYSDEC-Air Quality & 472200349190502 & $06-18-95(5)$ \\
\hline 905 & machining exhaust & NYSDEC-Air Quality & 472200349190503 & $05-15-01$ \\
\hline $919 A$ & solder exhaust & NYSDEC-Air Quality & 472200349191903 & $05-15-01$ \\
\hline 922 & cyclone exhaust & NYSDEC-Air Quality & 472200349192201 & $04-01-00$ \\
\hline 923 & electronic & & & \\
\hline 924 & $\begin{array}{l}\text { equip. cleaning } \\
\text { spray booth exhaust }\end{array}$ & $\begin{array}{l}\text { NYSDEC-Air Quality } \\
\text { NYSDEC-Air Quality }\end{array}$ & $\begin{array}{l}\text { submitted 3-93, } \\
472200349192401\end{array}$ & $\begin{array}{l}\text { status pending } \\
09-30-98(6)\end{array}$ \\
\hline 924 & magnet coil production press & NYSDEC-Air Quality & 472200349192402 & $05-15-01$ \\
\hline 924 & machining exhaust & NYSDEC-Air Quality & 472200349192403 & $05-03-98(6)$ \\
\hline 930 & electroplating/acid etching & NYSDEC-Air Quality & 472200349193001 & $05-15-01$ \\
\hline 930 & bead blaster & NYSDEC-Air Quality & 472200349193002 & $05-15-01$ \\
\hline 930 & $\begin{array}{l}\text { ultrasonic cleaner } \\
\text { spray aeration project }\end{array}$ & $\begin{array}{l}\text { NYSDEC-Air Quality } \\
\text { NYSDEC-Air Quality }\end{array}$ & $\begin{array}{l}472200349193003 \\
\text { submitted } 10-89\end{array}$ & $\begin{array}{l}02-01-97(5) \\
\text { status pending }\end{array}$ \\
\hline AGS Booster & accelerator & U.S. EPA - NESHAPS & BNL-188-01 & None \\
\hline $\mathrm{RHIC}$ & $\begin{array}{l}\text { accelerator } \\
\text { radiation therapy facility } \\
\text { radiation effects/neutral beam }\end{array}$ & $\begin{array}{l}\text { U.S. EPA - NESHAPS } \\
\text { U.S. EPA - NESHAPS } \\
\text { U.S. EPA - NESHAPS }\end{array}$ & $\begin{array}{l}\text { BNL-389-01 } \\
\text { BNL-489-01 } \\
\text { BNL-789-01 }\end{array}$ & $\begin{array}{l}\text { None } \\
\text { None } \\
\text { None }\end{array}$ \\
\hline $\operatorname{CSF}(\mathrm{a})$ & major petroleum facility & NYSDEC-Water Quality & $1-1700$ & $03-31-02$ \\
\hline $\begin{array}{l}\operatorname{STP}(b) \& \\
\operatorname{RCB}(c)\end{array}$ & $\begin{array}{l}\text { sewage plant \& } \\
\text { recharge basins }\end{array}$ & NYSDEC-Water Quality & NY-0005835 & $03-01-00$ \\
\hline HWMF(d) & waste management & $\begin{array}{l}\text { NYSDEC-Hazardous } \\
\text { Waste }\end{array}$ & $\begin{array}{l}\text { NYS ID No. } \\
1-4722-00032 / 00021-0\end{array}$ & $08-31-98$ \\
\hline WMF (e) & waste management & $\begin{array}{l}\text { NYSDEC-Hazardous } \\
\text { Waste }\end{array}$ & $1-4722-00032 / 00102-0$ & $07-12-05$ \\
\hline BNL Site & chem tanks-HSBSRC & NYSDEC & $1-000263$ & $07-27-99$ \\
\hline $\begin{array}{l}\text { (a) Central St } \\
\text { (b) Sewage Tr } \\
\text { (c) Recharge }\end{array}$ & $\begin{array}{l}\text { m Facility } \\
\text { atment Plant } \\
\text { asins }\end{array}$ & $\begin{array}{l}\text { ous Waste Management } \\
\text { aste Management Facilit } \\
\text { Hazardous Substance Bu }\end{array}$ & $\begin{array}{l}\text { Sility } \\
\text { Storage Registration Certi }\end{array}$ & \\
\hline $\begin{array}{l}\text { *Note: Rene } \\
\text { provi }\end{array}$ & $\begin{array}{l}\text { application submitted more th } \\
\mathrm{s} \text { of the NYS Uniform Proced }\end{array}$ & $\begin{array}{l}\text { days prior to expiratio } \\
\text { t. }\end{array}$ & process can continue & rate under \\
\hline Renew & submitted $9-6-95$, NYSDEC ind & s source subject to regis & tion only. & \\
\hline Proces & not in service. & & & \\
\hline $\begin{array}{l}\text { Source } \\
\text { not ne }\end{array}$ & $\begin{array}{l}\text { Nith past due expiration dates ar } \\
\text { to be renewed pursuant to Part }\end{array}$ & $\begin{array}{l}\text { ing evaluated by NYSDEC } \\
\text { provisions. }\end{array}$ & possible exempt and triv & sources which would \\
\hline $\begin{array}{l}\text { Source } \\
\text { methyl }\end{array}$ & $\begin{array}{l}\text { urrently out of service. If return } \\
\text { e chloride to clean vacuum con }\end{array}$ & $\begin{array}{l}\text { o service, an aqueous cle } \\
\text { lents. }\end{array}$ & ing solution will be used ir & lace of Freon 113 and \\
\hline $\begin{array}{l}\text { Source } \\
\text { these }\end{array}$ & $\begin{array}{l}\text { hich have been removed or per } \\
\text { urces removed from the Air Fac }\end{array}$ & $\begin{array}{l}\text { Sently decommissioned. A } \\
\text { System database. }\end{array}$ & quest will be submitted to & NYSDEC to have \\
\hline $\begin{array}{l}\text { Permit } \\
\text { Permit }\end{array}$ & $\begin{array}{l}\text { vas renewed indefinitely on June } \\
\text { and Registrations became effec }\end{array}$ & 1996, when revisions to $t$ & 6 NYCRR Part 201 - & \\
\hline
\end{tabular}


SPDES permit. Deviations from the permit's limitations or monitoring requirements which occurred during 1997 are described subsequently in this chapter. Figure 2-1 shows the location of each outfall.

Several modifications were made to the Laboratory's SPDES permit in 1997, including implementation of the December 1996 permit changes and a formal permit change received in September. The December 1996 modifications involved adopting a Schedule of Compliance for improving the efficiency of Biochemical Oxygen Demand $\left(\mathrm{BOD}_{5}\right)$ and Total Suspended Solids (TSS) removal of the STP process, and the deferment of the $85 \%$ removal requirement. The Schedule of Compliance included implementing a reduction of non-contact cooling water which resulted in a $10-15 \%$ overall decrease in its contributions to the sewage-treatment plant. The schedule also included completing upgrades to the sewage-treatment plant and achieving final operational level by April 1998. While implementing both the reduction in non-contact cooling water and completion of the construction upgrades, the 85\% BOD and TSS removal requirement was deferred. Compliance with the $85 \%$ removal will be reinstated in April 1998 upon achieving operational status of the STP modified process. The September modifications to the SPDES permit included adding mercury as a routine monitoring parameter for the STP discharge (Outfall 001) and undertaking a short-term high-intensity monitoring program for cadmium and polychlorinated biphenyls (PCBs). BNL met all scheduled milestones in both permit modifications which included completing of projects addressing non-contact cooling water reductions by December 31, 1997, and performing short-term high intensity monitoring by January 1998.

During negotiation of the SPDES permit, the NYSDEC deferred all radiological monitoring requirement to DOE Order 5400.5. Consequently, radiological parameters have not been reported as part of routine monitoring reports submitted to the NYSDEC. To document compliance with the DOE Order, daily, monthly or quarteriy samples are collected from the various outfalls and analyzed for radiological parameters. These data are reported in Chapter 6.

\subsubsection{Recharge Basins, SPDES Outfalls 002, 003, 004, 005, 006A, 006B, 007, 008, and 010}

The Laboratory maintains seven recharge basins for the discharge of process-cooling waters, stormwater runoff, and, in the case of recharge basin HX (Outfall 007), water-filter backwash from the WTP. Cooling water is discharged to basins HN (Outfall 002), HO (Outfall 003), HP (Outfall 004), HS (Outfall 005), and HT (Outfalls 006A and 006B); storm water is discharged to basins HN, HO, HS, HT, HW (Outfall 0008) and the CSF (Outfall 010). The SPDES permit requires that BNL monitor these discharges monthly for flow, $\mathrm{pH}$, and oil and grease, and quarterly for the numerous analytical parameters listed in Table 2-2. In addition, storm water discharged to Outfall 008 must be analyzed monthly for volatile organic compounds. There are no monitoring requirements for Outfall 009, which consists of numerous discharges to ground surfaces (e.g., air-compressor condensate, steam condensate, and miscellaneous residential cesspools).

Discharges of water to recharge basins are considered Class GA groundwater discharges and are regulated by the NYSDEC, as stipulated in 6 NYCRR Part 703.6; the discharge to the Peconic River is regulated in accordance with Class $C$ ambient water quality criteria. Effluent limitations are dictated by the receiving water quality standard; consequently, in some cases, discharges to the Peconic River are more stringent than discharges to groundwater.

Table 2-2 summarizes the analytical results for outfalls 002-010 for 1997. There were three excursions from the SPDES permit at the recharge basins. In December 1997, a pH excursion to 9.3 was reported for Outfall 010 (SPDES limit $=8.5$ ). Potential contributors included the application of hydro-seed mulch to the immediate area surrounding the stormwater catch basins, and construction of new storm water basins. Both hydro-seed mulch and fresh concrete contain excess lime, which raises the $\mathrm{pH}$ of water runoff. Reevaluation of the $\mathrm{pH}$ on January 7, 1998 showed it had resumed typical levels. All other pH values for this discharge 


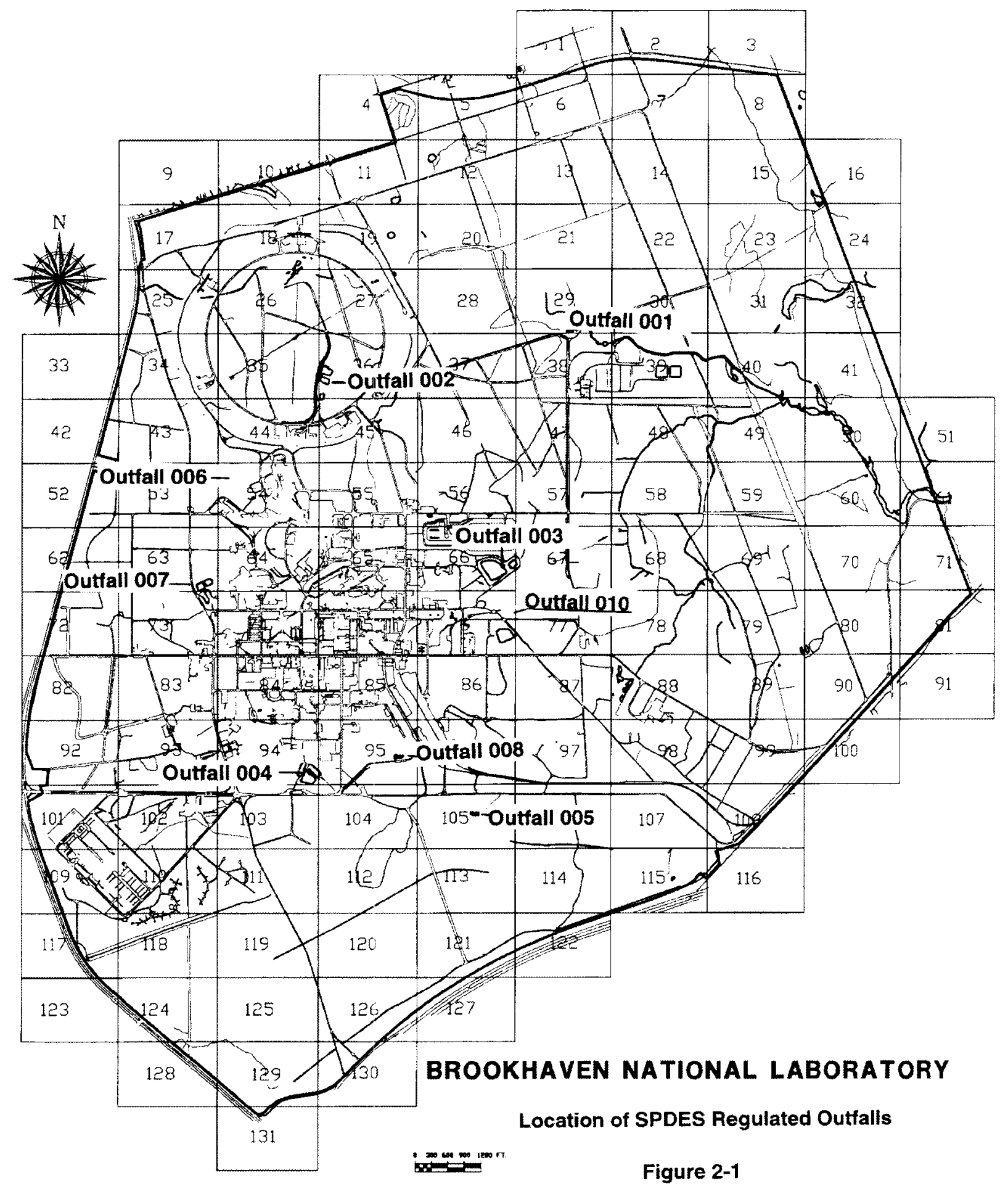


Table 2-2

BNL Site Environmental Report for Calendar Year 1997

Summary of Analytical Results for Waste Water Discharges to Outfalls 002 - 010

\begin{tabular}{|c|c|c|c|c|c|c|c|c|c|c|c|c|}
\hline Analyte & & $\begin{array}{l}\text { Outfall } \\
002\end{array}$ & $\begin{array}{l}\text { Outfall } \\
003\end{array}$ & $\begin{array}{l}\text { Outfall } \\
004\end{array}$ & $\begin{array}{l}\text { Outfall } \\
005\end{array}$ & $\begin{array}{l}\text { Outfall } \\
006 A\end{array}$ & $\begin{array}{l}\text { Outfall } \\
\text { 006B }\end{array}$ & $\begin{array}{l}\text { Outfall } \\
007\end{array}$ & $\begin{array}{l}\text { Outfall } \\
008\end{array}$ & $\begin{array}{l}\text { Outfall } \\
010\end{array}$ & $\begin{array}{l}\text { SPDES } \\
\text { Limit }\end{array}$ & $\begin{array}{l}\text { No. of } \\
\text { exceedances }\end{array}$ \\
\hline $\begin{array}{l}\text { Flow } \\
\text { MGD }\end{array}$ & $\begin{array}{l}\text { N } \\
\text { Min. } \\
\text { Max. }\end{array}$ & $\begin{array}{l}C R \\
0.05 \\
0.74\end{array}$ & $\begin{array}{l}C R \\
0.35 \\
2.5\end{array}$ & $\begin{array}{l}\text { CR } \\
0.006 \\
0.18\end{array}$ & $\begin{array}{l}\text { CR } \\
0.042 \\
0.18\end{array}$ & $\begin{array}{l}C R \\
0.03 \\
0.19\end{array}$ & $\begin{array}{l}\text { CR } \\
0.006 \\
0.26\end{array}$ & $\begin{array}{l}\mathrm{CR} \\
\mathrm{NF} \\
\mathrm{NF}\end{array}$ & $\begin{array}{l}11 \\
0.00018 \\
1.439\end{array}$ & $\begin{array}{l}11 \\
0.0005 \\
0.242\end{array}$ & & \\
\hline $\begin{array}{l}\mathrm{pH} \\
\mathrm{SU}\end{array}$ & $\begin{array}{l}\text { Min. } \\
\text { Max. }\end{array}$ & $\begin{array}{l}6.2 \\
7.6\end{array}$ & $\begin{array}{l}5.7 \\
8.3\end{array}$ & $\begin{array}{l}5.65 \\
6.3\end{array}$ & $\begin{array}{l}6.3 \\
7.7\end{array}$ & $\begin{array}{l}6.7 \\
8.3\end{array}$ & $\begin{array}{l}6.8 \\
8.2\end{array}$ & $\begin{array}{l}\text { NF } \\
\text { NF }\end{array}$ & $\begin{array}{l}6.03 \\
7.9\end{array}$ & $\begin{array}{l}5.94 \\
9.3\end{array}$ & 8.5 & 1 \\
\hline $\begin{array}{l}\text { Oil and Grea } \\
\mathrm{mg} / \mathrm{L}\end{array}$ & $\begin{array}{l}\text { N } \\
\text { Min. } \\
\text { Max. } \\
\text { Avg. }\end{array}$ & $\begin{array}{l}12 \\
\text { ND } \\
6.2 \\
\text { ND }\end{array}$ & $\begin{array}{l}12 \\
\text { ND } \\
7.6 \\
\text { ND }\end{array}$ & $\begin{array}{l}\text { NR } \\
\text { NR } \\
\text { NR } \\
\text { NR }\end{array}$ & $\begin{array}{l}11 \\
\text { ND } \\
6.3 \\
\text { ND }\end{array}$ & $\begin{array}{l}12 \\
\text { ND } \\
5 \\
\text { ND }\end{array}$ & $\begin{array}{l}12 \\
\text { ND } \\
\text { ND } \\
\text { ND }\end{array}$ & $\begin{array}{l}\text { NR } \\
\text { NR } \\
\text { NR } \\
\text { NR }\end{array}$ & $\begin{array}{l}12 \\
\text { ND } \\
5.3 \\
\text { ND }\end{array}$ & $\begin{array}{l}12 \\
\text { ND } \\
\text { ND } \\
\text { ND }\end{array}$ & 15 & 0 \\
\hline $\begin{array}{l}\text { Copper } \\
\mathrm{mg} / \mathrm{L}\end{array}$ & $\begin{array}{l}\text { N } \\
\text { Min. } \\
\text { Max. } \\
\text { Avg. }\end{array}$ & $\begin{array}{l}\text { NR } \\
\text { NR } \\
\text { NR } \\
\text { NR }\end{array}$ & $\begin{array}{l}\text { NR } \\
\text { NR } \\
\text { NR } \\
\text { NR }\end{array}$ & $\begin{array}{l}\text { NR } \\
\text { NR } \\
\text { NR } \\
\text { NR }\end{array}$ & $\begin{array}{l}4 \\
0.012 \\
0.025 \\
0.019\end{array}$ & $\begin{array}{l}\text { NR } \\
\text { NR } \\
\text { NR } \\
\text { NR }\end{array}$ & $\begin{array}{l}\text { NR } \\
\text { NR } \\
\text { NR } \\
\text { NR }\end{array}$ & $\begin{array}{l}\text { NR } \\
\text { NR } \\
\text { NR } \\
\text { NR }\end{array}$ & $\begin{array}{l}\text { NR } \\
\text { NR } \\
\text { NR } \\
\text { NR }\end{array}$ & $\begin{array}{l}\text { NR } \\
\text { NR } \\
\text { NR } \\
\text { NR }\end{array}$ & 1 & 0 \\
\hline $\begin{array}{l}\text { Zinc } \\
\mathrm{mg} / \mathrm{L}\end{array}$ & $\begin{array}{l}\mathrm{N} \\
\text { Min. } \\
\text { Max } \\
\text { Avg. }\end{array}$ & $\begin{array}{l}\text { NR } \\
\text { NR } \\
\text { NR } \\
\text { NR }\end{array}$ & $\begin{array}{l}4 \\
0.002 \\
0.027 \\
0.016\end{array}$ & $\begin{array}{l}\text { NR } \\
\text { NR } \\
\text { NR } \\
\text { NR }\end{array}$ & $\begin{array}{l}\text { NR } \\
\text { NR } \\
\text { NR } \\
\text { NR }\end{array}$ & $\begin{array}{l}\text { NR } \\
\text { NR } \\
\text { NR } \\
\text { NR }\end{array}$ & $\begin{array}{l}\text { NR } \\
\text { NR } \\
\text { NR } \\
\text { NR }\end{array}$ & $\begin{array}{l}\text { NR } \\
\text { NR } \\
\text { NR } \\
\text { NR }\end{array}$ & $\begin{array}{l}\text { NR } \\
\text { NR } \\
\text { NR } \\
\text { NR }\end{array}$ & $\begin{array}{l}\text { NR } \\
\text { NR } \\
\text { NR } \\
\text { NR }\end{array}$ & 5 & 0 \\
\hline $\begin{array}{l}\text { Iron (total) } \\
\mathrm{mg} / \mathrm{L}\end{array}$ & $\begin{array}{l}\mathrm{N} \\
\text { Min. } \\
\text { Max. } \\
\text { Avg. }\end{array}$ & $\begin{array}{l}\text { NR } \\
\text { NR } \\
\text { NR } \\
\text { NR }\end{array}$ & $\begin{array}{l}\text { NR } \\
\text { NR } \\
\text { NR } \\
\text { NR }\end{array}$ & $\begin{array}{l}\text { NR } \\
\text { NR } \\
\text { NR } \\
\text { NR }\end{array}$ & $\begin{array}{l}\text { NR } \\
\text { NR } \\
\text { NR } \\
\text { NR }\end{array}$ & $\begin{array}{l}\text { NR } \\
\text { NR } \\
\text { NR } \\
\text { NR }\end{array}$ & $\begin{array}{l}\text { NR } \\
\text { NR } \\
\text { NR } \\
\text { NR }\end{array}$ & $\begin{array}{l}0 \\
N F \\
N F \\
N F\end{array}$ & $\begin{array}{l}\text { NR } \\
\text { NR } \\
\text { NR } \\
\text { NR }\end{array}$ & $\begin{array}{l}\text { NR } \\
\text { NR } \\
\text { NR } \\
\text { NR }\end{array}$ & NA & 0 \\
\hline Iron (dissol & $\begin{array}{l}\text { d) } \\
\mathrm{N} \\
\mathrm{mg} / \mathrm{L} \\
\text { Max. } \\
\text { Avg. }\end{array}$ & $\begin{array}{l}\text { NR } \\
\text { Min. } \\
\text { NR } \\
\text { NR }\end{array}$ & $\begin{array}{l}\text { NR } \\
\text { NR } \\
\text { NR } \\
\text { NR }\end{array}$ & $\begin{array}{l}\text { NR } \\
\text { NR } \\
\text { NR } \\
\text { NR }\end{array}$ & $\begin{array}{l}\text { NR } \\
\text { NR } \\
\text { NR } \\
\text { NR }\end{array}$ & $\begin{array}{l}\text { NR } \\
\text { NR } \\
\text { NR } \\
\text { NR }\end{array}$ & $\begin{array}{l}\text { NR } \\
\text { NR } \\
\text { NR } \\
\text { NR }\end{array}$ & $\begin{array}{l}0 \\
\text { NR } \\
\text { NF } \\
\text { NF }\end{array}$ & $\begin{array}{l}\text { NR } \\
\text { NF } \\
\text { NR } \\
\text { NR }\end{array}$ & $\begin{array}{l}\text { NR } \\
\text { NR } \\
\text { NR } \\
\text { NR }\end{array}$ & $\begin{array}{l}\text { NR } \\
\text { NA }\end{array}$ & 0 \\
\hline $\begin{array}{l}\text { Chloroform } \\
u g / L\end{array}$ & $\begin{array}{l}\mathrm{N} \\
\text { Min. } \\
\text { Max. } \\
\text { Avg. }\end{array}$ & $\begin{array}{l}4 \\
\text { ND } \\
2 \\
\text { ND }\end{array}$ & $\begin{array}{l}\text { NR } \\
\text { NR } \\
\text { NR } \\
\text { NR }\end{array}$ & $\begin{array}{l}\text { NR } \\
\text { NR } \\
\text { NR } \\
\text { NR }\end{array}$ & $\begin{array}{l}\text { NR } \\
\text { NR } \\
\text { NR } \\
\text { NR }\end{array}$ & $\begin{array}{l}\text { NR } \\
\text { NR } \\
\text { NR } \\
\text { NR }\end{array}$ & $\begin{array}{l}\text { NR } \\
\text { NR } \\
\text { NR } \\
\text { NR }\end{array}$ & $\begin{array}{l}\text { NR } \\
\text { NR } \\
\text { NR } \\
\text { NR }\end{array}$ & $\begin{array}{l}\text { NR } \\
\text { NR } \\
\text { NR } \\
\text { NR }\end{array}$ & $\begin{array}{l}\text { NR } \\
\text { NR } \\
\text { NR } \\
\text { NR }\end{array}$ & 7 & 0 \\
\hline $\begin{array}{l}\text { Bromodichlc } \\
\mathrm{ug} / \mathrm{L}\end{array}$ & $\begin{array}{l}\text { ometh } \\
\text { Min. } \\
\text { Max. } \\
\text { Avg }\end{array}$ & $\begin{array}{l}\text { ne } \\
4 \\
\text { ND } \\
\text { ND } \\
\text { ND }\end{array}$ & $\begin{array}{l}\text { NR } \\
\text { NR } \\
\text { NR } \\
\text { NR }\end{array}$ & $\begin{array}{l}\text { NR } \\
\text { NR } \\
\text { NR } \\
\text { NR }\end{array}$ & $\begin{array}{l}\text { NR } \\
\text { NR } \\
\text { NR } \\
\text { NR }\end{array}$ & $\begin{array}{l}\text { NR } \\
\text { NR } \\
\text { NR } \\
\text { NR }\end{array}$ & $\begin{array}{l}\text { NR } \\
\text { NR } \\
\text { NR } \\
\text { NR }\end{array}$ & $\begin{array}{l}\text { NR } \\
\text { NR } \\
\text { NR } \\
\text { NR }\end{array}$ & $\begin{array}{l}\text { NR } \\
\text { NR } \\
\text { NR } \\
\text { NR }\end{array}$ & $\begin{array}{l}\text { NR } \\
\text { NR } \\
\text { NR } \\
\text { NR }\end{array}$ & 5 & 0 \\
\hline $\begin{array}{l}\text { 1,1,1-trichlo } \\
\mathrm{ug} / \mathrm{L}\end{array}$ & $\begin{array}{l}\text { Nethan } \\
\text { Min. } \\
\text { Max. } \\
\text { Avg. }\end{array}$ & $\begin{array}{l}4 \\
\text { ND } \\
\text { ND } \\
\text { ND }\end{array}$ & $\begin{array}{l}4 \\
\text { ND } \\
\text { ND } \\
\text { ND }\end{array}$ & $\begin{array}{l}4 \\
\text { ND } \\
\text { ND } \\
\text { ND }\end{array}$ & $\begin{array}{l}\text { NR } \\
\text { NR } \\
\text { NR } \\
\text { NR }\end{array}$ & $\begin{array}{l}\text { NR } \\
\text { NR } \\
\text { NR } \\
\text { NR }\end{array}$ & $\begin{array}{l}\text { NR } \\
\text { NR } \\
\text { NR } \\
\text { NR }\end{array}$ & $\begin{array}{l}\text { NR } \\
\text { NR } \\
\text { NR } \\
\text { NR }\end{array}$ & $\begin{array}{l}12 \\
\text { ND } \\
\text { ND } \\
\text { ND }\end{array}$ & $\begin{array}{l}\text { NR } \\
\text { NR } \\
\text { NR } \\
\text { NR }\end{array}$ & 5 & 0 \\
\hline $\begin{array}{l}\text { 1,1-dicloroe } \\
\mathrm{ug} / \mathrm{L}\end{array}$ & $\begin{array}{l}\text { N } \\
\text { Min. } \\
\text { Max. } \\
\text { Avg. }\end{array}$ & $\begin{array}{l}\text { NR } \\
\text { NR } \\
\text { NR } \\
\text { NR }\end{array}$ & $\begin{array}{l}\text { NR } \\
\text { NR } \\
\text { NR } \\
\text { NR }\end{array}$ & $\begin{array}{l}4 \\
\text { NR } \\
\text { NR } \\
\text { NR }\end{array}$ & $\begin{array}{l}\text { NR } \\
\text { NR } \\
\text { NR } \\
\text { NR }\end{array}$ & $\begin{array}{l}\text { NR } \\
\text { NR } \\
\text { NR } \\
\text { NR }\end{array}$ & $\begin{array}{l}\text { NR } \\
\text { NR } \\
\text { NR } \\
\text { NR }\end{array}$ & $\begin{array}{l}\text { NR } \\
\text { NR } \\
\text { NR } \\
\text { NR }\end{array}$ & $\begin{array}{l}12 \\
\text { ND } \\
\text { ND } \\
\text { ND }\end{array}$ & $\begin{array}{l}\text { NR } \\
\text { NR } \\
\text { NR } \\
\text { NR }\end{array}$ & 5 & 0 \\
\hline
\end{tabular}


Table 2-2 (cont'd.)

\begin{tabular}{|c|c|c|c|c|c|c|c|c|c|c|c|c|}
\hline Analyte & 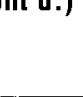 & $\begin{array}{l}\text { Outfall } \\
002\end{array}$ & $\begin{array}{l}\text { Outfall } \\
003\end{array}$ & $\begin{array}{l}\text { Outfall } \\
004\end{array}$ & $\begin{array}{l}\text { Outfall } \\
005\end{array}$ & $\begin{array}{l}\text { Outfall } \\
\text { 006A }\end{array}$ & $\begin{array}{l}\text { Outfall } \\
\text { O06B }\end{array}$ & $\begin{array}{l}\text { Outfall } \\
\text { 007 }\end{array}$ & $\begin{array}{l}\text { Outfall } \\
\text { 008 }\end{array}$ & $\begin{array}{l}\text { Outfall } \\
010\end{array}$ & $\begin{array}{l}\text { SPDES } \\
\text { Limit }\end{array}$ & $\begin{array}{l}\text { No. of } \\
\text { exceedances }\end{array}$ \\
\hline \multicolumn{13}{|c|}{ Dibromo-nitrilo-propionimide } \\
\hline $\mathrm{mg} / \mathrm{L}$ & $\mathrm{N}$ & NR & 4 & NR & $N R$ & $\mathrm{NR}$ & NR & NR & $\mathrm{NR}$ & $N R$ & \multirow{4}{*}{0.1} & \multirow{4}{*}{0} \\
\hline & Min. & NR & ND & NR & NR & NR & NR & NR & NR & $\mathrm{NR}$ & & \\
\hline & Max. & NR & ND & NR & NR & NR & NR & NR & $\mathrm{NR}$ & NR & & \\
\hline & Avg. & NR & ND & NR & NR & NR & NR & NR & NR & NR & & \\
\hline \multicolumn{13}{|c|}{ Hydroxyethylidene-diphosphonic Acid } \\
\hline $\mathrm{mg} / \mathrm{L}$ & $N$ & 4 & 4 & NR & 4 & 4 & 4 & NR & NR & $N R$ & \multirow{4}{*}{0.5} & \multirow{4}{*}{1} \\
\hline & Min. & 0.09 & 0.02 & NR & 0.02 & 0.02 & 0.04 & $\mathrm{NR}$ & $\mathrm{NR}$ & $\mathrm{NR}$ & & \\
\hline & Max. & 0.34 & 0.42 & NR & 0.5 & 2.15 & 0.4 & NR & NR & $\mathrm{NR}$ & & \\
\hline & Avg. & 0.19 & 0.15 & NR & 0.25 & 0.69 & 0.16 & NR & NR & NR & & \\
\hline \multirow{4}{*}{$\begin{array}{l}\text { Tolyltriazole } \\
\mathrm{mg} / \mathrm{L}\end{array}$} & $\mathrm{N}$ & 4 & 4 & $\mathrm{NR}$ & 4 & 4 & 4 & NR & $\mathrm{NR}$ & $\mathrm{NR}$ & \multirow{4}{*}{0.2} & \multirow{4}{*}{1} \\
\hline & Min. & ND & ND & NR & ND & ND & ND & NR & NR & NR & & \\
\hline & Max. & ND & ND & NR & 0.1 & 0.55 & ND & NR & NR & NR & & \\
\hline & Avg. & ND & ND & NR & 0.074 & ND & ND & NR & NR & NR & & \\
\hline
\end{tabular}

Notes:

CR: Continuous Recorder

NR: Analysis Is Not Required

ND: Anayte Was Not Detected

NF: No flow recorded to Outfall 007 for the duration of 1997.

were well within effluent limitations. There were two other excursions, both at Outfall 006A on January 10,1997 . This recharge basin receives cooling tower blowdown from cooling systems located at Building 930. These systems are chemically treated to prevent corrosion of heat exchange surfaces and buildup of algae. Several of the treatment reagents are regulated under the monitoring requirements of the SPDES permit. Samples of the effluent collected on January 10, exhibited concentrations of hydroxyethylidene diphosphonic acid (2.15 $\mathrm{mg} / \mathrm{l})$ and tolyltriazole $(0.55 \mathrm{mg} / \mathrm{ll})$ exceeding the SPDES effluent limits of $0.5 \mathrm{and} 0.2 \mathrm{mg} / \mathrm{L}$ respectively. The former is used to prevent deposition of mineral scale, and the latter is used to prevent galvanic action between copper and steel. The cause was attributed to the over addition of Drewgard 187 to the cooling system. Reducing this to the lowest dose necessary to effectively treat the cooling tower reduced the elevated concentration of these chemicals. To curtail future excursions, an alternate cooling-tower treatment was proposed in December 1997. This treatment replaces both hydroxyethylidene diphosphonic acid and tolyltriazole with an inorganic phosphate and an acrylic polymer. Final approval of these materials is pending. All remaining parameters were within the limitations of the SPDES permit during CY 1997.

Outfall 007, which receives water-filter backwash from the WTP remained out of service during 1997 to permit continued major improvements to the WTP process. These improvements included building dual air-stripping towers for VOC abatement, and installing a new clear well and wet well. Former analog control systems were replaced with a computerized control system. The SCDHS inspected the WTP modifications several times during 1997 and approved the restart of this facility. The Laboratory is now refurbishing two of the three wells that supply water to the WTP. Consequently, it will not commence operations until these are completed, expected in the first quarter of 1998. 


\subsubsection{STP Effluent, SPDES Outfall 001}

In accordance with the BNL SPDES permit, twenty-seven (27) parameters are reported in the monthly Discharge Monitoring Report (DMR) which is submitted to both the NYSDEC and SCDHS. In accordance with BNL's SOPs and QA protocols, BNL personnel collected the samples. Seventeen parameters including nitrogen, metals, organic, $\mathrm{BOD}_{5}$, total suspended solids, fecal coliform, and cyanide are analyzed by NYSDOH-certified contractor laboratories. The remaining parameters (i.e., flow, settleable solids, residual chlorine, and $\mathrm{pH}$ ) are recorded and analyzed by the STP operators. Table 2-3 summarizes the 1997 DMR analytical data for Outfall 001. They show that the SPDES permit discharge limit were exceeded six times at the STP effluent discharge point during 1997; once for ammonia nitrogen, four times for iron and once for silver.

On January 9,1997 , an ammonia concentration of $2.4 \mathrm{mg} / \mathrm{L}$ was recorded, which exceeded the permit level of $2.0 \mathrm{mg} / \mathrm{L}$. This increase was attributed to decreased maintenance of the STP's sandfilters and to the cold weather. Lower temperatures and increased water retention on the sandfilters reduces the biological oxidation of ammonia, which increases the ammonia concentration and lowers the nitrate concentration in the effluent. Although the Laboratory tries to

\section{Table 2-3}

BNL Site Environmental Report for Calendar Year 1997

Summary of Analytical Results for Waste Water Discharges to Outtall 001

\begin{tabular}{|c|c|c|c|c|c|c|}
\hline Analyte & Min. & Max. & Avg. & $\begin{array}{l}\text { Monitoring } \\
\text { Frequency }\end{array}$ & $\begin{array}{l}\text { SPDES } \\
\text { Limit }\end{array}$ & $\begin{array}{l}\text { No. of } \\
\text { Exceedarices }\end{array}$ \\
\hline \multicolumn{5}{|c|}{ Max. Temperature Degrees Farenheit } & & \\
\hline $\begin{array}{l}\mathrm{pH} \\
\mathrm{SU}\end{array}$ & 6 & 6.8 & NA & Cont. Recorder & $\begin{array}{l}\operatorname{Min}: \therefore 5.8 \\
\operatorname{Max}: \therefore 9.0\end{array}$ & $\begin{array}{l}0 \\
0\end{array}$ \\
\hline $\begin{array}{l}\text { Avg. } 5 \text { day } B O D \\
\mathrm{mg} / \mathrm{L}\end{array}$ & $<4$ & 3.5 & 2.6 & Monthly & Avg.: 10 & 0 \\
\hline $\begin{array}{l}\text { Max. } 5 \text { day BOD } \\
\text { mg/L }\end{array}$ & $<4$ & 5 & 3 & Monthly & Max: 20 & 0 \\
\hline$\%$ BOD Removal & 83 & 97 & 90 & Monthly & 85 & 0 \\
\hline $\begin{array}{l}\text { Avg. Total Susper } \\
\mathrm{mg} / \mathrm{L}\end{array}$ & $\begin{array}{l}\mathrm{ds} \text { (TSS) } \\
<4\end{array}$ & 5.1 & 4.3 & Monthly & Avg.:10 & 0 \\
\hline $\begin{array}{l}\text { Max. Total Suspe } \\
\mathrm{mg} / \mathrm{L}\end{array}$ & $\begin{array}{l}\text { ids (TSS) } \\
<4\end{array}$ & 10.2 & 5.8 & Monthly & $\operatorname{Max}: 20$ & 0 \\
\hline$\%$ TSS Removal & 86 & $>97$ & 92 & Monthly & 85 & 0 \\
\hline $\begin{array}{l}\text { Settleable Solids } \\
\mathrm{mg} / \mathrm{L}\end{array}$ & 0 & 0 & 0 & Daily & 0.1 & 0 \\
\hline $\begin{array}{l}\text { Ammonia Nitroge } \\
\mathrm{mg} / \mathrm{L}\end{array}$ & 0.03 & 2.4 & 0.95 & Monthly & 2 & 1 \\
\hline $\begin{array}{l}\text { Tutal Nitrogenen } \\
2.5\end{array}$ & 11.8 & 6.35 & Monthly & NA & NAmg/L & \\
\hline $\begin{array}{l}\text { Cyanide } \\
\text { ug/L }\end{array}$ & $<10$ & $<10$ & $<10$ & Twice Monthly & 100 & 0 \\
\hline $\begin{array}{l}\text { Copper } \\
\mathrm{mg} / \mathrm{L}\end{array}$ & 0.0397 & 0.088 & 0.06 & Monthly & 0.15 & 0 \\
\hline $\begin{array}{l}\text { Iron } \\
\mathrm{mg} / \mathrm{L}\end{array}$ & 0.104 & 1.57 & 0.382 & Monthly & 0.37 & 4 \\
\hline $\begin{array}{l}\text { Lead } \\
\mathrm{mg} / \mathrm{L}\end{array}$ & 0.001 & 0.004 & 0.002 & Monthly & 0.015 & 0 \\
\hline
\end{tabular}




\begin{tabular}{|c|c|c|c|c|c|c|}
\hline Analyte & Min. & Max. & Avg. & $\begin{array}{l}\text { Monitoring } \\
\text { Frequency }\end{array}$ & $\begin{array}{l}\text { SPDES } \\
\text { Limit }\end{array}$ & $\begin{array}{l}\text { No. of } \\
\text { Exceedances }\end{array}$ \\
\hline $\begin{array}{l}\text { Nickel } \\
\mathrm{mg} / \mathrm{L}\end{array}$ & 0.002 & 0.0079 & 0.004 & Monthly & 0.11 & 0 \\
\hline $\begin{array}{l}\text { Silver } \\
\mathrm{mg} / \mathrm{L}\end{array}$ & 0.003 & 0.018 & 0.007 & Monthly & 0.015 & 1 \\
\hline $\begin{array}{l}\text { Zinc } \\
\mathrm{mg} / \mathrm{L}\end{array}$ & 0.02 & 0.052 & 0.035 & Monthly & 0.1 & 0 \\
\hline $\begin{array}{l}\text { Toluene } \\
\mathrm{ug} / \mathrm{L}\end{array}$ & $<5$ & 2 & 1.04 & Twice Monthly & 50 & 0 \\
\hline $\begin{array}{l}\text { Methylene Chloride } \\
\text { ug/L }\end{array}$ & $<5$ & 9 & 1.5 & Twice Monthly & 50 & 0 \\
\hline $\begin{array}{l}\text { 1,1,1-Trichloroethane } \\
\mathrm{ug} / \mathrm{L}\end{array}$ & $<5$ & 1 & 1 & Twice Monthly & 50 & 0 \\
\hline $\begin{array}{l}\text { 2-Butanone } \\
\mathrm{ug} / \mathrm{L}\end{array}$ & $<5$ & 2 & 1.04 & Twice Monthly & 50 & 0 \\
\hline $\begin{array}{l}\text { Max. Flow } \\
\text { MGD }\end{array}$ & 0.68 & 0.962 & 0.79 & $\begin{array}{l}\text { Cont. } \\
\text { Recorder }\end{array}$ & Max. 2.3 & 0 \\
\hline $\begin{array}{l}\text { Avg. Flow } \\
\text { MGD }\end{array}$ & 0.542 & 0.722 & 0.619 & $\begin{array}{l}\text { Cont. } \\
\text { Recorder }\end{array}$ & NA & 0 \\
\hline $\begin{array}{l}\text { Residual Chlorine (1) } \\
\mathrm{mg} / \mathrm{L}\end{array}$ & 0 & 0.04 & 0.03 & Daily & 0.1 & 0 \\
\hline $\begin{array}{l}\text { Avg. Fecal Coliform } \\
\text { MPN/100 ml }\end{array}$ & $<2$ & 26 & 26 & Monthly & 200 & 0 \\
\hline $\begin{array}{l}\text { Max Fecal Coliform } \\
\text { MPN } / 100 \mathrm{ml}\end{array}$ & $<2$ & 50 & 21 & Monthly & 400 & 0 \\
\hline
\end{tabular}

enhance the biological activity of the sandfilters by routinely rotating and aerating the soils by discing, the frequency of discing is reduced during cold-weather months because the soils are frozen. After rotating the filters, an analysis of the effluent samples collected on January 13 showed the concentration to be in compliance.

There were exceedances of iron and silver in 1997. The excursions of iron occurred in June, July, August and October. Such exceedances have occurred intermittently since beginning the construction of improvements to the sewage-treatment plant. During the summer and early fall of 1997, improvements of the sewage-treatment plant included installing new manholes and interconnecting piping, building the new pump station, and installing the new ultraviolet (UV) disinfection system. These activities interrupted the normal flow of sewage through the plant, and most likely contributed to increased iron concentrations in STP effluent. Modifications to the primary clarifier effluent-chamber to accommodate the new pump station required pumping wastewater from the clarifier to the filter -bed dosing chambers. This effectively reduced the settling characteristics of the primary clarifier and reduced the efficiency of solids separation. Removing the chlorine-contact chamber from service also removed a final settling stage and altered the hydraulic profile of the STP by eliminating the final resistance to flow. Reduced primary clarification, loss of final settling, and alteration to the plant hydraulics are all contributing causes to increased iron concentrations and corresponding increases in suspended solids. To evaluate the effects of the slight increase in suspended solids due to reduced separation, iron concentration was plotted against suspended solids; there is a clear correlation between these factors (Figure 2-2). Upon completing the STP improvements, the iron concentration in the effluent fell to below SPDES limits. 


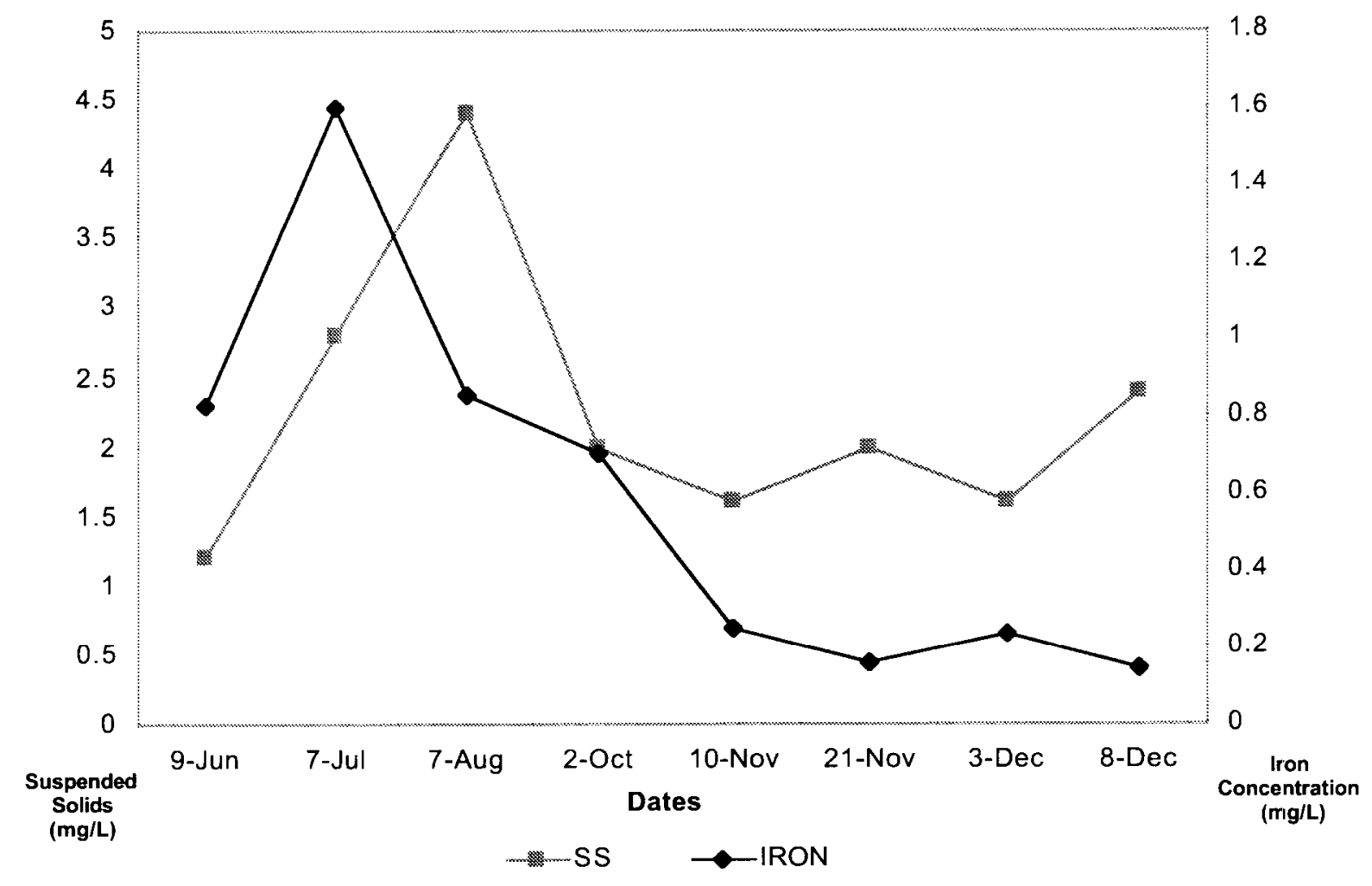

Figure 2-2. Effluent Concentration of Iron and Suspended Solids Discharge from BNL STP 1997

On September 5, 1997, the concentration of silver $(0.018 \mathrm{mg} / \mathrm{L})$ in the STP discharge exceeded the permit limit of $0.015 \mathrm{mg} / \mathrm{L}$; this was also attributed to upgrading the STP and increased concentrations of suspended solids in the discharge. Samples collected on September 8, 1997 showed that silver was within permitted levels.

In addition to monitoring the point-source discharges, the Laboratory also is required to monitor and report effluent concentrations for process-wastes discharged to the STP. This program includes quarterly monitoring of photo-developing waste waters generated at Buildings 197 and 118 , and rinse-waters from plating and metal-cleaning operations at Buildings 535 and 197, respectively. These discharges are monitored for pollutants specific to these operations. The pollutants include metallic elements, semi-volatile and volatile organic compounds, phenols, and cyanides. Flow and $\mathrm{pH}$ also are monitored. In addition, discharges of boiler blowdown from satellite boilers, and discharges from Building 902's cooling-tower are analyzed quarterly for flow and $\mathrm{pH}$.

The analytical data for 1997 show these discharges were insignificant contributors to the STP collection system. As part of a pollution-prevention initiative, the former Acid Cleaning Facility (ACF) in Building 197 was replaced by the Centralized Cleaning Facility, located in Building 498. The new facility, which became fully operational in mid 1997, replaces the harsh cleaning chemistry formerly used at the ACF (hydrofluoric-nitric and phosphoric-acid, and sodium hydroxide) with the environmentally conscientious alternatives, mild-borate and polyphosphate -inorganic compounds and citric acid. While chemical analysis of the concentrated wash baths show the waste cannot be discharged into the sewer due to elevated metals concentrations, the wastes are nonhazardous and can be cost-effectively managed on-site. The new process was evaluated by Brookhaven personnel working in conjunction with Dow Chemical, Advanced Cleaning Systems Division. This effort earned a DOE Pollution Prevention Award in 1996. 
The biomonitoring program specified in the SPDES permit is a Chronic Tier II Test using fathead minnows (Pimephales promelas) and water fleas (Ceriodaphnia dubia) as the test organisms. Chronic toxicity is assessed by exposing the organisms to varying concentrations (i.e., 100\%, 50\%, $25 \%, 12.5 \%$ and $6.25 \%$ ) of the STP effluent for seven days and monitoring their survival, growth, and rate of reproduction. The data are compared to a control group. The SPDES permit requires several rounds of toxicity testing, with all data reviewed by the NYSDEC. Toxicity testing completed in 1996 showed the STP discharge exceeded the Maximum Allowable Waste Concentration calculated for this round of tests. Due to significant upgrades to the STP, the NYSDEC deferred further testing until all upgrades were completed in September. Then, a new round of toxicity testing commenced with the first samples collected in December 1997. The results showed a "No Observable Adverse Effective Concentration" of 50\%. Testing will be continued for three additional quarters in 1998. Some concern was raised about starting these tests so close to the start-up of the new treatment process since there was not the necessary biomass needed to sustain the process. This caveat will be considered during a review of the analytical results. In an effort to identify the contributors to the exhibited toxicity, the Laboratory continued to conduct full-scale chemical analysis of aliquot samples during toxicity testing. These tests proved inconclusive; the analytical results were almost identical for samples which elicit a toxic response and those which do not. Copies of the analytical results for all toxicity tests were provided to the NYSDEC and the SCDHS.

\subsubsection{SPDES Inspections and Audits}

Until January 1993, the SCDHS made quarterly inspections of the STP. Due to reduced funding for monitoring and inspecting local sewage-treatment plants, inspections were not conducted by the SCDHS in CY 1997. Their quarterly inspections of the STP are expected to resume in 1998, based upon preliminary notification.

In May 1997 the EPA conducted a "Multimedia Audit" of the Laboratory's environmental compliance programs. The SPDES program was evaluated as part of it. During the inspection comments were made about the permitting of a stormwater discharge emanating from the former Waste Management facility. The Laboratory had previously reviewed this issue with both the NYSDEC and EPA and concluded that a permit was not required. However, upon EPA's recommendation, a permit was filed and is pending with the NYSDEC. There were no other issues identified during EPA's review.

\subsubsection{National Pollution Discharges Elimination System (NPDES) Analytical Quality Assurance}

The Laboratory participates in the NPDES Laboratory Performance Evaluation Program administered by the EPA. In May 1997, notification for participation in the USEPA DMR Quality Assurance Program, Study 17 was transmitted to the USEPA designee. Proficiency-check samples were forwarded by the EPA designee to the laboratories listed below for subsequent analysis. The respective analytical parameters determined by each Laboratory are listed below:

Name and Address

H2M Labs Inc. Melville, NY

BNL STP Operations Laboratory

Upton, NY

Cosper Environmental Inc.

Bohemia, NY

\section{Analytical Parameters}

Copper, Lead, Iron, Nickel, Zinc, Mercury, BOD ${ }_{5}$ Total Suspended Solids, Ammonia-N, Nitrate-N Total Kjeldahl Nitrogen, Cyanides, Oil and Grease Phenolics. $\mathrm{pH}$, Total Residual Chlorine

Tier II Chronic Toxicity 
The analytical data from the proficiency-check samples were sent to the EPA-designated facility by the individual laboratories in October 1997. All the results were acceptable. However, for 1996 Study 16, a single unacceptable result for BOD was reported. According to the contractor laboratory responsible for the analysis (NYTEST Environmental) an error was made in diluting the sample, resulting in under reporting the amount present.

\subsubsection{Major Petroleum Facility (MPF)}

The BNL CSF supplies steam for heating and cooling to all major areas of the Laboratory through an underground distribution system. The MPF, the storage area for the fuels used at the CSF, operates under license (No. 01-1700) issued by the NYSDEC. The current license was issued by NYSDEC on April 7, 1997, and expires on March 31, 2002.

The NYSDEC is required by Article 12 of the Navigation Law to protect and preserve the lands and waters of NYS from all discharges of petroleum, and specifically, from major petroleum storage facilities. To fulfill this responsibility, all major petroleum storage facilities are required to be registered with the NYSDEC and must have a license to operate. The license is contingent on several conditions including groundwater monitoring, periodic submittal of engineering evaluations and reports for secondary containment systems, and updates to Facility Response Plans and Spill Prevention Control and Counter Measures (SPCC) Plans.

All major petroleum storage facilities are required to install groundwater monitoring wells. The license has general conditions which include monthly testing of monitoring wells for floating products and semiannual testing for dissolved products. Typically, the facility owner can test for floating products, however, testing for dissolved products must be performed by an NYSDOHcertified laboratory.

Five groundwater wells, one upgradient and four downgradient, are used for monitoring regulatory compliance of the MPF. The well authorized for use by the NYSDEC as upgradient of the MPF is designated Well 76-25, and is located immediately upgradient (within $50 \mathrm{feet}$ ) of the former above-grade storage tanks $611 \mathrm{~A}$ and $611 \mathrm{~B}$. The four downgradient wells are designated 76-16, 76-17, 76-18, and 76-19. Figure 8-8 shows their locations. The 4-inch diameter well-casings are constructed of polyvinyl chloride (PVC); they have 20-feet long PVC screens which straddle the water table.

In accordance with conditions of the MPF license, samples were collected for regulatory compliance from these wells twice during 1997 and submitted to a NYSDOH-certified laboratory. The NYSDEC required that these analyses included polynuclear aromatics and base-neutral extractable compounds listed in EPA Method 625. The analytical results were transmitted to the NYS$\mathrm{DEC}$ in accordance with the MPF permit requirements. These wells were also monitored monthly for floating products; none were found during CY 1997.

In addition to the compliance samples, these wells also were monitored twice during $\mathrm{CY} 1997$ as part of BNL's routine EM program; the analytical results are discussed in Chapter 8.

The MPF license also requires that a Spill Prevention Control and Counter-Measures (SPCC) Plan is maintained and updated at least triennially. A copy of the updated Plan was filed with the NYSDEC on December 27, 1996. Its format and content were reviewed by the USEPA during a May 1997 multimedia audit. The deficiencies included failure to follow EPA's format, and an inadequate discussion of potential environmental release pathways. The SPCC Plan was again updated and reformatted to comply with EPA's directive, and submitted to the EPA and the NYSDEC in December 1997.

A facility-improvement project was implemented in 1995 to bring all tanks and fuel-handling facilities associated with the MPF into compliance with county-and state-regulations for petroleum storage facilities. This project included coating the internal tank bottoms with epoxy on 
four tanks, installing double bottoms on two tanks, upgrading above-and underground-piping systems, and building a fuel off-loading facility. Copies of plans and specifications were sent to the SCDHS and the NYSDEC for review and comments. As stipulated in the 1996 MPF License, construction of the fuel off-loading facility was finished by December 31, 1996. Demolition of MPF Tanks 611A and 611B was completed in January 1997. Soil samples collected from the base area of these tanks showed only trace concentrations of semi-volatile organic compounds. Their presence most probably was due to rust inhibitors originally applied to the base of the tanks. The secondary containment berms for these tanks were regraded, and the tank areas filled to restore the natural ground elevation.

\subsubsection{Spill Prevention, Control, and Countermeasures Plan and Facility Response Plans}

Brookhaven National Laboratory has had a SPCC Plan since the early 1980s with a complete list of all oil storage tanks, their capacity and building numbers. In the mid 1980s, direction from NYSDEC removed all but those storage tanks associated with the MPF and the Motor Pool Fuel Storage area (Building 326) in the S.PCC listing. This Plan was revised in 1982, 1983, 1985, 1987, 1990, 1993, 1996, and 1997. All revisions were submitted to the NYSDEC and EPA.

As a direct result of the disaster of the Exxon Valdez, the American Trader, and other accidents, Congress enacted the Oil Pollution. Act of 1990 (OPA-90). This Act significantly modified many provisions of the Clean Water Act (CWA). One requirement is that facility owners and operators must prepare plans outlining their response capability to a "Worst Case Discharge (WCD)" which is defined as the ". . . largest foreseeable discharge in adverse weather conditions." These terms were described in the legislative history to mean " . . . a case that is worse than either the largest spill to date or the maximum probable spill for the facility type." The way in which a facility expects to respond to the WCD must be outlined in a Facility Response Plan (FRP), together with information about the oil-recovery capabilities of the facility and any associated Oil Spill Response Organizations contracted by that facility.

BNL's FRP was originally prepared in 1993, and in accordance with comments and guidance received by EPA, revised and resubmitted in 1994 and 1995. The EPA allotted a five-year review period for commenting on the revised FRPs. No further guidance on the content of the FRP nor comment to the FRP was received from the EPA during 1997.

\subsubsection{Oil and Chemical Spills}

BNL's policy is to provide prompt and accurate notification of unexpected environmental releases of oil or chemicals as required by Federal, State, and local regulations. Anyone discovering a release must immediatcly report it using BNL's emergency telephone number. This number is monitored continuously by BNL's Police Group and the ES\&HS Fire Rescue Group. The latter group is the Laboratory's first responder. They assess the situation, and take measures for control and containment, while other specialists such as industrial hygienists and environmental compliance personnel, provide additional support.

During 1997, there were 68 incidents involving a minor release of oil or chemicals. Table 2-4 summarizes these incidents, giving the date each occurred, the material involved the amount released, and a brief explanation of the corrective actions taken. Twenty-six of these incidents required EPA, NYSDEC, and SCDHS notifications. These spills were cleaned up, and the contaminated absorbent and affected soil were sent off-site for approved disposal. All reportable instances were for release of petroleum products to soil. The remainder involved very small quantities of material which were typically contained on asphalt, concrete, or other impervious surfaces. Cleanup procedures were undertaken and there were no environmental impacts from these occurrences. Off-site regulatory agencies are notified based upon the type, quantity, and location of material spilled. Release of petroleum products that are known to be less than five gallons, contained or under the control of the responsible party, have not and will not reach soils and groundwater, 
and are cleaned up within two hours of discovery are not reportable to the NYSDEC. All releases to soils and surface water are reported, irrespective of the volume of release.

Releases of hazardous substance in quantities equal to, or greater than, their reportable quantity must be reported to the National Response Center under the requirements of Comprehensive Environmental Response, Compensation \& Liability Act (CERCLA). Such releases also must be reported to the NYSDEC, as mandated in the NY Navigation Law and Chemical release reports (6 NYCRR parts 595), and to the SCDHS, as specified in the Suffolk County Sanitary Code (SCSC). During 1997 there were no releases of hazardous substances which exceeded CERCLA reportable quantities.

\subsection{Clean Air Act}

\subsubsection{Conventional Air Pollutants}

During 1997, a variety of BNL emission sources were evaluated with respect to NYS and Federal permitting requirements. The applicable regulations for these sources are Title 6 Chapter III Parts 200 to 257 of the Codes, Rules and Regulations of the State of New York, and the Federal Clean Air Act (CAA). The sources reviewed and their current statuses are summarized below.

\section{No. of Status/Comments}

Actions

1 In February 1997, an equivalency application was submitted to the NYSDEC Bureau of Eastern Remedial Action in Albany for an air stripper designed to remove volatile organic compounds from contaminated groundwater in Operable Unit III. BNL received confirmation that the application was approved in June 1997.

1 In March 1997, following the receipt of acceptable stack test results for particulate emissions, an application for a certificate to operate Boiler 7 was submitted to the NYSDEC. Copies of the emissions-test report for particulates completed in December 1996 and revised calculations accompanied the application, which supported the laboratory's position that the requirements for preventing significant deterioration were not applicable. The NYSDEC subsequently issued a permit in December 1997 to operate the boiler.

1 In July 1997, an equivalency application was submitted to the NYSDEC Bureau of Eastern Remedial Action in Albany for the air-sparge and soil vapor-extraction system that removes volatile organic compounds from contaminated soil in Operable Unit IV. The application was approved in October 1997.

1 In July 1997, the laboratory informed the USEPA and the NYSDEC that an extension of a LILCO natural-gas main into the CSF was completed, and that Boilers 5, 6 and 7 were being equipped with dual-firing capabilities that would burn either natural gas or oil. Since the changes made to the boilers to accommodate the combustion of natural gas did not increase emissions regulated under 40 CFR Subpart Db and 6 NYCRR Part 227 2 , modifications to the permits issued for each boiler were not required.

1 In November 1997, a permit to construct and a certificate to operate application was submitted to the NYSDEC regional office for a lead- melting pot to process old lead shielding in Building 865 of the new Waste Management Facility.

1 The laboratory submitted its Title V Phase I application to the NYSDEC in December 1997. The application summarized the regulatory requirements applicable to BNL's emission sources, described laboratory operations and activities which are subject to federal and state regulatory requirements, and summarized the pollutants released by BNL's sources. The application also included a compliance plan that addressed three noncompliance situations that were identified during its preparation and a statement certifying that BNL will continue to comply with all other applicable requirements. 
Table 2-4

BNL Site Environmental Report for Calendar Year 1997

Summary of Chemical and OII Spill Reporting Record

\begin{abstract}
Number Date Material
97-01 1/8/97 crankcase oil/engine coolant
\end{abstract}

(18/5/ crankase olleng

97-02 1/21/97 Deionizing effluent

10-15 gals. No

\section{Quantity Rpt * Source/Cause; Corrective Actions}

$\sim 1$ gal No Spillage occurred due to damage to a contractor's pick-up truck after he drove over a fence post. All spillage was contained to the roadway. Absorbent material was used to clear the spill.

\begin{tabular}{|c|c|c|c|c|}
\hline $97-03$ & $2 / 4 / 97$ & Gasoline & $<2$ pint & No \\
\hline $97-04$ & $2 / 7 / 97$ & No. 6/No. 2 Fuel Oil and Water & $\sim 50$ gals. & \\
\hline $97-05$ & $2 / 18 / 97$ & Hydraulic fluid & $1-2$ pints & No \\
\hline $97-06$ & $2 / 20 / 97$ & Motor Oil & $\sim 1$ quart & No \\
\hline
\end{tabular}

Waste water from ion exchange column resins leaked from an outside storage tank onto the concrete. The effluent froze, which prevented migration to the storm drains. Containers were placed under the leak to catch further leakage. The effluent was transferred into another tank.

The Fire/Rescue vehicle developed a gas leak. All spillage was to the asphalt. Speedy dry was applied to the spill and all contaminated absorbent remove promptly. The vehicle was taken to the service station for repair.

During the demolition of BNL Tanks $611 \mathrm{~A}$ and $611 \mathrm{~B}$, Number 2 fuel oil was used to clean residual oil from the bottom of the tanks. The contaminated material (i.e., soils, piping etc.) was stored in lined and covered 20-yard dumpsters. During transport of these dumpsters, one of the rear hatches became loose resulting in spillage to the ground. All spillage was recovered using spill absorbents and heavy equipment.

Contaminated materials were transferred to covered dumpsters for off-site disposal.

Absorbent material was used to control a leaking valve on a trailer. The contractor fixed the leaking vaive and removed the absorbent material on the trailer for off-site disposal.

A leaking one-gallon container that was used to recover motor oil during oil changes was placed in a pail and speedy-dry was used to absorb the oil. The absorbent material and oil were recovered for offsite disposal.

97-07 2/26/97 Lubricating Oil <2 gals. Yes While an attempt was being made to blowdown compressor filter oil into a holding tank a fine mist of helium and lubricating oil sprayed vertically into the air. Absorbent pads were used to clean the thin layer of oil that had coated several compressor tanks. The absorbent pads and contaminated soil were removed for disposal.

\begin{tabular}{|c|c|c|c|c|c|}
\hline $97-08$ & $2 / 27 / 97$ & Ethylene Glycol & 2 gals & No & $\begin{array}{l}\text { A ruptured radiator on a portable generator released its contents } \\
\text { onto the asphalt. There was no contact with the soil. Absorbent } \\
\text { material was used to clean up and was disposed properly. }\end{array}$ \\
\hline $97-09$ & $3 / 10 / 97$ & Vacuum pump oil & $<1$ quart & Yes & $\begin{array}{l}\text { Oil from a vacuum pump spilled on the gravel drive/walk way. } \\
\text { The contaminated gravel and materials that were used to clean } \\
\text { up were carted away for off-site disposal. }\end{array}$ \\
\hline $97-10$ & $3 / 11 / 97$ & Battery Acid & 1 cup & No & $\begin{array}{l}\text { A new battery was cracked and its contents leaked onto the ce- } \\
\text { ment loading dock. Powdered neutralizing agent was applied. } \\
\text { The contaminated material and battery were disposed of through } \\
\text { the hazardous waste collection system. }\end{array}$ \\
\hline $97-11$ & $3 / 14 / 97$ & Diesel Fuel & $<35$ gals. & Yes & $\begin{array}{l}\text { The fitting between the hose and pump in a portable fuel tanker } \\
\text { came loose and caused a spill of oil along a stretch of heavy } \\
\text { roadway. The rain complicated cleanup. Absorbent booms and } \\
\text { pads were used as the main controls for the entire clean up pro- } \\
\text { cess. The road was sanded to minimize the driving hazard of oil } \\
\text { slick. The contaminated soil and sand were removed and prop- } \\
\text { erly disposed. }\end{array}$ \\
\hline $97-12$ & $3 / 15 / 97$ & Oil containing PCBs & $20-30$ gals. & Yes & $\begin{array}{l}\text { Dri-zorb and absorbent pads were used to control the release of } \\
\text { oil from a klystron that tipped over. The affected areas were } \\
\text { cleaned with a degreasing agent. Chemical analysis showed the } \\
\text { oil to contain PCBs @231ppm. The spill was cleaned in accor- } \\
\text { dance with EPA requirements. }\end{array}$ \\
\hline
\end{tabular}

1997 BNL Site Environmental Report 2 - 15 
Table 2-4 (cont'd.)

\begin{tabular}{lllll} 
Number & Date & Material & Quantity & Rpt* $^{*}$ \\
\hline $97-13$ & $3 / 17 / 97$ & Motor oil & 5 quarts & No \\
$97-14$ & $3 / 19 / 97$ & Dielectric fluid containing PCBs & $<1$ pint & Yes
\end{tabular}

$\begin{array}{lllll}97-15 & 4 / 3 / 97 & \text { Transmission Fluid } & <2 \text { liters } & \text { No } \\ 97-16 & 4 / 4 / 97 & \text { Ethylene Glycol } & \sim 1 \text { pint } & \text { No } \\ 97-17 & 4 / 7 / 97 & \text { Motor Oil } & \sim 2 \text { gal. } & \text { No } \\ 97-18 & 4 / 7 / 97 & \text { Alkaline Cleaner } & & \\ & & & & \\ & & & & \\ 9 & & & \end{array}$

97-19 4/21/97 Pine Sap

Unknown Yes

97-20 4/23/97 Dielectric Fluid

$<8$ gals. Yes

97-21A 4/23/97 Hydraulic Oil

$<1$ quart Yes

$97-21$

4/29/97 Contact cement

$<0.5$ gal. No

\begin{tabular}{|c|c|c|c|}
\hline $97-22$ & $5 / 5 / 97$ & Transmission fluid & $\sim 1$ quart \\
\hline $7-23$ & $5 / 8 / 97$ & Transformer Oil & $<1$ guart \\
\hline
\end{tabular}

$\begin{array}{lrlll}97-24 & 5 / 9 / 97 & \text { Hydraulic Oil } & & \\ 97-25 & 5 / 14-97 & \text { Vacuum Pump Oil } & \text { Yes } \\ 97-26 & 5 / 15 / 97 & \text { Transformer 0il } & <2 \text { pint } & \text { No } \\ & & & <1 \text { gal. } & \text { Yes } \\ 97-27 & 5 / 15 / 97 & \text { Transformer 0il } & <1 \text { gal. } & \text { Yes } \\ & & & & \\ 97-28 & 5 / 16 / 97 & \text { Compressor Oil } & <1 \text { pint } & \text { No }\end{array}$

\section{Source/Cause; Corrective Actions}

A lab vehicie leaked motor oil. Absorbent material was applied and the spilled product was collected for disposal.

A capacitor in a klystron modulator unit ruptured releasing dielectric fluid. The spill was contained in the steel cabinet in which the capacitor was mounted. Material was sampled and cleaned up using PCB clean-up procedures. All cleaning materials were drummed for disposal as PCB-contaminated waste.

Transmission fluid leaked from a private vehicle onto the pavement. Speedy-dry was used to absorb the spilled product. The absorbent material was recovered for off-site disposal.

A spill of glycol was discovered on the asphalt outside building 490 loading dock. Spill absorbent material was applied and recovered for proper disposal.

Engine oil leaked from a fuel truck. Speedy dry and absorbent pads were used to absorb the spilled product. The absorbent material was recovered for off-site disposal.

A spigot on a 55-gallon drum that contained Clean $J-1$ alkalin cleaner failed and caused a spill. The spilled material pooled into the bermed containment area. Neutracit neutralizing agent was added to the spill to neutralize it. The neutralized material was recovered and placed in drums for off-site disposal.

The leachate that collected in a depression near some tree stumps had distinct oil like sheen. Because the oily substance had the appearance of a petroleum product, the discovery was reported to off-site agencies. However, it was deduced that the oily leachate was pinesap and not of a petroleum product. NYSDEC Spills Unit later confirmed this conclusion.

Non-PCB dielectric fluid leaked from a transformer onto a concrete pad. Absorbent pads were used to clean oil stained surfaces of the concrete pad. Oil stained ballast material and soil around the perimeter of the transformer was removed and drummed tor disposal.

A hydraulic line on a front-end loader developed a pin hole leak. A bucket was placed under the leaking line. The contaminated soil was recovered and transferred to a 55 -galion drum for disposal. The leaking hose was replaced.

A can of contact cement fell from the rear of a transport vehicle and some of the contents were spilled to the road surface. Absorbent material was then applied and material was placed back in the can, which was then disposed.

Mechanical failure caused truck transmission fluid to be lost to soil. Absorbent pads were applied and the affected soil areas were shoveled out for proper disposal.

Non-PCB oil was discovered seeping from a transformer unit. Spill absorbent was applied to intercept additional leakage. Inspection of the rock ballast showed minimal oil contamination. Contaminated absorbent and rock ballast was collected for proper disposal.

Plastic sheeting was used to contain a leak from a backhoe. The vehicle was repaired and all contaminated soils and plastic were recovered for off-site disposal.

A small quantity of vacuum pump oil spilled while draining the pump prior to disposal. The spill was contained on asphalt and was mitigated using sand and other spill absorbents.

Oil contaminated soil was discovered in the Building 912B transformer yard. Impact to soil was negligible. Non-PCB contaminated soil and rock ballast was collected for off-site disposal.

Oil contaminated soil was discovered in the Building 901 trans. former yard. Impact to soil was negligible. Non-PCB contaminated soil and rock ballast was collected for off-site disposal.

A compressor leaked oil on to the pavement. Speedy dry was used swept up and placed into plastic bags for off-site disposal. 
Table 2 - 4 (cont'd)

Number Date Material Quantity Rpt ${ }^{\star}$ Source/Cause; Corrective Actions

97-29 5/16/97 Deionizing Effluent $\quad \sim 10$ gals. No

Wastewater from AGS operations was discovered leaking from pavement. Drums were placed beneath the leaking compartment to capture the leaking material. Water absorbent pads and speedydry were used to recover wastewater that had spilled onto the ground. The remaining liquid within the leaking compartment (2200 -2500 gals.) was pumped into another compartment of the tanker, a 1000-gallon tank supplied by Waste Management and twenty-one 55-gallon drums.

97-29 5/16/97 Deionizing Effluent $\quad \sim 10$ gals. No

Wastewater from AGS operations was discovered leaking from one compartment on an outside storage tank onto the asphalt pavement. Drums were placed beneath the leaking compartment to capture the leaking material. Water absorbent pads and speedydry were used to recover wastewater that had spilled onto the ground. The remaining liquid within the leaking compartment (2200 -2500 gals.) was pumped into another compartment of the tanker, a 1000-gallon tank supplied by Waste Management and twenty-one 55-gallon drums.

\begin{tabular}{|c|c|c|c|}
\hline $97-30$ & $5 / 20 / 97$ & Hydraulic Oil & 2 gals. \\
\hline $97-31$ & $5 / 30 / 97$ & No. $20 \mathrm{oll}$ & 1 quart \\
\hline
\end{tabular}

A tractor-trailer leaked hydraulic fluid onto local soils and standing water that remained from a recent rain event. Spill absorbent pads were applied to mitigate the floating oil and once the water subsided, the contaminated soil was excavated for disposal.

During an inspection of the containment area around Tank No. 5 , a leak from a drain tap nipple was discovered. Because the spill was to the containment area and did not reach soil, the spill was reportable only to Suffolk County Department of Health Services pursuant to Article 12 requirements. The oil stained ballast material was recovered for off-site disposal.

97-32 6/4/97 Hydraulic Oil < pint No

Hydraulic fluid leaked from a workers vehicle that was parked in the road west of BIdg. 496A. Absorbent rags were placed beneath the leak to capture the fluid. The residual fluid that leaked onto the asphalt pavement was cleaned with absorbent materials and placed into a 55gallon drum for disposal.

97-33 GLS6/5/97 Mineral O

$<1$ gal. Yes

Relief valve failed on air conditioner compressor outside of childcare center. Refrigerant mixed with mineral oil was released. Absorbent applied to accessible areas while bushes, shrubs and gravel were dug up and containerized.

\begin{tabular}{|c|c|c|c|c|c|}
\hline $97-34$ & $6 / 4 / 97$ & Hydraulic 0 il & $<1$ gal. & Yes & $\begin{array}{l}\text { A contracted drill rig developed a hydraulic leak. The fluid sprayed } \\
\text { onto the soil under the vehicle. All contaminated soil was exca- } \\
\text { vated and placed into a } 55 \text {-gallon drum for off-site disposal. }\end{array}$ \\
\hline $97-35$ & $6 / 9 / 97$ & Compressor 0il & $<1$ quart & No & $\begin{array}{l}\text { A portable air compressor developed a leak. Absorbent material } \\
\text { was used to clean up the spill. All contaminated absorbent was } \\
\text { contained for off-site disposal. }\end{array}$ \\
\hline $97-36$ & $6 / 11 / 97$ & Hydraulic 0il & $<2$ gal. & Yes & $\begin{array}{l}\text { A pay loader developed a hydraulic leak. The equipment was } \\
\text { immediately shutdown thereby limiting the amount of spillage. } \\
\text { Contaminated soils were removed and placed into a } 55 \text {-galion } \\
\text { drum for off-site disposal. }\end{array}$ \\
\hline $97-37$ & $6 / 20 / 97$ & Automotive Fuel & $<1$ quart & No & $\begin{array}{l}\text { Due to loose fittings, fuel leaked from F/R Group brush truck. } \\
\text { Spill occurred to pavement and was cleaned up with speedy-dry. }\end{array}$ \\
\hline $97-38$ & $6 / 24 / 97$ & Hydraulic Oil & 1 ounce & No & $\begin{array}{l}\text { A forklift spilled oil due to a leak from an o-ring seal on a hy- } \\
\text { draulic line solenoid valve. Oil absorbent pads were placed be- } \\
\text { neath the unit to capture any dripping fluid. The company that } \\
\text { owns the forklift was contacted and would replace the defective } \\
\text { seal on June } 25 \text {. }\end{array}$ \\
\hline $97-39$ & $6 / 27 / 97$ & Asphalt Primer & $\sim 1$ quart & No & $\begin{array}{l}\text { A can of asphalt primer leaked from the back of a maintenance } \\
\text { truck onto a paved area. Absorbent material was applied to the } \\
\text { spill. Recovered material was placed back into original container. }\end{array}$ \\
\hline $97-40$ & $6 / 27 / 97$ & Transformer 0il & Unknown & Yes & $\begin{array}{l}\text { During excavation to install a secondary containment berm } \\
\text { around the transformer yard to the south of Bldg. } 463 \text {, the con- } \\
\text { tractor uncovered what appeared to be petroleum-contaminated } \\
\text { soil. Screening of the headspace above the stained soils with a } \\
\text { TVA- } 1000 \text { Photo lonization / Flame lonization Detector provided } \\
\text { no evidence of contamination. To insure that the soil was not } \\
\text { contaminated, soil samples were collected for off-site analysis } \\
\text { for semi-volatiles and PCBs. Analytical results showed no evi- } \\
\text { dence of contamination. }\end{array}$ \\
\hline
\end{tabular}

1997 BNL Site Environmental Report $2-17$ 
Table 2-4 (cont'd.)

Number Date Material

Quantity Rpt* Source/Cause; Corrective Actions

97-41 7/2/97 Lacquer Thinne

1 quart No

A five gallon container of lacquer thinner was accidentally punctured by a forklift. It was quickly placed onto a safety storage pallet to capture the leaking fluid. The leaking container was then placed into an overpak and absorbent material was used to clean up the product that had leaked onto the floor. The leaking container and contaminated absorbent materials were disposed of as hazardous wastes.

\begin{tabular}{|c|c|c|c|}
\hline $97-42$ & $7 / 2 / 97$ & Gasoline & < 1 gal. \\
\hline $97-43$ & $7 / 7 / 97$ & Hydraulic Fluid & $100 \mathrm{ml}$ \\
\hline $97-44$ & $7 / 14 / 97$ & Hydraulic Oil & $4-5$ gals. \\
\hline $97-45$ & $7 / 21 / 97$ & Carbonaceous Silicide & $<1$ gal. \\
\hline $97-46$ & $7 / 23 / 97$ & Sodium Hypochlorite & $<1$ pint \\
\hline
\end{tabular}

Gasoline leaked from a parked vehicle over filled tank. Absorbent material was used to cleanup the spill. The contaminated absorbent material was recovered for off-site disposal.

Hydraulic fluid leaked onto the ground when an o-ring seal on a Grove Manlift failed while the vehicle was being used in the waste pit remediation area. Absorbent pads were place beneath the vehicle. The contaminated soil was then shoveled into a fivegallon pail for off-site disposal.

A boom truck hydraulic line ruptured resulting in spillage to the pavement. All oil was contained on asphalt surfaces and was cleaned-up using spill absorbent.

97-46 7/23/97 Sodium Hypochlorite <1 pint No North of Former Landfill.

While being transported a container of Sodium Hypochlorite fell and spilled a part of its contents onto the road. Fire rescue and S\&EP were alerted. The Sodium Hypochlorite was diluted with water allowed to run into the storm drain and then into the STP for discharge. No other clean up activity was necessary.

97-47 7/26/97 Hydraulic Oil $0.5-1$ gal. Yes

One of the hydraulic lines of a crane developed a leak. A plastic wading pool was placed beneath the crane to intercept additional spillage and the crane was repaired. All contaminated soil was collected for off-site disposal.

97-48 8/1/97 Mercury 3-5 pounds Yes

Metallic mercury was encountered in the craw/ space beneath the Building 197 high bay. The discernible mercury was subsequently removed and soil samples were collected to determine impact. Results show elevated residual mercury levels. Further actions are planned for continued remediation under the Facility Review Project and CERCLA Program.

97-49 8/8/97 Compressor Oil $4-5$ gals. No

During dismantling of a defunct refrigeration system oil spilled on the floor. Speedy-dry and other absorbents were used to remediate the spill. All contaminated absorbent was collected for proper disposal.

97-50A 8/15/97 Hydraulic Fluid <1 gal. Yes Hydraulic fluid leaked onto the ground when a hydraulic line seal failed on a front-end loader. The contaminated soil was recovered and was placed in a five-gallon pail for disposal. The vehicle was subsequently transported to the Heavy Equipment Shop for repairs.

\begin{tabular}{|c|c|c|c|c|}
\hline $97-50 \mathrm{~B}$ & $8 / 18 / 97$ & Hydraulic Fluid & 1 pint & Yes \\
\hline $97-51$ & $8 / 15 / 97$ & Engine Oil & $<1$ quart & No \\
\hline
\end{tabular}

Refer to Spill 97-50A

A leak was observed beneath a contractor >s truck. A tarp was placed beneath the leak to capture dripping fluid and absorbent material was applied to stained areas of pavement. Contaminated absorbent materials and the tarp were containerized for disposal. The leak was repaired before continuing with the job.

\begin{tabular}{|c|c|c|c|c|c|}
\hline $97-52$ & $8 / 25 / 97$ & Vacuum Oil & $<1$ gal. & No & $\begin{array}{l}\text { A seal failed on a vacuum pump and leaked oil onto the con- } \\
\text { crete. Speedy-dry and absorbent pads were used to clean up the } \\
\text { spill. The absorbent materials were containerized for off-site dis- } \\
\text { posal. The failed seal was replaced. }\end{array}$ \\
\hline $97-53$ & $8 / 27 / 97$ & Unknown Petroleum & Unknown & Yes & $\begin{array}{l}\text { During installation of utility poles, oil contaminated soils (odors } \\
\text { only) were encountered. A soil sample was collected for subse- } \\
\text { quent chemical analysis to confirm this observation. Chemical } \\
\text { analysis revealed no evidence of Petroleum contamination. }\end{array}$ \\
\hline $97-54$ & $9 / 15 / 97$ & Power Steering Fluid & $<1$ pint & No & $\begin{array}{l}\text { Power steering fluid leaked from a pump truck. Absorbent mate- } \\
\text { rials were placed beneath the leak and onto stained areas of the } \\
\text { asphalt pavement. The absorbent materials were recovered for } \\
\text { off-site disposal. }\end{array}$ \\
\hline
\end{tabular}


Table 2-4 (cont'd.)

Number Date Material

97-55 $9 / 23 / 97$ Antifreeze

97-56 9/29/97 Diesel Fuel

1 pint No

97-57 10/6/97 Gasoline $\quad<2$ pint No

\begin{tabular}{|c|c|c|}
\hline $97-62$ & 11/18/97 Ethylene Glycol & $<1$ quart \\
\hline $7-63$ & 11/21/97 Diesel Fuel & 1 gal. \\
\hline
\end{tabular}

$97-6$ 11/25/97 Deionizing Effluent

A

A contracted drill rig developed a hydraulic leak during installation of monitoring wells along Weaver road. Upon noticing the spiliage a plastic container was placed beneath the drill rig to intercept additional drippage. Oil was lost to the snow and ground immediately beneath the vehicle. All the contaminated snow and soil were collected and containerized.

\begin{tabular}{|c|c|c|c|c|}
\hline $97-68$ & 12/30/97 Hydraulic 0il & $\sim 1$ gal. & No & $\begin{array}{l}\text { During brush removal, a hydraulic line of a skid-steer front-end } \\
\text { loader ruptured after becoming entangled in the brush. All spilled } \\
\text { oil was contained on asphalt and was immediately removed us- } \\
\text { ing spill absorbent. }\end{array}$ \\
\hline
\end{tabular}

\footnotetext{
*Reportable to offsite agencies.
} 


\subsubsection{Employee Trip-Reduction Plan}

BNL submitted a final report on the Long Island Regional Improving Commute Grant awarded to BNL by the New York State Department of Transportation (NYSDOT) in 1996. It described the initiatives introduced and the work completed in 1995 and 1996 to meet the employee travelreduction goals established in BNL's grant proposal. The NYSDOT then reimbursed the Laboratory for many of the costs associated with BNL's rideshare program which was introduced in May 1995.

The NYSDOT repealed the Employee Travel Reduction Program rules (17 NYCRR Part 68) in September 1996, making employer's participation in these programs voluntary. The Laboratory discontinued several rideshare incentives that had been offered to encourage employees to participate. Although the program is now voluntary, the ES\&HS Division continues to assist employees in finding suitable rideshare partners by maintaining a ridematching database. The Laboratory also continues to subsidize the cost of a defensive-driver course for employees active in ridesharing partnerships, and guarantees ride service for program participants.

\subsubsection{Reasonable Available Control Technology (RACT) Requirements}

In March 1994, the Laboratory submitted a compliance plan which NYSDEC approved in June 1994 that described how the Laboratory intended to meet the reasonable available control technology (RACT) requirements of 6 NYCRR Subpart 227-2. Testing of boilers by BNL before submitting the plan confirmed that BNL complies with the NOx RACT emissions limit by burning residual fuel with a fuel-bound nitrogen content at, or below, 0.3 percent, and a similar fuel bound sulfur content. To ensure that fuel supplied to the CSF meets the requisite nitrogen limits, BNL agreed to collect composite samples of fuel deliveries each quarter, and submit them to an outside laboratory for analysis. Laboratory analysis is also used to confirm the sulfur content of the fuel. Samples were not taken in the fourth quarter of 1997 because no fuel was delivered.

During the peak ozone period, from May 1 to September 15, compliance with the $0.30 \mathrm{lbs} / \mathrm{MMBTU}$ NOx emissions limit for Boilers 6 and 7 was demonstrated by calculating the 24-hour daily arithmetic average rate of NOx emission from measured readings recorded by flue gas continuous emission monitoring systems (CEMS). From September 16 to April 30, the 30-day rolling average CEM emissions rate established compliance. In 1997, NOx emissions from Boilers 6 and 7 averaged $0.262 \mathrm{lbs} / \mathrm{MMBTU}$ and $0.243 \mathrm{lbs} / \mathrm{MMBTU}$, respectively, as measured by the CEMS for each boiler On June 14, 1997, NOx emissions from Boiler 7 averaged $0.31 \mathrm{lbs} / \mathrm{MMBTU}$, slightly above the daily limit. This exceedance and concurrent exceedance of the opacity limit were caused by a malfunction in a fuel-oil meter which, in turn, caused an erratic response of the boiler's combustion controls. The fuel oil meter was subsequently replaced and no further exceedances occurred. Throughout the year, the 30-day rolling average was not exceeded for either boiler.

\subsubsection{Phaseout of Halon Fire-Suppression Systems}

Based on recommendations in the 1994 Hughes Associates, Inc. study of existing Halon 1301 fire-suppression systems, two 90-pound halon fire suppression systems were removed from service during 1997. The systems were located at the IBM hutch in Building 725 and in Trailer 88, which is attached to a monitoring center for the linear-accelerator beam line. An earlier request to purchase a recovery unit that can be used to recover either Halon 1301 from stationary storage-vessels or Halon 1211 from unserviceable, portable fire extinguishers was approved for the 1998 fiscal year.

\subsubsection{Ozone Depleting Refrigerants}

Plant Engineering certified technicians service most of the refrigeration and air conditioning equipment on site. Covered equipment includes centrifugal, reciprocal and rotary screw chillers, split and package air conditioners. During equipment servicing and repair, refrigerants are recovered and recycled using EPA approved refrigerant recovery devices that are certified to meet re- 
frigerant evacuation levels specified by 40 CFR 82.158. All refrigeration and air conditioning equipment is regularly inspected and maintained under the Management Maintenance Center Preventative Maintenance Program. If a leak is found, technicians will either repair the leak immediately, isolate the leak whenever possible, or will prepare a work order for needed repairs. Commercial refrigeration equipment found in the food service areas of Buildings 30 and 488 are serviced by an outside contractor. The contract between the BNL Administrative Support Division and the service company requires contractor technicians to comply with applicable requirements of 40 CFR 82 Subpart F in servicing refrigeration appliances.

During the calendar year, approximately 380 pounds of R-22 were recovered and reclaimed for future use from existing equipment during servicing or decommissioning. Also in 1997, the Plant Engineering Maintenance Management Center (MMC) upgraded the refrigerant management software program purchased in 1995. The upgrade allows the MMC to better track the maintenance history of all the refrigeration-and air-conditioning systems serviced. Also, the MMC can better monitor refrigerant leak-rates, establish repair schedules, and document the type of service performed and the amount of refrigerant added to a system, in accordance with record-keeping requirements of 40 CFR Section 82.166.

\subsubsection{National Emission Standards for Hazardous Air Pollutants (NESHAPS)}

\subsubsection{Radioactive Airborne Effluent Emissions Governed by NESHAPs}

In 1997, the BNL radiological NESHAPs program was audited under two major reviews: the DOE Integrated Safety Management Evaluation (ISME), and the EPA Multi-Media Compliance Evaluation Inspection. The ISME identified the Laboratory's need to fully implement a plan ensuring periodic confirmatory monitoring of minor sources of radioactive air effluents, i.e., those sources which have the potential to cause a public dose of less than 0.1 mrem per year. (Such sources are primarily bench-top operations in which liquid radioactive sources are used in a lab hood exhausting to a roof vent.) The EPA's Multi-Media Inspection found no deficiencies in the radiological NESHAPs program.

In 1997, the maximum off-site dose due to airborne radioactive emissions from the Laboratory continued to be far below the $10 \mathrm{mrem}$ annual dose limit. The dose to the maximally exposed individual resulting from airborne emissions, calculated using EPA's CAP88-PC model, was 0.07 mrem $(0.7 \mathrm{uSv})$. All data on airborne effluent releases and dose calculations were transmitted to both DOE and EPA on time, fulfilling the June 30 annual reporting requirement.

\subsubsection{Asbestos}

In 1995, the NYSDEC issued a permit to operate an exhaust system for equipment used to mix and spray chrysotile asbestos insulation onto test panels in the former Inhalation Toxicology Facility (Building 490). To meet the pollution control requirements of 40 CFR Part 60 Subpart M, pre-filters and HEPA filters were installed in series in the exhaust systems of each of the three process hoods. Since fabrication of test panels commenced in 1995, Department of Applied Science personnel responsible for mixing and spraying have regularly inspected the pollution-control equipment and have monitored the equipment and exhaust systems daily for evidence of visible emissions, as required by Subpart M Section 61.144. No emissions of asbestos have been observed.

Since 1993, BNL has complied with 40 CFR 61 Subpart M regulations on airborne-fiber releases of asbestos. During 1997, the EPA Region II office was notified of three renovation or demolition jobs possibly involving the removal of regulated asbestos containing materials in conformance with Subpart $M$ notification requirements. Formal annual notification of nonscheduled small renovations for 1997 was also made to both DOE and EPA in compliance with Subpart M reporting requirements. Based on data from 1996, it was estimated that 749 linear feet of pipe insulation, and 247 square feet of surface material would be removed in calendar year 1997. 


\subsubsection{Maximum Available Control Technology (MACT) Requirements}

In September 1997, RHIC personnel opened discussions with the ES\&H Services division about reactivating a conveyorized ultrasonic/vapor degreaser located in Building 924. The unit had been used for cleaning residual Mobil 1-lubricant from copper cables used in magnet assemblies. The discussions initially focussed on the provisions of the NESHAPS standard entitled National Emissions Standards for Halogenated Solvent Cleaning (i.e., 40 CFR 63 Subpart T) that would apply if 1,1,1-trichloroethane or another halogenated solvent covered by the rule was used for cleaning. The following requirements of Subpart $T$ are applicable to in-line cleaning equipment: strict operational practices that must be followed during start-up, cleaning, and shutdown periods; provisions for monitoring and maintaining the vapor-zone temperature within the unit; and provisions for record-keeping and reporting. Other issues discussed included the limited availability and high cost of 1,1,1-trichloroethane and carbon tetrachloride caused by the EPAimposed production phaseout of Class I ozone-depleting substances and permitting requirements for the cleaning equipment.

A new product called HyperSolve was considered; it is a non-halogenated cleaning solvent being reviewed by EPA as a possible alternative to 1,1,1-trichloroethane under their significant new alternatives program. According to its manufacturer, HyperSolve could be used in the ultrasonic/ vapor degreaser with only minor adjustments to sump temperatures since the product's boiling point and vapor pressure are close to those of 1,1,1-trichloroethane. Had this product been used, the ultrasonic/vapor degreaser would have been under the less stringent requirements of 6 NYCRR Part 226, which are applicable to solvent-metal-cleaning operations. After evaluating the options, RHIC personnel approached the contractor who supplies the copper cable about making process changes to reduce or eliminate the need for cleaning. Ultimately, the contractor found a substitute lubricant that could be used in the cable-forming dyes. The new lubricant leaves a residue that is easily cleaned from the cable before it is delivered to BNL; hence, there was no need to reactivate the ultrasonic and the vapor degreaser.

\subsubsection{Facility Audits}

During EPA's multimedia audit of BNL environmental programs in May 1997, several CAA compliance issues were raised. In their subsequent report, the EPA noted various format deficiencies and past tardiness in the quarterly reports that BNL submits to demonstrate compliance with $\mathrm{NO}_{x}$ emission and particulate emission limits applicable to operations of the CSF boilers. Several changes to the reports were made to address the formatting deficiencies. In the past, BNL had to reduce the NOx CEM data to be consistent with the EPA reporting requirements. This very time consuming effort contributed to delays in submitting past reports. BNL addressed the delays by upgrading its data acquisition system.

During the audit, EPA reviewed several asbestos containing material (ACM) removal jobs for compliance with NESHAPS Subpart M requirements. The EPA report cited BNL with violations of these requirements on jobs that required removing asbestos insulated piping at the CSF and asbestos transite casing panels from a water tower outside Building 911. The report also cited BNL with violations of Subpart $M$ work practice and notification requirements relative to the removal of ceiling tiles in Building 902.

BNL has since determined the causes for each of these alleged violations. BNL failed to notify EPA of the removal of asbestos insulated piping at the CSF because the job was improperly classified as renovation work that involved the removal of less than 260 linear feet of piping. In retrospect, the work should have been classified as a demolition job and BNL should have notified the EPA before the job commenced. BNL does not believe the transite casing panel work was subject to Subpart $M$ notification requirements because the panels were considered Category II non-friable ACM prior to their removal and the contractor took precautions to ensure that the panels would not become friable as they were handled. Finally, a misinterpretation of 1988 inventory records of ceiling tiles in Building 902 led BNL personnel to conclude the tiles did not contain asbestos. 
During the removal process, the work supervisor requested analysis for asbestos content of debris from pipe insulation in the concealed space above them. Samples of the pipe insulation, as well as the ceiling tiles themselves revealed that they did, in fact, contain asbestos. The work was immediately suspended. Before work resumed, proper worker safety and environmental precautions were taken for removing the asbestos materials. Notification was made to the EPA after the job was completed.

\subsubsection{Title V Permit Application}

The NYS Operating Permit Progran approved by the EPA in November 1996, established a twophase schedule for the submittal of Title V permit applications. Schedule dates for the submission of the Phase I and Phase II applications are December 9, 1997 and December 9, 1998 respectively. The Phase I application must include an overview of significant facility operations that produce airborne emissions, summaries of facility emissions and federal and state regulatory requirements applicable to facility operations, and a statement certifying the compliance status of facility operations with applicable requirements. The Phase II application requires a detailed description of all emission sources, pollution control devices, alternate operating scenarios, applicable federal and state emission standards, reporting and record keeping requirements and, compliance assurance monitoring procedures.

In planning for the Title $\mathrm{V}$ application, BNL staff recognized the need for a data management system that would enable BNL to assemble the permit application directly onto state application forms. Furthermore, the system had to be sophisticated enough to address the anticipated data management requirements after the Phase II permit application is submitted. In February 1997, a software package developed by ERM-Northeast capable of meeting these needs was purchased and installed.

In April 1997, BNL staff began walk through inspections of facility buildings to gather the requisite information on emission sources for the Phase II permit application. By years end, approximately sixty percent of the buildings had been inspected. In July 1997, BNL staff began transferring emission source information compiled during facility inspections into the Title V data management system. In December 1997, the Laboratory's Phase I application was submitted to the NYSDEC.

\subsection{Suffolk County Sanitary Codes}

A significant change was made to the Laboratory's tank inventory and management program in 1997. Due to increased public and regulatory awareness surrounding the HFBR investigation, a thorough review of all the Laboratory's storage facilities was conducted by the Laboratory and the Suffolk County Department of Health Services. This review identified an additional 400 "storage facilities" currently or formerly used by BNL including all vessels and containment systems used at the Reactor Division which were not included in the Laboratory's inventory due to the overlapping jurisdiction of the DOE and the SCDHS. These facilities also include the closed-loop cooling water systems at the accelerator facilities, tanks removed before the BNL and the SCDHS agreement, and other facilities thought to have been long abandoned. All 400 facilities now have been listed in SCDHS's inventory of storage facilities and "information" forms filed for approximately 350. Forms for the remaining facilities will be filed by mid-1998. For underground storage facilities not currently used, plans were prepared for their immediate removal, and, if necessary, for investigation into their potential for environmental damage (i.e., collection of soils and groundwater samples). The regulatory status of many of these facilities is under review.

Since the signing of a 1987 Agreement between Suffolk County and BNL, which requires the Laboratory to comply with the environmental requirements of SCSC Articles 6, 7, 10, and 12, the Laboratory has made significant progress toward bringing all storage facilities into compliance. Below is a description of the status of the activities conducted during 1997: 


\section{Month Status/Comments}

\section{February}

The SCDHS gave Interim approval to operate the new centralized degreasing-facility for cleaning components used in ultrahigh vacuum environments. This facility replaced the former Acid Cleaning Facility which was closed in August 1997.

\section{March}

Conceptual design criteria for upgrading the HFBR spent fuel pool were submitted to the SCDHS for review. The design included installing a stainless-steel primary liner within the existing concrete structure, providing secondary containment. To ensure its impermeability, an epoxy sealant would be applied before installing the liner.

The SCDHS gave an interim permit to operate the Removal Action V (RAV) groundwater-treatment system installed and operated by the Environmental Restoration Division. This system uses two tanks to store groundwater-treatment reagents (i.e., sodium hypochlorite and polyphosphate).

\section{August}

Plans and specifications were submitted to the SCDHS to install two 20,000-gallon storage tanks at Building 811 to store water from the HFBR spent-fuel pool. Comments about these plans were received in September 1997; the deficiencies noted were adequately addressed during subsequent field inspections.

The former Acid Cleaning Facility was permanently closed. An SCDHS inspection verified that all tanks were emptied and permanently disconnected.

\section{September}

Tank tightness tests were conducted on seven underground storage petroleum tanks. All tanks were satisfactory. Copies of the test reports were filed with the SCDHS.

Plans and specifications for upgrades to Building 801 were submitted for review and approval. This project involves permanently removing numerous storage facilities from service and upgrading the remaining ones.

\section{October}

Tank registration forms were filed for 112 storage facilities identified during the SCDHS facility inspections.

SCDHS inspection of Bldg. 801 verified that fourteen storage facilities were removed.

SCDHS inspection of Building 933 verified the removal of heat exchangers, and five cable-oil tanks and associated oil formerly used by the Cryogenic Test Facility.

Temporary storage facilities were constructed at the Waste Management Facility to store waste water recovered from the BGRR air-duct system.

Plans and specifications were submitted and approved to upgrade one Co-60 source storage system at Bldg. 555.

\section{November}

SCDHS sent a rejection notice for upgrades to Building 801. Additional information on preexisting facilities was requested; this information was submitted expeditiously.

\section{December}

Plans and specifications were filed for upgrading thirty-one storage facilities. They are predominantly small, above-grade storage tanks used for oils, chemicals, and cooling water from the HFBR and BMRR; improvements to secondary containment systems were requested. 
The new storage facilities (two 20,000 gallon ASTs) at Building 811 had final inspections by the SCDHS. Minor issues were noted which were immediately rectified.

Routine meetings with the SCDHS were held throughout the year to discuss progress in attaining compliance with SCSC Article 12. Specifically, there were discussions of tank inventory issues, pending upgrades to reactor facilities, and Article 12 compliance. Special meetings were held to review the SCDHS/BNL agreement language and discuss plans for complying with Articles 7 and 12.

\subsection{Safe Drinking Water Act (SDWA)}

\subsubsection{Applicability to Brookhaven National Laboratory}

The Laboratory maintains six wells, two water-storage tanks, and a distribution piping system for supplying potable water to the Laboratory community. Safe Drinking Water Act Requirements pertaining to the distribution and monitoring of public water supplies are promulgated under Part 5 of the New York State Sanitary Code, which is enforced by the SCDHS as the agent for the NYSDOH. These regulations are applicable to any water supply that has at least five service connections or regularly serves at least 25 individuals. The Laboratory supplies water to approximately 3,500 individuals and must comply with these regulations.

\subsubsection{Potable Water Monitoring Requirements}

SCDHS specifies the annual minimum monitoring requirements for potable-water suppliers. In response, the Laboratory prepares a Potable Water System Sampling and Analysis Plan which outlines sampling procedures and schedules the annual monitoring of BNL's potable-water system. The SCDHS found BNL's Sampling and Analysis Plan acceptable. Routine monitoring of the potable wells and the potable-water distribution system by BNL exceeded the prescribed minimum monitoring requirements. The monitoring requirements for 1997 included monthly bacteriological analyses, quarterly analyses for POCs, annual analysis for SOCs and pesticides, semiannual inorganic chemicals analyses, and annual analyses of micro-extractables and asbestos. The monitoring requirements for CY 1996 and 1997 were similar. Potable water samples were collected by BNL personnel and analyzed by NYSDOH certified contractor laboratories using standard methods. During 1997, BNL drew the potable-water supply from three wells (Potable Wells 10, 11 and 12). After completing major improvements to the WTP, Potable Wells 4, 6, and 7 also were used on a limited basis in 1997. All analytical data were submitted to the SCDHS as required by Chapter I, Part 5, of the NYS Sanitary Code. Table 2-5 summarizes the analytical data on bacteriological, inorganic, radiological, and asbestos measurements. Table 2-6 summarizes the analytical data on POCs, SOCs, pesticides, and micro-extractables. In response to the HFBR tritium plume investigation, concerns were raised about the quality of on-site potable-water. Although the Potable Water Sampling and Analysis Plan did not require analysis and reporting of radiological parameters, the results of quarterly radiological sampling were reported to the SCDHS; they showed that concentrations were below the NYS Drinking Water Standard. These data are summarized in Table 2-5. Table 2-6 shows that the water from wells 6 and 7 contained elevated levels of iron ranging from 0.94 to $2.9 \mathrm{mg} / \mathrm{L}$. Water from wells 4,6 , and 7 is treated at the WTP to remove iron and associated contaminants before site distribution. The treatment includes aeration, lime softening, filtration, air stripping, and chlorination. The effluent from the WTP was tested and found to meet all DWSs.

All reported bacteriological, SOCs, pesticides, micro-extractables, and asbestos data collected during CY 1997 were within the NYS DWSs. Monitoring of lead and copper continued during CY 1997. Since the analytical results for 1996 showed all facilities to be within the Federal Action Levels for lead and copper, monitoring in 1997 was reduced to twenty locations, sampled annually. All analytical results again show BNL's potable-water system to be in compliance with the Action levels. 
The SCDHS inspected BNL's potable-water supply system in June 1997, including walk-through examinations of the WTP, support facilities, and potable-well support-facilities. The inspector noted that all operations were satisfactory. In water samples collected during this visit, all analytical parameters met all federal and state MCLs and guidelines except for iron in Wells 4, 6 and 7 which exceeded the standard of $0.30 \mathrm{mg} / \mathrm{L}$. Well 4 had an iron reading of 0.38 , Well 6 had a reading of 3.2 and Well 7 had $0.95 \mathrm{mg} / \mathrm{L}$. As previously described, water from these wells are treated to remove iron at the WTP.

\subsubsection{Cross-Connection Control}

The NYSDOH is authorized under Public Health Law 201 to supervise and regulate the sanitary aspects of potable-water supplies. Cross-connection control (CCC) is the means by which hazards associated with industrial or non-potable uses of the water supply are minimized. CCC consists of installing backflow prevention devices so that potentially contaminated water does not mix with the potable supply during low system-pressure. There are two categories of CCC devices. Primary devices consist of check-valves (CV), double check-valves (DCV), or reduced pressure zone (RPZ) devices that typically are installed between the facility's water connection and the potable water distribution system. These devices protect the main potable supply from contamination from facility operations, but they do not protect the facility's internal plumbing. Secondary devices, which may also consist of CV, DCV, RPZ, or vacuum breakers protect the internal plumbing systems. The degree of hazard posed by the occupancy determines which device is warranted.

The Laboratory has had an active CCC program since 1985, installing both primary and secondary CCC devices, and maintaining and testing of them annually as required by state regulations. Maintenance and testing is managed by the Plant Engineering Division, Maintenance Management Center, and all testing is done by NYS-certified backflow-prevention device testers. Annual test reports are transmitted to the SCDHS periodically throughout the year; during 1997, reports were submitted for 157 CCC devices.

\subsubsection{Underground-Injection Control}

Discharge of wastewater by underground injection is regulated under Part $\mathrm{C}$ of the SDWA, as codified under 40 CFR Part 144. Under the SDWA, an Underground Injection Control (UIC) program must be developed by each state for which the US EPA Administrator determines that underground injection could threaten a drinking-water source. The goal of the UIC program is to prevent the discharge of contaminants into the subsurface that could jeopardize the groundwater's quality. While all states have been deemed subject to these regulations, a NY State program was not been developed since, in the state's opinion, the existing SPDES program established under the CWA should meet the intent of the SDWA requirements. Due to NYS's reluctance to promulgate a new program, the Laboratory falls under the EPA UIC program wherein UIC devices are subject to permitting, sampling, analysis, and closure, if necessary. The EPA program defines five types of UIC wells: Class I and IV wells are used for injecting hazardous wastes, Class II wells are used for gas, oil, or hydrocarbon recovery, Class III wells are used for extracting minerals. Class $\mathrm{V}$ wells were generically defined as wells used for injecting a fluid not regulated under the previous classes, and which are deeper than their widest surface dimension. They include sanitary and other wastewater disposal systems including but not limited to, drywells, cesspools, septic tanks, and leach fields. BNL has only Class V wells.

Many Long Island communities that lack a central sanitary-and storm-water-sewer system discharge their sanitary-and process-waste-waters and stormwater runoff into cesspools, leaching pools, and drywells. The Laboratory maintains in excess of 200 UIC devices for discharging these wastewaters. In 1991, the Laboratory was cited by the EPA for operating numerous Class V UIC wells, which may have received industrial discharges and were, consequently, subject to UIC permitting. In response to this citation, an inventory of Class V UIC wells was provided to EPA, describing each of them and their status. To deal with those UIC wells which potentially were 
Table 2-5

BNL Site Environmental Repont for Calendar Year 1997

Potable Water Wells and Potable Distribution System,

Bacieriological, Inorganic Chemical and Radiological Analytical Data ${ }^{11}$

\begin{tabular}{|c|c|c|c|c|c|c|c|c|c|}
\hline Compound & $\begin{array}{l}\text { Well } \\
\text { No. } 4 \\
\text { (FD) }\end{array}$ & $\begin{array}{l}\text { Well } \\
\text { No. } 6 \\
\text { (FF) }\end{array}$ & $\begin{array}{l}\text { Well } \\
\text { No. } 7 \\
\text { (FG) }\end{array}$ & $\begin{array}{l}\text { Well } \\
\text { No. } 10 \\
\text { (Fo) }\end{array}$ & $\begin{array}{l}\text { Well } \\
\text { No. } 11 \\
\text { (FP) }\end{array}$ & $\begin{array}{l}\text { Well } \\
\text { No. } 12 \\
\text { (Fa) }\end{array}$ & $\begin{array}{l}\text { Potable } \\
\text { Distribution } \\
\text { Sample }\end{array}$ & \multicolumn{2}{|c|}{$\begin{array}{l}\text { NYS } \\
\text { Drinking } \\
\text { Water Standard }\end{array}$} \\
\hline Total Coliform & ND & ND & ND & ND & ND & ND & ND & \multicolumn{2}{|c|}{ Negative } \\
\hline Color & $<5$ & $\star 30$ & $<5$ & $<5$ & $<5$ & $<5$ & $<5$ & 15 & Units \\
\hline Odor & 0 & 0 & 0 & 0 & 0 & 0 & 0 & 3 & Units \\
\hline Cyanide & $<10$ & $<10$ & $<10$ & $<10$ & $<10$ & $<10$ & $<10$ & NS & $u g / L$ \\
\hline Conductivity & 119 & 106 & 138 & 100 & 140 & 123 & 142 & NS & umhos \\
\hline Chlorides & 19.3 & 15.8 & 23.3 & 10.8 & 18.6 & 16 & 22 & 250 & $\mathrm{mg} / \mathrm{L}$ \\
\hline Sulfates & 7.9 & 7.4 & 8.7 & 7.4 & 10 & 7.9 & 10.2 & 250 & $\mathrm{mg} / \mathrm{L}$ \\
\hline Nitrates & 0.3 & 0.3 & 0.4 & 0.4 & 0.6 & 0.3 & 0.3 & 10 & $\mathrm{mg} / \mathrm{L}$ \\
\hline Ammonia & $<0.02$ & 0.04 & $<0.02$ & $<0.02$ & $<0.02$ & $<0.02$ & $<0.02$ & NS & $\mathrm{mg} / \mathrm{L}$ \\
\hline $\begin{array}{l}\mathrm{pH} \\
\text { Methylene Blue }\end{array}$ & 5.5 & 5.5 & 5.6 & 5.9 & 5.7 & 6 & 8.4 & NS & SU \\
\hline Active Substances & $<0.04$ & $<0.04$ & $<0.014$ & $<0.04$ & $<0.04$ & $<0.04$ & $<0.04$ & NS & $\mathrm{mg} / \mathrm{L}$ \\
\hline Antimny & $<5.9$ & $<5.9$ & $<5.9$ & $<5.9$ & $<5.9$ & $<5.9$ & $<5.9$ & 6.0 & $\mathrm{ug} / \mathrm{L}$ \\
\hline Arsenic & $<3.0$ & $<3.0$ & $<3.0$ & $<3.0$ & $<3.0$ & $<3.0$ & $<3.0$ & 50 & $\mathrm{ug} / \mathrm{L}$ \\
\hline Barium & $<0.2$ & $<0.2$ & $<0.2$ & $<0.2$ & $<0.2$ & $<0.2$ & $<0.2$ & 2.0 & $\mathrm{mg} / \mathrm{L}$ \\
\hline Beryllium & $<3.0$ & $<3.0$ & $<3.0$ & $<3.0$ & $<3.0$ & $<3.0$ & $<3.0$ & 4.0 & $\mathrm{mg} / \mathrm{L}$ \\
\hline Cadmium & $<5.0$ & $<5.0$ & $<5.0$ & $<5.0$ & $<5.0$ & $<5.0$ & $<5.0$ & 5.0 & $\mathrm{ug} / \mathrm{L}$ \\
\hline Chromium & $<0.01$ & 0.1 & $\mathrm{mg} / \mathrm{L}$ & & & & & & \\
\hline Fluoride & $<0.1$ & $<0.1$ & $<0.1$ & $<0.1$ & $<0.1$ & $<0.1$ & $<0.1$ & 2.2 & $\mathrm{mg} / \mathrm{L}$ \\
\hline Iron & 0.1 & $\star 2.9$ & ${ }^{*} 0.94$ & $<0.02$ & $<0.02$ & 0.03 & 0.03 & 0.3 & $\mathrm{mg} / \mathrm{L}$ \\
\hline Lead & 2.8 & $<1.0$ & $<1.0$ & $<1.0$ & $<1.0$ & $<1.0$ & $<1.0$ & 15 & $u g / L$ \\
\hline Manganese & 0.17 & 0.23 & 0.02 & $<0.01$ & $<0.01$ & $<0.01$ & $<0.01$ & 0.3 & $\mathrm{mg} / \mathrm{L}$ \\
\hline Mercury & $<0.2$ & $<0.2$ & $<0.2$ & $<0.2$ & $<0.2$ & $<0.2$ & $<0.2$ & 2.0 & $\mathrm{ug} / \mathrm{L}$ \\
\hline Nickel & $<0.04$ & 0.06 & $<0.014$ & $<0.04$ & $<0.04$ & $<0.04$ & $<0.04$ & 0.1 & $\mathrm{mg} / \mathrm{L}$ \\
\hline Selenium & $<5.0$ & $<5.0$ & $<5.0$ & $<5.0$ & $<5.0$ & $<5.0$ & $<5.0$ & 10.0 & $\mathrm{ug} / \mathrm{L}$ \\
\hline Sodium & 11.5 & 9.8 & 15.8 & 8.2 & 12 & 12.4 & 22.4 & NS & $\mathrm{mg} / \mathrm{L}$ \\
\hline Thallium & $<1.9$ & $<1.9$ & $<1.9$ & $<1.9$ & $<1.9$ & $<1.9$ & $<1.9$ & 2.0 & $\mathrm{ug} / \mathrm{L}$ \\
\hline $\begin{array}{l}\text { Zinc } \\
\text { Turbidity }\end{array}$ & $<0.02$ & $<0.02$ & $<0 .(12$ & $<0.02$ & $<0.02$ & $<0.02$ & $\begin{array}{l}<0.02 \\
<1.0\end{array}$ & 5.0 & $\mathrm{mg} / \mathrm{L}$ \\
\hline Gross Alpha Activity & $<1.62$ & $<1.62$ & $<1.62$ & $4.78^{\{3\}}$ & $7.7^{(3)}$ & $4.5^{(3)}$ & NA & 15.0 & $\mathrm{pCi} / \mathrm{L}$ \\
\hline Beta & $<3.82$ & $<3.82$ & $<3.82$ & 8.3 & $14.3^{(3)}$ & $8.7^{(3)}$ & NA & 50.0 & $\mathrm{pCi} / \mathrm{L}$ \\
\hline Tritium & $<304$ & $<304$ & $<304$ & $<534$ & 373 & $<534$ & NA & 20000.0 & $\mathrm{pCi} / \mathrm{L}$ \\
\hline Strontium-90 & ND & ND & ND & 0.14 & 0.16 & 0.08 & NA & 8.0 & $\mathrm{pCi} / \mathrm{L}$ \\
\hline Gamma: & & & & & & & & & \\
\hline $\mathrm{K} 40$ & 3.91 & ND & ND & 2.75 & 2.12 & 3.64 & NA & 280.0 & $\mathrm{pCi} / \mathrm{L}$ \\
\hline MN-54 & ND & ND & ND & 0.2 & ND & ND & NA & 2000.0 & $\mathrm{pCi} / \mathrm{L}$ \\
\hline Asbestos & NA & NA & NA & NA & NA & NA & NA & 7 & M.Fibers/L \\
\hline Calcium & NA & NA & NA & NA & NA & NA & $9.6 \mathrm{mg} / \mathrm{L}$ & NS & $\mathrm{mg} / \mathrm{L}$ \\
\hline Alkalinity & NA & NA & NA & NA & NA & NA & $38 \mathrm{mg} / \mathrm{L}$ & NS & $\mathrm{mg} / \mathrm{L}$ \\
\hline
\end{tabular}

1. This table contains the maximum concentration (minimum $\mathrm{pH}$ value) reported by the contractor laboratory.

2. Due to constructing improvements to the $W^{\top} P$, Well 4,6 and 7 were not used for potable water distribution for the duration of 1997 .

3. These maximum gross activity values were reported to the SCDHS in 1997 . They were subsequently invalidated due to instrument error. (See Section 8.1.1.2 and chapter 10 for details)

(ND): Not Detected

(NS): DWS Not Specified

(NA): Analysis Not Required 
Table 2-6

BNL Site Environmental Report for Calendar Year 1997

Potable Water Wells, Analytical Data for Principal Organic Compounds,

Synthetic Organic Compounds Pesticides and Micro-Extractables

Compound

Dichlorodifluoromethane

Chloromethane

Vinyl Chloride

Bromomethane

Chioroethane

Fluorotrichloromethane

1,1-dichloroethene

Dichloromethane

trans-1,2-dichloroethene

1,1-dichloroethane

cis-1,2-dichloroethene

2,2-dichloropropane

Bromochloromethane

1,1,1-trichloroethane

Carbon Tetrachloride

1,1-dichloropropene

1,2-dichloroethane

trichloroethane

1,2-dichloropropane

Dibromomethane

trans-1,3-dichloropropene

cis-1,3-dichloropropene

1,1,2-trichloroethane

Trihalomethanes

1,1,2,2-tetrachloroethane

1,3-dichloropropane

Chlorobenzene

1,1,1,2-tetrachloroethane

Bromobenzene

1,1,2,2-tetrachloroethane

1,2,3-trichloropropane

2-chlorotoluene

4-chlorotoluene

1,3-dichlorobenzene

1,4-dichlorobenzene

1,2-dichlorobenzene

1,2,4-trichlorobenzene

Hexachlorobutadiene

1,2,3-trichlorobenzene

Benzene

Toluene

Ethylbenzene

p-xylene

0 -xylene

Styrene

Isopropylbenezene

n-propylbenzene

1,3,5-trimethylbenzene

tert-butylbenzene

1,2,4-trimethylbenzene

sec-butylbenzene

p-isopropyltoluene

n-butylbenzene

$\begin{array}{llllllll}\text { WTP } & \text { Well } & \text { Well } & \text { Well } & \text { Well } & \text { Well } & \text { Well } & \text { NYS } \\ \text { Effluent } & \text { No. } 4 & \text { No.6 } & \text { No. } 7 & \text { No.10 } & \text { No. 11 } & \text { No. 12 } & \text { Drinking } \\ \text { (F2) } & \text { (FD) } & \text { (FF) } & \text { (FG) } & \text { (F0) } & \text { (FP) } & \text { (F0) } & \text { Water Standard }\end{array}$
$\mu g / L$

ND

ND

ND

ND

ND

ND

ND

ND

ND

ND

ND

ND

ND

ND

ND

ND

ND

ND

ND

ND

ND

ND

ND

ND

ND

ND

ND

ND

ND

ND

ND

ND

ND

ND

ND

ND

ND

ND

ND

ND

ND

ND

ND

ND

ND

ND

ND

ND

ND

ND

ND

ND

ND

\section{ND}

ND

ND

ND

ND

ND

ND

ND

ND

ND

ND

ND

ND

1.1

ND

ND

ND

ND

ND

ND

ND

ND

ND

$$
8.7
$$

ND

ND

ND

ND

ND

ND

ND

ND

ND

ND

ND

ND

ND

ND

ND

ND

ND

ND

ND

ND

ND

ND

ND

ND

ND

ND

ND

ND

ND
ND ND

$\begin{array}{ll}\text { ND } & \text { ND } \\ \text { ND } & \text { ND }\end{array}$

ND ND

ND ND

ND ND

ND ND

ND ND

ND ND

ND ND

ND ND

ND ND

ND ND

ND ND

2.8 ND

ND ND

ND ND

ND ND

ND ND

ND ND

ND ND

ND ND

ND ND

ND ND

ND 0.8

ND ND

ND ND

ND ND

ND ND

ND ND

ND ND

ND ND

ND ND

ND ND

ND ND

ND ND

ND ND

ND ND

ND ND

ND ND

ND ND

ND ND

ND ND

ND ND

ND ND

ND ND

ND ND

ND ND

ND ND

ND ND

ND ND

ND ND

ND ND

ND ND
ND ND ND 5

ND ND ND $\quad 5$

ND ND ND 2

ND ND ND 5

ND ND ND 5

ND ND ND $\quad 5$

ND ND ND 5

ND ND ND 5

ND ND ND $\quad 5$

ND ND ND 5

ND ND ND 5

ND ND ND 5

ND ND ND 5

$\begin{array}{llll}0.7 & 4.2 & \text { ND } & 5\end{array}$

ND ND ND 5

ND ND ND 5

ND ND ND $\quad 5$

ND ND ND 5

ND ND ND 5

ND ND ND 5

ND ND ND 5

ND ND ND 5

ND ND ND 5

ND ND ND 100

ND ND ND 5

ND ND ND

ND ND ND $\quad 5$

ND ND ND 5

ND ND $\quad$ ND $\quad 5$

ND ND ND 5

ND ND ND 5

ND ND ND $\quad 5$

ND ND ND 5

ND ND ND 5

ND ND ND $\quad 5$

ND ND ND 5

ND ND ND 5

ND ND ND

ND ND ND 5

ND ND ND 5

ND ND ND

ND ND ND 5

ND ND ND 5

ND ND ND 5

ND ND ND 5

ND ND ND 5

ND ND ND

ND ND ND 5

ND ND $\quad$ ND $\quad 5$

ND ND ND 5

ND ND ND 5

ND ND ND $\quad 5$

ND ND ND 5 


\begin{tabular}{|c|c|c|c|c|c|c|c|c|}
\hline \multirow[t]{2}{*}{ Compound } & \multirow{2}{*}{$\begin{array}{l}\text { WTP } \\
\text { Effluent } \\
\text { (F2) }\end{array}$} & \multirow[t]{2}{*}{$\begin{array}{l}\text { Well } \\
\text { No. } 4 \\
\text { (FD) }\end{array}$} & $\begin{array}{l}\text { Well } \\
\text { No. } 6 \\
\text { (FF) }\end{array}$ & $\begin{array}{l}\text { Well } \\
\text { No. } 7 \\
\text { (FG) }\end{array}$ & $\begin{array}{l}\text { Well } \\
\text { No.10 } \\
\text { (FO) }\end{array}$ & $\begin{array}{l}\text { Well } \\
\text { No. } 11 \\
\text { (FP) }\end{array}$ & $\begin{array}{l}\text { Well } \\
\text { No. } 12 \\
\text { (FQ) }\end{array}$ & $\begin{array}{l}\text { NYS } \\
\text { Drinking } \\
\text { Water Standard }\end{array}$ \\
\hline & & & \multicolumn{3}{|c|}{$\mu \mathrm{g} / \mathrm{L}$} & & & \\
\hline Alachlor & ND & ND & ND & ND & ND & ND & ND & 2 \\
\hline Simazine & ND & ND & ND & ND & ND & ND & ND & 50 \\
\hline Atrazine & ND & ND & ND & ND & ND & ND & ND & 3 \\
\hline Metolachlor & ND & ND & ND & ND & ND & ND & ND & 50 \\
\hline Metribuzin & ND & ND & ND & ND & ND & ND & ND & 50 \\
\hline Butachlor & ND & ND & ND & ND & ND & ND & ND & 50 \\
\hline Lindane & ND & ND & ND & ND & ND & ND & ND & 0.2 \\
\hline Heptaclor & ND & ND & ND & ND & ND & ND & ND & 0.4 \\
\hline Aldrin & ND & ND & ND & ND & ND & ND & ND & 5 \\
\hline Heptachlor Epoxide & ND & ND & ND & ND & ND & ND & ND & 0.2 \\
\hline Dield rin & ND & ND & ND & ND & ND & ND & ND & 5 \\
\hline Endrin & ND & ND & ND & ND & ND & ND & ND & 0.2 \\
\hline Methoxychlor & ND & ND & ND & ND & ND & ND & ND & 40 \\
\hline Toxaphene & ND & ND & ND & ND & ND & ND & ND & 3 \\
\hline Chlordane & ND & ND & ND & ND & ND & ND & ND & 2 \\
\hline Total PCB's & ND & ND & ND & ND & ND & ND & ND & 0.5 \\
\hline Propachlor & ND & ND & ND & ND & ND & ND & ND & 50 \\
\hline $2,4,5,-T P$ (Silvex) & ND & ND & ND & ND & ND & ND & ND & 10 \\
\hline Dinoseb & ND & ND & ND & ND & ND & ND & ND & 50 \\
\hline Dalapon & ND & ND & ND & ND & ND & ND & ND & 50 \\
\hline Pichloram & ND & ND & ND & ND & ND & ND & ND & 50 \\
\hline Dicamba & ND & ND & ND & ND & ND & ND & ND & 50 \\
\hline Pentachlorophenol & ND & ND & ND & ND & ND & ND & ND & 1 \\
\hline Hexachlorcyclopentadiene & ND & ND & ND & ND & ND & ND & ND & 5 \\
\hline Di(2-ethylhexyl)Phthalate ${ }^{(2)}$ & ND & ND & ND & ND & ND & ND & ND & 50 \\
\hline Di(2-ethylhexyl)Adipate & ND & ND & ND & ND & ND & ND & ND & 50 \\
\hline Hexachlorobenzene & ND & ND & ND & ND & ND & ND & ND & 5 \\
\hline Benzo(A)Pyrene & ND & ND & ND & ND & ND & ND & ND & 50 \\
\hline Aldicarb Sulfone & ND & ND & ND & ND & ND & ND & ND & NS \\
\hline Aldicarb Sulfoxide & ND & ND & ND & ND & ND & ND & ND & NS \\
\hline Aldicarb & ND & ND & ND & ND & ND & ND & ND & NS \\
\hline Oxamyl & ND & ND & ND & ND & ND & ND & ND & 50 \\
\hline 3-Hydroxycarbofuran & ND & ND & ND & ND & ND & ND & ND & 50 \\
\hline Carbofuran & ND & ND & ND & ND & ND & ND & ND & 40 \\
\hline Carbaryl & ND & ND & ND & ND & ND & ND & ND & 50 \\
\hline Total Aldicarbs & ND & ND & ND & ND & ND & ND & ND & NS \\
\hline Glyphosate & ND & ND & ND & ND & ND & ND & ND & 50 \\
\hline Diquat & ND & ND & ND & ND & ND & ND & ND & 50 \\
\hline Ethylene Dibromide & ND & ND & ND & ND & ND & ND & ND & 0.05 \\
\hline Dibromochloropropane & ND & ND & ND & ND & ND & ND & ND & 0.2 \\
\hline
\end{tabular}

ND: Not detected at minimum detection limit.

NS: DWS Not Specified

Notes:

1. For compliance determination with NYSDOH standards, potable wells were analyzed quarterly during the year by $\mathrm{H}_{2} \mathrm{M}$ Labs, Inc., a NYS certified contract Laboratory.

2. The minimum detection limits for POC analytes are $0.5 \mu \mathrm{g} / \mathrm{L}$. Minimum detection limits for SOCs, Pesticides and Microextractables are compound specific and in all cases are less than the NYSDOH drinking water standard.

3. All concentrations contained in Table 2-6 are the maximum values reported by the contractor laboratory

4. Trace quantities of Di(2-ethylhexyl)phthalate were detected in the composite samples prepared from Welis 4, 6 and 7 . and Wells 10,11 and 12. All detected concentrations were less than one-half the NYSDWS. 
subject to Class V UIC permitting, a program was established to phaseout their use by redirecting these discharges into BNL's sanitary sewer. During 1996, major efforts were expended to eliminate discharges of potential industrial wastes to Class $\mathrm{V}$ wells and, where applicable, to close the wells. This project involved rerouting of floor and sanitary drains from Buildings $463,481,575$, $815,912,912 \mathrm{~A}, 913 \mathrm{~A}, 913 \mathrm{~B}, 913 \mathrm{D}, 913 \mathrm{E}, 914,922,925,927,928,929,960,961,962$, and 964 to the sanitary sewer system; they formerly discharged to either the BNL stormwater system or UIC wells. Reports containing the analytical results for these systems and describing the follow-up actions and proposed methods for closure were forwarded to the SCDHS in June 1997. SCDHS concurred in August 1997.

The UIC program also was evaluated as part of the 1997 EPA multimedia audit of the Laboratory; the review resulted in a preliminary Notice of Violation and pending Order on Consent. While many of the "industrial" Class V UICs were included on a lab-wide inventory provided to EPA in 1992, many drywells used to dispose of "clean" water were not (i.e., stormwater). In accordance with 40 CFR Part 144, all Class V UIC are permitted by rule, provided an inventory of these wells is on-file with the EPA. All wells which were not on the EPA inventory lost the permit by rule status, and consequently, became subject to the proposed Consent Order. The details of the Consent Order and follow-up actions are under review, and are being negotiated with the EPA.

\subsection{Toxic Substance Control Act (TSCA)}

\subsubsection{TSCA Program at BNL}

The use and disposal of specific substances, such as polychlorinated biphenyls (PCBs), is regulated under the Toxic Substance Control Act (TSCA). The requirements include labeling, inspections, record keeping, immediate notification, and cleanup upon discovery of spills, and proper disposal. In 1992, the Laboratory issued a Safety, Environment, and Administrative Procedures Manual (SEAPPM) for managing PCBs. This SEAPPM formalized BNL's policy and identified specific responsibilities to control PCBs in accordance with TSCA requirements. The ES\&HS Division maintains a database of PCB equipment in all Departments and Divisions to ensure proper tracking and record-keeping; it is updated from information supplied by the Departments and Divisions. In addition, the annual PCB Report for CY 1996, prepared in accordance with the requirements of TSCA, is retained on file at ES\&HS Division. A copy was sent to the DOE-Brookhaven Group on June 30, 1997.

The TSCA program was evaluated during the EPA multimedia audit. Several issues were raised which ultimately resulted in the issuance of a Notice of Non-Compliance. These included the use of PCBs in an other than totally enclosed manner, failure to dispose of PCB wastes within oneyear of date of generation and noncompliance with the thirty-day storage rule. All issues are being reviewed and discussed with the USEPA.

\subsection{NYSDEC Bulk Chemical Storage Registration}

Because improper storage and handling of hazardous substances are serious threats to New York's water supplies and to public safety, the New York State Legislature passed Article 40 of the Environmental Conservation Law (ECL), the Hazardous Substances Bulk Storage Act of 1986. This law required the NYSDEC to develop and enforce State regulations governing the sale, storage, and handling of hazardous substances to minimize leaks and spills. A closely related law, ECL Article 37 , requires the NYSDEC to issue a list of substances defined as hazardous.

The NYSDEC implemented these bulk storage laws for hazardous substances through five sets of Chemical Bulk Storage (CBS) regulations.

- 6 NYCRR 595 Releases of Hazardous Substances - Reporting, Response, and Corrective Actions.

- 6 NYCRR 596 Registration of Hazardous Substance Bulk Storage Tanks. 
- 6 NYCRR 597 List of Hazardous Substances.

- 6 NYCRR 598 Standards for Storing and Handling Hazardous Substances.

- 6 NYCRR 599 Standards for Constructing New Hazardous Substance Storage Facilities.

Owners of regulated storage tanks were responsible for registering these tanks with the NYSDEC by July 15, 1989. In accordance with Part 596, BNL submitted application forms to register Hazardous Substance Bulk Storage Tanks on July 13, 1989. The regulated tanks are used primarily to store water treatment chemicals. The NYSDEC issued a Registration Certificate in August 1989. In accordance with the NYS regulations, this certificate has been renewed every two years. The Laboratory submitted its most recent request for renewal to NYSDEC in June 1997. The application included revisions to reflect existing conditions; thus, four of the tanks previously included are no longer in service and one new tank was added. This tank is used to store sodium hydroxide at one of the potable wells and replaces a previous tank. The Certificate was issued by NYSDEC on July 3, 1997 and expires July 27, 1999.

\subsection{Resource Conservation and Recovery Act (RCRA)}

\subsubsection{Facility Upgrades}

Construction of the new Waste Management Facility (WMF) was completed in 1997. The facility consists of four separate buildings, including a hazardous waste storage facility (RCRA Building), a mixed-waste (hazardous and radioactive waste) storage facility (Mixed Waste Building), a radioactive waste processing and storage facility (Reclamation Building), and an administrative building (Operations Building). The Operational Readiness Review (ORR) was completed by DOE and BNL. All pre-start findings were addressed before operation began. WM began placing waste into the RCRA Building in October 1997, and intends to place waste into the Mixed Waste and Reclamation Building in the first quarter of CY1998. In addition, funding was secured for FY1998 to design and construct a Hot Cell for the Reclamation Building.

\subsubsection{RCRA Part B Permit (6 NYCRR Part 373 Permit) and RCRA Closure}

The two Part 373 Permits BNL received during 1995 remained active during 1997. The permit for the existing hazardous waste management facility (NYSDEC Permit \#1-4722-00032/00021-0) became effective on 04/05/95 and expires on 08/31/98. In the fall of 1996, planning was initiated to implement the Closure Plan for the existing facility as HWM moves to the new WMF in 1997. The RCRA Closure process applies to the hazardous-and mixed-waste-storage facilities, specifically buildings 483 (drum storage facility), 448 (labpack storage facility), 360 (ignitable labpack storage), 361 (ignitable labpack storage), 444 (mixed waste storage), and 368 (ignitable mixed waste storage). Closure is proceeding on schedule and the old hazardous waste management facility will be closed by $8 / 31 / 98$.

The Part 373 Permit for the new facility (NYSDEC Permit \#1-4722-00032/00102-0) became effective $07 / 13 / 95$ and expires on $07 / 12 / 05$.

\subsubsection{0-Day Accumulation Areas and Satellite Areas}

Training programs for generators of hazardous waste have played an important role in emphasizing regulatory compliance, as well as the importance in preventing pollution and minimizing waste. In 1997, training was given on a site-specific basis (generators were trained at the department or division's building). The training includes modules on identifying hazardous waste, satellite accumulation, preventing pollution, and minimizing waste. This training was well-received, and will continue to be provided annually. Additionally, for the convenience of the Laboratory's staff, a computer-based training module was developed for the RCRA generator- training course. Training on 90-Day Hazardous Waste Accumulation Area was given at each accumulation area for each 90-Day Area manager and his or her designee; this training also will be provided annually.

1997 BNL Site Environmental Report 2 - 31 


\subsubsection{Facility Audits}

EPA Region II conducted a comprehensive inspection of BNL in May 1997, reviewing several management areas, including RCRA compliance. Minor compliance concerns were noted and BNL is working closely with regulating authorities to address them by strengthening existing waste-management systems. In addition, the NYSDEC conducted a detailed RCRA compliance inspection in June and July of 1997. Again, they noted minor concerns that were fully addressed by BNL.

Waste Management Division (WMD) staff periodically participate in the Departmental and Divisional self inspection programs (Tier I Inspections) giving them a chance to interact with the staff and provide guidance on specific issues. Internal audits and inspections of 90-Day Storage Areas revealed an increased awareness of requirements and an increased level of compliance. Minor problems still occur at Satellite Areas.

Departments and Divisions conducted self-assessments of their ESH programs during 1997; ES\&HS Division assisted by developing an ESH Profile. HWM also provided a trend-analysis of waste generation, showing generation statistics for radioactive-mixed-hazardous-and industrial-waste. Additionally, a compliance summary was included in the ES\&H Profile.

\subsubsection{RCRA/TSCA Waste Moratorium}

BNL continues to operate the program for certifying nonradioactive hazardous wastes under a 1996 DOE approval. The program incorporates the use of analytical procedures for materials that can be representatively sampled, and standard survey techniques for difficult-to-sample materials. Release criteria were based on the EPA Practical Quantitation Limits (PQLs) for the analytical program, and the limits specified in DOE Order 5400.5 Table IV-1 (plus an activation check) for the survey program. Approval of this process, combined with the already approved Process Knowledge Certification program, enables BNL to determine whether wastes are nonradioactive, and to handle them accordingly.

\subsubsection{Pollution Prevention Program}

BNL's Waste Minimization and Pollution Prevention (Wmin/P2) Plan establishes the Wmin/P2 program. The plan combines the requirements for a Wmin Plan and a Pollution-Prevention Awareness Plan required under DOE Order 5400.1, and lays out a strategy for implementing a formal program at BNL. The plan also contains information on Waste Minimization accomplishments.

The pollution-prevention program at BNL focuses on identifying and using cost-effective opportunities to reduce waste. Such opportunities are identified by formal Pollution Prevention Opportunity Assessments (PPOAs), Waste Minimization Working Groups, and employee's suggestions. Funding for implementation is sought through the ES\&H Management Plan, the High Return on Investment Program, or through internal sources. In 1997, BNL's Wmin/P2 Program evaluated opportunities on waste batteries, fluorescent lights, oily rags and debris.

Specific examples of pollution prevention and waste minimization efforts for 1997 include the following:

- Construction of a new parts cleaning facility employing environmentally benign cleaning agents.

- Elimination of hazardous-waste generation at BNL's Vehicle Maintenance Shop.

- Use of nonhazardous substitutes for solutions containing mercury and lead.

\subsubsection{Liquid Waste Management}

Liquid chemical wastes generated during Laboratory operations are segregated by the waste generator and collected by the Waste Management Division (WMD) for temporary storage and off- 
site disposal. These wastes are packaged in accordance with Department of Transportation (DOT), EPA, NYSDEC and DOE regulations for licensed off-site disposal.

The WMD collects small quantities of low-level liquid radioactive waste from waste accumulation areas throughout the site. Depending on the radionuclides in the water and their concentrations, wastes are either directly solidified at the HWMF or processed at the WCF. Buildings where large volumes (up to several hundred liters) of low-level liquid radioactive waste are generated have dual waste handling systems. These systems are identified as 'radioactive' and 'potentially radioactive'. All radioactive liquids are collected for proper disposition through the WCF. Potentially radioactive liquid waste streams are sampled and analyzed. If the radionuclide concentrations in the liquid meet the DOE, SPDES and BNL criteria, it may be released to the sanitary waste system. Otherwise, the liquid is transferred to the WCF for processing and storage/disposal.

\subsubsection{Waste Disposal}

For FY 1997, BNL shipped the following quantities and types of waste off-site to DOE approved, licensed, treatment/disposal facilities:

- Hazardous Waste: 44.66 metric tons

- Mixed Waste: 17.73 metric toris

- Radioactive Waste: 268.8 metric tons

In addition, BNL processed 44,700 gallons of liquid low-level radioactive waste on-site.

\subsubsection{Federal Facilities Compliance Act (FFCA) Mixed Waste Site Treatment Plan}

The FFCA, passed by Congress in 1992, requires DOE sites to work with DOE and local regulatory agencies to develop plans to treat and dispose of mixed wastes. The plan must identify treatment technologies and disposal facilities, and include a schedule for their disposal.

The FFCA is updated annually by BNL to describe initiatives taken during the year to address problems with new and existing mixed wastes. One current initiative, proposed by BNL to the NYSDEC, is a comprehensive plan to deal with existing wastes that involves a Broad Spectrum Procurement process, identification of treatment options, and development of milestone timelines for specific mixed-waste streams.

\subsubsection{Mixed-Waste Inventory Report}

In 1997, BNL updated its Site Treatment Plan to reflect current mixed-waste inventory. BNL also responded to requests for other data from DOE on specific types of mixed waste (i.e. PCB mixed waste) to help schedule their treatment. These updates provide DOE with information on the types and quantity of mixed wastes in storage, progress made in treating them, and identifies problems in arranging for treatment.

\subsubsection{Comprehensive Environmental Response, Compensation and Liability Act (CERCLA)}

On November 21, 1989, BNL was irıcluded on the National Priorities List of the EPA's hazardous waste sites considered a high priority for cleanup under the federal Superfund Program known as CERCLA.

In 1991, BNL established the Environmental Restoration Division (ERD) to oversee the Laboratory's Superfund activities. It is ERD's responsibility to remediate areas of known contamination, and to identify, characterize, mitigate, and eliminate, as appropriate, other areas of potential contamination. 
In May 1992, an Interagency Agreement (IAG) came into effect among the DOE, the EPA, and the NYSDEC to insure compliance with CERCLA, the corrective action requirements of RCRA, the National Environmental Policy Act (NEPA), as well as corresponding New York State regulations. In particular, the IAG will insure that environmental impacts associated with past activities at BNL are thoroughly and adequately investigated so that appropriate response actions can be formulated, assessed, and implemented.

Before 1997, there were twenty-eight Areas of Concern (AOCs) at BNL, consisting of both active facilities, such as the STP, and the HWMF, and inactive facilities, such as former landfills, cesspools, and radioactive-waste storage tanks. After the discovery of the HFBR tritium plume, it was designated AOC twenty-nine in April 1997. The AOCs have been grouped and prioritized into Operable Units (OUs) and Removal Actions (RAs); the initial prioritization is documented in BNL's Response Strategy Document (RSD). The prioritization of response actions is a dynamic process, and is responsive to new characterization data, risk assessments, regulatory input, and public input. More detail on the Operable Units and Removal Actions are provided in Chapter 8.

The following are the highlights of accomplishments in 1997:

(1) Completion of free public water hookups to approximately 1,500 homes in NorthShirley and East Yaphank as a precautionary measure;

(2) Construction and operation of a groundwater cleanup system at the southern boundary that pumps and treats groundwater contaminated with common chemical solvents (OU III);

(3) Construction and operation of an air-sparging and soil-vapor-extraction cleanup system for soil and groundwater at a former Central Steam Facility oil spill (OU IV);

(4) Characterization of the HFBR tritium groundwater-contamination plume, then, construction and operation of a groundwater pump and recharge system along Princeton Avenue to hydraulically contain it, and elimination of the spent fuel pool as its continuing source by removing the spent-fuel rods and pumping out the pool's contents (OU III);

(5) Excavation, characterization, and backfilling of fifty-five unlined chemical/animal/glass holes from the Former Landfill area;

(6) Capping of the Interim Landfill;

(7) Public review and comment on the Remedial Investigation and Risk Assessment Report for OU I, which includes the radiological-contaminated soils at the former HWMF, and was subsequently finalized; and

(8) Submission of a pre-design report to DOE/EPA/DEC which evaluates alternatives to the removal action for cleaning up off-site groundwater contaminated with solvents (OU III).

The following summarizes the significant activities on the OUs and RAs by month for 1997:

January

Operable Unit I/VI: The draft Final Operable Unit I Feasibility Study and Proposed Plan was submitted to NYSDEC and USEPA.

Sampling of private wells for Ethylenedibromide (EDB) in the Weeks Avenue Area was completed by the SCDHS.

The draft Current Landfill 1996 Annual Environmental Report was submitted to the DOE, EPA, and NYSDEC.

Operable Unit III: BNL initiated a groundwater-characterization project for the tritium plume associated with the spent-fuel canal of the HFBR.

A Feasibility Study scoping meeting was held on $1 / 14 / 97$ with the DOE, EPA, NYSDEC, and BNL.

Operable Unit IV: The final Remedial Design for the air-sparging/soil-vapor-extraction system was submitted to DOE, EPA, and NYSDEC. 
Environmental Thermoluminescent Dosimeters (TLDs) were placed at the Sump Outfall Area of Building 650.

Groundwater monitoring was initiated for AOC 6.

Removal Action V: An In-Situ Air-Sparging pilot test was completed, and the draft report submitted to the EPA and NYSDEC.

\section{February}

Operable Unit I/VI: The draft Final Supplemental Characterization Report for the Chemical Holes was submitted by Argonne National Laboratory.

The Excavation Plan and Health and Safety Plan for the Chemical Holes were submitted to DOE, EPA, and NYSDEC.

Operable Unit III: The draft Remedial Investigation/Risk Assessment (RI/RA) Report was submitted to the EPA and NYSDEC. As part of the interim action for OU III, the SPDES equivalency package for the on-site south boundary groundwater treatment system was sent to the EPA and NYSDEC.

\section{March}

Operable Unit I/VI: The Certification (closeout) Report for capping the Former Landfill was submitted to the Administrative Record.

Operable Unit III: $\quad$ Five groundwater extraction wells were installed along the southern boundary. An action memorandum was updated to incorporate a sixth extraction well.

Operable Unit IV: The final Rernedial Design was submitted to DOE, EPA, and NYSDEC.

Operable Unit V: $\quad$ A draft Work/Quality Assurance (QA) Plan for a metals study of Peconic River sediments was submitted to the EPA and NYSDEC.

\section{April}

Operable Unit I/VI: A public notice was issued on the remediation of the Chemical Holes.

The final Evaluation of Alternatives Report was placed in BNL's

Administrative Record.

Operable Unit III: Additional off-site ground monitoring wells were installed.

Amended applications for Air and SPDES Equivalency permits incorporating the sixth extraction well were sent to the NYSDEC.

Removal Action III: Waste from Building 919 and 919A was solidified in preparation for offsite shipping and disposal.

Brookhaven Graphite Research Reactor:

Groundwater characterization was completed upgradient and downgradient of the Building 801 Sump.

\section{May}

Operable Unit III: The sixth extraction well was installed, along with sixteen new monitoring wells. The air-stripper tower for the extraction system was installed.

Operable Unit IV: An evaluation of impacts from the Removal Action V Recharge Basin on the groundwater of Building 650's Sump Outfall Area was presented to DOE.

A design to reroute stormwater runoff away from the Building 650 Sump Outfall was submitted to DOE in response to NYSDEC comments on the draft Interim Monitoring Program for AOC 6.

Operable Unit V: The Draft Closeout Report for Imhoff Tanks was submitted to DOE, EPA, and NYSDEC. 
Brookhaven Graphite Research Reactor:

Analytical data obtained just south of the 801 sump was transmitted to the DOE. A memorandum summarizing the status of the BGRR project was sent to DOE.

June

Operable Unit I/VI: The evacuation of the chemical/animal holes was initiated.

Operable Unit III: Thirty wells were installed as part of the investigation of the HFBR tritium plume.

Operation was started on the on-site south boundary groundwater-treatment system.

Removal Action V: Eight new permanent-monitoring wells and three piezometers were installed around the RA V recharge basin to monitor the HFBR tritium pump and recharge project.

July

Operable Unit III:

Groundwater sampling for cobalt-60 in the Building 830 area was completed.

Operable Unit IV: Groundwater monitoring wells were installed. The air-sparge wells and airsparge/soil vapor extraction wells were also completed in Remediation Area 2.

DOE-Environmental Measurement Laboratory completed an in-situ gamma spectroscopy survey of the Building 650 Sump Outfall area.

Removal Action III: The Building 481 Leaching Pit was closed out (backfilled).

Removal Action V: The Draft Supplemental Work Plan for on-site and off-site characterization was submitted to DOE.

Brookhaven Graphite Research Reactor:

A Baseline Change Proposal was processed under OU III to follow-up on additional groundwater characterization of the Pile Fan Sump.

\section{August}

Operable Unit IV:

Air-sparge-and soil-vapor-extraction wells were completed in areas 1 and 2 . Trenching and installing pipes for these wells also were completed.

Operable Unit V: Negotiations were finalized with BHG, EPA, and NYSDEC on the cleanupof the Peconic River.. This was presented to the Brookhaven Executive Round Table.

Removal Action V: Additional groundwater characterization of Sr-90 in the glass holes/former landfill area was completed.

\section{September}

Operable Unit I/VI: The Draft OU VI Final Feasibility Study was submitted to the EPA and NYSDEC.

Excavation and backfilling was completed of all Glass/Animal/Chemical Holes and Interim Landfill Pits. All excavated waste was sorted and processed.

Operable Unit III: A revised Remedial Investigation Report, incorporating the HFBR tritium plume, was submitted to the DOE, EPA, NYSDEC, and SCDHS.

Operable Unit V: $\quad$ Congressional staffs; Federal, state and county officials and citizen's advisory groups were briefed on the status of the Peconic River investigation. The OU V Feasibility Study was submitted to the EPA and NYSDEC. 


\section{October}

Operable Unit I/VI: A completed draft Close Out Report for the Chemical Holes was submitted to DOE, EPA, and NYSDEC. The Interim Landfill was capped.

Operable Unit III: The draft Operable Unit III Feasibility Study was submitted to BHG.

Operable Unit IV: The Air Equivalency Permit for the air-sparging/soil-vapor-extraction treatment system was approved by the NYSDEC.

Operable Unit V: The Riverhead Town Supervisor was briefed on the status of the Peconic River. Peconic River issues were presented to the SCDHS and the BNL oversight committee. Second and third organizational meetings were held on independent sampling of the Peconic River sediments. USEPA's Biological Technical Advisory Group toured the Peconic River.

\section{November}

Operable Unit III: Operable Unit V:
The HFBR Tritium Compilation Report was submitted to DOE. Independent sampling of the Peconic River sediments was completed.

\section{December}

Operable Unit I/VI: Nonhazardous/non-radiological soils from the chemical holes were disposed of off-site.

Operable Unit III: The draft Feasibility Study was submitted to EPA and NYSDEC.

\subsection{Superfund Amendments and Reauthorization Act (SARA) of 1986}

The SARA regulations require BNL to compile and submit Tier I (or the more detailed Tier II) reports to the State Emergency Response Commission (SERC), the Local Emergency Planning Committee (LEPC), and the responding fire organization. For BNL, the responding fire organization is the ES\&HS Fire and Rescue Group. Under Federal SARA regulations, BNL is required to submit the Tier II report only if requested by the SERC, LEPC, or Fire Rescue Group. In 1991, the SERC requested that BNL submit the Tier II report for 1990 and each year thereafter. The report lists the average and maximum daily amounts of each chemical on-site which exceeds the threshold listed in the current EPA List of Lists. The Tier II report for CY 1997 was sent in February 1998 to the Fire Response Group, and to the DOE-BHG office for transmittal to the SERC and LEPC.

Submission of Form R, the Toxic Chemical Release Inventory (TRI) Reporting Form to EPA is required by Section 313 of the Emergency Planning and Community Right-to-Know Act (EPCRA). This report gives the public information on releases of listed toxic chemicals in their communities, and provides EPA with release information to assist them in determining the need for future regulations.

In 1997, BNL did not meet the reporting date for submitting Form R.

EPCRA 302-303: Planning Notification

EPCRA 304: EHS Release Notification

EPCRA 311-312: *MSDS/Chemical Inventory

EPCRA 313: TRI Reporting

*Material Safety Data Sheet
YES [X] NO [] NOT REQUIRED [ ]

YES [X] NO [ ] NOT REQUIRED [ ]

YES [X] NO [ ] NOT REQUIRED [ ]

YES [ ] NO [ ] NOT REQUIRED [X] 


\subsection{National Environmental Policy Act}

Eighty-five projects were reviewed for compliance with 10 CFR 1021 in CY 1996. None required environmental evaluations, as they were deemed to be categorically excluded actions. An Environmental Impact Statement was initiated for the High Flux Beam Reactor.

\subsection{Federal Insecticide, Fungicide, and Rodenticide Act}

Brookhaven National Laboratory has two programs in which insecticides, herbicides, and pesticides are used. As per regulatory requirements, both users, the Biology Department and the PE Division, maintain a log of applications made, and a log of the inventory at each facility. Key personnel are trained and certified by the NYSDEC in handling and applying these chemicals.

Annual training is required to maintain their certification. The applicator's log books are available for inspection and verification by the regulatory agencies. Annual reports showing the types and quantities of pesticides used are submitted to the NYSDEC by each certified applicator.

\subsection{Endangered Species Act}

There were no new findings on endangered species in 1997. However, plans are being made to develop a Tiger Salamander Management Plan in concert with a Wildlife Management Plan; these are expected to be completed in 1998.

\subsection{National Historic Preservation Act}

No activities affected cultural or historic resources during CY 1997.

\subsection{Floodplain Management}

During 1997, no new constructions were contemplated near, or within, the 100-year floodplain. Upgrades of the STP which were restarted in November 1996, were completed in 1997. In redesigning this system, dewatering activities planned as part of the original construction project were dropped after adding wetwell and ejector pumps. Consequently, impacts to the 100-year floodplain were averted.

\subsection{New York Wild, Scenic, and Recreational River Systems Act}

The portion of the Peconic River that flows through BNL is classified as "Scenic" under New York's WSRRSA. During 1997, there were no new activities that would be impacted by the requirements of the WSRRSA. As previously stated, construction of the STP upgrades recommenced in November 1996, as authorized under a 1994 NYSDEC WSRRSA permit. This project included constructing dual-modular aeration-treatment tanks, blower building and interconnecting piping, sludge-pumping station, wetwell and ejector pumps, and replacing the chlorine disinfection system with a system relying upon UV light to control bacteria. This project also included an addition to the main control building, installation of two new generators, and electrical upgrades. The project was completed in October 1997.

\subsection{Protection of Wetlands}

Other than the STP upgrades discussed in Section 2.15, no activities during CY 1997 impacted the wetlands or their buffer zones.

\subsection{Environmental Compliance Audits}

\subsubsection{Integrated Safety Management Evaluation (ISME)}

The Integrated Safety Management Evaluation (ISME) was an in-depth examination conducted by the Office of Oversight in DOE's Division of Environment Safety \& Health (ES\&H) in February 
1997. It was designed to look at BNL's ES\&H, and those of the DOE organizations that oversee the Laboratory. Seven criteria or guiding principles were used to determine the findings and to develop recommendations for BNL:

Line Management Responsibility;

Roles and Responsibilities;

Competence Commensurate with Responsibilities;

Balanced Priorities;

Identification of Requirements;

Hazard Control, and

Operations Authorization.

The principal findings concerned environmental radiation protection, and protecting the surface water and groundwater.

Brookhaven National Laboratory developed a detailed plan - BNL's Management Systems Improvement Project (MSIP) - that outlined specific actions to be taken, together with associated costs, schedule and management information. To implement this plan, AUI established an external ES\&H management-improvement team, which included representatives from other national laboratories and industry. BNL also revitalized and reconstituted its ES\&H management Advisory Group by co-opting senior managers and representatives from DOE, NYSDEC, SCDHS, and the EPA. A communications plan was developed to assure public involvement.

\subsubsection{EPA Multimedia Audit}

EPA Region II Office in May 1997 announced that they would begin a compliance audit of BNL. They looked at air emissions, water discharges, underground storage-tanks, hazardous-waste storage, handling and disposal of chemical wastes, spill prevention, toxic-substances management, radiation controls, emergency planning, underground injection-wells, toxic-release inventory, and community's right-to-know requirements.

After this audit, EPA issued the following violations: two for the underground injection control program; four of the CAA; four of TSCA PCB; and five of RCRA. However, the report also emphasized that none of them posed an immediate threat to workers, the environment, nor public health.

Because DOE and BNL had worked closely with EPA during the audit, many of the issues have been corrected, or plans are in place to resolve them. The EPA also reiterated what DOE found in its earlier ES\&H review, that the Laboratory's management systems need to be strengthened.

BNL began the second phase of this multimedia review by minimizing the amount of waste produced and reducing emissions. The third phase, a review of environmental management issues at the Laboratory is expected to begin next year. These efforts, combined with the MSIP now being undertaken by the Laboratory's top administration and the DOE's 30-Day Action Plan, will improve environmental management at BNL.

\subsubsection{Gilbert Hill Associates Audit of the Analytical Laboratory}

At the request of the DOE headquarters, David L. Baldwin, Staff Scientist, PNNL, and Charles W. Miller, Principal Scientist, Gilbert Hill Associates, made an independent technical assessment of tritium data generated during the HFBR plume characterization. This assessment included a site visit to BNL on April 2-4, 1997, staff interviews, review of published data, review of the Laboratory's quality assurance and quality control data for about 70 batches of water samples analyzed for tritium activity, as well as numerous follow-up discussions, feedback, and comments from BNL staff. The assessment reached the following conclusions: 
a. There was a lack of reliability in selected batches of samples due to incomplete or inadequate quality-control (QC) and poor precision on selected reruns;

b. Some routine analyses reported during the period failed to meet a selected criterion of $10 \%$ Relative Percent Difference.

They identified specific batches of samples by date for critical assessment and possible reanalysis.

A final report was submitted on May 7, 1997, presenting the results of the technical data quality assessment and recommendations for corrective actions. Detailed information on this audit is given in their final report: "Assessment of Tritium Analytical Data at Brookhaven national Laboratory/Analytical Services Laboratory, dated May 7, 1997". A corrective plan was developed to address these findings. 


\section{Chapter 3}

\section{ENVIRONMENTAL PROGRAM INFORMATION}

\subsection{Environmental Program Elements}

Brookhaven National Laboratory is committed to environmental compliance and accountability. To evaluate BNL's impact on the environment, the Laboratory developed an environmental monitoring program that is designed to address the following issues:

- Evaluate the impact of Laboratory operations on the environment;

- Design and operate a program for assessing radiation exposures resulting from environmental releases;

- Determine trends in environmental radiological and nonradiological levels; and,

- Address government and public concerns about site operations.

\subsubsection{Environmental Regulations}

The BNL environmental monitoring program is designed to ensure that human health is adequately protected, to reflect environmental stewardship, and to verify that state and federal regulatory requirements for radiological and nonradiological programs are met. These requirements are stated in DOE Order 5400.1 (General Environmental Protection Program) and 5400.5 (Radiation Protection of the Public and the Environment), NESHAP, CERCLA, RCRA, CAA, SDWA, CWA, TSCA, and in NEPA. Compliance is monitored by USEPA, NYSDEC, NYSDOH, SCDHS, and by the DOE. Brookhaven National Laboratory's compliance activities for CY1997 are discussed in Chapter 2.

\subsubsection{Program Objectives}

The objectives of BNL's environmental monitoring program incorporate the requirements of DOE Order 5400.1, "General Environmental Protection Program," DOE/EH-0173T, "Environmental Regulatory Guide for Radiological Effluent Monitoring and Environmental Surveillance," and other applicable regulations. These objectives include the following:

- Assess actual or potential exposures of critical groups and populations to radioactive and nonradioactive materials resulting from normal operations or from accidents;

- Ensure that air and water discharges comply with authorized limits and regulatory requirements;

- Verify the adequacy of effluent controls in facilities;

- Notify proper officials of unusual or unforeseen conditions and, where appropriate, activate monitoring or remediation programs;

- Accurately communicate results of environmental monitoring and surveillance to DOE, other government agencies, and the public;

- Maintain an accurate, continuous record of the impact of the BNL operations on the environment;

- Determine concentrations of radioactive and nonradioactive-contaminants in environmental mediamedia to assess the immediate and long-term consequences of normal and accidental releases;

- Establish a baseline of environmental quality to characterize trends in the physical, chemical, and biological condition of environmental media;

- Evaluate and revise the environmental monitoring program in response to changing conditions dictated by facility operations and the results of environmental analyses; 
- Provide site-specific data for use in assessing risk to human populations near BNL;

- Identify and quantify new or existing problems in environmental quality and evaluate the need for remedial actions or mitigating measures; and

- Pinpoint exposure pathways in which contaminants are accumulated and transmitted to the public.

To meet these objectives, approximately 6,000 samples were collected and nearly 100,000 analyses were performed as part of the routine environmental monitoring programs during 1997. Additional samples were collected and analyzed (approximately 2,000 and 10,000, respectively) to characterize the nature and extent of the HFBR tritium plume.

\subsection{Program Organization}

The environmental protection initiatives discussed above are coordinated by three Laboratory organizations: the Environmental Restoration Division, the Environment, Safety and Health Services Division, and the Waste Management Division.

\subsubsection{Environmental Restoration Division}

The Environmental Restoration Division (ERD), formerly known as the Office of Environmental Restoration, was established in response to the BNL site being placed on the National Priority List (NPL) on November 21, 1989. The NPL is a list of hazardous waste sites that are considered high priority for cleanup under the federal Superfund Program, officially known as the CERCLA. BNL is one of 22 Superfund sites on Long İsland. In May 1992, an IAG between the DOE, the USEPA, and the NYSDEC became effective to insure compliance with the CERCLA, the corrective action requirements of the $\mathrm{RCRA}$, the $\mathrm{NEPA}$, as well as corresponding NYS regulations. In particular, the IAG was established to ensure that environmental impacts associated with past activities at BNL are thoroughly investigated and that appropriate response actions can be formulated, assessed, and implemented. It is mandated that all environmental restoration actions have the approval of the IAG signatories. The ERD has prime responsibility to remediate areas of known contamination, and identify, mitigate, and eliminate other areas of potential contamination. In this process, the ERD identifies areas of concern, prionitizes them, conducts Remedial Investigation/Feasibility Studies (RI/FSs), conducts characterization studies, identifies preferred remediation processes, and prepares a final Record of Decision (ROD) on the area of concern. When the preferred remedial alternative is approved by the IAG signatories, the ERD designs and implements remedial action and initiates programs for operating and maintaining the areas. Throughout this process, the ERD maintains an active, integrated public-involvement program.

\subsubsection{Environment, Safety and Health Services Division - Environmental Protection Office}

The ES\&HS Division's Environmental Protection Office (EPO) assists and advises the Laboratory in all areas of regulatory compliance, and prepares and submits compliance reports and permit applications to the regulatory agencies. This Office also provides technical oversight and assistance in conducting environmental monitoring and reviewing data for determining the impact on the environment from Laboratory operations. Reports based upon the review and assessment of the environmental data are disseminated to $\mathrm{BNL}$, the DOE, and regulatory agencies. The Office also is responsible for preparing the annual Environmental Monitoring Plan (EMP) that outlines the sampling program conducted by the ES\&HS Division and the ERD. The EMP specifies the required environmental sample locations, media, frequencies, and analyses. The Office also reviews plans for construction projects to identify potential environmental impacts and regulatory requirements. These environmental reviews are undertaken for new construction projects, as well as for modifications to existing facilities to assure that environmental protection requirements are satisfied, and that all necessary regulatory permits are obtained. Approximately 100 
projects were reviewed during CY 1997. Several members of the EPO are emergency responders, and are on 24-hour call in the event of a spill at BNL.

The EPO's Field Sampling Team is responsible for collecting environmental samples and submitting them to the ASL for radiological and non-radiological-analysis. The Team also responds to emergency situations where environmental sampling is required, and undertakes special sampling tasks for other BNL organizations.

\subsubsection{Waste Management Division}

The Waste Management Division (WMD) is responsible for the safe handling and disposal of all radioactive, hazardous, and mixed-wastes generated at BNL. During most of 1997, waste materials continued to be transferred to the HWMF for processing, storage, packaging, and preparation for off-site disposal. Starting in December 1997, waste management operations were transferred to a new centrally located WMF. This state-of-the-art facility contains separate buildings designed to safely store and package each type of waste. All waste material is properly tracked, and the final disposition is fully documented in accordance with applicable regulations. In addition to maintaining waste-storage facilities, the WMD supports BNL's hazardous waste management program in the following areas:

- Regulatory Compliance Program;

- Waste Minimization and Pollution Program;

- Quality Assurance Program;

- Training and Procedures Program; and,

- Special sample analyses.

\subsubsection{Supporting Groups}

The ES\&HS Division's Instrumentation and Calibration Group maintain monitoring equipment located in facility stacks and liquid-effluent systems. The assigned QA staff oversees the functions of the EPO in terms of the directives on QA pertaining to environmental sampling, analytical processes, and documentation, which include reviews of data. The Analytical Services Laboratory performs radiological and nonradiological analyses on most environmental surveillance samples (non-CERCLA).

\subsection{Regulatory Agency Monitoring Program}

The NYSDOH monitors the ambient-air quality on-site, and the NYSDEC participates jointly with BNL in the aquatic-and terrestrial-radioecological sampling. Samples collected under these joint programs are analyzed by these agencies, and the data are published in their departmental annual reports. In 1997, the SCDHS established an office on-site to closely monitor BNL's environmental protection activities.

\subsection{Environmental Programmatic Changes in 1997}

In 1997, the Laboratory initiated the following new programs to support the Site Environmental Monitoring Program, and the Environmental Restoration Program:

Brookhaven National Laboratory, in conjunction with the NYSDEC, expanded its surveillance program of the Peconic River. In addition to extending sampling in the river and adjoining freshwater bodies (started in 1995), sampling and radioactive analyses of clams, mussels, sediments, and seawater from the Peconic Estuary and other areas along the coast line (which serve as background locations as they are not influenced by the Peconic River's flow) were continued in 1997. Sampling enables the Laboratory to examine the potential impact on the estuarine and marine fauna of BNL releases through the intermittent Peconic River's off-site flow, ultimately reaching Peconic Bay at the river's mouth. The ERD also started special sampling of the Peconic River for 
nonradiological parameters after finding mercury and PCBs in the sediment from the Peconic River on-site.

As part of the ongoing restoration and facility monitoring programs, additional groundwater monitoring and remediation wells were installed. Over 75 new permanent monitoring wells were installed in the HFBR, BMRR and BGRR areas. During 1997, the BNL ERD made significant progress in its ongoing efforts to characterize and remediate contaminated soil and groundwater resulting from past spills, releases and disposal practices.

\subsection{Special Projects}

\subsubsection{High Flux Beam Reactor Tritium Investigation}

In January 1997, tritium was detected at concentrations that exceeded federal drinking water standards in a monitoring well located immediately south (downgradient) of the HFBR. The presence of tritium at nearly twice the drinking water standard resulted in an intensive 60-day campaign to identify the source of the tritium, characterize the extent of the contamination, and install a groundwater pumping system at the leading edge of the tritium plume. The tritium plume was delineated by the installation of over 120 temporary groundwater characterization wells, 70 permanent monitoring wells, and two horizontal wells that extend beneath the HFBR. BNL was able to characterize the tritium plume and begin pumping from the leading edge of the plume within 60-days. In addition to the groundwater investigation, BNL conducted an intensive evaluation of all HFBR components that had the potential to release tritium into the environment. As a result, the HFBR's Spent Fuel Pool was found to have been leaking at a rate of 6 to 9 gallons per day, and was determined to be the primary source of the tritium detected in the groundwater. Details on this investigation were summarized in several published reports prepared by the DOE, the US General Accounting Office (GAO), and BNL.

\subsubsection{Facility Review Project}

In the spring of 1997, BNL began a comprehensive examination of site facilities to identify any past or current activities that have the potential to degrade the environment. The operating history of each building (both existing and previously demolished structures) was obtained: to identify environmental vulnerabilities (i.e., potential contaminant release sites), and to recommend corrective actions, as needed.

This effort was an important element of BNL's and DOE's comprehensive plan to delineate, characterize, and remediate environmental issues at the Laboratory site. The findings will be used to develop strategies for making operational changes that will reduce the potential for future environmental impacts. To ensure long-term protection, review of BNL operations will be coordinated on an ongoing basis with the U.S. Environmental Protection Agency, the New York State Department of Environmental Conservation, and various Suffolk County agencies.

The Facility Review Project was coordinated by the Environment, Safety and Health Services (ES\&HS) Division. This extensive effort involved all Laboratory organizations, particularly the Environmental Restoration Division (ERD), the Plant Engineering Division (PE), and the Department of Advanced Technology (DAT); extensive support was provided by the Department of Energy (DOE). The Chief, Office of Water Resources, from the Suffolk County Department of Health Services (SCDHS) actively participated in the planning and review of the project. In addition, SCDHS inspectors and engineers took part in the physical examinations of the buildings.

All buildings and structures were categorized as either a Priority One or Priority Two Facility. This grouping of the buildings was based primarily on previous uses and age of the facility. In particular, because of public concerns about radioactivity, facilities, which used or generated significant quantities of radioactive material during the 1950 s and 1960s, were selected for Priority One consideration. This period was selected since the more modern environmental regula- 
tions and standards were developed in the 1970s. All other Laboratory buildings were considered Priority Two Buildings.

The program managers of each Building were responsible for conducting each facility review. Every organization was responsible for reviewing the facility's design and layout drawings, inspection reports, safety analysis reports, annual Site Environmental Reports, and other pertinent documents, such as operating, reports and log books. Current and former employees with knowledge of the operations or practices over the operating history were interviewed. Extensive walk-downs and examinations of the interior and exterior of the facilities were also performed.

To ensure the timely completion of this review, BNL technical staff were supplemented with staff from the following institutions: the Pacific Northwest National Laboratory (PNNL); Pantex; Lawrence Berkeley National Laboratory (LBNL); Lawrence Livermore National Laboratory (LLNL); Idaho National Engineering and Environmental Laboratory (INEEL); Princeton Plasma Physics Laboratory (PPPL); Argonne National Laboratory (ANL); Fermi National Accelerator Laboratory; and, the Oak Ridge National Laboratory (ORNL).

The Interim Report for Priority One Buildings was issued on September 9, 1997 (Royce, 1997) and the Interim Report for Priority Two Buildings was issued on December 3, 1997 (Royce and Collins, 1997). Thirty-five "Significant" findings were reported in the Priority One and Two Reports. The interim reports also identified findings of lesser potential impact. Issues that were deemed "lesser" had the potential to contaminate the groundwater, but at levels below the drinking water standards. A significant finding was defined as a potential environmental vulnerability where there is, or was, a possibility for chemical or radiological releases that would result in concentrations of contaminants above either soil or drinking water standards. The significant findings identified in the Priority One Interim Report are summarized in two broad categories: underground sumps, tanks, lines and ducts; and historic discharges of solvents, oils and mercury. Some of the most serious findings were the sumps identified at the BGRR. The significant findings identified in the Priority Two Interim Report are summarized in two broad categories: underground tanks, pipes, pits and sumps; and cesspools and drywells. Corrective action plans were developed for each of them. Significant progress has been made at eliminating or reducing the potential for environmental impact from them. Implementation of the corrective actions will remain a high priority until they are completed.

\subsection{Waste Minimization and Pollution Prevention Programs}

The BNL Waste Minimization and Pollution Prevention (Wmin/P2) Plan establishes the Wmin/P2 program. The plan combines the need for separate Waste Minimization and Pollution Prevention Awareness Plans required under DOE Order 5400.1, and lays out a strategy for implementing a formal waste-minimization and pollution-prevention program. Since initiating this program in 1995 , DOE has realized a payback of about $\$ 8$ for each $\$ 1$ invested and has seen most projects pay for themselves in less than three years. The plan also discusses Waste Minimization accomplishments.

The Wmin/P2 program focuses on identifying and implementing cost-effective opportunities for waste reduction. Such opportunities are identified by formal Pollution Prevention Opportunity Assessments (PPOAs), Waste Minimization Working Groups, and employee's suggestions. Funding for implementation is sought through the ES\&H Management Plan, the High Return on Investment Program, and internal sources. Since 1995, BNL received about $\$ 1,000,000$ in grants covering about a dozen $\mathrm{Wmin} / \mathrm{P} 2$ projects. In 1997, the following Wmin/P2 projects were implemented:

I. As a result of a PPOA of Photographic Waste completed in 1995, BNL applied for, and was awarded, funding from the High Return on Investment program, to convert much of the traditional wet-photographic processes in Photography and Graphic Arts to digital processes. (This was considered as the largest routine hazardous-waste stream.) Al-

1997 BNL Site Environmental Report $3-5$ 
though this investment required an initial outlay of about $\$ 350,000$, nearly $\$ 130,000$ in reduced waste management costs was realized in the first year. The project was implemented in 1996, and has reduced the quantity of hazardous waste by over 60 percent in 1997.

II. A proposal to fund the recommendations of the PPOA of AGS low-level radioactive wastewater (conducted in 1995) was submitted to the High Return on Investment program. The project seeks to retrofit or replace ion-exchange vessels to allow resins to be easily removed and disposed of as LLW instead of regenerating them. Its adoption will significantly reduce LLW water, cutting 15,000 gallons of radioactive waste annually.

III. An activated metal-waste-compactor for the AGS LLW stream was purchased through the High Return on Investment program. This opportunity, identified by the Wmin/P2 Working Group in AGS, will significantly reduce the volume of the active-metal waste stream (the largest LLW stream at BNL), saving BNL $\$ 170,000$ and 1,600 cubic feet of LLW waste per year.

IV. The PPOA of the NSLS Acid Cleaning process successfully developed a new process that uses ultrasonic cleaning and mild organic acid and detergent-based cleaning solutions. Construction of the new Centralized Degreasing Facility was completed in 1997. The process eliminates the use of hydrofluoric and nitric acids. Chemical analysis of the contents of the cleaning baths show the liquids to be nonhazardous. In addition, this process does not require any environmental permits, is significantly safer for workers, and is expected to save $\$ 5,000$ in the first year of operation.

V. Hazardous waste production by the BNL's vehicle maintenance facility was completely eliminated.

VI. Nonhazardous substitutes were used to replace solutions containing lead and mercury in scientific work and fabrication processes.

VII. In 1997, the Riverhead School District began a white-paper recycling program based on suggestions made in 1996 by BNL and DOE. BNL's staff, working with the school district's administration and facilities maintenance staff, went "dumpster diving" to characterize the amounts and types of potentially recyclable materials that the schools were throwing away. This has resulted in savings for the District in trash hauling expenses.

VIII. BNL joined forces with the Suffolk County Water Authority (SCWA), New York Institute of Technology, State University of New York at Stony Brook, Polytechnic University, Rhode Island Center for Pollution Prevention, and New York State Department of Environmental Conservation's Pollution Prevention Unit to form the Long Island Pollution Prevention Partnership. Under a grant from EPA, SCWA managed the partnership's "Students and Industries for Pollution Prevention" project, in which 25 college students learned pollution-prevention techniques and conducted free pollution-prevention assessments for local and businesses and industry.

\subsection{Public Outreach}

1997 was marked by heightened public awareness of BNL operations because of the discovery of the HFBR tritium leak. The DOE and BNL established various communication programs aimed at informing the public, responding to feedback about groundwater contamination, and responding to the news media to ensure timely, accurate, and consistent distribution of information.

As part of BNL's environmental program, the ES\&HS Division, the ERD, and the Community Involvement, Government and Public Affairs Division engage in routine public-outreach activities. Many BNL staff members participate in public meetings, civic-organization briefings, the Speakers Bureau, tours and educational programs, all of which encourage public interaction with 
the Laboratory. Print and broadcast media, as well as the Brookhaven Bulletin, are the traditional communication channels used to inform on-site staff and the public about environmental activities. Due to mounting public interest in BNL activities, BNL conducted public tours of the research and support facilities, held public forums on groundwater quality and protection, and on the planned facility improvements at the Sewage Treatment Plant. The Laboratory also hosted meetings on Pine Barrens research and pollution-prevention, sponsored jointly by BNL, state, and local governmental agencies. The BNL home page was expanded to include additional environmental information.

The newly formed Community Work Group also served as a focal point for discussions on a range of environmental issues. The environment was also the main focus of the BNL "Summer Sunday" public tour program, and BNL also presented exhibits at the Pine Barrens Discovery Day. Through the Community Summer Science Program, local high-school students assisted in research on the Pine Barrens ecosystem on BNL's site. In 1997, approximately 24,250 people visited BNL.

\subsection{Environmental Audits}

Several audits, assessments, and appraisals of environmental functions were conducted in 1997:

- Immediately following the discovery of the HFBR tritium plume in January 1997, the DOE's Office of Oversight conducted a Safety Management Evaluation (ISME). The ISME consisted of an in-depth examination of BNL operations in the area of ES\&H (DOE, 1997b). They looked at BNL's activities, and those of the DOE organization that oversees the Laboratory. The Office of Oversight also performed two other reviews that specifically addressed DOE and BNL efforts to identify the source of the tritium leak and mitigate the tritium plume. These efforts were documented in two reports, the "Interim Evaluation of Tritium Plume Recovery Activities at BNL" and "Status of Groundwater Tritium Plume Recovery Activities at BNL," which were completed in February and October 1997, respectively (DOE, 1997a; DOE, 1997d). In July 1997, BNL submitted a detailed Implementation Plan that outlined specific actions to be taken to address the ISME findings (DOE, 1997).

- As a follow up to the ISME report, the Laboratory Director appointed a committee to review the Laboratory's decision-making process in addressing ES\&H issues. The committee was headed by Robert Bari, Chair of BNL's DAT, and included a representative from the SCDHS. The committee's recommendations discussed the need for clearer management roles and responsibilities at the Laboratory, addressed how funds are allocated for ES\&H projects, how these projects are ranked, how the laboratory considers community sensitivities and regulatory commitments, and the benefits of instituting a comprehensive, proactive site-wide hazards assessment and control system (Bari et al., 1997).

- In May 1997, USEPA Region II announced that they would conduct a multimedia compliance audit of the BNL site. The audit looked at air emissions, water discharges, underground storage-tanks, hazardous-waste storage, handling and disposal, spill-prevention, toxic-substance management, radiation controls, emergency planning, underground injection-wells, toxic-release inventory, and the community's right-to-know requirements. EPA cited DOE in four environmental programs areas: RCRA; TSCA, principally PCBs; Underground Injection Control (UIC); and CAA. During the EPA inspection, DOE and AUI immediately corrected. RCRA deficiencies, and since then, have corrected all RCRA deficiencies identified in the EPA enforcement action through improved management of hazardous waste at points of generation in those facilities cited, including an improved procedure for labeling and storage. TSCA violations were addressed by removing improperly stored wastes. The DOE and the Laboratory are preparing an inventory of unpermitted UIC wells, including cesspools and storm drains. Clean Air Act findings are being addressed through improved operating and reporting procedures for asbestos 
projects, boilers and monitoring equipment, and labeling of service-station gasoline pumps to warn against overfilling tanks.

- In response to a request from Congressional Science Committee Chairman Sensenbrenner and ranking Democrat Brown, the General Accounting Office issued a report that reviewed the circumstances that led up to the January 1997 discovery of a tritium leak from BNL's HFBR Spent-Fuel Pool, and subsequent actions taken by the DOE and BNL (GAO, 1997).

- DOE took the first step toward a formal environmental review of the HFBR by issuing a Notice of Intent to prepare an Environmental Impact Statement for public review and comment. The review, which will take approximately one year to complete, will define the environmental and public-health-impacts of various alternatives for the future of the reactor which is used for advanced research in solid-state physics, nuclear physics, materials technology, structural biology, medicine, and chemistry.

- In October 1997, DOE reviewed BNL's ES\&H and Infrastructure Prioritization Program. This review was carried out by the DOE's Energy Research Department (ER-81) and focused on evaluating the process BNL established for prioritizing projects to determine if the funding plan adequately addressed critical ES\&H activities. Earlier in 1997, BNL had established a new review process to prioritize work activities and to ensure that those related to environment improvements were given the appropriate recognition and support via a risk-ranked score. The review team included environmental regulators with oversight responsibilities at the site.

- In December 1997, DOE cited AUI for several significant regulatory violations of nuclear safety rules identified in June 1997, and issued a preliminary notice of violation to assure that the problems are corrected. While the actual individual consequences were not serious, DOE found that when combined they reflected a trend of noncompliance with regulatory and $B N L$ procedural requirements. AUI was required to respond to this notice by documenting actions taken or planned to prevent recurrence of problems.

The findings from the assessments discussed above are being tracked and reported to the appropriate level(s) of management.

\subsection{Site Environmental Performance Measures Program}

At the start of Fiscal Year (FY) 1996, DOE implemented a new Prime Contract with Associated Universities, Inc. (AUI) which contained several performance measures on environment, safety, and health. The measures were implemented contractually by Articles 6 and 7, with Appendix B to the contract containing the actual Performance Objectives, Criteria, and Measures. DOE, AUI, and BNL developed them by reviewing past experience and operations at the Laboratory. The following summarizes the performance measures associated with BNL's environmental protection activities in CY1997:

\subsubsection{Waste Generation Reports}

- Hazardous Waste: Figure 3-1 shows the hazardous waste generation (in metric tons) for CY 1993 to CY 1997. It includes routine hazardous waste, non-routine hazardous waste, and TSCA (or PCB) waste. Routine waste is defined as waste from ongoing operations. Examples of generation of non-routine waste are from construction, demolition, and environmental restoration. The routine waste-streams are those that BNL can reduce using pollution-prevention techniques.

The chart shows that BNL reduced the generation of hazardous waste by $54 \%$ from 1993 through 1997. The Pollution Prevention program aggressively targeted hazardous wastes that are particular problems for the site. An example is the targeting of the solvent TCA, 
a common groundwater pollutant on Long Island. Since 1990, BNL has reduced generation of TCA by $99 \%$ (Figure 3-2).

- Low Level Radioactive Waste: Figure 3-3 shows the generation of low-level radioactive waste (LLW) (in cubic feet) for CY 1993 through 1997. LLW is tracked as four waste streams; routine liquid and solid, and non-routine liquid and solid. The routine waste is from ongoing operations, while the non-routine waste is as defined above. Routine generation of LLW fluctuates considerably. The variability can often be traced to specific research activities or projects. The generation of non-routine LLW rose sharply in 1996 and the increase is expected to continue as the environmental restoration of BNL proceeds from the investigation phase to the cleanup phase. The routine LLW stream (both liquid and solid) has been targeted for reduction by the BNL Pollution Prevention program since 1995. Major investments were made in 1997 that should help BNL reduce the volume of routine LLW requiring disposal. These include the use of disposable resins and procurement of a metal waste compactor. It is anticipated that this waste stream will continue to rank high for future pollution prevention funding.

- Mixed Waste: Figure 3-4 shows the production of mixed waste (hazardous waste mixed with low-level radioactive waste), in cubic feet, for calendar year 1993 through 1997. Mixed waste is tracked as routine and non-routine waste. BNL reduced generation of routine mixed waste by approximately $67 \%$ from 1993 through 1997 . The BNL Pollution Prevention program continues to target mixed waste for opportunities due to the difficulty and cost of its disposal. The rates of non-routine generation are related to environmental restoration projects, specifically, the removal of storage tanks and disposal of mixed-waste sludge held therein.

- Industrial Waste: Figure 3-5 shows the metric tons of industrial waste (principally photographic wastes) generation (measured in pounds) for calendar year 1993 through 1997; it represents over $60 \%$ in reduction of photographic wastes.

\subsubsection{SPDES Compliance}

Another Performance Measure initially established in 1996 was compliance with SPDES parameters as an indicator of satisfactory performance. A ranking scheme was developed associating a numerical score with a SPDES permit excursion; the sum of individual scores for the year is used to determine overall performance. For example, the score for a specific SPDES excursion is determined as follows: 1) the specific inorganic or volatile organic pollutant is first evaluated for toxicity, with toxic elements being assigned a higher score than nontoxic elements; 2 ) the ratio of the concentration relative to the SPDES limit is evaluated, with discharges of high concentration being assigned a higher score; and 3) repeat offenses are penalized heavier (i.e., given more points). Considering the permit excursions detailed in Chapter 2, the total score for 1997 was 65, which placed the SPDES performance measure in the "Marginal" category. However, the 1997 performance is biased low due to persistent iron exceedances that occurred during the summer. As described in Chapter 2, the iron excursions were attributed to construction activities. Excluding these iron excursions, the score for 1997 could be recalculated to be 19 , which would categorize this performance indicator as "Excellent".

\subsubsection{Solid Waste Sent to Landfill}

The amount of solid waste sent to the off-site landfill is a general indicator of the effectiveness of waste-minimization and material-recycling efforts. For 1997, BNL sent 866 tons of solid waste to the landfill which is considered a "Marginal" level of performance. This measure is flawed because it does not take into account the amount of programmatic or operational activity that occurs on-site. That is, the measure is not adjusted if on-site activity is higher or lower. Additional programs, such as a new mixed-paper recycling program and reminders to employees to recycle, have improved BNL's recycling program. BNL will continue its recycling efforts, as well as look for additional opportunities to reduce solid waste. 


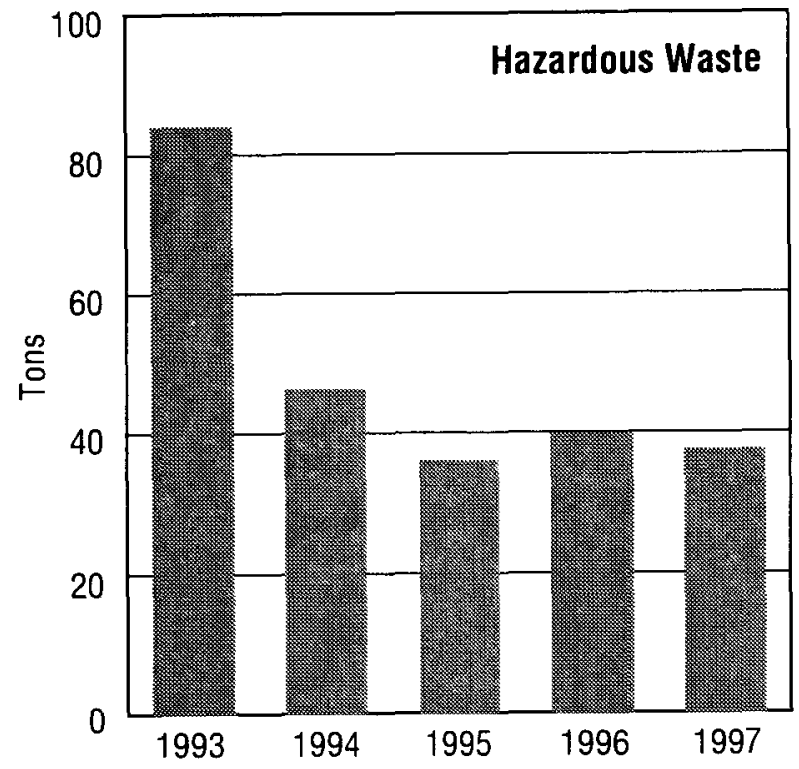

Figure 3-1.

Annual Hazardous Waste Generation

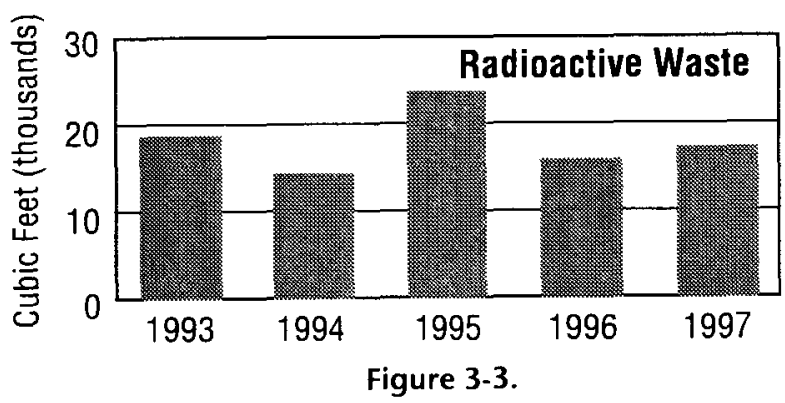

Annual Radioactive Waste Generation

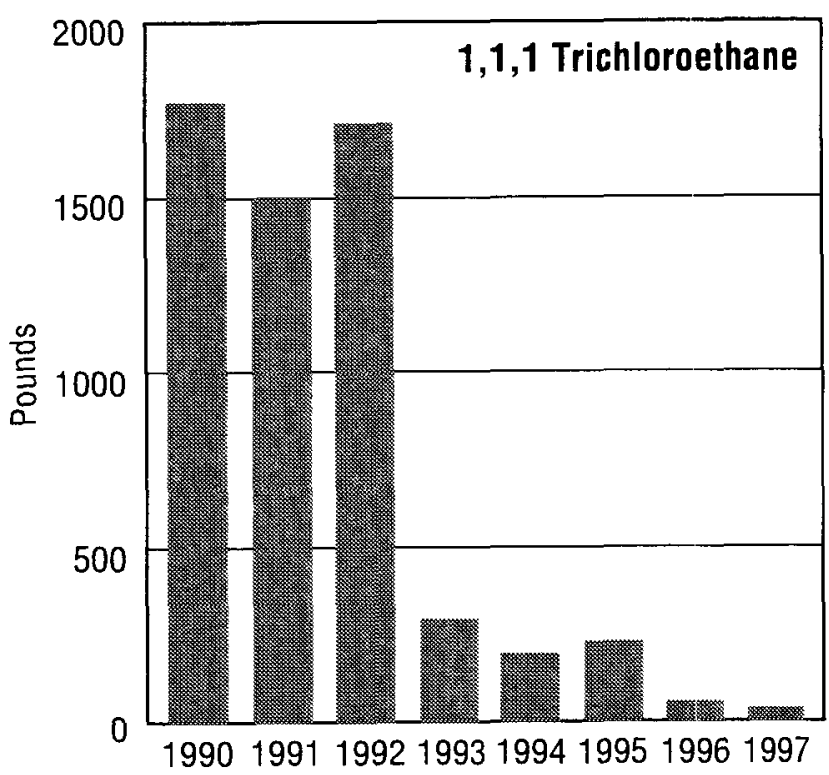

Figure 3-2.

Annual TCA Use

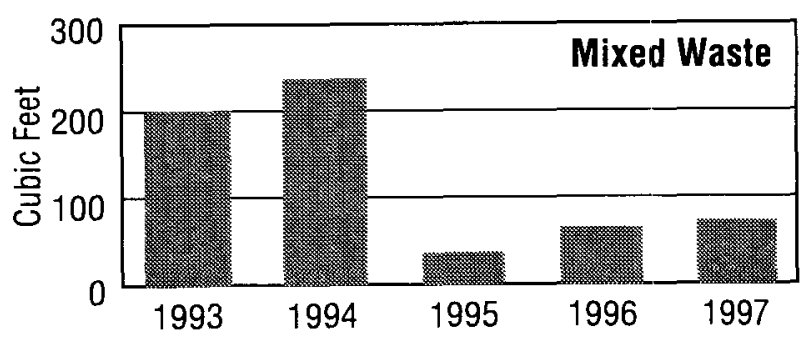

Figure 3-4.

Annual Mixed Waste Generation

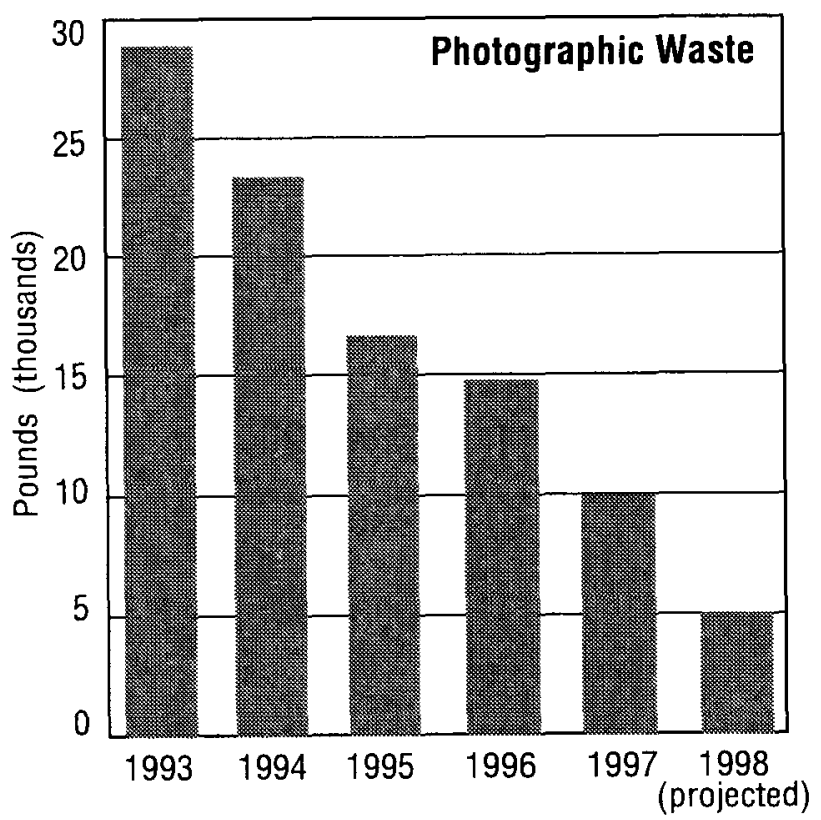

Figure 3-5.

Annual Photographic Waste Generation 


\section{Chapter 4}

\section{RADIOACTIVITY}

To define radiation, it is necessary to discuss the atom. The atom, the basic constituent of all matter, is one of the smallest units into which matter can be divided. It is composed of a tiny central core of particles, or nucleus, surrounded by a cloud of negatively charged particles called electrons. Most atoms in the physical world are stable, meaning that they are nonradioactive. However, some atoms possess an excess of energy which causes them to be physically unstable. In order to become stable, an atom rids itself of this extra energy by casting it off in the form of radiation. Radiation is the emission of a charged particle or electromagnetic wave from the atom. The three most important types of radiation are described in the following section.

\subsection{Types of Radiation}

Alpha An alpha particle is identical in make-up to the nucleus of a helium atom. Alpha particles have a positive charge, and have little or no penetrating power in matter. They are easily stopped by materials such as paper and have a range in air of only an inch or so. Naturally occurring radioactive elements such as radon emit alpha radiation.

Beta Beta radiation is composed of particles which are identical to electrons. As a result, beta particles have a negative charge. Beta radiation is slightly more penetrating than alpha, but may be stopped by materials such as aluminum foil. They have a range in air of a few inches. Naturally occurring radioactive elements such as potassium-40 emit beta radiation.

Gamma Gamma radiation is a form of electromagnetic radiation, like radio waves or visible light, but with a much smaller wavelength. It is more penetrating than alpha or beta radiation, and is capable of passing through dense materials such as concrete. $\mathrm{X}$-rays are essentially a form of gamma radiation.

\subsection{Nomenclature}

Throughout this report, radioactive elements (also called radionuclides) are referred to by a name followed by a number, e.g., potassium-40. The number following the name of the element is called the mass of the element and is equal to the total number of particles contained in the nucleus of the atom. Another way to specify the identity of potassium- 40 is by writing it as K-40, where ' $\mathrm{K}$ ' is the chemical symbol for potassium as it appears in the standard Periodic Table of the Elements. This type of abbreviation is used throughout many of the data tables in this report. 


\subsection{Sources of Radiation}

Radioactivity and radiation are part of the earth's natural environment. Human beings are exposed to radiation from a variety of common sources, the most significant of which are listed below.

Cosmic Primarily consists of charged particles which originate in space, beyond the earth's atmosphere. This includes radiation from the sun and secondary radiation generated by the entry of charged particles into the earth's atmosphere at high speeds and energies. Radioactive elements, such as hydrogen-3 (tritium), beryllium-7, carbon-14, and sodium-22, are produced in the atmosphere by cosmic radiation.

\section{Terrestrial}

Released by radioactive elements present in the soil since the formation of the earth about five billion years ago. Common radioactive elements contributing to terrestrial exposure include isotopes of potassium, thorium, actinium, and uranium.

Internal Internal exposure occurs when radionuclides are ingested absorbed or inhaled. Radioactivity in food occurs through the uptake of terrestrial radionuclides by plant roots. Human ingestion of natural radionuclides occurs when plant matter or animals that consume plant matter are eaten.

Radon Radon is a naturally-occurring radionuclide that is generated by the decay of uranium ores in the soil. It is by far the greatest contributor to an individual's radiation dose. Exposure occurs through the inhalation of radon decay products in the atmosphere. The level of exposure varies greatly from person to person depending on the quality of home insulation (which determines the degree to which the radon concentration will build up), the presence of a basement, ventilation rate, and geographic location.

Medical Millions of people every year undergo medical procedures which utilize radiation. Such procedures include chest and dental $\mathrm{x}$ rays, mammography, thallium heart stress tests, tumor irradiation therapies and many others.

\section{Anthropogenic}

Sources of anthropogenic (man-made) radiation include consumer products such as static eliminators (containing polonium-210), smoke detectors (containing americium-241), cardiac pacemakers (containing plutonium-238), fertilizers (containing isotopes of the uranium and thorium decay series), and tobacco products (containing polonium-210 and lead-210). 


\subsection{Dose Units}

The amount of energy that radiation deposits in body tissue, when corrected for human risk factors, is referred to as dose equivalent or, more generally, as dose. Radiation doses are measured in units of rem. Since the rem is a fairly large unit, it is convenient to express most doses in terms of millirem. A millirem, abbreviated mrem, is equal to $0.001 \mathrm{rem}$. To give a feeling for the size and importance of a 1 mrem exposure, the following figure indicates the number of mrem received by an individual in one year from natural sources. These values represent typical values for residents of the United States, giving a total of 295 mrem.

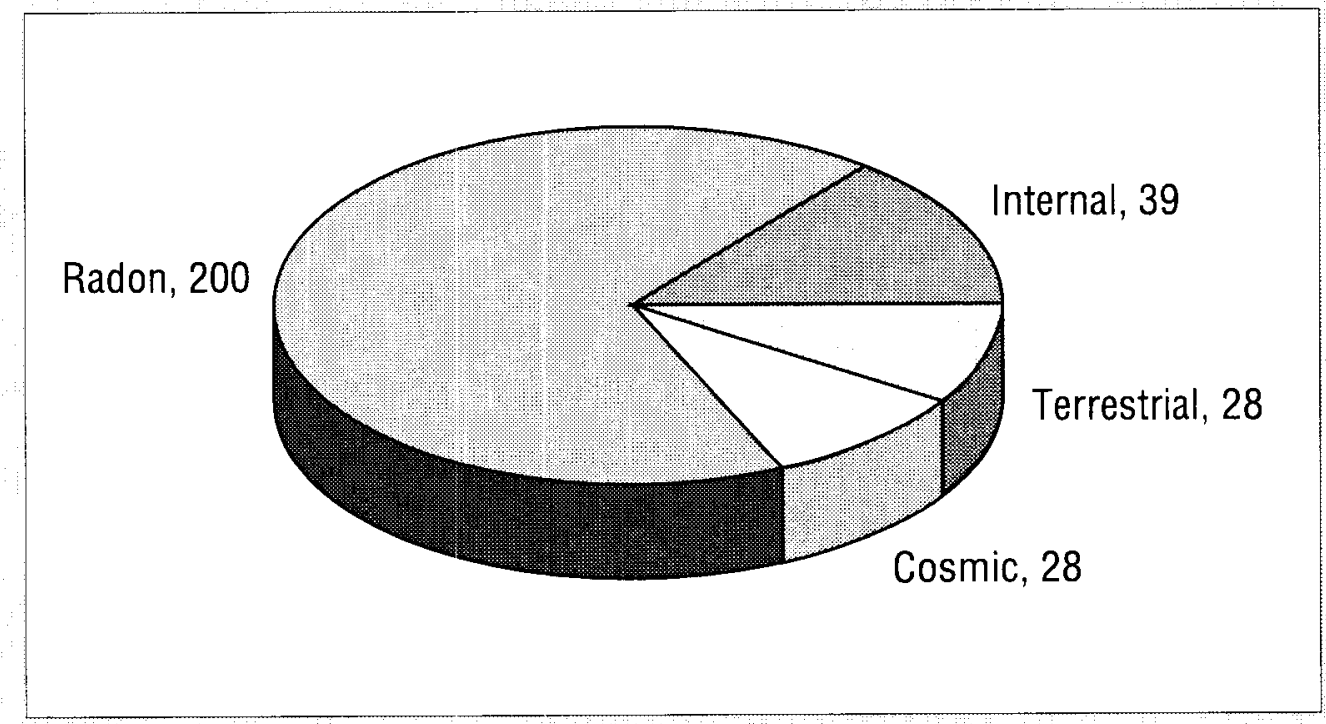

Figure 4-1. Typical annual dose due to natural sources (mrem).

Note that the alternate unit of dose measurement, commonly used internationally and increasingly in the United States is the Sievert, abbreviated Sv. One Sv is equivalent to 100 rem. Likewise, 1 millisievert ( $\mathrm{mSv}$ ) is equal to $100 \mathrm{mrem}$. 


\subsection{Types of Radiological Analyses}

The following section deals with radiological parameters for which various effluents are evaluated. These parameters include gross alpha activity, gross beta activity, tritium and Strontium-90 content, and gamma-emitting radionuclides. The quality of environmental air, water and soil can be assessed in several ways when dealing with radioactive material. The analyses most commonly used to measure radioactivity in these media are described below.

Gross Alpha Many naturally-occurring radionuclides contained in environmental media emit alpha radiation. The alpha particles emitted by these radionuclides have many different energies, measured in electron volts, or eV. Frequently, analysis equipment is used which measures all alpha particle activity simultaneously, without regard to their particular energy. Hence, this is a gross alpha activity measurement. It is valuable as a screening tool to indicate the magnitude of radioactivity that may be present in a sample.

Gross Beta This is the same concept as described above, except that it applies to the measurement of beta particle activity.

Tritium Due to the nature of the radiation emitted from the tritium atom, a special analysis known as liquid scintillation counting is required to quantify it. See Section 4.9 .2 for further details.

\section{Gamma Spectroscopy}

This is an analysis technique which identifies specific radionuclides, unlike a gross analysis which measures overall activity without identifying the source. It measures the specific energy of a radionuclide's gamma radiation emissions. The energy of these emissions is unique for each nuclide, acting as a 'fingerprint' to identify a specific nuclide.

\subsection{Statistics}

\subsubsection{Uncertainty}

Because the emission of radiation from an atom is a random process, a sample counted several times will yield a slightly different result each time; a single measurement is, therefore, not definitive. To account for this phenomenon, the concept of uncertainty is applied to radiological data. Each individual analysis result is shown in this report in the format of $x+/-y$, where $x$ is the result and $y$ is the $95 \%$ confidence interval of the result. That is, there is a $95 \%$ probability that the true value of $x$ lies between the range of $x+y$ and $x-y$. Conversely, there is a 5\% probability that the true value of $x$ lies outside of this range. The value of $y$ is also referred to as the $2 \sigma$ error of the result.

\subsubsection{Average Values}

Average (or mean) values are calculated throughout this report for sample locations for which multiple data points are available. The average indicates a central trend for multiple data points. Following each average value is a second number given as $+/-x$, where $x$ is equal to two times the standard deviation of the data point population. This value is an indicator of the variability of 
the data, i.e., how widely values in the population are dispersed from the average. A large value indicates a high variability between data points in the population, while a small value indicates that the data points are in close agreement.

\subsubsection{Negative values}

It is possible for a radiological measurement to result in a negative number. Every sample which is analyzed for radioactive material is compared to an instrument background, which is the number of radiation events observed in a blank sample. Since naturally-occurring radiation cannot be completely isolated in a sample measurement, the instrument background must be subtracted from the sample analysis. When measuring very low levels of radiation (such as those encountered in environmental media), where only a few radiation events are counted, it is common for the sample result to be below the instrument background. When the background is subtracted, a negative net value results, signifying, that the sample was found to contain no detectable radioactive material. Similarly, an average of several individual values in which some are positive and some are negative can result in a negative mean, indicating that the central trend of the data is a value which is not detectable.

\subsection{Scientific Notation}

Since many of the numbers used in measurement and quantification in this report are either very large or very small, many zeroes are required to express their value. Because this is inconvenient, scientific notation is used as a kind of numerical shorthand. Scientific notation is based on the principle of representing numbers in multiples of ten. For example, the number one million could be written as $1,000,000$. Alternatively, this number could be written in scientific notation as $1 \times 10^{6}$. That is, "one times ten raised to the sixth power." Since even this shorthand can be cumbersome, it can be reduced even further by using the capital letter E to stand for $10^{\mathrm{x}}$, or "ten raised to the power of some value $x . "$ Using this notation, 1,000,000 would be represented as 1E6. Scientific notation is also used to represent very small numbers like 0.0001 , which can be written as $1 \times 10^{-4}$ or $1 \mathrm{E}-4$. A minus sign on the power of ten represents a decimal value.

\subsection{Prefixes}

Another method of representing very large or very small numbers without the use of many zeroes is to use prefixes to represent multiples of ten. For example, the prefix milli- means that the value being represented is one thousandth of a whole unit, so that one milligram is equal to one thousandth of a gram. Other common prefixes used in this report are shown in Table 4-1.

\begin{tabular}{|c|c|c|c|c|c|}
\hline Proty & \multicolumn{2}{|c|}{ Munples } & Protix & \multicolumn{2}{|c|}{ Woluplor } \\
\hline milli $(\mathrm{m})$ & $1 \times 10^{-3}$ & $1 E-3$ & kilo (k) & $1 \times 10^{3}$ & $1 \mathrm{E} 3$ \\
\hline micro $(\mu)$ & $1 \times 10^{-6}$ & $1 \mathrm{E}-6$ & mega $(\mathrm{M})$ & $1 \times 10^{6}$ & $1 \mathrm{E} 6$ \\
\hline nano $(n)$ & $1 \times 10^{-s}$ & $1 \mathrm{E}-9$ & giga (G) & $1 \times 10^{9}$ & $1 \mathrm{E} 9$ \\
\hline pico (p) & $1 \times 10^{-12}$ & $1 \mathrm{E}-12$ & tera $(\mathrm{T})$ & $1 \times 10^{12}$ & $1 \mathrm{E} 12$ \\
\hline
\end{tabular}

Table 4-1 Common Measurement Unit Prefixes 


\subsection{Radionuclides of Environmental Interest}

\subsubsection{Strontium-90}

Strontium-90 is a beta-emitting radionuclide with a half-life of 28 years. It is found in the environment as a result of commercial power reactor operations, and, more importantly, nuclear weapons fallout. (Fallout refers to the deposition of radionuclides on soils and water bodies as a result of being dispersed high into the earth's atmosphere during nuclear explosions.) Because Strontium-90 released during weapons testing has such a lengthy half-life, it can still be detected in the environment today. Additionally, nations which were not signatories of the Nuclear Test Ban Treaty of 1963 have conducted tests which have contributed to the global Strontium-90 inventory. This radionuclide was also released as a result of the 1986 Chernobyl accident in the former Soviet Union.

Strontium-90 emits beta radiation only, which cannot be detected by gamma spectroscopy. It can only be detected by a specific chemical analysis (see Appendix C for description), followed by measurements of beta particle emissions. This is why it is reported as a separate parameter in the tables of this report. The level of sensitivity for detecting Strontium-90 using state-of-the-art analyses methods is less than $1 \mathrm{pCi} / \mathrm{L}$, which makes it possible to detect Strontium-90 at levels which are indicative of the environmental sources described above.

No processes on the BNL site actively release Strontium-90 during their operation. When it is detected on the BNL site at levels above those associated with fallout and other background sources, it is due to historic landfill practices of the 1950 s and 60 s or the former operation of the Brookhaven Graphite Research Reactor, which ceased operation in 1969.

\subsubsection{Tritium}

Among the radioactive materials that are used or produced at Brookhaven National Laboratory, tritium has received some of the greatest public attention. Tritium, the common name for the isotope hydrogen-3, exists in nature and is formed when cosmic radiation from space interacts with the gaseous element nitrogen in the earth's upper atmosphere. Approximately 4 million $\mathrm{Ci}$ (1.5E5 TBq) per year are produced in the atmosphere in this way, with the total global quantity being about 70 million $\mathrm{Ci}(2.6 \mathrm{E} 6 \mathrm{TBq})$ at any given time (NCRP, 1979). Human activities such as nuclear power reactor operations and nuclear weapons testing have also released tritium into the environment. Commercially, tritium is used in such products such as self-illuminating exit signs and wrist watches ('exit' signs may contain as much as 20 Ci [740 GBq] of tritium). It also has many uses in medical and biological research as a labeling agent in chemical compounds and is frequently used in universities and other research settings.

Tritium has a physical half-life of 12.3 years and a biological half-life of about 10 days, meaning that 50 percent of any tritium in the body is eliminated in approximately 10 days. When an atom of tritium decays, it releases a beta particle, transforming the tritium atom into stable (nonradioactive) helium. This beta radiation is of a very low energy when compared to the emissions of other radioactive elements and it is easily stopped by the body's outer layer of dead skin cells; only when taken into the body can tritium cause any significant exposure. Because of its low energy radiation and short residence time in the body, the health threat posed by tritium is very small for most credible exposures.

Environmental tritium is found in two forms: gaseous elemental tritium and tritiated water (or water vapor), in which at least one of the hydrogen atoms in the $\mathrm{H}_{2} \mathrm{O}$ water molecule has been replaced by a tritium atom. Hence, its short hand notation HTO. All tritium released from BNL sources is in the form of HTO. Since tritium is incorporated directly into the water molecule, absorbed or ingested HTO passes through the body as water does, minimizing the accumulation in the body over time from one-time exposures. 
Of the sources mentioned above, the most significant contributor to tritium in the environment has been above-ground nuclear weapons testing. In the early $60 \mathrm{~s}$, the average tritium concentration in surface streams in the United States reached a value of $4,000 \mathrm{pCi} / \mathrm{L}(148 \mathrm{kBq} / \mathrm{L})(\mathrm{NCRP}$, 1979). Approximately the same concentration was measurable in precipitation. Today, the level of tritium in surface waters in New York State is below $200 \mathrm{pCi} / \mathrm{L}(7.4 \mathrm{kBq} / \mathrm{L})(\mathrm{NYSDOH}, 1993)$, less than the detection limit of most analytical laboratories.

\subsubsection{Cesium-137}

Cesium-137 is a man-made, fission-produced radionuclide with a half-life of 30 years. It is found in the general environment as a result of past above-ground nuclear weapons testing and can be observed in the upper levels of environmental soils at very low concentrations, of around $1 \mathrm{pCi} / \mathrm{g}$ $(0.4 \mathrm{~Bq} / \mathrm{g})$ or less. It is a beta-emitting radionuclide, but can be detected by gamma spectroscopy by the gamma emissions of its decay product, barium $-137 \mathrm{~m}$.

\subsection{Definition of Radiological Terms}

The following terms are used throughout this report where radiation and radioactive material are discussed:

Activation The process by which a non-radioactive material is made radioactive through exposure to neutrons or high energy particles.

Activation Product

An element which has become radioactive through the process of activation.

Activity Synonym for radioactivity.

Anthropogenic Radionuclides

Radionuclides produced as a result of human activity, i.e., manmade.

\section{Background Radiation}

Radiation present in the environment as a result of naturallyoccurring radioactive materials, cosmic radiation, or fallout radionuclides deposited on the earth as a result of above-ground weapons testing.

Becquerel A quantitative measure of radioactivity, abbreviated $B q$. This is an alternate measure of activity used internationally and with increasing frequency in the United States. One Bq of activity is equal to one nuclear decay per second. All references to quantities of radioactive material in this report are made in curies, followed in parentheses by the equivalent in $\mathrm{Bq}$.

\section{Derived Concentration Guide (DCG)}

The concentration of a radionuclide in air or water that, under conditions of continuous exposure for one year by a single pathway (e.g. air inhalation/immersion, water ingestion), would result in an effective dose equivalent of $100 \mathrm{mrem}(1 \mathrm{mSv})$. Established by DOE Order 5400.5, "Radiation Protection of the Public and Environment". 
Curie A quantitative measure of radioactivity, abbreviated $\mathrm{Ci}$. One $\mathrm{Ci}$ of activity is equal to $3.7 \times 10^{10}$ disintegrations per second, which is equal to $3.7 \times 10^{10} \mathrm{~Bq}$ (see radioactivity).

\section{Effective Dose Equivalent}

A normalized value which allows the inter-comparison of doses to various parts of the body. It is equal to the sum of the doses to different organs of the body multiplied by their respective weighting factors. Also referred to as the "whole body" dose, or simply "dose."

Fallout Radioactive material made airborne as a result of above-ground nuclear weapons testing that has been deposited on the earth's surface.

Half-Life The time required for the activity of a radioactive sample to be reduced by one half.

MDL Minimum Detection Limit. This is the lowest level to which an analytical parameter can be measured with certainty in the Laboratory. While results below the MDL are sometimes measurable, they represent values which have a reduced statistical confidence associated with them (less than $95 \%$ confidence).

\section{Radioactivity}

The spontaneous transition of an atomic nucleus from a higher energy to a lower energy state. This transition is accompanied by the release of a charged particle or electromagnetic wave from the atom. Also known as activity.

Radionuclide A radioactive element.

Rem The unit by which human radiation exposure is measured. This is a risk-based value used to estimate the potential health effects to an exposed individual or population. Because the rem is a relatively large unit, doses are usually specified in millirems, abbreviated mrem. One mrem is equal to $0.001 \mathrm{rem}$. Typical exposure to natural sources of radiation in the environment results in a dose of 200 to 400 mrem per year. See also Section 5.

Sievert $\quad$ The alternate unit of measuring human radiation exposure used internationally and with increasing frequency in the United States, is the Sievert, abbreviated $S v$. One sievert is equal to 100 rem.

Spallation The process by which a high energy particle striking a nucleus causes fragments to be ejected from the nucleus. The resulting atom is usually radioactive.

Stable Non-radioactive.

TLD Thermoluminescent Dosimeter. A device used to measure radiation exposure to occupational workers or radiation levels in the environment. 


\section{Chapter 5}

\section{AIRBORNE EFFLUENTS}

\subsection{Airborne Effluent Emissions - Radioactive}

The following sections describe the radioactive effluents released to the atmosphere in 1997 and the facilities and operations which produced them. Locations of facilities within the BNL site which release airborne radionuclides are shown in Figure 5-1. Chapter 9 contains a discussion of projected radiological doses which would have been received by a member of the public residing at the BNL site boundary .

\subsubsection{BMRR}

The Brookhaven Medical Research Reactor (BMRR) is the first nuclear reactor built exclusively for medical research. It produces neutrons in an optimal energy range for a promising experimental treatment for a type of brain cancer known as glioblastoma multiforme. The BMRR is fueled with enriched uranium, moderated and cooled by light water, and is operated intermittently at power levels up to $3 \mathrm{MW}$ (thermal).

To cool the neutron reflector surrounding the core of the BMRR reactor vessel, air from the interior of the containment building is used. When air is drawn through the reflector, it is exposed to a neutron field which causes the argon component of the air to become radioactive. This radioactive form is known as argon-41. It is a chemically inert gas with a short half-life of 1.8 hours. After passage through the reflector, the air is routed through a roughing filter, a high efficiency particulate air (HEPA) filter to remove any particulate matter, and finally, a charcoal filter to remove radioiodines. The air is then exhausted to a $150 \mathrm{ft}$. (46 meter) stack adjacent to the containment building.

A real time monitor is in place to monitor argon-41 in the effluent, while passive filter media are used to collect and quantify radioparticulates. Data from this monitor are used to confirm expected release rates and maintain annual radionuclide release inventories. Though the list of radionuclides released from this facility (see Table 5-1) is longer than what was reported in the past, this does not reflect an increase in emissions, but rather an increased level of monitoring initiated in 1996 for very small radionuclide quantities. These non-argon isotopes are of negligible dosimetric importance $(\ll 0.1 \mathrm{mrem} / \mathrm{yr})$ because of their short half-life and extremely low total activity. In 1997, the BMRR released 2,219 $\mathrm{Ci} \mathrm{(82} \mathrm{TBq)} \mathrm{of} \mathrm{argon-41} \mathrm{as} \mathrm{an} \mathrm{airborne} \mathrm{effluent.}$

\subsubsection{HFBR}

The High Flux Beam Reactor (HFBR) is one of the premier neutron physics research facilities in the world. Neutron beams produced at the HFBR are used to investigate the molecular structure of materials which aid in drug design and materials development, as well as expanding the current knowledge base of physics, chemistry and biology. This reactor is capable of operating at power levels ranging from 30 to $60 \mathrm{MW}$ (thermal). The HFBR has been shutdown since January, 1997 following the discovery of an underground plume of tritium emanating from beneath the facility.

The HFBR uses heavy water to cool the reactor fuel and moderate neutrons used in the fission process. (Heavy water, or $\mathrm{D}_{2} \mathrm{O}$, is water which is composed of a nonradioactive isotope of hydrogen known as deuterium.) Heavy water flowing in the core is exposed to a dense neutron field which activates the deuterium atoms in the water to produce tritium (half-life $=12.3$ years). The rate at which the tritium concentration builds in the primary cooling water depends on the reactor power level and the amount of time elapsed since the last reactor shutdown or coolant 


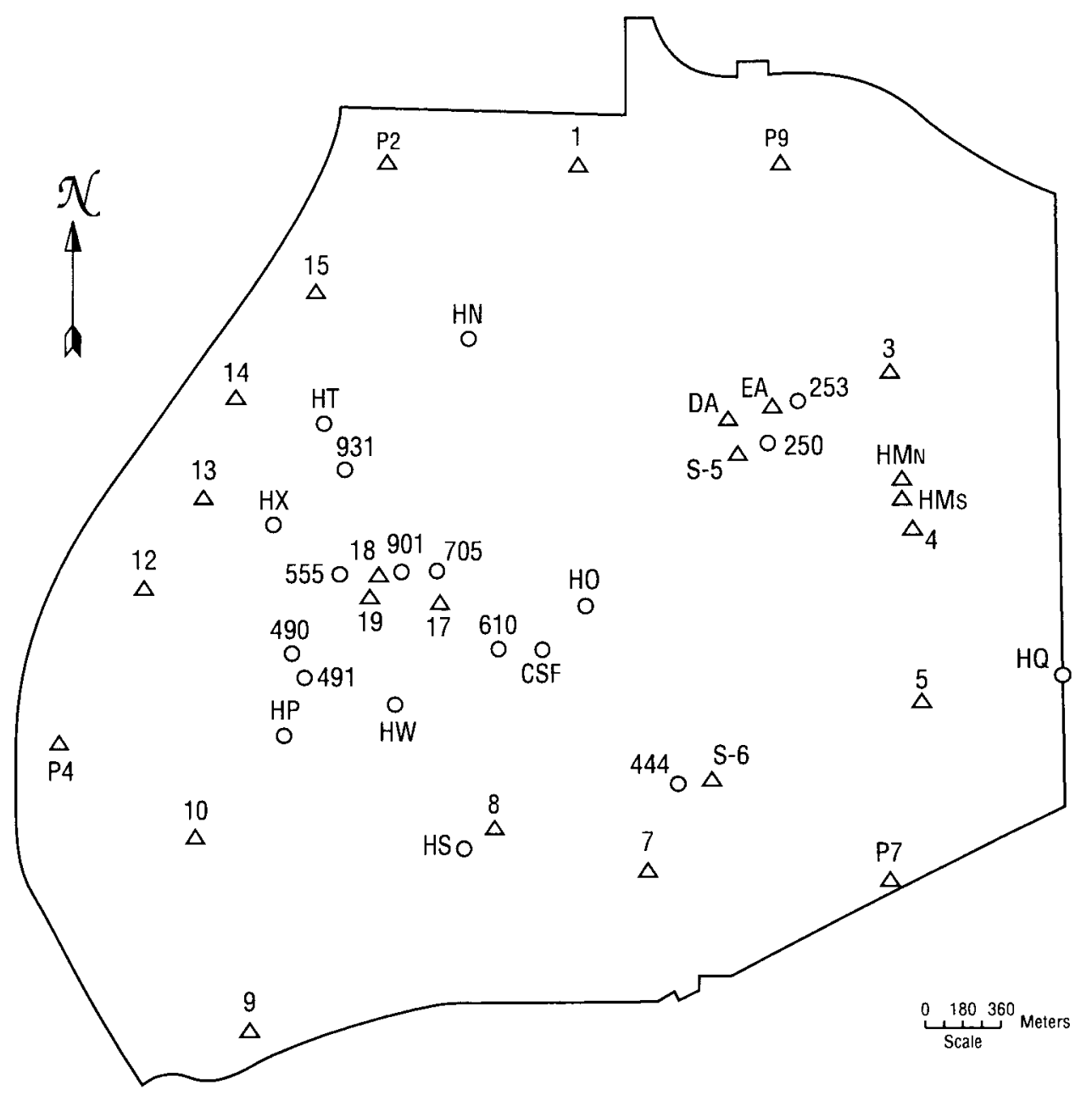

$\Delta$ Environmental Monitoring Stations

Air

1 thru 16 Perimeter Stations

S-6 Waste Management Area

S-5 Sewage Treatment Plant

$17,18,19$ Center of Site

Water

DA Sewage Treatment Plant Influent

EA Sewage Treatment Plant Effluent

HM Peconic River, 0.5 mi. Downstream From Treatment Plant

HQ Peconic River, Site Boundary
O Designation

250

253

491

555

705

931

444

610

CSF

HN

$\mathrm{HO}$

HP

HS

HT

$\mathrm{HX}$

HW
Effluent Release

Point

Sand filter Beds

Peconic R. Stream Bed

BMRR

Chemistry Bldg.

HFBR

BLIP

Waste Management Incinerator

Steam Plant

Storm Water Outfall

Recharge Basin

Recharge Basin

Recharge Basin

Recharge Basin

Recharge Basin

Recharge Basin

Recharge Basin

Figure 5-1.

Brookhaven National Laboratory

Effluent Release Points and On-site Environmental Monitoring Stations 
Table 5-1

BNL. Site Environmental Report for Calendar Year 1997

Airborne Radionuclide Releases from Monitored Facilities

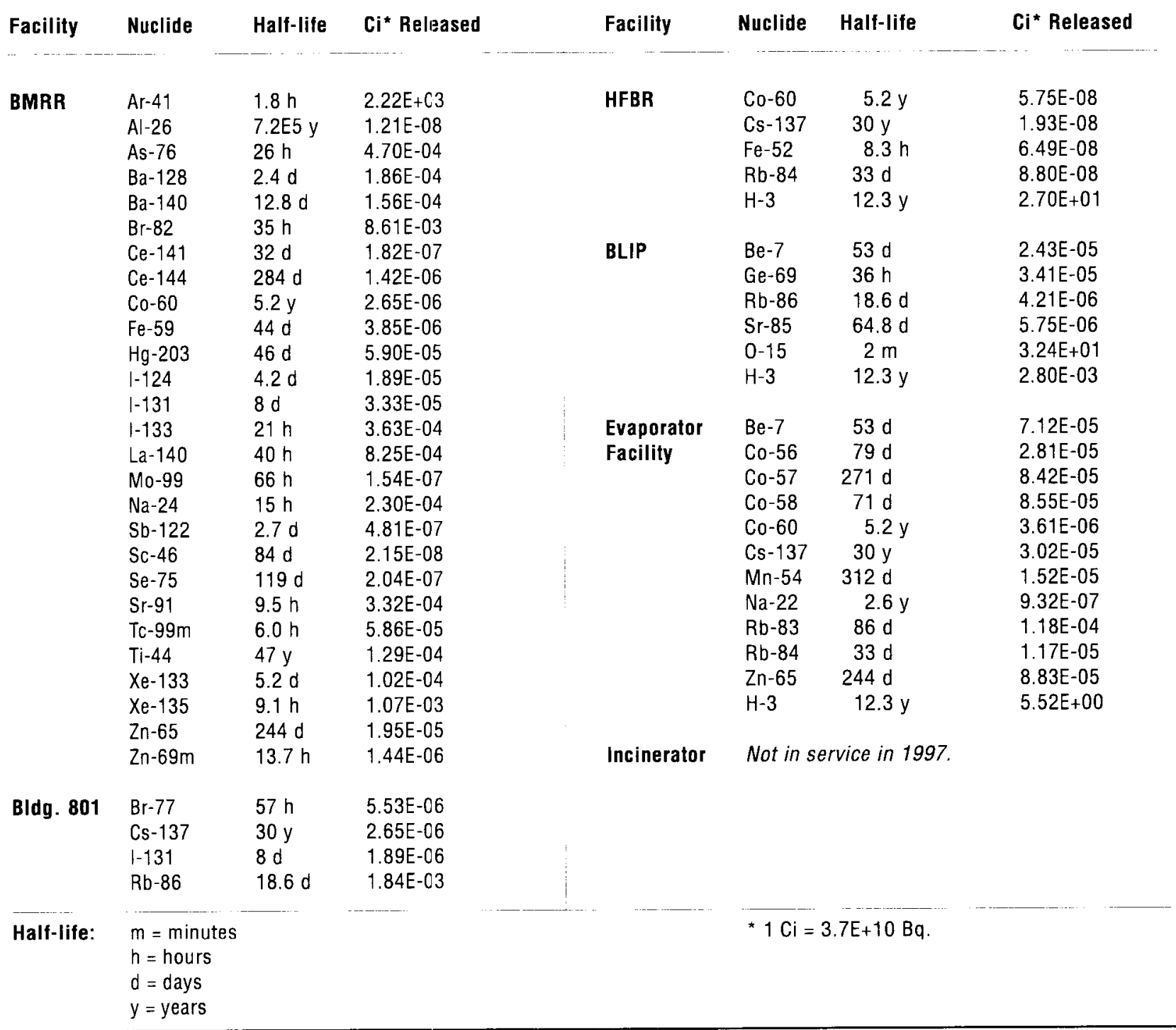

change out. This, in turn, determines the amount of tritium which may eventually be released as an airborne effluent. The primary mechanism by which tritium is transferred from the interior coolant system to the building atmosphere is depressurization of the reactor vessel and evaporative losses during maintenance and refueling. Diffusion at valve seals and other fittings also occurs. Tritiated water vapor is thus released from reactor systems to the building air exhaust where it is routed to the facility's $320 \mathrm{ft}$. (98 meter) stack. Concentrations of tritiated water vapor (abbreviated "HTO") in the air effluent are determined by the use of a silica gel absorbent as it is released.

Though the HFBR did not operate in CY 1997 due to the tritium plume source investigations, the reactor vessel remained filled with heavy water coolant which contains significant amounts of tritium. This tritium is still a source of radioactivity which may be released to the atmosphere via 
the mechanisms described above. In 1997, $27 \mathrm{Ci} \mathrm{(1} \mathrm{TBq)} \mathrm{of} \mathrm{airborne} \mathrm{HTO} \mathrm{was} \mathrm{released} \mathrm{from} \mathrm{the}$ HFBR (Table 5-1). Figure 5-2 illustrates the trend for emissions over the last ten years. While this constitutes the second largest source of total airborne activity released from the BNL site, tritium is a very minor contributor to off-site dose (i.e., $\ll 0.1 \mathrm{mrem} / \mathrm{yr}$ ).

Other radionuclides are also released from the HFBR in very small quantities, typically in the millicurie to microcurie range, annually. These nuclides are primarily released during the purge of the helium "cover gas" present above the surface of the reactor vessel's cooling water. Any fission products which have been transferred from the cooling water to the cover gas may be released during a routine depressurization purge. They are passed through charcoal and HEPA filters to remove the greatest fraction possible before atmospheric release.

\subsubsection{BLIP}

The Brookhaven LINAC Isotope Producer (BLIP) is designed to produce radionuclides for medical applications. It is one of the key production facilities in the nation for radioisotopes which are crucial to clinical nuclear medicine. It also supports research at BNL on new diagnostic and therapeutic radiopharmaceuticals.

Protons from the LINAC are sent via an underground beam tunnel to the BLIP Facility where they strike various target metals. These metals, which become activated by the proton beam, are then processed at Building 801 for use in radiopharmaceutical production. The targets are cooled by a continuously recirculating water system. During irradiation, several radioisotopes are produced in this cooling water, the most significant of which is gaseous oxygen-15, a radionuclide with a very short half-life of 123 seconds. This isotope is released as an airborne effluent.

The BLIP facility underwent significant upgrades between 1994 and 1996 in support of the Brookhaven Isotope Research Center (BIRC) program. In an effort to determine any possible changes in the airborne effluent emission rates that these changes may have caused, measurements were conducted in 1996. They indicated a smaller oxygen-15 production rate than measurements made before the BIRC upgrades. As a result, the calculated annual source term release for this facility has decreased compared to previous years. A total of $32 \mathrm{Ci} \mathrm{(1.2} \mathrm{TBq)} \mathrm{of} \mathrm{oxygen-15} \mathrm{was}$ released as an airborne effluent in 1997 (see Table 5-1).

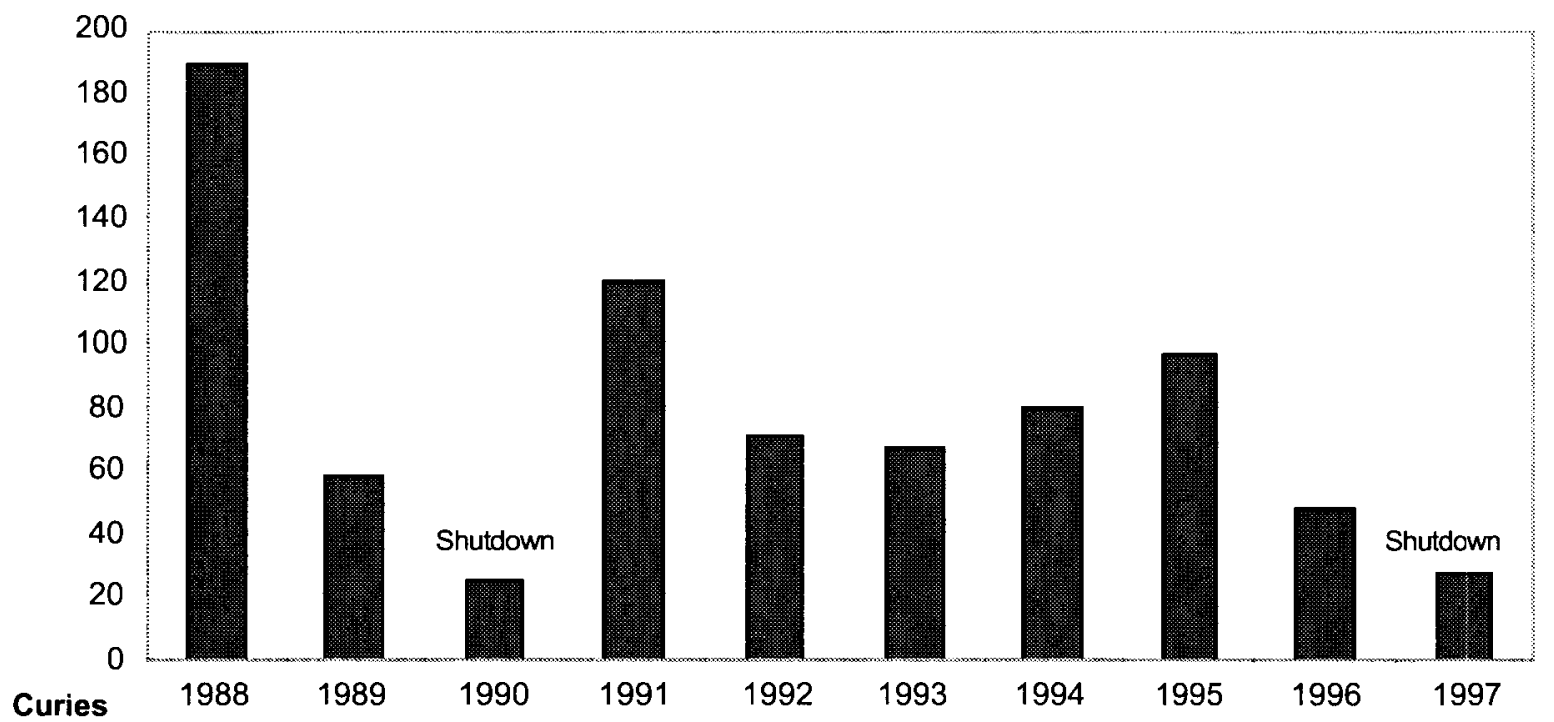

Figure 5-2. HFBR Airborne Tritium Emissions, 10 Year Trend 


\subsubsection{Tritium Evaporator Facility}

First proposed in 1985, the Tritium Evaporator Facility was constructed to reduce the total amount of tritiated water released to the Peconic River. Since the proposal followed the promulgation of NESHAPs, the facility was evaluated for compliance with the Rule prior to its construction. Following submission of an application to construct the facility, formal approval from the EPA Region II was awarded (Approval No. BNL-288-01). The facility became operational in 1995.

Liquid waste generated on-site which contains residual radioactive material is processed at the Building 811 Waste Concentration Facility. At the WCF, suspended solids are removed from the liquid along with a high percentage of radionuclides using a reverse osmosis process. However, because of its chemical properties, tritium is not removed during this process. The tritiated water which remains following waste concentration is delivered to the Evaporator where it is converted to steam and released as an airborne effluent. This method is preferable to release via surface water because (1) there is virtually no potential to influence the underlying aquifer, and (2) the potential for this tritium to contribute to an off-site dose is reduced by atmospheric dispersion. The effluent is directed to the same 98 meter stack used by the HFBR for building air exhaust. In 1997, $5.5 \mathrm{Ci}(204 \mathrm{GBq})$ of HTO were released as an airborne effluent from the evaporator facility.

Since the waste concentration process does not completely remove all other radionuclides, nuclides other than tritium are released at much lower activity levels (see Table 5-1 for a listing). The activity values are estimated ones since facility emissions are tracked by an inventory system in place of in-line monitoring. Liquid shipments to the Evaporator are sampled and analyzed before delivery to determine radionuclide concentrations. The total emissions for a water tanker delivery are calculated by computing the product of the concentration and total volume evaporated. This method is very conservative and airborne releases and projected doses from this facility are likely to be overestimated.

\subsubsection{Building 801}

Airborne radionuclides are also released from Building 801 (see Table 5-1 for isotopes and quantities). These quantities are very small, typically in the millicurie to microcurie range, annually. This facility serves as a laboratory for chemical separation procedures employed in the routine extraction of radioisotopes from targets irradiated at the BLIP facility.

\subsubsection{New Sources Evaluated in 1997}

\subsubsection{Removal Action V Recharge Basin}

In 1997, an interim pump-and-recharge system was constructed to control the leading edge of the plume of tritium from the spent fuel storage pool at the HFBR. Three extraction wells pump groundwater containing both tritium and volatile organic compounds (from a source unrelated to the HFBR) from approximately 150 feet below ground surface to carbon filtration units, and ultimately, to the Removal Action $V$ recharge basin, located 3,000 ft. to the north. By recharging this water to a northern, upgradient area, groundwater containing tritium will take an additional 19 years to reach BNL's southern boundary, thus allowing for additional dilution and radioactive decay. Potential air emissions from this source were evaluated before the system became operational.

The tritium concentrations of the groundwater reaching the recharge basin were expected to be in the range of $3,500 \mathrm{pCi} / \mathrm{L}(130 \mathrm{~Bq} / \mathrm{L})$ or less. However, for purposes of assessing air emissions, more conservative assumptions were employed; it was assumed that the water would contain up to $20,000 \mathrm{pCi} / \mathrm{L}(740 \mathrm{~Bq} / \mathrm{L})$ of tritium, the drinking water standard. Also, assuming year round summer time evaporation rates, a total annual airborne tritium source term of $100 \mathrm{mCi}(3.7 \mathrm{GBq})$ was estimated. 
Following the start of pumping operations, analysis of the water entering the Recharge Basin showed that tritium was rarely present above detectable levels. These data verified that the initial source calculations used in evaluating the air emissions were overly conservative.

\subsubsection{Building 830 Kinetic Mixer}

The Kinetic Mixer, located in Bldg. 830, was designed to evaluate mixing thermoplastic polymers with waste materials as a viable method for the encapsulation of wastes. The viability of kinetic mixing was demonstrated by processing actual wastes. The polyethylene microencapsulation process used waste samples including: (1) clean BNL soil; (2) BNL soil from the former Hazardous Waste Management Facility; (3) surrogate of DOE Fernald Site silo waste; and (4) mixed waste samples from the Fernald Site. Total estimated atmospheric release of radium, uranium, and thorium decay products from this process was less than $1 \mathrm{mCi}(0.04 \mathrm{MBq})$.

\subsubsection{HFBR Spent Fuel Pool Dewatering Operation}

This operation removed water from the HFBR spent fuel pool (SFP). The SFP is the source of the tritium plume detected in groundwater to the south of the HFBR. Plans were developed to pump the water out of the SFP and into liquid waste storage tanks at the Building $811 \mathrm{WCF}$ after removing all spent fuel elements. The water was pumped via a double-walled underground line constructed with leak detection equipment. The volume pumped was approximately 60,000 gallons.

As water entered one of four waste receiving tanks, any radionuclides made airborne inside a tank as a result of agitation could have been forced out of the air vents by volume displacement. (There were no forced ventilation fans or emissions controls at these tank vents.) Given its physical properties as water vapor, the radionuclide evaluated for off-site dose potential from this operation was tritium. In this scenario, the maximum amount of airborne tritium that could have been generated was estimated to be $2.5 \mathrm{Ci}(93 \mathrm{GBq})$.

\subsubsection{BGRR Deep Drain Sump Pumping Operation}

The BGRR is a research reactor facility which last operated in 1969. During a visual inspection of the facility in 1997, standing water was observed in what is known as the Deep Drain Sump. The source of this standing water is an underground air exhaust duct which had accumulated water through rain intrusion and air cooler water leaks. Analysis showed this water to contain radioactive materials, including tritium. To remove this water as a potential source of groundwater contamination, it was pumped out of the sump and into mobile tankers within the reactor building. The water was then moved to a temporary on-site storage facility while treatment and disposal options are evaluated.

The possibility was considered that radioactive material could become airborne from agitation caused by pumping the water from the underground duct into the mobile tanker through hoses. Given its physical properties as water vapor, tritium was evaluated for off-site dose potential. The maximum amount of airborne tritium generated was estimated to have been $1 \mathrm{mCi}(37 \mathrm{MBq})$.

\subsubsection{Fugitive Emissions}

The potential fugitive emission sources evaluated in CY 1997 were the Removal Action V Recharge Basin (described above) and the STP holding ponds.

During 1997, the STP holding ponds contained only trace quantities of tritiated water. However, since these ponds provide the opportunity for airborne radionuclide generation through evaporation, they are considered fugitive sources. The maximum inventory within the ponds at any time during CY1997 was approximately $30 \mathrm{mCi}(1 \mathrm{GBq})$. The total quantity of airborne activity was estimated to be $3 \mathrm{mCi}(111 \mathrm{MBq})$. 


\subsubsection{Additional Minor Sources}

Several Departments within BNL conduct research involving very small quantities of radioactive materials (in the microcurie to millicurie range). This material is often used in fume hoods designated for use with radioactive materials. Operations such as transferring material between containers, pipetting, and chemical compound labeling are typical of this work. Due to exhaust filters, the type of work conducted and the small quantities involved, these operations have a very low potential for atmospheric release of any environmentally significant quantity of radioactive material. Compliance with 40 CFR 61 Subpart $\mathrm{H}$ is demonstrated through the use of an inventory system which allows an upper estimate of potential releases to be calculated. Facilities which demonstrate compliance in this way include the Biology Dept. (Bldg. 463), the Chemistry Dept., (Bldg. 555), the Dept. of Applied Science (Bldgs. 318 and 490A), the Medical Dept. (Bldg. 490), and the Dept. of Advanced Technology (Bldg. 703).

\subsection{Airborne Effluent Emissions - Nonradioactive}

Nonradioactive emissions are generated from a variety of processes at BNL. Boilers at the Central Steam Facility (CSF) account for most of the nonradioactive air emissions at the Laboratory. Since potential emissions of $\mathrm{NO}_{x}$ and $\mathrm{SO}_{2}$ from the CSF boilers exceed the major facility thresholds of 25 tons and 100 tons, respectively, BNL is required to submit a Title V operating permit application to the NYSDEC by December 9, 1998 pursuant to 6 NYCRR Part 201 provisions. One of the goals of the Title $\mathrm{V}$ operating permit program is to consolidate all emission sources and all federal and state regulatory requirements applicable to the sources at major facilities into a document known as the Title $V$ permit. To ensure that all potential emission sources are included in BNL's Title $\mathrm{V}$ permit application, BNL conducted walk through inspections of most on-site buildings beginning in April 1997. More than 1800 emission sources were identified. Most were classified as exempt or trivial sources in accordance with provisions of Part 201, and include processes such as welding/soldering, degreasing, sandblasting, machining, aerosol painting and parts cleaning. Aside from the boilers at the CSF, other significant sources subject to applicable state and/or federal regulatory include the Asbestos Test Facility, the Building 458 paint booth, and the onsite gasoline refueling facilities.

\subsubsection{Central Steam Facility (CSF)}

The CSF is located along the eastern perimeter of the developed portion of the BNL site. The CSF supplies steam for heating and cooling to all major facilities through the underground steam distribution and condensate grid. The combustion units at the CSF are designated as Boiler Nos. 1A, 5, 6 and 7. Boiler 1A is a Babcock and Wilcox FM unit that was installed in 1962, and has a heat input of 56.7 MMBtu/hr. Boiler 5 is a Combustion Engineering VU-60 unit installed in 1965 that has a heat input of $225 \mathrm{MMBtu} / \mathrm{hr}$. Boiler No. 6 is a Combustion Engineering 28-A-14 unit, installed in 1984, with a heat input of $147 \mathrm{MMBtu} / \mathrm{hr}$. Boiler No. 7 is a new Babcock \& Wilcox FM-117-8-97 unit with a heat input of $147 \mathrm{MMBtu} / \mathrm{hr}$ installed in 1996. Boiler Nos. 6 and 7 are subject to the New Source Performance Standard, 40 CFR Subpart Db, and are equipped with continuous emissions monitors for $\mathrm{NO}_{x}$. Boiler No. 7 emissions are also continuously monitored for opacity in accordance with Subpart $\mathrm{Db}$ requirements. All four boilers are monitored for $\mathrm{O}_{2}$ and $\mathrm{CO}_{2}$. Emissions from these boilers are reported quarterly to the NYSDEC.

In the spring of 1997, LILCO completed work to extend a natural gas main into the CSF. To accommodate the combustion of natural gas, new gas rings were added to the burners of Boiler 5 and natural gas trains were installed to connect the gas main to Boiler Nos. 5 and 7 . Plans to upgrade Boiler No. 6, which included replacing existing steam atomized oil burners with two Peabody-Hamworthy DFL low $\mathrm{NO}_{x}$ burners, and the adding a natural gas train connection to the gas main are expected to be completed in 1998. Upgrades to carry the gas from the gas main to each of the boilers and new burners were installed. Before the upgrades proceeded, BNL entered into an agreement with LILCO, whereby the Laboratory is required to burn at least 1.8 million dekatherms over three years. During this period, LILCO can interrupt gas flow to the site when 
ambient temperatures fall below $30^{\circ} \mathrm{F}$. After shakedown testing of the boilers was completed, Boiler Nos. 5 and 7 started burning natural gas in November and September 1997, respectively. Because natural gas was used, annual emissions of $\mathrm{NO}_{x}$ and $\mathrm{SO}_{2}$ at the CSF in 1997 declined by 34 tons and 21 tons, respectively, from totals recorded in 1996. On an equivalent heat input basis, $\mathrm{NO}_{x}$ emissions at the CSF dropped by 17 tons while $\mathrm{SO}_{2}$ emissions fell 28 tons.

\subsubsection{Asbestos Test Facility}

Since August 1995, the Department of Applied Sciences (DAS) has used the former Inhalation Toxicology Facility in Building 490 to fabricate GVF-12.7 fireproofing test panels as part of a Cooperative Research and Development Agreement with a private company. The primary goal was to develop a process to treat fire proofing products with a conversion agent which would chemically convert the asbestos containing material to a non-regulated asbestos-free product that retains its fire proofing properties. The work is conducted in three stages in three separate enclosures (i.e., hoods). The exhaust systems for all three enclosure have their own pollution control systems to remove potential releases of asbestos fibers; the third enclosure is equipped with a wet scrubber system to control caustic and acidic aerosols generated in applying conversion agents to fabricated asbestos test samples. The exhaust systems for each of the project's three hoods were designed to exceed pollution control requirements established by NESHAPs Subpart M. Exhaust from each processing step pass through a series of fabric pre-filters and two HEPA filters before their release to the atmosphere. To satisfy Subpart M monitoring requirements, each process hood exhaust is visually monitored on a daily basis for evidence of visible emissions of asbestos. In addition, the pre-filters and HEPA filters associated with each hood are inspected at least once per week to ensure that they are functioning properly. This is accomplished by visually inspecting the clean side of pre-filters, recording the pressure drop readings across each filter and comparing these readings with the manufacturer's recommendations. Since panel fabrication and testing began, DAS has prepared quarterly reports documenting the inspections of emission filter devices and the monitoring of exhausts for visible emissions; none were observed in 1997.

\subsubsection{Spray Paint Booth}

The spray paint booth located in Building 458 paint shop is used primarily to apply both protective and decorative coatings to miscellaneous metal parts and metal and wood room furnishings. The coatings have VOC contents that comply with the VOC limitations described in 6 NYCRR Part 228. To ensure compliance with the VOC requirements, Paint Shop personnel keep a running log of the substrates coated and the coating products applied during the year. Paint overspray is controlled by a bank of disposal fabric cartridges. This is a low volume shop that typically applies less than 200 gallons of coating annually.

\subsubsection{Gasoline Refueling Facilities}

In 1989, BNL replaced the existing single wall steel underground storage tanks at the fleet vehicle refueling facility at Building 423 and the contractor operated facility at Building 630 with double walled underground storage tanks to comply with Suffolk County Article 12 requirements. The two 8,000 gallon tanks installed at Building 423 and the three 8,000 gallon tanks installed at Building 630 were each equipped with stage I fill connections, submerged fill drop tubes and with NYSDEC approved stage II vapor recovery systems. The stage I collection system consists of a vapor-tight return line connected from the gasoline delivery tanker to the tank fill pipe during filling operations. Displaced vapors are returned to the gasoline delivery tanker through the vapor return line as gasoline is pumped into the tanks. The stage II recovery systems are designed to recover more than 90 percent by weight of the gasoline vapors displaced from a motor vehicle gas tank during refueling. Both stage I and stage II systems were installed to comply with 6 NYCRR Part 230 requirements. In 1997 the combined annual throughput of gasoline for the two facilities was 430,354 gallons. Using EPA AP-42 emission factors, the combined VOC emissions from the two facilities for 1997 were estimated to be less than 1,800 pounds. 


\section{Chapter 6}

\section{Liquid Effluents}

\subsection{Policy}

The Department of Energy and Brookhaven National Laboratory are committed to the safety and protection of the environment, cornmunity and employees in the conduct of their operations. Because facilities at BNL discharge or have the potential to discharge radioactive and chemical liquid effluents, effluent monitoring is conducted to ensure that the public and environment are protected during operations and verify that all discharges comply with applicable Federal, State, and local standards.

\subsection{Sanitary System Effluents}

In 1997, significant improvements were made in the treatment of sanitary wastes at BNL. The former process, which included primary clarification followed by intermittent sand filtration, was enhanced by adding modular aeration and ultraviolet disinfection steps. Construction of the enhanced treatment system started in 1996 and was completed in September 1997. Treatment of the sanitary waste stream now includes primary clarification to remove settleable solids and floatable materials, aerobic oxidation for secondary removal of biological matter and nitrification of ammonia, secondary clarification, intermittent sand filtration for final effluent polishing, and ultraviolet disinfection for bacterial control before discharge to the Peconic River. Lacking an impermeable barrier beneath the sand filters, approximately $15 \%$ of the effluent is lost during filtration with the majority of the loss recharging to the groundwater. The STP's Peconic River outfall is a SPDES-permitted discharge point. The Peconic River is an intermittent stream within the BNL site.

Off-site flow occurs during periods of sustained precipitation, typically in the spring; consequently, flow was recorded at the BNL boundary from January through June 1997. Due to the dry summer and fall, there was no flow recorded off-site for the remainder of the year. Figure 6-1 shows a schematic of the STP and its related sampling arrangements.

Real-time monitoring of the clarifier influent for radioactivity, $\mathrm{pH}$, and conductivity, takes place at two locations: about $1.8 \mathrm{~km}$ upstream of the STP, and as the influent is about to enter the primary clarifier. The upstream station gives about 30 minutes of advanced warning to the STP operator that waste water which may exceed BNL effluent release criteria or SPDES limits has entered the sewer system. Effluent leaving the clarifier is monitored a third time for radioactivity. Influent or effluent that does not meet BNL or SPDES effluent release criteria is automatically or manually diverted to one of two lined holdup ponds. Diversion continues until the effluent quality meets the permit limitations or the release criteria. Disposal options for the diverted effluent are evaluated and action taken based on the criteria that radionuclide releases are less than $50 \%$ of the DWS and concentrations of other materials are below the limits established by the BNL SPDES permit. The total combined capacity of the two holding ponds exceeds 26.5 million liters or approximately eight days of typical sanitary flow.

Solids separated in the clarifiers are pumped to a digester where they are reduced in volume by anaerobic bacteria. Periodically, a fraction of the sludge is emptied into a self-contained drying bed to reduce moisture content. The drying bed uses solar energy to dry the watery sludge to a semisolid cake. The dried sludge is then containerized for off-site disposal. 


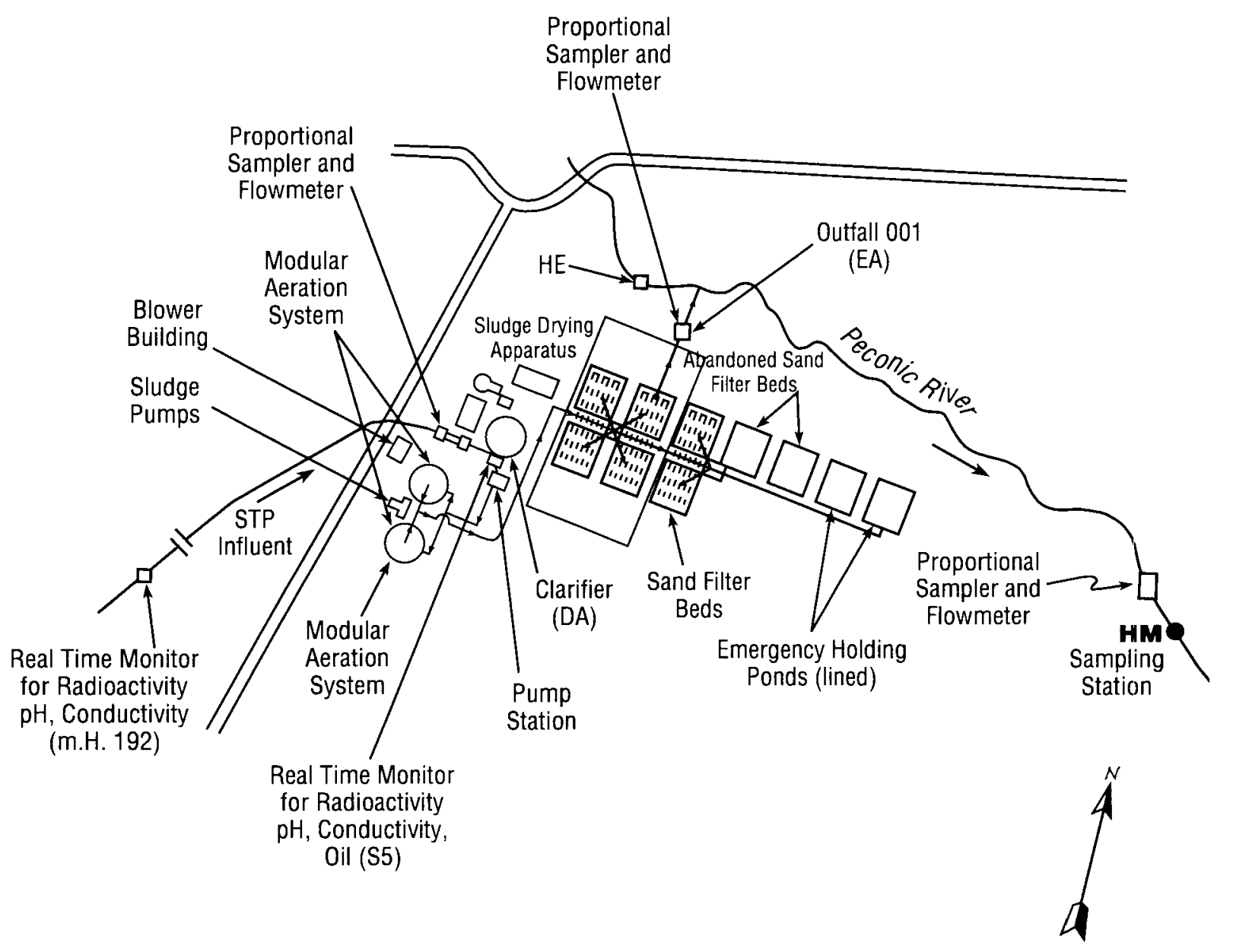

Figure 6-1. Sewage Treatment Plant - Sampling Stations

\subsubsection{Sanitary System Effluent - Radiological}

The STP is sampled at the output of the clarifier (location "DA") and at the Peconic River Outfall (location "EA"). Samples with a volume proportional to the total water flow through the Plant are collected daily. These samples are analyzed for gross alpha, gross beta, and tritium activity. Samples from these locations are also composited on a monthly basis and analyzed for gammaemitting radionuclides and strontium-90.

The Safe Drinking Water Act (SDWA) specifies that no individual may receive an annual dose greater than 4 mrem $(0.04 \mathrm{mSv})$ from radionuclides in drinking water. Although the Peconic River is not used as a source of potable water, drinking water standards are applied for comparison. Under the SDWA, the annual average gross alpha activity limit is $15 \mathrm{pCi} / \mathrm{L}(0.5 \mathrm{~Bq} / \mathrm{L})$ (including radium-226, but excluding radon and uranium). The Act also stipulates a $50 \mathrm{pCi} / \mathrm{L}(2 \mathrm{~Bq} / \mathrm{L})$ gross beta activity screening level, above which nuclide-specific analysis is required. BNL goes beyond this basic screening requirement by performing nuclide-specific analysis, regardless of the gross beta activity. Other specified limits are $20,000 \mathrm{pCi} / \mathrm{L}(740 \mathrm{~Bq} / 1)$ for tritium and $8 \mathrm{pCi} / \mathrm{L}(0.3 \mathrm{~Bq} / \mathrm{L})$ for strontium-90. For all other radionuclides, DOE Order 5400.5 Derived Concentration Guides (DCGs) are used to determine the concentration of the radionuclide which, if continuously in- 
Table 6-1

BNL Site Environmental Report for Calendar Year 1997

Gross Activity and Tritium Results at STP Clarifier Influent
Flow
(liters)
Gross Alpha

Average Maximum
Gross Beta

Average

Maximum
$(\mathrm{pCi} / \mathrm{L})$

Tritium

Average

Maximum

\section{STP Clarifier}

January

$6.43 E+07$

$0.4 \pm 1.3<2.7$

February

$6.70 E+07$

$0.1 \pm 2.3 \quad 3.0 \pm 2.0$

March

$7.00 \mathrm{E}+07$

$0.4 \pm 2.0<2.7$

April

$6.58 \mathrm{E}+07$

$0.9 \pm 2.1 \quad 4.1 \pm 2.2$

May

June

$6.72 E+07$

$1.7 \pm 3.2 \quad 5.5 \pm 2.6$

$6.13 E+07$

$1.5 \pm 3.0 \quad 4.9 \pm 2.6$

July

$8.42 E+07$

$2.6 \pm 4.9 \quad 11.0 \pm 3.4$

August

$8.48 \mathrm{E}+07$

September

$7.51 \mathrm{E}+07$

$2.2 \pm 5.6 \quad 13.1 \pm 3.9$

$2.8 \pm 2.7 \quad 6.4 \pm 2.4$

October $\quad 7.54 \mathrm{E}+07$

$0.9 \pm 3.0 \quad 3.6 \pm 2.3$

November

$6.66 \mathrm{E}+07$

December

$6.37 \mathrm{E}+07$

Annual Avg.

SDWA Limit (Annual Avg.)

Typical Detection Limit

Notes:

1. Maximum values reported with $2 \sigma(95 \%)$ confidence interval.

2. Average values calculated as arithmetic mean of individual measurements \pm 2 standard errors of the mean.

* This value reflects the tritium spike observed in July. See text for full discussion.

gested over a calendar year, would produce an effective dose equivalent of 4 mrem. These limit values are shown at the bottom of Table 6-3 under "SDWA Limit".

Gross activity measurements are used as a screening tool for detecting the presence of radioactivity without identifying the specific radionuclide(s) causing it. The annual average gross alpha and beta activity in the outfall stream has remained consistent with background levels for many years; this continued in 1997. Average gross alpha and beta activity at the STP Outfall was $1.7 \mathrm{pCi} / \mathrm{L}(0.06 \mathrm{~Bq})$ and $7.6 \mathrm{pCi} / \mathrm{L}(0.28 \mathrm{~Bq} / \mathrm{L})$, respectively. See Tables 6-1 and 62 for complete data. Quality assurance data indicate that some samples analyzed in the second half of CY 1997 may have a positive bias. Chapter 10 has further discussion.

Gamma spectroscopy analysis detected beta/gamma-emitting radionuclides at DA and EA sporadically throughout the year, although levels were close to, or below, the minimum detection limits of the analysis system (Tables 6-3 and 6-4). The presence of cesium-137 at the STP Outfall is due to the continued leaching of very small amounts of cesium-137 from the sand filter beds which were deposited during an unplanned sanitary release in June, 1988 (Miltenberger et al., 
Table 6-2

BNL. Site Environmental Report for Calendar Year 1997

Gross Activity and Tritium Results at STP Peconic River Outfall

\begin{tabular}{|c|c|c|c|c|c|c|c|}
\hline \multirow[b]{2}{*}{ STP Outfall } & $\begin{array}{l}\text { Flow } \\
\text { (liters) }\end{array}$ & \multicolumn{2}{|c|}{$\begin{array}{l}\text { Gross Alpha } \\
\text { Average Maximum }\end{array}$} & \multicolumn{2}{|c|}{$\begin{array}{l}\text { Gross Beta } \\
\text { Average Maximum } \\
\qquad(\mathrm{pCi} / \mathrm{L})\end{array}$} & $\begin{array}{l}\text { Tritium } \\
\text { Average }\end{array}$ & Maximum \\
\hline & $6.36 \mathrm{E}+07$ & $0.9 \pm 1.8$ & $3.2 \pm 1.9$ & $5.6 \pm 9.9$ & $24.6 \pm 5.8$ & $1,752 \pm 2,319$ & $5,320 \pm 500$ \\
\hline February & $5.68 \mathrm{E}+07$ & $0.5 \pm 1.7$ & $<2.7$ & $5.3 \pm 4.4$ & $10.5 \pm 4.7$ & $1,433 \pm 1,001$ & $3,250 \pm 376$ \\
\hline March & $7.14 E+07$ & $1.0 \pm 1.9$ & $<3.4$ & $5.2 \pm 6.9$ & $12.9 \pm 4.9$ & $1,599 \pm 1,303$ & $4,210 \pm 455$ \\
\hline April & $7.13 E+07$ & $0.7 \pm 1.5$ & $2.2 \pm 1.4$ & $5.5 \pm 5.4$ & $10.8 \pm 5.2$ & $1,037 \pm 463$ & $1,500 \pm 278$ \\
\hline May & $6.22 E+07$ & $1.1 \pm 2.7$ & $4.0 \pm 1.6$ & $7.3 \pm 5.8$ & $15.1 \pm 5.1$ & $1,080 \pm 777$ & $2,180 \pm 325$ \\
\hline June & $6.93 E+07$ & $1.7 \pm 3.6$ & $6.7 \pm 2.8$ & $10.3 \pm 17.0$ & $42.7 \pm 6.7$ & $1,195 \pm 1,068$ & $3,110 \pm 405$ \\
\hline July & $8.17 E+07$ & $2.1 \pm 2.6$ & $5.8 \pm 2.9$ & $8.9 \pm 6.0$ & $17.0 \pm 5.1$ & $4,699 \pm 28,332$ & $67,300 \pm 1,570^{*}$ \\
\hline August & $7.85 \mathrm{E}+07$ & $2.6 \pm 3.9$ & $7.3 \pm 2.8$ & $9.7 \pm 15.3$ & $41.8 \pm 7.0$ & $1,061 \pm 2,205$ & $5,020 \pm 380$ \\
\hline September & $8.20 \mathrm{E}+07$ & $3.3 \pm 3.0$ & $6.1 \pm 2.6$ & $8.9 \pm 6.8$ & $15.8 \pm 5.3$ & $1,649 \pm 2,288$ & $3,330 \pm 311$ \\
\hline October & $4.87 E+07$ & $1.5 \pm 3.6$ & $6.2 \pm 2.8$ & $7.4 \pm 6.8$ & $16.8 \pm 5.7$ & $228 \pm 208$ & $420 \pm 197$ \\
\hline November & $5.03 E+07$ & $2.2 \pm 4.3$ & $6.7 \pm 3.0$ & $7.3 \pm 7.3$ & $16.8 \pm 5.4$ & $280 \pm 199$ & $472 \pm 189$ \\
\hline December & $4.05 \mathrm{E}+07$ & $3.3 \pm 4.5$ & $8.3 \pm 3.3$ & $9.8 \pm 4.9$ & $15.4 \pm 5.6$ & $242 \pm 309$ & $560 \pm 193$ \\
\hline Ânnuai Âvg. & & $1.7 \pm 3.6$ & & $7.6 \pm 9.6$ & & $1,366 \pm 8,608$ & \\
\hline Total & $7.76 \mathrm{E}+08 \mathrm{~L}$ & $1.4 \mathrm{mCi}$ & & $5.9 \mathrm{mCi}$ & & $1,149 \mathrm{mCi}$ & \\
\hline $\begin{array}{l}\text { SDWA Limit } \\
\text { Typical Detec }\end{array}$ & $\begin{array}{l}\text { Annual Avg.) } \\
\text { ion Limit }\end{array}$ & $\begin{array}{l}15 \\
2.9\end{array}$ & & $\begin{array}{l}50 \\
8.5\end{array}$ & & $\begin{array}{l}20,000 \\
300\end{array}$ & \\
\hline $\begin{array}{l}\text { Notes: } \\
\text { 1. Maximun } \\
\text { 2. Average } \\
\text { * This value }\end{array}$ & $\begin{array}{l}\text { ues report } \\
\text { es calculat } \\
\text { ects the tr }\end{array}$ & ke obse & $\begin{array}{l}\text { eean of } \\
\text { ed in } \mathrm{Ju}\end{array}$ & 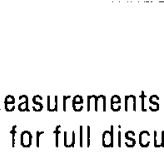 & 0 & the mean & \\
\hline
\end{tabular}

1989). This is clear when comparing cesium detected in plant influent and effluent; detections in influent are low and infrequent, where detections in effluent consistently are measurably higher (Figure 6-2). Total cesium-137 released at the Outfall during the year was less than $1 \mathrm{mCi}$ (37 $\mathrm{MBq}$ ), and average concentrations in STP effluent were less than $1 \%$ of the drinking water standard.

Stronitum-90 was occasionally detected in monthly composite samples of STP influent and effluent, though at levels that were very close to the minimum detection limit. The largest single value recorded for a monthly effluent sample was $1.4 \mathrm{pCi} / \mathrm{L}(0.05 \mathrm{~Bq} / \mathrm{L})$, or $17 \%$ of the drinking water standard of $8 \mathrm{pCi} / \mathrm{L}(0.3 \mathrm{~Bq} / \mathrm{L})$. Because the detected concentrations were so close to the detection limit, there is a reduced certainty associated with them. However, since it is known that strontium-90 was discharged from the STP in the past, it is likely that some residual remains in the sand filter beds and is available for leaching, as with the cesium-137 discussed above. Strontium-90 values observed in the influent samples during the first half of CY 1997 are also 
Table 6-3

BNL Site Environmental Report for Calendar Year 1997

Gamma-Emitting Radionuclides and Strontium-90 Detected at STP Clarifler and Peconic River Outfall

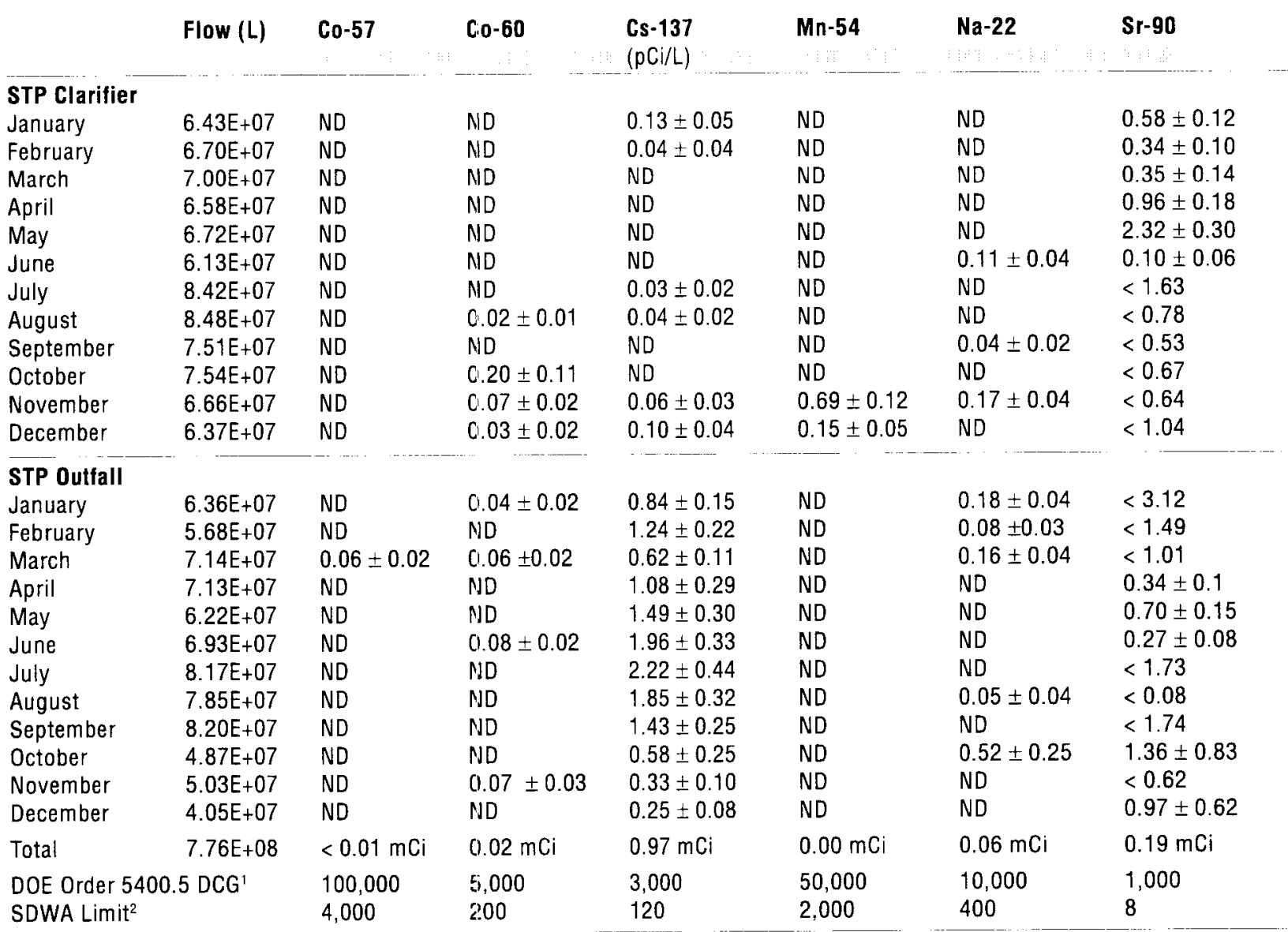

1 Derived Concentration Guide. Concentration which, if ingested $2 \mathrm{~L} /$ day for 1 year, would result in an individual committed effective dose of 100 mrem.

${ }^{2}$ Concentration required to produce Safe Drinking Water Act limit of $4 \mathrm{mrem} / \mathrm{yr}$ under conditions of continuous consumption.

Notes:

a. Maximum values reported with $2 \sigma(95 \%)$ confidence interval.

b. Average values calculated as arithmetic mean of individual measurements \pm 2 standard errors of the mean.

c. ND = Not Detected.

very close to the minimum detection limit with the exception of the May sample $(2.3 \mathrm{pCi} / \mathrm{L}[0.09$ $\mathrm{Bq} / \mathrm{L}]$ ). This result may be due to either (1) an analytical anomaly, or (2) residual material which has been flushed out after being entrapped in the site sanitary piping system.

Tritium detected at the STP previcusly originated from three sources: (1) HFBR sanitary system releases, (2) small, infrequent batch releases, and (3), the on-site liquid waste concentration process at the WCF generated tritiated distillate. However, this latter source was eliminated with the introduction of the Evaporator Facility in 1995. A plot of 1997 tritium concentrations recorded in the STP effluent is presented in Figure 6-3. A 10-year trend of annual average tritium concentrations measured in the Peconic is shown in Figure 6-5.

In addition to the airborne releases discussed in Section 5.1, tritium is also released from the HFBR via the liquid pathway. Tritiated water vapor accumulates inside the containment building 


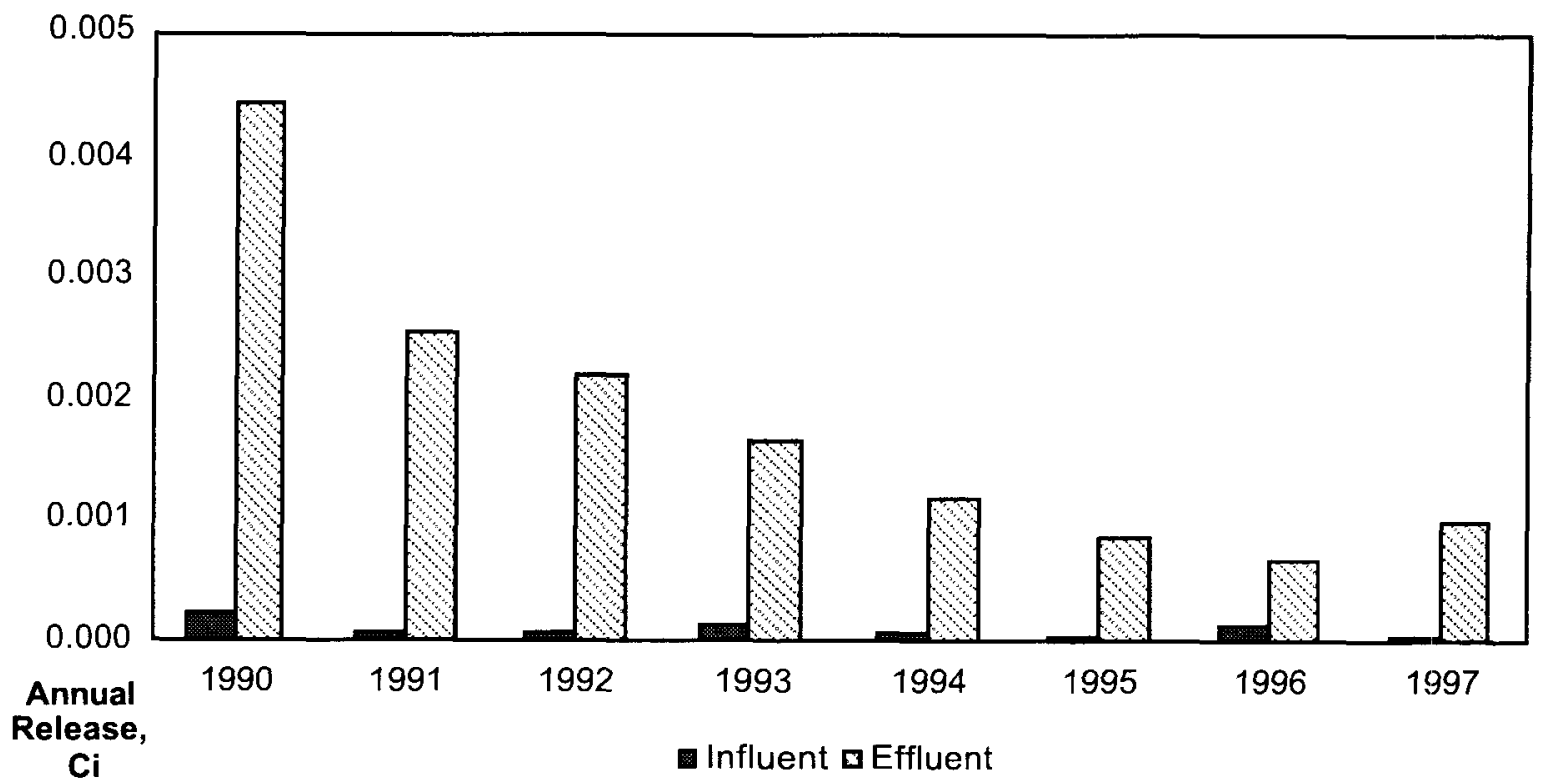

Figure 6-2. Cs-137 Trend in STP Influent and Effluent

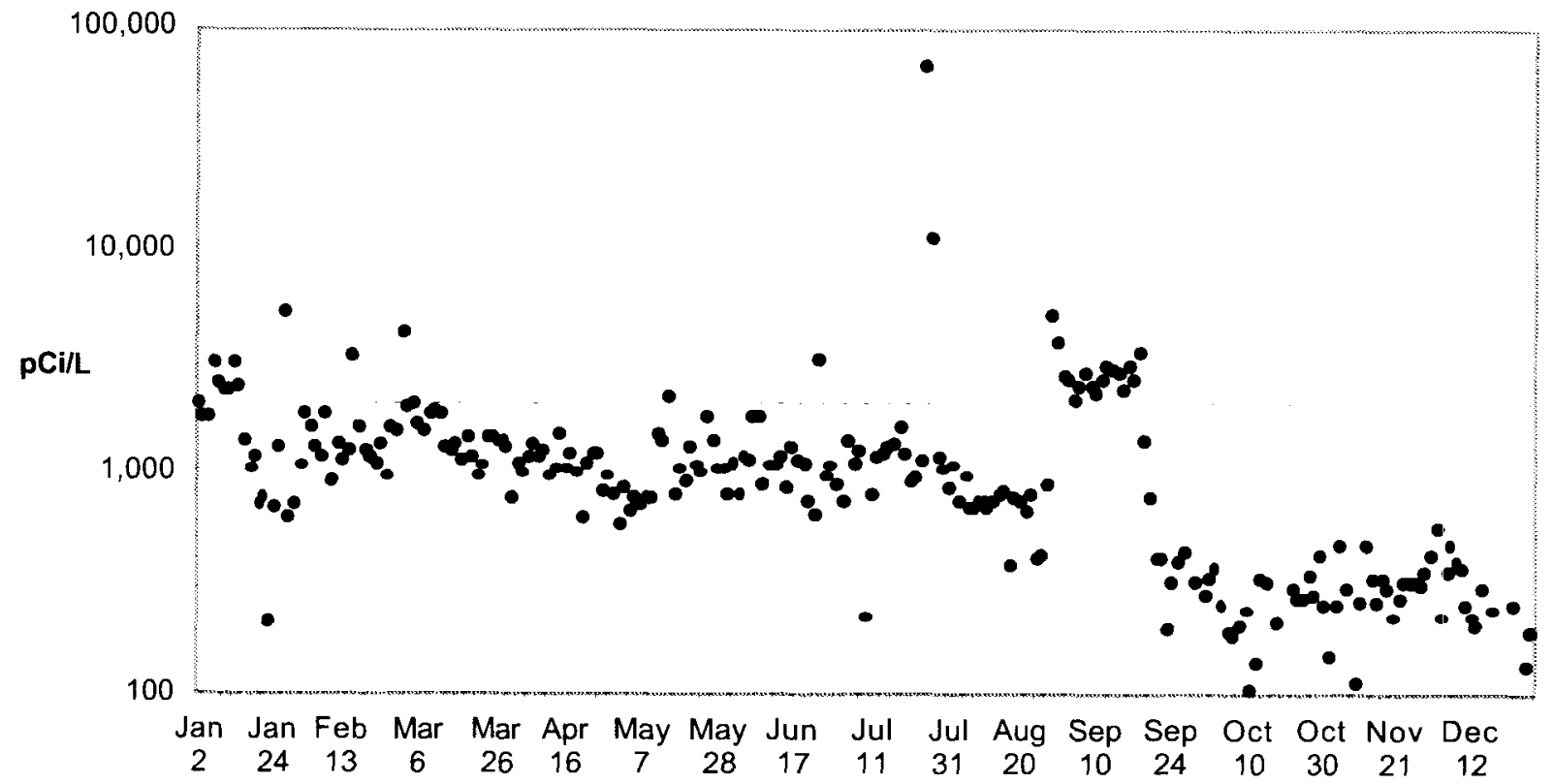

Figure 6-3. Tritium Concentrations in STP Effluent, 1997

as a result of vessel depressurizations during open fuel handling, or operations which require the opening of primary coolant systems. Some of this tritium enters the building's sanitary waste system, providing a release pathway to the STP. In 1997, the tritium released by this pathway constituted less than $4 \%$ of the total HTO released from the HFBR.

In 1997, the annual average tritium concentration measured at the Peconic River Outfall was $1,366 \mathrm{pCi} / \mathrm{L}(51 \mathrm{~Bq} / \mathrm{L})$, or $7 \%$ of the Drinking Water Standard. A total source term of 1.1 Ci (41 GBq) of tritium was released during the year. This is the lowest annual release of tritium to the Peconic River observed since routine measurements began in 1966 (Figure 6-4). 


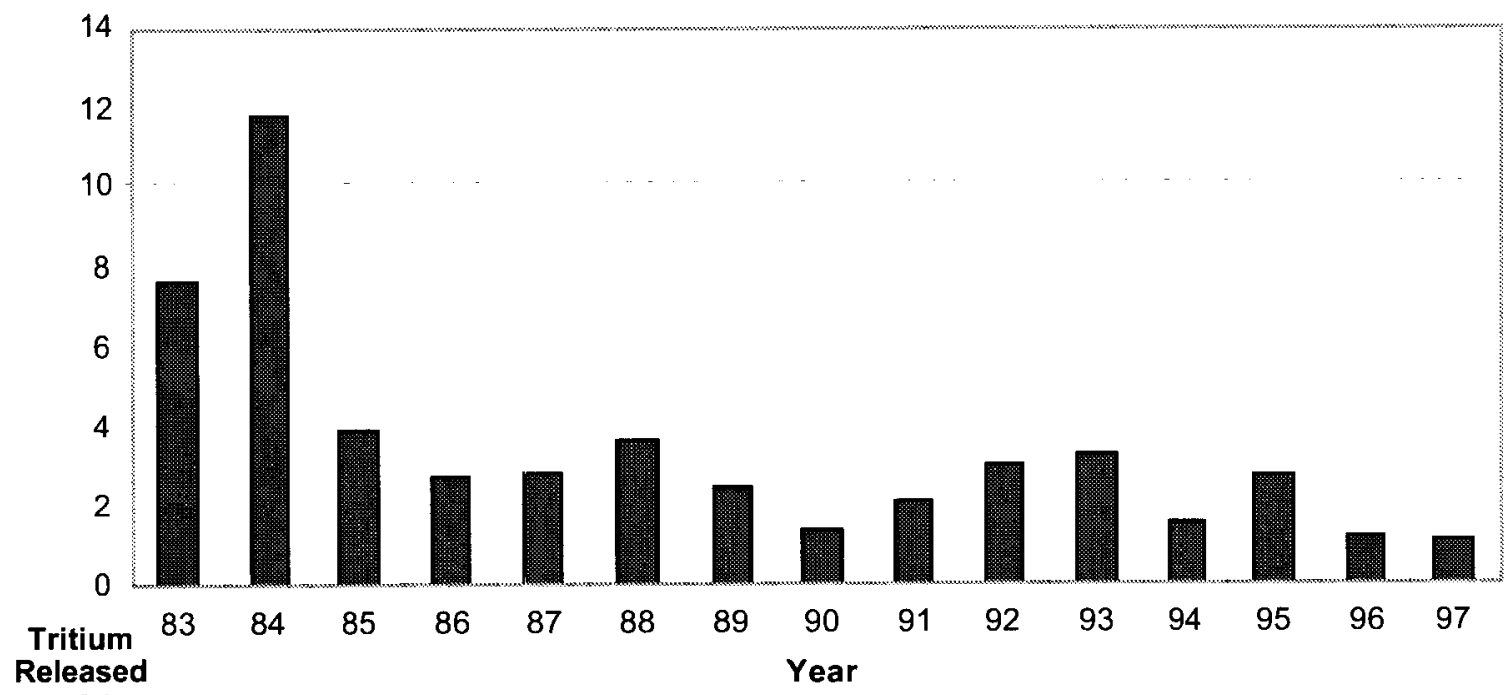

(Ci)

Figure 6-4. Tritium Released to Peconic River, 15 Year Trend

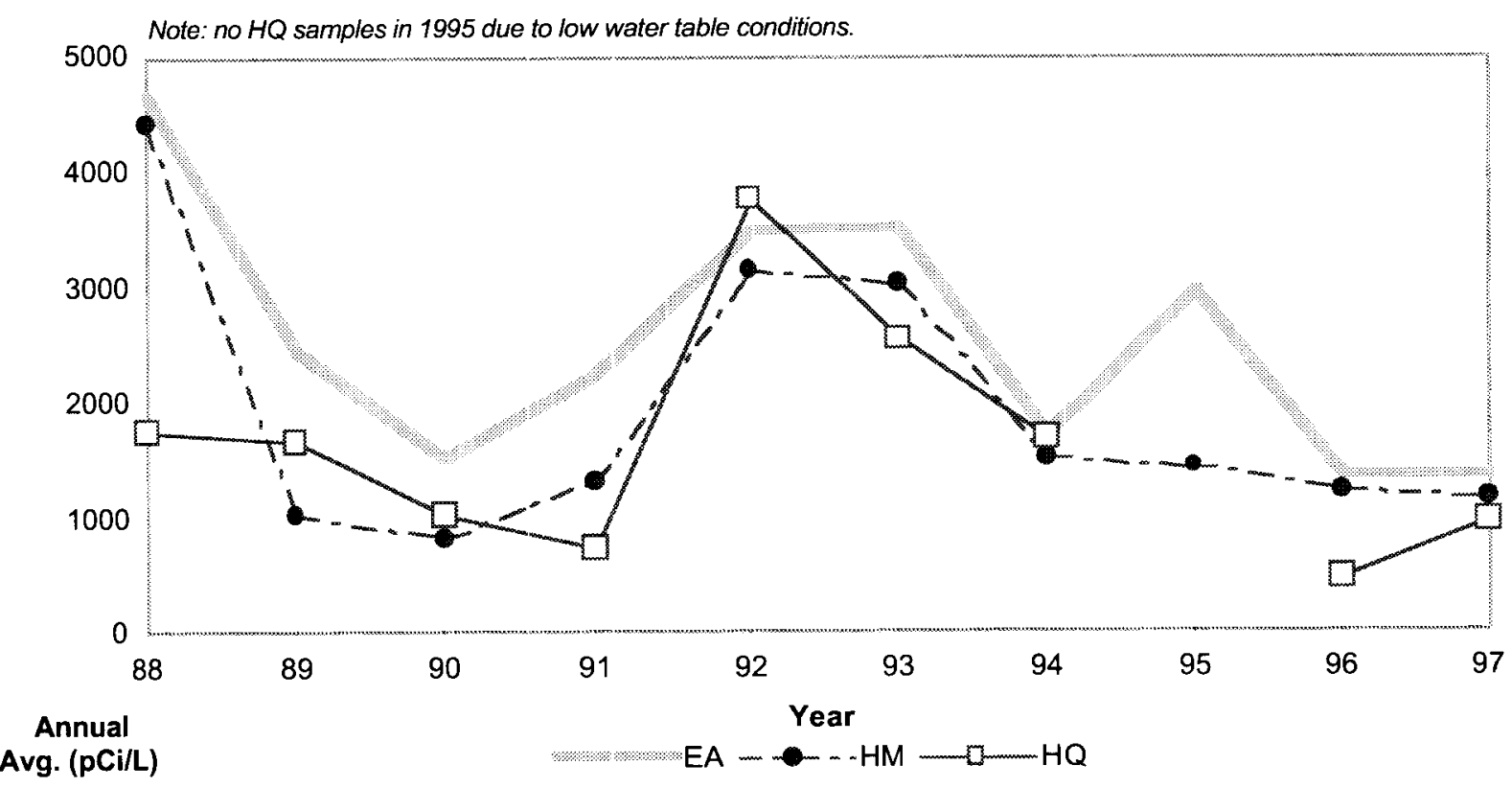

Figure 6-5. STP/Peconic River Annual Average Tritium Concentrations, 10 Year Trend

\subsubsection{Tritium Concentration Increase in July, 1997}

Monitoring data indicated that sanitary water entering the Sewage Treatment Plant between 8 AM, July 24 and 6 AM July 25 experienced a sharp increase (or "spike") in tritium concentrations. Analysis of samples from the July 2524 -hour composite samples showed a maximum value of $90,000 \mathrm{pCi} / \mathrm{L}(3,330 \mathrm{~Bq} / \mathrm{L})$ at the clarifier output and $67,000 \mathrm{pCi} / \mathrm{L}(2,480 \mathrm{~Bq} / \mathrm{L})$ at the Peconic River Outfall. Figure 6-6 shows the trend in STP and Peconic River tritium data for that week, indicating typical values two days before and after the elevated concentrations. It is apparent that a slug of high concentration tritiated water entered the sanitary system. Due to the fluid 


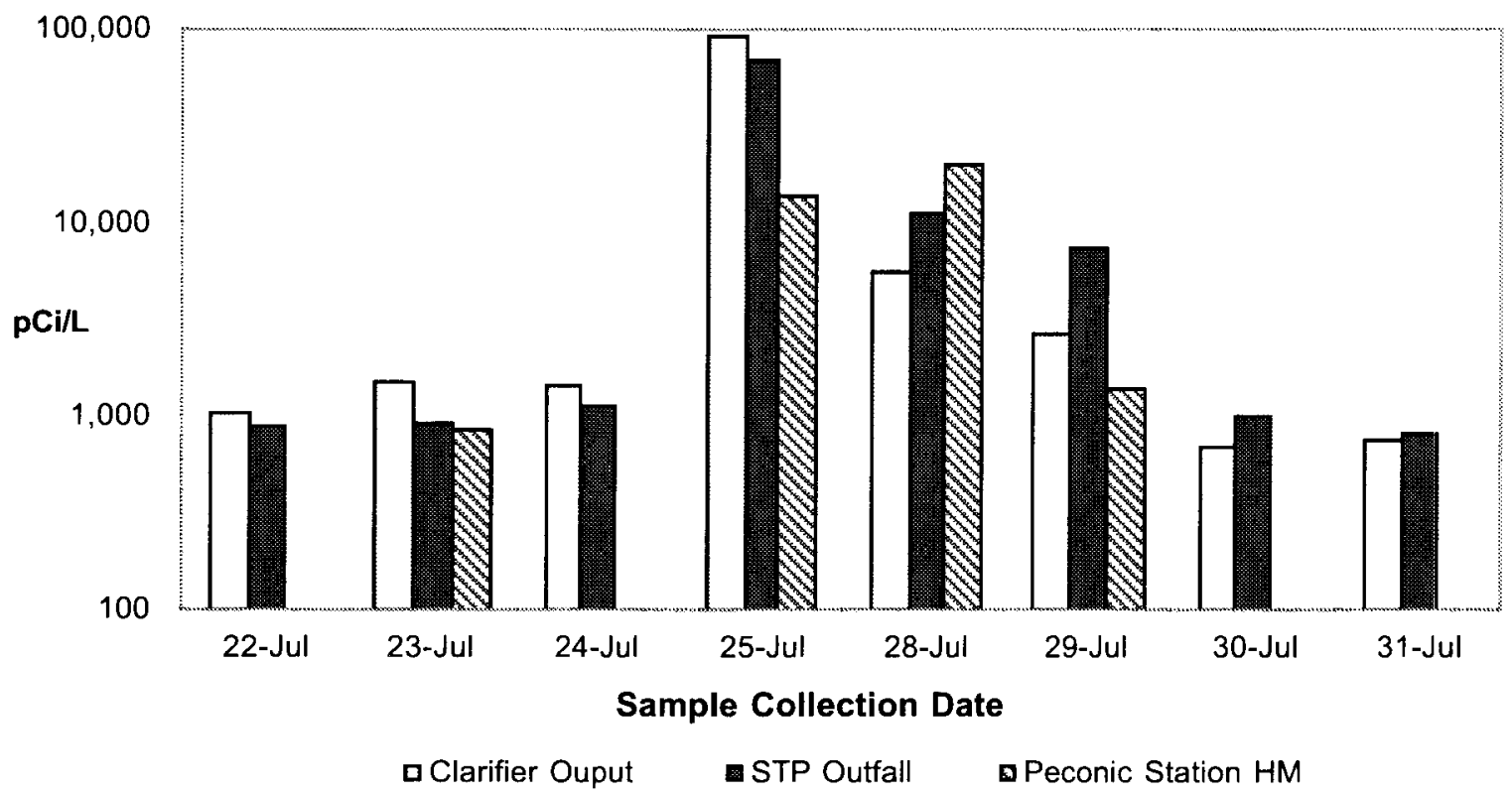

Figure 6-6. STP and Peconic River Tritium Levels, July 22 to July 31, 1997

dynamics of the STP, which introduces dilution at the clarifier and delay during transit through the sand filter beds, the resulting tritium concentrations at the Peconic River Outfall peaked and then trailed off over the next several days before returning to normal. During the period of elevated concentration, the total released source term was approximately $0.3 \mathrm{Ci}(11 \mathrm{GBq})$. Under normal operating conditions, the daily output from the Plant is about $0.002 \mathrm{Ci}(74 \mathrm{MBq})$. Though this short-term elevation produced concentrations which exceeded the $20,000 \mathrm{pCi} / \mathrm{L}(740 \mathrm{~Bq} / \mathrm{L})$ drinking water standard, no violation of the Safe Drinking Water Act, the SPDES permit, or DOE Orders occurred.

Due to local low water table conditions during this time, there was no significant flow of the Peconic beyond the BNL site boundary. Though standing water was observed at Station HQ, the BNL side and the off-site side of the river are effectively separated during low flow conditions by a land mass that runs across it. The river runs through a culvert at HQ when water levels are high enough. Samples collected on July 29 from the eastern (off-site) portion of the river showed no detectable tritium, and a sample collected on August 1 had a value just above the detection limit. Based on this data, the activity associated with the spike appears to have been retained in the onsite portion of the river.

In response to the tritium spike, an Investigation Committee was formed on July 29, specifically charged with considering what systems or processes could have released activity consistent with values seen at the STP. To determine the point of release of the tritium, the departments and facilities within BNL which handle tritium were extensively reviewed. However, no single source could be positively identified.

\subsubsection{Sanitary System Effluent - Non-radiological}

The effluent from the Laboratory STP discharges into the Peconic River at location EA (Outfall 001) and is subject to the conditions of the SPDES Permit No. NY-0005835, issued by the NYSDEC. Monthly Discharge Monitoring Reports (DMRs), with detailed analytical results and information about the operational performance of the STP, are submitted to the NYSDEC and SCDHS. The BNL SPDES compliance program is discussed in detail in Chapter 2.

In addition to collecting and analyzing the STP effluent samples for compliance with SPDES, BNL monitored locations DA and EA routinely during 1997. Daily composite samples were col- 
Table 6-4

BNL Site Environmental Report for Calendaj Year 1997

Sewage Treatment Plant (STP) lat.

Average Water Quality and Metals Data

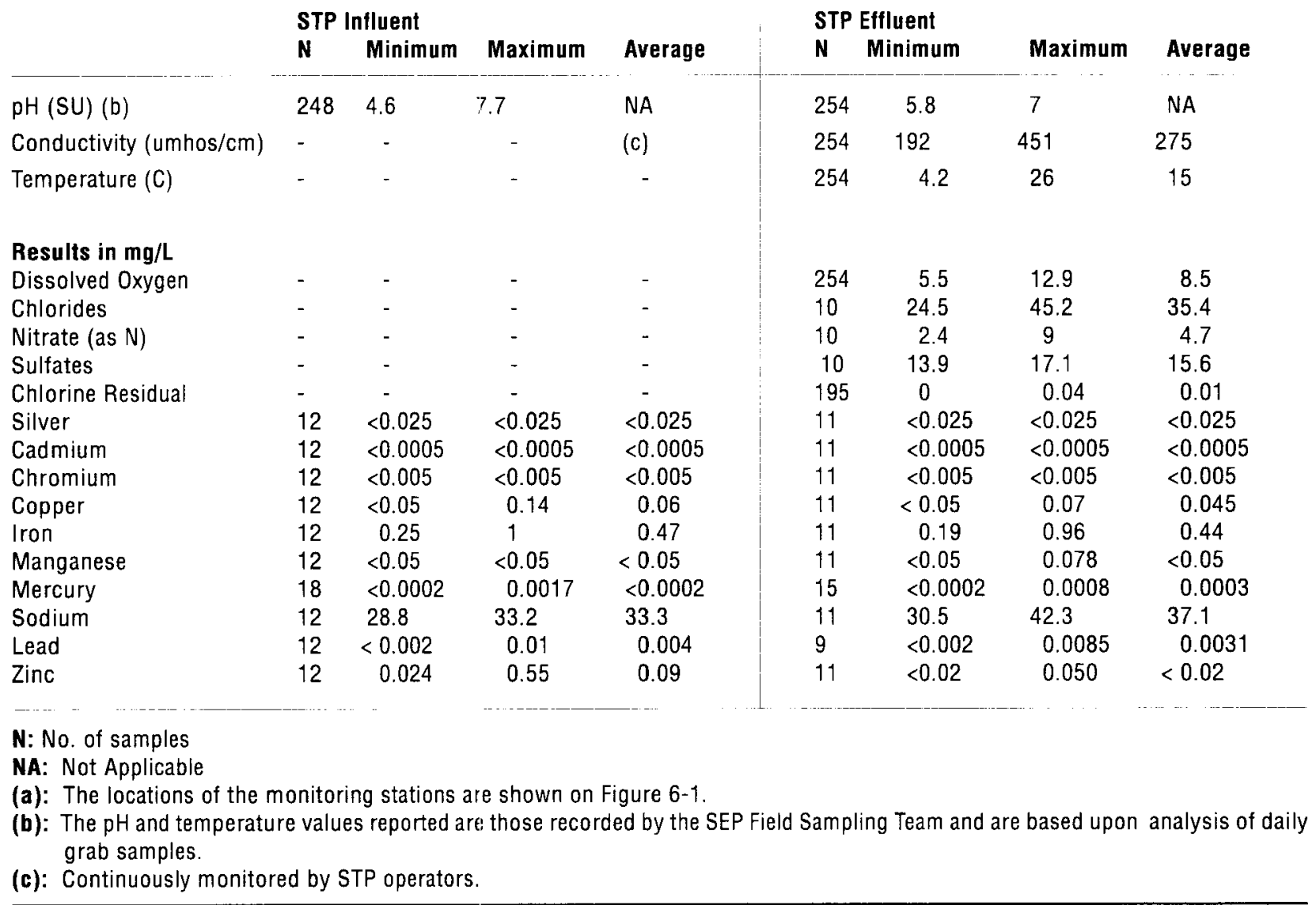

lected by the Field Sampling Team using a flow proportional refrigerated sampling device (ISCO Model 1600). The ES\&HS Division's Analytical Services Laboratory (ASL) analyzed these composite samples for metals and anions. Metals analysis is conducted on a monthly composite of the daily samples, whereas anions are analyzed using a single daily sample. Grab samples were collected daily at Location EA and monitored for field-measured parameters including $\mathrm{pH}$, conductivity, temperature, dissolved oxygen, and chlorine residual. Daily influent and effluent logs are also maintained by the STP operators for flow, $\mathrm{pH}$, temperature, settleable solids, and chlorine residual.

Table 6-4 summarizes the results of water quality and metals analyses for these samples. Comparison of the effluent data to the SPDES effluent limitations shows that all analytical parameters, except iron, were within SPDES effluent limitations. Iron exceeded SPDES permitted levels on several occasions, as was similarly reported in the SPDES data in Chapter 2. Construction at the STP was deemed the most likely contributor to this increase. Modifications to the chlorine contact chamber, primary clarifier effluent chamber, and installation of new manholes and piping, all contributed to reduced separation efficiencies and ultimately, increased concentrations of suspended solids in the effluent. All other data corresponds well with the compliance data reported in Chapter 2 (Table 2-3). With the implementation of UV disinfection, monitoring for chlorine residual was stopped in October 1997. Bacteriological data for the UV disinfection system show no detection of fecal nor total coliform in the STP effluent. 


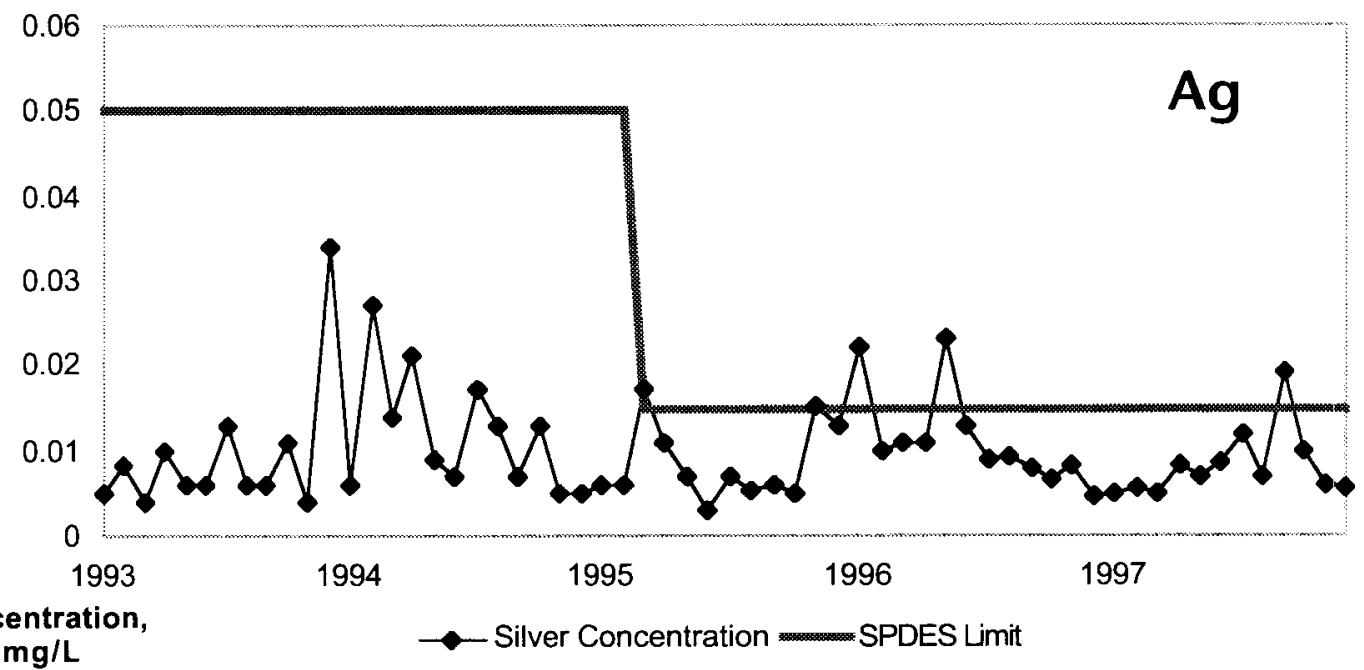

Concentration

Figure 6-7. Maximum Concentration of Silver Discharged from STP, 1993 - 1997

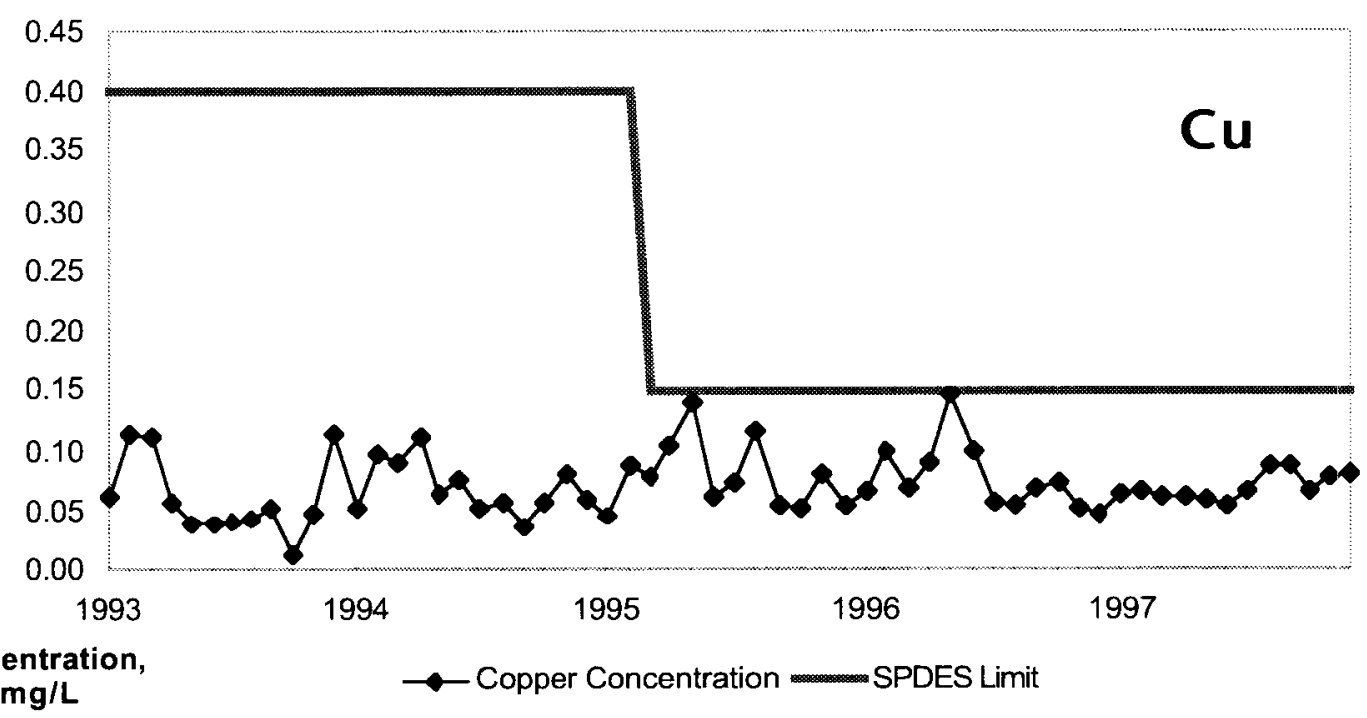

Figure 6-8. Maximum Concentration of Copper Discharged from STP, 1993 - 1997

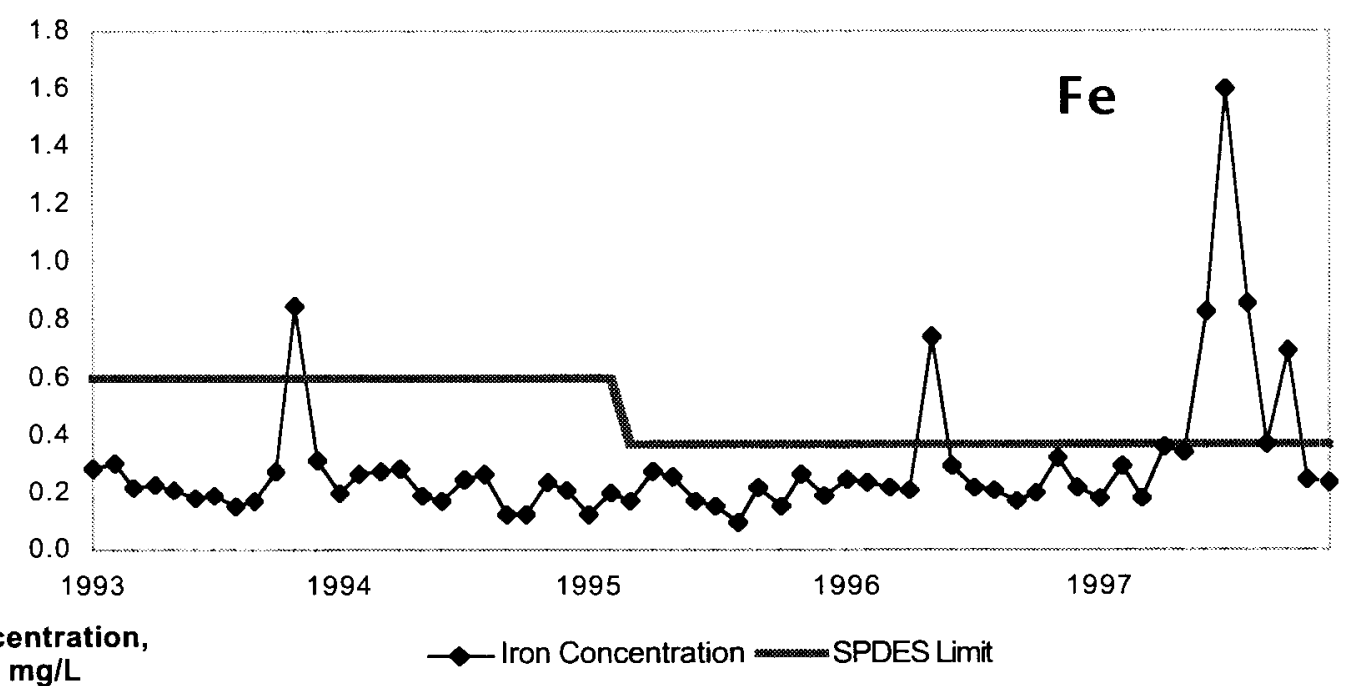

Figure 6-9. Maximum Concentration of Iron Discharged from STP, 1993 - 1997 


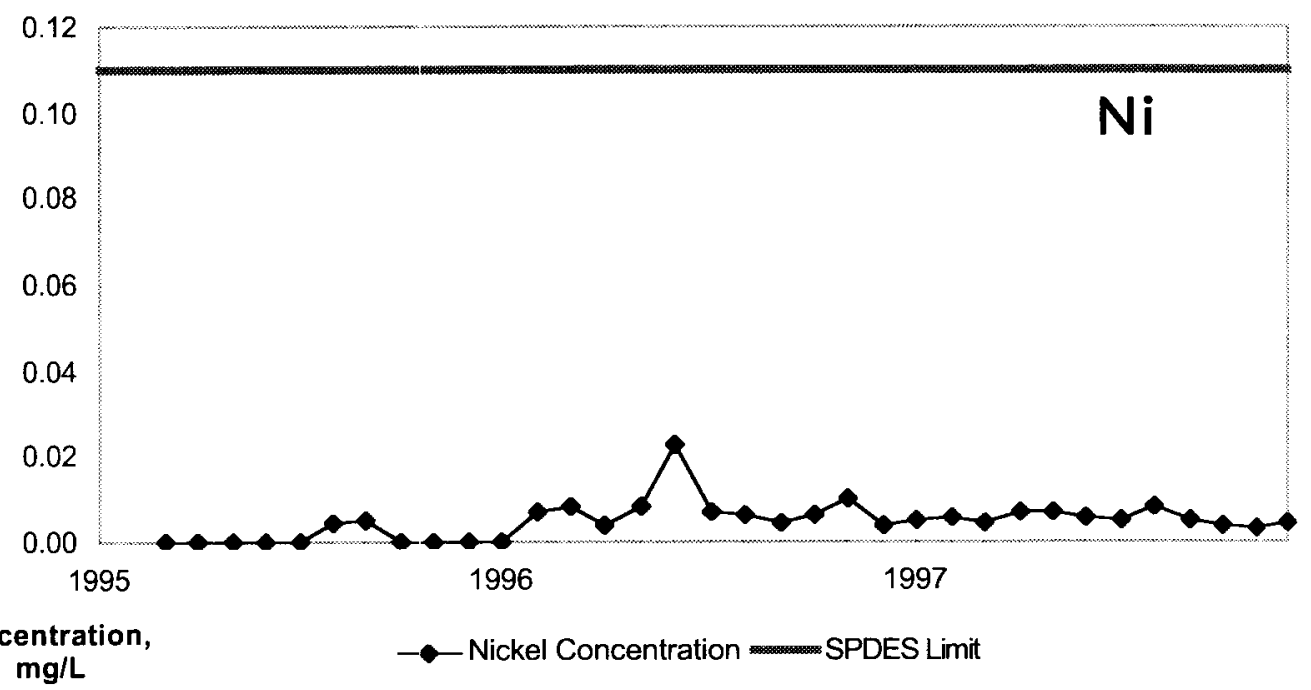

Figure 6-10. Maximum Concentration of Nickel Discharged from STP, 1993 - 1997

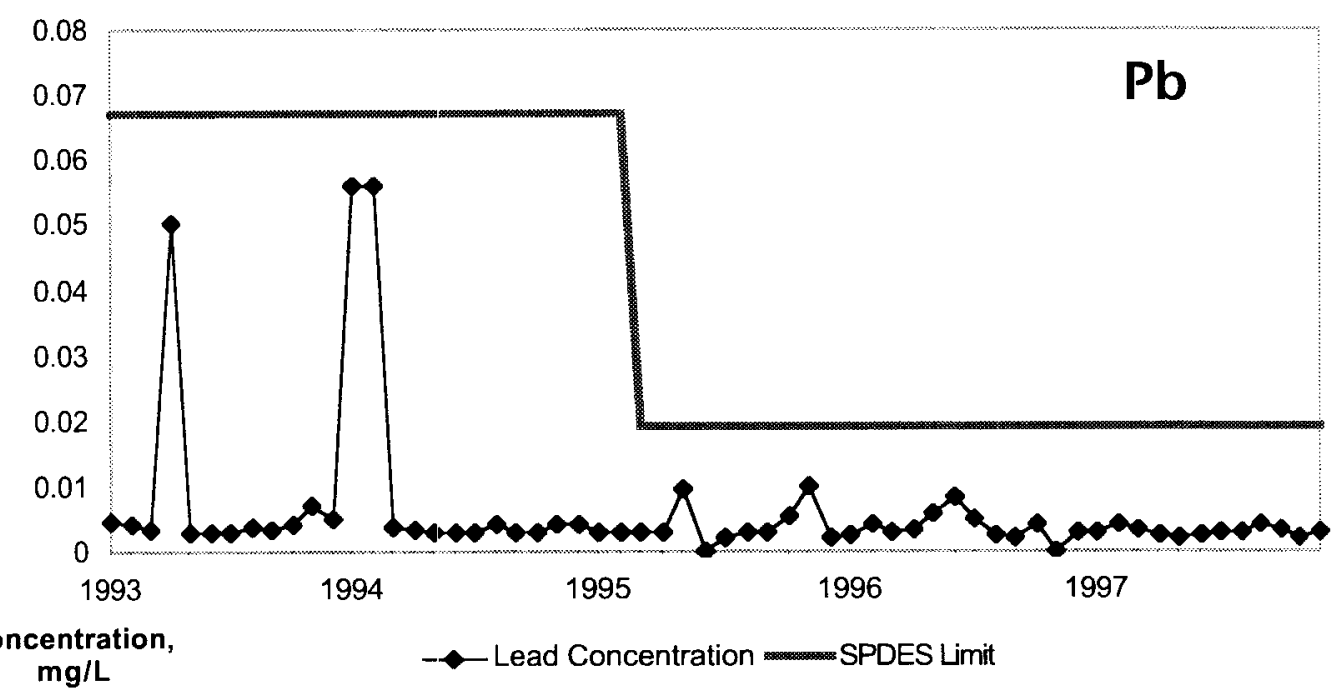

Figure 6-11. Maximum Concentration of Lead Discharged from STP, 1993 - 1997

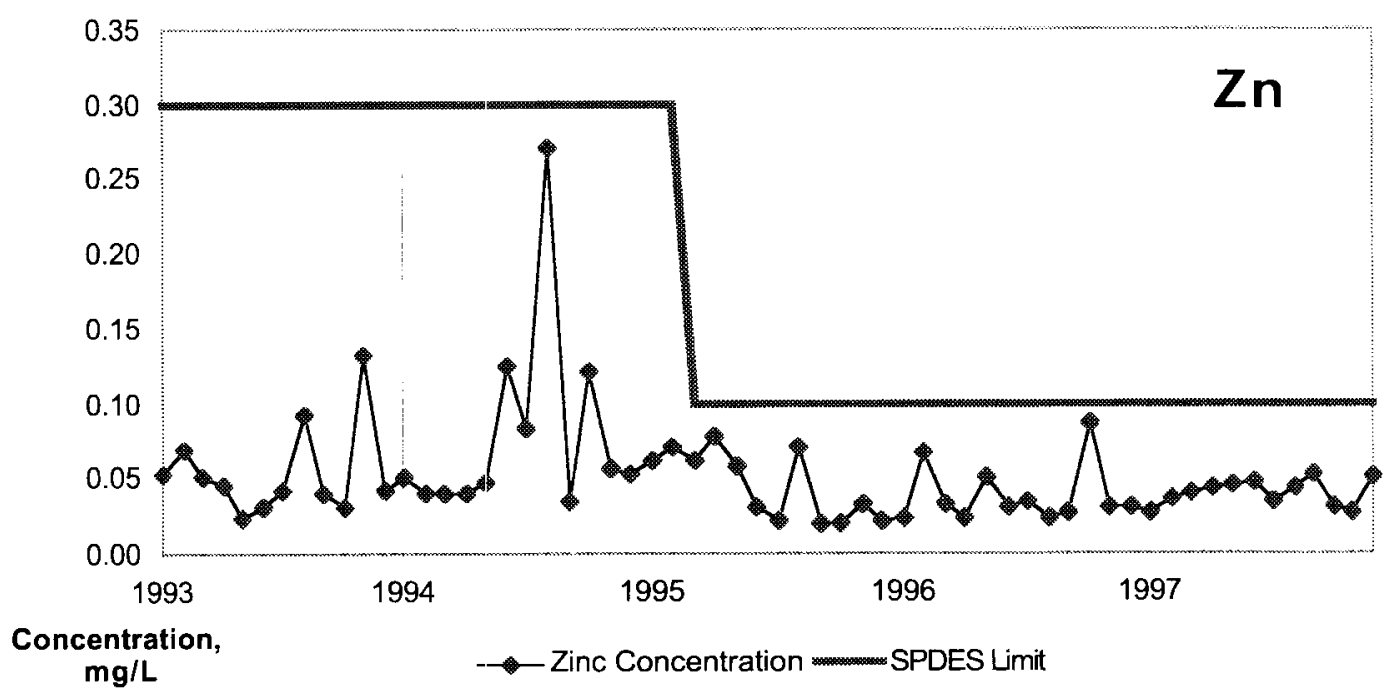

Figure 6-12. Maximum Concentration of Zinc Discharged from STP, 1993 - 1997 
Figures 6-7 through 6-12 plot five year trends for the maximum monthly concentrations of copper, iron, lead, silver, nickel, and zinc in the STP outfall as reported in the DMRs; the SPDES permit limits are also shown. Due to the inclusion of nickel in the SPDES permit from 1995, the plot only contains analytical results for CY 1995 through 1997.

\subsubsection{Assessments of Process-Specific Waste Water}

Waste water which has the potential to violate SPDES permit limitations or groundwater effluent standards is held and characterized to determine the appropriate means of disposal. The analytical results are compared with the appropriate limitation and released only if the discharge does not jeopardize the quality of the effluent.

The SPDES permit includes requirements for quarterly sampling and analysis of process-specific waste waters discharged from the photographic developing operations in Buildings 118 and 197B, the printed-circuit-board fabrication operations in Building 535B, and the metal cleaning operations in Building 197C. These operations were monitored for chemical contaminants, such as inorganic elements (i.e., metals), cyanide, and volatile and semi-volatile organic compounds. All analytical results were reported quarterly to the NYSDEC.

Analytical results for the photo developing operations show that silver from Building 197B exceeded the BNL SPDES permit limitation for the STP discharge; concentrations in this discharge ranged from non-detectable to $68 \mathrm{ug} / \mathrm{L}$. To reduce the impact of silver on the STP, as well as the quantity of silver bearing hazardous wastes, digital photographic equipment was obtained in late 1996. It is anticipated that replacing of wet photo developing processes with digitally produced photos will reduce the silver bearing waste stream by up to $75 \%$. While the concentration of silver discharged from the photo developers is not expected to change, a net decrease in the total mass of silver discharged to the STP should be realized due to their less frequent use.

Efforts continued to replace the Building 197C Acid Cleaning Facility with an environmentally acceptable alternative. Following recommendations from DOW Chemical Corp. Advanced Cleaning Systems Division, construction of an alternate cleaning process commenced. The new process replaces the strong acids and bases formerly used to clean the aluminum, stainless steel and copper components used in experimental beam lines, with mild phosphate, borate and inorganic acid solutions. Construction of the new Centralized Degreasing Facility was completed in the spring of 1997 and the former Acid Cleaning Facility ceased operations in August. Assessment of the cleaning process by the National Synchrotron Light Source shows the process meets all expectations. Based upon analytical results for spent cleaning baths the wastes can be managed inhouse as nonhazardous thus attaining the goal of a zero hazardous waste process.

Process waste waters, which were not evaluated for incorporation into the SPDES permit or were not expected to be of consistent quality, were held for characterization by ES\&HS before release to the sewer. Typical waste waters, which are routinely evaluated, are ion-exchange column regeneration wastes, primary closed-loop cooling water systems, and other industrial waste waters. To determine the method of disposal, samples are analyzed for specific contaminants. The analyses then are reviewed and the concentrations compared to the SPDES effluent limitations. If the concentrations are within standards, authorization for sewer disposal is granted, if not, alternate means of disposal are evaluated. In all instances, any waste which contains hazardous levels of chemical contaminants or elevated radiological contamination is sent to the WMD for disposal.

\subsubsection{Recharge Basins}

Figure 6-13 depicts the locations of BNL's recharge basins. Figure 6-14 is an overall schematic of water use at the Laboratory. Recharge Basins HN and HT receive once-through cooling water discharges generated at the AGS as well as cooling tower blow-down and storm water runoff. Recharge Basin HS receives predominantly storm water runoff and minimal cooling tower blowdown from the NSLS. Basin HX receives WTP-filter backwash water. Basin HP receives once-through cooling water from the Medical Research Reactor. Recharge Basin HO receives cooling water and 
cooling tower discharges from the AGS and HFBR, and storm water runoff. A polyelectrolyte and dispersant is added to the supply of AGS cooling-and process-water to keep the ambient iron in solution. Approximately 3.9 million liters per day (MLD) of water used to cool the main heat exchangers at the AGS was discharged to the HO Basin. The HFBR secondary-cooling-system water recirculates through mechanical cooling towers and is treated with inorganic polyphosphate and tolytriazole to control corrosion and deposition of solids. The blow-down from this system, combined with once-through cooling water used at the Cold Neutron Facility and the Cyclotrons, is also discharged to the HO Basin. Due to the shutdown of the HFBR in December of 1996, the rate of discharge to Recharge Basin HO was significantly less in 1997. In addition, several other recharge areas are used exclusively for discharging storm water runoff; these include Basin HW (Outfall 008) and the CSF storm water outlet.

The recharge basins are permitted point source discharges under the Laboratory's SPDES permit. To facilitate monitoring of these discharges, each is equipped with flow monitoring stations. Weekly recordings of flow are maintained by the ES\&HS Division, along with records of $\mathrm{pH}$, conductivity and temperature. The specifics of the SPDES compliance monitoring program are provided in Chapter 2. To supplement the SPDES program, samples are also collected routinely and analyzed under the environmental monitoring program for VOCs, metals and anions.

During 1997, water samples were collected from Basins HN, HO, HP, HS, HT, HW, and the CSF storm water outfall. There was no discharge to Recharge Basin HX in 1997 due to renovations at the Water Treatment Plant and associated wells. As required by the BNL SPDES permit, each recharge basin was sampled monthly and quarterly for SPDES-specified parameters. A description of this monitoring program follows.

\subsubsection{Recharge Basins - Radiological Analyses}

All recharge basins are sampled throughout the year for gross activity, gamma-emitting radionuclides and tritium. Basin HN was found to contain radionuclides attributable to Laboratory operations. This basin receives secondary-loop magnet cooling water from the AGS. Secondary radiation in the vicinity of the beam line, where coolant lines run, may interact with elements in the water to produce radioactive species. Metal corrosion products present in the system may also become activated, generating such radionuclides as beryllium-7, chromium-51, cobalt-58 and 60 . Radiological results for water samples collected at the recharge basins are presented in Tables 6-5 and 6-6. All detected gamma-emitting radionuclide concentrations were far below applicable DCGs.

\subsubsection{Recharge Basins - Non-radiological Analyses}

To determine the overall impact of these discharges on the environment, the analytical data for samples collected from the recharge basins were compared to groundwater discharge standards promulgated under 6NYCRR Part 703.6. Samples were collected quarterly for water quality parameters, metals and VOCs and analyzed by the ES\&HS ASL. Field measured parameters (i.e., pH, conductivity and temperature) are routinely monitored and recorded. The field measured water quality data, and metals data are summarized in Tables 6-8 and 6-9, respectively. For VOCs, trace concentrations (i.e., $<2 \mathrm{ppb}$ ) of chloroform and TCA were detected in the samples collected from Basins $\mathrm{HO}$ and $\mathrm{HN}$, respectively. While identification of these contaminants is speculative due to their low levels, chloroform may be present as a water chlorination by-product. There are no known operations that would explain the source of TCA. In addition to the routine analytical parameters, a data search identified $15 \mathrm{ug} / \mathrm{L}$ trichlorofluoromethane (Freon 11) and $1.4 \mathrm{ug} / \mathrm{L}$ $1,1,2$ trichloroethane in water samples collected from Recharge Basin HT. Freon 11 is a common refrigerant used in older air conditioners and refrigerators. Many air conditioning units at BNL are water cooled, consequently a minor leak of freon could explain the detection of this compound. Subsequent sampling of this discharge failed to detect the presence of these compounds.

The analytical data in Tables 6-7 and 6-8 show all parameters, except iron, comply with the respective groundwater discharge standards. Iron was found typically in one or more samples 


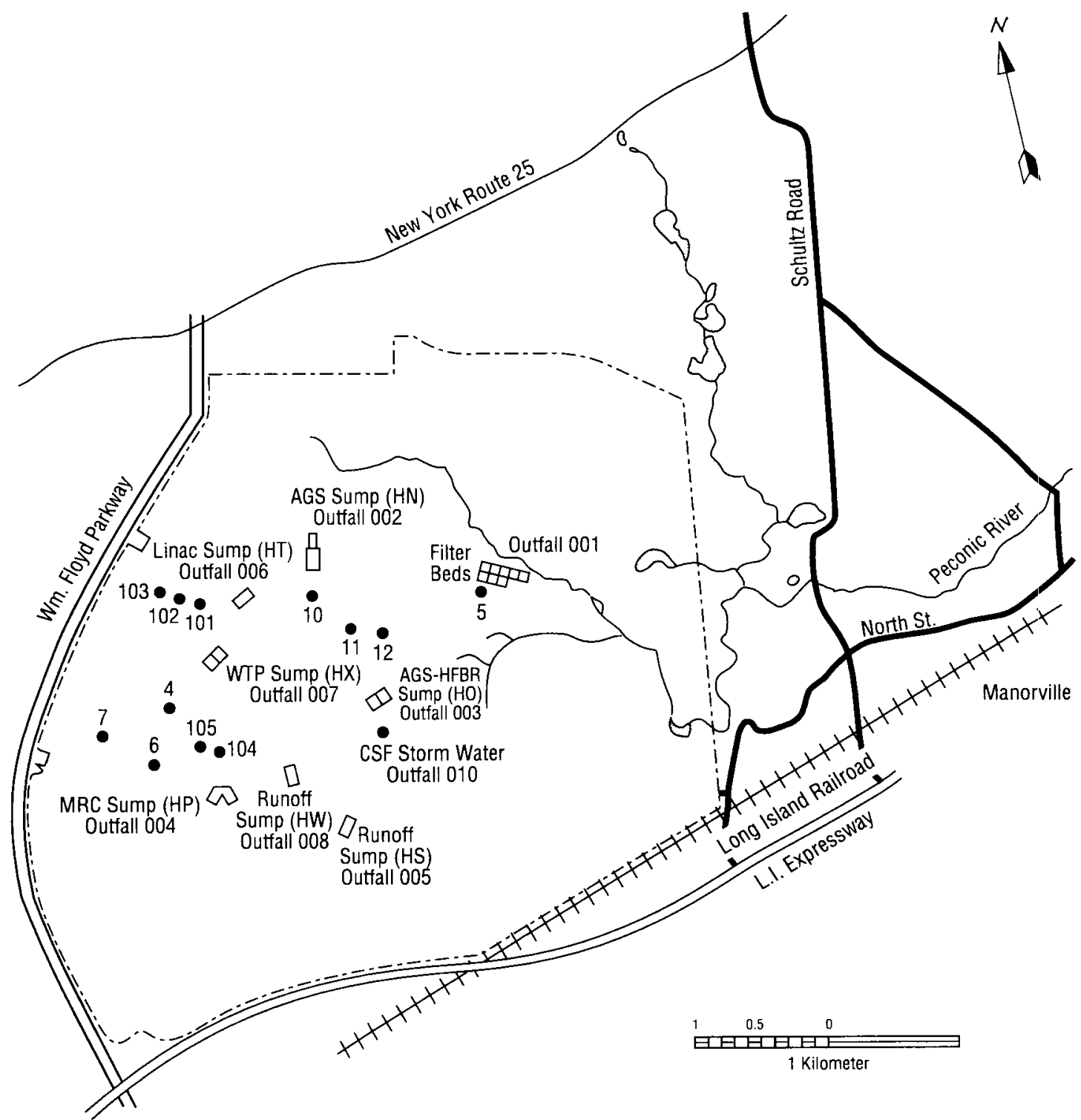

Figure 6-13. Potable and supply wells and recharge sumps

collected from each recharge basin at concentrations which exceed discharge standards. Its presence is due to discharge of groundwater used in once through heat exchangers at the AGS and BMRR, and to the discharge of storm water runoff. Storm water runoff contains a significant concentration of suspended solids washed from road surfaces and landscaped areas. Native soils contain a high concentration of iron $(6,000-10,000 \mathrm{mg} / \mathrm{Kg})$ which when dissolved, acts as a significant contributor to the elevated iron observations. Lead was also identified in the discharge to the HW Recharge Basin. This discharge receives only storm water runoff from the warehouse area. The source of lead is expected to be from natural sediments contained in the outwash. The $\mathrm{pH}$ measured at several of the recharge basins was typically less than the groundwater discharge criteria of $6.5 \mathrm{SU}$. Groundwater used in once-through cooling systems and storm water are known to be less than the standard and are the most likely causes of these observations. The $\mathrm{pH}$ measured in the CSF discharge exceeded the upper $\mathrm{pH}$ limit of 8.5 in December 1997. This excursion is discussed in detail in Chapter 2. 


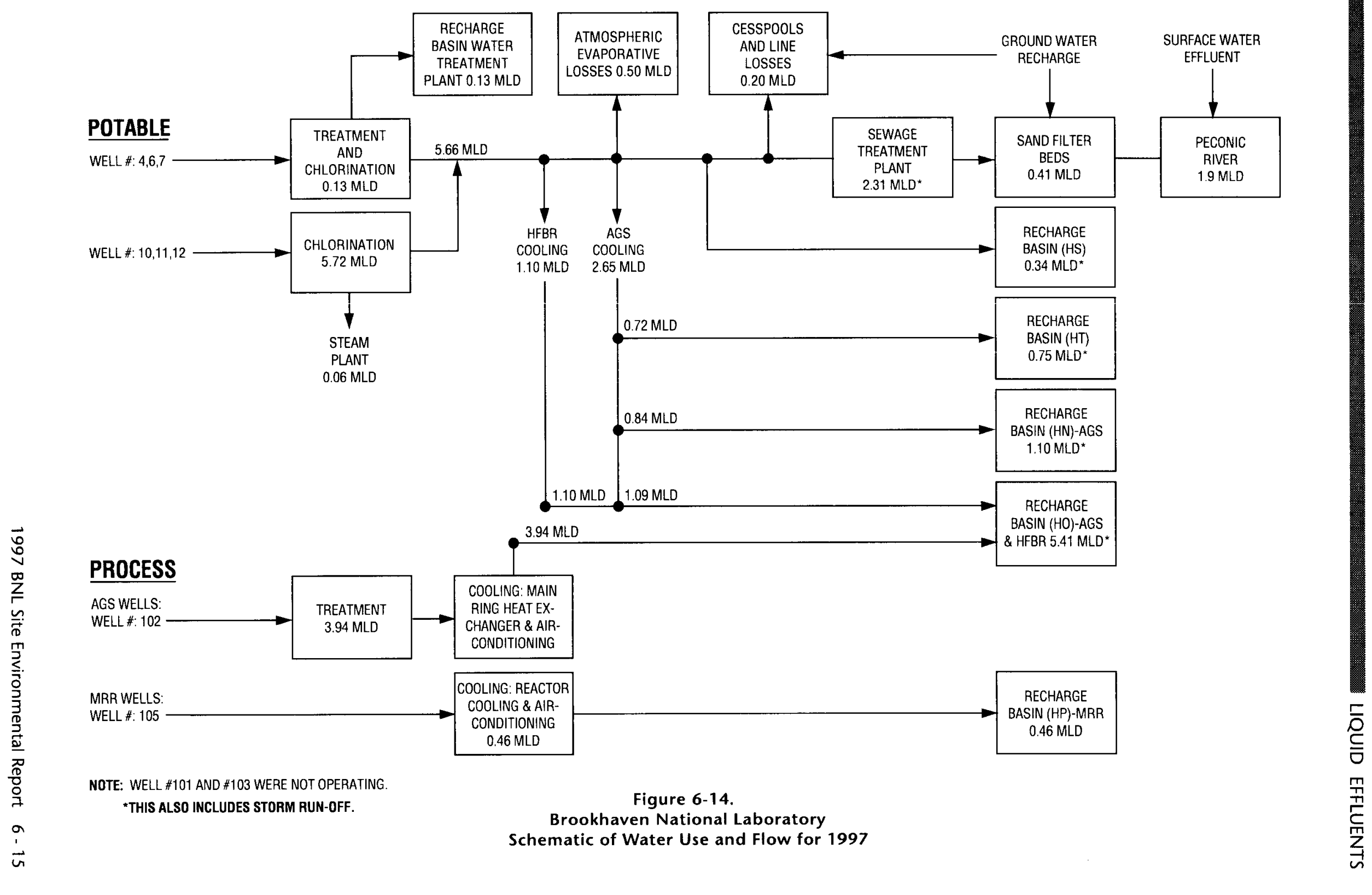


Table 6-5

BML Site Environmental Report for Calendar Year 1997

Gross Activity and Tritium in Recharge Basin Water

\begin{tabular}{|c|c|c|c|c|}
\hline Basin & $\begin{array}{l}\text { Collection } \\
\text { Date }\end{array}$ & Gross Alpha & $\begin{array}{l}\text { Gross Beta } \\
(\mathrm{pCi} / \mathrm{L})\end{array}$ & Tritium \\
\hline HN & $\begin{array}{l}\text { 3-Apr-97 } \\
\text { 6-Aug-97 } \\
25-\text { Aug-97 } \\
27-\text { Sep-97 } \\
\text { 18-Nov-97 } \\
\text { 22-Nov-97 }\end{array}$ & $\begin{array}{l}<0.7 \\
2.2 \pm 1.1 \\
5.1 \pm 1.3 \\
8.6 \pm 1.6 \\
4.3 \pm 1.2 \\
10.4 \pm 1.7\end{array}$ & $\begin{array}{l}3.2 \pm 1.1 \\
7.5 \pm 2.3 \\
17.9 \pm 2.8 \\
12.7 \pm 2.7 \\
7.9 \pm 2.6 \\
11.9 \pm 2.7\end{array}$ & $\begin{array}{l}<333 \\
<304 \\
<324 \\
<291 \\
<276 \\
\text { (a) }\end{array}$ \\
\hline HO & $\begin{array}{l}\text { 6-Mar-97 } \\
25-J u l-97 \\
\text { 19-Aug-97 } \\
22-S e p-97 \\
9-0 c t-97 \\
12-\text { Nov-97 }\end{array}$ & $\begin{array}{l}<0.7 \\
\text { (b) } \\
5.3 \pm 1.3 \\
6.5 \pm 1.5 \\
8.4 \pm 1.6 \\
2.1 \pm 1.0\end{array}$ & $\begin{array}{l}<1.6 \\
\text { (b) } \\
8.5 \pm 2.4 \\
8.2 \pm 2.5 \\
16.2 \pm 2.9 \\
<3.8\end{array}$ & $\begin{array}{l}<375 \\
<327 \\
<324 \\
<291 \\
<276 \\
<322\end{array}$ \\
\hline HP & $\begin{array}{l}\text { 10-Apr-97 } \\
29-\text { Sep-97 }\end{array}$ & $\begin{array}{l}<0.7 \\
4.3 \pm 1.2\end{array}$ & $\begin{array}{l}4.3 \pm 1.2 \\
7.4 \pm 2.6\end{array}$ & $\begin{array}{l}<352 \\
265 \pm 152\end{array}$ \\
\hline HS & $\begin{array}{l}\text { 6-Mar-97 } \\
23-J u \mid-97\end{array}$ & $\begin{array}{l}<0.7 \\
4.5 \pm 2.3\end{array}$ & $\begin{array}{l}4.6 \pm 1.2 \\
16.0 \pm 4.7\end{array}$ & $\begin{array}{l}477 \pm 175 \\
<304\end{array}$ \\
\hline HTw & $\begin{array}{l}\text { 13-Mar-97 } \\
23-J u l-97 \\
22-S e p-97 \\
9-0 c t-97 \\
12-\text { Nov-97 }\end{array}$ & $\begin{array}{l}<0.7 \\
2.1 \pm 1.1 \\
2.7 \pm 1.1 \\
1.7 \pm 0.9 \\
2.2 \pm 1.0\end{array}$ & $\begin{array}{l}1.9 \pm 1.1 \\
16.1 \pm 2.7 \\
5.3 \pm 2.4 \\
<3.8 \\
31.1 \pm 3.3\end{array}$ & $\begin{array}{l}<333 \\
<304 \\
<291 \\
<276 \\
<322\end{array}$ \\
\hline HTe & $\begin{array}{l}\text { 13-Mar-97 } \\
25-J u l-97 \\
\text { 19-Aug-97 } \\
22-\text { Sep-97 } \\
\text { 10-Oct-97 } \\
\text { 12-Nov-97 }\end{array}$ & $\begin{array}{l}<0.7 \\
18.7 \pm 2.3 \\
4.2 \pm 1.2 \\
3.9 \pm 1.3 \\
\text { (b) } \\
1.4 \pm 0.9\end{array}$ & $\begin{array}{l}<1.6 \\
28.3 \pm 3.1 \\
6.9 \pm 2.4 \\
5.6 \pm 2.4 \\
\text { (b) } \\
<3.8\end{array}$ & $\begin{array}{l}<333 \\
<327 \\
<324 \\
<291 \\
<263 \\
<322\end{array}$ \\
\hline HW & $\begin{array}{l}\text { 4-Mar-97 } \\
22-J u l-97\end{array}$ & $\begin{array}{l}<0.7 \\
5.1 \pm 1.4\end{array}$ & $\begin{array}{l}2.6 \pm 1.1 \\
11.2 \pm 2.5\end{array}$ & $\begin{array}{l}<375 \\
<304\end{array}$ \\
\hline SDWA Limit & & 15 & $50(c)$ & 20,000 \\
\hline
\end{tabular}

Notes:

1. All values reported with $2 \sigma(95 \%)$ confidence interval.

(a) Sample result invalidated due to improper addition of scintillation cocktail.

(b) Sample invalidated due to analytical instrument malfunction.

(c) Screening level above which analysis for individual radionuclides is required. 
Table 6-6

BNL Site Environmental Report for Calendar Year 1997 Gross Activity and Tritium in Recharge Basin Water

\begin{tabular}{|c|c|c|c|c|}
\hline Basin & $\begin{array}{l}\text { Collection } \\
\text { Date }\end{array}$ & $\begin{array}{l}\text { Gross Alpha } \\
\text { (pCi/L) }\end{array}$ & Gross Beta & Tritium \\
\hline$\cdots \cdots+\cdots \cdots$ & $\begin{array}{llll}\cdots & \cdots & \cdots & \cdots\end{array}$ & $\cdots$ & & \\
\hline HN & 3-Apr-97 & $<0.7$ & $3.2 \pm 1.1$ & $<333$ \\
\hline HN & 6-Aug-97 & $2.2 \pm 1.1$ & $7.5 \pm 2.3$ & $<304$ \\
\hline HN & 25-Aug-97 & $5.1 \pm 1.3$ & $17.9+2.8$ & $<324$ \\
\hline HN & $27-\operatorname{Sep}-97$ & $8.6 \pm 1.6$ & $12.7 \pm 2.7$ & $<291$ \\
\hline $\mathrm{HN}$ & 18-Nov-97 & $4.3 \pm-1.2$ & $7.9 \pm 2.6$ & $<276$ \\
\hline $\mathrm{HN}$ & 22-Nov-97 & $10.4=-1.7$ & $11.9 \pm 2.7$ & (a) \\
\hline $\mathrm{HO}$ & 6-Mar-97 & $<0.7$ & $<1.6$ & $<375$ \\
\hline HO & 25-Jul-97 & (b) & (b) & $<327$ \\
\hline $\mathrm{HO}$ & 19-Aug-97 & $5.3 \pm 1.3$ & $8.5 \pm 2.4$ & $<324$ \\
\hline $\mathrm{HO}$ & 22-Sep-97 & $6.5 \pm 1.5$ & $8.2 \pm 2.5$ & $<291$ \\
\hline $\mathrm{HO}$ & $9-0 c t-97$ & $8.4 \pm 1.6$ & $16.2 \pm 2.9$ & $<276$ \\
\hline $\mathrm{HO}$ & 12-Nov-97 & $2.1 \pm 1,0$ & $<3.8$ & $<322$ \\
\hline HP & 10-Apr-97 & $<0.7$ & $4.3 \pm 1.2$ & $<352$ \\
\hline HP & 29-Sep-97 & $4.3 \pm 1.2$ & $7.4 \pm 2.6$ & $265 \pm 152$ \\
\hline HS & 6-Mar-97 & $<0.7$ & $4.6 \pm 1.2$ & $477 \pm 175$ \\
\hline HS & 23-Jul-97 & $4.5+2.3$ & $16.0 \pm 4.7$ & $<304$ \\
\hline HTw & 13-Mar-97 & $<0.7$ & $1.9 \pm 1.1$ & $<333$ \\
\hline HTw & 23-Jul-97 & $2.1 \pm 1$ & $16.1 \pm 2.7$ & $<304$ \\
\hline HTw & 22-Sep-97 & $2.7 \pm .1$ & $5.3 \pm 2.4$ & $<291$ \\
\hline HTw & $9-0$ ct -97 & $1.7 \pm 0.9$ & $<3.8$ & $<276$ \\
\hline HTw & 12-Nov-97 & $2.2 \pm .0$ & $31.1 \pm 3.3$ & $<322$ \\
\hline HTe & 13-Mar-97 & $<0.7$ & $<1.6$ & $<333$ \\
\hline $\mathrm{HTe}$ & $25-J u l-97$ & $18.7=-2.3$ & $28.3 \pm 3.1$ & $<327$ \\
\hline HTe & 19-Aug-97 & $4.2 \pm 1.2$ & $6.9 \pm 2.4$ & $<324$ \\
\hline HTe & 22-Sep-97 & $3.9 \pm 1.3$ & $5.6 \pm 2.4$ & $<291$ \\
\hline HTe & $10-0 c t-97$ & (b) & (b) & $<263$ \\
\hline HTe & 12-Nov-97 & $1.4 \pm 0.9$ & $<3.8$ & $<322$ \\
\hline HW & 4-Mar-97 & $<0.7$ & $2.6 \pm 1.1$ & $<375$ \\
\hline $\mathrm{HW}$ & 22-Jul-97 & $5.1 \pm 1.4$ & $11.2+2.5$ & $<304$ \\
\hline SDWA Limit & & 15 & $50(c)$ & 20,000 \\
\hline
\end{tabular}

Notes:

1. All values reported with $2 \sigma(95 \%)$ confidence interval.

(a) Sample result invalidated due to improper addition of scintillation cocktail.

(b) Sample invalidated due to analytical instrument malfunction.

(c) Screening level above which analysis for individual radionuclides is required. 
Table 6-7

BNL Site Environmental Report for Calendar Year 1997

Recharge Basin Gamma-Emitting Radionuclide Analysis

\begin{tabular}{|c|c|c|c|c|c|c|}
\hline Basin & $\begin{array}{l}\text { Collect } \\
\text { Date }\end{array}$ & $\mathrm{Be}-7$ & Co-57 & $\begin{array}{l}\mathbf{C o}_{0}-58 \\
(p \mathrm{Ci} / L)\end{array}$ & $C_{0}-60$ & Cs-137 \\
\hline HN & 13-Mar-97 & ND & $0.8 \pm 0.2$ & $0.6 \pm 0.4$ & $0.2 \pm 0.1$ & ND \\
\hline $\mathrm{HN}$ & $23-J u l-97$ & ND & ND & ND & ND & ND \\
\hline HN & 19-Aug-97 & ND & ND & ND & ND & ND \\
\hline HN & $22-\operatorname{Sep}-97$ & $5.2 \pm 3.5$ & ND & ND & ND & ND \\
\hline HN & $9-0$ ct -97 & ND & ND & ND & ND & ND \\
\hline HN & 12-Nov-97 & ND & ND & ND & ND & ND \\
\hline $\mathrm{HN}$ & $5-D e c-97$ & ND & ND & ND & ND & ND \\
\hline HTW & 13-Mar-97 & ND & ND & ND & ND & ND \\
\hline HTw & $23-J u l-97$ & ND & ND & ND & ND & ND \\
\hline HTw & 22-Sep-97 & ND & ND & ND & ND & ND \\
\hline HTw & $9-0$ ct-97 & ND & ND & ND & ND & ND \\
\hline HTw & 12-Nov-97 & ND & ND & ND & ND & ND \\
\hline HTw & $5-\operatorname{Dec}-97$ & ND & ND & ND & ND & ND \\
\hline $\mathrm{HO}$ & 6-Mar-97 & ND & ND & ND & ND & ND \\
\hline $\mathrm{HO}$ & $25-J u l-97$ & ND & ND & ND & ND & ND \\
\hline $\mathrm{HO}$ & 19-Aug-97 & ND & ND & ND & ND & ND \\
\hline $\mathrm{HO}$ & 22-Sep-97 & ND & ND & ND & ND & ND \\
\hline $\mathrm{HO}$ & $9-0$ ct-97 & ND & ND & ND & ND & ND \\
\hline $\mathrm{HO}$ & 12-Nov-97 & ND & ND & ND & ND & ND \\
\hline $\mathrm{HO}$ & 5-Dec-97 & ND & ND & ND & ND & ND \\
\hline HP & $29-$ Sep-97 & ND & ND & ND & ND & ND \\
\hline HP & 10-Dec-97 & ND & ND & ND & ND & ND \\
\hline HS & 6-Мат-97 & ND & ND & ND & ND & ND \\
\hline HS & 23-Jul-97 & ND & ND & ND & ND & ND \\
\hline HS & $5-D e c-97$ & ND & ND & ND & ND & ND \\
\hline HW & 4-Mar-97 & $6.5 \pm 6.1$ & ND & ND & ND & $0.2 \pm 0.2$ \\
\hline HW & 22-Jul-97 & $11.6 \pm 3.5$ & ND & ND & ND & ND \\
\hline \multirow{2}{*}{\multicolumn{2}{|c|}{$\begin{array}{l}\text { DOE Order } 5400.5 \text { DCG (a) } \\
\text { SDWA Limit (b) }\end{array}$}} & 40,000 & 100,000 & 40,000 & 5,000 & 3,000 \\
\hline & & 1,600 & 4,000 & 1,600 & 200 & 120 \\
\hline
\end{tabular}

(a) Derived Concentration Guide. Concentration which, if ingested at $2 \mathrm{~L}$ /day for 1 year, would result in an individual committed effective dose of 100 mrem.

(b) Concentration required to produce the Safe Drinking Water Act dose limit of $4 \mathrm{mrem} / \mathrm{yr}$, under conditions of continuous ingestion. Notes:

1. All values reported with $2 \sigma(95 \%)$ confidence interval.

2. $N D=$ Not Detected. 
Table 6-8

BNL Site Environmental Report for Calendar Year 1997

Water Quality Data for On-Site Recharge Basins

\begin{tabular}{|c|c|c|c|c|c|c|c|}
\hline Location (a) & & $\begin{array}{l}\mathrm{pH} \\
\mathrm{SU}\end{array}$ & $\begin{array}{l}\text { Temp } \\
\text { C }\end{array}$ & $\begin{array}{l}\text { Conductivity } \\
\text { umhos/cm }\end{array}$ & $\begin{array}{l}\text { Chlorides } \\
\mathrm{mg} / \mathrm{L}\end{array}$ & $\begin{array}{l}\text { Sulfates } \\
\mathrm{mg} / \mathrm{L}\end{array}$ & $\begin{array}{l}\text { Nitrate as } N(b) \\
\mathrm{mg} / \mathrm{L}\end{array}$ \\
\hline $\begin{array}{l}\text { HN } \\
\text { (RHIC Recharge) }\end{array}$ & $\begin{array}{l}\mathrm{N} \\
\text { Minimum } \\
\text { Maximum } \\
\text { Average }\end{array}$ & $\begin{array}{l}21 \\
6.4 \\
8 \\
\text { NA }\end{array}$ & $\begin{array}{l}21 \\
5.8 \\
21.4 \\
13.8\end{array}$ & $\begin{array}{l}8 \\
64 \\
199 \\
157\end{array}$ & $\begin{array}{l}4 \\
4 \\
23.8 \\
16.7\end{array}$ & $\begin{array}{l}4 \\
7.1 \\
15.7 \\
11.7\end{array}$ & $\begin{array}{l}4 \\
<1.0 \\
<1.0 \\
<1.0\end{array}$ \\
\hline $\begin{array}{l}\text { HO } \\
\text { (HFBR-AGS) }\end{array}$ & $\begin{array}{l}\mathrm{N} \\
\text { Minimum } \\
\text { Maximum } \\
\text { Average }\end{array}$ & $\begin{array}{l}21 \\
5.9 \\
6.3 \\
\text { NA }\end{array}$ & $\begin{array}{l}21 \\
5.8 \\
26.6 \\
16.4\end{array}$ & $\begin{array}{l}8 \\
127 \\
157 \\
140\end{array}$ & $\begin{array}{l}4 \\
16.5 \\
19.6 \\
18.1\end{array}$ & $\begin{array}{l}4 \\
8.9 \\
11.4 \\
10\end{array}$ & $\begin{array}{l}4 \\
<1.0 \\
<1.0 \\
<1.0\end{array}$ \\
\hline $\begin{array}{l}\mathrm{HP} \\
(\mathrm{BMRR})\end{array}$ & $\begin{array}{l}\mathrm{N} \\
\text { Minimum } \\
\text { Maximum } \\
\text { Average }\end{array}$ & $\begin{array}{l}4 \\
5.9 \\
6.3 \\
\text { NA }\end{array}$ & $\begin{array}{l}4 \\
18.5 \\
32.3 \\
24.2\end{array}$ & $\begin{array}{l}2 \\
196 \\
196 \\
196\end{array}$ & $\begin{array}{l}3 \\
32 \\
33.1 \\
32.4\end{array}$ & $\begin{array}{l}3 \\
8 \\
14.5 \\
14.1\end{array}$ & $\begin{array}{l}3 \\
<1.0 \\
<1.0 \\
<1.0\end{array}$ \\
\hline $\begin{array}{l}\text { HS } \\
\text { (Storm Water) }\end{array}$ & $\begin{array}{l}\mathrm{N} \\
\text { Minimum } \\
\text { Maximum } \\
\text { Average }\end{array}$ & $\begin{array}{l}14 \\
6.3 \\
7.7 \\
\text { NA }\end{array}$ & $\begin{array}{l}12 \\
4.2 \\
24.2 \\
11.8\end{array}$ & $\begin{array}{l}3 \\
69 \\
218 \\
122\end{array}$ & $\begin{array}{l}3 \\
<4 \\
43.4 \\
14.5\end{array}$ & $\begin{array}{l}3 \\
6.7 \\
7 \\
6.9\end{array}$ & $\begin{array}{l}3 \\
<1.0 \\
<1.0 \\
<1.0\end{array}$ \\
\hline $\begin{array}{l}\mathrm{HT}(\mathrm{c}) \\
\text { (LINAC) }\end{array}$ & $\begin{array}{l}\mathrm{N} \\
\text { Minimum } \\
\text { Maximum } \\
\text { Average }\end{array}$ & $\begin{array}{l}36 \\
6.8 \\
8.6 \\
\text { NA }\end{array}$ & $\begin{array}{l}36 \\
6 \\
26 \\
15\end{array}$ & $\begin{array}{l}13 \\
143 \\
191 \\
167\end{array}$ & $\begin{array}{l}8 \\
17 \\
20.6 \\
18.6\end{array}$ & $\begin{array}{l}8 \\
11 \\
13.5 \\
12.2\end{array}$ & $\begin{array}{l}8 \\
<1.0 \\
<1.0 \\
<1.0\end{array}$ \\
\hline $\begin{array}{l}\text { HW } \\
\text { (Weaver Rd.) }\end{array}$ & $\begin{array}{l}\mathrm{N} \\
\text { Minimum } \\
\text { Maximum } \\
\text { Average }\end{array}$ & $\begin{array}{l}12 \\
6.3 \\
7.9 \\
\text { NA }\end{array}$ & $\begin{array}{l}12 \\
5.6 \\
24.7 \\
11.8\end{array}$ & $\begin{array}{l}2 \\
65 \\
100 \\
83\end{array}$ & $\begin{array}{l}4 \\
<4 \\
6.6 \\
<4\end{array}$ & $\begin{array}{l}4 \\
<4 \\
13.2 \\
6.5\end{array}$ & $\begin{array}{l}4 \\
<1.0 \\
2.5 \\
<1.0\end{array}$ \\
\hline $\begin{array}{l}\text { CSF } \\
\text { (Storm Water) }\end{array}$ & $\begin{array}{l}\mathrm{N} \\
\text { Minimum } \\
\text { Maximum } \\
\text { Average }\end{array}$ & $\begin{array}{l}11 \\
5.9 \\
9.3 \\
\text { NA }\end{array}$ & $\begin{array}{l}11 \\
4.2 \\
23.8 \\
12.7\end{array}$ & $\begin{array}{l}1 \\
92 \\
92 \\
92\end{array}$ & $\begin{array}{l}4 \\
<4 \\
7.3 \\
<4\end{array}$ & $\begin{array}{l}4 \\
4.1 \\
10 \\
7.2\end{array}$ & $\begin{array}{l}4 \\
<1.0 \\
<1.0 \\
<1.0\end{array}$ \\
\hline $\begin{array}{l}\text { NYSDEC } \\
\text { Effluent Standard }\end{array}$ & & $6.5-8.5$ & (d) & (d) & 500 & 500 & 20 \\
\hline Typical MDL & & NA & NA & 10 & 4 & 4 & 1 \\
\hline
\end{tabular}

N: No. of samples

MDL: Minimum Detection Limit

NA: Not Applicable

(a): The location of the recharge basins is provided on Figure 6-11.

(b): The holding times specified by the USEPA were exceeded for the majority of the nitrate analyses.

(c): Recharge Basin HT is comprised of two discharge structures; consequently twice as many readings have been recorded.

(d): No effluent standard specified. 
Table 6-9

BNL Site Environmental Report for Calendar Year 1997

Metals Data for On-Site Recharge Basins

\begin{tabular}{|c|c|c|c|c|c|c|c|c|c|c|c|c|}
\hline Location (a) & \multicolumn{2}{|l|}{$\mathbf{N}$} & $\begin{array}{l}\mathrm{Ag} \\
\mathrm{mg} / \mathrm{L}\end{array}$ & $\begin{array}{l}\mathrm{Cd} \\
\mathrm{mg} / \mathrm{L}\end{array}$ & $\begin{array}{l}\mathrm{Cr} \\
\mathrm{mg} / \mathrm{L}\end{array}$ & $\begin{array}{l}\mathrm{Cu} \\
\mathrm{mg} / \mathrm{L}\end{array}$ & $\begin{array}{l}\mathrm{Fe} \\
\mathrm{mg} / \mathrm{L}\end{array}$ & $\begin{array}{l}\mathrm{Hg} \\
\mathrm{mg} / \mathrm{L}\end{array}$ & $\begin{array}{l}\mathrm{Mn} \\
\mathrm{mg} / \mathrm{L}\end{array}$ & $\begin{array}{l}\mathrm{Na} \\
\mathrm{mg} / \mathrm{L}\end{array}$ & $\begin{array}{l}\mathrm{Pb} \\
\mathrm{mg} / \mathrm{L}\end{array}$ & $\begin{array}{l}\mathrm{Zn} \\
\mathrm{mg} / \mathrm{L}\end{array}$ \\
\hline $\begin{array}{l}\text { HN } \\
(\mathrm{RHIC})\end{array}$ & 4 & $\begin{array}{l}\text { Min. } \\
\text { Max. } \\
\text { Avg. }\end{array}$ & $\begin{array}{l}<0.025 \\
<0.025 \\
<0.025\end{array}$ & $\begin{array}{l}<0.0005 \\
<0.0005 \\
<0.0005\end{array}$ & $\begin{array}{l}<0.005 \\
<0.005 \\
<0.005\end{array}$ & $\begin{array}{l}<0.05 \\
0.065 \\
<0.05\end{array}$ & $\begin{array}{l}0.18 \\
2.5 \\
0.87\end{array}$ & $\begin{array}{l}<0.0002 \\
<0.0002 \\
<0.0002\end{array}$ & $\begin{array}{l}<0.05 \\
0.36 \\
0.09\end{array}$ & $\begin{array}{l}3.8 \\
24.9 \\
13.3\end{array}$ & $\begin{array}{l}<0.002 \\
0.008 \\
0.004\end{array}$ & $\begin{array}{l}0.03 \\
0.1 \\
0.067\end{array}$ \\
\hline HO & 5 & Min. & $<0.025$ & $<0.0005$ & $<0.005$ & $<0.05$ & 0.35 & $<0.0002$ & $<0.05$ & 15.1 & $<0.002$ & $<0.02$ \\
\hline \multirow[t]{2}{*}{ (AGS/HFBR) } & & Max. & $<0.025$ & $<0.0005$ & $<0.005$ & $<0.05$ & 2.1 & $<0.0002$ & $<0.05$ & 21.5 & $<0.002$ & 0.141 \\
\hline & & Avg. & $<0.025$ & $<0.0005$ & $<0.005$ & $<0.05$ & 0.99 & $<0.0002$ & $<0.05$ & 18.3 & $<0.002$ & 0.046 \\
\hline HP & 3 & Min. & $<0.025$ & $<0.0005$ & $<0.005$ & $<0.05$ & $<0.075$ & $<0.0002$ & $<0.05$ & 18 & $<0.002$ & $<0.02$ \\
\hline \multirow[t]{2}{*}{ (BMRR) } & & Max. & $<0.025$ & $<0.0005$ & $<0.005$ & 0.065 & 0.15 & $<0.0002$ & 0.061 & 18.8 & $<0.002$ & 0.03 \\
\hline & & Avg. & $<0.025$ & $<0.0005$ & $<0.005$ & $<0.05$ & 0.08 & $<0.0002$ & 0.064 & 18.3 & $<0.002$ & $<0.02$ \\
\hline HS & 3 & Min. & $<0.025$ & $<0.0005$ & $<0.005$ & $<0.05$ & $<0.075$ & $<0.0002$ & $<0.05$ & 2.9 & 0.003 & 0.049 \\
\hline \multirow[t]{2}{*}{ (Storm Water) } & & Max. & $<0.025$ & 0.0005 & $<0.005$ & $<0.05$ & 0.89 & $<0.002$ & $<0.05$ & 31.9 & 0.017 & 0.18 \\
\hline & & Avg. & $<0.025$ & $<0.0005$ & $<0.005$ & $<0.05$ & 0.34 & $<0.0002$ & $<0.05$ & 12.9 & 0.008 & 0.1 \\
\hline$H T(b)$ & 8 & Min. & $<0.025$ & $<0.0005$ & $<0.005$ & $<0.05$ & $<0.075$ & $<0.0002$ & $<0.05$ & 18.7 & $<0.002$ & $<0.02$ \\
\hline \multirow[t]{2}{*}{ (LINAC) } & & Max. & $<0.025$ & $<0.0005$ & $<0.005$ & $<0.05$ & 0.31 & $<0.0002$ & $<0.05$ & 30.3 & 0.002 & 0.05 \\
\hline & & Avg. & $<0.025$ & $<0.0005$ & $<0.005$ & $<0.05$ & 0.087 & $<0.0002$ & $<0.05$ & 23.5 & $<0.002$ & $<0.02$ \\
\hline HW & 3 & Min. & $<0.025$ & $<0.0005$ & $<0.005$ & $<0.05$ & 0.18 & $<0.0002$ & $<0.05$ & 2.1 & 0.006 & 0.05 \\
\hline \multirow[t]{2}{*}{ (Weaver Rd.) } & & Max. & $<0.025$ & 0.0014 & 0.019 & $<0.05$ & 0.72 & $<0.0002$ & 0.07 & 66.1 & 0.11 & 0.31 \\
\hline & & Avg. & $<0.025$ & 0.0008 & $<0.005$ & $<0.05$ & 0.47 & $<0.0002$ & $<0.05$ & 23.4 & 0.065 & 0.14 \\
\hline $\mathrm{CSF}$ & & Min. & $<0.025$ & $<0.0005$ & $<0.005$ & $<0.05$ & 0.4 & $<0.0002$ & $<0.05$ & 2.8 & 0.007 & 0.06 \\
\hline \multirow[t]{2}{*}{ (Storm Water) } & & Max. & $<0.025$ & 0.0007 & 0.0065 & $<0.05$ & 3.7 & $<0.0002$ & 0.07 & 9.7 & 0.04 & 0.16 \\
\hline & & Avg. & $<0.025$ & $<0.0005$ & $<0.005$ & $<0.05$ & 2.3 & $<0.0002$ & $<0.05$ & 5.1 & 0.019 & 0.088 \\
\hline \multicolumn{13}{|l|}{ NYSDEC } \\
\hline \multicolumn{3}{|c|}{ Effluent Limitation } & 0.1 & 0.02 & 0.1 & 1 & 0.6 & 0.004 & 0.6 & (c) & 0.05 & 5 \\
\hline \multicolumn{3}{|l|}{ Typical MDL } & 00.025 & 0.0005 & 0.005 & 0.05 & 0.075 & 0.0002 & 0.05 & 1 & 0.002 & 0.02 \\
\hline
\end{tabular}

N: $\quad$ No. of samples.

MDL: Minimum Detection Limit.

(a): Locations of recharge basins are shown on Figure 6-11.

(b): Recharge Basin HT is comprised of two discharge structures, hence twice as many samples are collected and analyzed.

(c): No effluent standard specified. 


\section{Chapter 7}

\section{ENVIRONMENTAL SURVEILLANCE}

\subsection{Policy}

It is DOE policy to conduct its operations in an environmentally responsible manner and comply with applicable environmental regulations and standards. At BNL, a wide variety of environmental activities are conducted to demonstrate compliance with federal, state, and local regulations. This chapter summarizes the results of the BNL Environmental Monitoring Program, which consists of the collection and analysis of samples of air, water, soil, sediment, vegetation, foodstuffs, and biota from the local area. The program also includes measuring external radiation to demonstrate compliance with applicable standards, to assess radiation exposure to members of the public, and to assess effects, if any, on the local environment.

\subsection{External Radiation Monitoring}

BNL measures of environmental background radiation through a network of on-site and off-site dosimeter units. These units, called thermoluminescent dosimeters, or TLDs, measure gamma radiation originating from cosmic and terrestrial sources (see Section 4.1 for discussion) as well as any contribution from Laboratory operations. Calcium fluoride $\left(\mathrm{CaF}_{2}: \mathrm{Dy}\right)$ type TLDs are used. There are 24 on-site locations which have TLDs in place (Figure 7-1). In addition to the dosimeters on Laboratory property, 25 off-site locations are monitored (Figure 7-2) to provide background comparisons and verification that Laboratory operations have had no impact on the ambient radiation levels of the surrounding area.

The 1997 TLD data are summarized in Table 7-1. Each TLD is exposed for one calendar quarter. The annual external radiation dose quoted for each location is the sum of four separate measurements. Where the total number of samples collected is less than four, theft, vandalism, or loss of the unit due to other reasons has occurred. For ease of comparison, all individual measurements have been summed and normalized to a 365 day exposure period to calculate a single annual value.

The average annual off-site external radiation dose value was $67 \pm 5 \mathrm{mrem}(0.67 \pm 0.05 \mathrm{mSv})$ (the error term represents the standard deviation of the sample population). This is consistent with the value of $67 \pm 7 \mathrm{mrem} / \mathrm{yr}(0.67 \pm 0.07 \mathrm{mSv} / \mathrm{yr})$ measured in 1996 . The average on-site external radiation dose rate was $70 \pm 6 \mathrm{mrem} / \mathrm{yr}(0.70 \pm 0.06 \mathrm{mSv} / \mathrm{yr})$. These average values are statistically indistinguishable and are within the normal background exposure range typical of the northeastern part of the United States (NCRP, 1987). The measurements recorded from the TLD program cannot be used to assess exposure due to internally deposited radionuclides or inhaled radon progeny. Figure 7-3 presents average on-site and off-site doses for the past five years.

\subsubsection{Building 650 Sump Outfall Monitoring}

From approximately 1959 to 1969, radiologically contaminated heavy equipment was decontaminated on a concrete pad adjacent to Building 650. The drainage from this pad was designated for containment in underground storage tanks. However, in 1969 it was determined that the drainage system for the pad was not routed as facility operators believed it to be; it was instead routed to a depression in a wooded area approximately 800 feet northeast of Building 650 . This depression is referred to as the Building 650 Sump Outfall. It is a source of localized radiological soil and groundwater contamination which is being remediated through the CERCLA program (OU IV, AOC 6). Identified radionuclides in soil include strontium-90, cesium-137, and isotopes of europium and plutonium. 


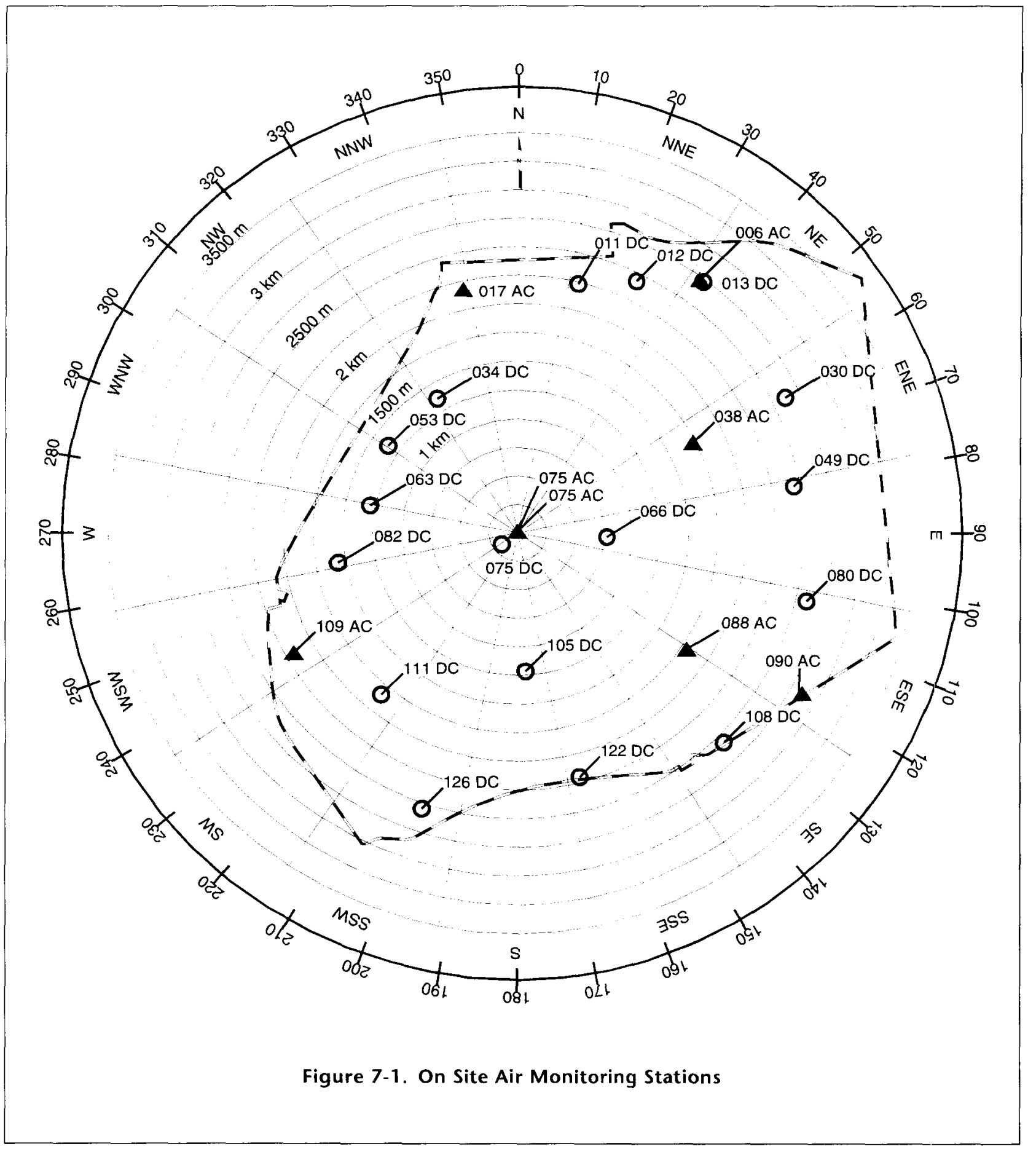

As part of the OU IV Interim Remedy Plan, the Outfall was fenced to exclude pedestrian traffic, and a network of 16 TLDs was installed in 1997 to monitor gamma radiation exposure levels in the area (Figure 7-4). Four fence perimeter dosimeters were also installed, as well as two background dosimeters located at the site of the $11^{\text {th }}$ International Intercomparison of Environmental Dosimeters, an area uninfluenced by AOC 6 or other site radiation sources.

Data from these dosimeters indicate that the highest concentration of radionuclides is located in the area of position $\mathrm{C} 4$, where a dose rate of $1.4 \mathrm{rem} / \mathrm{yr}(0.14 \mathrm{~Sv} / \mathrm{yr}$ ) was recorded (Table 7-2). 


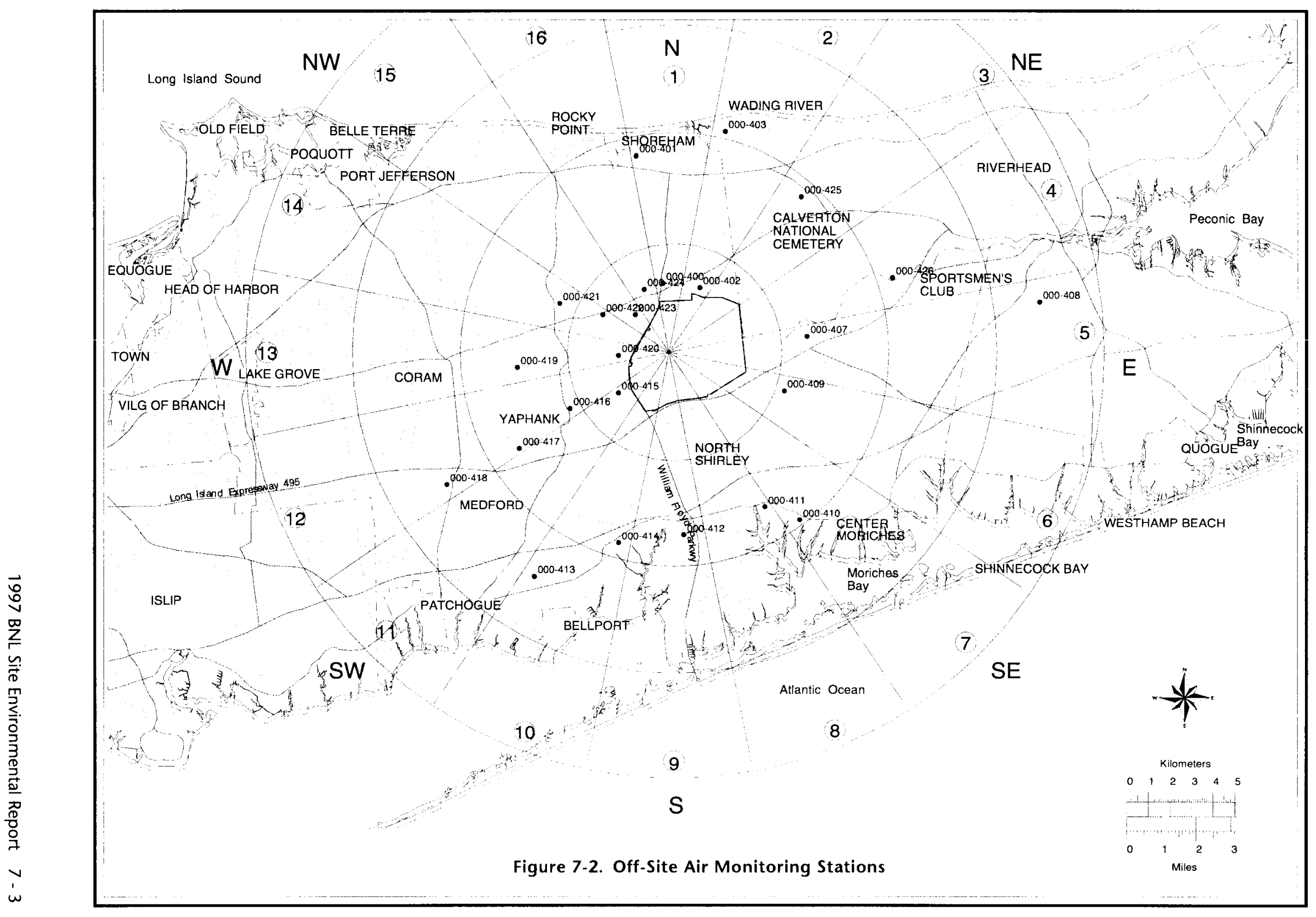


Table 7-1

BNL Site Environmental Report for Calendar Year 1997

On-Site and Off-Site Annual Exposure Measurements

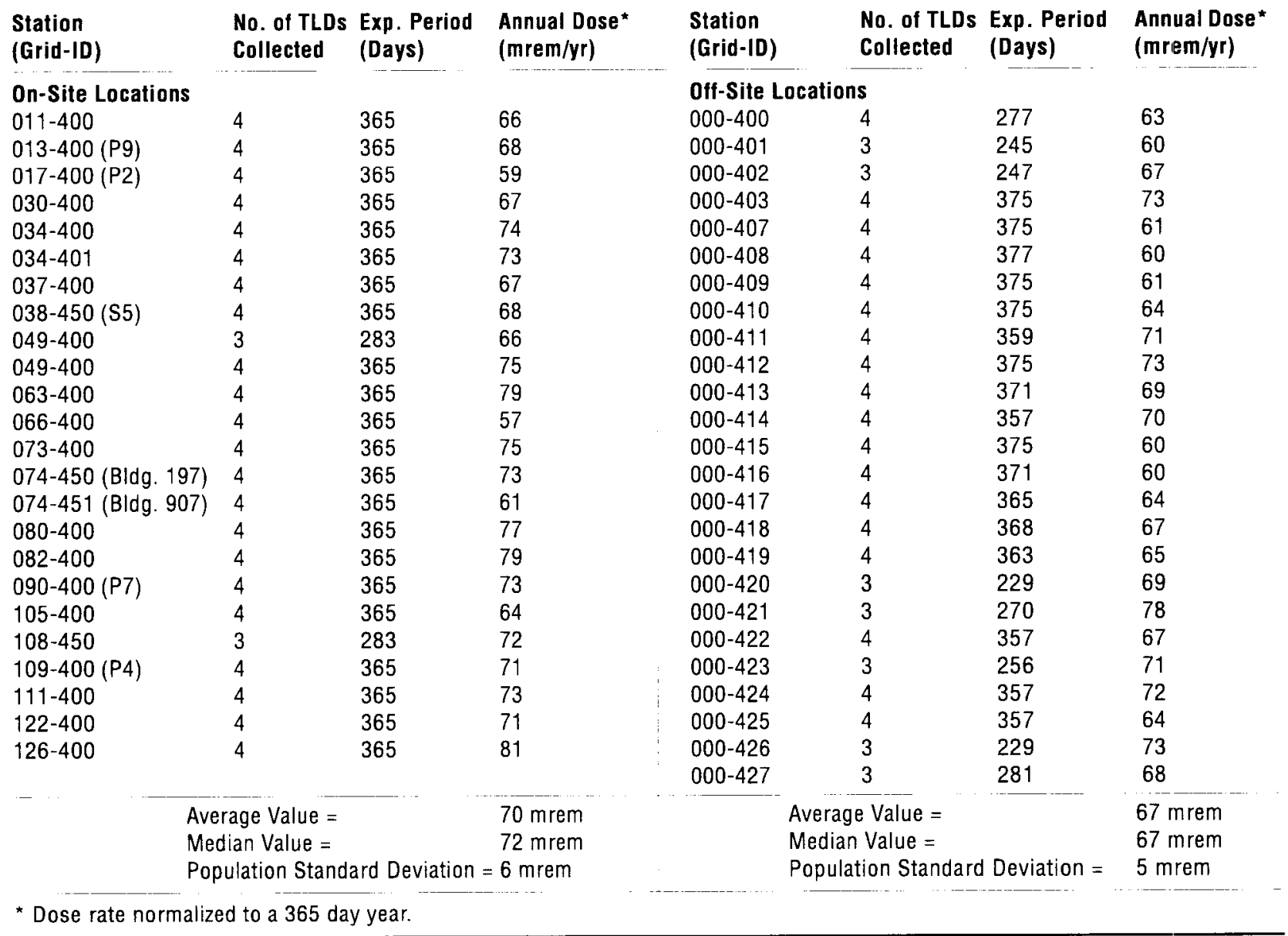

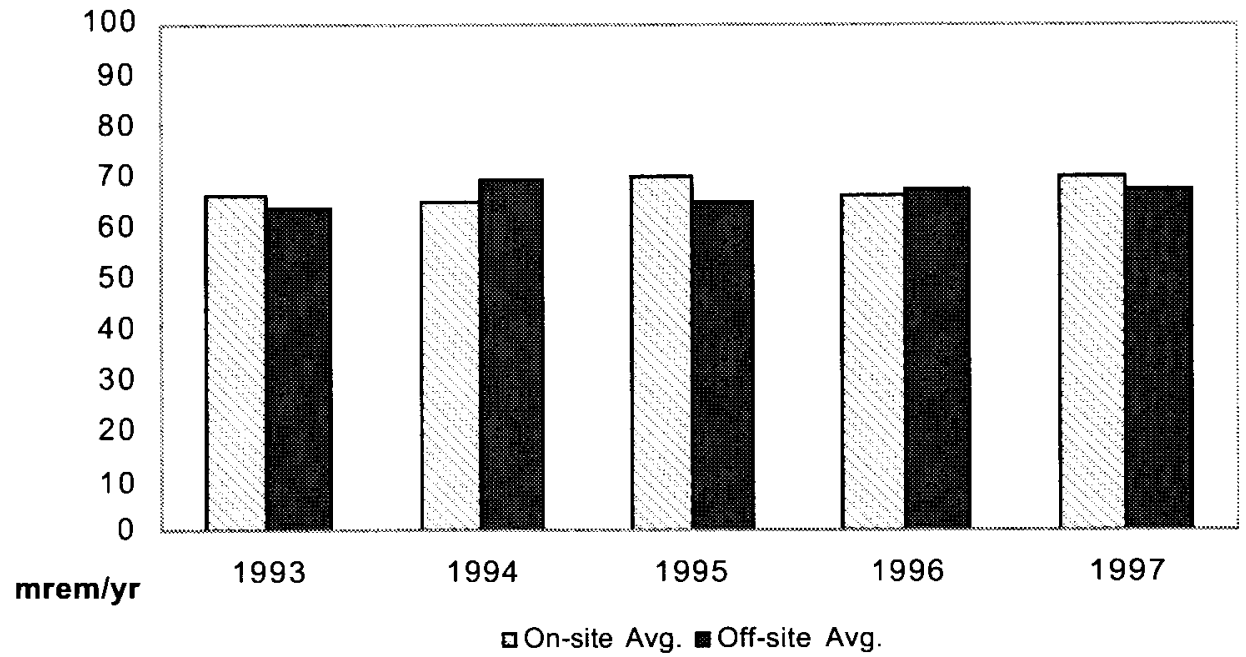

Figure 7-3. Environmental TLD Measurements, 5-Year Trend 


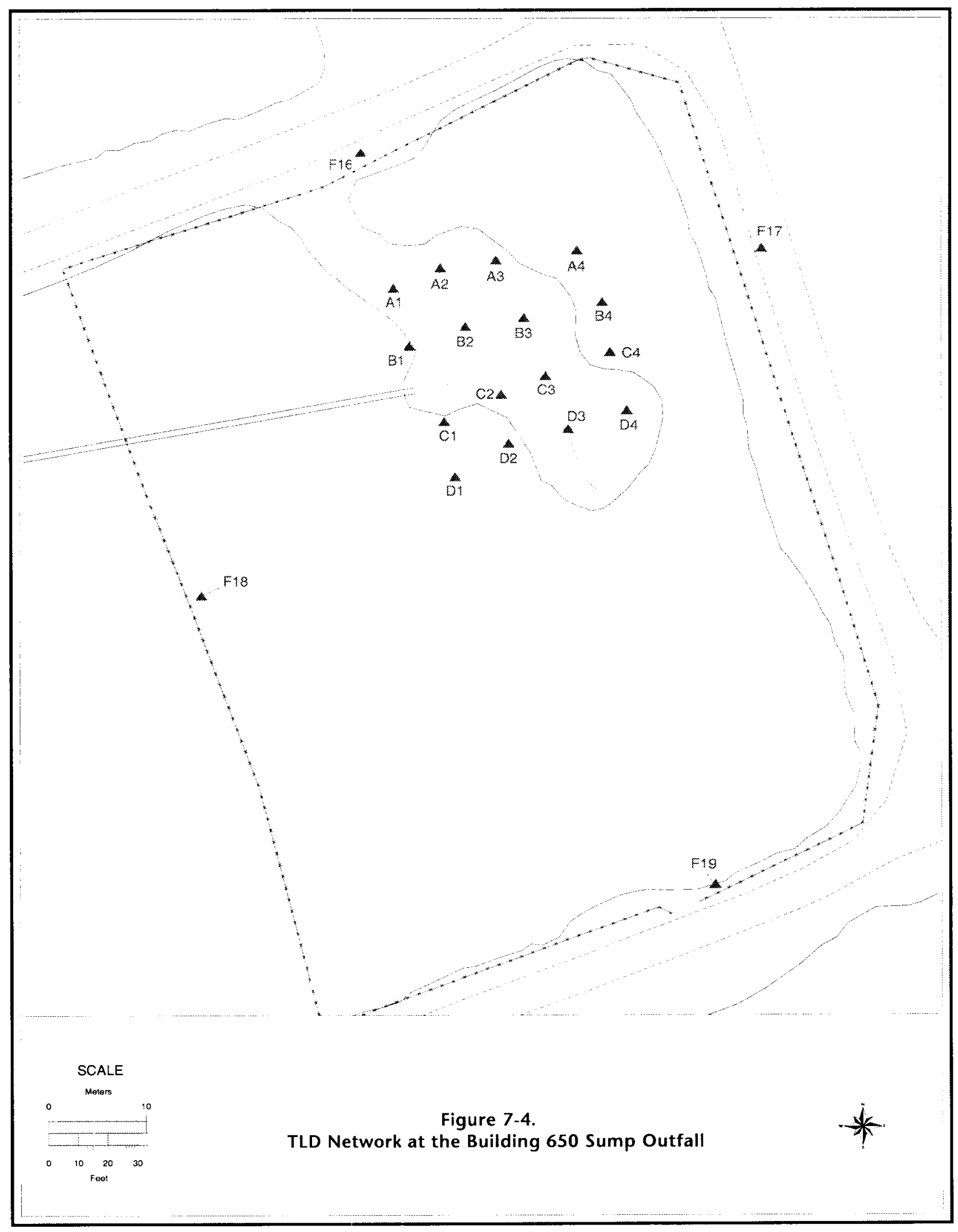


Table 7-2

BNL Site Environmental Report for Calendar Year 1997

Bidg. 650 Sump Outfall TLD Network Data

\begin{tabular}{|c|c|c|c|c|c|}
\hline Location & atr. 1 & Qtr. 2 & Qtr. 3 & Qtr. 4 & $\begin{array}{l}\text { Total } \\
\text { (mrem/yr) }\end{array}$ \\
\hline $\begin{array}{l}\mathrm{A} 1 \\
\mathrm{~A} 2 \\
\mathrm{~A} 3 \\
\mathrm{~A} 4\end{array}$ & $\begin{array}{l}19 \\
69 \\
25 \\
19\end{array}$ & $\begin{array}{l}20 \\
73 \\
25 \\
21\end{array}$ & $\begin{array}{l}19 \\
74 \\
27 \\
20\end{array}$ & $\begin{array}{l}21 \\
73 \\
27 \\
21\end{array}$ & $\begin{array}{l}78 \\
290 \\
103 \\
80\end{array}$ \\
\hline $\begin{array}{l}\mathrm{B} 1 \\
\mathrm{~B} 2 \\
\mathrm{~B} 3 \\
\mathrm{~B} 4\end{array}$ & $\begin{array}{l}16 \\
36 \\
80 \\
37\end{array}$ & $\begin{array}{l}17 \\
40 \\
80 \\
39\end{array}$ & $\begin{array}{l}17 \\
38 \\
79 \\
39\end{array}$ & $\begin{array}{l}17 \\
38 \\
80 \\
39\end{array}$ & $\begin{array}{l}67 \\
152 \\
318 \\
153\end{array}$ \\
\hline $\begin{array}{l}\mathrm{C} 1 \\
\mathrm{C} 2 \\
\mathrm{C} 3 \\
\mathrm{C} 4\end{array}$ & $\begin{array}{l}20 \\
45 \\
164 \\
348\end{array}$ & $\begin{array}{l}21 \\
49 \\
167 \\
357\end{array}$ & $\begin{array}{l}21 \\
47 \\
173 \\
362\end{array}$ & $\begin{array}{l}22 \\
47 \\
171 \\
344\end{array}$ & $\begin{array}{l}83 \\
187 \\
674 \\
1411\end{array}$ \\
\hline $\begin{array}{l}\text { D1 } \\
\text { D2 } \\
\text { D3 } \\
\text { D4 }\end{array}$ & $\begin{array}{l}20 \\
29 \\
128 \\
193\end{array}$ & $\begin{array}{l}19 \\
32 \\
132 \\
199\end{array}$ & $\begin{array}{l}21 \\
30 \\
128 \\
200\end{array}$ & $\begin{array}{l}20 \\
32 \\
132 \\
197\end{array}$ & $\begin{array}{l}80 \\
122 \\
519 \\
789\end{array}$ \\
\hline $\begin{array}{l}\text { Fence, } N \\
\text { Fence, } \mathrm{S} \\
\text { Fence, } \mathrm{E} \\
\text { Fence, } \mathrm{W}\end{array}$ & $\begin{array}{l}13 \\
13 \\
15 \\
15\end{array}$ & $\begin{array}{l}14 \\
13 \\
15 \\
14\end{array}$ & $\begin{array}{l}13 \\
13 \\
15 \\
15\end{array}$ & $\begin{array}{l}14 \\
13 \\
15 \\
15\end{array}$ & $\begin{array}{l}54 \\
51 \\
60 \\
60\end{array}$ \\
\hline $\begin{array}{l}\mathrm{Bkg} 1 \text { 1* } \\
\mathrm{Bkg} 2 \text { * }\end{array}$ & $\begin{array}{l}15 \\
15\end{array}$ & $\begin{array}{l}15 \\
14\end{array}$ & $\begin{array}{l}15 \\
15\end{array}$ & $\begin{array}{l}16 \\
16\end{array}$ & $\begin{array}{l}61 \\
60\end{array}$ \\
\hline
\end{tabular}

Other locations showed dose rates which varied from background levels up to $789 \mathrm{mrem} / \mathrm{yr}$ ( $7.9 \mathrm{mSv} / \mathrm{yr})$. Fence dosimeters showed no elevated dose rates and were consistent with the two distant background TLDs, demonstrating that the radiation field generated by the Sump Outfall contaminants is limited to the immediate area of the Outfall itself. The Building 650 Sump Outfall is not an exposure hazard for either site workers nor the surrounding public.

\subsection{Atmospheric Radiological Monitoring}

As part of the environmental air monitoring program, six stations are in place around the BNL site which sample the air for (non-tritium) radioactive content. Glass fiber filter paper is used to capture airborne particulate matter and charcoal cartridges are used to collect radioiodines, should any be present. Filter paper is collected weekly and analyzed for gross alpha and beta activity using a proportional counter, while charcoal cartridges are collected monthly and analyzed using gamma spectroscopy. No radioiodines were detected in these samples in 1997.

In addition to these samples, the NYSDOH receives duplicate filter samples which are collected at Station P7 in BNL Grid 090 (southeast boundary). These samples are also collected on a weekly basis and are analyzed by an independent NYSDOH Laboratory. Analysis results are reported annually in a document called "Environmental Radiation In New York State". As part of their state wide monitoring program, the NYSDOH collects air samples in Albany, NY, a control location uninfluenced by nuclear facility effluents (NYSDOH, 1993). The NYSDOH reports that typical airborne gross beta activity at that location varies between 0.005 and $0.025 \mathrm{pCi} / \mathrm{m}^{3}(0.2$ to $0.9 \mathrm{mBq} / \mathrm{m}^{3}$ ). 
Table $7-3$

BNL Site Environmental Report for Calendar Year 1997

Gross Activity Detected in Air Particulate Fllters

\begin{tabular}{|c|c|c|c|c|}
\hline $\begin{array}{l}\text { Sample } \\
\text { Station }\end{array}$ & $\begin{array}{l}\text { Grid } \\
\text { Location }\end{array}$ & & $\begin{array}{l}\text { Gross Alpha } \\
\left(\mathrm{pCi} / \mathrm{m}^{3}\right)\end{array}$ & $\begin{array}{l}\text { Gross Beta } \\
\left(\mathrm{pCi} / \mathrm{m}^{3}\right)\end{array}$ \\
\hline P2 & 017 & $\begin{array}{l}\text { N } \\
\text { NBD } \\
\text { Max. } \\
\text { Avg. }\end{array}$ & $\begin{array}{l}52 \\
51 \\
0.002 \pm 0.001 \\
0.001 \pm 0.001\end{array}$ & $\begin{array}{l}52 \\
0 \\
0.029 \pm 0.003 \\
0.015 \pm 0.010\end{array}$ \\
\hline P4 & 109 & $\begin{array}{l}\mathrm{N} \\
\text { NBD } \\
\text { Max. } \\
\text { Avg. }\end{array}$ & $\begin{array}{l}52 \\
51 \\
0.002 \pm 0.001 \\
0.001 \pm 0.001\end{array}$ & $\begin{array}{l}52 \\
0 \\
0.022 \pm 0.003 \\
0.014 \pm 0.008\end{array}$ \\
\hline P7 & 090 & $\begin{array}{l}\text { N } \\
\text { NBD } \\
\text { Max. } \\
\text { Avg. }\end{array}$ & $\begin{array}{l}52 \\
51 \\
0.003 \pm 0.003 \\
0.001 \pm 0.001\end{array}$ & $\begin{array}{l}52 \\
2 \\
0.021 \pm 0.003 \\
0.012 \pm 0.010\end{array}$ \\
\hline P9 & 006 & $\begin{array}{l}\text { N } \\
\text { NBD } \\
\text { Max. } \\
\text { Avg. }\end{array}$ & $\begin{array}{l}52 \\
45 \\
0.005 \pm 0.001 \\
0.001 \pm 0.002\end{array}$ & $\begin{array}{l}52 \\
2 \\
0.023 \pm 0.007 \\
0.014 \pm 0.010\end{array}$ \\
\hline S5 & 038 & $\begin{array}{l}\mathrm{N} \\
\text { NBD } \\
\text { Max. } \\
\text { Avg. }\end{array}$ & $\begin{array}{l}36 \\
36 \\
0.003 \pm 0.002 \\
0.001 \pm 0.001\end{array}$ & $\begin{array}{l}36 \\
0 \\
0.023 \pm 0.002 \\
0.015 \pm 0.009\end{array}$ \\
\hline S6 & 088 & $\begin{array}{l}\text { N } \\
\text { NBD } \\
\text { Max. } \\
\text { Avg. }\end{array}$ & $\begin{array}{l}52 \\
50 \\
0.003 \pm 0.001 \\
0.001 \pm 0.001\end{array}$ & $\begin{array}{l}52 \\
3 \\
0.023 \pm 0.003 \\
0.014 \pm 0.011\end{array}$ \\
\hline
\end{tabular}

Particulate filter analysis results are reported in Table 7-3. Annual average gross alpha activity levels were equal to $0.001 \mathrm{pCi} / \mathrm{m}^{3}\left(0.04 \mathrm{mBq} / \mathrm{m}^{3}\right)$, while gross beta results ranged from undetectable to $0.029 \mathrm{pCi} / \mathrm{m}^{3}\left(1.1 \mathrm{mBq} / \mathrm{m}^{3}\right)$. Annual gross beta activity trends are plotted in Figures $7-5$ through 7-7 for all sampling stations. These trends show a seasonal variation of concentrations within a range representative of natural background. (Gross alpha activity is not plotted because the vast majority of results are below the analytical detection limit.) Measurable activity is primarily due to radionuclide decay products associated with natural uranium and thorium. Data issued by NYSDOH for the Albany control location indicates results similar to those obtained at BNL, demonstrating that radiological air quality is consistent with that observed in other parts of NY State not located near radiological facilities.

\subsubsection{Airborne Tritium Monitoring}

Airborne tritium in the form of tritiated water vapor (HTO) is monitored throughout the BNL site. Twenty monitors are located at or near the property boundary (Figure 5-1). HTO is collected by a pump that draws air through a column of silica gel, a water-absorbent medium which retains atmospheric moisture. The absorbed water is recovered in the Analytical Services Laboratory and analyzed using liquid scintillation techniques (Appendix $\mathrm{C}$ describes the methodology). 

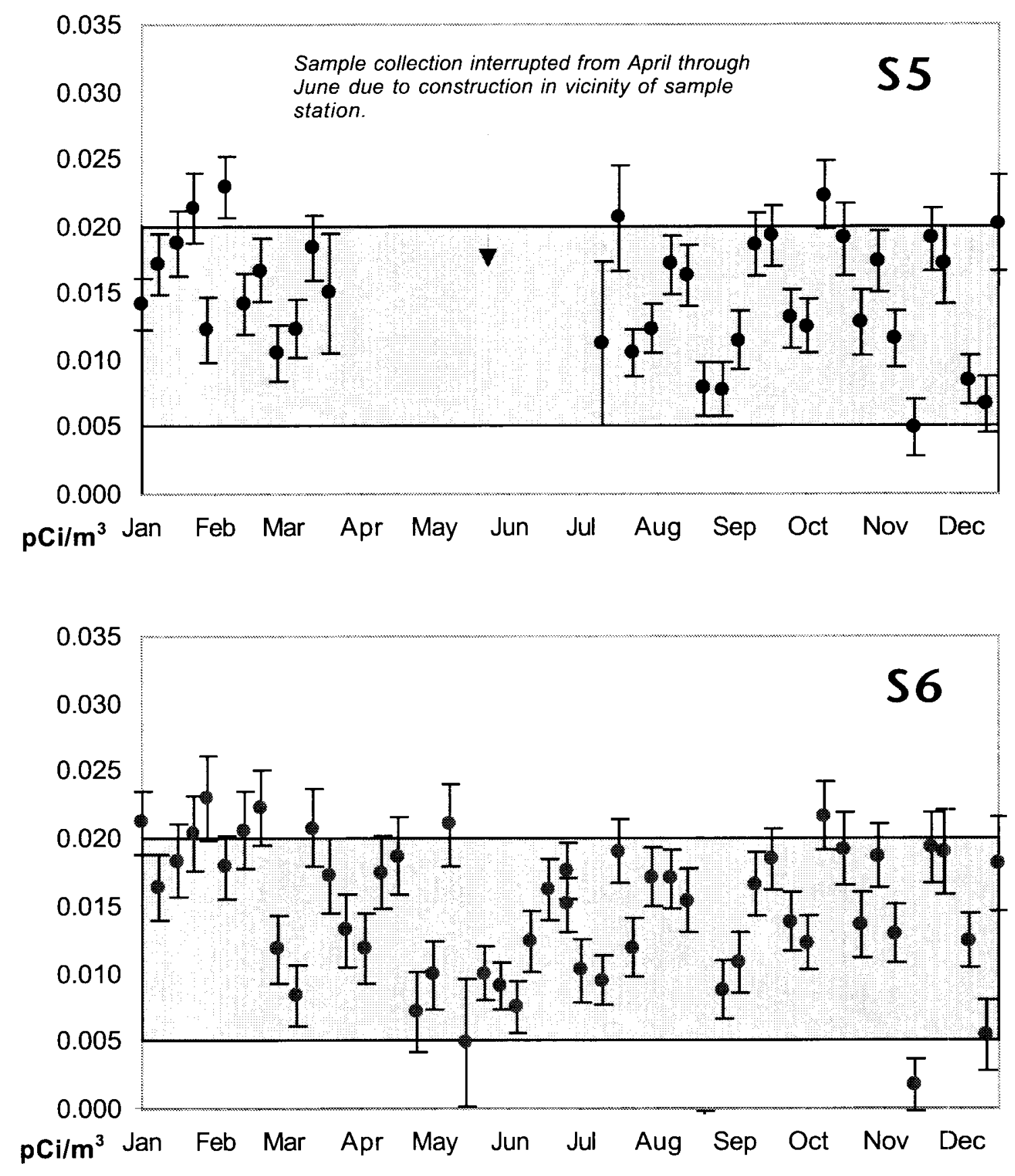

Figure 7-5. Gross beta trend data for air particulate samples at Stations S5 and S6. (Shaded area indicates typical background range reported by NYSDEC in Albany, N.Y.) 


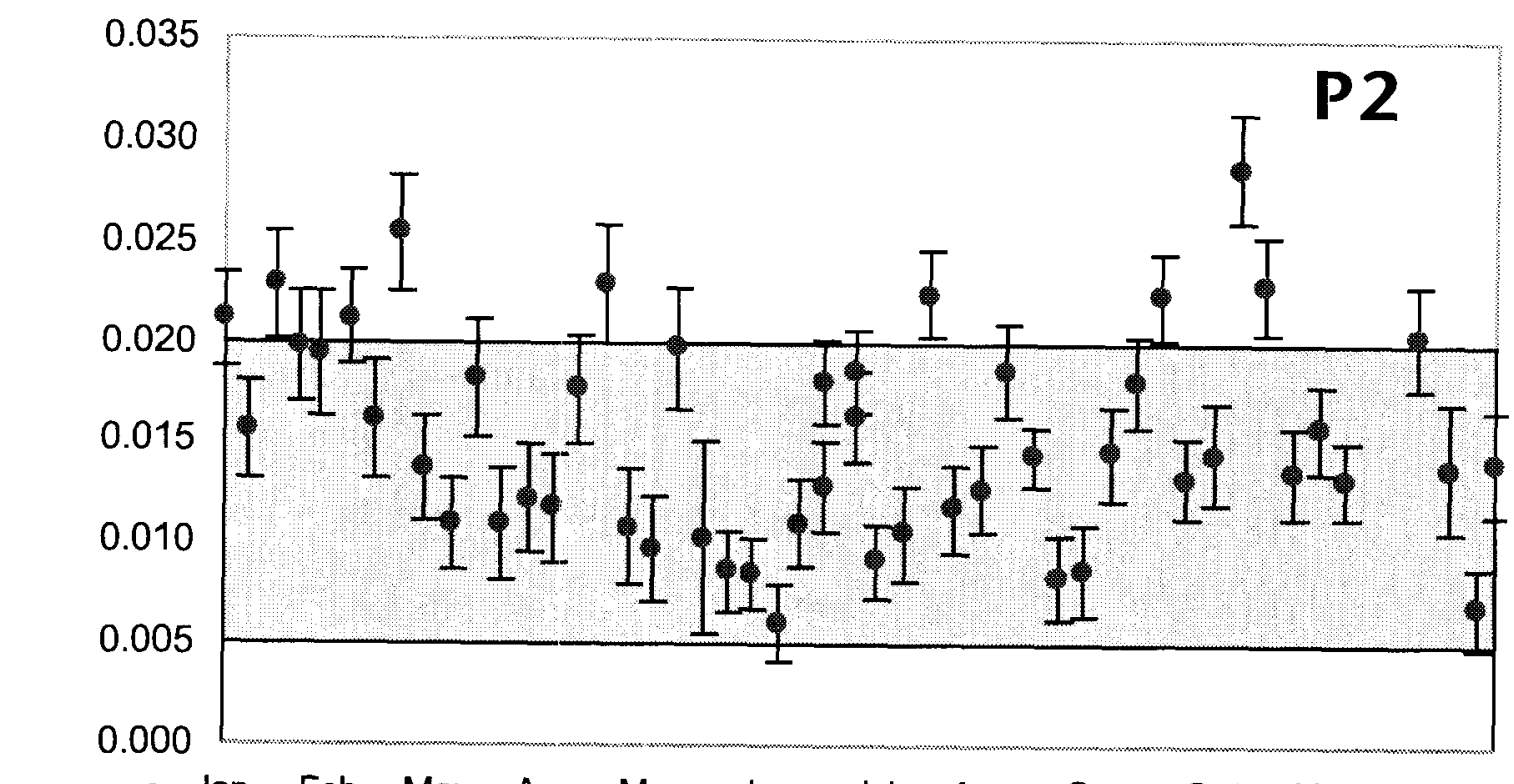

$\mathbf{p C i} / \mathbf{m}^{3}$ Jan Feb Mar Apr May Jun Jul Aug Sep Oct Nov Dec

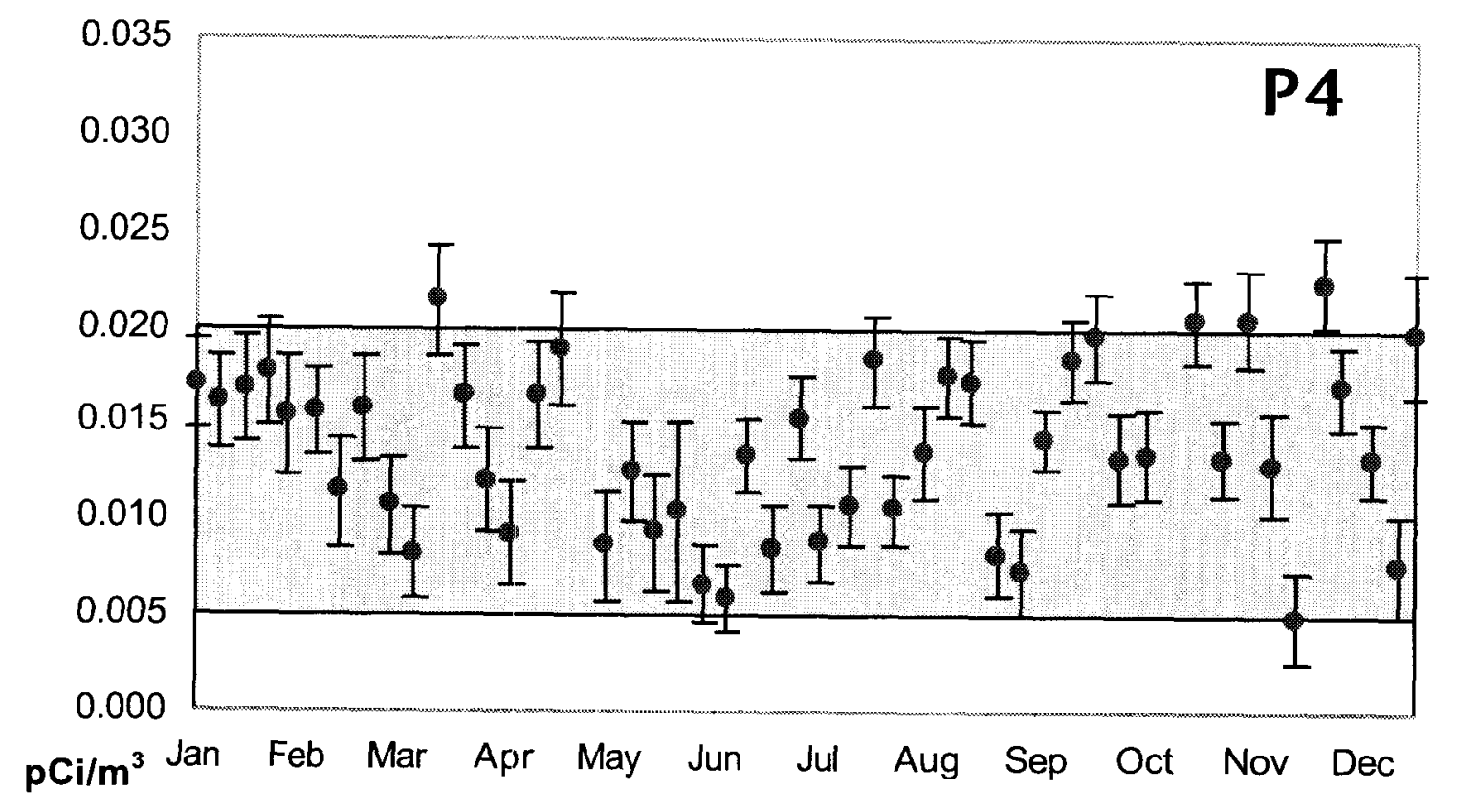

Figure 7-6. Gross beta trend data for air particulate samples at Stations P2 and P4. (Shaded area indicates typical background range reported by NYSDEC in Albany, N.Y.) 

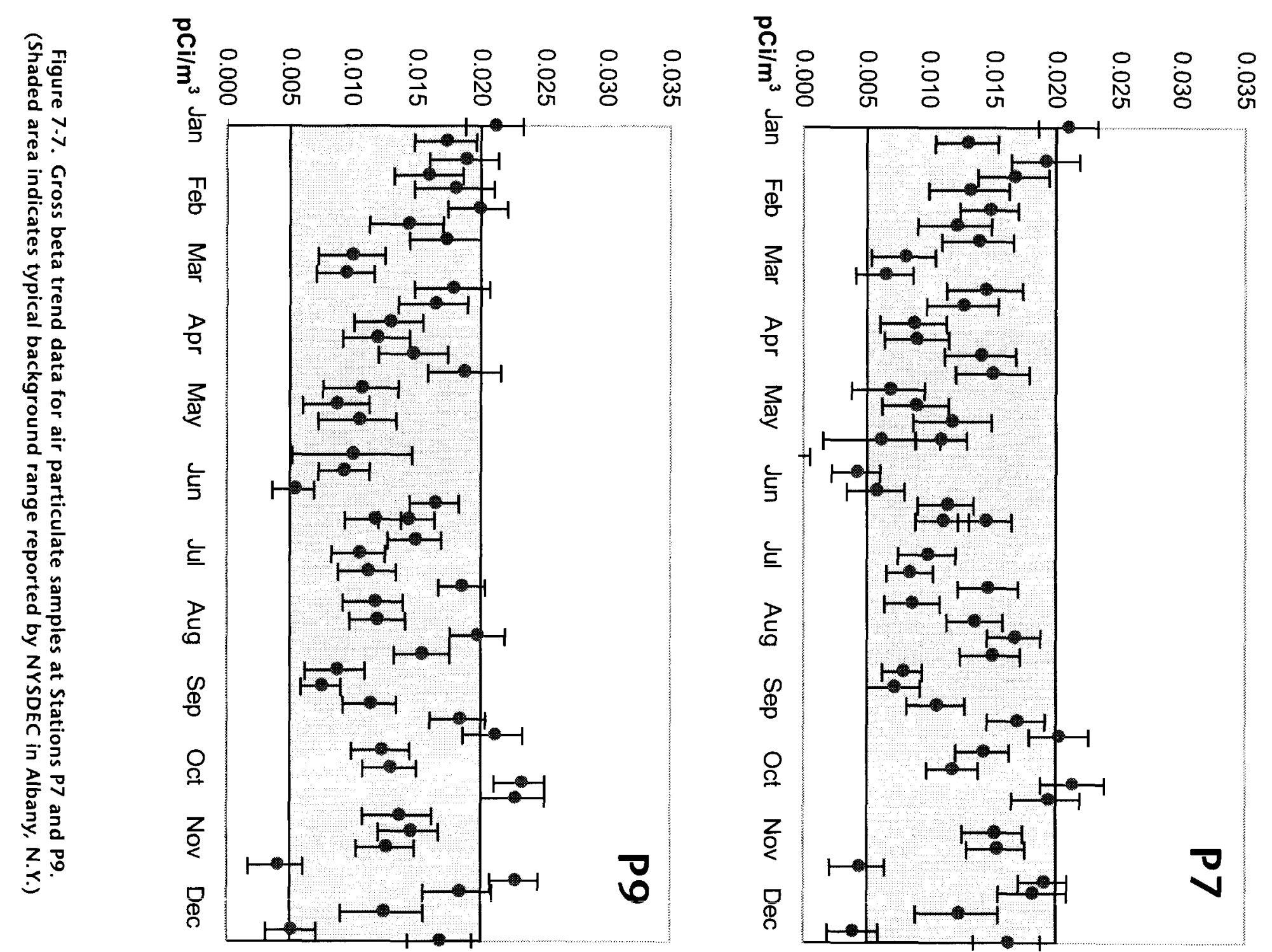
Table 7-4

BNL Site Environmental Report for Calendar Year 1997

Ambient Airborne Tritium Measurements

\begin{tabular}{|c|c|c|c|c|}
\hline $\begin{array}{l}\text { BNL Grid } \\
\text { Location }\end{array}$ & $\begin{array}{l}\text { Wind } \\
\text { Sector }\end{array}$ & $\begin{array}{l}\text { No. of Validated } \\
\text { Samples }\end{array}$ & $\begin{array}{l}\text { Maximum } \\
\left(\mathrm{pCi} / \mathrm{m}^{3}\right)\end{array}$ & $\begin{array}{l}\text { Average } \\
\left(\mathrm{pCi} / \mathrm{m}^{3}\right)\end{array}$ \\
\hline 006 & NE & 50 & $8.8 \pm 3.4$ & $0.2 \pm 4.0$ \\
\hline 011 & NNE & 44 & $6.4 \pm 5.0$ & $-0.6 \pm 4.9$ \\
\hline 012 & NNE & 36 & $9.1 \pm 3.3$ & $0.2 \pm 3.7$ \\
\hline 017 & NNW & 48 & $6.5 \pm 3.3$ & $-0.1 \pm 3.7$ \\
\hline 030 & ENE & 38 & $9.2 \pm 2.7$ & $-0.3 \pm 5.8$ \\
\hline 034 & NNW & 44 & $4.1 \pm 1.3$ & $-0.8 \pm 4.3$ \\
\hline 049 & E & 43 & $5.6 \pm 1.2$ & $-0.8 \pm 8.0$ \\
\hline 053 & NW & 40 & $10.9 \pm 3.8$ & $-0.2 \pm 5.8$ \\
\hline 063 & W & 40 & $2.8 \pm 1.1$ & $-0.6 \pm 3.7$ \\
\hline 066 & $E$ & 26 & $5.9 \pm 4.2$ & $-0.4 \pm 9.8$ \\
\hline 075 & sW & 39 & $14.4 \pm 5.5$ & $0.7 \pm 6.1$ \\
\hline 080 & ESE & 43 & $14.4 \pm 2.4$ & $0.4 \pm 7.4$ \\
\hline 082 & $w$ & 45 & $17.7 \pm 2.0$ & $-0.5 \pm 7.0$ \\
\hline 090 & ESE & 47 & $50.4 \pm 3.0$ & $1.4 \pm 16.1$ \\
\hline 105 & $S$ & 44 & $6.1 \pm 2.2$ & $-0.1 \pm 4.2$ \\
\hline 108 & SE & 47 & $17.0 \pm 5.8$ & $0.4 \pm 6.5$ \\
\hline 109 & WSW & 49 & $13.9 \pm 3.4$ & $-0.1 \pm 5.4$ \\
\hline 111 & sw & 44 & $14.1 \pm 3.5$ & $-1.0 \pm 8.3$ \\
\hline 122 & SSE & 43 & $4.1 \pm 4.0$ & $-0.2 \pm 3.9$ \\
\hline 126 & SsW & 44 & $6.7 \pm 2.2$ & $-0.2 \pm 4.0$ \\
\hline
\end{tabular}

Notes:

1. Maximum values reported with $95 \%$ confiderice interval.

2. Average values reported as arithmetic mean with +2 population standard deviations.

3. Typical minimum detection limit $=4 \mathrm{pCi} / \mathrm{m}^{3}$.

Table 7-4 lists the number of samples collected at each location, the maximum value observed and the annual average concentration. While each location showed a maximum value at some point in the year which was above the typical detection limit of about $4 \mathrm{pCi} / \mathrm{m}^{3}\left(0.15 \mathrm{~Bq} / \mathrm{m}^{3}\right)$, the vast majority of sample results were below the detectable level. These data demonstrate that there is no significant increase in ambient tritium concentrations at the site boundary as a result of Laboratory operations. All annual average concentrations were below the analytical detection limit. The maximum concentration recorded in a single measurement occurred at the station located in BNL Grid 090, the Laboratory's southeastern boundary; the concentration was $50 \mathrm{pCi} / \mathrm{m}^{3}$ $\left(1.9 \mathrm{~Bq} / \mathrm{m}^{3}\right)$. By comparison, the DOE Order $5400.5 \mathrm{DCG}$ for tritium in air is $100,000 \mathrm{pCi} / \mathrm{m}^{3}$ $\left(3.7 \mathrm{kBq} / \mathrm{m}^{3}\right)$. The airborne DCG is the concentration of a radionuclide in air which, if inhaled at that level for one year, would result in an effective dose equivalent of 100 mrem ( $1 \mathrm{mSv})$ to the exposed individual. Only three out of 47 samples collected at the Grid 090 station were above the MDL during 1997.

\subsubsection{RA V Recharge Basin}

Airborne monitoring was also conducted in the vicinity of the RA V Recharge Basin to determine whether tritium in the basin presented a potential airborne fugitive emission source (Section 5.2). Two monitors were installed immediately adjacent to the basin at the northeast and south- 
Table 7-5

BNL Site Environmental Report for Calendar Year 1997

Ambient Tritium Monitoring Results at RA V Recharge Basin

\begin{tabular}{|c|c|c|c|c|}
\hline Location & No. of Samples & Detections & & $\mathrm{pCi} / \mathrm{m}^{3}$ \\
\hline Northeast corner of basin & 12 & 2 & $\begin{array}{l}\text { Max. } \\
\text { Avg. }\end{array}$ & $\begin{array}{l}11.7 \pm 1.6 \\
1.2 \pm 8.5\end{array}$ \\
\hline Southeast corner of basin & 14 & 0 & $\begin{array}{l}\text { Max. } \\
\text { Avg. }\end{array}$ & $\begin{array}{l}<2.3 \\
0.6 \pm 1.4\end{array}$ \\
\hline $\begin{array}{l}\text { National Weather Service } \\
\text { Building }\end{array}$ & 13 & 3 & $\begin{array}{l}\text { Max. } \\
\text { Avg. }\end{array}$ & $\begin{array}{l}3.6 \pm 2.1 \\
0.8 \pm 3.3\end{array}$ \\
\hline
\end{tabular}

east corners, the downwind directions of the predominant winds on site. An additional station was placed near the National Weather Service building, approximately $0.3 \mathrm{~km}(900 \mathrm{ft}$.) to the east of the basin. Table 7-5 shows that no trend of measurable airborne tritium was observed. Only five of 39 total samples showed results greater than the detection limit, and those five were at values consistent with what was observed throughout the site. This is as expected since direct analysis of the basin water showed tritium values which were rarely large enough to be detected, i.e., $<1,000 \mathrm{pCi} / \mathrm{L}(<37 \mathrm{~Bq} / \mathrm{L})$.

\subsection{Precipitation Sampling}

As part of the environmental monitoring program, precipitation samples are collected approximately once a month at Stations P4 and S5 (located in BNL Grids 109 and 038) and analyzed for radioactive content (Table 7-6 and Figure 5-1). Measurements of gross alpha activity samples collected at both stations indicated average values below the typical minimum detection limit of $2 \mathrm{pCi} / \mathrm{L}(0.07 \mathrm{~Bq} / \mathrm{L})$. Gross beta activity was occasionally measurable at levels at or slightly above typical MDLs, although gamma spectroscopy analysis confirmed the absence of any anthropogenic radionuclides. Tritium values for the precipitation samples were near or below the minimum detection limit for all 20 samples, indicating that the Laboratory's airborne emissions had no measurable impact on local rainwater or snowfall.

Table $7-6$

BNL Site Environmental Report for Calendar Year 1997 Radiological Analysis of Precipitation

\begin{tabular}{|c|c|c|c|c|c|c|c|}
\hline Station & Grid & $\begin{array}{l}\text { Compass } \\
\text { Sector }\end{array}$ & $\mathbf{N}$ & & $\begin{array}{l}\text { Gross Alpha } \\
\text { (pCi/L) }\end{array}$ & Gross Beta & Tritium \\
\hline P4 & 017 & WSW & 10 & $\begin{array}{l}\text { Max. } \\
\text { Avg. }\end{array}$ & $\begin{array}{l}3.6 \pm 2.4 \\
1.5 \pm 2.1\end{array}$ & $\begin{array}{l}10.9 \pm 5.5 \\
5.4 \pm 4.8\end{array}$ & $\begin{array}{l}355 \pm 202^{*} \\
-25 \pm 284\end{array}$ \\
\hline S5 & 038 & ENE & 10 & $\begin{array}{l}\text { Max. } \\
\text { Avg. }\end{array}$ & $\begin{array}{l}3.3 \pm 2.2 \\
0.9 \pm 2.3\end{array}$ & $\begin{array}{l}8.3 \pm 5.1 \\
4.3 \pm 3.8\end{array}$ & $\begin{array}{l}<263 \\
-9 \pm 170\end{array}$ \\
\hline
\end{tabular}




\subsection{Terrestrial and Ecological Radioactivity Studies}

BNL maintains a soil and vegetation-sampling program for the site, including semiannual faunasampling, first initiated in 1992. In 1992 and 1993 samples were collected which included a wide variety of on-site species such as fox, raccoon, rabbit, skunk, opossum, and muskrat. On-site fauna sampling was again conducted in 1997, but was limited to the deer population. Similarly, an on-site soil and vegetation collection program was begun in 1993. This program calls for sampling every five years, so on-site sampling was not conducted in 1997. However, as part of a cooperative effort between BNL and the SCDHS, vegetation, fruit and soil samples from farms in the vicinity of the Laboratory are collected annually.

\subsubsection{Radiological Analysis of Deer}

A deer population study for the BNL site conducted in 1992 indicated that the total number of deer on site might be as high as 700 . Since there are no natural predators on site and no sport hunting, there are no significant pressures on the population to migrate beyond their typical geographical range of approximately one mile. Recent destruction of habitat to the southwest of BNL property and the resulting influx of deer has contributed to the size of the on-site population.

Deer in New York State typically grow to large sizes, with males having average weights of approximately $68 \mathrm{~kg}$ (150 lbs.); females are slightly less at about $45 \mathrm{~kg}$. (100 lbs.). However, deer on Long Island tend to be much smaller, with an average weight of less than $36 \mathrm{~kg}$ (80 lbs.). The available meat on local deer ranges from 9 to $18 \mathrm{~kg}$ (20 to $40 \mathrm{lbs}$.) per deer.

In 1997, an off-site deer-sampling program was again conducted in cooperation with the NYSDEC Wildlife Branch. Licensed hunters were approached by the NYSDEC at checkpoints where meat and liver samples were requested. However, due to limited support from local hunters, only two samples were obtained from off-site locations adjacent to the Laboratory. Therefore, the majority of samples collected are from the BNL site. All on-site samples were obtained from deer killed by cars. Samples were analyzed for gamma-emitting radionuclides; the results are shown in Table 7-7. It was previously established that deer taken on BNL property contain cesium-137 concentrations at levels above those taken from off-site (see the BNL Site Environmental Report for Calendar Year 1996). This is most likely the result of deer grazing in areas where elevated cesium-137 levels are known to exist in soils. Cesium contained in these soils is transferred to plant matter via root uptake, where it then becomes available for consumption by browsing animals.

The maximum concentration of cesium-137 detected in hind meat samples was $6.0 \mathrm{pCi} / \mathrm{g}$ $(0.22 \mathrm{~Bq} / \mathrm{g})$; this sample was collected near Bldg. 555 on Center Street. The average concentration of all samples of hind meat in which cesium was detected was $1.8 \mathrm{pCi} / \mathrm{g}(0.07 \mathrm{~Bq} / \mathrm{g})$. This average includes the sample collected by the NYSDEC to the northeast of the site which showed a concentration of $4.7 \mathrm{pCi} / \mathrm{g}(0.17 \mathrm{~Bq} / \mathrm{g})$. This result appears consistent with values previously observed in on-site samples, suggesting that this animal may have migrated from an on-site location. Figure $7-8$ shows the ranges of cesium-137 concentrations in on-site deer sampled since 1992.

\subsubsection{Radiological Analysis; of Vegetation}

In August 1997, vegetation and soil samples were collected from farms surrounding BNL and locations further away from the Laboratory, and were analyzed by the BNL ASL for gamma-emitting radionuclides. The results are shown in Table 7-8 and show the presence of potassium-40 at levels which are consistent with expectations for this type of environmental sample. No radionuclides attributable to Laboratory operations were detected. While cesium-137 was detected in a few vegetation samples, the results are typical of levels due to fallout observed in the United States (Golchert and Kolzow 1994). 
Table 7-7

BNL Site Environmental Report for the Calendar year 1997 Radiological Analysis of Deer Meat

\begin{tabular}{|c|c|c|c|c|c|}
\hline Location & Sex & $\begin{array}{l}\text { Date } \\
\text { Collected }\end{array}$ & $\begin{array}{l}\text { Tissue } \\
\text { Analyzed }\end{array}$ & $K-40$ & Cs.137 \\
\hline Main gate & doe & $13-0 \mathrm{ct}-97$ & $\begin{array}{l}\text { Hind Meat } \\
\text { Liver }\end{array}$ & $\begin{array}{l}2.51 \pm 0.48 \\
3.51 \pm 0.98\end{array}$ & $\begin{array}{l}0.23 \pm 0.05 \\
0.50 \pm 0.12\end{array}$ \\
\hline Bldg. 1001 & doe & 18-Nov-97 & $\begin{array}{l}\text { Hind Meat } \\
\text { Liver }\end{array}$ & $\begin{array}{l}3.27 \pm 0.58 \\
2.24 \pm 0.41\end{array}$ & $\begin{array}{l}1.35 \pm 0.24 \\
0.41 \pm 0.07\end{array}$ \\
\hline Bldg. 830 & doe & $8-0 \mathrm{ct}-97$ & $\begin{array}{l}\text { Hind Meat } \\
\text { Liver }\end{array}$ & $\begin{array}{l}2.81 \pm 0.68 \\
1.68 \pm 0.30\end{array}$ & $\begin{array}{l}2.39 \pm 0.56 \\
0.21 \pm 0.04\end{array}$ \\
\hline Bldg. 830 & doe & $7-0 \mathrm{ct}-97$ & $\begin{array}{l}\text { Hind Meat } \\
\text { Liver }\end{array}$ & $\begin{array}{l}3.19 \pm 0.54 \\
1.84 \pm 0.33\end{array}$ & $\begin{array}{l}0.19 \pm 0.04 \\
0.03 \pm 0.01\end{array}$ \\
\hline $\begin{array}{l}\text { Center St/ } \\
\text { Chemistry Bldg. }\end{array}$ & buck & 7-Sep-97 & $\begin{array}{l}\text { Hind Meat } \\
\text { Liver }\end{array}$ & $\begin{array}{l}2.81 \pm 0.47 \\
2.21 \pm 0.40\end{array}$ & $\begin{array}{l}6.04 \pm 1.03 \\
3.73 \pm 0.64\end{array}$ \\
\hline Railroad Avenue & doe & 10-Nov-97 & $\begin{array}{l}\text { Hind Meat } \\
\text { Liver }\end{array}$ & $\begin{array}{l}3.58 \pm 0.60 \\
1.68 \pm 0.29\end{array}$ & $\begin{array}{l}1.04 \pm 0.16 \\
0.16 \pm 0.03\end{array}$ \\
\hline $\begin{array}{l}0.5 \mathrm{mi} \text {. SW of Shultz } \\
\text { Road/Wading River- } \\
\text { Manorville Rd (NYSDEC) } \\
\text { ND = Not Detected. }\end{array}$ & doe & 13-Nov-97 & Hind Meat & $1.94 \pm 0.33$ & $4.71 \pm 0.80$ \\
\hline
\end{tabular}

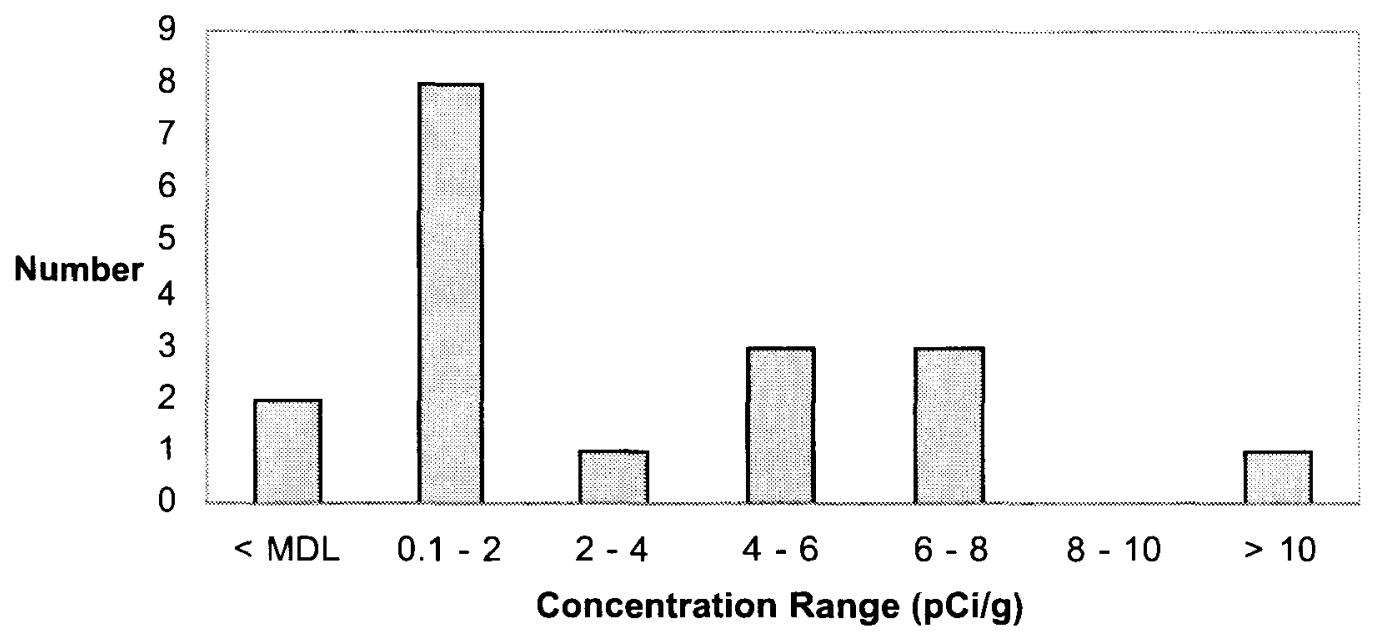

Figure 7-8. Distribution of Cs-137 in On-site Deer Collection Since 1992 
Table 7-8

BNL Site Environmental Report for Calendar Year 1997

Radiological Analysis of Vegetation Samples

\begin{tabular}{|c|c|c|c|c|}
\hline Sample Location & Sample Type & $k-40$ & (pCi/g, wet) & Cs-137 \\
\hline Farm A & Italian hot peppers & $6.0 \pm 1.5$ & & ND \\
\hline $6 \mathrm{~km}(3.7 \mathrm{mi})$ & Strawberries & $1.5 \pm 0.3$ & & ND \\
\hline \multirow[t]{2}{*}{ northeast of BNL site. } & Sweet corn & $4.2 \pm 1.0$ & & ND \\
\hline & & & & ND \\
\hline Farm B & Tomato & $1.9 \pm 0.3$ & & ND \\
\hline $22.4 \mathrm{~km}(14 \mathrm{mi})$. & Yellow squash & $2.5 \pm 0.4$ & & ND \\
\hline \multirow[t]{2}{*}{ east-northeast of $B N L$ site } & Sweet corn & $2.0 \pm 0.4$ & & ND \\
\hline & & & & ND \\
\hline Farm C & Yellow squash & $1.4 \pm 0.3$ & & ND \\
\hline $5 \mathrm{~km}(3 \mathrm{mi})$. & Broccoli - stems/ & $4.7 \pm 1.3$ & & ND \\
\hline \multirow[t]{8}{*}{ east-southeast of BNL site. } & leaves & & & ND \\
\hline & Eggplant & $2.0+0.4$ & & ND \\
\hline & Yellow squash & $1.5 \pm 0.2$ & & $0.01 \pm 0.004$ \\
\hline & Zucchini & $1.7 \pm 0.4$ & & ND \\
\hline & Broccoli-stems & $4.9 \pm 1.0$ & & ND \\
\hline & Broccoli - flcrets & $5.6 \pm 1.2$ & & ND \\
\hline & Sweet corn & $2.2+0.4$ & & ND \\
\hline & Tomato & $1.6 \pm 0.3$ & & ND \\
\hline \multicolumn{5}{|l|}{ Farm D } \\
\hline $6.4 \mathrm{~km}$ (4 mi.) southwest & Feed corn & $2.1 \pm 0.4$ & & ND \\
\hline \multirow{4}{*}{ of $B N L$ site. } & Pumpkin seeds & $3.2 \pm 0.6$ & & $0.02 \pm 0.01$ \\
\hline & Pumpkin flesh & $1.4 \pm 0.3$ & & \\
\hline & Pumpkin flesh & $1.5 \pm 0.2$ & & $0.01 \pm 0.004$ \\
\hline & Pumpkin flesh & $1.6 \pm 0.5$ & & ND \\
\hline $\begin{array}{l}\text { ND }=\text { Not Detected } \\
\text { All samples collected on } A\end{array}$ & 997. & & & \\
\hline
\end{tabular}

\subsubsection{Radiological Analysis of Soils and Sediments}

Sediment samples were collected from Flanders Bay, Swan Pond, and the Carmans River (Swan Pond and the Carmans River were used as control locations), and soil samples were collected from farms in the vicinity of the Laboratory. These samples were analyzed for gamma-emitting radionuclides. The results are presented in Table 7-9. These data confirmed the presence of natural radionuclides such as potassium-40 and lead-212 at uniform levels in the marine and terrestrial environments sampled. Cesium-137, a globally distributed radionuclide, was detected in two out of five sediment samples at extremely low levels close to the detection limits of the analytical system. The cesium-137 concentration in sediment from Flanders Bay did not differ from those collected at the control location of the Carmans River.

\subsection{Peconic River Surveillance}

\subsubsection{Peconic River Surveillance - Non-radiological Analyses}

The Peconic River was sampled at six locations during 1997; three on-site (Sampling Locations HMn, HMs and HQ) and four off-site (Sampling Locations HA, HB, HC, and HR) (Figure 7-9). In addition, the Carmans River was also sampled (Location $\mathrm{HH}$ ) as an off-site control location. These samples were analyzed for water quality parameters (i.e., $\mathrm{pH}$, temperature, conductivity, and dis- 


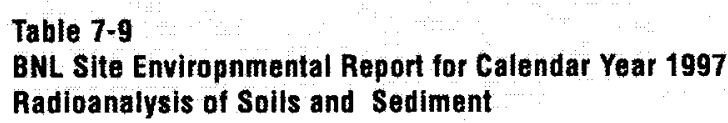

\begin{tabular}{|c|c|c|c|c|c|c|c|c|c|c|}
\hline $\begin{array}{l}\text { Sample } \\
\text { Location }\end{array}$ & $\begin{array}{l}\text { Sample } \\
\text { Date }\end{array}$ & $\begin{array}{l}\text { Sample } \\
\text { Type }\end{array}$ & $K-40$ & Cs-137 & TI-208 & $\begin{array}{l}\mathrm{Pb}-212 \\
\text { (pCi/g,wet) }\end{array}$ & Pb-214 & Bi-214 & Ac-228 & Th-232 \\
\hline NYS Farm & 20-Aug-97 & Soil & $5.47 \pm 1.84$ & $0.44 \pm 0.13$ & $0.35 \pm 0.14$ & $0.51 \pm 0.24$ & $0.67 \pm 0.21$ & ND & ND & ND \\
\hline $\begin{array}{l}\text { Yaphank Honor } \\
\text { Farm (Site A) }\end{array}$ & 20-Aug-97 & Soil & $6.11 \pm 1.09$ & $0.16 \pm 0.05$ & $0.24 \pm 0.06$ & $0.78 \pm 0.12$ & $0.66 \pm 0.16$ & $0.80 \pm 0.11$ & $0.72 \pm 0.12$ & $0.98 \pm 0.23$ \\
\hline $\begin{array}{l}\text { Yaphank Honor } \\
\text { Farm (Site B) }\end{array}$ & & Soil & $7.09 \pm 1.25$ & $0.15 \pm 0.05$ & $0.33 \pm 0.07$ & $0.98 \pm 0.15$ & $0.82 \pm 0.17$ & $0.95 \pm 0.12$ & $0.93 \pm 0.13$ & $0.99 \pm 0.25$ \\
\hline $\begin{array}{l}\text { Yaphank Honor } \\
\text { Farm (Site C) }\end{array}$ & & Soil & $6.34 \pm 1.24$ & $0.26 \pm 0.07$ & $0.35 \pm 0.08$ & $0.91 \pm 0.15$ & $1.14=0.16$ & $1.10 \pm 0.16$ & $0.91 \pm 0.17$ & $0.88 \pm 0.34$ \\
\hline $\begin{array}{l}\text { Lewins Farm } \\
\text { (Site A) }\end{array}$ & 2-Jul-98 & Soil & $8.55 \pm 1.44$ & $0.21 \pm 0.05$ & $0.39=0.07$ & $1.09 \pm 0.15$ & $1.15 \pm 0.14$ & $1.07 \pm 0.12$ & $1.17 \pm 0.13$ & $1.00 \pm 0.22$ \\
\hline $\begin{array}{l}\text { Lewins Farm } \\
\text { (Site B) }\end{array}$ & & Soil & $7.67 \pm 1.30$ & $0.12 \pm 0.04$ & $0.34 \pm 0.06$ & $0.95 \pm 0.13$ & $0.86=0.11$ & $0.83+0.11$ & $1.01 \pm 0.12$ & $1.05 \pm 0.41$ \\
\hline Glover's Farm & 24-Jun-97 & Soil & $11.82 \pm 2.52$ & ND & $0.76 \pm 0.18$ & $2.29 \pm 0.43$ & $2.03 \pm 0.36$ & $1.73 \pm 0.28$ & $2.24 \pm 0.39$ & $2.13 \pm 0.70$ \\
\hline Bruno's Farm & 20-Aug-97 & Soil & $7.46 \pm 1.86$ & $0.15 \pm 0.10$ & $0.38 \pm 0.14$ & $0.89 \pm 0.20$ & $1.14 \pm 0.24$ & $1.29 \pm 0.28$ & $1.10 \pm 0.32$ & $N D \pm 0.00$ \\
\hline $\begin{array}{l}\text { May's Farm } \\
\text { (Site A) }\end{array}$ & 2-Jul-97 & Soil & $7.63 \pm 1.34$ & ND & $0.40 \pm 0.07$ & $0.95 \pm 0.14$ & $0.99 \pm 0.19$ & $0.95 \pm 0.12$ & $1.00 \pm 0.13$ & $1.07 \pm 0.25$ \\
\hline $\begin{array}{l}\text { May's Farm } \\
\text { (Site B) }\end{array}$ & 20-Aug-97 & Soil & $6.32 \pm 1.11$ & $0.05 \pm 0.03$ & $0.26 \pm 0.06$ & $0.82 \pm 0.12$ & $0.86 \pm 0.12$ & $0.83 \pm 0.11$ & $0.85 \pm 0.11$ & $0.92 \pm 0.23$ \\
\hline $\begin{array}{l}\text { Carmans River } \\
\text { (Site A) }\end{array}$ & 26-Aug-97 & Sediment & $1.56 \pm 0.42$ & ND & $0.09 \pm 0.03$ & $0.24 \pm 0.05$ & $0.21 \pm 0.05$ & ND & $0.34 \pm 0.08$ & ND \\
\hline $\begin{array}{l}\text { Carmans River } \\
\text { (Site B) }\end{array}$ & & & $1.25 \pm 0.32$ & $0.05 \pm 0.02$ & $0.08 \pm 0.03$ & $0.26 \pm 0.05$ & $0.22 \pm 0.05$ & $0.19 \pm 0.04$ & $0.27 \pm 0.06$ & ND \\
\hline Swan Pond & 26-Aug-97 & Sediment & $0.70 \pm 0.21$ & ND & $0.05 \pm 0.02$ & $0.16 \pm 0.03$ & $0.09 \pm 0.03$ & $0.12 \pm 0.03$ & ND & ND \\
\hline $\begin{array}{l}\text { Flander's Bay } \\
\text { (Site A) }\end{array}$ & 29-Jul-97 & Sediment & $1.91 \pm 0.63$ & ND & ND & $0.17 \pm 0.07$ & ND & ND & ND & ND \\
\hline $\begin{array}{l}\text { Flander's Bay } \\
\text { (Site B) }\end{array}$ & & Sediment & $1.73 \pm 0.39$ & $0.02 \pm 0.01$ & $0.05 \pm 0.02$ & $0.16 \pm 0.03$ & $0.08 \pm 0.02$ & $0.16 \pm 0.03$ & $0.24 \pm 0.04$ & $0.27 \pm 0.07$ \\
\hline
\end{tabular}

ND $=$ Not Detected 
solved oxygen), anions (i.e., chlorides, sulfates, and nitrates), metals, and VOCs routinely during 1997.

A summary of water quality and metals analytical data for surface waters is given in Tables 7-10 and 7-11, respectively. Location HMn, which is downstream of the BNL STP, has characteristics very similar to the STP discharge. With the exception of $\mathrm{pH}$, all water quality and metal parameters were typical of the STP discharge. Whereas the STP effluent is compared to SPDES effluent limits, concentrations in surface water samples are compared to the ambient water quality standard (AWQS). Comparison to the NYS AWQS for a Class C water system shows the concentration of iron, lead, mercury, and zinc to be slightly higher in the water samples collected at HMn. However, the AWQS is based upon the dissolved fraction whereas all analyses are total recoverable (i.e., acid digested). Due to the low AWQS, the detection limit is insufficient to evaluate samples against the AWQS. Beginning in 1999 surface water samples will be filtered prior to analysis to allow better comparison. The $\mathrm{pH}$ of the Peconic River, as measured downstream of the STP discharge, is frequently lower than the ambient water quality standard. Contributions of groundwater, natural decay products, such as humic acids, and storm water runoff, all of which have $\mathrm{pH}$ values typically less than 5.8 , contribute to this. Location $\mathrm{HQ}$, which is located at the site boundary, also had similar characteristics to the STP discharge. Again, the pH was typically lower than that recorded at the STP and HMn, most probably due to groundwater and storm water contributions. Iron and lead are present at station HQ at concentrations, which slightly exceed ambient water quality standards but are consistent wiht the off-site control location.

Locations $\mathrm{HA}, \mathrm{HB}, \mathrm{HC}$, and $\mathrm{HR}$ are at various points along the Peconic River, off-site and down stream of BNL. Again, with the exception of $\mathrm{pH}$, all water quality parameters are consistent with either the NYS AWQS, off-site control location, or with historical data. The low $\mathrm{pH}$ values recorded at the river stations may be attributed to the natural low $\mathrm{pH}$ of groundwater and storm water and by the contributions of natural decay products. All concentrations of metals, except iron and zinc, were within the AWQS and were consistent with the off-site control. Zinc was detected at HMn in May and HB in March at significantly higher concentrations than other locations. Both observations were single events, with all other values being much less than the standard. Iron was detected at all locations. Iron and zinc are naturally occurring elements and are present in sediments which make up the sample. As previously noted, beginning in 1999 river water samples will be filtered prior to acid preservation to obtain a better comparison to the AQWS. The occurrences are clearly isolated and do not represent a pattern of consistently high concentrations. All other metal parameters were consistent with historical data, and the background levels at the Carmans River station.

During 1997, all surface waters locations were analyzed for VOC contamination by the ES\&HS Division Analytical Laboratory. With the exception of trace concentrations (i.e., less than $2 \mathrm{ug} / \mathrm{L}$ ) of chloroform, TCA and DCA, no VOCs were detected above the Laboratory detection limit of $2 \mathrm{ug} / \mathrm{L}$ in samples collected from the Peconic or Carmans River stations. Chloroform was detected at Location HMn and is most likely present as a chlorination-by-product. The cessation of chlorination at the STP should eliminate future detections of this compound. TCA and DCA were detected at Location HR. Due to its location, and the absence of these compounds at stations closer to the BNL site, their presence is not attributable to BNL operations.

\subsubsection{Peconic River Surveillance - Radiological Analyses}

Radionuclides were measured in surface water samples collected from the Peconic River at seven locations: Station HMn, 790 meters downstream of the STP Outfall; Station HMs, a typically dry tributary of the Peconic River; Station HQ, $2.1 \mathrm{~km}$ downstream from the STP; Location HA and $\mathrm{HB}, 5 \mathrm{~km}$ downstream; Location $\mathrm{HC}, 7 \mathrm{~km}$ downstream; and Location HR in Riverhead, $21 \mathrm{~km}$ downstream from the STP Outfall. The Carmans River (Location $\mathrm{HH}$ ) in North Shirley, was sampled as a control location not influenced by BNL liquid effluents. Sampling points along the Peconic River are identified in Figure 7-9. Routine samples at Location HMn were collected three times per week. Since February 1995, this location has been equipped with a Parshall flume al- 
Table 7-10

BNL Site Environmental Report for Calendar Year 1997

Water Quality Data for Surface Water Samples

Collected Along the Peconic and Carmans Rivers

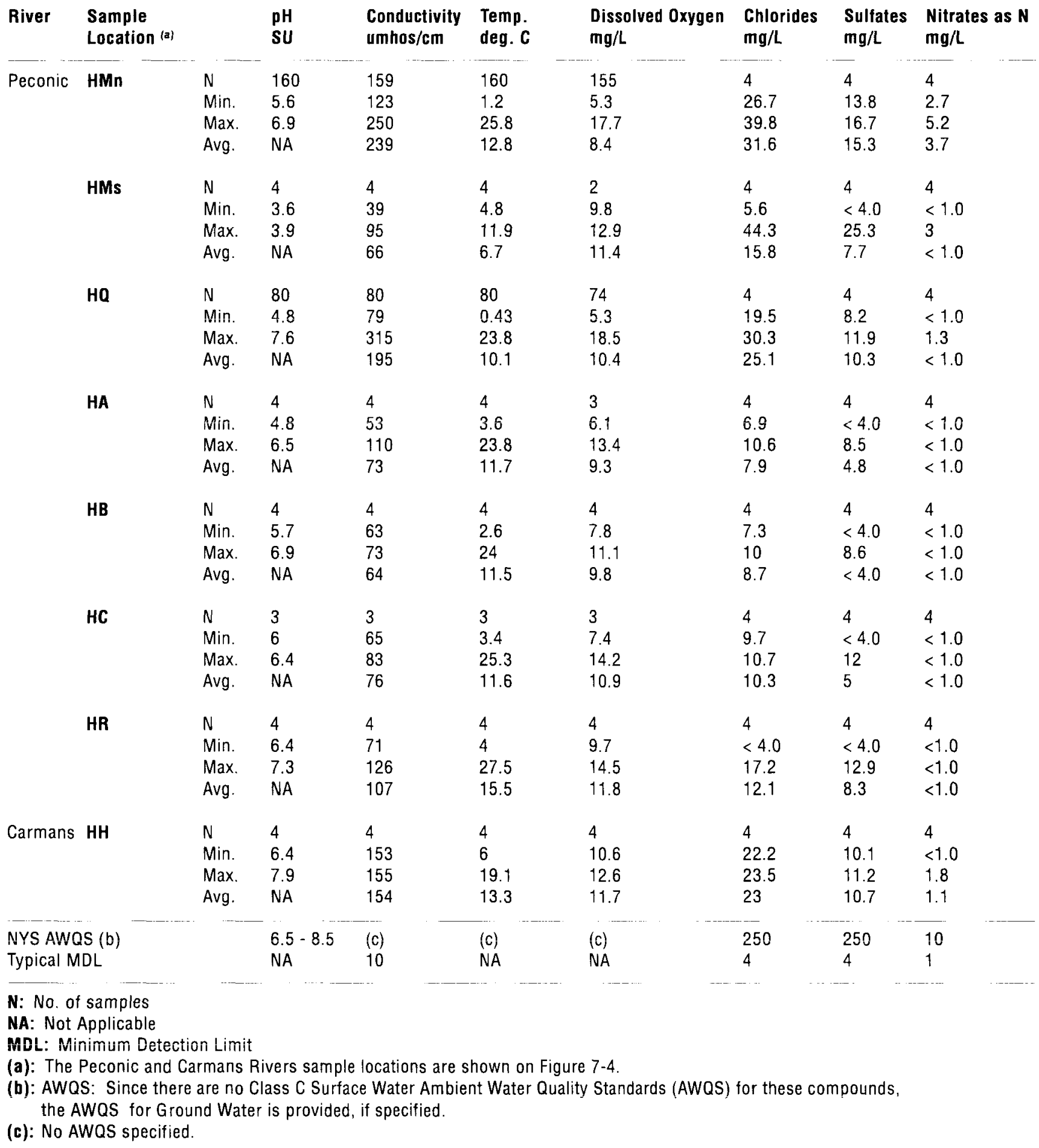


Table 7-11

BNL Site Environmental Report for Calendar Year 1997 Metals Concentration Data for Surface Water Samples

Collected Along the Peconic and Carmans Rivers

\begin{tabular}{|c|c|c|c|c|c|c|c|c|c|c|c|c|}
\hline River & $\begin{array}{l}\text { Sample } \\
\text { Location (a) }\end{array}$ & & $\mathrm{Ag}$ & Cd & $\mathrm{Cr}$ & $\mathrm{Cu}$ & ${ }_{(\mathrm{mg} / \mathrm{L}}$ & $\mathrm{Hg}$ & Mn & $\mathrm{Na}$ & $\mathbf{P b}$ & $\mathrm{Zn}$ \\
\hline \multirow[t]{7}{*}{ Peconic } & HMn & $\begin{array}{l}\text { N } \\
\text { Min. } \\
\text { Max. } \\
\text { Avg. }\end{array}$ & $\begin{array}{l}11 \\
<0.025 \\
<0.025 \\
<0.025\end{array}$ & $\begin{array}{l}11 \\
<0.0005 \\
<0.0005 \\
<0.0005\end{array}$ & $\begin{array}{l}11 \\
<0.005 \\
<0.005 \\
<0.005\end{array}$ & $\begin{array}{l}11 \\
<0.05 \\
<0.05 \\
<0.05\end{array}$ & $\begin{array}{l}11 \\
<0.075 \\
0.53 \\
0.22\end{array}$ & $\begin{array}{l}11 \\
<0.0002 \\
0.0004 \\
<0.0002\end{array}$ & $\begin{array}{l}11 \\
<0.05 \\
0.19 \\
<0.05\end{array}$ & $\begin{array}{l}11 \\
28.4 \\
42.7 \\
33.6\end{array}$ & $\begin{array}{l}11 \\
<0.002 \\
0.003 \\
<0.002\end{array}$ & $\begin{array}{l}11 \\
<0.02 \\
0.3 \\
0.04\end{array}$ \\
\hline & HMs & $\begin{array}{l}\text { N } \\
\text { Min. } \\
\text { Max. } \\
\text { Avg. }\end{array}$ & $\begin{array}{l}5 \\
<0.025 \\
<0.025 \\
<0.025\end{array}$ & $\begin{array}{l}5 \\
<0.0005 \\
<0.0005 \\
<0.0005\end{array}$ & $\begin{array}{l}5 \\
<0.005 \\
<0.005 \\
<0.005\end{array}$ & $\begin{array}{l}5 \\
<0.05 \\
<0.05 \\
<0.05\end{array}$ & $\begin{array}{l}5 \\
<0.075 \\
2.3 \\
0.65\end{array}$ & $\begin{array}{l}5 \\
<0.0002 \\
<0.0002 \\
<0.0002\end{array}$ & $\begin{array}{l}5 \\
<0.05 \\
<0.05 \\
<0.05\end{array}$ & $\begin{array}{l}5 \\
3.3 \\
30.3 \\
8.8\end{array}$ & $\begin{array}{l}5 \\
<0.002 \\
0.003 \\
<0.002\end{array}$ & $\begin{array}{l}5 \\
0.028 \\
0.04 \\
0.033\end{array}$ \\
\hline & HQ & $\begin{array}{l}\text { N } \\
\text { Min. } \\
\text { Max. } \\
\text { Avg. }\end{array}$ & $\begin{array}{l}7 \\
<0.025 \\
<0.025 \\
<0.025\end{array}$ & $\begin{array}{l}7 \\
<0.0005 \\
<0.0005 \\
<0.0005\end{array}$ & $\begin{array}{l}7 \\
<0.005 \\
<0.005 \\
<0.005\end{array}$ & $\begin{array}{l}7 \\
<0.05 \\
<0.05 \\
<0.05\end{array}$ & $\begin{array}{l}7 \\
0.11 \\
0.35 \\
0.2\end{array}$ & $\begin{array}{l}7 \\
<0.0002 \\
<0.0002 \\
<0.0002\end{array}$ & $\begin{array}{l}7 \\
<0.05 \\
<0.05 \\
<0.05\end{array}$ & $\begin{array}{l}7 \\
23.4 \\
45 \\
31\end{array}$ & $\begin{array}{l}7 \\
<0.002 \\
0.003 \\
<0.002\end{array}$ & $\begin{array}{l}7 \\
<0.02 \\
0.032 \\
<0.02\end{array}$ \\
\hline & $H A$ & $\begin{array}{l}\text { N } \\
\text { Min. } \\
\text { Max. } \\
\text { Avg. }\end{array}$ & $\begin{array}{l}4 \\
<0.025 \\
<0.025 \\
<0.025\end{array}$ & $\begin{array}{l}4 \\
<0.0005 \\
<0.0005 \\
<0.0005\end{array}$ & $\begin{array}{l}4 \\
<0.005 \\
<0.005 \\
<0.005\end{array}$ & $\begin{array}{l}4 \\
<0.05 \\
<0.05 \\
<0.05\end{array}$ & $\begin{array}{l}4 \\
0.19 \\
2.6 \\
1.6\end{array}$ & $\begin{array}{l}4 \\
<0.0002 \\
<0.0002 \\
<0.0002\end{array}$ & $\begin{array}{l}4 \\
<0.05 \\
0.09 \\
<0.05\end{array}$ & $\begin{array}{l}4 \\
5.1 \\
8.7 \\
7.1\end{array}$ & $\begin{array}{l}4 \\
<0.002 \\
<0.002 \\
<0.002\end{array}$ & $\begin{array}{l}4 \\
<0.02 \\
0.05 \\
0.02\end{array}$ \\
\hline & $\mathrm{HB}$ & $\begin{array}{l}\text { N } \\
\text { Min. } \\
\text { Max. } \\
\text { Avg. }\end{array}$ & $\begin{array}{l}4 \\
<0.025 \\
<0.025 \\
<0.025\end{array}$ & $\begin{array}{l}4 \\
<0.0005 \\
<0.0005 \\
<0.0005\end{array}$ & $\begin{array}{l}4 \\
<0.005 \\
<0.005 \\
<0.005\end{array}$ & $\begin{array}{l}4 \\
<0.05 \\
<0.05 \\
<0.05\end{array}$ & $\begin{array}{l}4 \\
0.54 \\
9.3 \\
4\end{array}$ & $\begin{array}{l}4 \\
<0.0002 \\
<0.0002 \\
<0.0002\end{array}$ & $\begin{array}{l}4 \\
<0.05 \\
0.13 \\
0.08\end{array}$ & $\begin{array}{l}4 \\
5.6 \\
8.1 \\
7.8\end{array}$ & $\begin{array}{l}4 \\
<0.002 \\
<0.002 \\
<0.002\end{array}$ & $\begin{array}{l}4 \\
<0.02 \\
0.19 \\
0.08\end{array}$ \\
\hline & $\mathrm{HC}$ & $\begin{array}{l}\text { N } \\
\text { Min. } \\
\text { Max. } \\
\text { Avg. }\end{array}$ & $\begin{array}{l}4 \\
<0.025 \\
<0.025 \\
<0.025\end{array}$ & $\begin{array}{l}4 \\
<0.0005 \\
<0.0005 \\
<0.0005\end{array}$ & $\begin{array}{l}4 \\
<0.005 \\
<0.005 \\
<0.005\end{array}$ & $\begin{array}{l}4 \\
<0.05 \\
<0.05 \\
<0.05\end{array}$ & $\begin{array}{l}4 \\
0.44 \\
6.7 \\
3.3\end{array}$ & $\begin{array}{l}4 \\
<0.0002 \\
<0.0002 \\
<0.0002\end{array}$ & $\begin{array}{l}4 \\
<0.05 \\
0.24 \\
0.13\end{array}$ & $\begin{array}{l}4 \\
5.9 \\
7.3 \\
6.8\end{array}$ & $\begin{array}{l}4 \\
<0.002 \\
0.006 \\
<0.002\end{array}$ & $\begin{array}{l}4 \\
<0.02 \\
0.07 \\
0.03\end{array}$ \\
\hline & HR & $\begin{array}{l}\text { N } \\
\text { Min. } \\
\text { Max. } \\
\text { Avg. }\end{array}$ & $\begin{array}{l}4 \\
<0.025 \\
<0.025 \\
<0.025\end{array}$ & $\begin{array}{l}4 \\
<0.0005 \\
<0.0005 \\
<0.0005\end{array}$ & $\begin{array}{l}4 \\
<0.005 \\
<0.005 \\
<0.005\end{array}$ & $\begin{array}{l}4 \\
<0.05 \\
<0.05 \\
<0.05\end{array}$ & $\begin{array}{l}4 \\
0.34 \\
0.97 \\
0.56\end{array}$ & $\begin{array}{l}4 \\
<0.0002 \\
<0.0002 \\
<0.0002\end{array}$ & $\begin{array}{l}4 \\
0.05 \\
0.07 \\
0.07\end{array}$ & $\begin{array}{l}4 \\
10.1 \\
16 \\
12.2\end{array}$ & $\begin{array}{l}4 \\
<0.002 \\
<0.002 \\
<0.002\end{array}$ & $\begin{array}{l}4 \\
<0.02 \\
0.041 \\
<0.02\end{array}$ \\
\hline Carmans & $\mathrm{HH}$ & $\begin{array}{l}\text { N } \\
\text { Min. } \\
\text { Max. } \\
\text { Avg. }\end{array}$ & $\begin{array}{l}4 \\
<0.025 \\
<0.025 \\
<0.025\end{array}$ & $\begin{array}{l}4 \\
<0.0005 \\
<0.0005 \\
<0.0005\end{array}$ & $\begin{array}{l}4 \\
<0.005 \\
<0.005 \\
<0.005\end{array}$ & $\begin{array}{l}4 \\
<0.05 \\
<0.05 \\
<0.05\end{array}$ & $\begin{array}{l}4 \\
0.41 \\
0.5 \\
0.47\end{array}$ & $\begin{array}{l}4 \\
<0.0002 \\
<0.0002 \\
<0.0002\end{array}$ & $\begin{array}{l}4 \\
<0.05 \\
0.09 \\
0.06\end{array}$ & $\begin{array}{l}4 \\
10.4 \\
16.7 \\
14.4\end{array}$ & $\begin{array}{l}4 \\
<0.002 \\
<0.002 \\
<0.002\end{array}$ & $\begin{array}{l}4 \\
<0.02 \\
0.026 \\
<0.02\end{array}$ \\
\hline $\begin{array}{l}\text { NYSDEC } \\
\text { NYSDEC }\end{array}$ & $\begin{array}{l}\text { PDES Limit } \\
\text { AWQS }\end{array}$ & & $\begin{array}{l}0.015 \\
0.0001\end{array}$ & $\begin{array}{l}\text { (b) } \\
0.001\end{array}$ & $\begin{array}{l}\text { (b) } \\
0.034\end{array}$ & $\begin{array}{l}0.15 \\
0.004\end{array}$ & $\begin{array}{l}0.37 \\
0.3\end{array}$ & $\begin{array}{l}0.0008 \\
0.0000007\end{array}$ & $\begin{array}{l}\text { (b) } \\
0.3\end{array}$ & $\begin{array}{l}\text { (b) } \\
\text { (b) }\end{array}$ & $\begin{array}{l}0.019 \\
0.001\end{array}$ & $\begin{array}{l}0.1 \\
0.03\end{array}$ \\
\hline Typical M & & & 0.025 & 0.0005 & 0.005 & 0.05 & 0.075 & 0.0002 & 0.05 & 1 & 0.002 & 0.02 \\
\hline
\end{tabular}

N: No. of samples

AWas: Ambient Water Quality Standard for Class C Surface Water

MDL: Minimum Detection Limit

(a): The Peconic and Carmans River sample locations are shown on Figure 7-4

(b): There are no SPDES limits or AWQS specified for these compounds. 


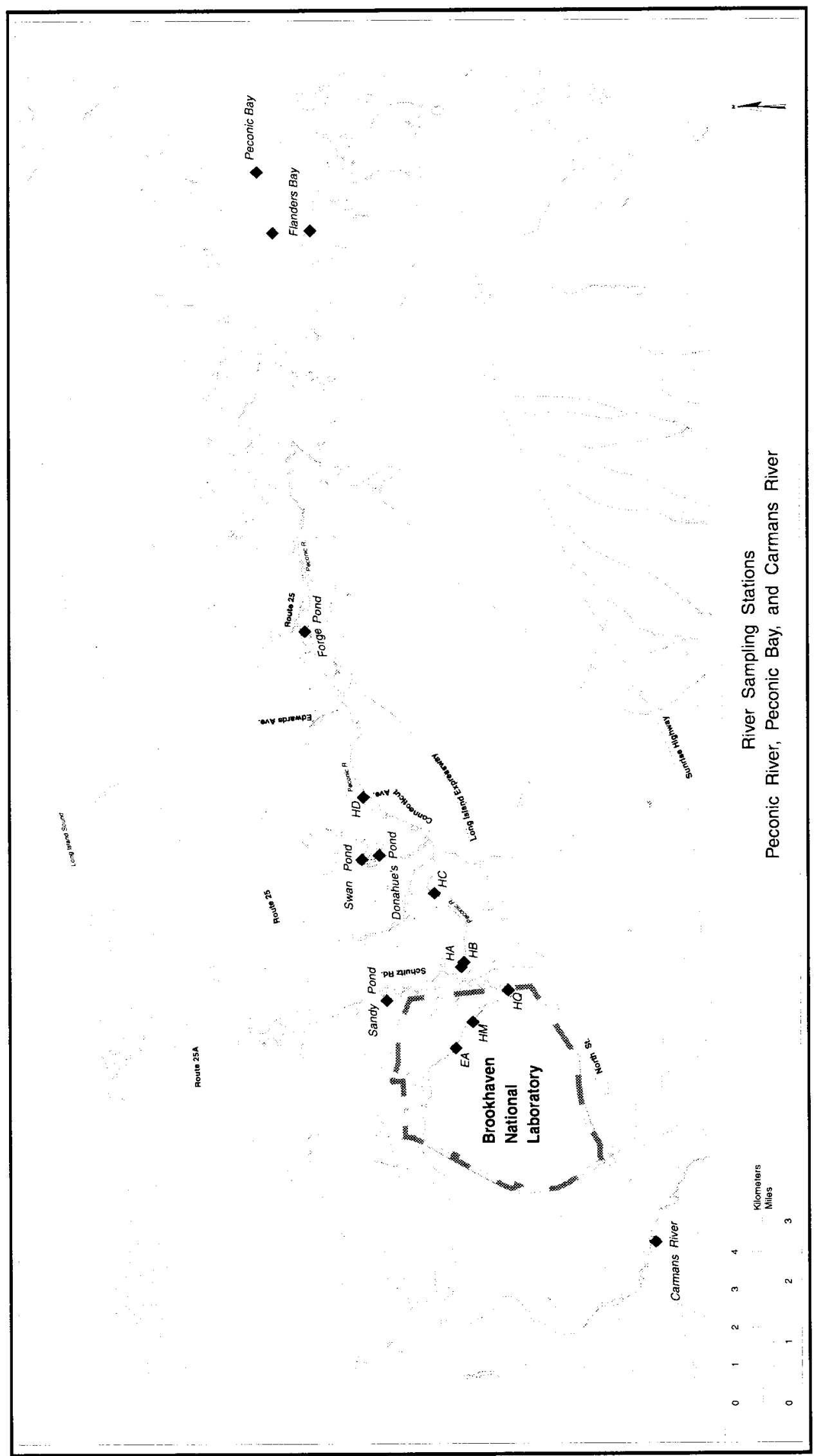


Table 7-12

BNL Site Environmental Report tor Calendar Year 1997

Gross Activity and Tritium Analysis of the Peconic River

\begin{tabular}{|c|c|c|c|c|c|}
\hline $\begin{array}{l}\text { Sample } \\
\text { Station }\end{array}$ & $\begin{array}{l}\text { Geographic } \\
\text { Location }\end{array}$ & $\begin{array}{l}\text { Collect } \\
\text { Date }\end{array}$ & Gross Alpha & $\begin{array}{l}\text { Gross Beta } \\
(\text { pCi/L) }\end{array}$ & Tritium \\
\hline HMn* & $\begin{array}{l}\text { Peconic River, } \\
0.7 \text { km from STP } \\
\text { On-Site }\end{array}$ & $\begin{array}{l}\text { N } \\
\text { Max. } \\
\text { Avg. }\end{array}$ & $\begin{array}{l}153 \\
13.3 \pm 3.7 \\
1.4 \pm 3.6\end{array}$ & $\begin{array}{l}153 \\
17.6 \pm 5.6 \\
6.5 \pm 6.7\end{array}$ & $\begin{array}{l}155 \\
20,600 \pm 832 \\
1,158 \pm 4,061\end{array}$ \\
\hline $\mathrm{HQ}^{*}$ & $\begin{array}{l}\text { Peconic River, } \\
\text { BNL Site } \\
\text { Boundary }\end{array}$ & $\begin{array}{l}\text { N } \\
\text { Max. } \\
\text { Avg. }\end{array}$ & $\begin{array}{l}79 \\
4.1 \pm 2.3 \\
0.7 \pm 2.1\end{array}$ & $\begin{array}{l}79 \\
12.9 \pm 5.3 \\
4.3 \pm 5.4\end{array}$ & $\begin{array}{l}82 \\
7,680 \pm 543 \\
968 \pm 1,704\end{array}$ \\
\hline HMs & $\begin{array}{l}\text { Peconic River } \\
\text { Tributary } \\
\text { On-Site }\end{array}$ & $\begin{array}{l}\text { 28-Jan- } 97 \\
\text { 7-Feb-97' } \\
\text { 2-Apr-97 } \\
\text { 5-May-97 }\end{array}$ & $\begin{array}{l}<2.7 \\
<3.1 \\
0.6 \pm 0.3 \\
1.5 \pm 0.9\end{array}$ & $\begin{array}{l}<7.0 \\
<7.3 \\
<1.7 \\
6.7 \pm 2.4\end{array}$ & $\begin{array}{l}<372 \\
<375 \\
<372 \\
<416\end{array}$ \\
\hline HA & $\begin{array}{l}\text { Peconic River } \\
\text { Off-Site }\end{array}$ & $\begin{array}{l}\text { 18-Mar-97 } \\
10-J u l-97 \\
9-D e c-97\end{array}$ & $\begin{array}{l}<3.1 \\
<3.2 \\
<1.2\end{array}$ & $\begin{array}{l}10.4 \pm 5.3 \\
<7.6 \\
<4.8\end{array}$ & $\begin{array}{l}<333 \\
<304 \\
<336\end{array}$ \\
\hline HB & $\begin{array}{l}\text { Peconic River } \\
\text { Off-Site }\end{array}$ & $\begin{array}{l}\text { 18-Mar-97 } \\
10-J u l-97 \\
9-D e c-97\end{array}$ & $\begin{array}{l}<3.1 \\
3.3 \pm 2.2 \\
<1.7\end{array}$ & $\begin{array}{l}9.6 \pm 5.2 \\
22.9 \pm 5.4 \\
<4.4\end{array}$ & $\begin{array}{l}<333 \\
<304 \\
<334\end{array}$ \\
\hline $\mathrm{HC}$ & $\begin{array}{l}\text { Peconic River } \\
\text { Off-Site }\end{array}$ & $\begin{array}{l}\text { 18-Mar-97 } \\
10-J u l-97 \\
9-D e c-97\end{array}$ & $\begin{array}{l}<3.1 \\
<3.2 \\
<1.2\end{array}$ & $\begin{array}{l}7.8 \pm 5.1 \\
<7.6 \\
<4.8\end{array}$ & $\begin{array}{l}<333 \\
<304 \\
<335\end{array}$ \\
\hline HR & $\begin{array}{l}\text { Peconic River, } \\
\text { Riverhead }\end{array}$ & $\begin{array}{l}\text { 18-Mar-97 } \\
10-J u l-97 \\
9-D e c-97\end{array}$ & $\begin{array}{l}<3.1 \\
<3.2 \\
<1.7\end{array}$ & $\begin{array}{l}<7.8 \\
<7.6 \\
<4.4\end{array}$ & $\begin{array}{l}<333 \\
<304 \\
<343\end{array}$ \\
\hline HH & $\begin{array}{l}\text { Carmans River } \\
\text { (Control Location) }\end{array}$ & $\begin{array}{l}\text { 18-Mar- } 97 \\
\text { 10-Jul-97 } \\
9-\text { Dec-97 }\end{array}$ & $\begin{array}{l}<3.1 \\
<1.6 \\
<1.2\end{array}$ & $\begin{array}{l}<7.8 \\
<3.8 \\
<4.8\end{array}$ & $\begin{array}{l}<333 \\
<304 \\
<335\end{array}$ \\
\hline \multicolumn{3}{|c|}{ SDWA Limit } & 15 & 50 (screening) & 20,000 \\
\hline
\end{tabular}

lowing flow proportional sampling and volume measurements to be made by an automated system. All other sites were "grab" sampled, either as flow allowed (in the case of HMs and HQ), or quarterly (HA, $\mathrm{HB}, \mathrm{HC}, \mathrm{HH}$, and $\mathrm{HR}$ ).

The radiological data generated from the analysis of Peconic River surface water sampling are summarized in Tables 7-12 and 7-13. Though occasionally detectable at levels around $11 \mathrm{pCi} / \mathrm{L}$ $(0.4 \mathrm{~Bq} / \mathrm{L})$, average gross beta activity at Station HMn was below the minimum detection limit of approximately $7 \mathrm{pCi} / \mathrm{L}(0.3 \mathrm{~Bq} / \mathrm{L})$. The majority of gross alpha activity measurements were also below the detection limit.

Samples at Station HQ (located at the eastern site boundary) were collected much more frequently than in recent years due to increased flow of the Peconic there. Since the Peconic is a groundwater-fed river, elevated water table conditions in 1997 provided frequent flow at HQ. At least 
Table 7-13

BNL Site Environmental Report for Calendar Year 1997

Gamma-Emitting Radionuclides and Sr-90 Analysis of Peconic River

\begin{tabular}{|c|c|c|c|c|c|c|c|c|}
\hline $\begin{array}{l}\text { Sample } \\
\text { Station }\end{array}$ & $\begin{array}{l}\text { Geographic } \\
\text { Location }\end{array}$ & $\begin{array}{l}\text { Collect } \\
\text { Date }\end{array}$ & $\mathrm{Be}-7$ & Co-60 & $\begin{array}{l}\mathrm{Cs}-137 \\
\text { (pC }\end{array}$ & & $\mathrm{Na}-22$ & Sr-90 \\
\hline HMn & $\begin{array}{l}\text { Peconic River, } \\
0.7 \text { km from STP } \\
\text { On-Site }\end{array}$ & $\begin{array}{l}31-\text { Mar-97 } \\
30-J u n-97 \\
30-\text { Sep-97 } \\
31-\text { Dec-97 }\end{array}$ & $\begin{array}{l}\text { ND } \\
\text { ND } \\
\text { ND } \\
\text { ND }\end{array}$ & $\begin{array}{l}\text { ND } \\
\text { ND } \\
\text { ND } \\
0.05 \pm 0.02\end{array}$ & $\begin{array}{l}0.84 \pm 0.30 \\
1.20 \pm 0.22 \\
2.17 \pm 0.37 \\
0.52 \pm 0.10\end{array}$ & $\begin{array}{l}\text { ND } \\
3.48 \pm, 0.89 \\
4.25 \pm 0.92 \\
4.18 \pm 0.91\end{array}$ & $\begin{array}{l}\text { ND } \\
\text { ND } \\
\text { ND } \\
0.11 \pm 0.04\end{array}$ & $\begin{array}{l}1.21 \pm 0.07 \\
\text { NS } \\
<0.95 \\
<3.16\end{array}$ \\
\hline HMs & $\begin{array}{l}\text { Peconic River, } \\
\text { Tributary, } \\
\text { On-Site }\end{array}$ & $\begin{array}{l}\text { 28-Jan-97 } \\
7-\text { Feb-97 } \\
\text { 2-Apr-97 } \\
\text { 5-May-97 }\end{array}$ & $\begin{array}{l}\text { ND } \\
\text { ND } \\
\text { ND } \\
\text { ND }\end{array}$ & $\begin{array}{l}\text { ND } \\
\text { ND } \\
\text { ND } \\
\text { ND }\end{array}$ & $\begin{array}{l}\text { ND } \\
\text { ND } \\
\text { ND } \\
\text { ND }\end{array}$ & $\begin{array}{l}\text { ND } \\
\text { ND } \\
\text { ND } \\
\text { ND }\end{array}$ & $\begin{array}{l}\text { ND } \\
\text { ND } \\
\text { ND } \\
\text { ND }\end{array}$ & $\begin{array}{l}0.83 \pm 0.06 \\
<0.17 \\
<0.19 \\
\text { NS }\end{array}$ \\
\hline HQ & $\begin{array}{l}\text { Peconic River, } \\
\text { BNL Site } \\
\text { Boundary }\end{array}$ & $\begin{array}{l}31-\text { Mar-97 } \\
30-J u n-97 \\
31-J u l-97\end{array}$ & $\begin{array}{l}0.55 \pm 0.31 \\
\text { ND } \\
\text { ND }\end{array}$ & $\begin{array}{l}\text { ND } \\
\text { ND } \\
\text { ND }\end{array}$ & $\begin{array}{l}0.61 \pm 0.11 \\
1.23 \pm 0.22 \\
2.65 \pm 0.70\end{array}$ & $\begin{array}{l}2.31 \pm 0.64 \\
3.16 \pm 0.79 \\
14.90 \pm 7.18\end{array}$ & $\begin{array}{l}0.15 \pm 0.05 \\
0.08 \pm 0.05 \\
\text { ND }\end{array}$ & $\begin{array}{l}1.18 \pm 0.07 \\
\text { NS } \\
<3.14\end{array}$ \\
\hline HA & $\begin{array}{l}\text { Peconic River } \\
\text { Off-Site }\end{array}$ & $\begin{array}{l}\text { 18-Mar-97 } \\
10-J u l-97 \\
25-\text { Sep-97 } \\
10-\text { Dec-97 }\end{array}$ & $\begin{array}{l}\text { ND } \\
\text { ND } \\
\text { ND } \\
\text { ND }\end{array}$ & $\begin{array}{l}\text { ND } \\
\text { ND } \\
\text { ND } \\
\text { ND }\end{array}$ & $\begin{array}{l}0.29 \pm 0.17 \\
0.33 \pm 0.21 \\
\text { ND } \\
\text { ND }\end{array}$ & $\begin{array}{l}\text { ND } \\
4.68 \pm 3.14 \\
\text { ND } \\
\text { ND }\end{array}$ & $\begin{array}{l}\text { ND } \\
\text { ND } \\
\text { ND } \\
\text { ND }\end{array}$ & $\begin{array}{l}\text { (a) } \\
\text { (a) } \\
<0.39 \\
<0.35\end{array}$ \\
\hline HB & $\begin{array}{l}\text { Peconic River } \\
\text { Off-Site }\end{array}$ & $\begin{array}{l}\text { 18-Mar-97 } \\
10-J u l-97 \\
25-\text { Sep-97 } \\
\text { 9-Dec-97 }\end{array}$ & $\begin{array}{l}\text { ND } \\
\text { ND } \\
\text { ND } \\
\text { ND }\end{array}$ & $\begin{array}{l}\text { ND } \\
\text { ND } \\
\text { ND } \\
\text { ND }\end{array}$ & $\begin{array}{l}\text { ND } \\
\text { ND } \\
\text { ND } \\
\text { ND }\end{array}$ & $\begin{array}{l}\text { ND } \\
\text { ND } \\
2.12 \pm 2.04 \\
\text { ND }\end{array}$ & $\begin{array}{l}\text { ND } \\
\text { ND } \\
\text { ND } \\
\text { ND }\end{array}$ & $\begin{array}{l}\text { (a) } \\
<1.0 \\
<0.35 \\
<0.29\end{array}$ \\
\hline $\mathrm{HC}$ & $\begin{array}{l}\text { Peconic River } \\
\text { Off-Site }\end{array}$ & $\begin{array}{l}\text { 18-Mar-97 } \\
10-J u l-97 \\
18-S e p-97 \\
9-D e c-97\end{array}$ & $\begin{array}{l}\text { ND } \\
\text { ND } \\
\text { ND } \\
\text { ND }\end{array}$ & $\begin{array}{l}\text { ND } \\
\text { ND } \\
\text { ND } \\
\text { ND }\end{array}$ & $\begin{array}{l}\text { ND } \\
\text { ND } \\
\text { ND } \\
\text { ND }\end{array}$ & $\begin{array}{l}\text { ND } \\
2.64 \pm 2.37 \\
2.72 \pm 2.18 \\
\text { ND }\end{array}$ & $\begin{array}{l}\text { ND } \\
\text { ND } \\
\text { ND } \\
\text { ND }\end{array}$ & $\begin{array}{l}\text { (a) } \\
<1.0 \\
\text { NS } \\
<0.23\end{array}$ \\
\hline HR & $\begin{array}{l}\text { Peconic River, } \\
\text { Riverhead }\end{array}$ & $\begin{array}{l}\text { 18-Mar-97 } \\
10-J u l-97 \\
18-S e p-97 \\
9-D e c-97\end{array}$ & $\begin{array}{l}\text { ND } \\
N D \\
N D \\
N D\end{array}$ & $\begin{array}{l}\text { ND } \\
\text { ND } \\
\text { ND } \\
\text { ND }\end{array}$ & $\begin{array}{l}\text { ND } \\
\text { ND } \\
\text { ND } \\
\text { ND }\end{array}$ & $\begin{array}{l}\text { ND } \\
\text { ND } \\
\text { ND } \\
\text { ND }\end{array}$ & $\begin{array}{l}\text { ND } \\
\text { ND } \\
\text { ND } \\
\text { ND }\end{array}$ & $\begin{array}{l}\text { (a) } \\
\text { (a) } \\
\text { NS } \\
<0.70\end{array}$ \\
\hline $\mathrm{HH}$ & $\begin{array}{l}\text { Carmans River } \\
\text { (Control Location) }\end{array}$ & $\begin{array}{l}\text { 18-Mar-97 } \\
\text { 10-Jul-97 } \\
\text { 18-Sep-97 } \\
\text { 9-Dec-97 }\end{array}$ & $\begin{array}{l}\text { ND } \\
N D \\
N D \\
N D \\
\end{array}$ & $\begin{array}{l}\text { ND } \\
\text { ND } \\
\text { ND } \\
\text { ND }\end{array}$ & $\begin{array}{l}\text { ND } \\
\text { ND } \\
\text { ND } \\
\text { ND }\end{array}$ & $\begin{array}{l}3.28 \pm 2.46 \\
3.80 \pm 3.45 \\
\text { ND } \\
\text { ND }\end{array}$ & $\begin{array}{l}\text { ND } \\
\text { ND } \\
\text { ND } \\
\text { ND }\end{array}$ & $\begin{array}{l}\text { (a) } \\
<1.0 \\
\text { NS } \\
<0.39\end{array}$ \\
\hline \multicolumn{2}{|c|}{$\begin{array}{l}\text { DOE Order } 5400.5 \text { DCG } \\
\text { SDWA Limit }\end{array}$} & & $\begin{array}{l}1,000,000 \\
40,000\end{array}$ & $\begin{array}{l}5,000 \\
200\end{array}$ & $\begin{array}{l}3,000 \\
120\end{array}$ & $\begin{array}{l}7,000 \\
280\end{array}$ & $\begin{array}{l}10,000 \\
400\end{array}$ & $\begin{array}{l}8(b) \\
8\end{array}$ \\
\hline \multicolumn{9}{|c|}{$\begin{array}{l}\text { Notes: } \\
\text { 1. Values reported with } 2 \sigma(95 \%) \text { confidence interval. } \\
\text { 2. ND = Not Detected. } \\
\text { 3. NS = Not sampled for this analyte. } \\
\text { 4. DCG = Derived Concentration Guide, the concentration of a radionuclide which would produce an individual dose } \\
\text { of } 100 \text { mrem if ingested at a rate of } 2 \text { liters per day for for one year. } \\
\text { (a) Sample result invalidated during QA review. } \\
\text { (b) Safe Drinking Water Act limit shown. }\end{array}$} \\
\hline
\end{tabular}


80 samples were collected at HQ for gross alpha and beta activity and tritium analysis. Annual average gross activity values were below typical minimum detection limits. Tritium was detectable at HQ sporadically throughout the year. The highest instantaneous concentration of 7,680 $\mathrm{pCi} / \mathrm{L}(284 \mathrm{~Bq} / \mathrm{L})$ was observed in July following the STP tritium spike (Section 6.2.1.2 for details); the annual average concentration at this station was less than $1,000 \mathrm{pCi} / \mathrm{L}(37 \mathrm{~Bq} / \mathrm{L})$. Tritium was not detected in any quarterly Peconic River samples collected beyond the BNL site boundary.

Cesium-137 continues to be detectable at very low levels $(0.5$ to $2 \mathrm{pCi} / \mathrm{L}[0.02$ to $0.07 \mathrm{~Bq} / \mathrm{L}])$ at HMn and HQ as it continues to leach out of the STP sand filter beds (see Section 6.2.1.1for discussion). Cesium-137 levels observed at these stations are consistent with those measured at the STP Outfall. These levels are very small fractions of the DOE Order 5400.5 DCG for cesium137 which is $3,000 \mathrm{pCi} / \mathrm{L}(111 \mathrm{~Bq} / \mathrm{L})$. Cesium was not detected at any off-site sampling location beyond Station HA.

In Peconic River samples collected at Riverhead (Location HR), gross alpha and gross beta activity was less than detection limits throughout the year. No man-made gamma-emitting radionuclides were detected.

\subsection{Aquatic Biological Surveillance}

\subsubsection{Radiological Analysis of Local Fish}

The Laboratory, in collaboration with the NYSDEC Fisheries Division, maintains an ongoing program for the collection of fish from the Peconic River and surrounding fresh water bodies. The program was significantly expanded in 1996, and repeated in 1997, to include more sampling locations, types of fish caught, and analyses performed. Fish samples were collected from on-site portions of the Peconic River, Donahue's Pond, Forge Pond, Swan Pond, and also from Massapequa Pond, Smith Pond (Roosevelt), Meadow Lake, Searington Pond and the Carmans River (Figure 7-9) which are not connected to the Peconic River system and are, therefore, used as control locations to indicate environmental background. Brown Bullhead (Ictalurus nebulosus), Golden Shiner (Notemigonus crysoleucas), Chain Pickerel (Esox niger), Large Mouth Bass (Micropterus salmoides), Blue Gill (Lepomis macrochirus), Eel, Pumpkinseed (Lepomis gibbosus), Gizzard Shad, Black Crappie, Creek Chubsucker (Erimyzon oblongus), and White and Yellow Perch (Perca flavescens) species were collected and analyzed by gamma spectroscopy. Specific information on the sampling point, species collected, and analytical results are presented in Table 7-14.

Analyses were performed separately on the flesh and skin, the viscera and bones, and the whole fish. Segregating the analyses in this way provides important information regarding the localization of radionuclides in certain parts of the fish, and allows more realistic dose calculations to be performed. For example, some radionuclides such as strontium-90 may localize in bone due to their chemical characteristics. However, bones are usually discarded when fish are eaten, eliminating a significant source of radionuclides and reducing the potential dose to people.

The only anthropogenic radionuclide found in these samples was cesium-137; it is detectable throughout the environment of the Northern Hemisphere as a result of past global fallout. This is evident when examining results from the control location of Swan Pond, where cesium-137 levels in fish flesh are comparable to those of fish taken from Peconic River-fed water bodies such as Donahue's Pond (Figure 7-10).

Though it is clear that BNL operations have contributed to radionuclide levels in the Peconic River system, most of these radionuclides (except tritium) were released between the late 1950s and early 1970s. In light of control data, present day cesium-137 concentrations in fish in the Peconic River system appear to be within the range of variability seen in local waters which receive no discharges from $B N L$. This is feasible when considering the lack of significant new discharges of cesium-137, time elapsed for radioactive decay, and sediment turnover which segregates old contaminants below the riverbed.

1997 BNL Site Environmental Report 7 - 23 
Table 7-14

BNL Site Environmental Report for Calendar Year 1997

Radiological Analysis of Fish

Fish - Sample Type

\section{Massapequa}

Carp - whole

Carp - flesh/skin

Carp - bones/viscera

Smith Pond (Roosevelt)

Eet - whole

Pumpkinseed - whole

Pumpkinseed - flesh/skin

Pumpkinseed - bones/viscera

\section{Meadow Lake}

Gizzard shad - whole

Gizzard shad - flesh/skin

Gizzard shad - bones/viscera

Gizzard shad - whole

Gizzard shad - whole

Gizzard shad - flesh/skin

Gizzard shad - bones/viscera

Gizzard shad - whole

White perch - whole

White perch - whole

\section{Searington Pond}

Black crappie - whole

Goldfish - flesh/skin

Goldfish - bones/viscera

Peconic River - Schultz Road

Pumpkinseed - whole

Golden shiner - whole

\section{Donahue's Pond}

Bluegill - whote

Bluegill - flesh/skin

Bluegill - bones/viscera

Bluegill - whole

Bluegill - flesh/skin

Bluegill - bones/viscera

Chain pickerel - whole

Largemouth bass - whole

Frog - whole

Forge Pond

Bluegill - whole

Bluegill - flesh/skin

Bluegill - bones/viscera

Bluegill - whole

Golden shiner - whole

Pumpkinseed - whole

Pumpkinseed - flesh/skin

Pumpkinseed - bones/viscera

Bluegill - whole

Bluegill - flesh/skin

Bluegill - bones/viscera

\section{Notes}

Sample Date

K-40

Cs-137

pCi/g.wet

$\begin{array}{lll}11-J u l-97 & 2.85 \pm 0.53 & \text { ND } \\ & \text { ND } & \text { ND } \\ & 2.65 \pm 1.06 & \text { ND }\end{array}$

12-Aug-97

$2.48 \pm 0.52$

$1.56 \pm 0.29$

$4.15 \pm 1.25$

$3.88 \pm 2.49$

5-June-97

$2.31 \pm 0.50$

$7.15 \pm 2.05$

$3.12 \pm 0.68$

$1.80 \pm 0.32$

$2.19 \pm 0.40$

$4.16 \pm 1.18$

$1.83 \pm 0.58$

$1.56 \pm 0.36$

$1.86 \pm 0.43$

$1.36 \pm 0.42$

15-Jul-97

$12.91 \pm 4.48$

$2.33 \pm 0.54$

$1.40 \pm 0.62$

$2.14 \pm 1.32$

$4.88+2.59$

13-May-97

$1.98 \pm 0.36$

$6.40 \pm 2.15$

$0.92 \pm 0.19$

$3.46 \pm 1.14$

$3.83 \pm 0.86$

ND

$4.86 \pm 1.74$

$2.12 \pm 0.41$

ND

30-Apr-97

$2.93 \pm 0.54$

$4.66 \pm 0.92$

$3.32 \pm 1.99$

$2.47 \pm 0.62$

ND

$2.77 \pm 0.97$

$2.04 \pm 0.52$

$2.89 \pm 2.36$

$2.57 \pm 0.81$

$2.63 \pm 0.59$

$2.21 \pm 0.45$
ND

ND

ND

$0.01 \pm 0.01$

ND

ND

ND

ND

ND

$0.01 \pm 0.01$

$0.01 \pm 0.01$

ND

ND

$0.02 \pm 0.01$

ND

ND

ND

ND

ND

$0.22 \pm 0.12$

$0.70 \pm 0.30$

$0.13 \pm 0.03$

ND

$0.06 \pm 0.02$

$0.28 \pm 0.09$

$0.18 \pm 0.05$

$0.25 \pm 0.10$

$0.46 \pm 0.16$

$0.29 \pm 0.06$

ND

$0.08 \pm 0.02$

$0.20 \pm 0.05$

ND

$0.11 \pm 0.03$

ND

$0.11 \pm 0.07$

$0.14 \pm 0.04$

$0.47 \pm 0.29$

$0.12 \pm 0.05$

$0.11 \pm 0.03$

$0.09 \pm 0.03$

1. All results reported with $2 \sigma(95 \%)$ confidence interval.

2. ND = Not Detected. 


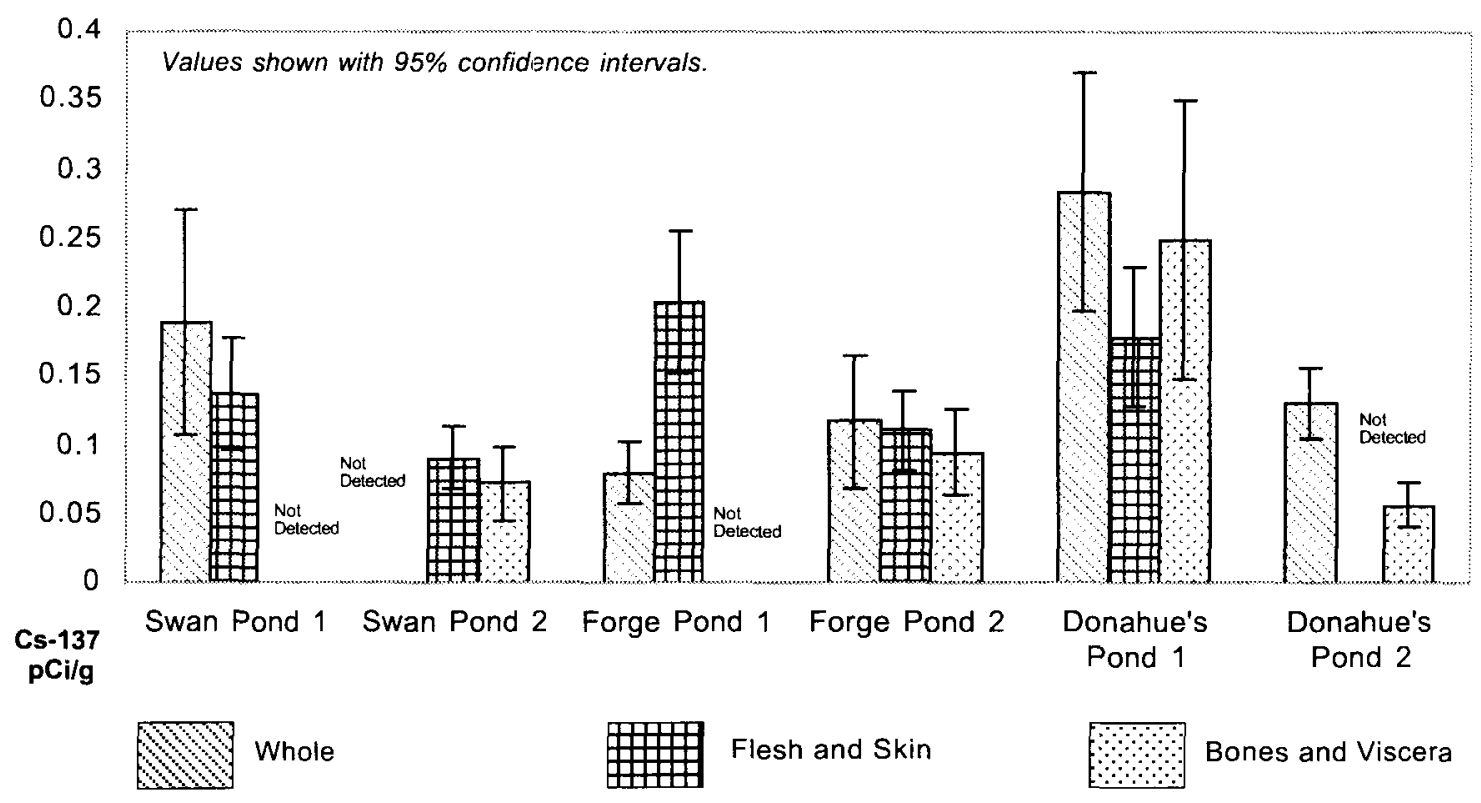

Figure 7-10. Cesium-137 Concentrations in Fish Collected From Peconic River, Bluegill Species

\subsubsection{Radiological Analysis of Shellfish}

In 1997, clams, mussels, and sediment samples were collected from Flanders Bay and Indian Point in Riverhead to determine whether past BNL discharges to the Peconic River system have made a measurable contribution to shellfish radionuclide uptake. Similar samples were also collected from Lloyd Harbor, a background location not influenced by the Peconic River system. All samples were analyzed for gamma-emitting radionuclides (Table 7-15). Only naturally-occurring radionuclides such as potassium-40 were observed. Neither cesium-137 nor any other man-made radionuclides were detected in any of the samples. These data are consistent with the shellfish analysis results reported in the 1996 BNL Site Environmental Report indicating that there are no detectable Laboratory-produced radionuclides present in shellfish collected from Flanders Bay.

\subsection{Chronic Toxicity Tests}

The Chronic Toxicity Testing program initiated in 1993 for the STP effluent was continued after the STP upgrades were completed in September 1997. Samples were collected in December and submitted to a contract laboratory for testing. As required by BNL's SPDES permit, this program consists of performing seven-day, Tier II Chronic Toxicity Tests of the BNL STP effluent. Two fresh water organisms, water fleas (Ceriodaphnia dubia) and fathead minnows (Pimphales promelas), are used for testing. The animals, in replicates of ten, were exposed to varying concentrations of the STP effluent (i.e., $100 \%, 50 \%, 25 \%, 12.5 \%$, and $6.25 \%$ ) for seven days. The size of fish and/or rate of reproduction for the water flea is measured and compared to untreated animals. The results were transmitted to the NYSDEC for review in January 1998.

The data show there was no acute toxicity for either organism, nor were there any chronic effects such as changes in the rate of reproduction for the water flea. The growth rate for the minnows raised in the $25 \%$ sample was lower than the control group. A "No Observable Effect Concentration" of $12.5 \%$ was reported for this organism. Toxicity testing will continue through 1998 . 
Table 7-15

Site Environmental Report for Calendar Year 1997

Radiological Analysis of Local Mussels and Clams

\begin{tabular}{lllll} 
Sample Location & $\begin{array}{l}\text { Sample } \\
\text { Date }\end{array}$ & $\begin{array}{l}\text { Sample } \\
\text { Type }\end{array}$ & K-40 & $\begin{array}{c}\text { Cs-137 } \\
\text { (pCi/g, wet) }\end{array}$ \\
Flander's Bay - Site A & 29-Jul-97 & Clams & $1.24 \pm 0.30$ & ND \\
Flander's Bay - Site B & & Clams & $0.96 \pm 0.16$ & ND \\
Flander's Bay - Site C & & Clams & $1.03 \pm 0.17$ & ND \\
Flander's Bay - Site C & & Conch & $2.34 \pm 0.46$ & \\
Flander's Bay - Site D & & Clams & $0.89 \pm 0.19$ & ND \\
Flander's Bay - Site E & & Clams & $1.03 \pm 0.19$ & ND \\
& & & & \\
Indian Point - Site A & $30-J u l-97$ & Mussels & $1.01 \pm 0.18$ & ND \\
Indian Point - Site B & & Mussels & $1.00 \pm 0.29$ & ND \\
& & & & ND \\
Lloyd Harbor - Site A & $4-A u g-97$ & Clams & $1.13 \pm 0.19$ & ND \\
Lloyd Harbor - Site B & & Clams & $1.83 \pm 0.47$ & ND \\
Lloyd Harbor - Site C & & Clams & $1.73 \pm 0.45$ & ND \\
Lloyd Harbor - Site D & & Clams & $1.23 \pm 0.22$ & \\
\hline ND = Not Detected. & & & & \\
\hline
\end{tabular}

\subsection{OU V Remedial Investigation Fish Tissue Bioaccumulation Study}

The Operable Unit V draft Remedial Investigation Report concluded that sediments in the Peconic River contain elevated concentrations of mercury and silver. To better determine the potential for bioaccumulation of these sediment contaminants, a more rigorous study of concentrations in fish obtained from the Peconic River, both on the site and off, was conducted. This section summarizes the results of the chemical and radiological analyses of the fish samples. Ninety-seven fish samples were analyzed for mercury and other inorganic analytes (cadmium, copper, lead, nickel, and silver), pesticides (DDT and its derivatives, endosulfan, and chlordane), and PCB aroclor-1254 (Tables 7-16 and 7-17). Thirteen composite samples were also analyzed for radionuclides (Table 7-18). Locations of sampling stations are given in Figures 7-11 through 7-13.

Cadmium was detected in most of the fish samples. The highest concentrations of cadmium were detected in pickerel at PR-29 near the STP discharge with concentrations of $0.14 \mathrm{mg} / \mathrm{kg}$ to 0.21 $\mathrm{mg} / \mathrm{kg}$. Average concentrations in predator fish (i.e., bass, pickerel, and pumpkinseed) at on-site stations PR-29 $(0.16 \mathrm{mg} / \mathrm{kg})$ and PR-30 $(0.10 \mathrm{mg} / \mathrm{kg})$ were significantly higher than the Sandy Pond reference fish $(0.04 \mathrm{mg} / \mathrm{kg}$ at PR-32). Average concentrations in bottom feeders at PR-29 $(0.10 \mathrm{mg} / \mathrm{kg})$, PR-30 $(0.11 \mathrm{mg} / \mathrm{kg})$, and PR-31 $(0.07 \mathrm{mg} / \mathrm{kg})$ were significantly higher than the reference fish $(0.02 \mathrm{mg} / \mathrm{kg})$. Cadmium was not detected in the surface water samples. Sediment on-site at PR-30 and PR-31 contained detectable levels of cadmium $(1.29 \mathrm{mg} / \mathrm{kg}$ and $1.84 \mathrm{mg} / \mathrm{kg}$, respectively).

Copper was detected in all fish samples, the highest concentration in the only brown bullhead collected at PR-29. Average predator fish concentrations ranged from $1.70 \mathrm{mg} / \mathrm{kg}$ at PR-35 (Donahues Pond) to $3.90 \mathrm{mg} / \mathrm{kg}$ at PR-29. None were significantly higher than the average predator fish concentration at the reference station $(2.45 \mathrm{mg} / \mathrm{kg})$. Average bottom feeder concentrations at on-site stations PR-29 $(4.38 \mathrm{mg} / \mathrm{kg})$ and PR-30 $(3.87 \mathrm{mg} / \mathrm{kg})$ were significantly higher 
than the reference fish $(2.53 \mathrm{mg} / \mathrm{kg})$. Copper was detected in the on-site surface water samples from PR-29 $(47.8 \mathrm{ug} / \mathrm{L})$, PR-30 $(36.3 \mathrm{ug} / \mathrm{L})$, and PR-31 $(17.2 \mathrm{ug} / \mathrm{L})$, but in none of the off-site surface water samples. The sediment concentrations ranged from $0.69 \mathrm{mg} / \mathrm{kg}$ to $94.37 \mathrm{mg} / \mathrm{kg}$.

Lead was detected in all fish samples, the highest concentration in a largemouth bass collected from the reference location PR-32 at Sandy Pond $(1.15 \mathrm{mg} / \mathrm{kg})$. The highest average predator fish and bottom feeder concentrations were at PR-32 $(0.59 \mathrm{mg} / \mathrm{kg}$ and $0.45 \mathrm{mg} / \mathrm{kg}$, respectively). Lead was not detected in the surface water samples, and was only detected in two sediment samples. Both locations were on-site: PR-30 $(12.6 \mathrm{mg} / \mathrm{kg})$ and PR-31 (19 mg/kg).

Mercury was detected in all fish samples. The highest level of mercury was detected in a pumpkinseed collected at on-site location PR-31 $(1.26 \mathrm{mg} / \mathrm{kg})$. The average predator fish concentration at PR-29 $(0.62 \mathrm{mg} / \mathrm{kg})$ was higher than the reference fish $(0.22 \mathrm{mg} / \mathrm{kg})$. The average bottom feeder concentrations at PR-29 $(0.60 \mathrm{mg} / \mathrm{kg})$ and PR-30 $(0.33 \mathrm{mg} / \mathrm{kg})$ were greater than the reference fish $(0.14 \mathrm{mg} / \mathrm{kg})$. Mercury was detected in surface water samples from PR-29 $(0.25 \mu \mathrm{g} / \mathrm{L})$ and PR-30 $(0.24 \mu \mathrm{g} / \mathrm{L})$ and in sediments from PR-29 $(0.14 \mathrm{mg} / \mathrm{kg})$, PR-30 $(3.08 \mathrm{mg} / \mathrm{kg})$, PR-31 (1.25 mg/kg), and PR-33 $(0.47 \mathrm{mg} / \mathrm{kg})$.

Nickel was detected in all fish samples; the highest levels were in a pickerel from PR-33 $(0.56 \mathrm{mg} / \mathrm{kg})$ and a brown bullhead from the reference area PR-32 $(0.31 \mathrm{mg} / \mathrm{kg})$. The average predator fish concentrations ranged from $0.10 \mathrm{mg} / \mathrm{kg}$ at PR-34 to $0.16 \mathrm{mg} / \mathrm{kg}$ at PR-33. None were significantly higher than the reference fish $(0.13 \mathrm{mg} / \mathrm{kg})$. The average bottom feeder concentrations ranged from $0.05 \mathrm{mg} / \mathrm{kg}$ at PR-36 to $0.20 \mathrm{mg} / \mathrm{kg}$ at PR-34. None were significantly higher than the reference fish $(0.15 \mathrm{mg} / \mathrm{kg})$.

Silver was detected in most of the bottom feeders and more than half of the predator fish. The highest concentrations were in brown bullheads from on-site locations PR-29 $(0.39 \mathrm{mg} / \mathrm{kg}), \mathrm{PR}-30$ $(0.23 \mathrm{mg} / \mathrm{kg})$, and PR-31 $(0.23 \mathrm{mg} / \mathrm{kg})$. The average predator concentrations at PR-29 $(0.08 \mathrm{mg} /$ $\mathrm{kg})$, PR-30 $(0.07 \mathrm{mg} / \mathrm{kg})$, and PR-31 $(0.06 \mathrm{mg} / \mathrm{kg})$ were significantly higher than that in the reference fish $(0.01 \mathrm{mg} / \mathrm{kg})$. The average bottom feeder fish concentrations at PR-29 $(0.16 \mathrm{mg} / \mathrm{kg})$, PR-30 $(0.12 \mathrm{mg} / \mathrm{kg})$, and PR-31 $(0.13 \mathrm{mg} / \mathrm{kg})$ were significantly higher than in the reference fish $(0.01 \mathrm{mg} / \mathrm{kg})$. Silver was detected in only one surface water sample $(5.6 \mathrm{ug} / \mathrm{L}$ at PR-30), but was detected in four sediment samples: $0.11 \mathrm{mg} / \mathrm{kg}$ at PR-29, $0.03 \mathrm{mg} / \mathrm{kg}$ at PR-30, $0.04 \mathrm{mg} / \mathrm{kg}$ at PR-31, and $0.01 \mathrm{mg} / \mathrm{kg}$ at PR-33.

DDT was detected in only two fish samples. The highest concentration of DDT was detected in a pumpkinseed collected at on-site station PR-31, and the other was in a pickerel collected on-site at PR-29. DDT was not detected in the surface water nor sediment samples (except at PR-36).

DDE was detected in most of the fish samples. Nine fish did not have detectable levels of DDE, seven of which were collected on the BNL site at PR-29, PR-30, and PR-31. The highest concentration was detected in largemouth bass at PR-35 at Swan Pond (the second reference location) having a concentration of $136 \mathrm{ug} / \mathrm{kg}$. Average predator fish concentrations ranged from 87.6 $\mathrm{ug} / \mathrm{kg}$ at PR-35 (Swan Pond) to $8.5 \mathrm{ug} / \mathrm{kg}$ at PR-34 (Manor Road). Average bottom feeder concentrations were highest for brown bullheads at PR-29 (near the STP), PR-31 (North Street), and PR-37 (Forge Pond) with values of $50.2 \mathrm{ug} / \mathrm{kg}, 51.02 \mathrm{ug} / \mathrm{kg}$, and $50.85 \mathrm{ug} / \mathrm{kg}$, respectively. DDE was detected in two on-site and two off-site sediment samples: on-site at $4.83 \mathrm{ug} / \mathrm{kg}$ at PR-30 and $6.61 \mathrm{ug} / \mathrm{kg}$ at PR-31, and off-site at $7.24 \mathrm{ug} / \mathrm{kg}$ at PR-33 and $12.94 \mathrm{ug} / \mathrm{kg}$ at PR-36.

DDD was detected in most of the fish samples. Twenty-eight of the thirty-six fish collected on the BNL site had non-detectable levels of DDD. Most off-site fish had detectable levels of DDD. The highest concentrations were detected in two brown bullheads: $76.9 \mathrm{ug} / \mathrm{kg}$ at PR-31 (North Street) and $70.3 \mathrm{ug} / \mathrm{kg}$ at PR-37 (Forge Pond). Average predator fish concentrations ranged from 33.13 $\mathrm{ug} / \mathrm{kg}$ at PR-35 (Swan Pond) to non-detect at PR-29 (near the STP). Average bottom feeder fish concentrations ranged from $30.88 \mathrm{ug} / \mathrm{kg}$ at PR-36 (Donahues Pond) to non-detect at PR-29 (near the STP). DDD was found in most sediment samples. It was not detected at either PR-29 (near the STP) or PR-37 (Forge Pond). The highest concentration was $14.90 \mathrm{ug} / \mathrm{kg}$ at PR-33 (Schultz Road). DDD was not detected in any surface water samples. 
Alpha-chlordane was detected in fourteen of the thirty-six samples collected on the BNL site. No off-site fish contained detectable levels of alpha-chlordane. The highest concentration was 32.5 $\mathrm{ug} / \mathrm{kg}$ in a brown bullhead collected at PR-29 (near the STP). It was detected in two sediment samples (4.43 ug/ $\mathrm{kg}$ at PR-30 and $3.43 \mathrm{ug} / \mathrm{kg}$ at PR-31), but was not detected in surface water samples.

Aroclor-1254, a PCB, was detected in most of the fish collected on the BNL site and in only one fish collected off the BNL site ( $423 \mathrm{ug} / \mathrm{kg}$ at PR-34 at Manor Road). The highest concentrations were detected in bottom feeders (creek chubsuckers and brown bullheads) collected at PR-29. Aroclor-1254 was not detected in any surface water or sediment samples collected during this study, though the previous Remedial Investigation sampling detected Aroclor-1254.

Gamma-chlordane, chlordane, endosulfan one, and endosulfan two were not detected in any fish samples.

Radiological analysis consisted of measurements for gamma-emitting radionuclides and strontium-90. Analysis for tritium was not performed since it does not tend to bioaccumulate, but, instead, is quickly eliminated from the body. Radionuclide analysis was usually performed on composite fish samples because of the analytical technique mass requirements. Station PR-34 at Manor Road did not have sufficient fish for radionuclide analysis. -Strontium-90 was detected in most fish samples ranging from an average of $3.16 \mathrm{pCi} / \mathrm{g}(0.12 \mathrm{~Bq} / \mathrm{g})$ at PR-32 (Sandy Pond) to non-detect at PR-29 (near the STP) and PR-33 (Schultz Road). Cesium-137 was detected in all fish samples ranging from an average of $1.79 \mathrm{pCi} / \mathrm{g}(0.07 \mathrm{~Bq} / \mathrm{g}$ ) at PR-29 (near the STP) to an average of $0.58 \mathrm{pCi} / \mathrm{g}(0.02 \mathrm{~Bq} / \mathrm{g})$ at PR-32 (Sandy Pond). No other radionuclides were detected in fish samples.

In sediment, cesium-137 was detected in most samples ranging from $9.63 \mathrm{pCi} / \mathrm{g}(0.36 \mathrm{~Bq} / \mathrm{g})$ at

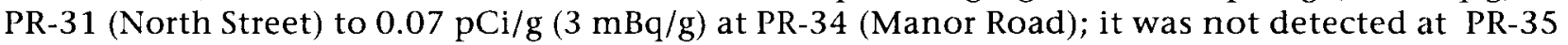
(Swan Pond). Radium-226 levels ranged from $1.88 \mathrm{pCi} / \mathrm{g}(0.07 \mathrm{~Bq} / \mathrm{g}$ ) at PR-33 (Schultz Road) to non-detect at PR-35 (Sandy Pond). However, the radium-226 content was determined by gamma spectroscopy, which tends to overestimate radium-226 concentrations. Americium-241 was only detected in the two furthest upstream on-site samples and cobalt-60 was only detected at on-site location PR-30 (east of the firebreak) at $0.19 \mathrm{pCi} / \mathrm{g}(7 \mathrm{mBq} / \mathrm{g})$. 
Table 7-16

BNL Site Environmental Report tor Calendar Year 1997

ou V Fish Tissue Bioaccumulation Data, Metals

\begin{tabular}{|c|c|c|c|c|c|c|c|c|c|c|c|}
\hline \multirow{4}{*}{$\begin{array}{l}\text { Analyte } \\
\text { Cadmium }\end{array}$} & \multirow{2}{*}{\multicolumn{2}{|c|}{ Matrix }} & \multirow[b]{2}{*}{ PR-29 } & \multicolumn{7}{|c|}{ Peconic River Sampling Stations } & \multirow[b]{2}{*}{ PR-37 } \\
\hline & & & & PR-30 & PR-31 & PR-32 & $\begin{array}{l}\text { PR-33 } \\
(\mathrm{mg} / \mathrm{kg})\end{array}$ & PR-34 & PR-35 & PR-36 & \\
\hline & \multirow{2}{*}{\multicolumn{2}{|c|}{$\begin{array}{l}\text { Surface Water } \\
\text { Sediment }\end{array}$}} & ND & ND & ND & ND & ND & $\mathrm{ND}$ & ND & ND & ND \\
\hline & & & ND & 1.29 & 1.84 & ND & ND & ND & ND & ND & ND \\
\hline & \multirow{2}{*}{ Predator Fish } & Avg. & 0.16 & 0.10 & 0.07 & 0.04 & 0.04 & 0.04 & 0.01 & 0.01 & 0.01 \\
\hline & & Max. & 0.21 & 0.13 & 0.12 & 0.07 & 0.06 & 0.07 & 0.02 & 0.02 & 0.02 \\
\hline & \multirow{2}{*}{\multicolumn{2}{|c|}{$\begin{array}{r}\text { Bottm Feeder Fish Avg. } \\
\text { Max. }\end{array}$}} & 0.10 & 0.11 & 0.07 & 0.02 & NA & 0.04 & NA & 0.01 & 0.01 \\
\hline & & & 0.15 & 0.18 & 0.20 & 0.02 & - & 0.04 & ;一- & 0.01 & 0.01 \\
\hline \multirow[t]{6}{*}{ Copper } & \multirow{2}{*}{\multicolumn{2}{|c|}{$\begin{array}{l}\text { Surface Water } \\
\text { Sediment }\end{array}$}} & 47.8 & 36.3 & 17.2 & ND & ND & ND & ND & ND & ND \\
\hline & & & 14.56 & 94.37 & 80.91 & 0.69 & 4.10 & 2.66 & 1.35 & & 1.23 \\
\hline & \multirow[t]{2}{*}{ Predator Fish } & Avg. & 3.88 & 3.31 & 2.35 & 2.45 & 2.23 & 3.45 & 1.70 & 1.45 & 2.13 \\
\hline & & Max. & 5.42 & 3.96 & & & 3.53 & 5.51 & 1.89 & 1.61 & 3.60 \\
\hline & \multirow{2}{*}{\multicolumn{2}{|c|}{$\begin{array}{l}\text { Bottm Feeder Fish Avg. } \\
\text { Max. }\end{array}$}} & 4.38 & 3.87 & 3.5 & 2.53 & NA & 4.73 & NA & 2.11 & 2.25 \\
\hline & & & 8.49 & 6.06 & 4.19 & 2.9 & -- & 6.77 & - & 3.01 & 2.53 \\
\hline \multirow[t]{6}{*}{ Lead } & \multirow{2}{*}{\multicolumn{2}{|c|}{$\begin{array}{l}\text { Surface Water } \\
\text { Sediment }\end{array}$}} & ND & ND & ND & ND & ND & ND & ND & ND & ND \\
\hline & & & ND & 12.60 & 19 & ND & ND & ND & ND & ND & ND \\
\hline & \multirow[t]{2}{*}{ Predator Fish } & Avg. & 0.18 & 0.23 & 0.33 & 0.59 & 0.34 & 0.22 & 0.12 & 0.25 & 0.77 \\
\hline & & Max. & 0.19 & 0.38 & 0.64 & 1.15 & 0.92 & 0.30 & 0.20 & 0.48 & 0.08 \\
\hline & \multirow{2}{*}{\multicolumn{2}{|c|}{$\begin{array}{r}\text { Bottm Feeder Fish Avg. } \\
\text { Max. }\end{array}$}} & 0.14 & 0.18 & 0.24 & 0.45 & NA & 0.13 & NA & 0.44 & 0.31 \\
\hline & & & 0.23 & 0.22 & 0.32 & 0.65 & - & 0.13 & - & 0.97 & 0.63 \\
\hline \multirow[t]{6}{*}{ Mercury } & \multirow{2}{*}{\multicolumn{2}{|c|}{$\begin{array}{l}\text { Surface Water } \\
\text { Sediment }\end{array}$}} & 0.25 & 0.24 & ND & ND & ND & ND & ND & ND & ND \\
\hline & & & 0.14 & 3.08 & 1.25 & ND & 0.47 & ND & ND & ND & ND \\
\hline & \multirow[t]{2}{*}{ Predator Fish } & Avg. & 0.62 & 0.53 & 0.42 & 0.22 & 0.52 & 0.33 & 0.14 & 0.43 & 0.25 \\
\hline & & Max. & 0.75 & 0.73 & 1.26 & 0.36 & 0.91 & 0.34 & 0.23 & 0.82 & 0.76 \\
\hline & \multicolumn{2}{|c|}{ Bottm Feeder Fish Avg. } & 0.60 & 0.33 & 0.28 & 0.14 & NA & 0.32 & NA & 0.16 & 0.08 \\
\hline & & Max. & 0.69 & 0.66 & 0.64 & 0.24 & -- & 0.34 & -- & 0.20 & 0.13 \\
\hline \multirow[t]{6}{*}{ Nickel } & \multirow{2}{*}{\multicolumn{2}{|c|}{$\begin{array}{l}\text { Surface Water } \\
\text { Sediment }\end{array}$}} & ND & ND & ND & ND & ND & ND & ND & ND & ND \\
\hline & & & 2.09 & 10.68 & 5.86 & ND & ND & ND & ND & ND & ND \\
\hline & Predator Fish & Avg. & 0.11 & 0.13 & 0.11 & 0.13 & 0.16 & 0.10 & 0.11 & 0.13 & 0.14 \\
\hline & & Max. & 0.16 & 0.16 & 0.13 & 0.22 & 0.56 & 0.10 & 0.16 & 0.17 & 0.23 \\
\hline & Bottm Feeder Fi & Avg. & 0.11 & 0.10 & 0.11 & 0.15 & NA & 0.20 & NA & 0.05 & 0.13 \\
\hline & & Max. & 0.18 & 0.13 & 0.16 & 0.31 & -- & 0.27 & -- & 0.09 & 0.18 \\
\hline Silver & Surface Water & & ND & 5.6 & ND & ND & ND & ND & ND & ND & ND \\
\hline & Sediment & & 0.11 & 0.03 & 0.04 & 0.01 & ND & 0.01 & ND & 0.02 & 0.01 \\
\hline & Predator Fish & Avg. & 0.08 & 0.07 & 0.06 & 0.01 & 0.02 & 0.01 & 0.01 & 0.01 & 0.01 \\
\hline & & Max. & 0.08 & 0.22 & 0.28 & 0.01 & 0.04 & 0.01 & 0.01 & 0.01 & 0.01 \\
\hline & Bottm Feeder Fi & רAvg. & 0.16 & 0.12 & 0.13 & 0.01 & NA & 0.02 & NA & 0.03 & 0.01 \\
\hline & & Max. & 0.39 & 0.23 & 0.23 & 0.01 & - & 0.02 & & 0.04 & 0.01 \\
\hline & ed & & & & & & & & & & \\
\hline & & & & & & & & & & & \\
\hline & & & & & & & & & & & \\
\hline & & & & & & & & & & & \\
\hline & & & & & & & & & & & \\
\hline
\end{tabular}


Table 7-17

BNL Site Environmental Report for Calendar Year 1997

oU V Fish Tissue Bioaccumulation Data, Pesticides and PCBs

\begin{tabular}{|c|c|c|c|c|c|c|c|c|c|c|c|c|}
\hline Analyte & Matrix & Units & & PR-29 & PR-30 & PR-31 & $\begin{array}{l}\text { Peconi } \\
\text { PR-32 }\end{array}$ & $\begin{array}{l}\text { ic River } \\
\text { PR-33 }\end{array}$ & $\begin{array}{l}\text { ampling } \\
\text { PR-34 }\end{array}$ & $\begin{array}{c}\text { Stations } \\
\text { PR-35 }\end{array}$ & PR-36 & PR-37 \\
\hline \multirow[t]{6}{*}{ DDT } & Surface Water & $u g / L$ & & ND & ND & ND & ND & ND & ND & ND & ND & ND \\
\hline & Sediment & $\mathrm{ug} / \mathrm{kg}$ & & ND & ND & ND & ND & ND & ND & ND & 6.61 & ND \\
\hline & Predator Fish & $\mathrm{ug} / \mathrm{kg}$ & Avg. & 5.11 & ND & 7.93 & ND & ND & ND & ND & ND & ND \\
\hline & & $u g / k g$ & Max. & 5.57 & - & 22.60 & - & - & - & - & - & - \\
\hline & Bottm Feeder Fish & $\mathrm{ug} / \mathrm{kg}$ & Avg. & ND & ND & ND & ND & NA & ND & ND & ND & ND \\
\hline & & $\mathrm{ug} / \mathrm{kg}$ & Max. & -- & -- & - & -- & - & - & - & -- & - \\
\hline \multicolumn{13}{|l|}{ DDE } \\
\hline & Surface Water & $u g / L$ & & ND & ND & ND & ND & ND & ND & ND & ND & ND \\
\hline & Sediment & $u g / \mathrm{kg}$ & & ND & 4.83 & 6.61 & ND & 7.24 & ND & ND & 12.94 & ND \\
\hline & Predator Fish & $\mathrm{ug} / \mathrm{kg}$ & Avg. & 15.85 & 14.09 & 33.41 & 24.73 & 27.82 & 8.50 & 87.61 & 31.36 & 42.71 \\
\hline & & $\mathrm{ug} / \mathrm{kg}$ & Max. & 21.90 & 26.00 & 75.20 & 64.20 & 52.20 & 12.00 & 136.00 & 72.20 & 75.20 \\
\hline & Bottm Feeder Fish & $\mathrm{ug} / \mathrm{kg}$ & Avg. & 23.35 & 34.00 & 51.02 & 35.40 & NA & 20.9 & NA & 44.58 & 50.85 \\
\hline \multirow{2}{*}{\multicolumn{13}{|c|}{ 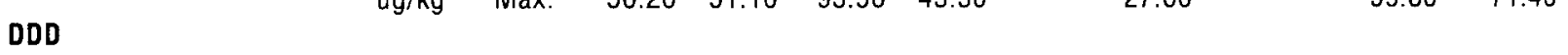 }} \\
\hline & & & & & & & & & & & & \\
\hline & Surface Water & $u g / L$ & ND & ND & ND & ND & ND & ND & ND & ND & ND & \\
\hline & Sediment & $\mathrm{ug} / \mathrm{kg}$ & ND & 7.92 & 10.46 & 4.30 & 14.9 & 7.24 & 8.43 & 3.72 & ND & \\
\hline & Predator Fish & $\mathrm{ug} / \mathrm{kg}$ & Avg. & ND & 5.67 & 28.09 & 21.13 & 21.25 & 5.63 & 33.13 & 12.00 & 17.24 \\
\hline & & $u g / k g$ & Max. & - & 6.00 & 142.0 & 100.0 & 68.90 & 6.26 & 38.70 & 23.10 & 30.70 \\
\hline & Bottm Feeder Fish & $\mathrm{ug} / \mathrm{kg}$ & Avg. & ND & 9.97 & 28.46 & 24.06 & NA & 24.20 & NA & 30.88 & 44.9 \\
\hline & & $\mathrm{ug} / \mathrm{kg}$ & Max. & - & 44.80 & 76.90 & 40.10 & -- & 32.20 & - & 37.70 & 70.30 \\
\hline \multicolumn{13}{|c|}{ Alpha-chlordan } \\
\hline & Surface Water & $u g / L$ & & ND & ND & ND & ND & ND & ND & ND & ND & ND \\
\hline & Sediment & $\mathrm{ug} / \mathrm{kg}$ & & ND & 4.43 & 3.43 & ND & ND & ND & ND & ND & ND \\
\hline & Predator Fish & $\mathrm{ug} / \mathrm{kg}$ & Avg. & 10.4 & 7.64 & ND & 6.11 & ND & ND & ND & ND & ND \\
\hline & & $\mathrm{ug} / \mathrm{kg}$ & Max. & 13.80 & 13.50 & -- & 10.00 & - & - & - & -- & - \\
\hline & Bottm Feeder Fish & $u g / k g$ & Avg. & 10.06 & 8.34 & 7.50 & ND & NA & ND & NA & ND & ND \\
\hline & & $\mathrm{ug} / \mathrm{kg}$ & Max. & 32.50 & 13.90 & 17.20 & - & - & - & -- & - & - \\
\hline \multicolumn{13}{|c|}{ Aroclor-1254 } \\
\hline & Surface Water & $u g / L$ & & ND & ND & ND & ND & ND & ND & ND & ND & ND \\
\hline & Sediment & $\mathrm{ug} / \mathrm{kg}$ & & ND & ND & ND & ND & ND & ND & ND & ND & ND \\
\hline & Predator Fish & $\mathrm{ug} / \mathrm{kg}$ & Avg. & 2009 & 1793 & 1584 & ND & ND & 262 & ND & ND & ND \\
\hline & & $\mathrm{ug} / \mathrm{kg}$ & Max. & 3020 & 2540 & 4800 & - & - & 423 & - & - & - \\
\hline & Bottm Feeder Fish & $\mathrm{ug} / \mathrm{kg}$ & Avg. & 3393 & 1654 & 505 & ND & NA & ND & NA & ND & ND \\
\hline & & $\mathrm{ug} / \mathrm{kg}$ & Max. & 4260 & 3510 & 2050 & - & - & - & - & - & - \\
\hline \multicolumn{13}{|c|}{$\begin{array}{l}\text { Notes: } \\
\text { ND }=\text { Not Detected } \\
\text { NA }=\text { Parameter not analyzed for at this location. } \\
\text { 1. All concentration represent wet weight of matrix } \\
\text { 2 Station locations shown in Fiaures } 7-11 \text { to } 7-13\end{array}$} \\
\hline
\end{tabular}


Table 7-18

BNL Site Environmental Report for Calendar Year 1997

0U V Fish Tissue Bioaccumulation Data, Radionuclides

\begin{tabular}{|c|c|c|c|c|c|c|c|c|c|c|c|c|}
\hline \multirow[b]{2}{*}{ Analyte } & \multirow[b]{2}{*}{ Matrix } & \multirow[b]{2}{*}{ Units } & & \multicolumn{9}{|c|}{ Peconic River Sampling Stations } \\
\hline & & & & PR-29 & PR-30 & PR-31 & PR-32 & PR-33 & PR-34 & PR-35 & PR-36 & PR-37 \\
\hline \multirow[t]{4}{*}{ Cs-137 } & Surface Water & $\mathrm{pCi} / \mathrm{L}$ & & ND & ND & ND & ND & ND & ND & ND & ND & ND \\
\hline & Sediment & $\mathrm{pCi} / \mathrm{g}$ & 0.23 & & 6.96 & 9.63 & 0.11 & 8.15 & 0.07 & ND & 0.12 & 0.18 \\
\hline & Fish & $\mathrm{pCi} / \mathrm{g}$ & Avg. & 1.79 & 1.60 & 1.07 & 0.58 & 1.66 & NA & 0.52 & 1.27 & 0.76 \\
\hline & & & Max. & 1.88 & 1.6 & 1.07 & 0.63 & 1.66 & -- & 0.66 & 1.42 & 0.97 \\
\hline \multirow[t]{4}{*}{ Am-241 } & Surface Water & $p C i / L$ & & ND & ND & ND & ND & ND & ND & ND & ND & ND \\
\hline & Sediment & $\mathrm{pCi} / \mathrm{g}$ & & 0.11 & 0.96 & ND & ND & ND & ND & ND & ND & ND \\
\hline & Fish & $\mathrm{pCi} / \mathrm{g}$ & Avg. & ND & ND & ND & ND & ND & ND & ND & ND & ND \\
\hline & & & Max. & - & - & - & 一- & - & - & - & - & - \\
\hline \multicolumn{13}{|l|}{$\mathrm{C}_{0}-60$} \\
\hline & Surface Water & $\mathrm{pCi} / \mathrm{L}$ & & ND & ND & ND & ND & ND & ND & ND & ND & ND \\
\hline & Sediment & $\mathrm{pCi} / \mathrm{g}$ & & ND & 0.19 & ND & ND & ND & ND & ND & ND & ND \\
\hline & Fish & $\mathrm{pCi} / \mathrm{g}$ & Avg. & ND & ND & ND & ND & ND & ND & ND & ND & ND \\
\hline & & & Max. & -- & - & - & -- & - & - & - & - & - \\
\hline \multirow[t]{4}{*}{ Ra-226 } & Surface Water & $\mathrm{pCi} / \mathrm{L}$ & & ND & ND & ND & ND & ND & ND & ND & ND & ND \\
\hline & Sediment & $\mathrm{pCi} / \mathrm{g}$ & & 0.35 & 0.80 & 0.85 & ND & 1.88 & 0.33 & 0.24 & 0.19 & 1.09 \\
\hline & Fish & $\mathrm{pCi} / \mathrm{g}$ & Avg. & ND & ND & ND & ND & ND & NA & ND & ND & ND \\
\hline & & & $\operatorname{Max}$ & - & - & - & - & - & - & -- & - & -- \\
\hline \multirow[t]{4}{*}{ Sr-90 } & Surface Water & $\mathrm{pCi} / \mathrm{L}$ & & ND & ND & ND & ND & ND & ND & ND & ND & ND \\
\hline & Sediment & $\mathrm{pCi} / \mathrm{g}$ & & ND & ND & ND & ND & 0.43 & ND & ND & ND & ND \\
\hline & Fish & $\mathrm{pCi} / \mathrm{g}$ & Avg. & ND & 0.38 & 0.42 & 3.18 & ND & NA & 0.36 & 1.21 & 0.48 \\
\hline & & & Max. & - & 0.38 & 0.42 & 4.31 & - & - & 0.40 & 1.22 & 0.59 \\
\hline $\begin{array}{l}\text { ND }=\text { No } \\
\text { NA = Par } \\
\text { Notes: } \\
\text { 1. All col } \\
\text { 2. Statio } \\
\text { 3. Statio }\end{array}$ & $\begin{array}{l}\text { Detected } \\
\text { Imeter not analyz } \\
\text { centration repres } \\
\text { locations shown } \\
\text { PR-32 is a contr }\end{array}$ & $\begin{array}{l}\text { ed for a } \\
\text { ent wet } \\
\text { in Figu } \\
\text { ol samp }\end{array}$ & $\begin{array}{l}\text { this loc } \\
\text { veight } 0 \\
\text { es } 7-11 \\
\text { ing loce }\end{array}$ & $\begin{array}{l}\text { tion. } \\
\text { matrix } \\
07-13 .\end{array}$ & dup Pon & & & & & & & \\
\hline
\end{tabular}




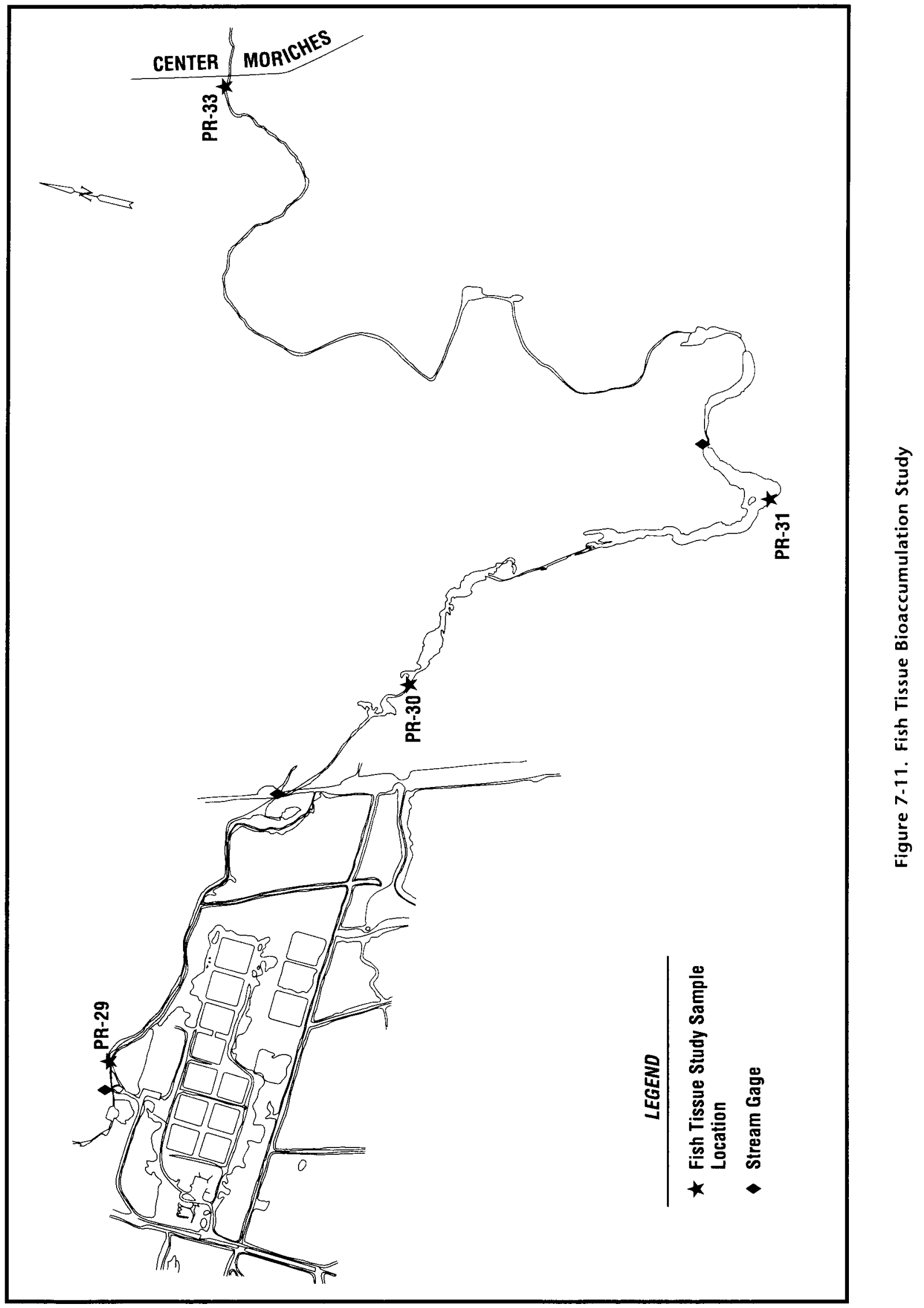




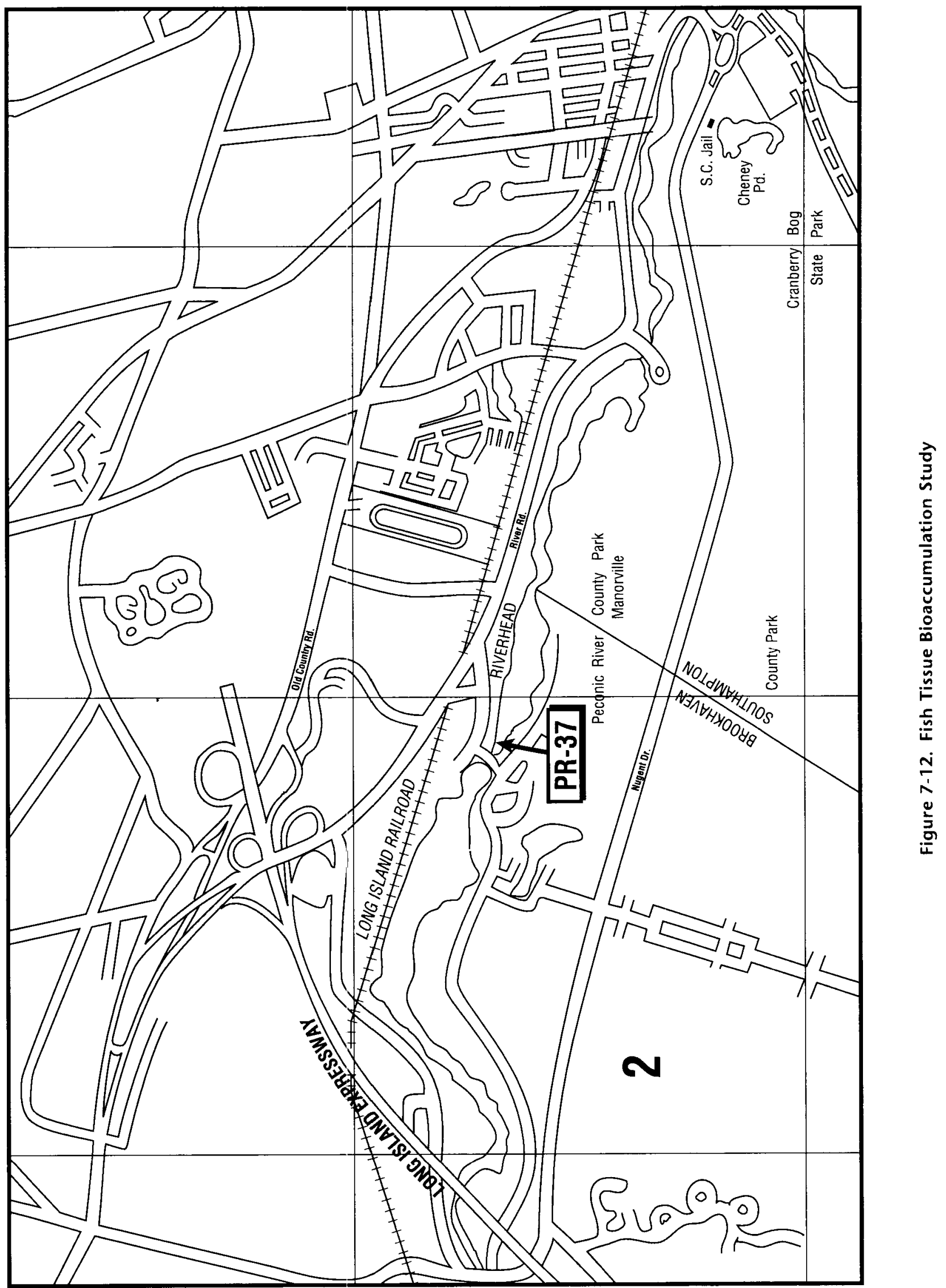




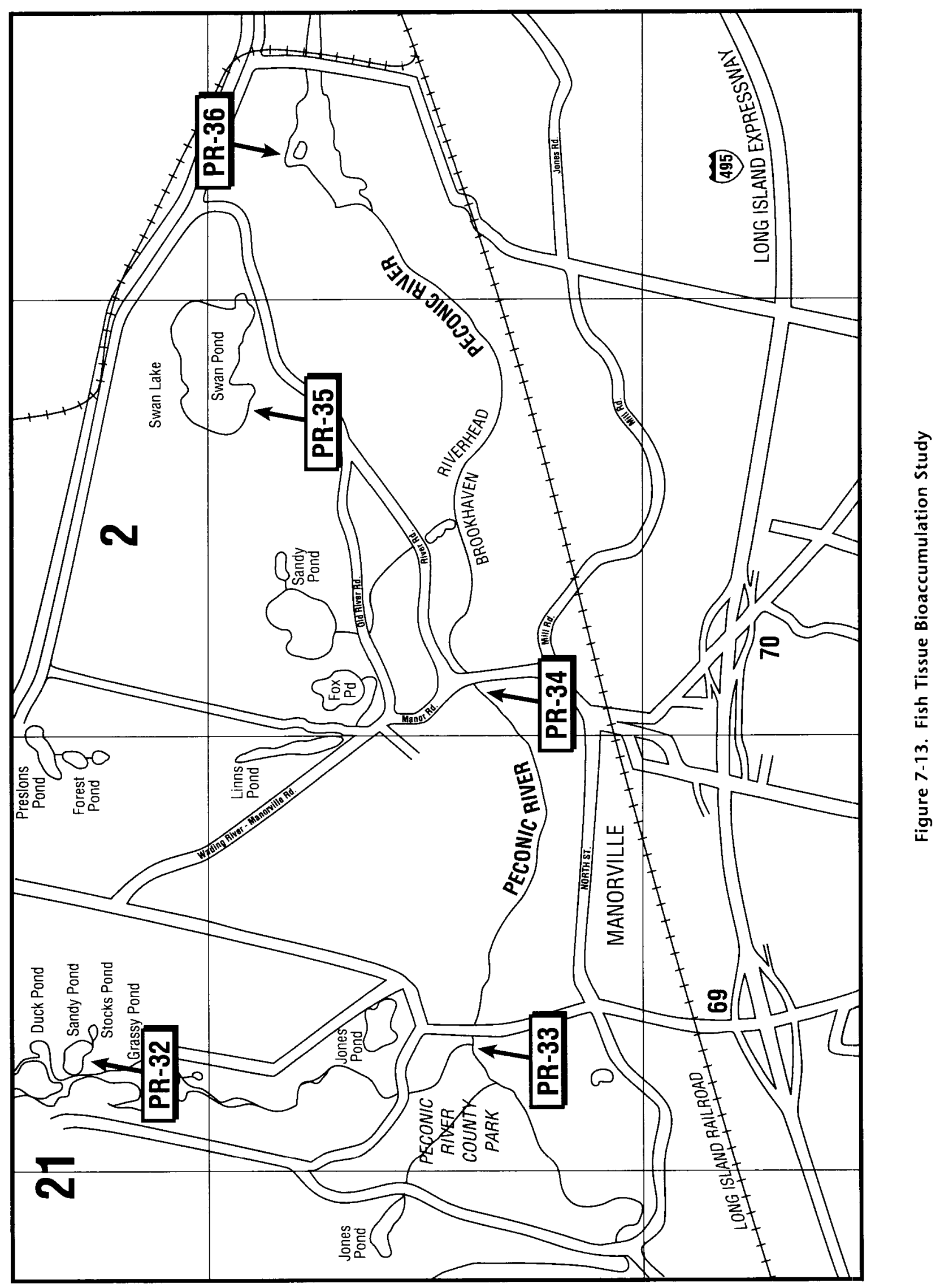




\section{Chapter 8}

\section{GROUNDWATER PROTECTION}

Groundwater protection at BNL is addressed by both prevention and minimization environmental emissions, and active remediation in areas where past operations have impacted groundwater quality. All remediation work is carried out under the Interagency Agreement (IAG) among the DOE, EPA, and NYSDEC.

The strategy for protecting groundwater at the BNL site includes the following elements:

- Reviewing engineering designs and conducting environmental assessments for new and existing facilities to ensure that potential environmental impacts are fully evaluated and reduced to the lowest possible level, or eliminated;

- Upgrading existing facilities to reduce the risk of accidental release of contaminants to the environment (i.e., upgrading underground storage tanks, replacing of deteriorated sewer lines, constructing new waste management facilities using best available environmental prevention technologies);

- Responding promptly and remediating spills to prevent contaminant migration to surface waters and groundwater;

- Conducting groundwater and surface water monitoring programs at active facilities that have the potential to impact the environment, so that accidental contaminant releases are detected quickly;

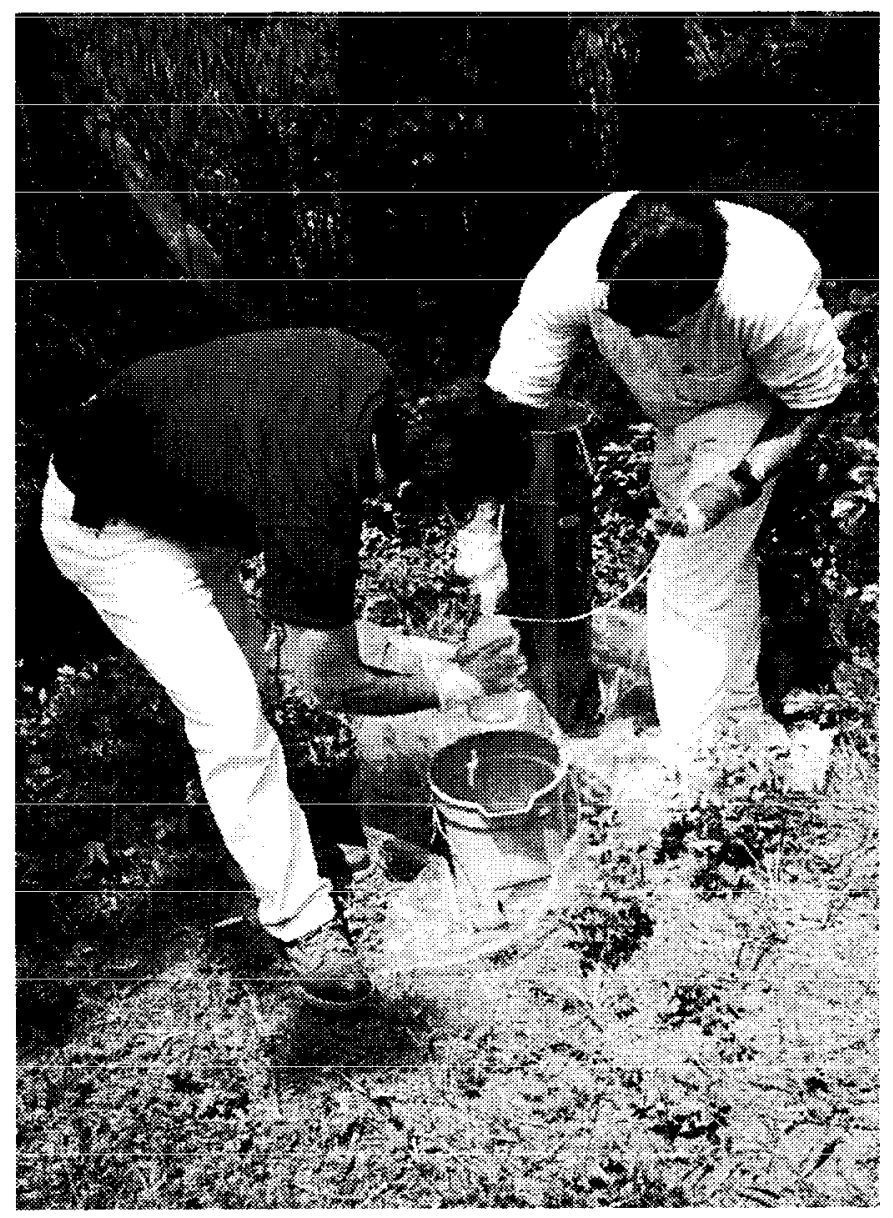

Groundwater Sampling

- Conducting groundwater monitoring programs at inactive chemical and radioactive materials storage and disposal sites and spill areas to assess the distribution and movement of existing groundwater contamination;

- Conducting environmental restoration in areas where soils and groundwater were contaminated by chemicals and radionuclides from past accidental spills, storage, or disposal;

- Implementation of waste minimization practices to reduce the volume and toxicity of all wastes, and using best management practices to manage and properly dispose of generated wastes; and,

- Implementation of a Pollution. Prevention Awareness Program to ensure that employees are cognizant of their responsibilities for the proper storage, use, and disposal of chemicals in the work place. 


\subsection{Groundwater Surveillance}

Groundwater quality at BNL is routinely monitored through a network of approximately 220 onsite and 40 off-site surveillance wells. Surveillance wells are generally used to monitor specific facilities where degradation of the groundwater is known or suspected to have occurred, to fulfill permit requirements, and to assess the quality of groundwater entering or leaving the site at BNL boundaries. Monitored facilities include the following: the Sewage Treatment Plant/Peconic River Area, Meadow Marsh-Upland Recharge Area, Waste Management Facility (WMF), "Current" Landfill, Former Landfill, Ash Repository, Central Steam Facility/Major Petroleum Facility (CSF/ MPF), AGS, Waste Concentration Facility (WCF), Supply and Materiel, and several other smaller facilities.

Groundwater quality is also routinely monitored at all active potable supply wells and process supply wells. Figures 8-1 through 8-14 show the wells located in specific areas of concern (AOCs). In addition to groundwater quality assessments, water levels are measured from over 500 on-site and off-site wells to assess variations in directions and velocities of groundwater flow.

\subsubsection{Potable Water and Process Supply Wells}

During 1997, approximately 10.25 million liters per day (MLD) were pumped from the BNL potable and process-water supply network. This network consists of six potable supply wells (Wells 4 , $6,7,10,11$, and 12) and five secondary cooling/process water supply wells (Wells 9, 101, 102, 103 , and 105); all are screened entirely within the Upper Glacial aquifer. Due to continued modifications of the treatment system at the Water Treatment Plant, only wells 10, 11, and 12 supplied drinking water in 1997 . Wells 102 and 103 provided the secondary cooling water at the AGS, and Well 9 supplied process water to the Biology Department's fish house. Secondary-cooling water for the Brookhaven Medical Research Reactor (BMRR) was supplied exclusively from Well 105.

The radiological sampling data discussed in Section 8.1.1.2 is compared to Federal and New York State Drinking Water Standards.

Grab samples were obtained quarterly from Potable Wells 10, 11 and 12 and analyzed for radioactivity, water quality indices, metals, and VOCs. Regulatory compliance samples were collected and analyzed in accordance with the BNL Potable Water System Sampling Plan. The results of the regulatory compliance samples were discussed in Chapter 2.

Process Supply Wells 9, 102, 103, and 105 were used periodically during 1997 and were analyzed for water quality, inorganic and organic contaminants. Water chemistry analyses (i.e., pH and conductivity) were also performed for Well 102 by the AGS facility operators, as needed, to meet their operational requirements.

\subsubsection{Non-radiological Analyses}

Potable Wells 10,11 , and 12 were used to supply potable water to the BNL community during CY 1997. The NYSDOH governs the quality of potable water supplies and requires that the water purveyor routinely monitor the supply for organic, bacteriological, and inorganic constituents. The NYSDOH requirements (under authority of the SDWA) are implemented by the SCDHS. Monitoring requirements for 1997 included quarterly analyses for Principal Organic Compounds (POCs), monthly bacteriological analyses, annual analyses for asbestos, micro-extractables, Synthetic Organic Compounds (SOCs) and pesticides, and annual inorganic and lead and copper analyses. Potable water samples were collected by BNL personnel and analyzed by an NYSDOHcertified contractor laboratory using standard methods of analysis. All analytical data were submitted to the SCDHS as required by Chapter I, Part 5 of the NYS Sanitary Code. The full details of the potable water compliance sampling and analysis program are discussed in detail in Chapter 2.

Potable Wells 4, 6 and 7, which are typically used to supply water to the BNL Water Treatment Plant (WTP), remained out of service in 1997 due to the continued improvements to the WTP. 


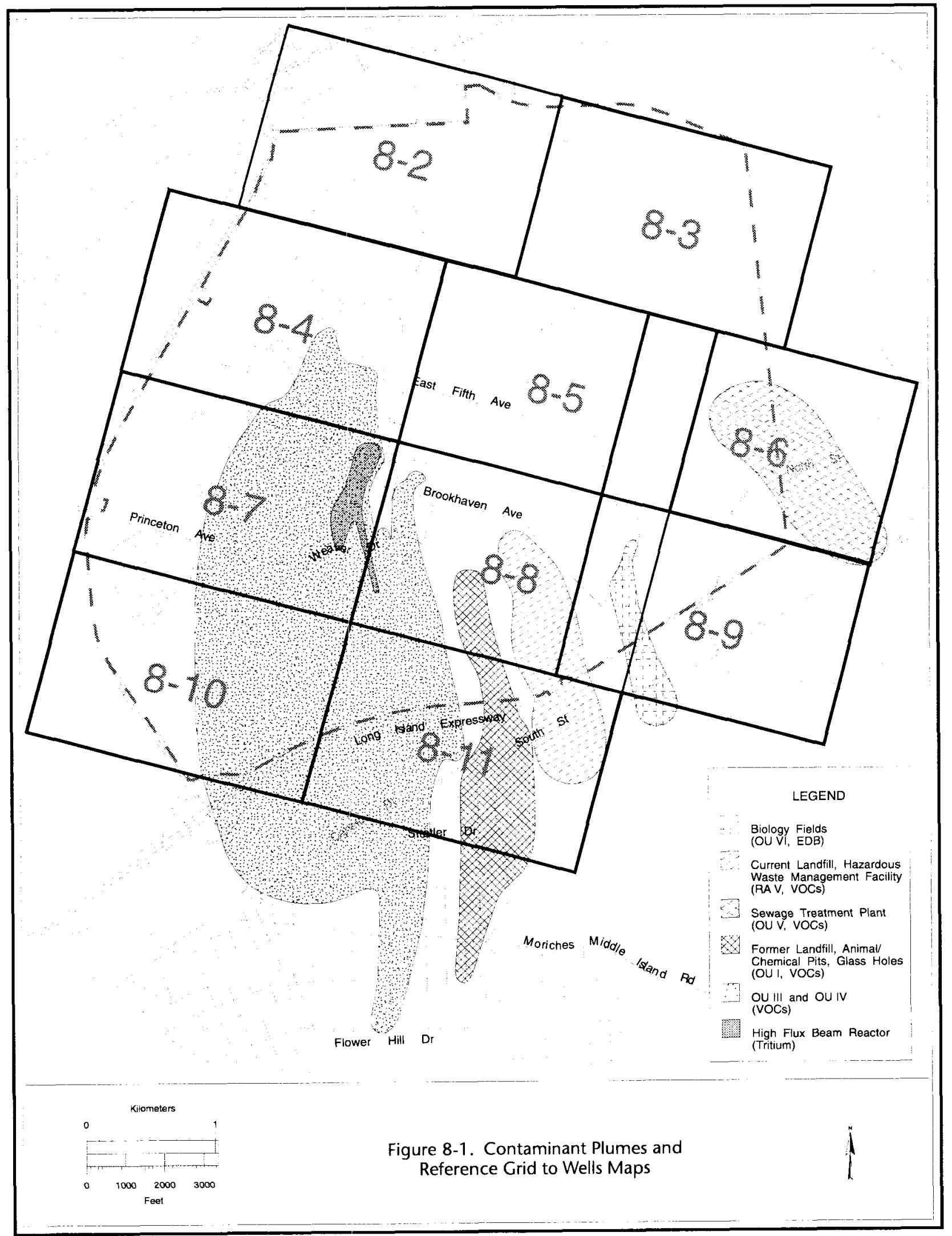




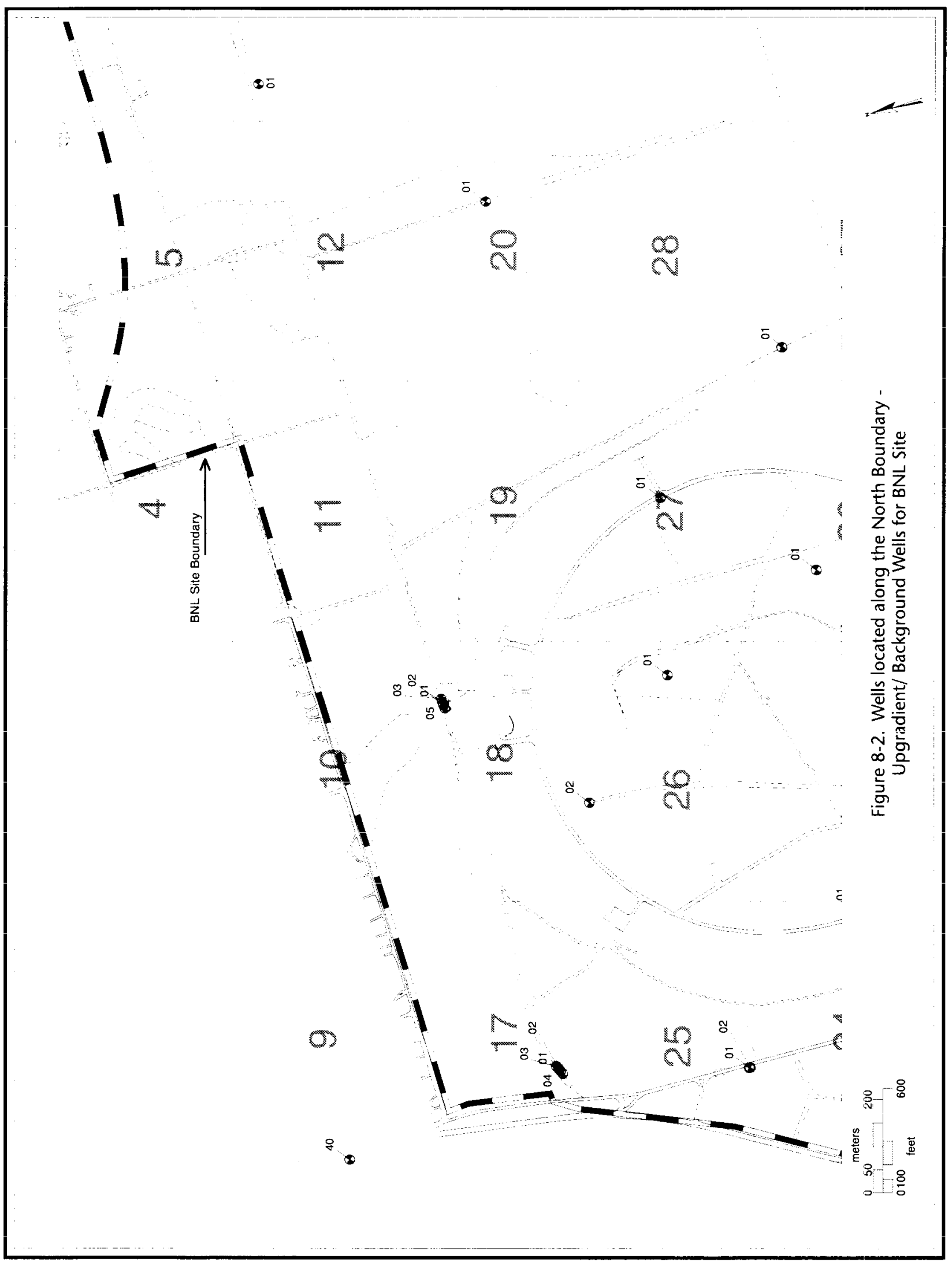




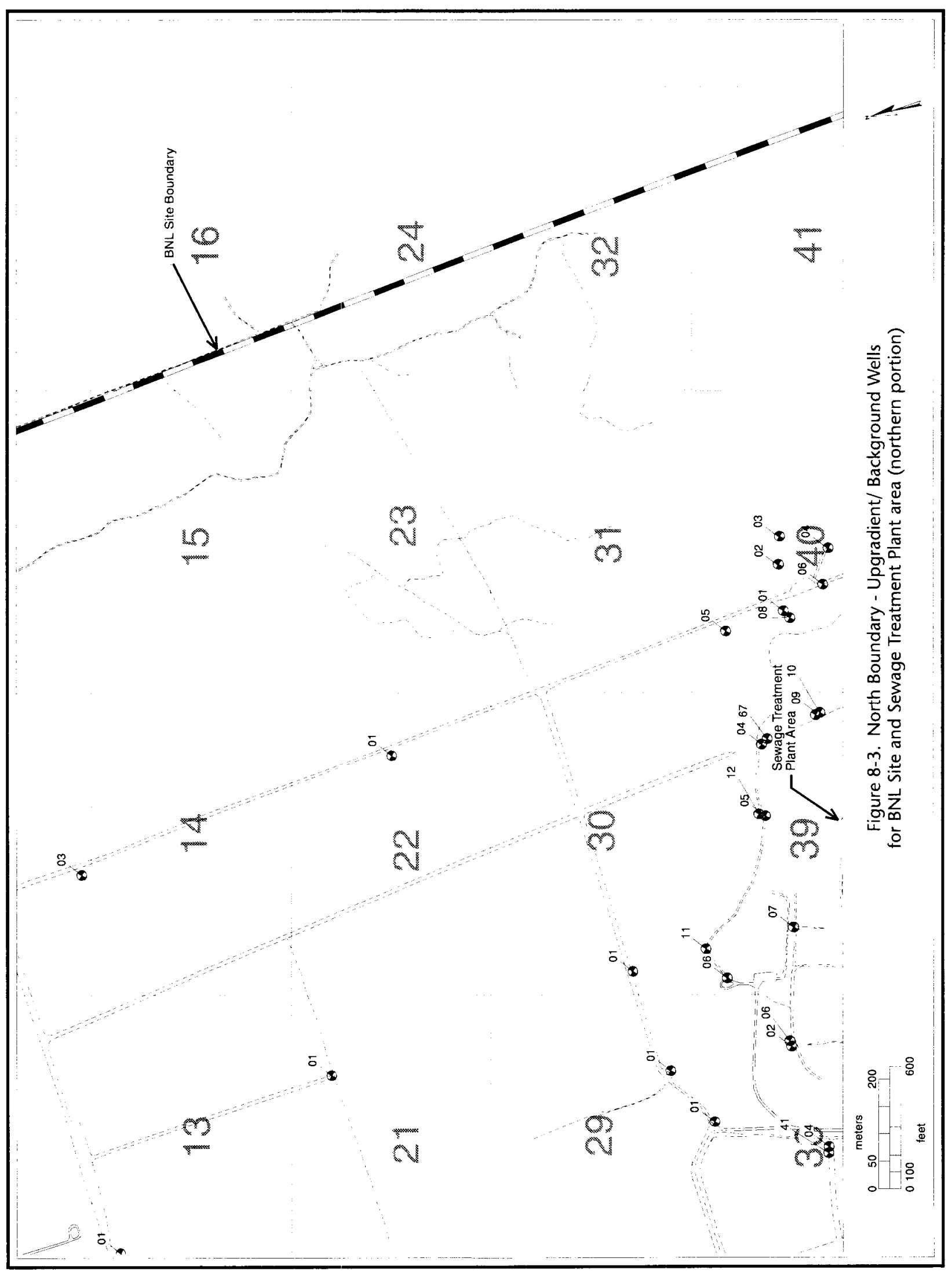




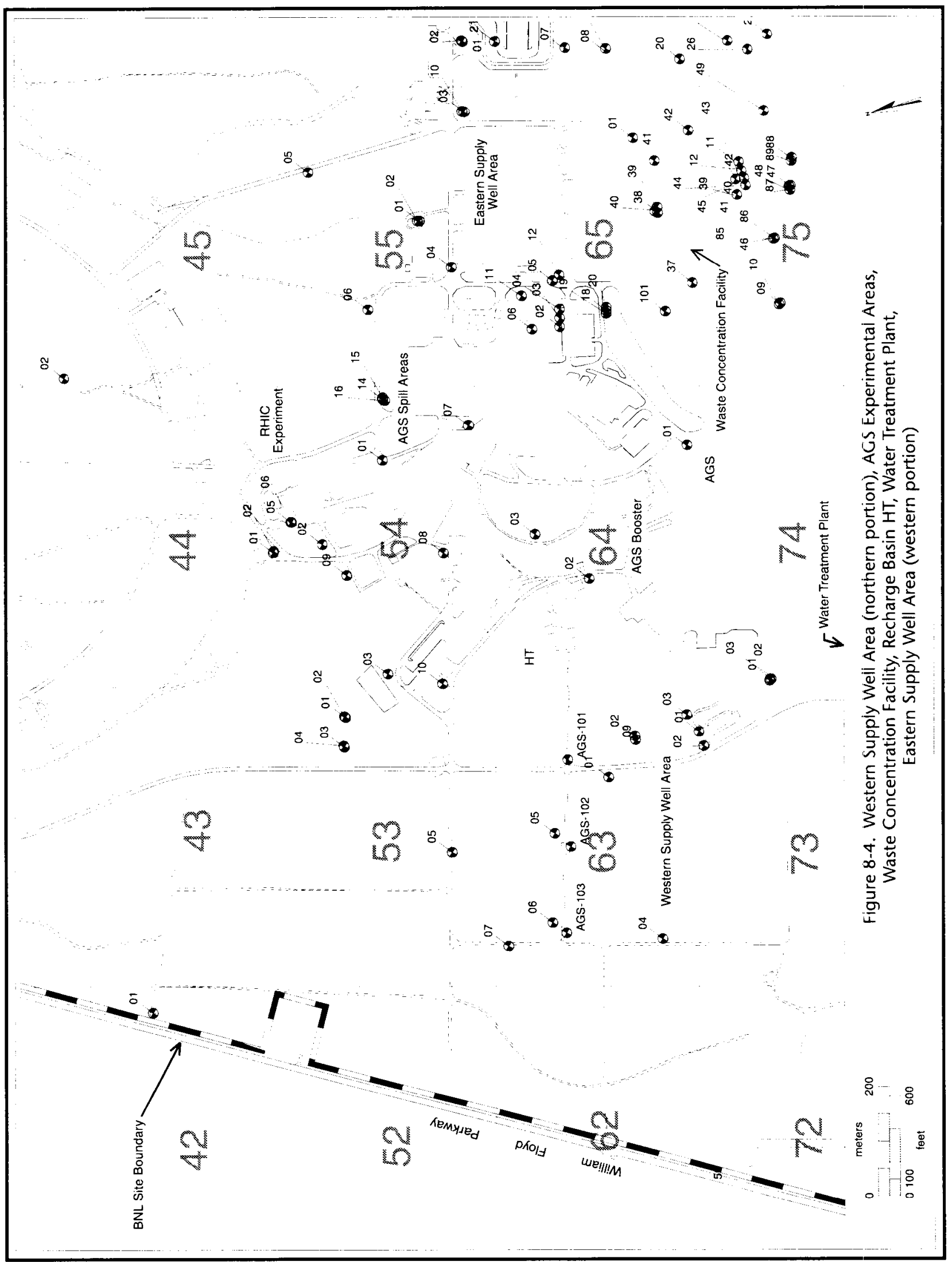




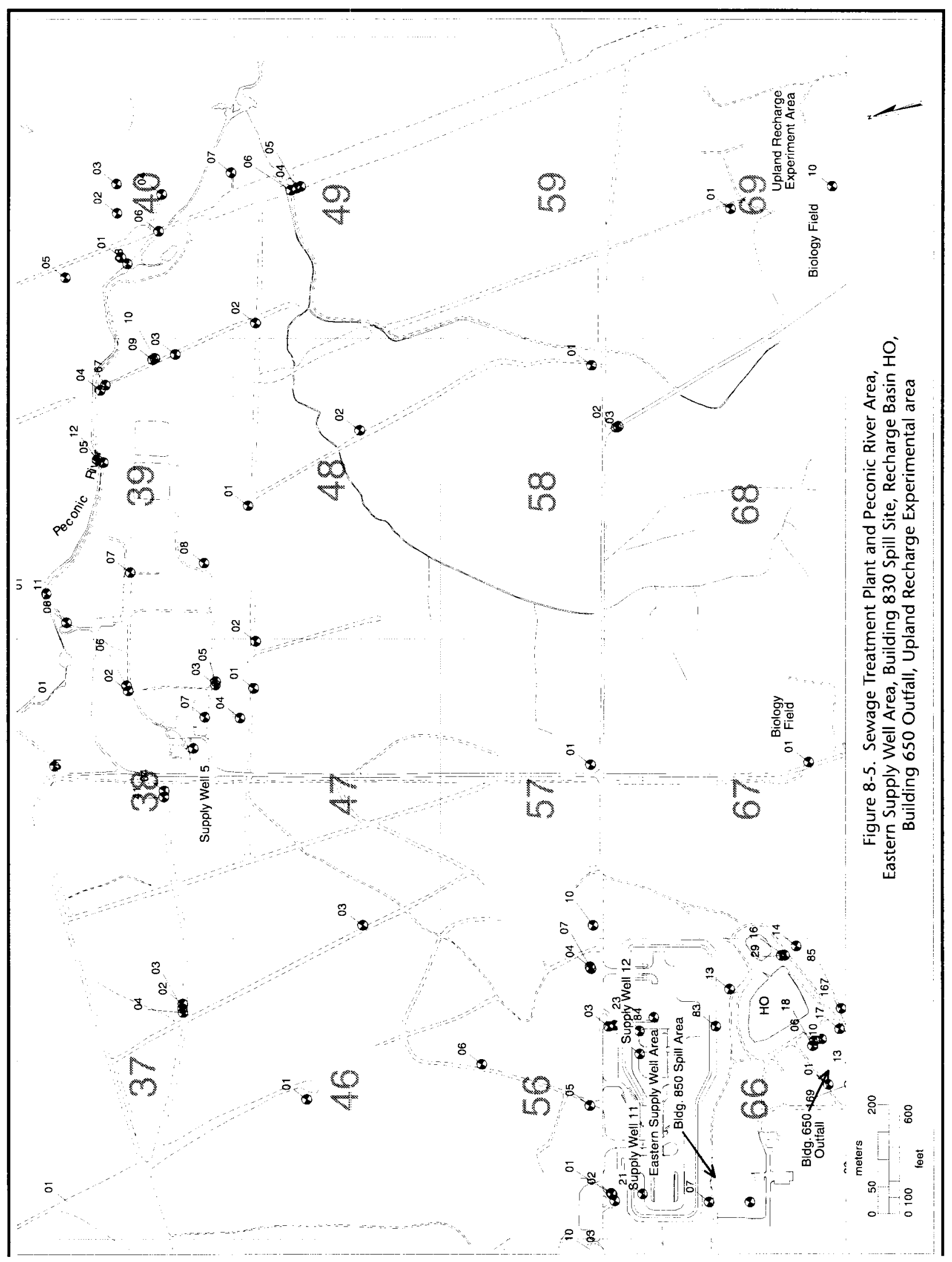




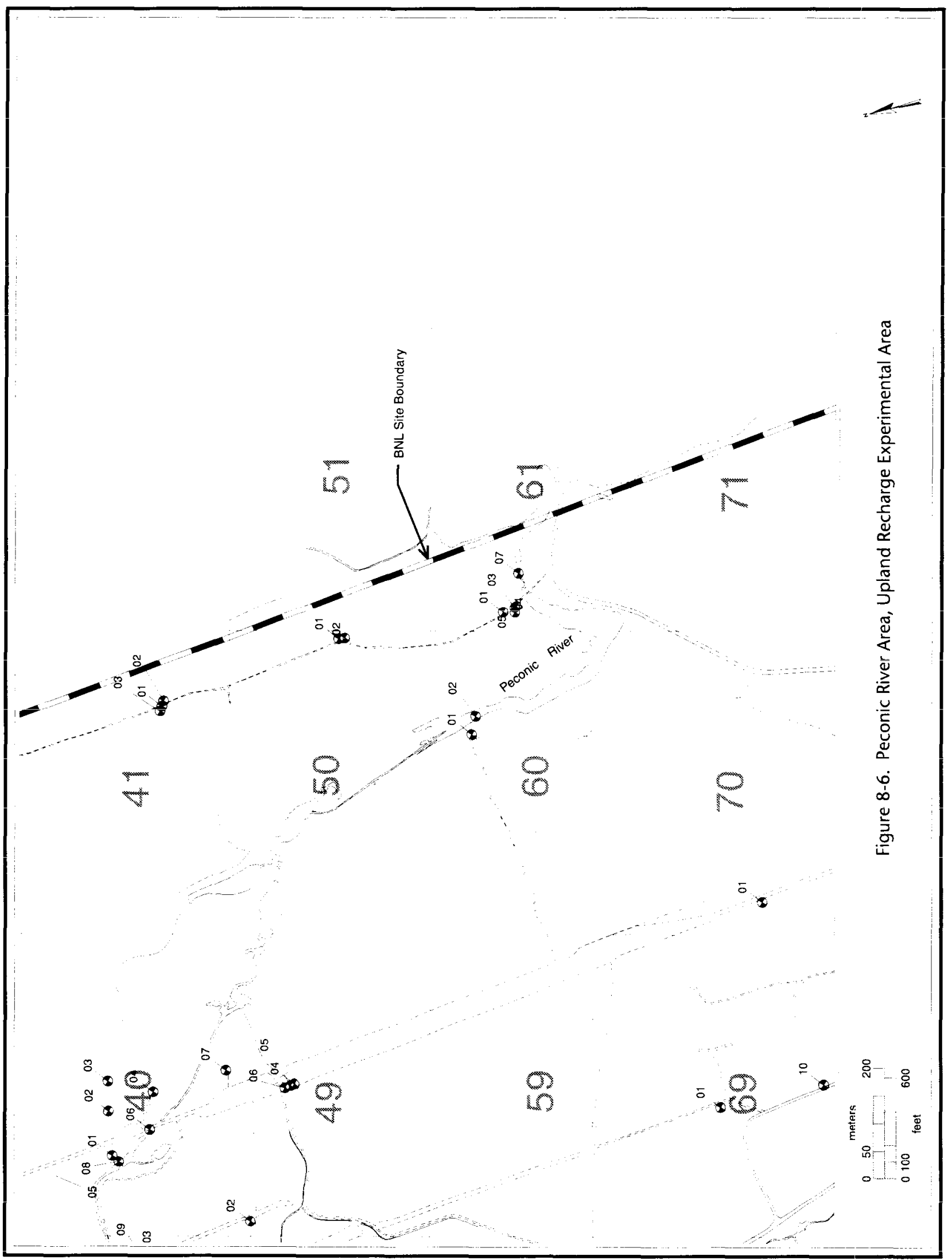


GROUNDWATER PROTECTION

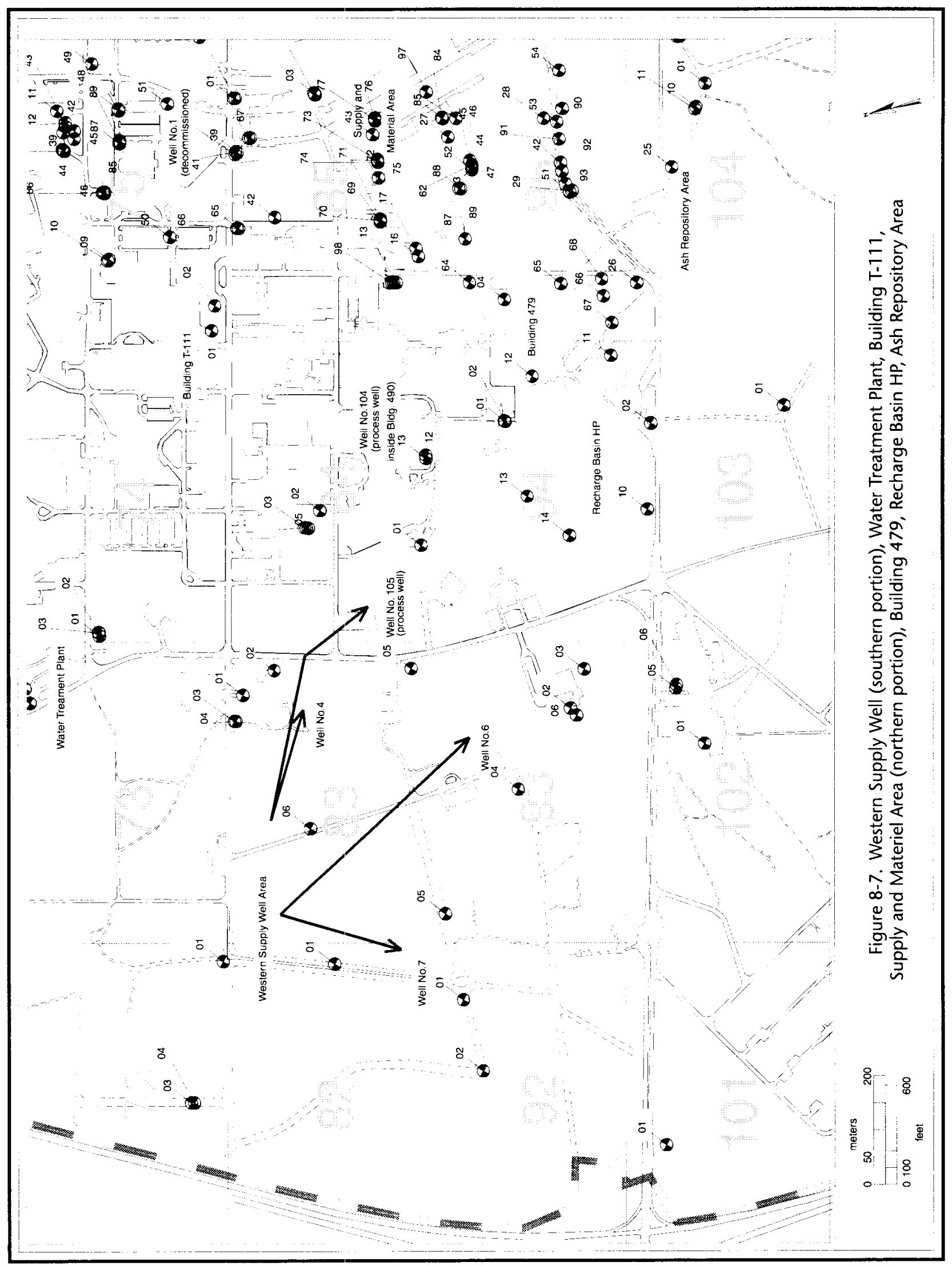

1997 BNL Site Environmental Report 8 - 9 


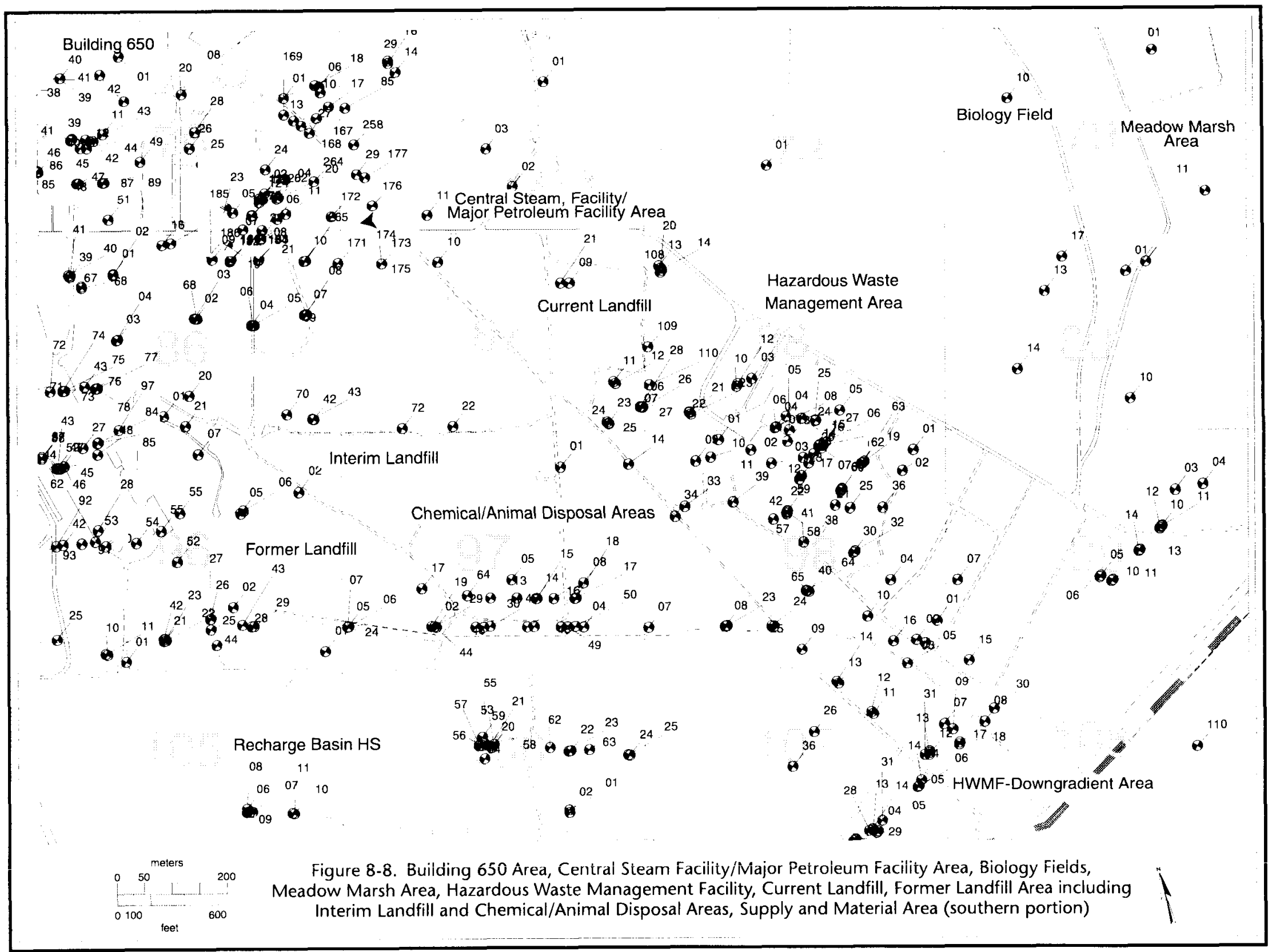



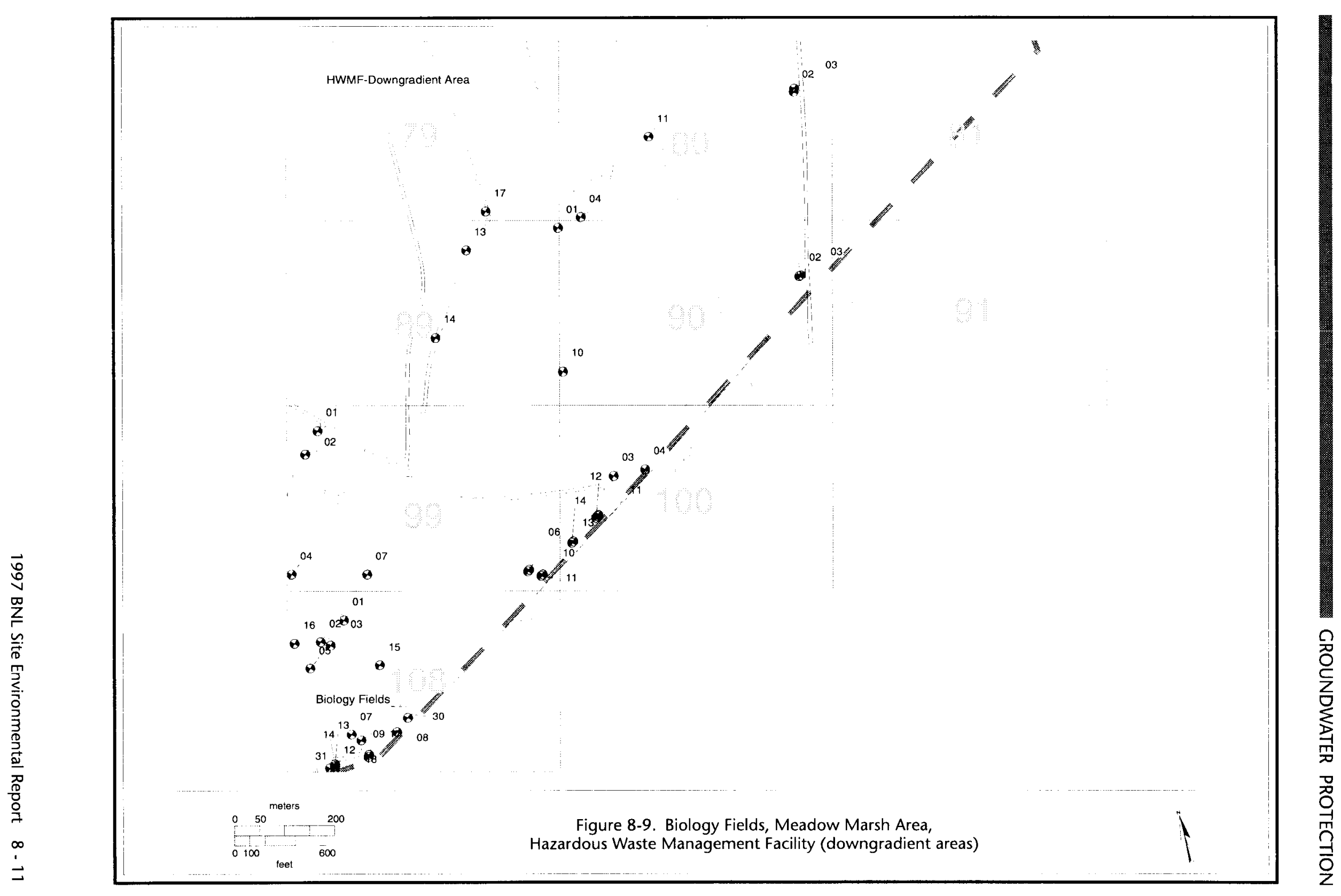


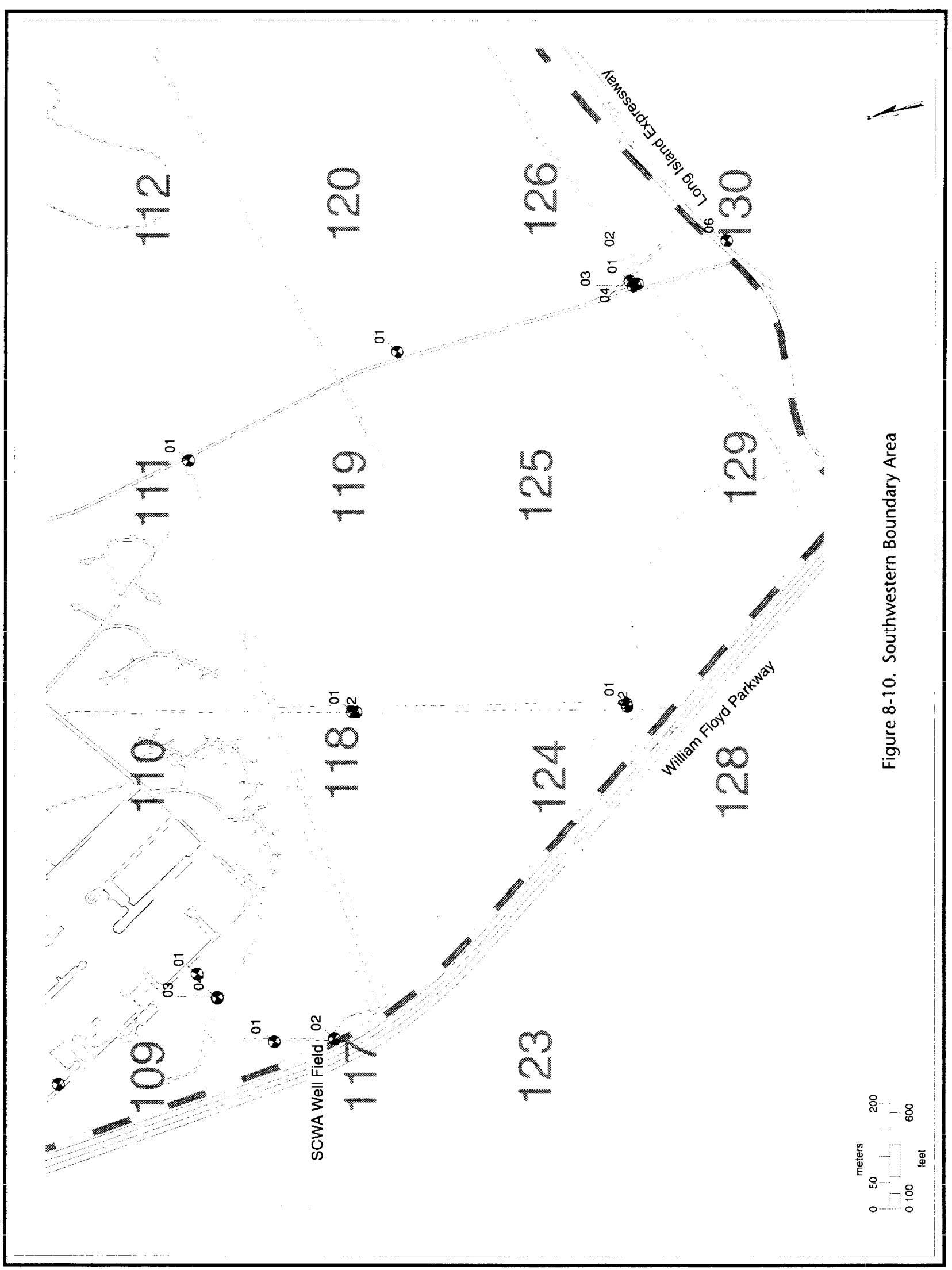




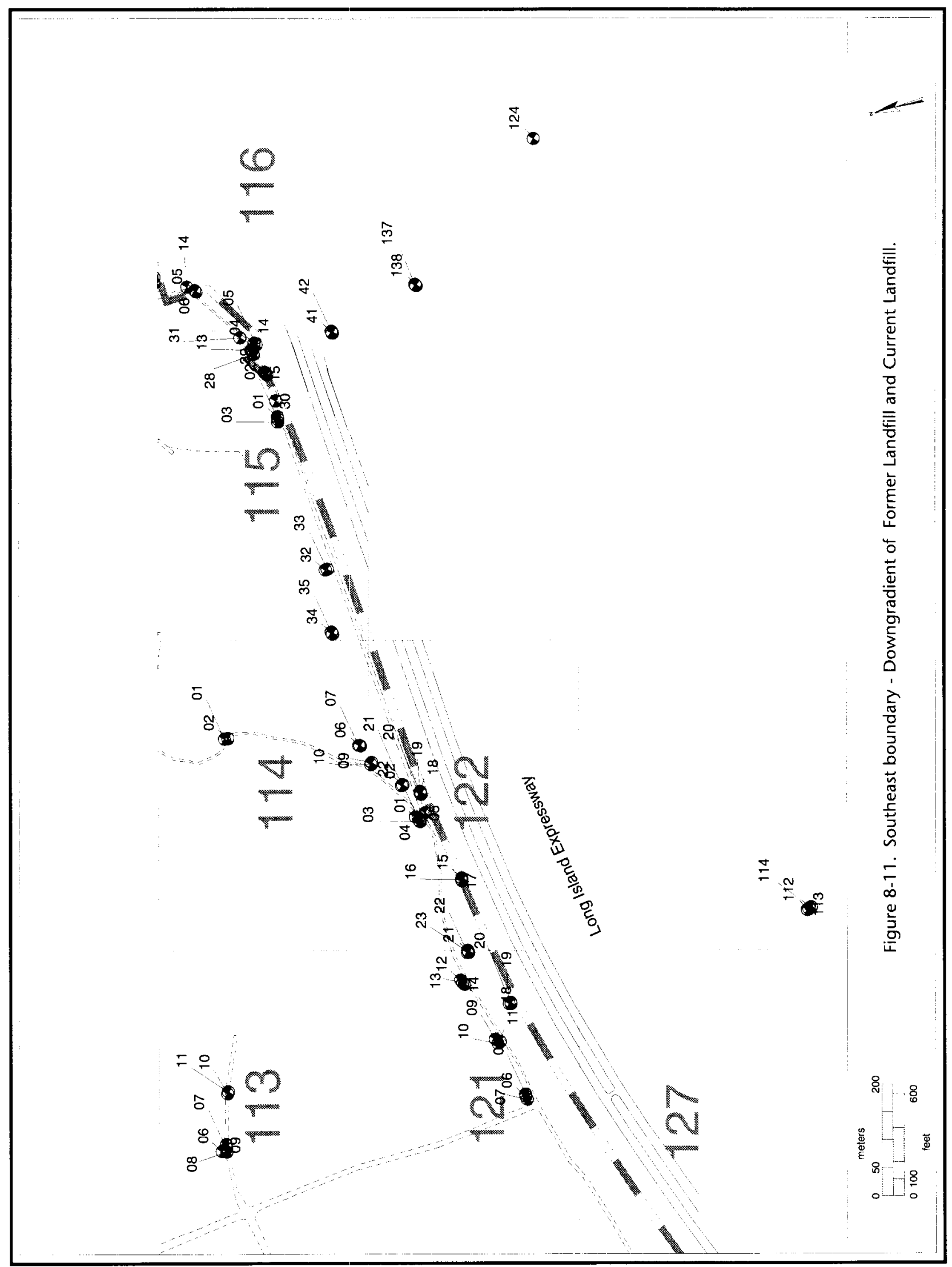




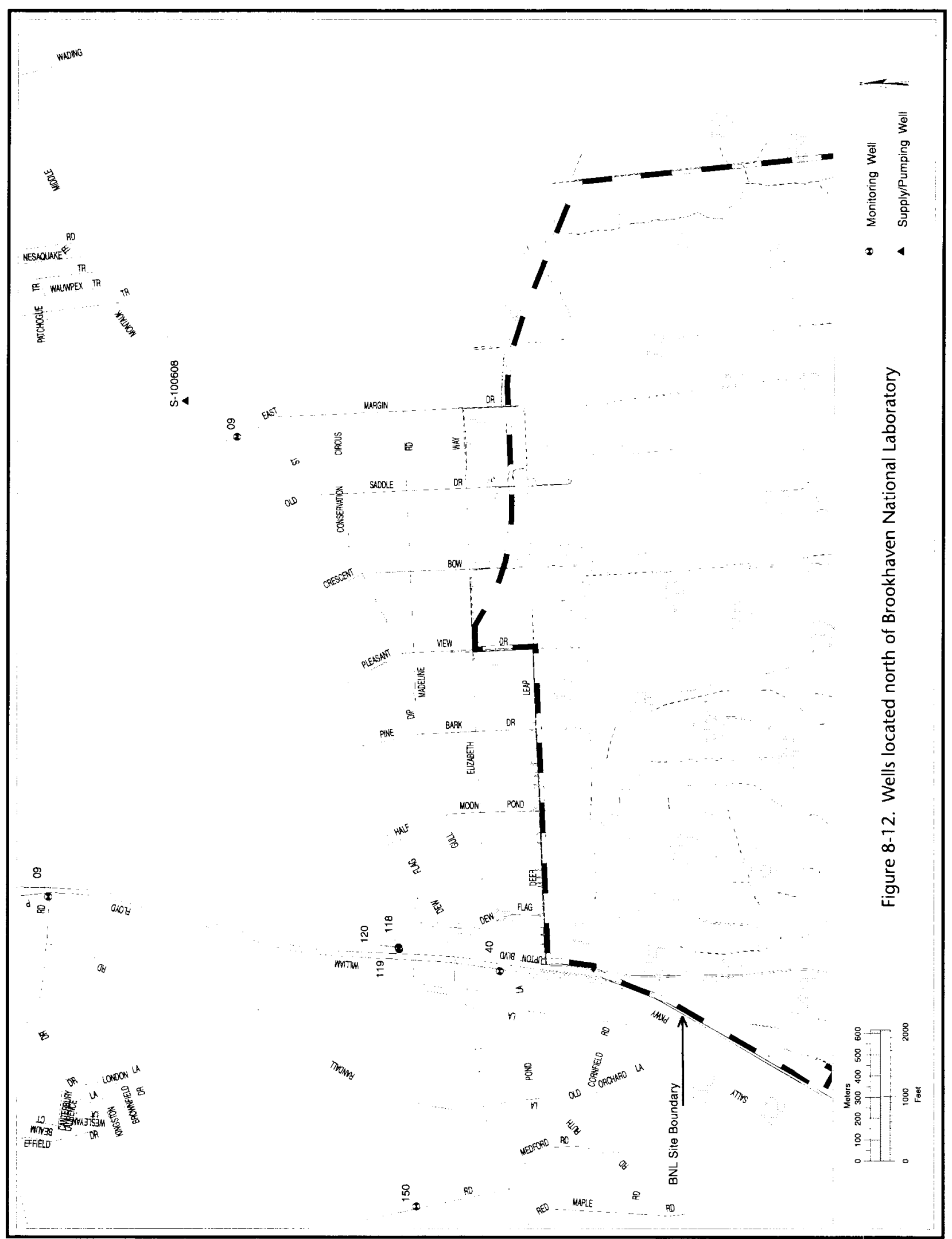




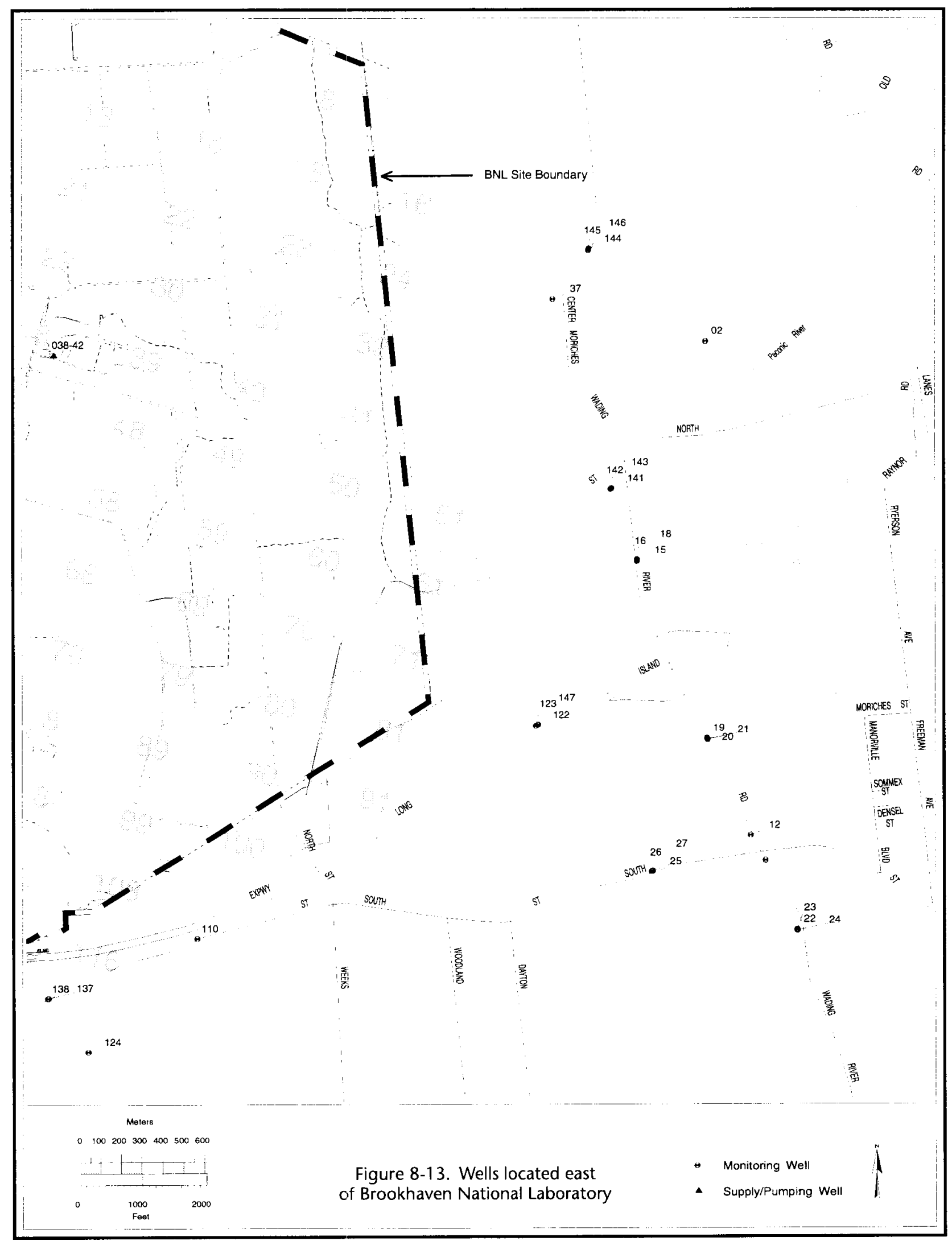




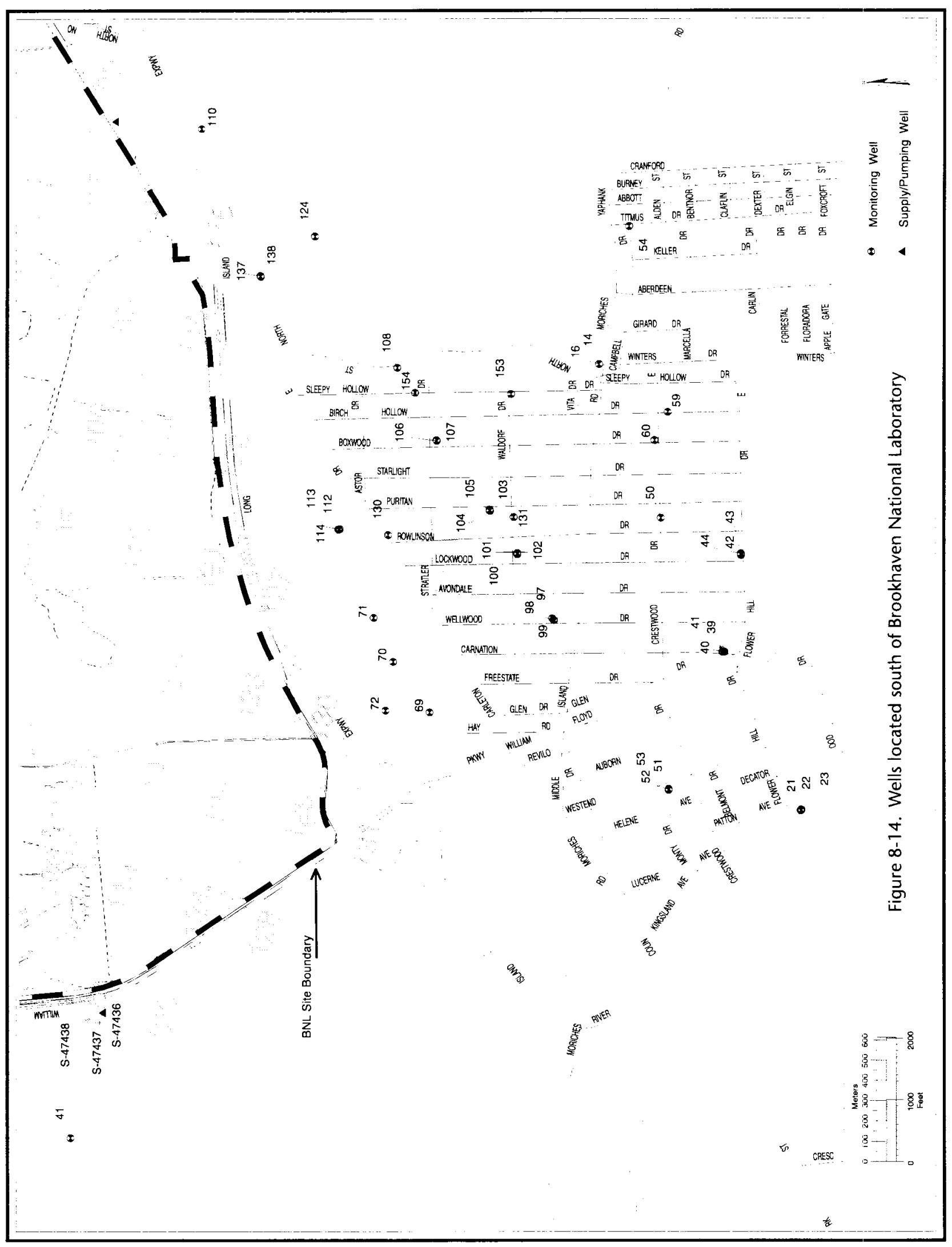


Water obtained from Wells 4,6 and 7 contains naturally occurring iron at concentrations which exceed drinking water guidelines. The water is treated at the WTP by a conventional lime softening process to precipitate the iron from solution. This water also contains elevated levels of VOCs, which must be treated to reduce their concentrations to below drinking water standards. To improve the efficiency of VOC removal, as well as to update WTP controls, modifications to the WTP were initiated in 1995 . This project included the construction of dual 10 -foot diameter by 35 -foot tall air stripping towers, each with a rated capacity of 2,400 gallons per minute, for the removing of VOCs. The project also included construction of a new wetwell, which stores the iron-free water before air stripping, and a new clearwell, which stores the VOC treated water prior to site distribution. Although WTP improvements were completed in the summer of 1997, due to the build-up of iron scale within the screen zones of Wells 4 and 7, start-up of the facility was limited. Each of the wells was subsequently descaled and pump sections rebuilt to improve the yield. Consequently, the WTP and Wells 4, 6, and 7 were not sampled in 1997. The WTP is expected to be restarted in the summer of 1998.

In addition to the requirements of NYSDOH compliance monitoring, the ES\&HS Division maintains a supplemental sampling and analysis program for the BNL potable water supply. During 1997, the S\&EP Division monitored: these wells for metals, water quality parameters, and VOCs. All analyses were conducted by the ES\&HS Division ASL using EPA-approved methods. Tables 8$1,8-2$, and 8-3 summarize all the 1997 data.

The water-quality data show that nitrates, sulfates, and chlorides are well within the limits established in the NYS DWS (Part 5 NYS Sanitary Code). The pH values in these wells ranged from $5.9-7.2$ and are typical of natural Long Island groundwater. To reduce the corrosivity of the groundwater Wells 10,11, and 12 are equipped with metering pumps, which add sodium hydroxide to maintain the $\mathrm{pH}$ of the potable water effluent at approximately 8 .

The majority of metals, including silver, cadmium, chromium, mercury, manganese and lead were not typically detected in the Laboratory's potable supply wells. Zinc and iron were detected at levels below their respective NYS DWS. Sodium occurred in all wells at ambient concentrations, which were well within NYS drinking water guidance values.

During the second or third month of each quarter, BNL collects samples which are analyzed onsite by the ES\&HS ASL for ten organic compounds, consisting of the primary volatile halogenated aliphatic hydrocarbons and aromatic hydrocarbons detected in groundwater at the BNL site. These samples serve both as a quality control on the contractor laboratory, and as an additional source of organic data used in trend analysis of water quality. Water samples are collected from the well head before treatment. These data are summarized in Table 8-1. The data show that only TCA and chloroform were detected in the potable wells. The concentration of TCA in Well 11 exceeded the NYS DWS; however, this well was fitted with a carbon-adsorption treatment system during CY 1992 which reduced the concentration of TCA to levels well below the NYS DWS. The maximum concentration of TCA detected after the carbon filter was $2.7 \mu \mathrm{g} / \mathrm{L}$. Chloroform was detected in several of the wells but only at trace levels. The remaining eight organic compounds were not detected in water samples collected during CY 1997.

Process Wells 9, 102, 103, and 105 were also sampled and analyzed during CY 1997. Wells 102 and 103 are used solely for supplying cooling water to the AGS, Well 9 supplies fresh water to the fish tanks housed in Building 463 (Biology Dept.), and Well 105 provides once-through cooling water for the Brookhaven Medical Research Reactor (BMRR). Tables 8-2 and 8-3 show that the concentrations of water-quality and inorganic elements are within ambient levels. Ambient groundwater quality in the western half of the BNL developed site is characterized by low $\mathrm{pH}$ and elevated concentrations of iron. Consequently, iron is present in all process wells at concentrations which exceed NYS AWQS. As in past years, VOCs continued to be detected in Biology Department process well 9, which is located within a portion of the defined Operable Unit III (OU III) VOC plume (see Section 8.1.2.1.3, below), contained concentrations of TCA and DCE which exceed the NYS DWS. This water is not used for drinking and the concentrations present do not interfere with the fish experiments conducted in Building 463. 
Table 8-1

BNL Site Environmental Report for Calendar Year 1997

Potable Water and Process Supply Wells

Volatile Organic Compound Data ${ }^{(b)}$

Well Id. (a)

10 (FO)

$12(\mathrm{FQ})$

11 (FP)

9 (FM)

$102(F \mid)$

$03(F J)$

$05(F L)$

NYSDWS

Typical MDL

N: No. of samples

NYSDWS: New York State Drinking Water Standard

MOL: Minimum Detection Limit

(a): The location of potable and process wells is shown on Figure 6-11.

(b): Prefiltration

\begin{tabular}{|c|c|c|}
\hline $\begin{array}{l}\text { Chloroform } \\
u g / L\end{array}$ & $\begin{array}{l}1,1 \text { Dichloroethylene } \\
\mathrm{ug} / \mathrm{L}\end{array}$ & $\begin{array}{l}\text { 1,1,1 - Tichloroethane } \\
\mathrm{ug} / \mathrm{L}\end{array}$ \\
\hline $\begin{array}{l}5 \\
<2.0 \text { (trace) } \\
<2.0 \\
<2.0\end{array}$ & $\begin{array}{l}5 \\
<2.0 \\
<2.0 \\
<2.0\end{array}$ & $\begin{aligned} & 5 \\
< & 2.0 \text { (trace) } \\
< & 2.0 \\
< & 2.0\end{aligned}$ \\
\hline $\begin{aligned} & 5 \\
< & 2.0 \\
<2.0 & <2.0\end{aligned}$ & $\begin{array}{l}5 \\
<2.0 \text { (trace) } \\
<2.0 \\
<2.0\end{array}$ & $\begin{array}{l}5 \\
3.0 \\
6.2 \\
5\end{array}$ \\
\hline $\begin{array}{l}5 \\
<2.0 \text { (trace) } \\
<2.0 \\
<2.0\end{array}$ & $\begin{array}{c}5 \\
<2.0 \\
<2.0 \\
<2.0\end{array}$ & $\begin{array}{l}5 \\
<2.0 \\
<2.0 \\
<2.0\end{array}$ \\
\hline $\begin{array}{l}3 \\
2.5 \\
3.7 \\
2.9\end{array}$ & $\begin{array}{r}3 \\
<2.0 \\
5.4 \\
3.3\end{array}$ & $\begin{array}{c}3 \\
12.1 \\
17.5 \\
14.7\end{array}$ \\
\hline $\begin{array}{l}1 \\
<2.0 \\
<2.0 \\
<2.0\end{array}$ & $\begin{array}{c}1 \\
<2.0 \\
<2.0 \\
<2.0\end{array}$ & $\begin{array}{l}1 \\
<2.0 \\
<2.0 \\
<2.0\end{array}$ \\
\hline $\begin{aligned} & 1 \\
< & 2.0\end{aligned}$ & $\begin{aligned} & 1 \\
< & 2.0\end{aligned}$ & $\begin{aligned} & 1 \\
< & 2.0\end{aligned}$ \\
\hline $\begin{array}{c}5 \\
<2.0 \\
3 \\
2\end{array}$ & $\begin{aligned} & 5 \\
&<2.0 \\
&<2.0 \\
&<2.0\end{aligned}$ & $\begin{array}{r}5 \\
<2.0 \\
2.2 \\
<2.0\end{array}$ \\
\hline 100 & 5 & 5 \\
\hline 2 & 2 & 2 \\
\hline
\end{tabular}

\subsubsection{Radiological Analyses}

Potable and process well water were sampled and analyzed for gross alpha and gross beta activity, tritium and strontium-90; the results are listed in Table 8-4. Nuclide-specific gamma spectroscopy was also performed, supplementing the requirements of the SDWA, which does not strictly require this analysis unless gross beta activity exceeds $50 \mathrm{pCi} / \mathrm{L}(1.9 \mathrm{~Bq} / \mathrm{L})$. In 1997 , the total number of samples collected was increased from previous years. Collection frequency for potable wells was increased from four to eight times per year. The gross activity data for all potable well samples collected on August 19, 1997 were rejected and removed from the data set after a QA review indicated a uniform positive bias for all samples (see Chapter 10 for discussion). 
Table 8-2

BNL Site Environmental Report for Calendar Year 1997

Potable Water and Process Supply Wells

Water Qualify Data

\begin{tabular}{|c|c|c|c|c|c|c|}
\hline Well Id. (a) & & $\begin{array}{l}\mathbf{p H} \\
\text { SU }\end{array}$ & $\begin{array}{l}\text { Conductivity } \\
\text { umhos/cm }\end{array}$ & $\begin{array}{l}\text { Chlorides } \\
\mathrm{mg} / \mathrm{L}\end{array}$ & $\begin{array}{l}\text { Sulfates( c) } \\
\mathrm{mg} / \mathrm{L}\end{array}$ & $\begin{array}{l}\text { Nitrate as } \mathrm{N}(\mathrm{c}) \\
\mathrm{mg} / \mathrm{L}\end{array}$ \\
\hline $10(\mathrm{FO})$ & $\begin{array}{l}\mathrm{N} \\
\text { Minimum } \\
\text { Maximum } \\
\text { Average }\end{array}$ & $\begin{array}{l}8 \\
6.1 \\
6.8 \\
\text { NA }\end{array}$ & $\begin{array}{r}7 \\
98 \\
116 \\
105\end{array}$ & $\begin{array}{l}4 \\
12.2 \\
13.8 \\
13\end{array}$ & $\begin{array}{c}4 \\
10.1 \\
10.9 \\
10.6\end{array}$ & $\begin{array}{c}4 \\
<1.0 \\
<1.0 \\
<1.0\end{array}$ \\
\hline $11(\mathrm{FP})$ & $\begin{array}{l}\mathrm{N} \\
\text { Minimum } \\
\text { Maximum } \\
\text { Average }\end{array}$ & $\begin{array}{c}9 \\
5.9 \\
6.5 \\
\text { NA }\end{array}$ & $\begin{array}{r}7 \\
140 \\
149 \\
144\end{array}$ & $\begin{array}{c}4 \\
18.4 \\
19.7 \\
19.3\end{array}$ & $\begin{array}{l}4 \\
12.4 \\
13.4 \\
13\end{array}$ & $\begin{array}{l}4 \\
<1.0 \\
<1.0 \\
<1.0\end{array}$ \\
\hline $12(F Q)$ & $\begin{array}{l}\mathrm{N} \\
\text { Minimum } \\
\text { Maximum } \\
\text { Average }\end{array}$ & $\begin{array}{c}9 \\
6.2 \\
6.5 \\
\text { NA }\end{array}$ & $\begin{array}{r}8 \\
123 \\
129 \\
125\end{array}$ & $\begin{array}{c}4 \\
16.2 \\
16.7 \\
16.5\end{array}$ & $\begin{array}{c}4 \\
11 \\
11.9 \\
11.5\end{array}$ & $\begin{array}{l}4 \\
<1.0 \\
<1.0 \\
<1.0\end{array}$ \\
\hline $102(\mathrm{FI})$ & $\begin{array}{l}\mathrm{N} \\
\text { Minimum } \\
\text { Maximum } \\
\text { Average }\end{array}$ & $\begin{array}{c}2 \\
6.2 \\
6.6 \\
\text { NA }\end{array}$ & $\begin{array}{r}2 \\
130 \\
131 \\
130\end{array}$ & $\begin{array}{c}2 \\
20.4 \\
20.4 \\
20.4\end{array}$ & $\begin{array}{l}2 \\
8.6 \\
9 \\
8.8\end{array}$ & $\begin{array}{l}2 \\
<1.0 \\
<1.0 \\
<1.0\end{array}$ \\
\hline $103(\mathrm{FJ})$ & $\begin{array}{l}\mathrm{N} \\
\text { Value }\end{array}$ & $\begin{array}{l}1 \\
6.4\end{array}$ & $\begin{array}{r}1 \\
135\end{array}$ & $\begin{array}{c}1 \\
20.1\end{array}$ & $\begin{array}{l}1 \\
8.7\end{array}$ & $\begin{array}{c}1 \\
<1.0\end{array}$ \\
\hline $9(\mathrm{FM})$ & $\begin{array}{l}\mathrm{N} \\
\text { Minimum } \\
\text { Maximum } \\
\text { Average }\end{array}$ & $\begin{array}{c}5 \\
6.3 \\
7.2 \\
\text { NA }\end{array}$ & $\begin{array}{r}4 \\
120 \\
126 \\
124\end{array}$ & $\begin{array}{c}4 \\
17.6 \\
18.5 \\
18.2\end{array}$ & $\begin{array}{c}4 \\
11.01 \\
11.5 \\
11.3\end{array}$ & $\begin{array}{c}4 \\
<1.0 \\
<1.0 \\
<1.0\end{array}$ \\
\hline $105(\mathrm{FL})$ & $\begin{array}{l}\mathrm{N} \\
\text { Minimum } \\
\text { Maximum } \\
\text { Average }\end{array}$ & $\begin{array}{c}5 \\
6.4 \\
7.1 \\
\text { NA }\end{array}$ & $\begin{array}{r}4 \\
182 \\
194 \\
189\end{array}$ & $\begin{array}{c}4 \\
28.3 \\
32.3 \\
30.8\end{array}$ & $\begin{array}{c}4 \\
13.4 \\
14.8 \\
13.8\end{array}$ & $\begin{aligned} & 4 \\
< & 1.0 \\
< & 1.0 \\
< & 1.0\end{aligned}$ \\
\hline NYSDWS & & (b) & (b) & 250 & 250 & 10 \\
\hline Typical MDL & & NA & 10 & 4 & 4 & 1 \\
\hline \multicolumn{7}{|c|}{$\begin{array}{l}\text { N: No. of samples } \\
\text { NA: Not Applicable } \\
\text { MDL: Minimum Detection Limit } \\
\text { NYSDWS: New York State Drinking Water Standard } \\
\text { (a): The location of potable and process wells is shown on Figure 6-11. } \\
\text { (b): No standard specified. } \\
\text { (c): Holding times for nitrates and sulfates were typically exceeded. }\end{array}$} \\
\hline
\end{tabular}

Gross activity levels in the potable water wells were consistent with those of typical background environmental water samples. Note that the maximum gross activity data summarized in Table 8-4 is lower than the values reported to the County in 1997 as presented in Table 2-5. Several datum listed in Table 2-5 were biased high due to an analytical instrument error. Table 8-4 includes only those results which were validated. Neither tritium nor strontium-90 were observed above the MDL in any of these wells. No man-made gamma-emitting radionuclides were detected in any of the potable water samples, with the exception of one detection of manganese-54 in Well 10 at $0.23 \pm 0.16 \mathrm{pCi} / \mathrm{L}(9 \pm 5 \mathrm{mBq} / \mathrm{L})$. This result is near the detection limit of the analysis method, making its positive identification uncertain. 
Table 8-3

BNL Site Environmental Report for Calendar Year 1997

Potable and Process Supply Wells

Metals Data

\begin{tabular}{|c|c|c|c|c|c|c|c|c|c|c|c|}
\hline Well Id. (a) & & $\begin{array}{l}\mathrm{Ag} \\
\mathrm{mg} / \mathrm{L}\end{array}$ & $\begin{array}{l}\mathrm{Cd} \\
\mathrm{mg} / \mathrm{L}\end{array}$ & $\begin{array}{l}\mathrm{Cr} \\
\mathrm{mg} / \mathrm{L}\end{array}$ & $\begin{array}{l}\mathrm{Cu} \\
\mathrm{mg} / \mathrm{L}\end{array}$ & $\begin{array}{l}\mathrm{Fe} \\
\mathrm{mg} / \mathrm{L}\end{array}$ & $\begin{array}{l}\mathrm{Hg} \\
\mathrm{mg} / \mathrm{L}\end{array}$ & $\begin{array}{l}\mathrm{Mn} \\
\mathrm{mg} / \mathrm{L}\end{array}$ & $\begin{array}{l}\mathrm{Na} \\
\mathrm{mg} / \mathrm{L}\end{array}$ & $\begin{array}{l}\mathrm{Pb} \\
\mathrm{mg} / \mathrm{L}\end{array}$ & $\begin{array}{l}\mathrm{Zn} \\
\mathrm{mg} / \mathrm{L}\end{array}$ \\
\hline $10(F 0)$ & $\begin{array}{l}\mathrm{N} \\
\text { Minimum } \\
\text { Maximum } \\
\text { Average }\end{array}$ & $\begin{array}{l}4 \\
<0.025 \\
<0.025 \\
<0.025\end{array}$ & $\begin{array}{c}4 \\
<0.0005 \\
<0.0005 \\
<0.0005\end{array}$ & $\begin{array}{l}4 \\
<0.005 \\
<0.005 \\
<0.005\end{array}$ & $\begin{array}{c}4 \\
<0.05 \\
<0.05 \\
<0.05\end{array}$ & $\begin{array}{c}4 \\
<0.075 \\
0.11 \\
<0.075\end{array}$ & $\begin{aligned} & 4 \\
&<0.0002<0.0002 \\
&<0.0002\end{aligned}$ & $\begin{array}{l}4 \\
<0.05 \\
<0.05 \\
<0.05\end{array}$ & $\begin{array}{l}4 \\
8.8 \\
9.4 \\
9.2\end{array}$ & $\begin{array}{c}4 \\
<0.002 \\
0.01 \\
<0.002\end{array}$ & $\begin{array}{c}4 \\
<0.02 \\
0.049 \\
<0.02\end{array}$ \\
\hline $11(F P)$ & $\begin{array}{l}\mathrm{N} \\
\text { Minimum } \\
\text { Maximum } \\
\text { Average }\end{array}$ & $\begin{array}{l}5 \\
<0.025 \\
<0.025 \\
<0.025\end{array}$ & $\begin{array}{l}5 \\
<0.0005 \\
<0.0005 \\
<0.0005\end{array}$ & $\begin{array}{l}5 \\
<0.005 \\
<0.005 \\
<0.005\end{array}$ & $\begin{aligned} & 5 \\
< & 0.05 \\
< & 0.05 \\
< & 0.05\end{aligned}$ & $\begin{aligned} & 5 \\
&<0.075 \\
&<0.075 \\
&<0.075\end{aligned}$ & $\begin{aligned} & 5 \\
< & 0.0002 \\
< & 0.0002 \\
< & 0.0002\end{aligned}$ & $\begin{array}{l}5 \\
<0.05 \\
<0.05 \\
<0.05\end{array}$ & $\begin{array}{c}5 \\
12.8 \\
13.2 \\
12.9\end{array}$ & $\begin{aligned} & 5 \\
< & 0.002 \\
< & 0.002 \\
< & 0.002\end{aligned}$ & $\begin{array}{l}5 \\
<0.02 \\
0.225 \\
0.055\end{array}$ \\
\hline $12(F Q)$ & $\begin{array}{l}\mathrm{N} \\
\text { Minimum } \\
\text { Maximum } \\
\text { Average }\end{array}$ & $\begin{array}{l}5 \\
<0.025 \\
<0.025 \\
<0.025\end{array}$ & $\begin{array}{l}5 \\
<0.0005 \\
<0.0005 \\
<0.0005\end{array}$ & $\begin{array}{l}5 \\
<0.005 \\
<0.005 \\
<0.005\end{array}$ & $\begin{array}{l}5 \\
<0.05 \\
<0.05 \\
<0.05\end{array}$ & $\begin{array}{c}5 \\
<0.075 \\
0.11 \\
<0.075\end{array}$ & $\begin{aligned} & 5 \\
&< 0.0002 \\
&<0.0002 \\
&<0.0002\end{aligned}$ & $\begin{array}{l}5 \\
<0.05 \\
<0.05 \\
<0.05\end{array}$ & $\begin{array}{c}5 \\
13.1 \\
14 \\
13.7\end{array}$ & $\begin{array}{l}5 \\
<0.002 \\
<0.002 \\
<0.002\end{array}$ & $\begin{aligned} & 5 \\
< & 0.02 \\
& 0.1 \\
& 0.022\end{aligned}$ \\
\hline $9(F M)$ & $\begin{array}{l}\mathrm{N} \\
\text { Minimum } \\
\text { Maximum } \\
\text { Average }\end{array}$ & $\begin{array}{l}5 \\
<0.025 \\
<0.025 \\
<0.025\end{array}$ & $\begin{array}{l}5 \\
<0.0005 \\
<0.0005 \\
<0.0005\end{array}$ & $\begin{aligned} & 5 \\
&<0.005 \\
&<0.005 \\
&<0.005\end{aligned}$ & $\begin{array}{l}5 \\
<0.05 \\
<0.05 \\
<0.05\end{array}$ & $\begin{array}{l}5 \\
0.21 \\
0.89 \\
0.39\end{array}$ & $\begin{aligned} & 5 \\
< & 0.0002 \\
< & 0.0002 \\
< & 0.0002\end{aligned}$ & $\begin{array}{l}5 \\
<0.05 \\
<0.05 \\
<0.05\end{array}$ & $\begin{array}{c}5 \\
10.2 \\
11.1 \\
10.9\end{array}$ & $\begin{array}{l}5 \\
<0.002 \\
<0.002 \\
<0.002\end{array}$ & $\begin{array}{l}5 \\
<0.02 \\
0.095 \\
0.024\end{array}$ \\
\hline $102(F)$ & $\begin{array}{l}\mathrm{N} \\
\text { Minimum } \\
\text { Maximum } \\
\text { Average }\end{array}$ & $\begin{array}{l}2 \\
<0.025 \\
<0.025 \\
<0.025\end{array}$ & $\begin{array}{l}2 \\
<0.0005 \\
<0.0005 \\
<0.0005\end{array}$ & $\begin{array}{l}2 \\
<0.005 \\
<0.005 \\
<0.005\end{array}$ & $\begin{array}{l}2 \\
<0.05 \\
<0.05 \\
<0.05\end{array}$ & $\begin{array}{l}2 \\
3.8 \\
3.9 \\
3.8\end{array}$ & $\begin{array}{l}2 \\
<0.0002 \\
<0.0002 \\
<0.0002\end{array}$ & $\begin{array}{l}2 \\
0.47 \\
0.48 \\
0.48\end{array}$ & $\begin{array}{c}2 \\
14 \\
14.4 \\
14.2\end{array}$ & $\begin{aligned} & 2 \\
&< 0.002 \\
& 0.022 \\
& 0.011\end{aligned}$ & $\begin{array}{l}2 \\
0.06 \\
0.1 \\
0.08\end{array}$ \\
\hline $103(\mathrm{FJ})$ & $N$ & $\begin{array}{c}1 \\
<0.025\end{array}$ & $\begin{array}{c}1 \\
<0.0005\end{array}$ & $\begin{array}{c}1 \\
<0.005\end{array}$ & $\begin{array}{c}1 \\
<0.05\end{array}$ & $\begin{array}{l}1 \\
3.7\end{array}$ & $\begin{array}{l}1 \\
<0.0002\end{array}$ & $\begin{array}{l}1 \\
0.46\end{array}$ & $\begin{array}{c}1 \\
14.65\end{array}$ & $\begin{array}{c}1 \\
<0.002\end{array}$ & $\begin{array}{l}1 \\
0.03\end{array}$ \\
\hline $105(\mathrm{FL})$ & $\begin{array}{l}\mathrm{N} \\
\text { Minimum } \\
\text { Maximum } \\
\text { Average }\end{array}$ & $\begin{array}{l}5 \\
<0.025 \\
<0.025 \\
<0.025\end{array}$ & \begin{tabular}{r}
\multicolumn{1}{l}{5} \\
$<0.0005$ \\
0.0012 \\
$<0.0005$
\end{tabular} & $\begin{array}{l}5 \\
<0.005 \\
<0.005 \\
<0.005\end{array}$ & $\begin{aligned} & 5 \\
&< 0.05 \\
& 0.11 \\
& 0.05\end{aligned}$ & $\begin{aligned} & 5 \\
&< 0.075 \\
& 20.8 \\
& 4.7\end{aligned}$ & $\begin{aligned} & 5 \\
&< 0.0002 \\
&<0.0002 \\
&<0.0002\end{aligned}$ & $\begin{aligned} & 5 \\
&< 0.05 \\
& 0.07 \\
& 0.05\end{aligned}$ & $\begin{array}{c}5 \\
17.4 \\
18.8 \\
18.1\end{array}$ & $\begin{array}{l}\quad 5 \\
<0.002 \\
0.24 \\
0.05\end{array}$ & $\begin{array}{l}5 \\
0.024 \\
4.8 \\
1.3\end{array}$ \\
\hline NYSDWS & & 0.05 & 0.01 & 0.05 & 1.3 & 0.3 & 0.002 & 0.3 & (b) & 0.015 & 5 \\
\hline Typical MDL & & 0.025 & 0.0005 & 0.005 & 0.05 & 0.075 & 0.0002 & 0.05 & 1 & 0.002 & 0.02 \\
\hline
\end{tabular}

N: No. of samples

NYSDWS: New York State Drinking Water Standard

MDL: Minimum Detection Limit

(a): The location of potable and process wells is shown on Figure 6-11.

(b): No standard specified.

Compliance with the Safe Drinking Water Act is based on the analysis results obtained from an annual composite of four quarterly samples or the average of the analyses of four quarterly samples. Compliance is demonstrated if annual average gross alpha activity is less than 15 $\mathrm{pCi} / \mathrm{L}(0.6 \mathrm{~Bq} / \mathrm{L})$, gross beta activity is less than $50 \mathrm{pCi} / \mathrm{L}(1.9 \mathrm{~Bq} / \mathrm{L})$, strontium is less than 8 $\mathrm{pCi} / \mathrm{L}(0.3 \mathrm{~Bq} / \mathrm{L})$, and tritium is less than $20,000 \mathrm{pCi} / \mathrm{L}(740 \mathrm{~Bq} / \mathrm{L})$. All detected radionuclides combined must not cause a person consuming the water to receive an effective dose equivalent greater than $4 \mathrm{mrem}$ in a year. All of these criteria were satisfied. Therefore, in CY 1997, the $B N L$ portable water system was in full compliance with the radiological requirements of $40 \mathrm{CFR}$ 141.

Process wells 9, 102, and 105 showed radiological results throughout the year that were consistent with ambient environmental values. 
Table 8-4

BNL Site Environmental Report for Calendar Year 1997

Potable and Process Well Gross Activity and Tritium Results

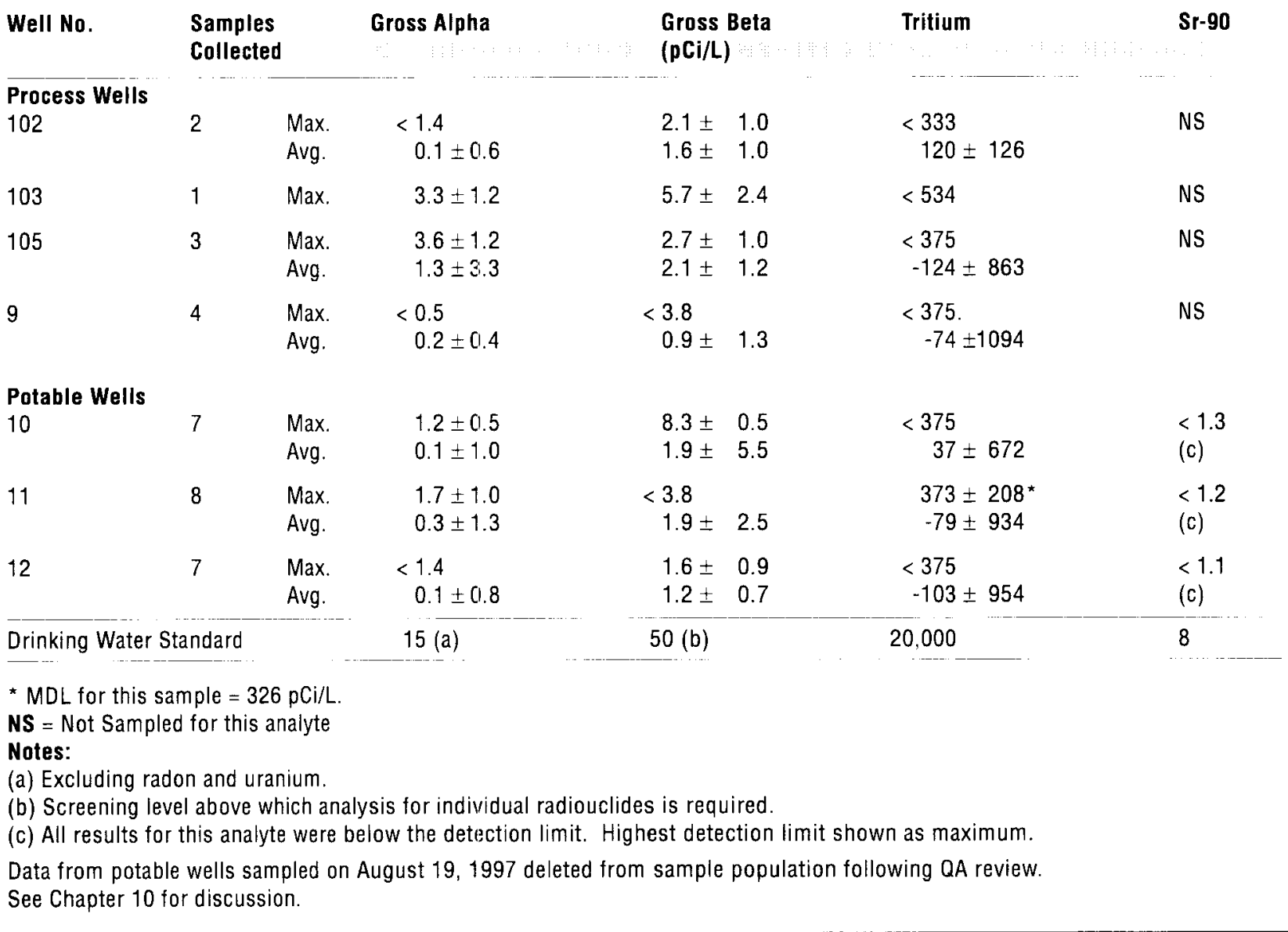

\subsubsection{Environmental Restoration (CERCLA) Groundwater Monitoring}

The BNL Environmental Restoration Division's Sitewide Groundwater Monitoring Program was established to integrate grourdwater sampling, and database activities required for the various CERCLA projects managed by ERD. The mission of ERD's Program is to monitor the various contaminant plumes both on- and off-site, as well as the effects of remedial actions on them. The ES\&HS Division is responsible for facility and regulatory compliance monitoring at BNL (see 8.1.3). The ES\&HS Division and ERD programs are coordinated to ensure completeness, and to prevent duplication of effort in sampling and analyzing the groundwater.

The long-term groundwater monitoring projects coordinated under the Sitewide Groundwater Monitoring Program are designed to address the following issues:

1. Pre-Record of Decision (ROD) Monitoring: Addresses the short-term monitoring of plumes to track their movement following the Remedial Investigation characterization and prior to remediation;

2. Post-Record of Decision (ROD) Monitoring: Addresses the long-term monitoring of plumes to track their movement following the initiation of remediation systems, including: 
a. Source Removal Effectiveness: Includes monitoring wells installed to verify that remediation projects, such as the capping of previously used landfills, are performing to specifications; and,

b. Treatment System/Hydraulic Containment Effectiveness: Includes monitoring the active pump-and-treat systems to verify that they are capturing and removing contaminants.

3. Outpost Monitoring: Samples the wells located downgradient of the leading edge of contaminant plumes to give early warning of the arrival of the leading edge of the plume.

Sections 8.1.2.1 and 8.1.2.2 are overviews of significant CERCLA groundwater monitoring and remediation activities for CY 1997. Detailed analytical results for each sample obtained under the Sitewide Groundwater Program are provided in the "1997 ERD Sitewide Groundwater Monitoring Report" (BNL, 1998).

For each significant contaminant source area and plume described below, groundwater contaminant distribution maps and cross sections are provided. These maps depict the areal extent of contamination, and were created by selecting the highest contaminant concentration for a given well cluster observed during a selected sample period. Associated cross sections show the vertical distribution/extent of contamination, as well as the hydrogeology. The cross sections are generally oriented through along the highest contaminant concentration sections of each plume. The position for each line of the cross section is identified on the corresponding plume maps.

A review of the groundwater data indicates that in most areas there was little overall change in contaminant distribution during CY 1997 in any of the plumes. However, slight decreases in VOC concentrations were observed near the OU III southern boundary, groundwater extraction well area. CY 1997 was the first full year of active CERCLA groundwater remediation activities, and it is expected that significant changes in plume distributions will be observed in future years as these remediation systems remove the contaminants from the groundwater. The locations of all BNL groundwater monitoring wells are shown in Figures 8-1 through 8-14. All wells sampled during CY 1997 are listed in Appendix D.

\subsubsection{Non-radiological Analyses}

This section is an overview of non-radiological groundwater contamination issues across the BNL site, typically VOCs. The 1997 ERD Sitewide Groundwater Monitoring Report (BNL, 1998) gives detailed information on these plumes.

\subsection{Site Background}

Ambient (or background) groundwater quality for the BNL site is monitored through a network of 13 wells located in the northern portion of the site and in off-site areas to the north. The site background wells provide information on the chemical and radiological composition of groundwater that has not been impacted by activities at BNL. These background data are a valuable reference for comparison with groundwater quality data from areas that have been affected. This well network also provides early warning of contaminants originating from potential upgradient sources of contamination.

There were no significant detections of VOCs in background wells. The highest concentration was tetrachloroethylene (PCE) at 1.4 micrograms per liter $(\mu \mathrm{g} / \mathrm{L})$ in well 017-03, a deep Upper Glacial aquifer well located in the northwest corner of the site. In previous years, both VOCs and nitrates were found at concentrations slightly above NYS AWQS in several background wells.

\subsection{Operable Unit I}

Former Landfill, Animal/Chemical Pits and Glass Holes: The Former Landfill area initially was used by the United States Army during World Wars I and II, then BNL used the southeast corner of the landfill from 1947 through 1966 to dispose of construction and demolition debris, sewage sludge, chemical and low-level radioactive waste, used equipment, and animal carcasses. From 


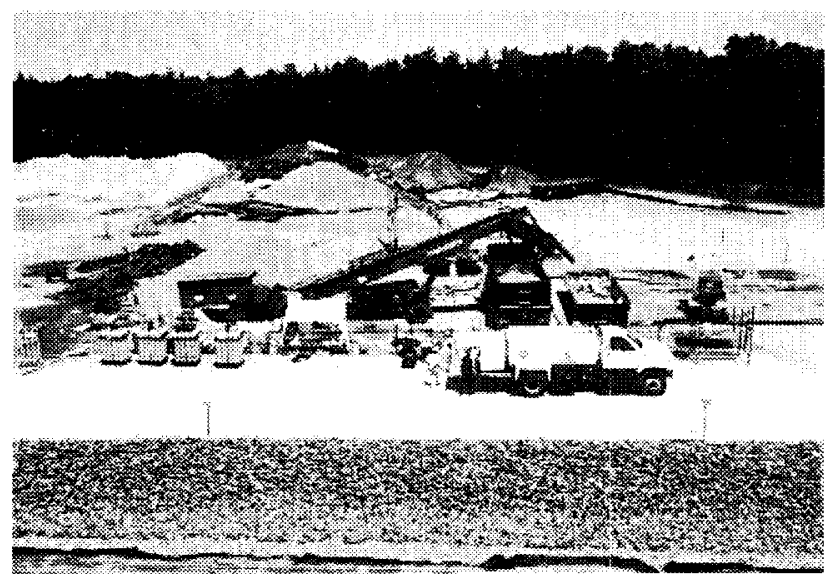

Animal Chemical Pits \& Glass Holes

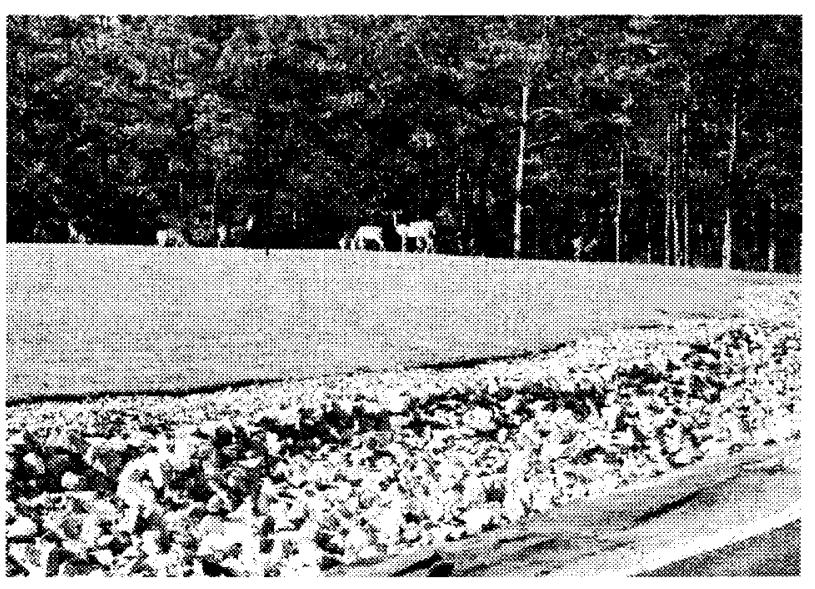

Former Landfill

1960 through 1966, Laboratory waste, glassware containing chemical and radioactive waste, and animal carcasses containing radioactive tracers were disposed of in shallow pits in an area directly east of the Former Landfill. From 1966 through 1981, the Laboratory continued to dispose of used glassware in shallow pits located directly north of these chemical/animal pits.

A network of seven monitoring wells is situated directly upgradient and downgradient of the Former Landfill. It was designed in accordance with post-closure operation and maintenance (O\&M) requirements specified in 6 NYCRR Part 360, "Solid Waste Management Facilities." These requirements specify that the well network be monitored quarterly for a minimum of five years, upon which BNL may petition the NYSDEC to modify the frequency and types of analyses based on supporting data. The objective of this program is to monitor radiological and non-radiological contamination in the shallow Upper Glacial aquifer immediately downgradient of the landfill. The program was initiated following the capping of the Former Landfill in November 1996, and will verify whether the cap effectively prevents the continued leaching of contaminants from the landfill, and anticipated long-term improvements to groundwater quality occur. In addition to these seven wells, BNL established a separate well network to monitor the Animal/ Chemical Pits and Glass Holes areas and the downgradient portions of the Former Landfill plume, and plumes originating from the Animal/Chemical Pits and Glass Holes areas. The downgradient portions of these plumes are currently being monitored as part of the OU I/IV Pre-ROD Monitoring Program.

The primary chemical contaminants observed in the Former Landfill - Animal/Chemical Pits and Glass Holes plume are carbon tetrachloride (CT), 1,1,1-trichloroethane (TCA), 1,1-dichloroethylene (DCE), trichloroethylene (TCE), and chloroform. All of these constituents are observed in wells extending from the source area to the southern site boundary at concentrations generally less than $20 \mu \mathrm{g} / \mathrm{L}$ total concentration VOCs (TVOCs). The New York State Ambient Water Quality Standards (NYS AWQS) for CT, TCA, DCE, and TCE is $5 \mu \mathrm{g} / \mathrm{L}$, whereas the standard for chloroform is $7 \mu \mathrm{g} / \mathrm{L}$. The same constituents are also found south of the site boundary, to just beyond Moriches Middle Island Road in North Shirley. Figure 8-15 depicts the extent of TVOC contamination (as defined by the $5 \mu \mathrm{g} / \mathrm{L}$ TVOC iso-concentration contour). The plume is approximately 3,500 feet at its maximum width. The higher concentration segment of the plume $(>50 \mu \mathrm{g} / \mathrm{L})$ is approximately 1,600 feet wide (Figure 8-15). The area of the plume showing the highest TVOC concentration is off-site. This area of the plume is composed primarily of CT, with a TVOC concentration of $825 \mu \mathrm{g} / \mathrm{L}$ observed in October 1997.

The distribution of VOC contamination with depth is shown on Figure 8-16. In general, VOCs are found in the shallow portions of the Upper Glacial aquifer in the vicinity of the Former Landfill, Animal/Chemical Pits and Glass Holes area. As the contamination migrates southward, it moves into the middle Upper Glacial at the site boundary, and the deep Upper Glacial aquifer off-site in North Shirley. 
GROUNDWATER PROTECTION

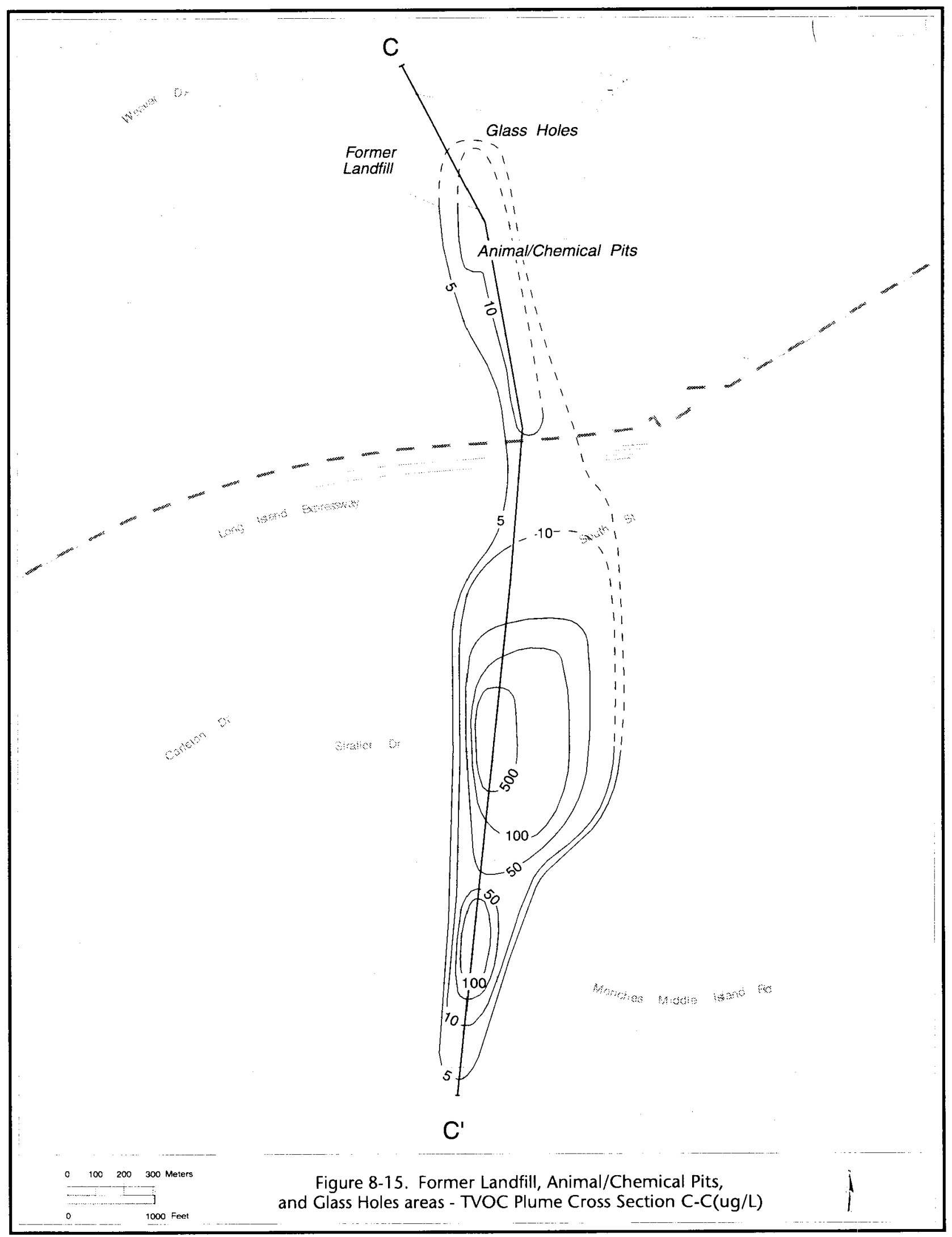

8 - 241997 BNL Site Environmental Report 


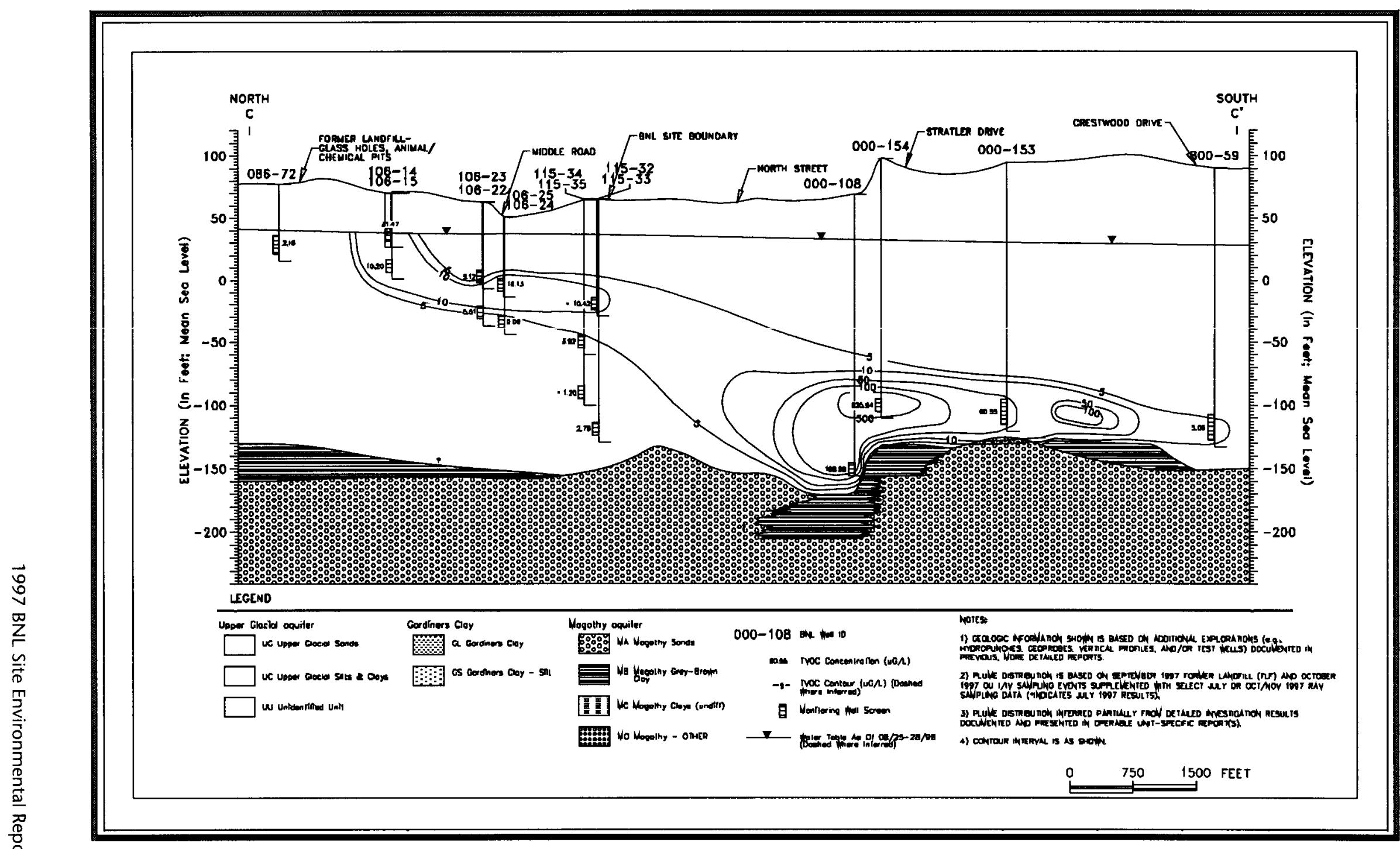

Figure 8-16. Former Landfill, Animal/Chemical Pits, and Glass Holes areas TVOC plume cross section C-C (ug/L) 


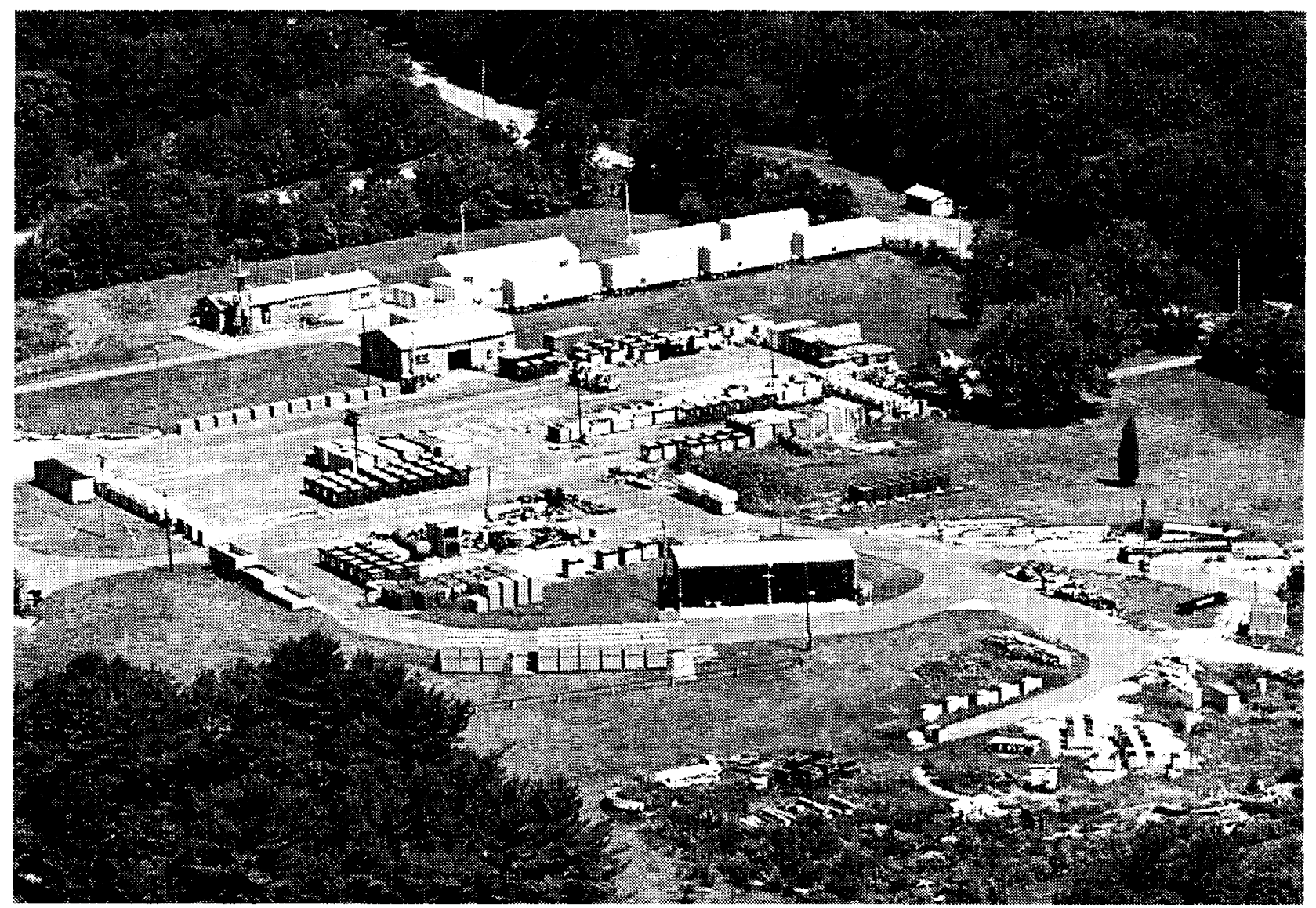

Old Hazardous Waste Management Facility

Figure 8-17 shows the trend in VOC concentration for two key wells (000-108 and 000-154) located off-site in the high concentration portion of the plume. Data from well 000-108 indicates a general increase with time. The Former Landfill - Animal/Chemical Pits and Glass Holes plume characterization is ongoing, and additional monitoring wells will be installed during CY 1998.

Current Landfill Area: The "Current" Landfill operated from 1967 through 1990, when it was closed in accordance with the Long Island Landfill Law. It was used to dispose of putrescible garbage, sludge containing precipitated iron from the potable WTP, and anaerobic digester sludge from the STP. The latter contained low concentrations of radionuclides, and possibly metals and organic compounds. The Laboratory also disposed of limited quantities of laboratory wastes containing radioactive and chemical material at the landfill. As a result, the Current Landfill is a source of groundwater contamination. Permanent closure (i.e., capping) of this landfill was completed in November 1995 as part of the CERCLA Program.

The Current Landfill Post-Closure Monitoring Program consists of a network of 11 monitoring wells situated adjacent to the landfill in both upgradient and downgradient locations. These wells are monitored quarterly, and will be used to determine the cap's effectiveness in preventing the continued leaching of contaminants from the landfill, and to document the anticipated longterm improvements to groundwater quality. The monitoring well network was designed in accordance with post-closure O\&M requirements specified in 6 NYCRR Part 360, "Solid Waste Management Facilities." These requirements specify that the well network be monitored quarterly for a minimum of five years, upon which BNL may petition the NYSDEC to modify the frequency and types of analyses based on supporting data.

During CY 1997, VOCs were consistently detected in wells located downgradient of the Current Landfill (see Figures 8-18 and 8-19), including chloroethane, benzene, and DCA. Chloroethane 


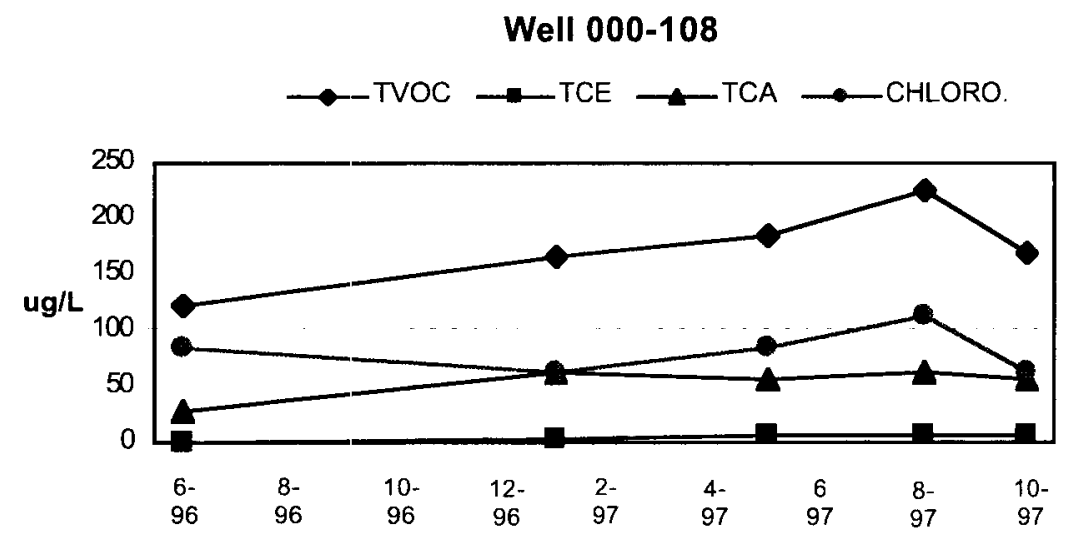

Well 000-154

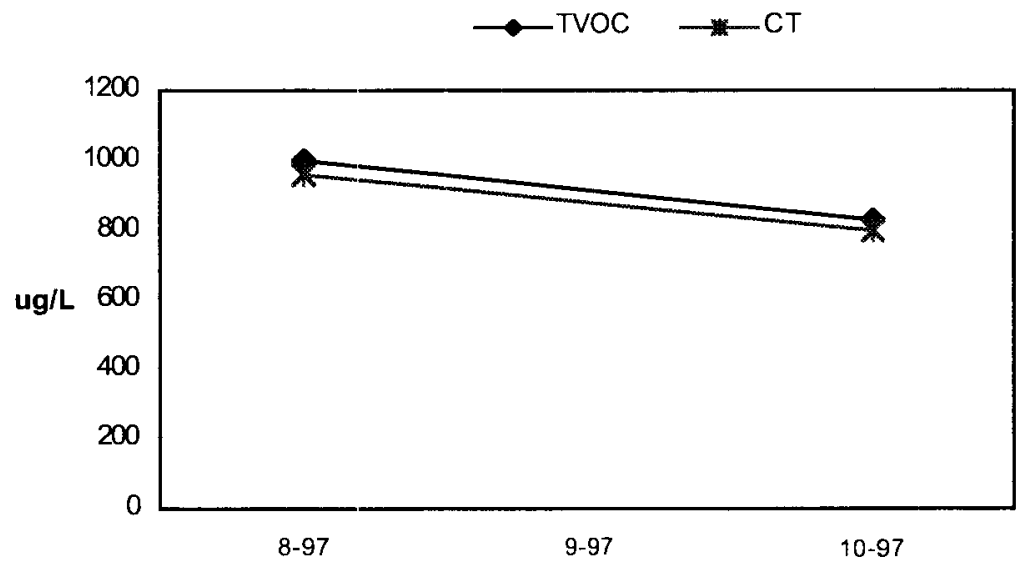

Figure 8-17. Time-vs.-VOC concentration trend plots for selected off-site wells in the Former Landfill Plume: well 000-108 located on North Street approximately $900 \mathrm{~m}$ south of Long Island Expressway; and well 000-154 located on Sleepy Hollow Drive approximately $900 \mathrm{~m}$ south of the Long Island Expressway.

was detected at concentrations exceeding the NYS AWQS of $5 \mu \mathrm{g} / \mathrm{L}$ in monitoring wells 087-11, $087-27,087-23,088-22,088-23,088-109$, and $088-110$, with a maximum concentration of 350 $\mu \mathrm{g} / \mathrm{L}$ detected in well 088-22. Benzene was found in monitoring wells 087-11, 087-23, 088-22, 088-109, and 088-110 at concentrations exceeding the NYS AWQS of $0.7 \mu \mathrm{g} / \mathrm{L}$, with a maximum concentration of $5 \mu \mathrm{g} / \mathrm{L}$ detected in well 087-11. DCA was detected in monitoring wells 088-109 and 088-22 at concentrations exceeding the NYS AWQS of $5 \mu \mathrm{g} / \mathrm{L}$, with a maximum concentration of $81 \mu \mathrm{g} / \mathrm{L}$ detected in well 088-22. The only other VOC exceeding the NYS AWQS (of $5 \mu \mathrm{g} / \mathrm{L})$ was toluene, which ranged from $1 \mu \mathrm{g} / \mathrm{L}$ to $130 \mu \mathrm{g} / \mathrm{L}$. 
HWMF Plume and (Downgradient) Current Landfill Plume (Removal Action V): Groundwater contamination originating from the HWMF and the downgradient section of the Current Landfill plume is being monitored under the Removal Action V (RA V) Program. As noted above, the Current Landfill was capped in November 1995. Until 1997, the HWMF was BNL's central RCRA receiving facility for processing, neutralizing, and storing hazardous and radioactive wastes before off-site disposal. As the result of past waste handling and storage practices, the soil and groundwater at the HWMF have become contaminated with both chemical and radionuclides at concentrations that exceed NYS AWQS.

The RA V monitoring program uses a network of 51 monitoring wells located in areas downgradient of the Current Landfill and HWMF. The RA V monitoring program is specifically designed to address the following issues on groundwater contamination and plume remediation:

- Monitoring of VOC and radiological contamination of groundwater in the shallow zone of the Upper Glacial aquifer at, and immediately adjacent to, the HWMF;

- Monitoring of VOC and radiological contaminant plumes located south of the Current Landfill and HWMF that have been commingled due to the effects of the former Spray Aeration Groundwater Remediation System, which was located to the south of the HWMF; and,

- Evaluating the effectiveness of the RA V groundwater pump-and-treat system that was initiated in December 1996 at the southern site boundary using wells EW-1 and EW-2. The monitoring program will characterize the effects of this treatment system on the contaminant plume, and provide data necessary to make decisions on the future operations of the system.

The RA V system is remediating groundwater contamination that originates from the Current Landfill and the former HWMF. Contaminant plumes from these two sources became commingled south of the HWMF due, at least partially, to the effects of the Former Spray Aeration System, which operated from 1984 to 1990 . The primary chemical contaminants found in the Current Landfill/HWMF plume are chloroethane, TCA, and DCA (on-site) and TCE in off-site areas. The areal extent of VOC contamination is shown on Figure 8-18. The Current Landfill/HWMF plume (as defined by the $5 \mu \mathrm{g} / \mathrm{L}$ iso-concentration contour) extends from the Current Landfill and HWMF areas south to an area approximately 1,500 feet south of South Street (a distance of approximately 7,000 feet). The maximum width of the plume is about 1,700 feet wide. And the width of its higher concentration portions ( $>50 \mu \mathrm{g} / \mathrm{L}$ TVOCs) is about 600 feet. Two areas of the plume display TVOC concentrations of $>200 \mu \mathrm{g} / \mathrm{L}$; the first is immediately downgradient of the Current Landfill, and the second is off-site, south of the Long Island Expressway (Figure 8-18).

The vertical distribution of VOCs is shown on Figure 8-19. Chloroethane, TCA, and DCA are found in the shallow portions of the Upper Glacial aquifer near the source areas and in the deep Upper Glacial aquifer at the site boundary and off-site. TCA, DCE, TCE and chloroform are found in the middle to deep Upper Glacial aquifer off-site, south of North Street.

Figure 8-20 shows trends in VOC concentration for key wells located near the source areas, at the southern site boundary in the vicinity of the RA V Remediation Extraction wells, and off-site. The effects of the groundwater extraction system are reflected in declining VOC concentrations in monitoring wells located at the site boundary.

\subsection{Operable Unit III}

The monitoring well network established to monitor the OU III VOC and radionuclide source areas and resulting contaminant plumes is composed of approximately 90 monitoring wells positioned from the north-central portion of the site to the southern site boundary and off-site. The OU III groundwater-monitoring program is specifically designed to address the following groundwater contamination issues and plume remediation:

- Monitor VOC plumes with identified or suspected sources in the AGS Complex, Paint Shop, Building 96 area, and the Supply and Materiel area. These plumes extend from the 
GROUNDWATER PROTECTION

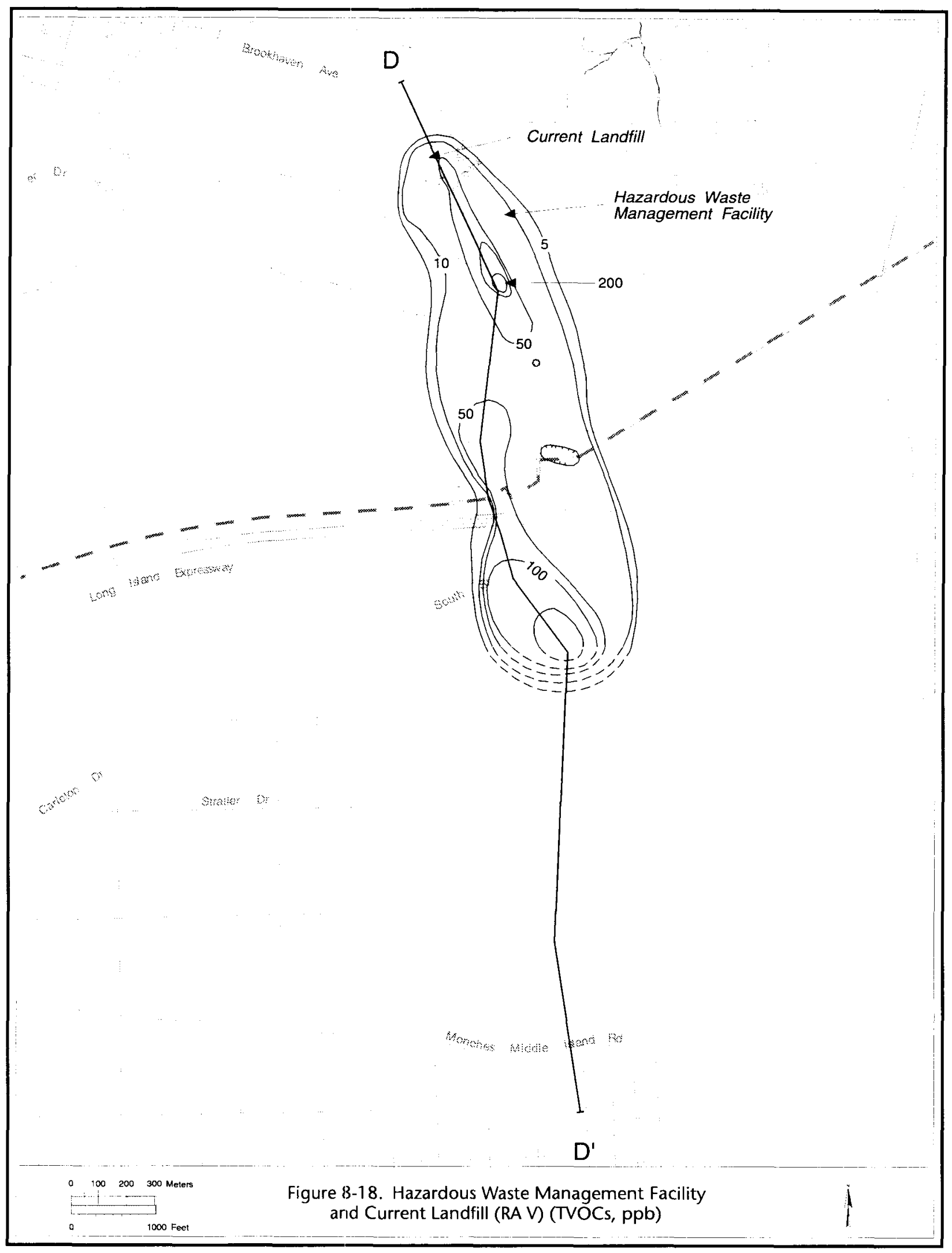

1997 BNL Site Environmental Report $\quad 8$ - 29 


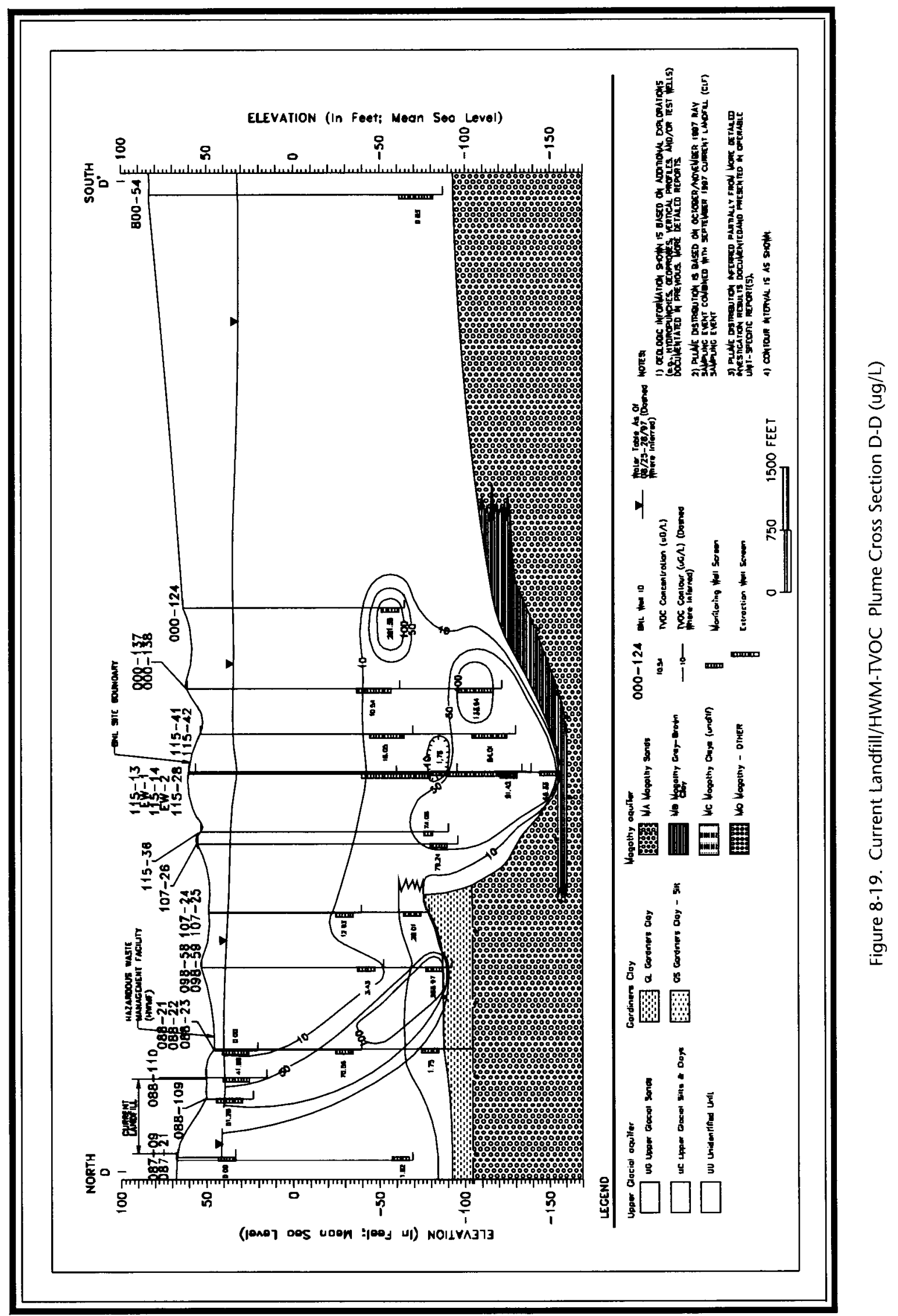


Well 88-22

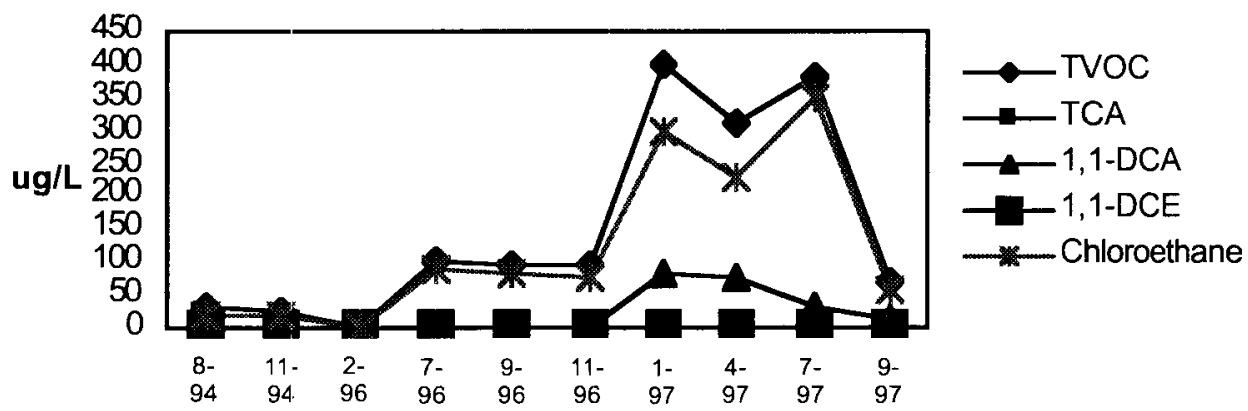

Well 88-109
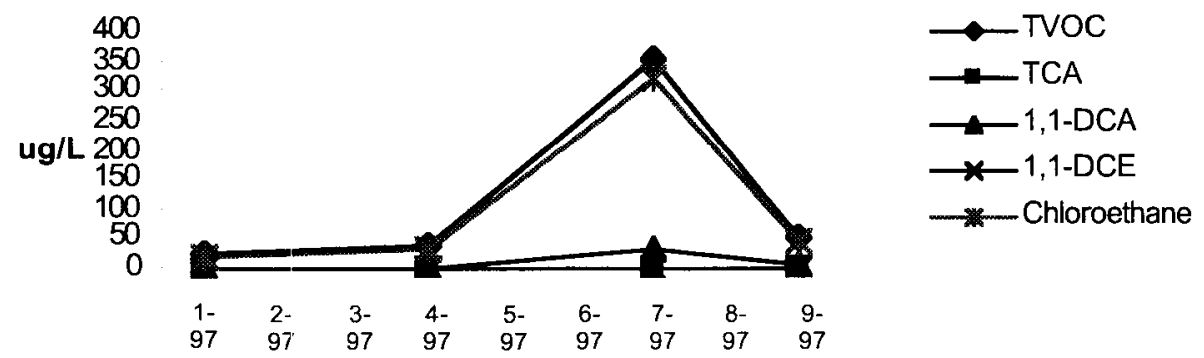

Well 115-36
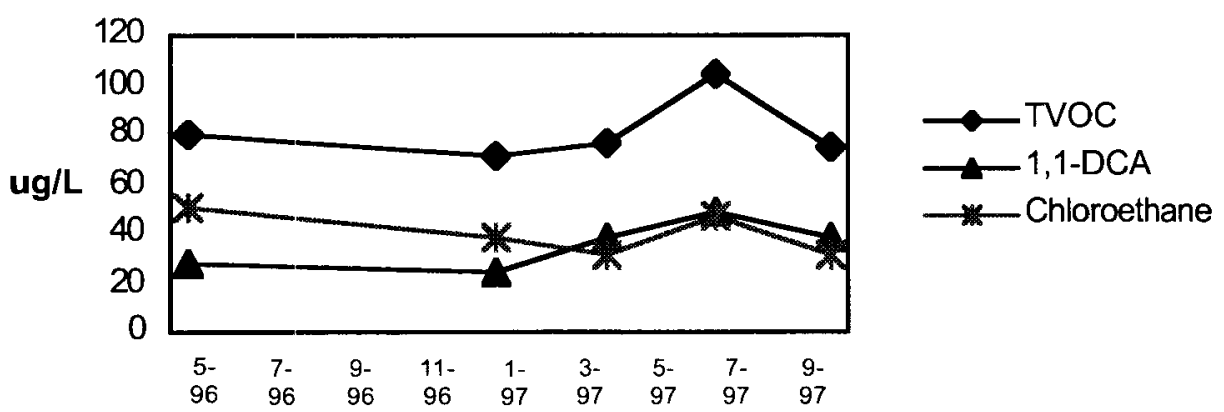

Well 000-124

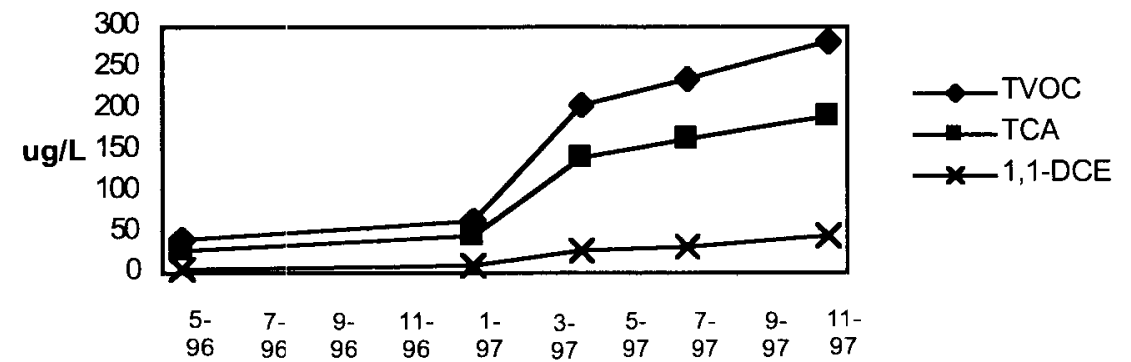

Figure 8-20. Time-vs. VOC concentration trend plots for selected wells in the Current Landfill/ HWMF TVOC plume: well 88-109 located directly downgradient of landfill; well 88-22 located 120m downgradient of landfill; well 115-36 located approximately $900 \mathrm{~m}$ downgradient of landfill near the southern boundary; and well 000-124 located off-site approximately 500m south of the Long Island Expressway. 
north-central portion of the site to south of the site boundary and then into North Shirley (Figures 8-21 and 8-22). The plumes become deeper as the distance from the source areas increases. Plumes at the southern site boundary and off-site are in the deep portion of the Upper Glacial aquifer and the upper portion of the Magothy aquifer;

- Evaluate the effectiveness of the OU III south boundary groundwater pump-and-treat system initiated in May 1997 (extraction wells EW-3 through EW-8). The monitoring program will characterize the effects of this pumping on the contaminant plume and provide data that are necessary for making decisions on the future operations of the extraction wells; and,

- Monitor "outpost" wells located to the south (downgradient) of the defined extent of the off-site VOC plume to provide data on the future downgradient migration of the plume. Outpost wells are also situated in the southeastern portion of BNL, directly upgradient of the SCWA Parr Village Well Field on William Floyd Parkway. These wells are used to verify groundwater quality south of the BNL Apartment areas, and they would also provide an early warning of potential contaminant migration towards the SCWA well field.

The OU III "plume" is composed of multiple commingled plumes, some of which can be traced directly to their source area. Some identified sources that were evaluated during the OU III RI/FS include spill areas within the AGS Complex, former Building 96 area (a former vehicle maintenance area), and Building 208 located within the Supply and Materiel Facility area. Figure 8-21 depicts the OU III "TVOC" contamination plume. The primary OU III VOCs detected in on-site monitoring wells include CT, TCA, and PCE, whereas CT is the primary VOC in off-site wells. The OU III plume extends from the AGS Complex in the north-central part of the site southward to the vicinity of Flower Hill Drive in North Shirley (approximately 17,000 feet). The plume is about 5,000 feet wide at its maximum, as defined by the $5 \mu \mathrm{g} / \mathrm{L}$ isoconcentration contour on Figure 8 21 . The width of the high concentration portion of the plume (i.e., $>50 \mu \mathrm{g} / \mathrm{L}$ ), which appears to have originated from the former Building 96 vehicle maintenance area, is approximately 1,800 feet at the site boundary. The area defined by the $5 \mu \mathrm{g} / \mathrm{L}$ isoconcentration line should not be interpreted to mean that there is continuous VOC contamination from the western $5 \mu \mathrm{g} / \mathrm{L}$ line eastward to the central core of the OU III plume. In actuality, the plume is comprised of low concentration VOC contamination occurring discontinuously in this area.

Figure 8-22 is a cross sectional view of the OU III plume. Some of the highest VOC concentrations are found near the former Building 96 vehicle maintenance area. This plume is composed primarily of PCE and lower levels of TCA, with TVOC concentrations ranging from 1,000 to slightly more than 5,000 $\mu \mathrm{g} / \mathrm{L}$. In general, PCE and TCA are observed in the shallow portions of the Upper Glacial aquifer in the central portion of OU III and in the deep Upper Glacial aquifer at the southern site boundary and off-site.

The plume from the Building 96 area appears to be traceable to the southern boundary, where TVOC concentrations of $>500 \mu \mathrm{g} / \mathrm{L}$ have been detected. TVOC concentrations greater than $1,000 \mu \mathrm{g} / \mathrm{L}$ were detected in the vicinity of off-site well 000-130 located near Carleton Drive. However, in this case the primary contaminant of concern is CT. As depicted in Figure 8-22, CT contamination is also found in the upper portion of the Magothy aquifer; its extent there is not well defined, and additional characterization is necessary.

As depicted in Figure 8-23, VOC concentration trends in wells located near identified source areas in the central portion of the OU III area (e.g., wells 64-03, 65-03, 96-07 and 105-23) are showing either a fluctuating or slightly decreasing concentration. In Figure 8-24, VOC concentrations appear to be decreasing in wells located near the southern boundary extraction system (e.g., wells 121-10 and 121-14), which could be attributed to the actions of the OU III groundwater treatment system.

The OU III monitoring wells are also sampled and analyzed for radiological contaminants such as strontium-90 which has been found in the groundwater extending south from the WCF, Pile Fan Sump, and Brookhaven Graphite Research Reactor (BGRR) areas, and tritium from the HFBR (see Section 8.1.2.2). 


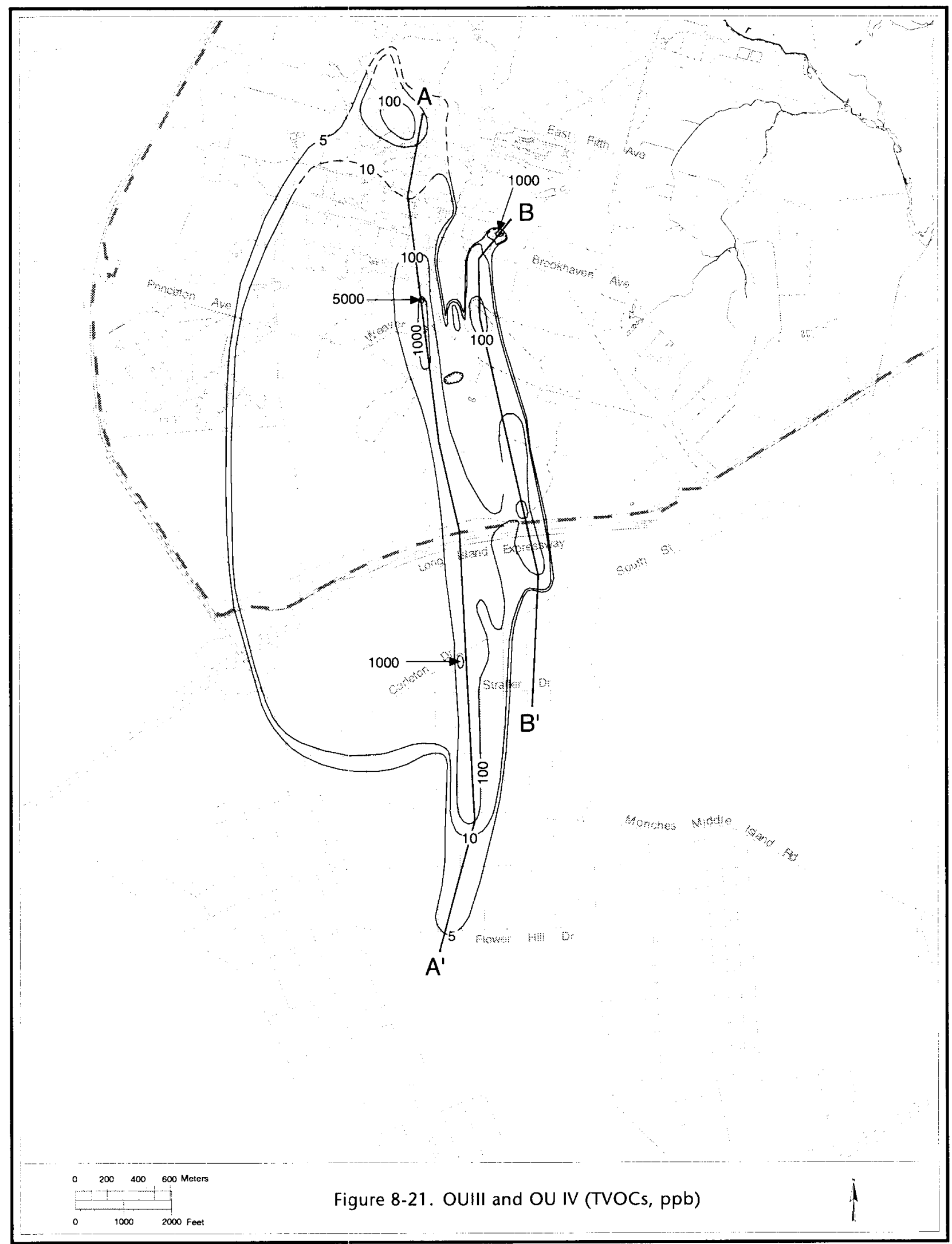




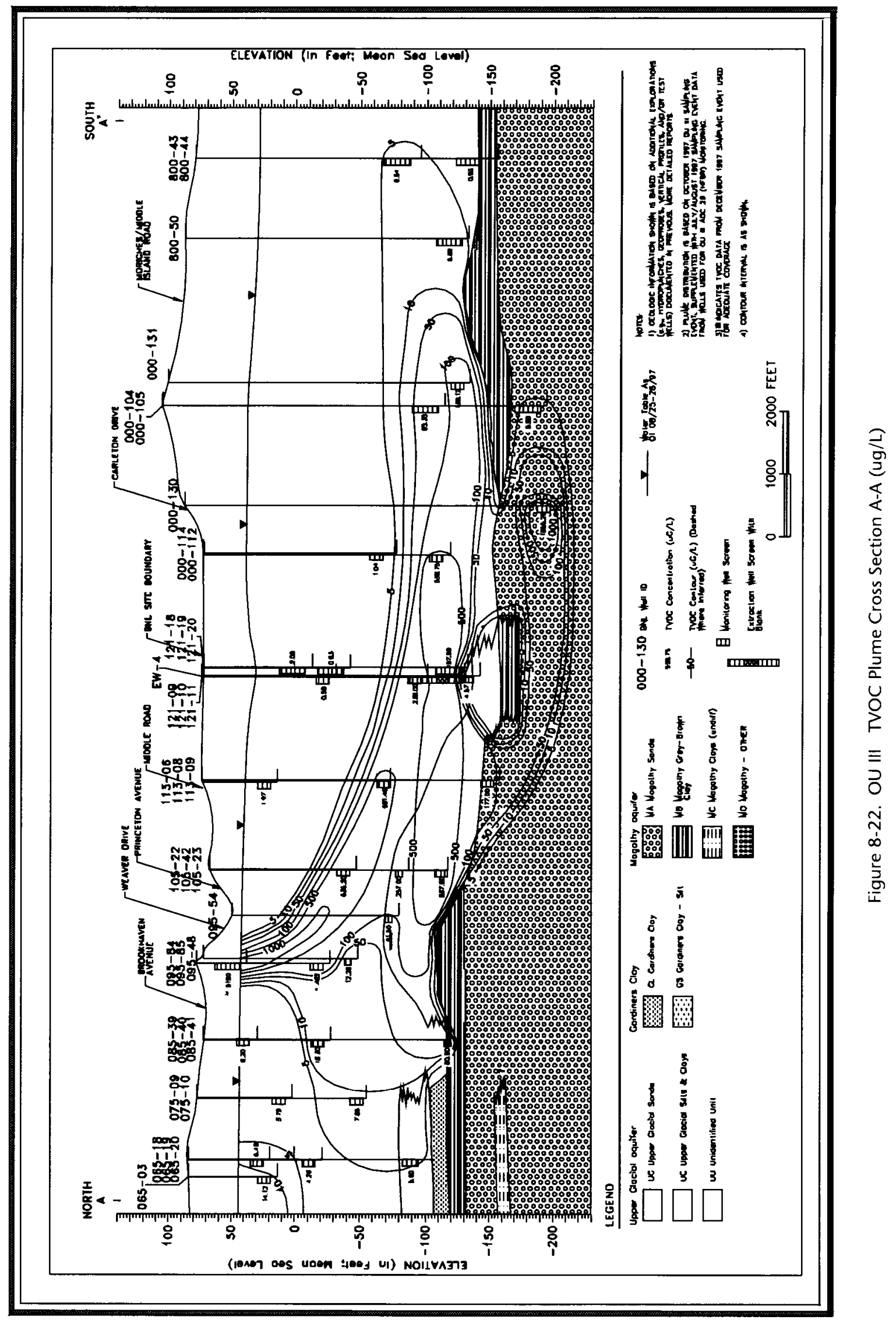


Well 64-03

Well 65-03
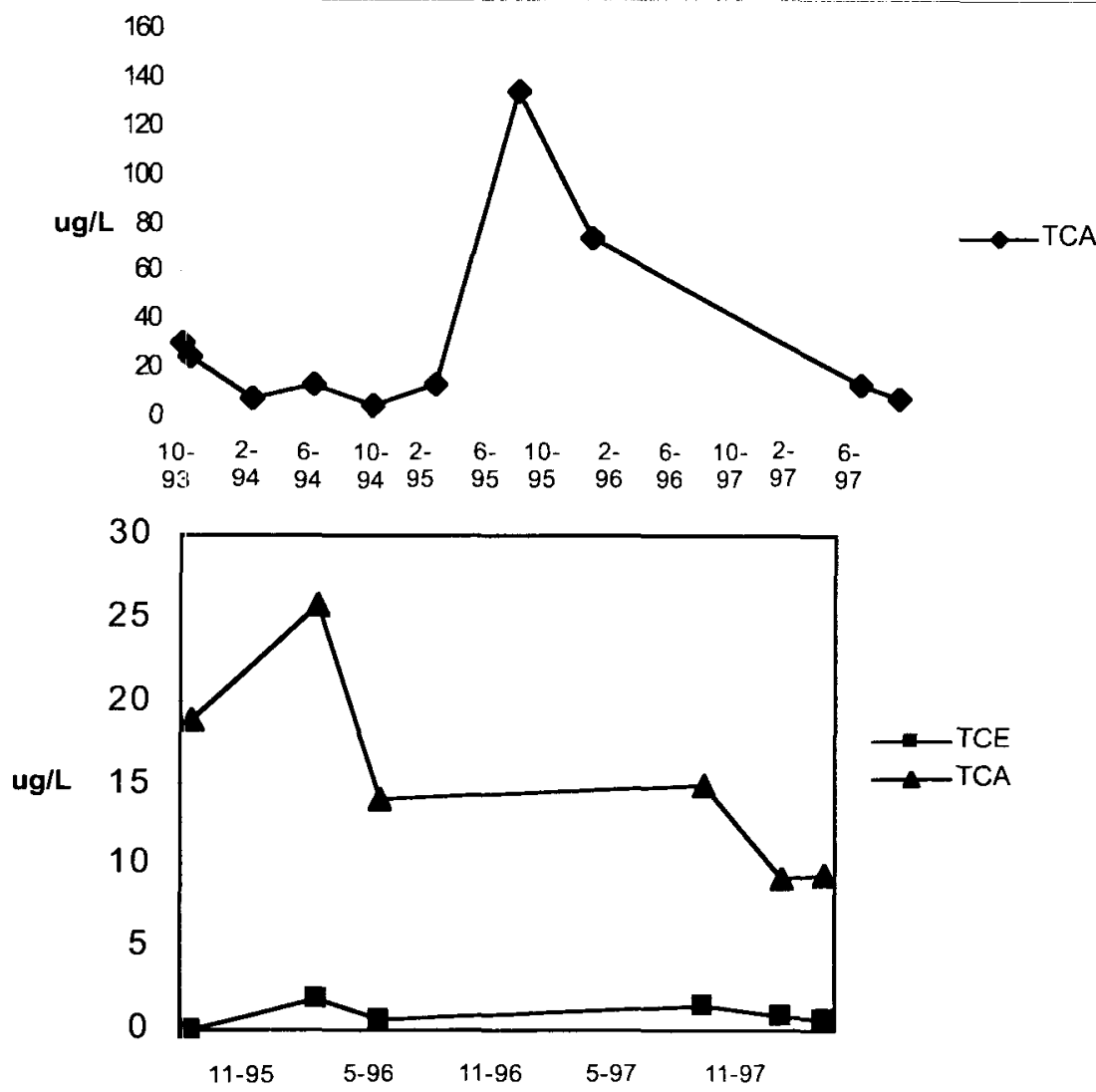

Well 96-07

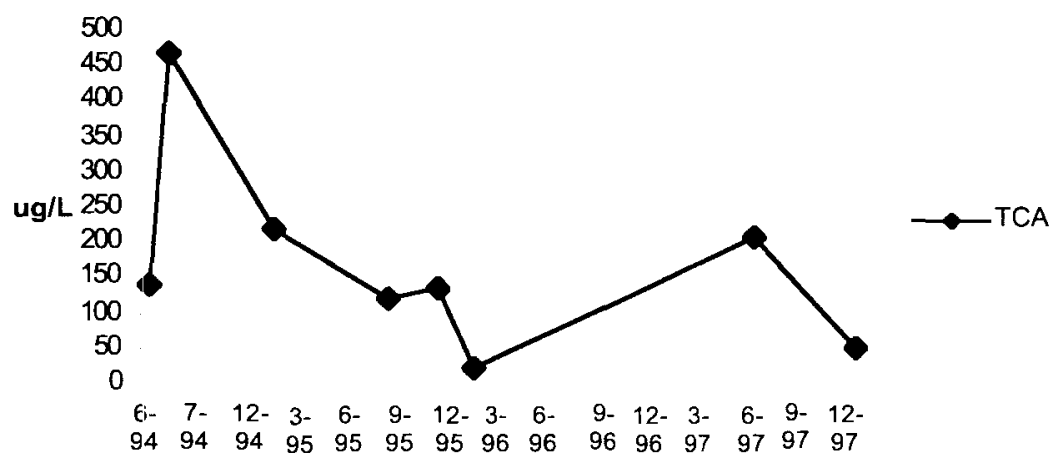

Well 105-23

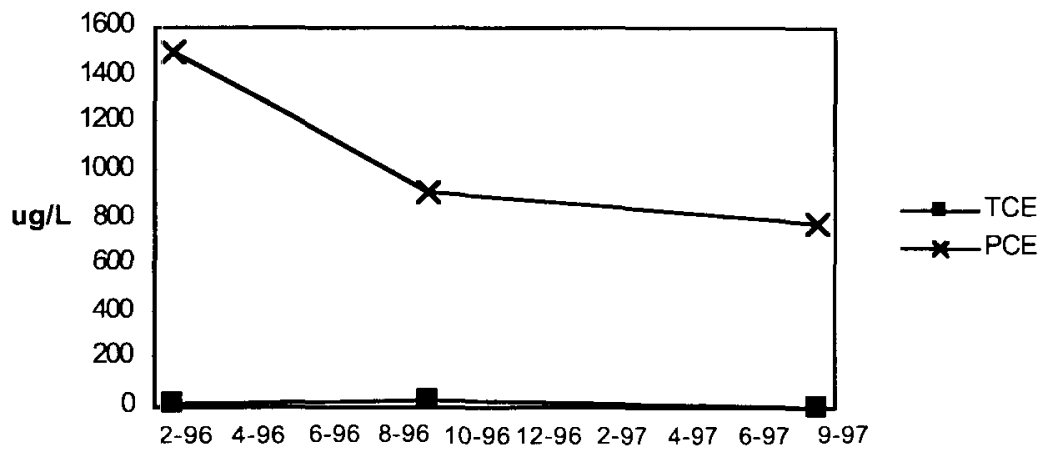

Figure 8-23. Time-vs.-VOC concentration trend plots for selected wells in the OU III Plume (Central Area): well 64-03 located within the ACS area; well 65-03 located downgradient of the AGS area; well 96-07 located downgradient of Supply and Materiel Building 208; and well 105-23 located near East Princeton Avenue. 
Well 121-10

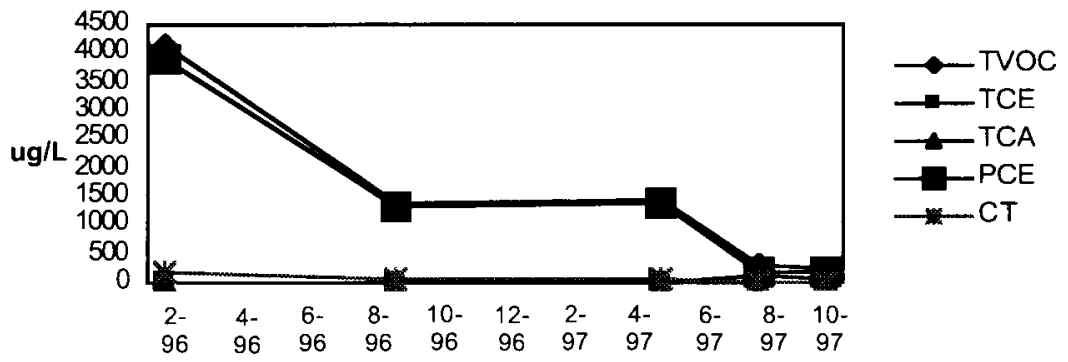

Well 121-14

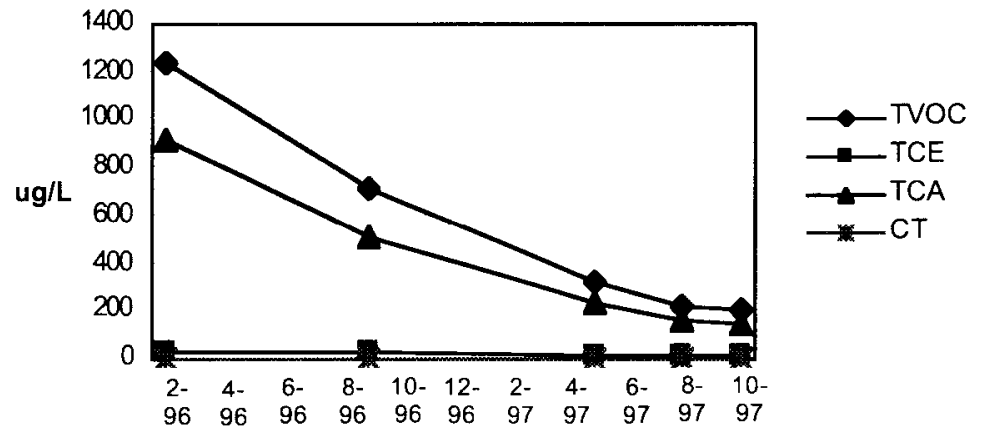

Well 000-112

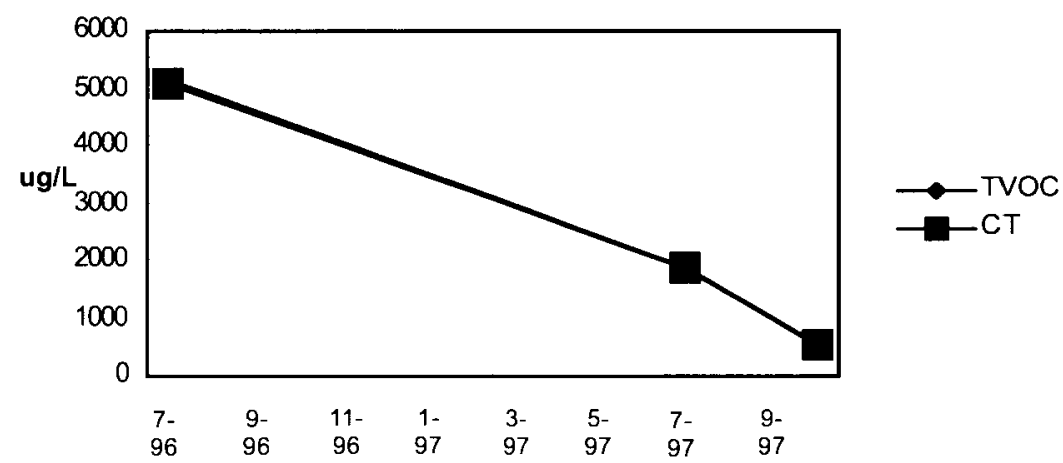

Well 000-130

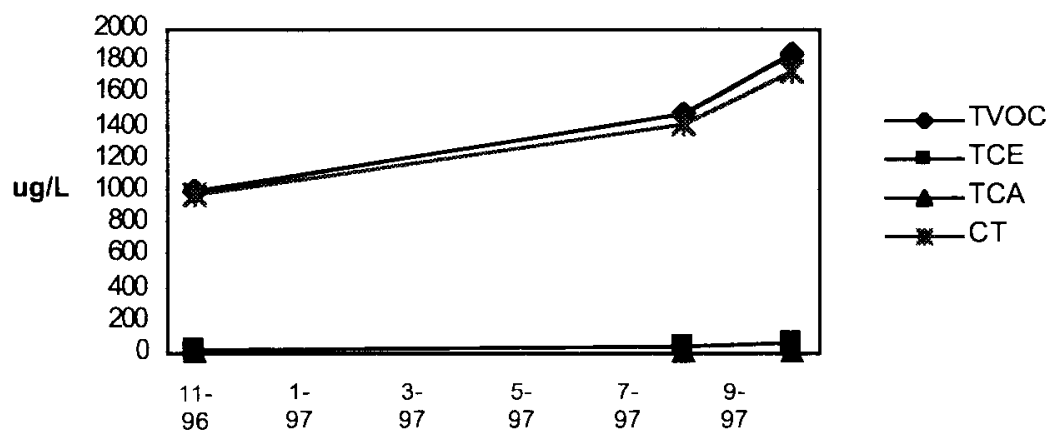

Figure 8-24. Time-vs.-VOC concentration trend plots for selected wells in the OU III Plume (south boundary and off-site): wells $121-10$ and 121-14 located near the southern boundary; off-site well 000-112 located $400 \mathrm{~m}$ south of the Long Island Expressway in the Brookhaven Industrial Complex; and off-site well 000-108 located on Carleton Drive. 


\subsection{Operable Unit IV}

In 1977 , a mixture of 23,000 to 25,000 gallons of Number 6 fuel oil and mineral spirits was released from a ruptured pipe used to transfer the contents from an underground storage tank to above ground storage tanks at the BNL Central Steam Facility (CSF). In addition, several small spills of Number 6 fuel oil from the CSF fuel unloading area were documented between 1988 and 1993, and it is suspected that small volumes of solvents, such as PCE, have been released to the ground in the vicinity of the CSF.

Contamination originating from the Central Steam Facility area is currently monitored under two programs: the OU IV 1977 spill area cleanup program (AOC 5); and the OU I/VI Program which monitors the downgradient (south of Brookhaven Avenue) component of the OU IV plume.

1977 Spill Site (AOC 5): The OU IV AOC 5 Program consists of 18 wells located in close proximity to the source area. These wells are used to assess the effects of the OU IV Air Sparge/Soil Vapor Extraction Remediation System that was started in November 1997 to remediate soils and groundwater near the 1977 spill site. The primary contaminants found in groundwater near the 1977 spill site are toluene, ethylbenzene, xylenes (total), TCA, PCE, DCE, and TCE. Total VOC concentrations in some wells can be as much as $4,000 \mu \mathrm{g} / \mathrm{L}$. The toluene, ethylbenzene, and xylene components of the plume are highly localized to the spill area and directly downgradient of it. Figure 8-21 shows the extent of OU IV VOC contamination.

Downgradient Portion of the OU IV Plume: The OU I/IV Groundwater Monitoring Program consists of 28 monitoring wells located downgradient of OU IV source areas southward to the site boundary and off-site. This program was initiated during 1997, and will provide groundwater quality data from key wells until the completion of the OU III FS under which plumes monitored by this program will ultimately be addressed. The wells are monitored quarterly.

The OU IV plume extends from the CSF/1977 Waste Oil Solvent Spill area in the north to an offsite area between the southern site boundary and Carleton Drive (a total distance of approximately 7,500 feet) (Figure 8-21). The plume is approximately 900 feet wide, as defined by the $5 \mu \mathrm{g} / \mathrm{L}$ isoconcentration contour. The higher concentration segment of the plume $(>50 \mu \mathrm{g} / \mathrm{L})$ is approximately 700 feet wide.

Figure 8-21 shows several areas of high VOC contamination (> $100 \mu \mathrm{g} / \mathrm{L}$ TVOC). Definition of these high concentration areas is based primarily upon data from temporary vertical profile wells rather than permanent monitoring wells. Additional permanent wells will be installed to provide long-term monitoring coverage of these high concentration portions of the plume. One of the areas containing the highest VOC concentrations is the 1977 Spill site, which consists primarily of ethylbenzene, toluene, and xylene, TCA, PCE, DCE, and TCE at concentrations ranging up to $4,000 \mu \mathrm{g} / \mathrm{L}$ TVOC. The highest VOC levels in the southern portion of the plume are found in wells located at the southern site boundary, consisting primarily of TCA, DCE and TCE up to $2,240 \mu \mathrm{g} / \mathrm{L}$ TVOC.

The vertical distribution of TVOC contamination is shown on Figure 8-25. In general, VOCs are present in the shallow sections of the Upper Glacial aquifer near the source area, and in the deep Upper Glacial aquifer and upper Magothy aquifer at the southern site boundary and just off-site respectively. Figure 8-26 depicts VOC concentration trends for southern boundary wells 122-04, 122-19 and 122-22.

\subsection{Operable Unit $v$}

The Sewage Treatment Plant processes sanitary sewage for BNL facilities. The treatment includes primary clarification to remove settleable solids and floatable materials, aerobic oxidation for secondary removal of biological matter and nitrification of ammonia, secondary clarification, sand filtration for final effluent polishing, and ultraviolet disinfection for bacterial control prior to discharge into the Peconic River. Approximately $15 \%$ of the water released to the filter beds is either lost to evaporation or to direct groundwater recharge; the remaining water is discharged to the Peconic River. This discharge is regulated under a NYSDEC SPDES permit. Past radiological 


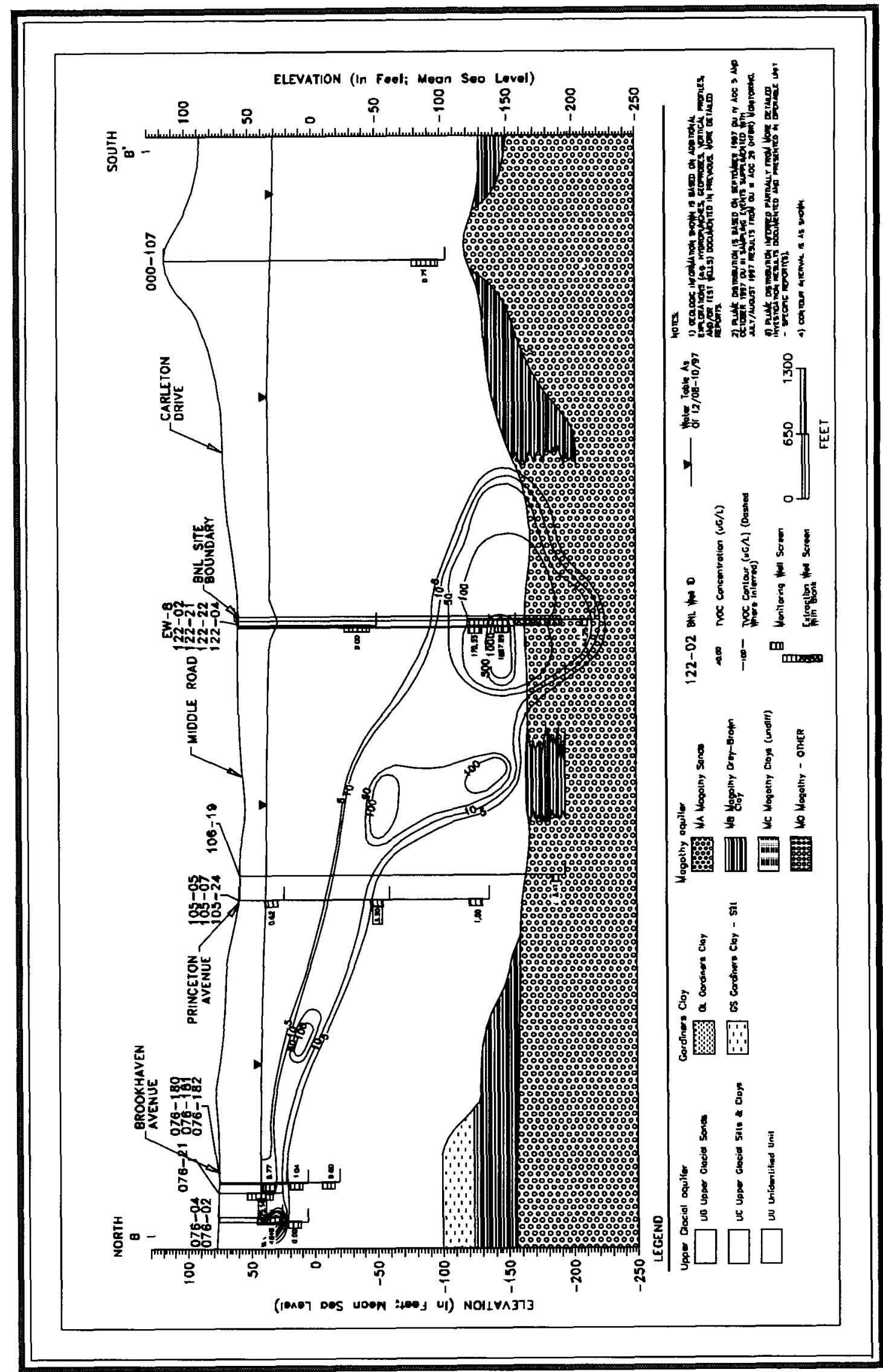

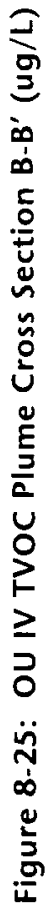


Well 122-04

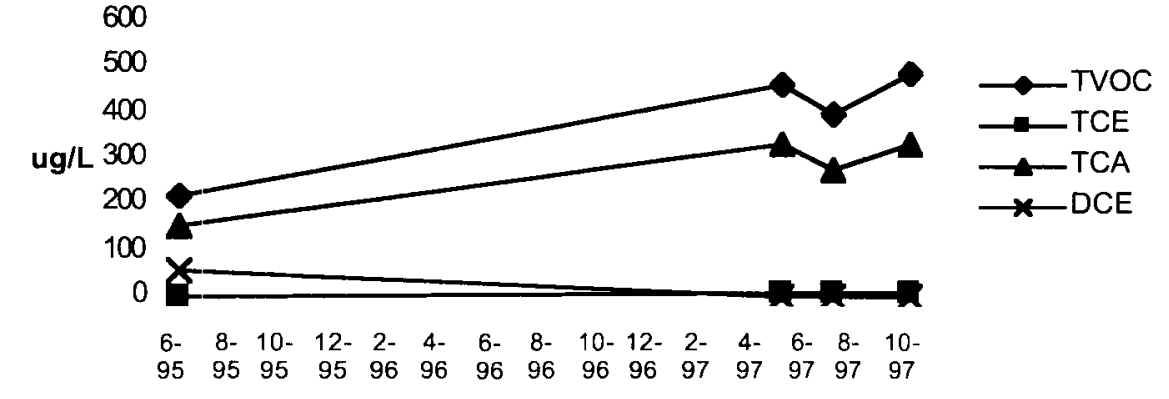

Well 122-19

Well 122-22
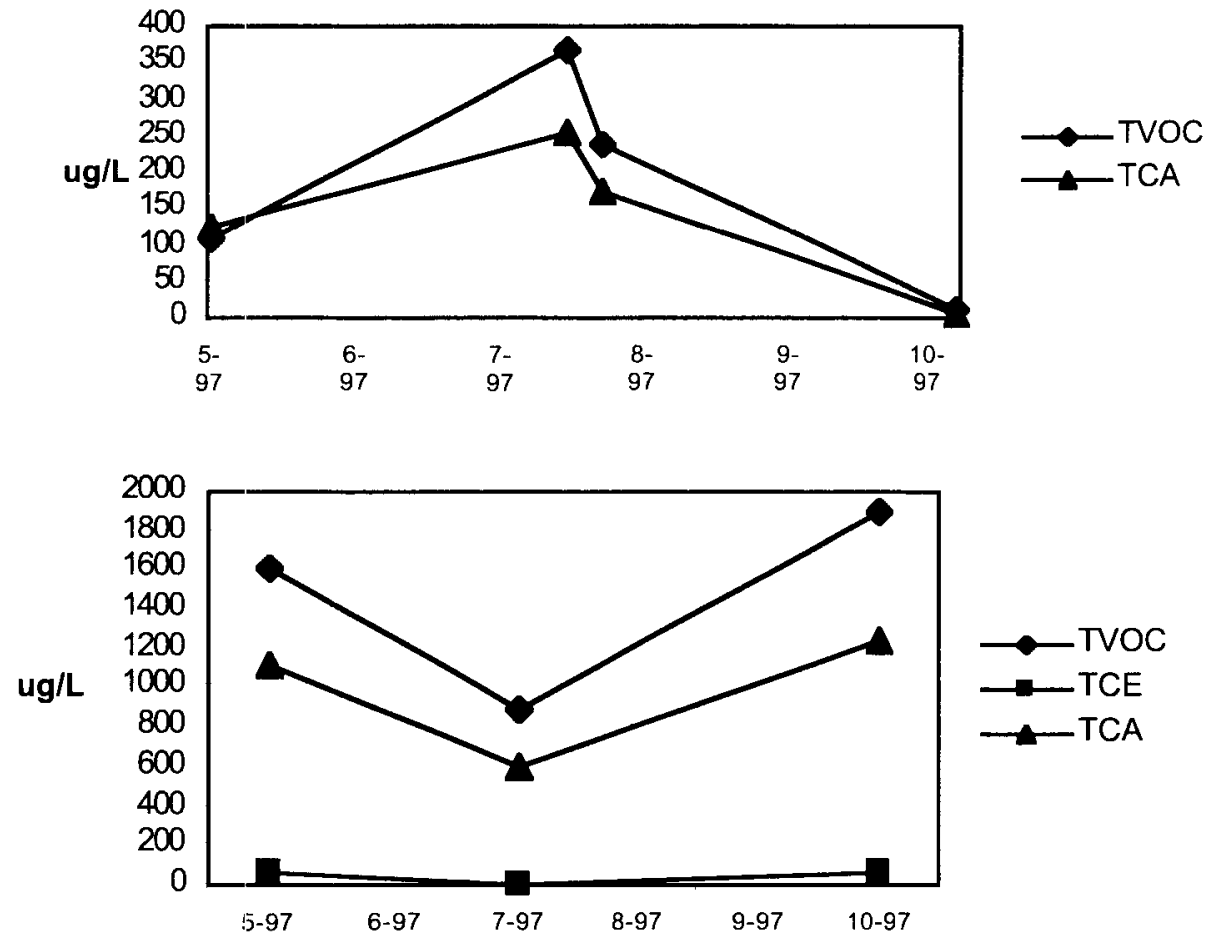

Figure 8-26. Time-vs.-VOC concentration trend plots for selected OU IV South Boundary Monitoring Wells

and chemical releases to the sanitary system contaminated soils, sediments and groundwater in the STP and Peconic River areas.

The OU V Pre-ROD Monitoring Program, started in March 1997, and uses 34 monitoring wells located downgradient of the Sewage Treatment Plant (STP). This monitoring program provides groundwater quality data for this area for the period between the completion of the RI/FS and the ROD. In particular, the wells monitor VOC and tritium contamination resulting from historical releases at the STP. These contaminants are currently being detected in wells located at the BNL eastern site boundary, and off-site between the site boundary and the Long Island Expressway (Figure 8-27). Monitoring of present groundwater quality at the STP is performed as part of the BNL Facility Surveillance Monitoring Program (see Section 8.1.3). In addition, a number of outpost wells are being monitored off-site; they are downgradient of the leading edge of the plume, and will detect any future migration of VOCs and tritium. The wells are monitored semi-annually. 
The STP plume (defined by the $5 \mu \mathrm{g} / \mathrm{L}$ isoconcentration contour) extends from southeast of the STP on-site to the Long Island Expressway (LIE) off-site (approximately 6,000 feet) (Figure 8-27). It is approximately 2,000 feet wide. The STP plume primarily consists of TCE, with a maximum observed concentration of $21 \mu \mathrm{g} / \mathrm{L}$. Low concentrations of toluene $(<4 \mu \mathrm{g} / \mathrm{L})$ were also detected in several off-site wells. Several of the OU V wells were also analyzed for Target Analyte List (TAL) metals and pesticides/PCBs during 1997. None of these metals, including mercury and hexavalent chromium, were above NYS AWQS. Of the groundwater samples from off-site wells that were analyzed for pesticides/PCBs, the only detection was a trace amount $(0.009 \mu \mathrm{g} / \mathrm{L})$ of $4,4^{\prime}$-DDT in deep Upper Glacial aquifer well 600-21, an off-site well. The vertical distribution of VOCs is shown in Figure 8-28. Sampling results indicate that VOCs are present in the deep Upper Glacial aquifer near the southeastern site boundary and off-site in the vicinity of the LIE.

Figure 8-29 plots the concentration trend for monitoring wells showing the highest VOC concentrations on-site near the site boundary (e.g., wells 50-01 and 61-05) and at the downgradient fringe of the plume (well 000-122).

\subsection{Operable Unit VI}

Ethylene dibromide (EDB) was used as a fumigant in the biological agricultural fields located in the southeast portion of the site. Available records indicate that the application of EDB in this area took place in the 1970s. EDB is detected in several on-site and off-site monitoring wells at concentrations exceeding the NYS DWS of $0.05 \mu \mathrm{g} / \mathrm{L}$.

The OU VI Pre-ROD groundwater monitoring program consists of 16 monitoring wells that extend from the Biology Fields southeast to the site boundary, and off-site (Figure 8-30). This program was initiated in June 1997, and will continue as outlined in the "Operable Unit VI ROD." The wells are currently monitored on a semi-annual basis.

EDB is the only contaminant of concern for the Biology Fields plume. Figure 8-30 shows the limits of EDB groundwater impacts (defined by a concentration of $0.01 \mu \mathrm{g} / \mathrm{L}$ ). The plume extends from the Biology Fields to an area just south of South Street (a distance of approximately 5,000 feet). The width of the plume is approximately 1,000 feet. During CY 1997, the highest EDB concentration was found in off-site well 000-110, at a concentration of $1.48 \mu \mathrm{g} / \mathrm{L}$. The vertical distribution of EDB is shown on Figure 8-31. The EDB is observed in the Shallow Glacial aquifer in the vicinity of the Biology Fields and in the deep Upper Glacial aquifer at the southern site boundary and off-site. Characterization of the off-site portion of the plume is ongoing, and additional monitoring wells will be installed during CY 1998.

Plots of EDB concentration trends for selected OU VI wells are shown on Figure 8-32. These wells are located near the source area (089-14), at the southern site boundary (100-13 and 100-14), and off-site (000-110). All of them displayed decreasing concentrations or EDB in CY 1997.

\subsubsection{Radiological Analyses}

This section gives an overview of significant radiological issues that are being addressed under the Environmental Restoration Program. The primary radiological contaminants of concern in groundwater include tritium and strontium-90. The following briefly summarizes the CY 1997 findings for each monitoring area.

\subsection{Site Background}

Radionuclides in the site background monitoring wells did not exceed either the NYS DWS or NYS AWQS. The maximum observed concentrations of gross alpha and gross beta activity were $1.5 \mathrm{pCi} / \mathrm{L}(0.06 \mathrm{~Bq} / \mathrm{L})$ and $3.8 \mathrm{pCi} / \mathrm{L}(0.14 \mathrm{~Bq} / \mathrm{L})$, respectively (see $\mathrm{BNL}, 1998)$. These radionuclide values are typical of ambient environmental values. 
GROUNDWATER PROTECTION

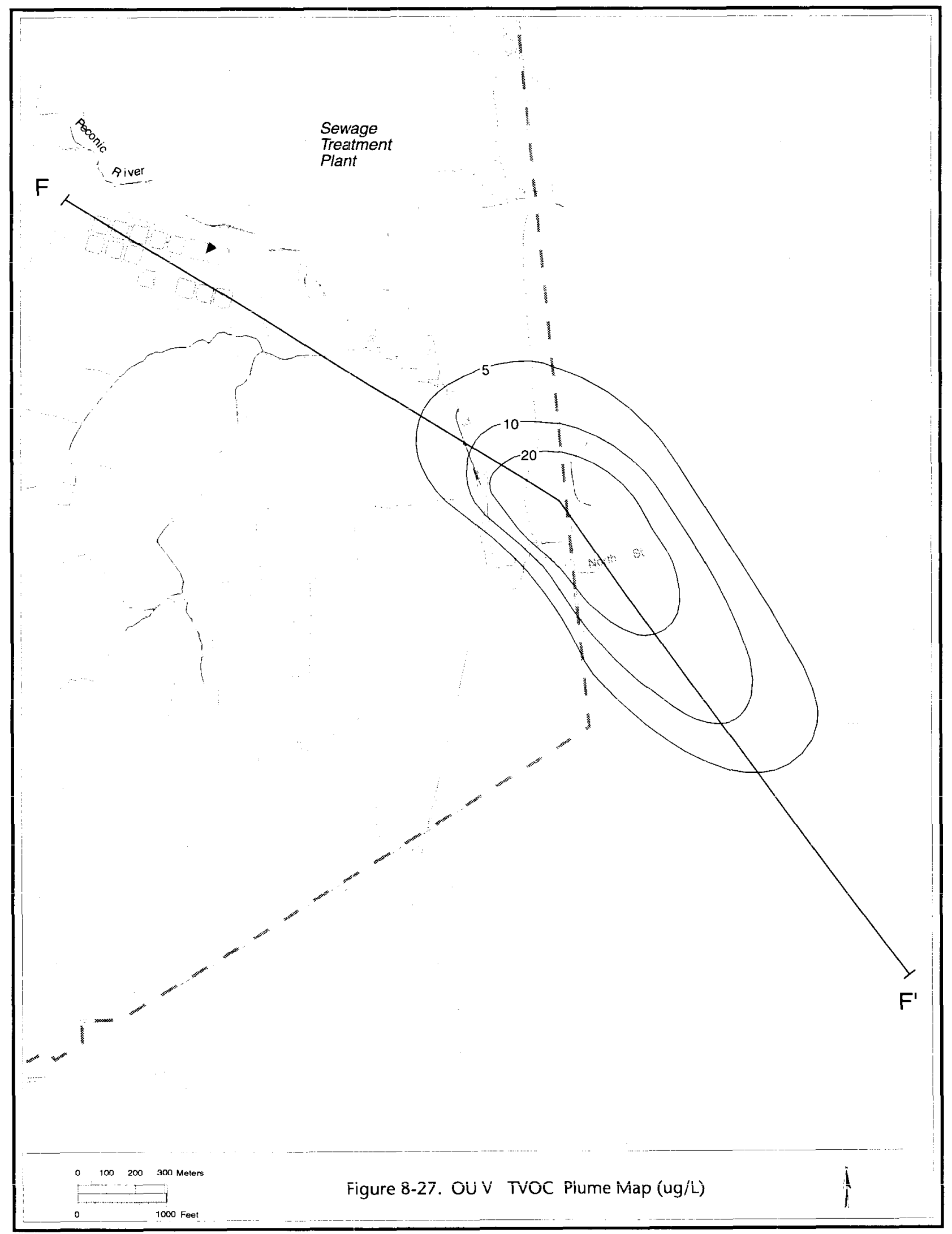

1997 BNL Site Environmental Report 8 - 41 


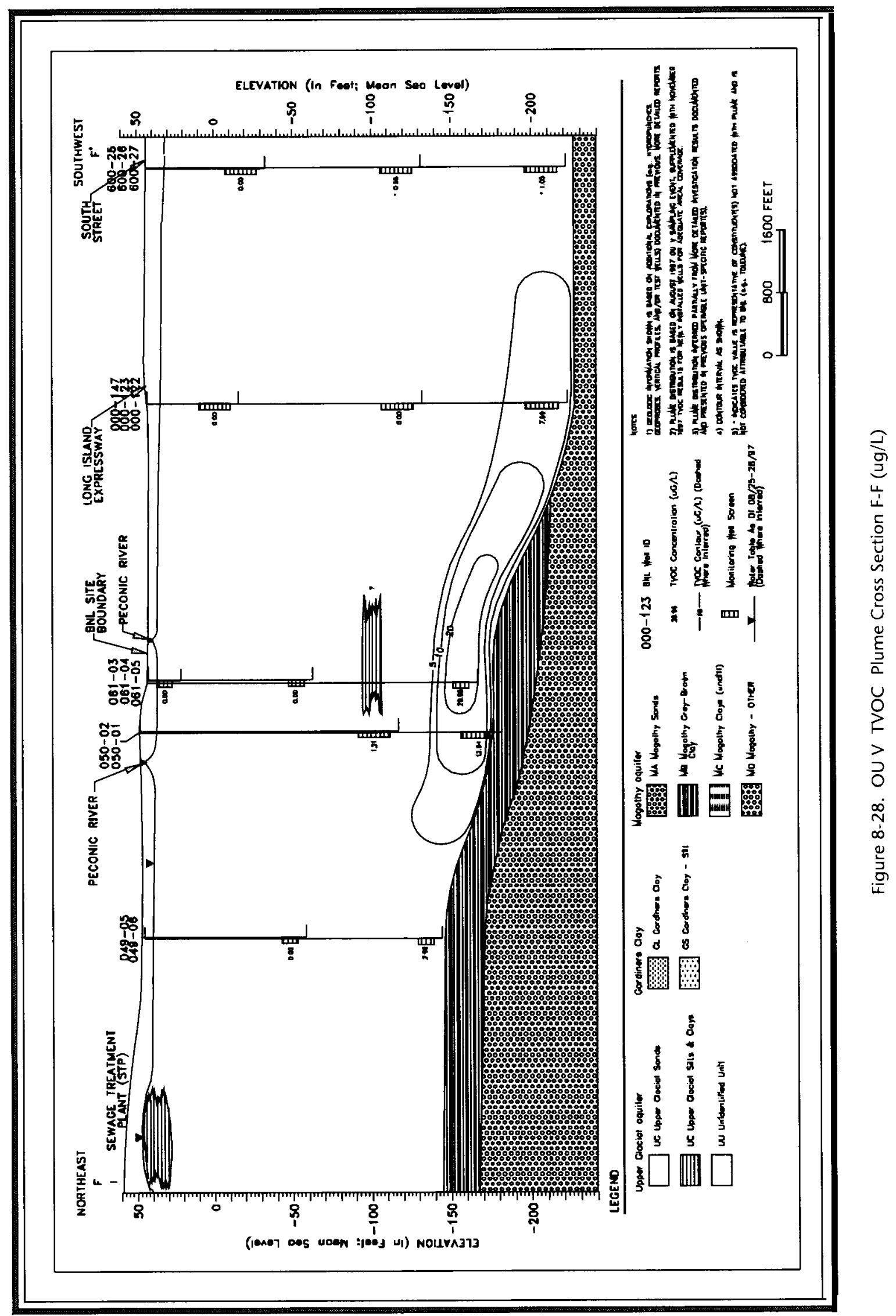


Well 50-01

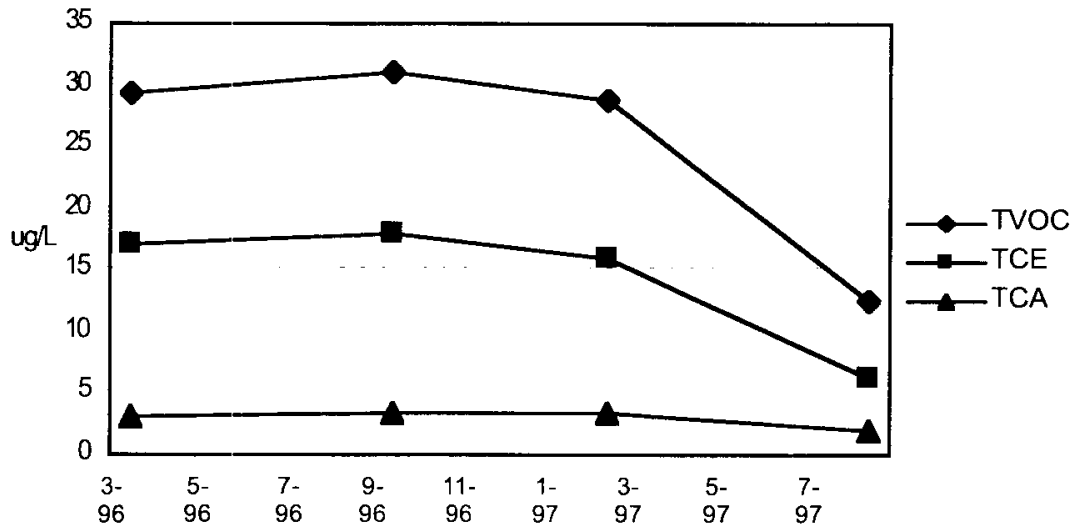

Well 61-05

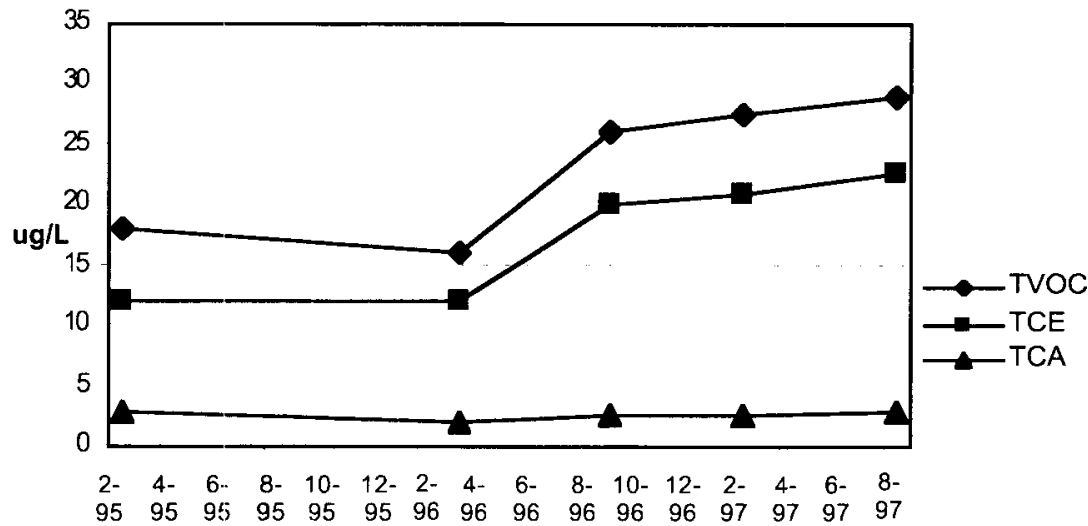

Well 000-122

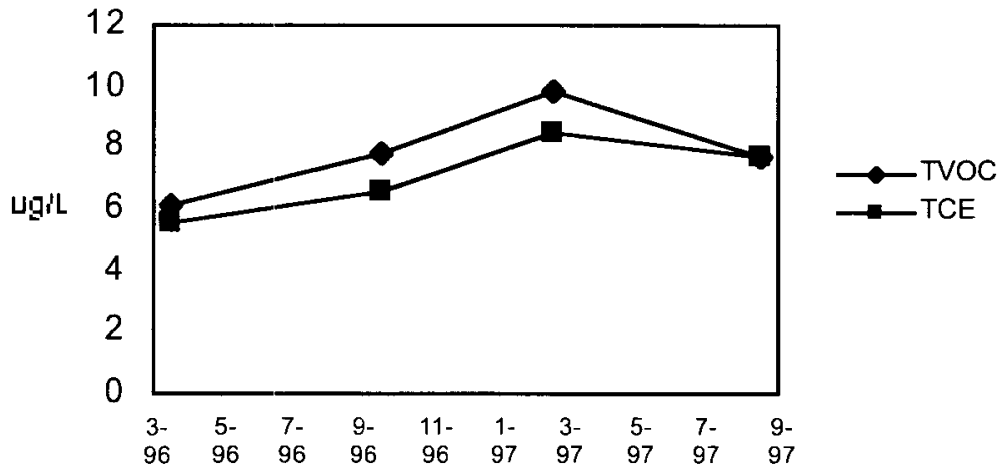

Figure 8-29. Time-vs.-VOC concentration trend plots for selected wells in the OU V Plume: Wells 50-01 and 61-05 located near the eastern boundary; and off-site well 000122 located just north of the Long Island Expressway. 
GROUNDWATER PROTECTION

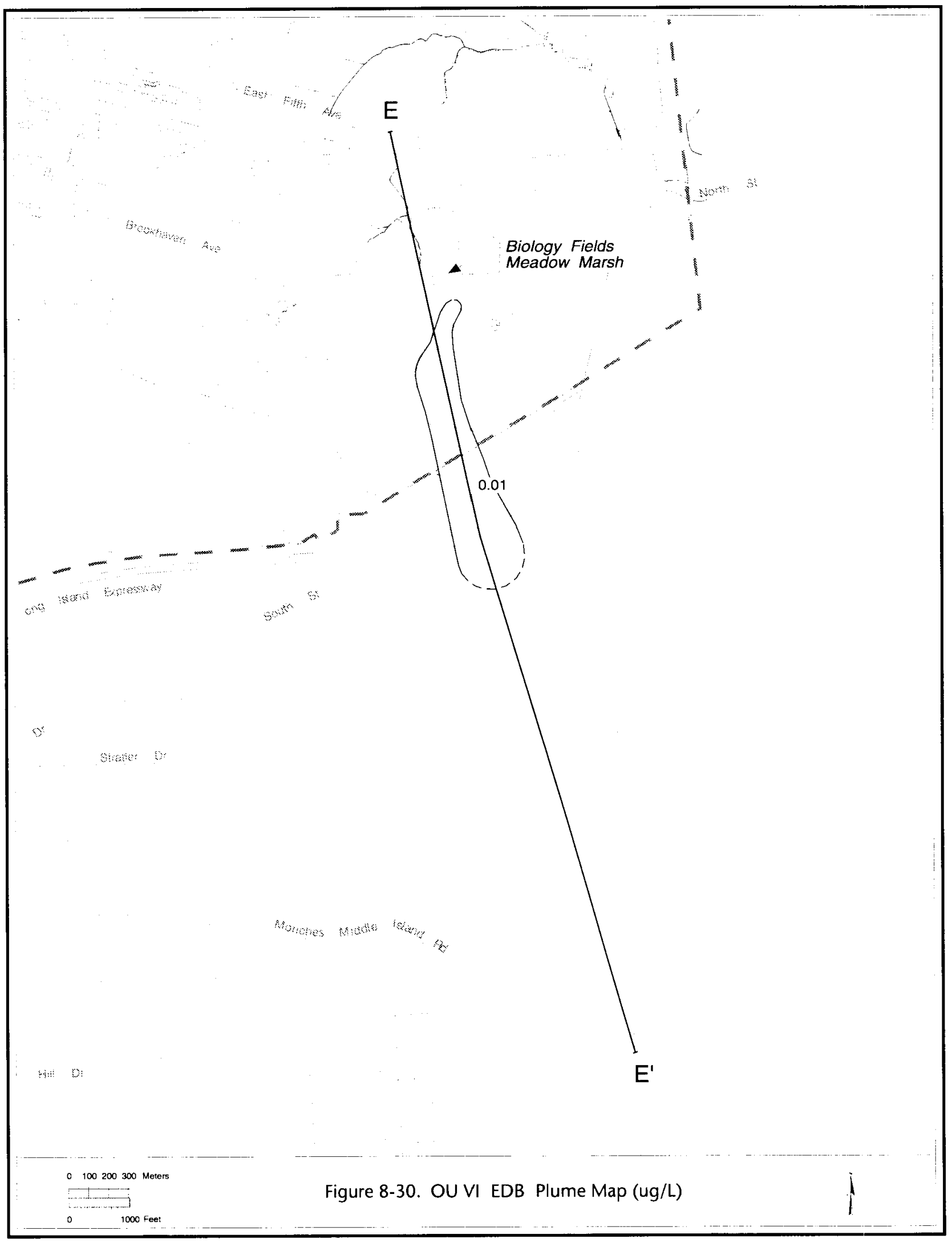

8 - 441997 BNL Site Environmental Report 


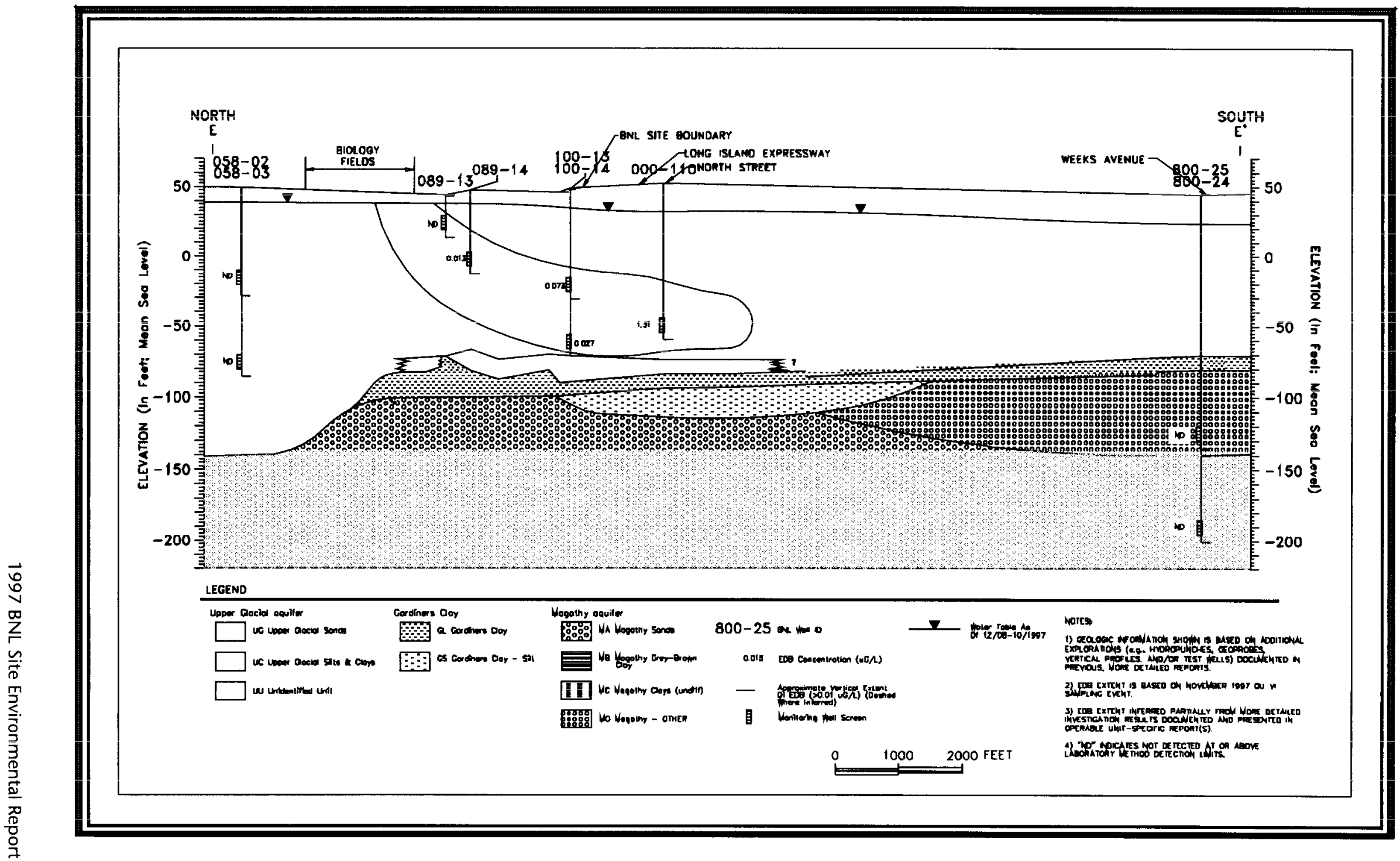

Figure 8-31. OU VI EDB Plume Cross Section E-E (ug/L) 
Well 122-04

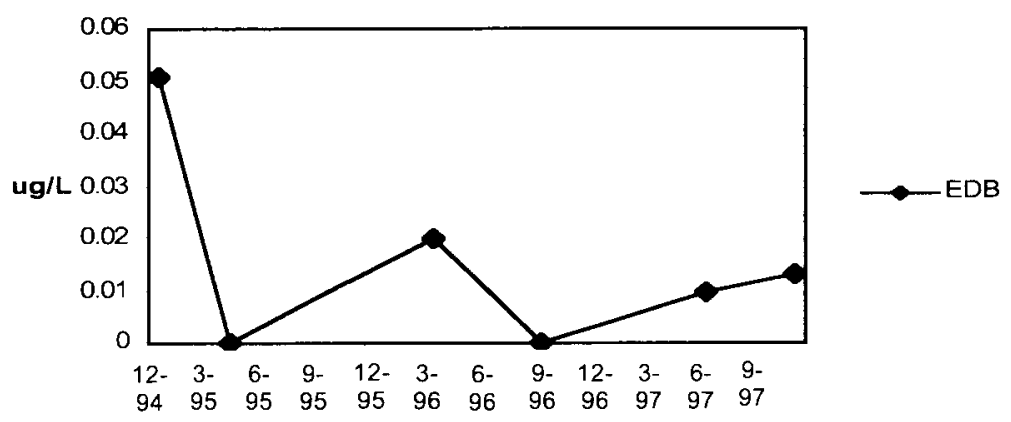

Well 122-04

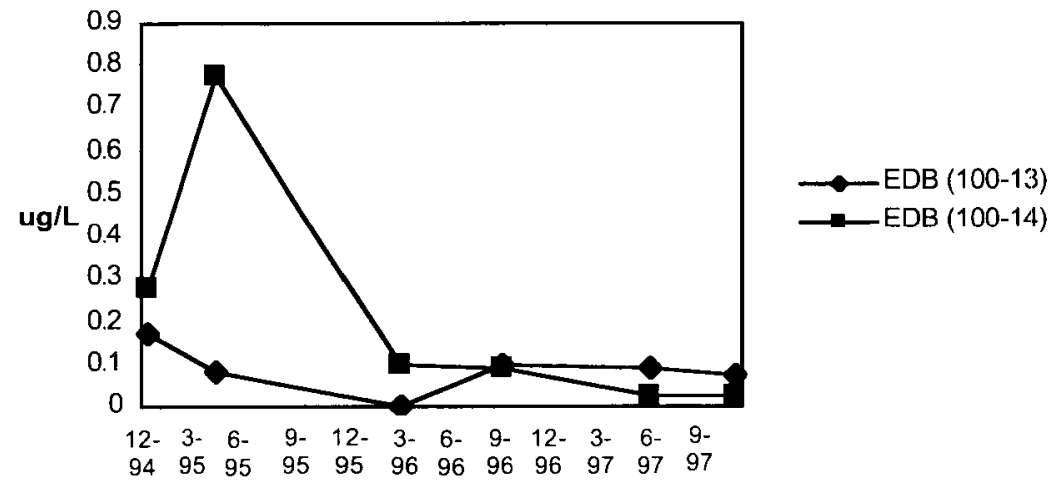

Well 122-04

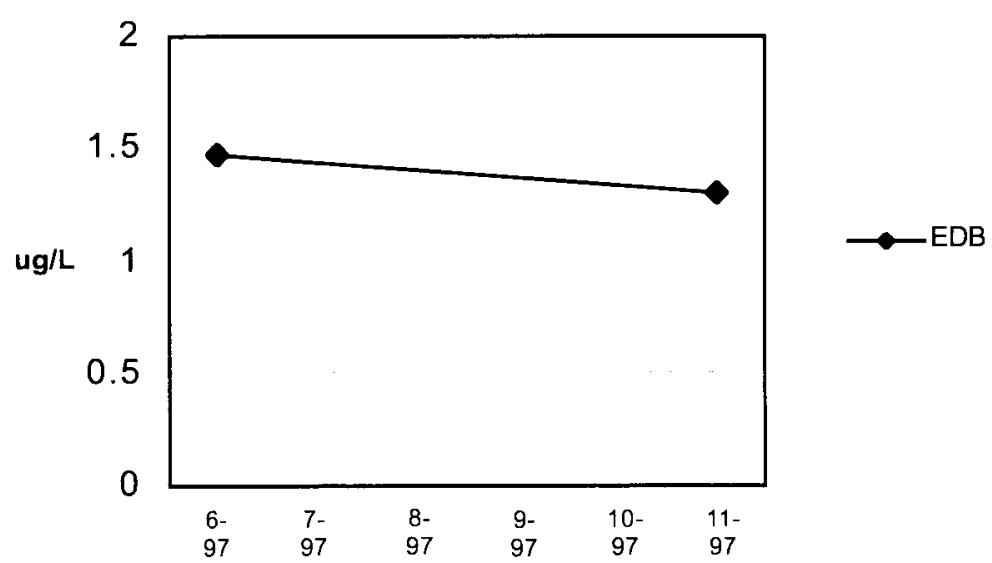

Figure 8-32. Time-vs.-EDB concentration trend plots for selected wells in the OU VI EDB Plume: Well 89-14 located immediately downgradient of the Biology Fields; well cluster 100-13/100-14 located at the southeastern boundary; and off-site well 000-110 located on South Street.

\subsection{Operable Unit I}

Hazardous Waste Management Facility/Current Landfill Areas: The Current Landfill, which was closed in 1990, received waste such as animal carcasses and protective clothing contaminated with low specific-activity radioactive material (CDM, 1996). The former HWMF was used to handle, process, and store radioactive materials since the late 1940s. Due to past waste handling methods and accidental spills, the soils and groundwater at the HWMF have become contaminated with radionuclides at concentrations exceeding NYS DWS or AWQS. Groundwater for the Current Landfill and HWMF is monitored as part of the RA V project. 
During 1997, low-levels of tritium were detected in several of Current Landfill and RA V Monitoring Program wells (Figure 8-33). However, concentrations exceeding the $20,000 \mathrm{pCi} / \mathrm{L}(740 \mathrm{~Bq} / \mathrm{L}$ ) drinking water standard were only detected in HWMF well 88-26 at a maximum of 43,691 pCi/L $(1,617 \mathrm{~Bq} / \mathrm{L})$. The maximum tritium concentration in off-site wells was found in well 000-137, at $2,384 \mathrm{pCi} / \mathrm{L}(88 \mathrm{~Bq} / \mathrm{L})$. A plot of trends in tritium concentration for well 88-26 is shown on Figure 8-34. A complete set of CY 1997 tritium results is provided in the 1997 ERD Sitewide Groundwater Monitoring Report (BNL, 1998). Additional characterization in off-site areas is planned for CY 1998.

During 1997, strontium-90 was also detected in three wells in the HWMF area at concentrations slightly exceeding the NYS DWS of $8 \mathrm{pCi} / \mathrm{L}$. Specifically, strontium-90 was detected in wells 088 $13(8.4 \mathrm{pCi} / \mathrm{L}[0.31 \mathrm{~Bq} / \mathrm{L}]), 088-26(9.2 \mathrm{pCi} / \mathrm{L}[0.34 \mathrm{~Bq} / \mathrm{L}])$, and $98-30(8.5 \mathrm{pCi} / \mathrm{L}[0.31 \mathrm{~Bq} / \mathrm{L}])$.

Former Landfill, Animal/Chemical Pits and Glass Holes Area: The Former Landfill and the Animal/Chemical Pits and Glass Holes area received low-level radioactive wastes when they were used.

During 1997, strontium-90 was detected above drinking water standards in Former Landfill well 97-03 at a maximum concentration of $11.6 \mathrm{pCi} / \mathrm{L}(0.4 \mathrm{~Bq} / \mathrm{L})$, and in Animal/Chemical Pits and Glass Holes Area wells $106-16$ and $106-13$ at maximum concentrations of $769 \mathrm{pCi} / \mathrm{L}(28 \mathrm{~Bq} / \mathrm{L})$ and $36 \mathrm{pCi} / \mathrm{L}(1.3 \mathrm{~Bq} / \mathrm{L})$, respectively. Figure 8-35 plots the concentration trend for strontium-90. During CY 1997, several temporary wells were installed to determine the downgradient extent of the strontium-90 contamination. Low levels of strontium-90 (up to $1.5 \mathrm{pCi} / \mathrm{L}[0.06 \mathrm{~Bq} / \mathrm{L}]$ ) were detected in on-site temporary wells installed at a distance of approximately 1,500 feet from the source area. The installation of additional monitoring wells is planned for this area in CY 1998.

\subsection{Operable Unit III}

High Flux Beam Reactor (HFBR): The HFBR is a heavy water moderated and cooled research reactor used principally for basic experimental research requiring external neutron beams. The reactor began operation in October 1965, and was in service until the fall of 1996. In January 1997, tritium was detected at levels exceeding the drinking water standard in wells installed immediately downgradient of the facility. As a result of these findings, an extensive field investigation was conducted from January through December 1997 to characterize the nature and extent of the tritium contamination. (see ITC, 1997). It was determined that leakage of tritiated water from the HFBR's spent fuel pool was the primary source of the tritium detected in the groundwater. The groundwater characterization aspects of this investigation consisted of the following:

- The collection and analysis of 231 groundwater samples collected from 45 Geoprobe ${ }^{\mathrm{TM}}$ wells located upgradient and downgradient of the HFBR. Analysis of the samples consisted of one or more of the following: tritium, gross alpha/beta activity, gamma spectroscopy, and strontium-90; and

- The collection of nearly 1,600 groundwater samples from 77 temporary wells installed downgradient of the HFBR for one or more of the following analyses: VOCs, tritium, gross alpha/beta activity, gamma spectroscopy and strontium-90.

Using the data collected from the temporary well samples, a permanent network of 88 existing and newly installed monitoring wells was developed for long-term surveillance of the HFBR tritium plume.

The HFBR tritium plume (defined by wells having tritium concentrations $>1,000 \mathrm{pCi} / \mathrm{L}[37 \mathrm{~Bq} / \mathrm{L}]$ ) extends from the HFBR, approximately 3,800 feet south to a location on-site near East Princeton Road (Figure 8-36). Tritium concentrations up to $1.6 \mathrm{million} \mathrm{pCi} / \mathrm{L}(59,200 \mathrm{~Bq} / \mathrm{L})$ were detected in wells directly downgradient of the HFBR. The leading edge of the portion of the plume, with concentrations exceeding the drinking water standard of $20,000 \mathrm{pCi} / \mathrm{L}(740 \mathrm{~Bq} / \mathrm{L})$ is located north of Weaver Drive (a distance of approximately 2,800 feet from the HFBR). The vertical distribution 
of tritium contamination is shown on Figure 8- 37. Tritium is detected in the shallow Upper Glacial aquifer in the vicinity of the HFBR and in the deep Upper Glacial aquifer just to the north of Weaver Drive.

Waste Concentration Facility (WCF): Historically, the WCF (Building 811) was used to reduce the volume of liquid radioactive wastes by removing suspended solids and applying limited treatment. Currently, the facility is used primarily for the temporary storage and limited treatment of radioactive liquids prior to off-site treatment or disposal. All operational liquid storage vessels and transfer lines comply with Suffolk County Article 12 requirements. Past leakage from above ground waste storage tanks and transfer operations led to radiological groundwater contamination in the immediate area. During CY 1997, strontium-90 was detected at concentrations exceeding the $8 \mathrm{pCi} / \mathrm{L}$ drinking water standard in well 65-18, at a maximum observed concentration of $18.3 \mathrm{pCi} / \mathrm{L}(0.7 \mathrm{~Bq} / \mathrm{L})$.

Building 830 Area: In 1986, it was discovered that a waste transfer line between Building 830 and an underground storage tank had leaked. Approximately 900 gallons of liquid radioactive waste were lost (Miltenburger et al., 1989). Soil contaminated by the leak was excavated and removed in 1988. During 1997, cobalt-60 (half-life $=5.2$ years) was detected in temporary wells installed downgradient of the transfer line and underground storage tank. In a temporary well located directly downgradient of the tank, cobalt-60 was detected at a concentration of $242 \mathrm{pCi} /$ $\mathrm{L}(8.9 \mathrm{~Bq} / \mathrm{L})$, which is slightly above the $200 \mathrm{pCi} / \mathrm{L}(7.4 \mathrm{~Bq} / \mathrm{L})$ drinking water standard (i.e., $4 \%$ of the DOE DCG). Low-levels of cobalt-60 were also detected in four wells downgradient of the transfer line, with concentrations ranging between 5.3 and $28 \mathrm{pCi} / \mathrm{L}(0.2$ and $1.0 \mathrm{~Bq} / \mathrm{L})$. The underground storage tank and transfer line are scheduled to be removed during CY 1998.

Brookhaven Graphite Research Reactor Area: Starting in late 1996, BNL initiated an extensive effort to characterize the soil and groundwater in the vicinity of the BGRR. Water samples were obtained from several BGRR water and air handling systems that could impact groundwater resources. For example, sediment samples obtained from three nearby storm drains showed elevated gross alpha and beta activity, cesium-137, and strontium-90 (up to $41 \mathrm{pCi} / \mathrm{g}[1.5 \mathrm{~Bq} / \mathrm{g}])$. Standing water samples were also obtained from a vault that previously contained a tank, and the Pile Fan Sump (PFS). Although analytical results from the vault indicated only low-level contamination, samples obtained from the PFS showed high concentrations of strontium-90 (up to $2,270 \mathrm{pCi} / \mathrm{L}[84 \mathrm{~Bq} / \mathrm{L}]$ ), tritium $(340,000 \mathrm{pCi} / \mathrm{L}[12,600$ $\mathrm{Bq} / \mathrm{L}])$, and cesium-137 (2,458 pCi/L [91 Bq/L]).

During 1997, 45 temporary Geoprobe wells were installed downgradient of the BGRR and PFS areas to determine the extent of radionuclide contamination in groundwater (Figure 838 ). The results showed strontium-90 contamination exceeding drinking water standards in wells extending from the BGRR area to an area just south of Cornell Avenue (a distance of approximately 200 meters). Strontium -90 was detected at a concentration of $54 \mathrm{pCi} / \mathrm{L}(2 \mathrm{~Bq} /$ L) in a temporary well installed approximately 50 meters downgradient of the BGRR. Strontium-90 concentrations decrease to $<37 \mathrm{pCi} / \mathrm{L}(<1.4 \mathrm{~Bq} / \mathrm{L})$ in wells located south of Cornell Avenue.

In the PFS area, strontium-90 and tritium were detected in temporary wells installed directly downgradient of the sump, at maximum concentrations of $565 \mathrm{pCi} / \mathrm{L}(21 \mathrm{~Bq} / \mathrm{L})$ and $14,700 \mathrm{pCi} /$ $\mathrm{L}(544 \mathrm{~Bq} / \mathrm{L})$, respectively. However, strontium-90 and tritium also were detected in temporary wells installed approximately 20 meters north of the PFS, which may be related to upgradient source areas such as the Waste Concentration Facility. Strontium-90 was not detected in temporary wells installed approximately 170 meters south (downgradient of the PFS, near Cornell Avenue. Tritium was detected in several of these wells, however, at a maximum observed concentration of $4,660 \mathrm{pCi} / \mathrm{L}(172 \mathrm{~Bq} / \mathrm{L})$. The results from this study, and a complete evaluation of potential sources located within the BGRR and upgradient areas will be presented in the OU III RI Report that is expected to be finalized by the fall of 1998. 


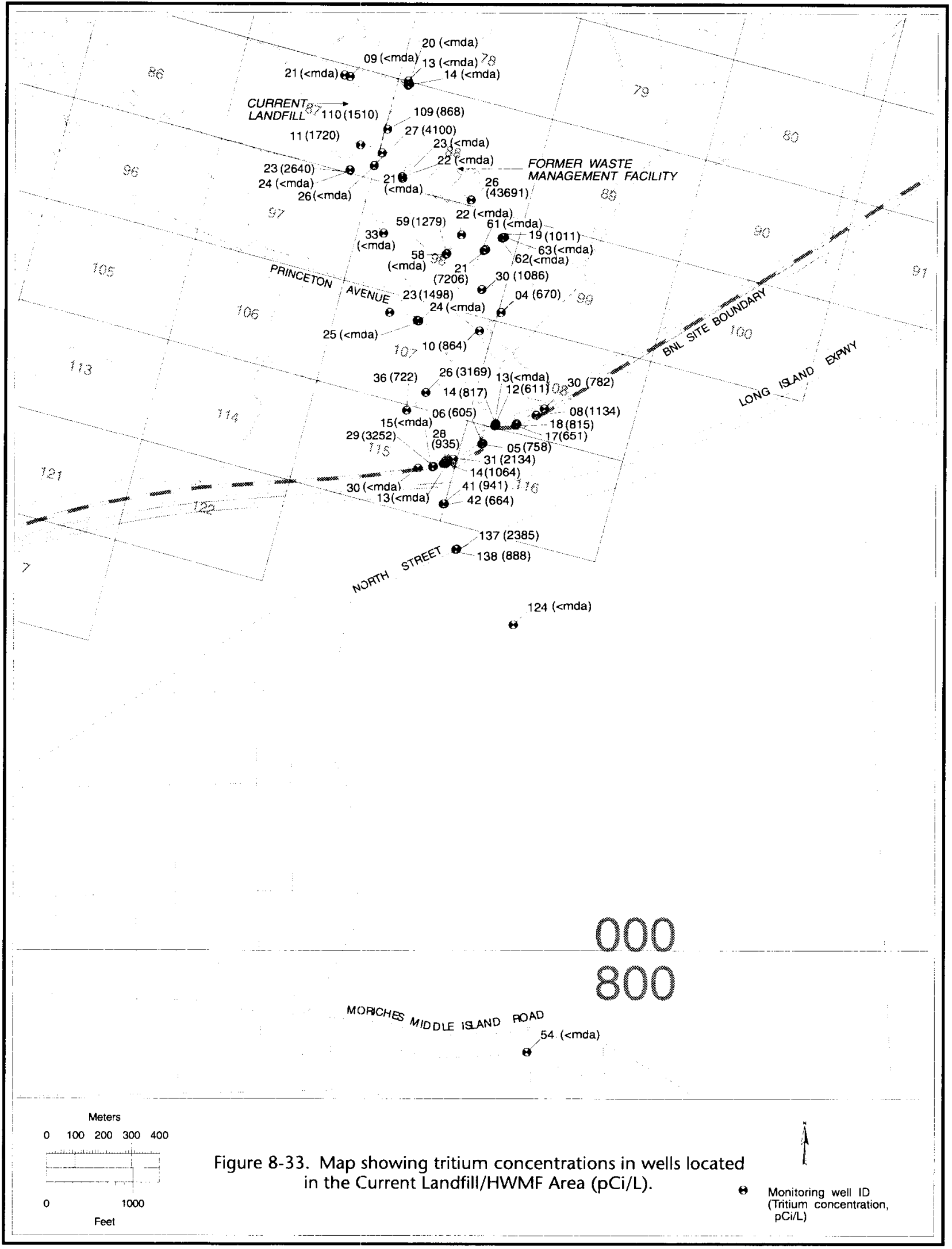




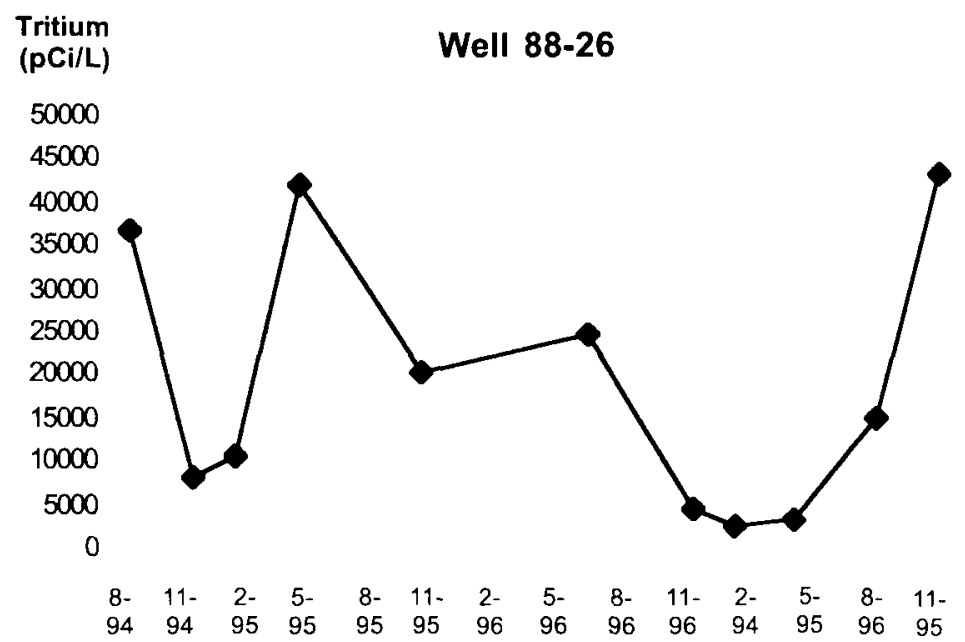

Figure 8-34. Time-vs.-tritium concentration trend plots for well 88-26 located in the HWMF area.

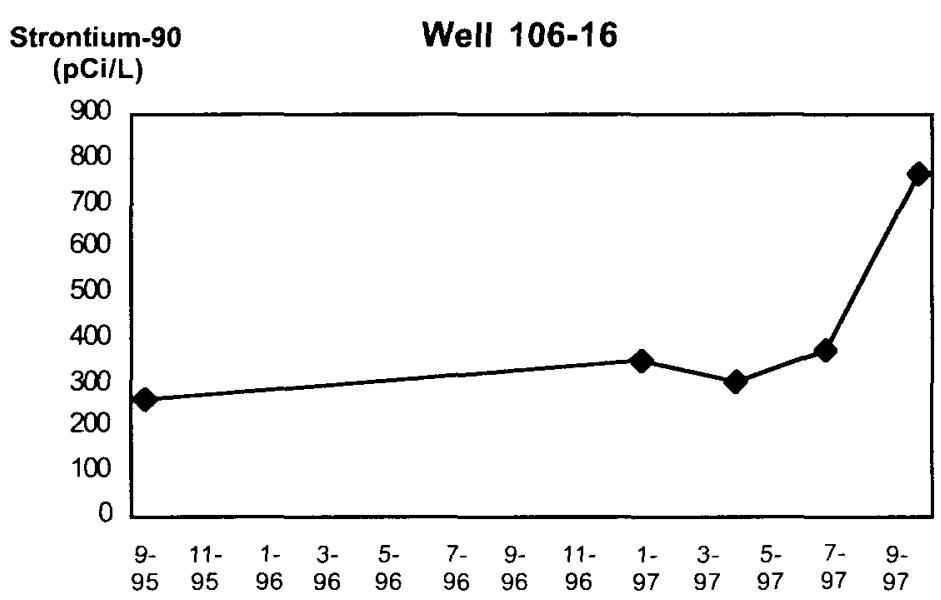

Figure 8-35. Time-vs.-strontium-90 concentration trend plots for well 106-16 located in Former Landfill area. 


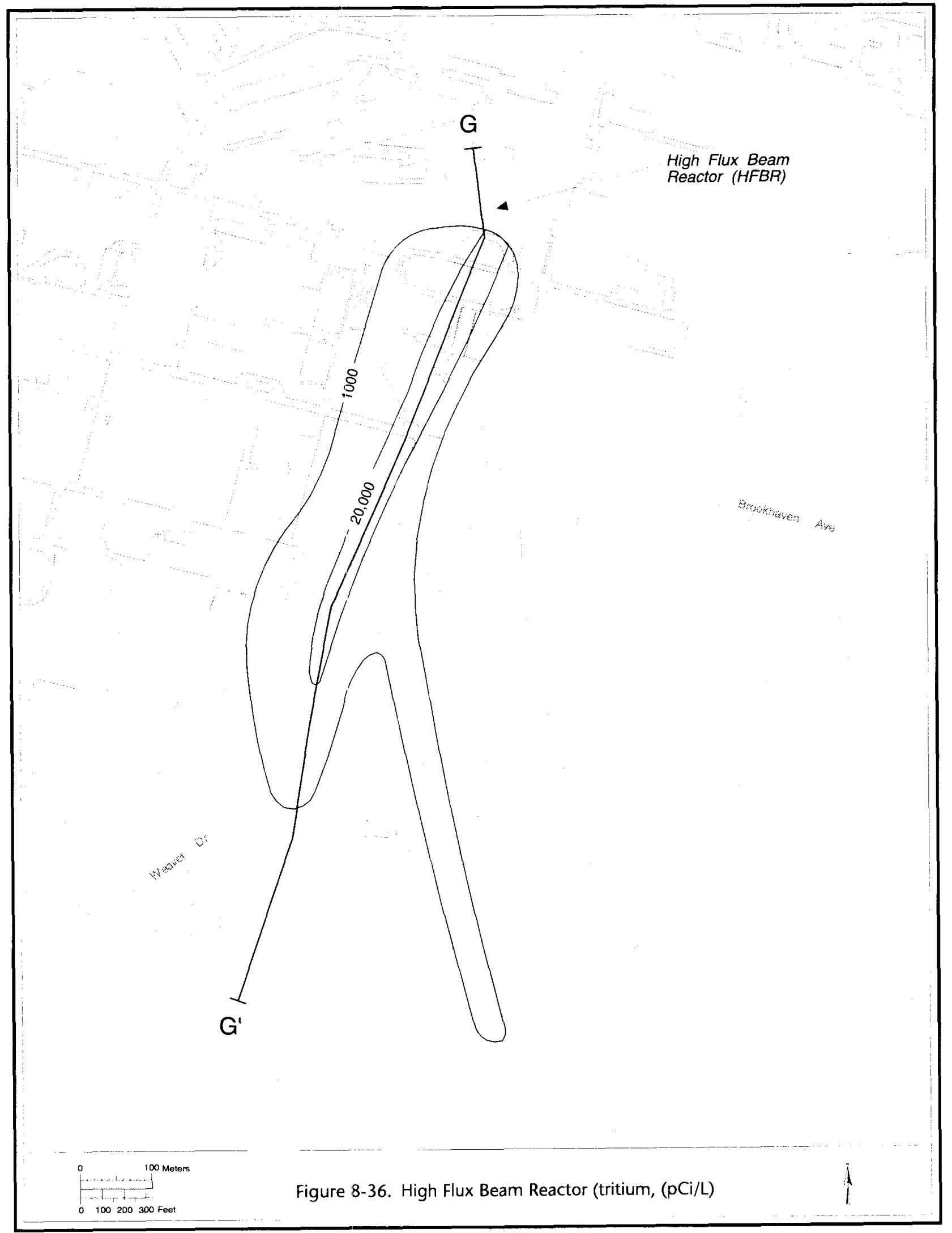




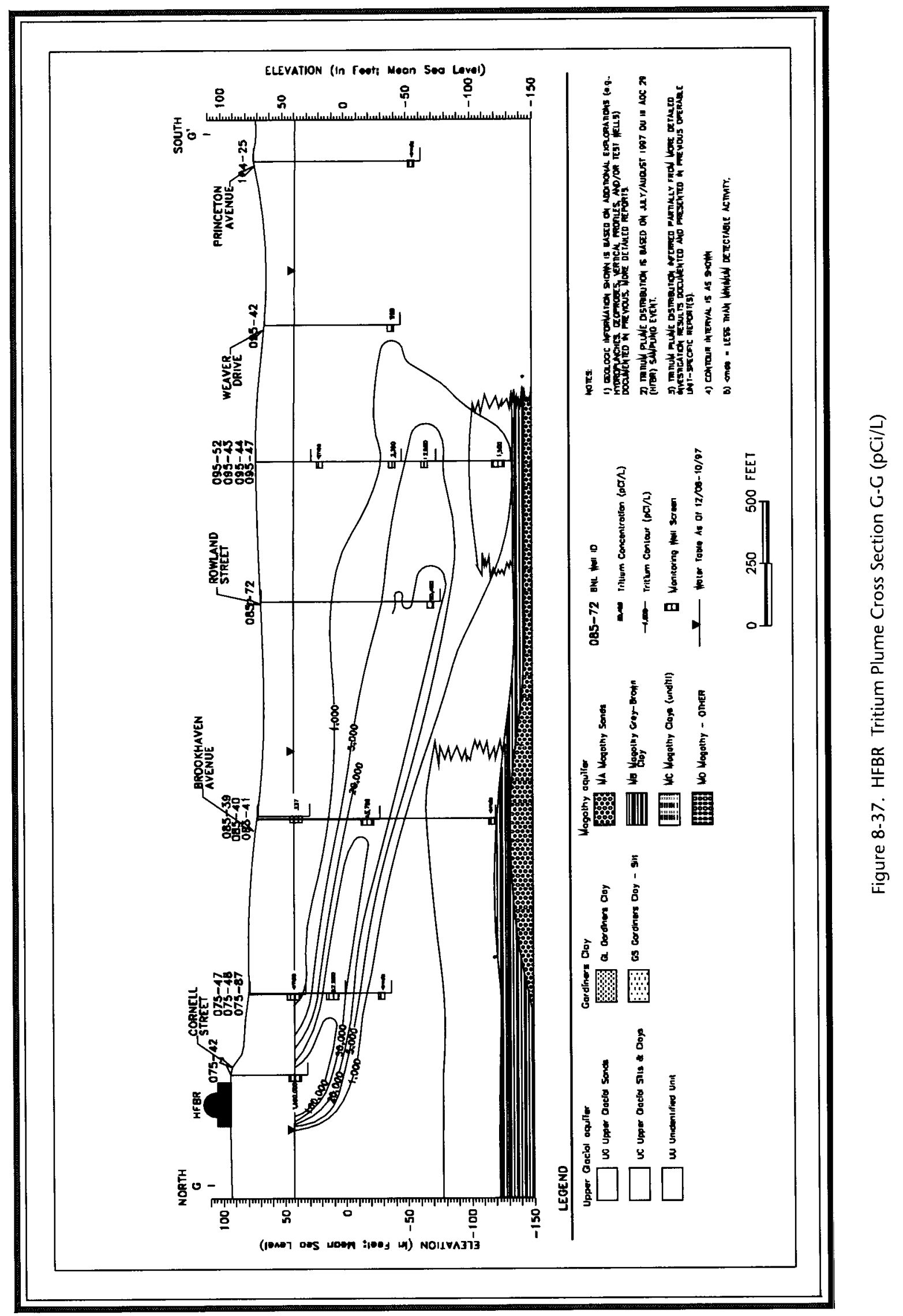




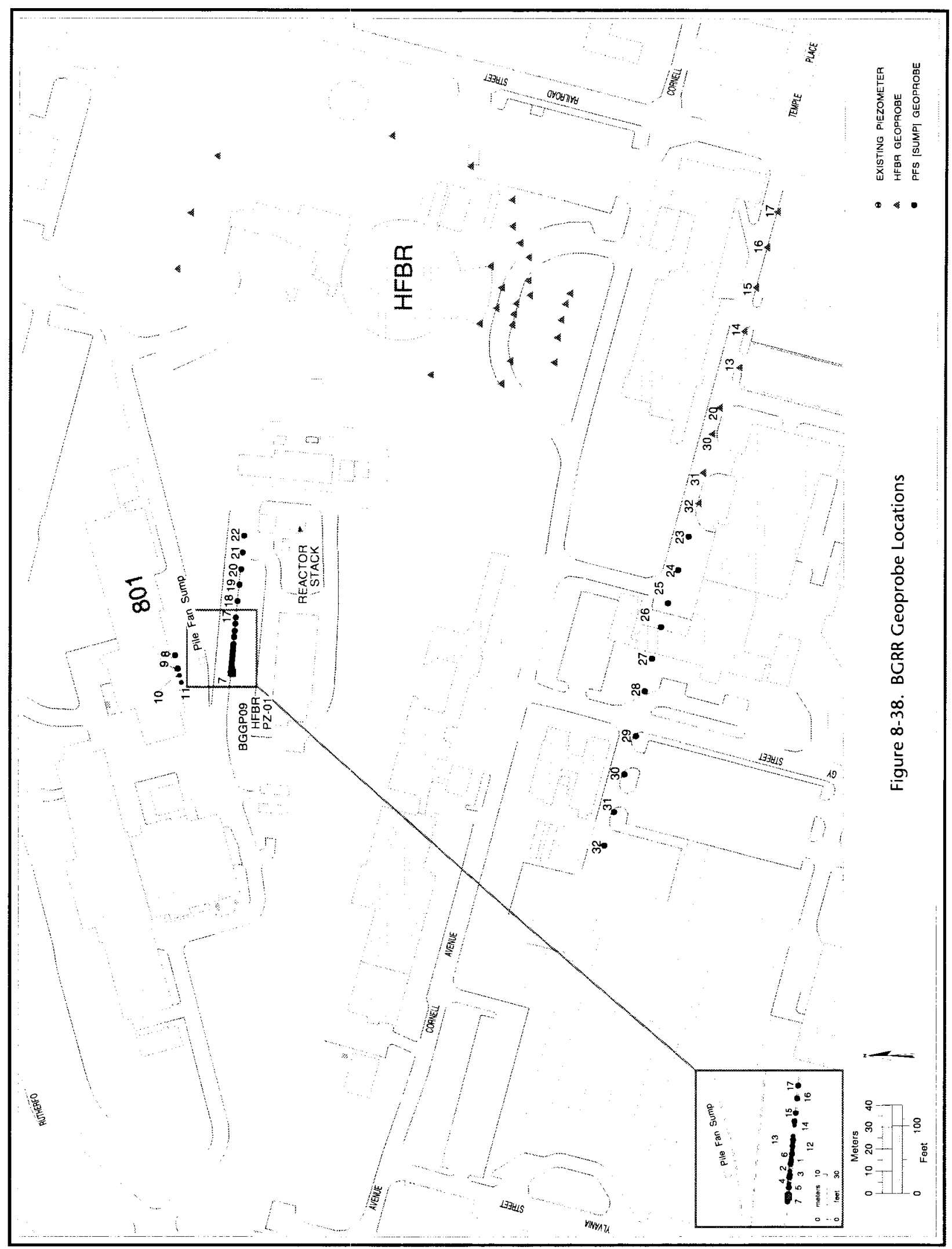




\subsection{Operable Unit IV}

Building 650 Sump Outfall: Building 650 was used as a decontamination facility to remove radioactive material from clothing and heavy equipment. Drainage from outdoor decontamination of heavy equipment was routed to a drain system, which emptied out into a naturall depression (known as the Building 650 Sump Outfall) 800 feet to the northeast, adjacent to Recharge Basin HO.

Detectable levels of strontium-90 were historically observed in wells located directly downgradient of the Building 650 Sump Outfall. Figure 8-39 shows the radionuclide data for samples collected during August 1997. Strontium-90 was detected at concentrations exceeding the $8 \mathrm{pCi} / \mathrm{L}$ $(0.3 \mathrm{~Bq} / \mathrm{L})$ drinking water standard in wells $76-13(14.9 \mathrm{pCi} / \mathrm{L}[0.55 \mathrm{~Bq} / \mathrm{L}])$ and $76-169(14.7 \mathrm{pCi} /$ $\mathrm{L}[0.54 \mathrm{~Bq} / \mathrm{L}])$. Radium-226 was detected by gamma spectroscopy screening in monitoring wells 66-17 (41.4 pCi/L) and 76-167 (27.6 pCi/L) during CY 1997 sampling. These wells were re-sampled during early CY 1998 and analyzed specifically for isotopic radium-226. Radium-226 was not detected in either sample using this method. Monitoring wells 66-17 and 76-167 will continue to be monitored for radium-226.

\subsection{Operable Unit V}

Although tritium is routinely detected in several of the OU V Pre-ROD monitoring wells near the southeast site boundary, concentrations are well below the drinking water standard of 20,000 $\mathrm{pCi} / \mathrm{L}(740 \mathrm{~Bq} / \mathrm{L})$. The tritium results from the August and November 1997 samples are shown on Figure 8-40. The highest level was in 50-02, at 3,320 pCi/L (123 Bq/L). Time-versus-concentration trends for wells 50-01 and 50-02 are shown on Figure 8-41. Tritium was not detected in any of the OU V Pre-ROD monitoring wells located off-site.

During the November 1997 sample period, elevated gross alpha (64 pCi/L $[2.4 \mathrm{~Bq} / \mathrm{L}])$ and gross beta $(54 \mathrm{pCi} / \mathrm{L}[2.0 \mathrm{~Bq} / \mathrm{L}])$ levels were detected in off-site well $000-143$, which is screened in the upper Magothy aquifer. The water from this well was highly turbid due to the fine-grained sediments in which the well is screened. This well was sampled again in March 1998, and gross alpha and gross beta values were only 9 and $4 \mathrm{pCi} / \mathrm{L}(0.33$ and $0.15 \mathrm{~Bq} / \mathrm{L})$, respectively. The initial elevated gross activity appears to be due to naturally occurring radionuclides due to the presence of suspended soil particles in the turbid sample water. To determine the contribution of suspended solids to the detection of gross alpha and gross beta, both filtered and unfiltered samples will be collected from this well during CY 1998.

\subsubsection{CERCLA Groundwater Treatment Systems Operational in 1997}

A primary mission of BNL's Environmental Restoration program is remediating soil and groundwater contamination and preventing additional contamination from migrating off the BNL site. To that end, four groundwater treatment systems are operating at BNL, and a fifth system will be installed in 1999. Figure 8-42 shows the locations of these four. The following is a brief description of the groundwater treatment systems that were operational during 1997 and a summary of their performance:

South Boundary Remediation System for OU III: Construction of the OU III pump-andtreat system was completed in June 1997. The system uses six wells to extract VOC contaminated groundwater that originated from a number of sources located in the developed central portion of the BNL site. The water is pumped approximately one mile north to an airstripping tower located near the Medical Department complex (Figure 8-42) where air from a powerful blower separates the VOCs from the water. The removal efficiency is close to 100 percent (see Table 8-5). The clean water is discharged to a nearby recharge basin, and the VOCs stripped from the water are released into the air at concentrations below state and federal emissions standards. The system processes approximately 600 gallons of water per minute. 


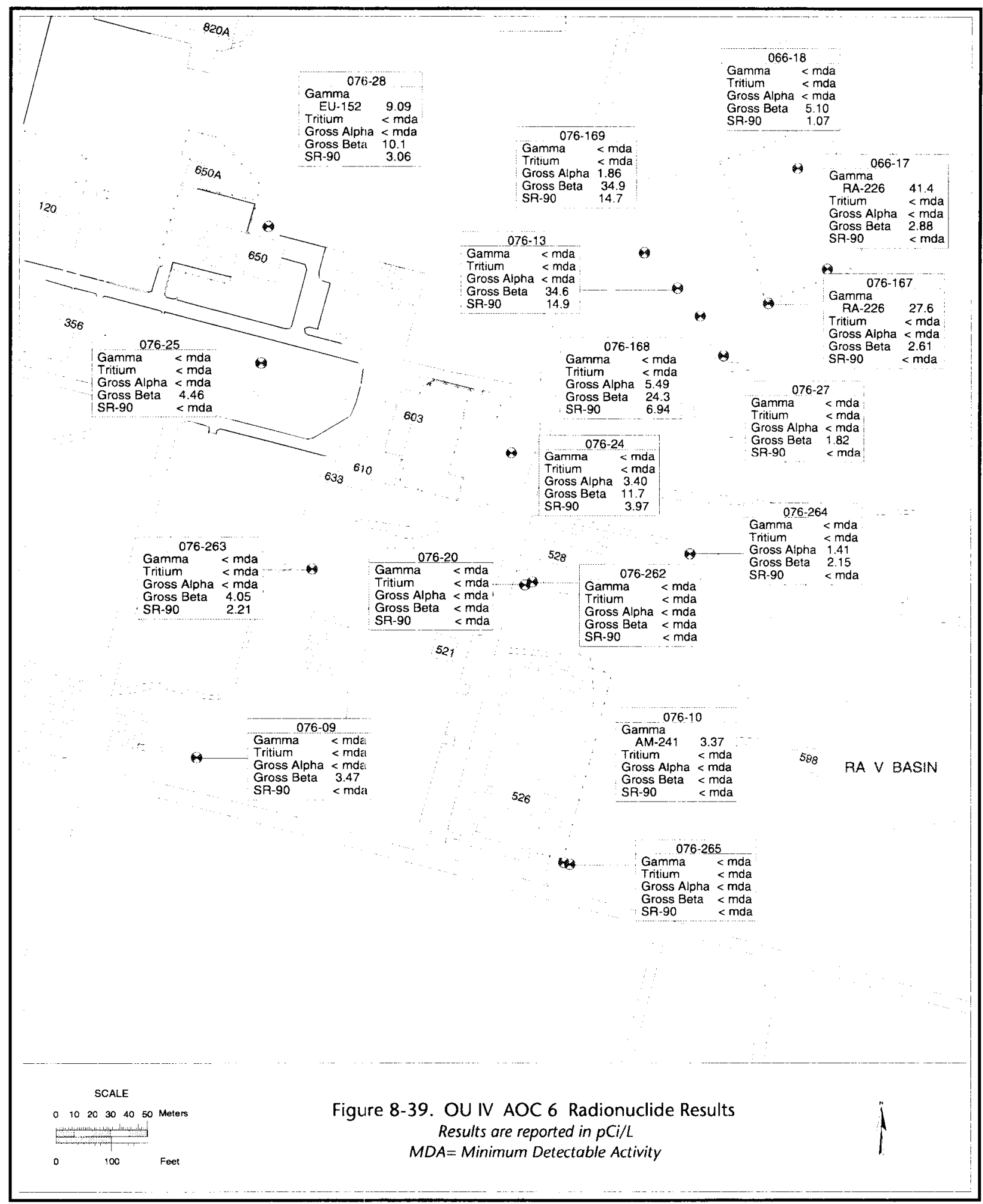




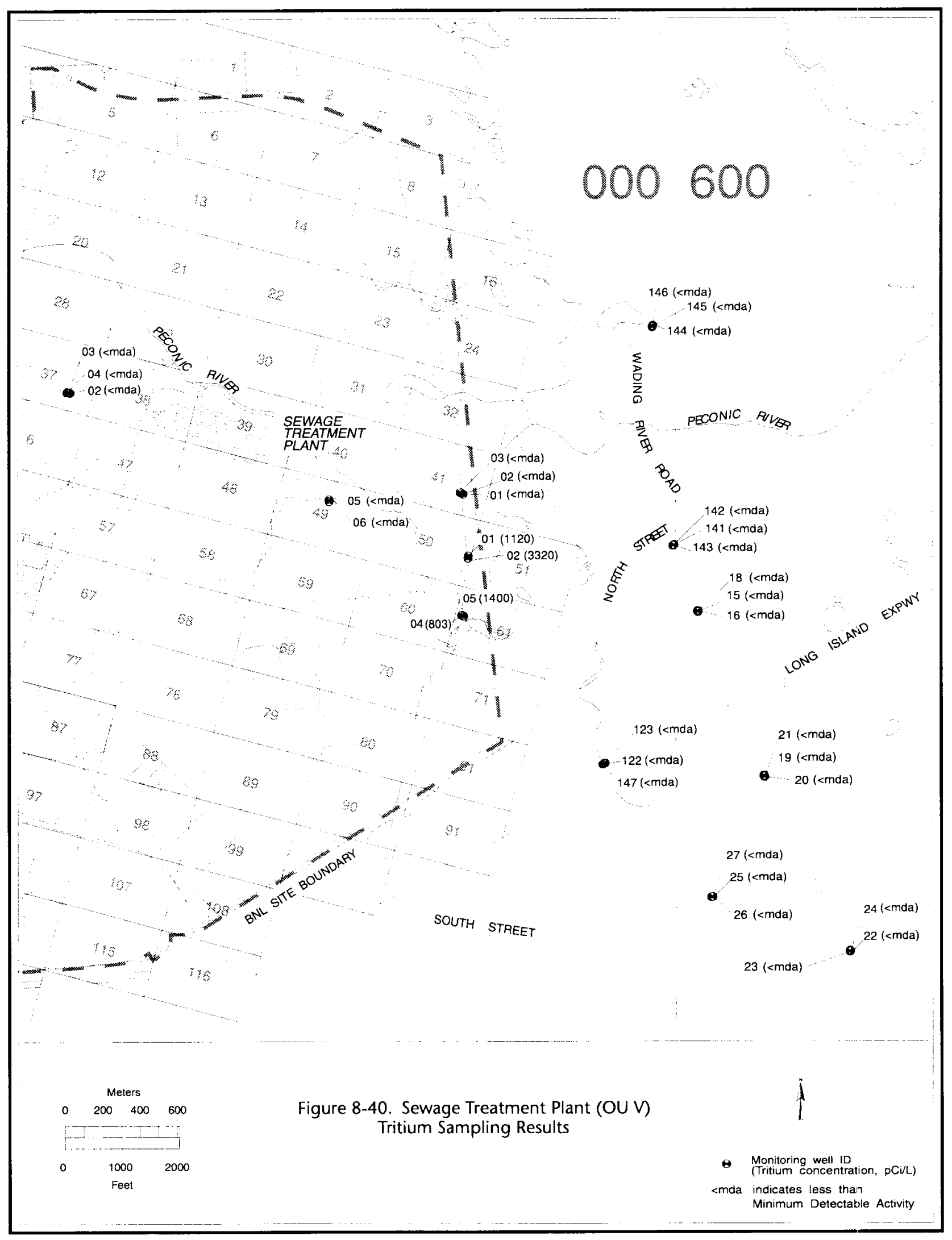


Well 122-04

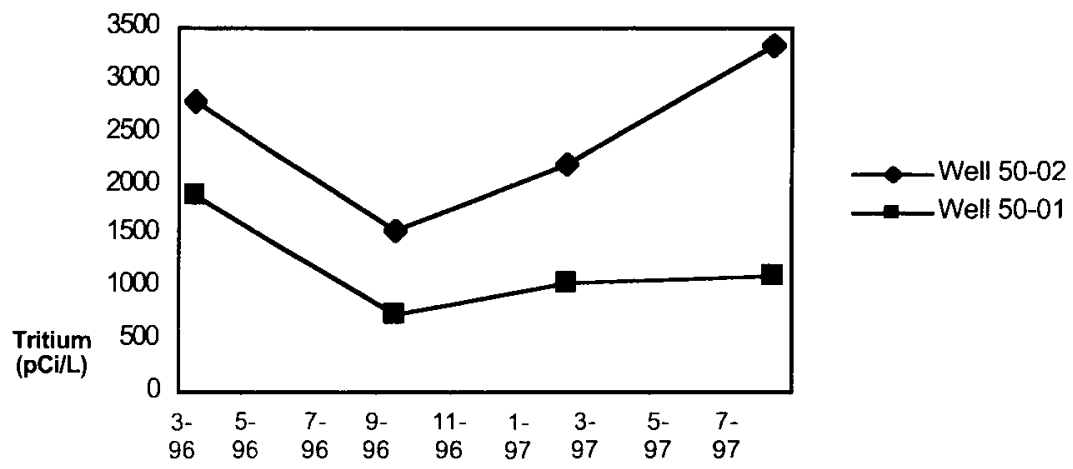

Figure 8-41. Time-vs.- tritium concentration trend plots for well cluster 50-01/50-02 located in the OU V Plume near the eastern site boundary.

Approximately 340 pounds of VOCs were removed from the groundwater during 1997, and $166,000,000$ gallons of treated groundwater returned to the aquifer.

South Boundary Remediation System for OU I (RA V): This pump-and-treat system was completed in December 1996. The system uses two extraction wells to remove contaminated groundwater that originated from the Current Landfill (now closed and capped) and the former HWMF. The water is pumped approximately one mile north to an air stripper system (Figure 8-42). This system processes more than 700 gallons of water per minute. Like the OU III treatment system, the RA V system removes close to 100 percent of the chemical contamination (Table 8-6). The clean water is discharged to a nearby recharge basin, and the VOCs stripped from the water are released into the air at concentrations below state and federal emissions standards.

Approximately 120 pounds of VOCs were removed from the groundwater during 1997, and $340,000,000$ gallons of treated groundwater returned to the aquifer.

Geoprobe Sampling

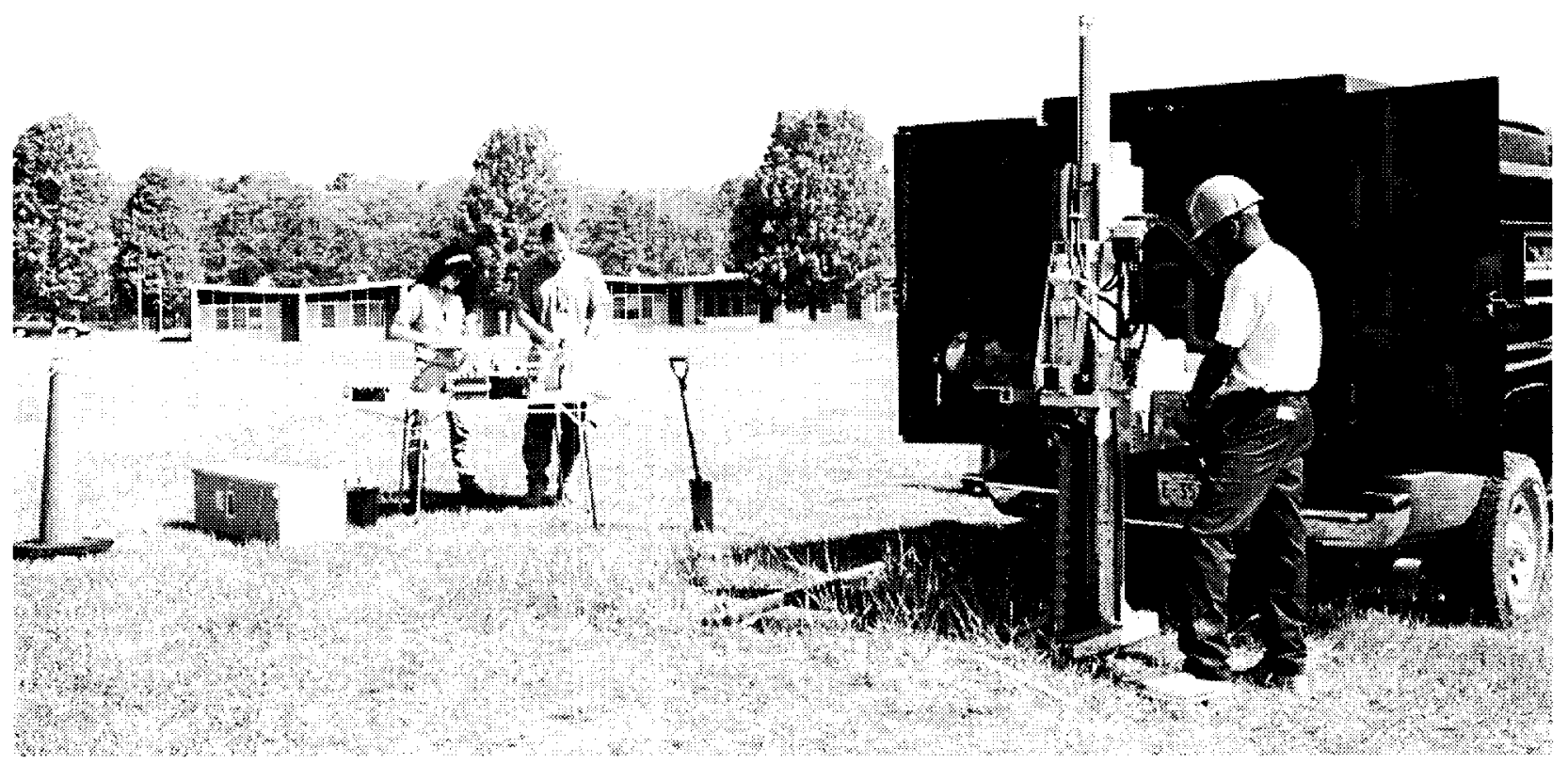




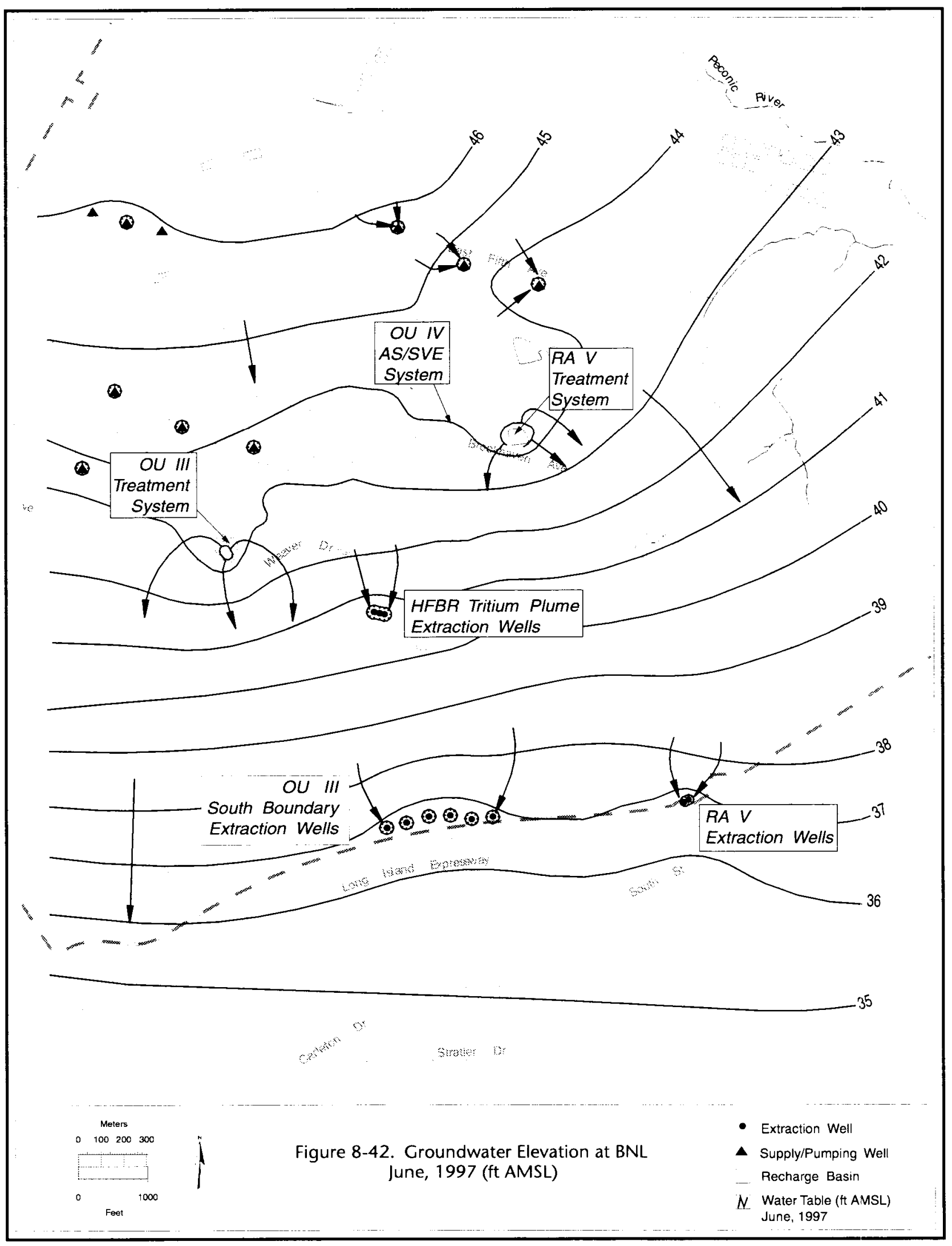


Table 8-5

BNL Site Environmental Report for Calendar Year 1997

OU III South Boundary Groundwater Remediation System

Comparision of Monthly Average Influent and Effluent vac Concentrations

\begin{tabular}{|c|c|c|c|c|c|c|c|}
\hline $\begin{array}{l}\text { Month } \\
\text { (Ibs) }\end{array}$ & $\begin{array}{l}\text { voc } \\
\text { Removal }\end{array}$ & & $\begin{array}{l}\text { Carbon } \\
\text { Tetrachloride }\end{array}$ & $\begin{array}{l}1,1 \text { - } \\
\text { Dichloroethylene }\end{array}$ & $\begin{array}{c}\text { Tetrachloroethylene } \\
\mu \mathrm{g} / \mathrm{L}\end{array}$ & Trichloroethane & $\begin{array}{l}1,1,1- \\
\text { Trichloroethylene }\end{array}$ \\
\hline $\begin{array}{l}\text { June } \\
(n=7)\end{array}$ & 29 & $\begin{array}{l}\text { Influent } \\
\text { Effluent }\end{array}$ & $\begin{array}{l}14 \\
<0.5\end{array}$ & $\begin{array}{l}52 \\
<0.5\end{array}$ & $\begin{array}{l}118 \\
<0.5\end{array}$ & $\begin{array}{l}155 \\
<0.5\end{array}$ & $\begin{array}{l}12 \\
<0.5\end{array}$ \\
\hline $\begin{array}{l}\text { July } \\
(n=4)\end{array}$ & 62 & $\begin{array}{l}\text { Influent } \\
\text { Effluent }\end{array}$ & $\begin{array}{l}12 \\
<0.5\end{array}$ & $\begin{array}{l}40 \\
<0.5\end{array}$ & $\begin{array}{l}94 \\
<0.5\end{array}$ & $\begin{array}{l}128 \\
<0.5\end{array}$ & $\begin{array}{l}11 \\
<0.5\end{array}$ \\
\hline $\begin{array}{l}\text { August } \\
(n=4)\end{array}$ & 50 & $\begin{array}{l}\text { Influent } \\
\text { Effluent }\end{array}$ & $\begin{array}{l}10 \\
<0.5\end{array}$ & $\begin{array}{l}40 \\
<0.5\end{array}$ & $\begin{array}{l}78 \\
<0.5\end{array}$ & $\begin{array}{l}120 \\
<0.5\end{array}$ & $\begin{array}{l}41 \\
<0.5\end{array}$ \\
\hline $\begin{array}{l}\text { September } \\
(n=5)\end{array}$ & 59 & $\begin{array}{l}\text { Influent } \\
\text { Effluent }\end{array}$ & $\begin{array}{l}9 \\
<0.5\end{array}$ & $\begin{array}{l}44 \\
<0.5\end{array}$ & $\begin{array}{l}75 \\
<0.5\end{array}$ & $\begin{array}{l}108 \\
<0.5\end{array}$ & $\begin{array}{l}10 \\
<0.5\end{array}$ \\
\hline $\begin{array}{l}\text { October } \\
(n=4)\end{array}$ & 47 & $\begin{array}{l}\text { Influent } \\
\text { Effluent }\end{array}$ & $\begin{array}{l}8 \\
<0.5\end{array}$ & $\begin{array}{l}43 \\
<0.5\end{array}$ & $\begin{array}{l}63 \\
<0.5\end{array}$ & $\begin{array}{l}106 \\
<0.5\end{array}$ & $\begin{array}{l}9 \\
<0.5\end{array}$ \\
\hline $\begin{array}{l}\text { November } \\
(n=4)\end{array}$ & 45 & $\begin{array}{l}\text { Influent } \\
\text { Effluent }\end{array}$ & $\begin{array}{l}8 \\
<0.5\end{array}$ & $\begin{array}{l}37 \\
<0.5\end{array}$ & $\begin{array}{l}54 \\
<0.5\end{array}$ & $\begin{array}{l}101 \\
<0.5\end{array}$ & $\begin{array}{l}8 \\
<0.5\end{array}$ \\
\hline $\begin{array}{l}\text { December } \\
n=5 \text { ) }\end{array}$ & 52 & $\begin{array}{l}\text { Influent } \\
\text { Effluent }\end{array}$ & $\begin{array}{l}8 \\
<0.5\end{array}$ & $\begin{array}{l}40 \\
<0.5\end{array}$ & $\begin{array}{l}45 \\
<0.5\end{array}$ & $\begin{array}{l}101 \\
<0.5\end{array}$ & $\begin{array}{l}7 \\
<0.5\end{array}$ \\
\hline
\end{tabular}

HFBR Tritium Plume Remediation System (OU III): This groundwater pump and recharge system was constructed as an interim remedial action after discovering the HFBR tritium plume, and has operated since May 1997. Three groundwater extraction wells were installed approximately 3,500 feet south of the HFBR. The tritiated groundwater (generally $<2,000$ $\mathrm{pCi} / \mathrm{L}$ ) is pumped from the aquifer at a rate of about 120 gallons per minute and piped north to a treatment facility adjacent to the RA V treatment system (see Figure 8-42). Because the tritiated water also contains VOCs that originated from another source(s), the water is treated by passing it through a granular carbon filter to remove the VOCs before discharging the water to the RA $V$ recharge basin. This interim remediation system is designed to prevent the further southward migration of the HFBR tritium plume while long-term remediation options are evaluated as part of the OU III FS.

During CY 1997, 63,000,000 gallons of water were treated by the granular activated carbon filters (to remove VOCs), and then recharged to the aquifer system.

Air Sparging/Soil Vapor Extraction System for OU IV: This remediation system, which has operated since November 1997, combines two technologies to remove VOC and Semi-VOC contaminants from soil and groundwater located near the BNL Central Steam Facility. The system uses air sparging and soil vapor extraction which forces pressurized air into the groundwater to "bubble" or strip these volatile compounds out of the water and soil and into a vapor phase. Powerful vacuum pumps then recover the resulting vapors and pipe them to a nearby treatment facility where the VOC vapors are removed by a granular carbon filter system before the air is released into the atmosphere. 
Table 8-6

BNL Site Environmental Report for Calendar Year 1997

Removal Action $\mathbf{V}$ Groundwater Remediation System

Comparison of Monthly Average Influent and Effluent voc Concentrations (a)

\begin{tabular}{|c|c|c|c|c|c|c|}
\hline Month & $\begin{array}{l}\text { voc Removal } \\
\text { (lbs.) }\end{array}$ & & Chloroethane & 1,1 - Dichloroethane & Chloroform & 1,1,1-Tichloroethane \\
\hline $\begin{array}{l}\text { January } \\
(n=16)\end{array}$ & 17 & $\begin{array}{l}\text { Influent } \\
\text { Effluent }\end{array}$ & $\begin{array}{l}14 \\
<1\end{array}$ & $\begin{array}{l}49 \\
<1\end{array}$ & $\begin{array}{l}2 \\
<1\end{array}$ & $\begin{array}{l}6 \\
<1\end{array}$ \\
\hline $\begin{array}{l}\text { February } \\
(n=18)\end{array}$ & 12 & $\begin{array}{l}\text { Influent } \\
\text { Effluent }\end{array}$ & $\begin{array}{l}12 \\
<1\end{array}$ & $\begin{array}{l}38 \\
<1\end{array}$ & $\begin{array}{l}2 \\
<1\end{array}$ & $\begin{array}{l}7 \\
<1\end{array}$ \\
\hline $\begin{array}{l}\text { March } \\
(n=1)\end{array}$ & 14 & $\begin{array}{l}\text { Influent } \\
\text { Effluent }\end{array}$ & $\begin{array}{l}11 \\
<1\end{array}$ & $\begin{array}{l}34 \\
<1\end{array}$ & $\begin{array}{l}<1 \\
<1\end{array}$ & $\begin{array}{l}7 \\
<1\end{array}$ \\
\hline $\begin{array}{l}\text { April } \\
(n=0)\end{array}$ & 15 & $\begin{array}{l}\text { Influent } \\
\text { Effluent }\end{array}$ & - & - & - & - \\
\hline $\begin{array}{l}\text { May } \\
(n=5)\end{array}$ & 10 & $\begin{array}{l}\text { Influent } \\
\text { Effluent }\end{array}$ & $\begin{array}{l}3 \\
<1\end{array}$ & $\begin{array}{l}20 \\
<1\end{array}$ & $\begin{array}{l}<1 \\
<1\end{array}$ & $\begin{array}{l}5 \\
<1\end{array}$ \\
\hline $\begin{array}{l}\text { June } \\
(n=4)\end{array}$ & 17 & $\begin{array}{l}\text { Influent } \\
\text { Effluent }\end{array}$ & $\begin{array}{l}3 \\
<1\end{array}$ & $\begin{array}{l}13 \\
<1\end{array}$ & $\begin{array}{l}44 \\
<1\end{array}$ & $\begin{array}{l}4 \\
<1\end{array}$ \\
\hline $\begin{array}{l}\text { July } \\
(n=4)\end{array}$ & 10 & $\begin{array}{l}\text { Influent } \\
\text { Effluent }\end{array}$ & $\begin{array}{l}4 \\
<1\end{array}$ & $\begin{array}{l}18 \\
<1\end{array}$ & $\begin{array}{l}1 \\
<1\end{array}$ & $\begin{array}{l}5 \\
<1\end{array}$ \\
\hline $\begin{array}{l}\text { August } \\
(n=4)\end{array}$ & 6 & $\begin{array}{l}\text { Influent } \\
\text { Effluent }\end{array}$ & $\begin{array}{l}3 \\
<1\end{array}$ & $\begin{array}{l}16 \\
<1\end{array}$ & $\begin{array}{l}<1 \\
<1\end{array}$ & $\begin{array}{l}4 \\
<1\end{array}$ \\
\hline $\begin{array}{l}\text { September } \\
(n=4)\end{array}$ & 5 & $\begin{array}{l}\text { Influent } \\
\text { Effluent }\end{array}$ & $\begin{array}{l}3 \\
<1\end{array}$ & $\begin{array}{l}14 \\
<1\end{array}$ & $\begin{array}{l}<1 \\
<1\end{array}$ & $\begin{array}{l}4 \\
<1\end{array}$ \\
\hline $\begin{array}{l}\text { October } \\
(n=4)\end{array}$ & 8 & $\begin{array}{l}\text { Influent } \\
\text { Effluent }\end{array}$ & $\begin{array}{l}3 \\
<1\end{array}$ & $\begin{array}{l}13 \\
<1\end{array}$ & $\begin{array}{l}<1 \\
<1\end{array}$ & $\begin{array}{l}3 \\
<1\end{array}$ \\
\hline $\begin{array}{l}\text { November } \\
(n=1)\end{array}$ & 4 & $\begin{array}{l}\text { Influent } \\
\text { Effluent }\end{array}$ & $\begin{array}{l}2 \\
<1\end{array}$ & $\begin{array}{l}11 \\
<1\end{array}$ & $\begin{array}{l}<1 \\
<1\end{array}$ & $\begin{array}{l}2 \\
<1\end{array}$ \\
\hline $\begin{array}{l}\text { December } \\
(n=1)\end{array}$ & 2 & $\begin{array}{l}\text { Influent } \\
\text { Effluent }\end{array}$ & $\begin{array}{l}2 \\
<1\end{array}$ & $\begin{array}{l}9 \\
<1\end{array}$ & $\begin{array}{l}<1 \\
<1\end{array}$ & $\begin{array}{l}3 \\
<1\end{array}$ \\
\hline
\end{tabular}

(a): Other compounds detected (typically $<3 \mu \mathrm{g} / \mathrm{L}$ ).

Approximately 12 pounds of contaminants were removed from the soil and groundwater through the treatment of $1,300,000,000$ cubic feet of air collected in the soil vapor extraction system.

Off-site Groundwater Treatment System for OU III: A fifth groundwater remediation system is expected to be operational in the spring of 1999. The system will be constructed south of the BNL site to remove VOC contamination that has migrated to an industrial area located between the Long Island Expressway and the residential areas of North Shirley. This remediation system will consists of a series of innovative "in-well sparging" wells that use the same air stripping treatment concept as the OU III south boundary systems, but all treatment and recharge occur within 
the same well. Within each well, contaminated water will be pumped from a deep well screen to a treatment section located near the top of the well where VOCs will be stripped from the water. The treated water will then be routed to shallow screened section of the same well where it will re-enter the aquifer, and the VOC vapors will be captured by a granular carbon filter.

\subsubsection{Facility Surveillance (NON-CERCLA) Groundwater Monitoring}

Groundwater monitoring is an integral part of BNL's Environmental Monitoring Program which is conducted to fulfill DOE Orders and NYS permits. This program includes monitoring at active waste processing and temporary storage facilities to comply with RCRA, waste-treatment facilities, operational monitoring around accelerators, and in other areas of known or suspected soil and groundwater contamination. During 1997,105 surveillance wells were monitored during nearly 400 individual sampling events. The locations of all BNL groundwater monitoring wells are presented in Figures 8-1 through 8-14. All wells sampled during CY 1997 are listed in Appendix D.

Most groundwater monitoring wells on the site are two to four inches in diameter, and typically constructed of PVC material. A few wells are constructed of stainless steel materials. The majority of the wells used for the groundwater monitoring program were installed after the mid-1980s, following the appropriate RCRA and CERCLA protocols. Groundwater samples are collected following documented sampling procedures based on EPA guidelines (EPA, 1987). The analytical techniques used are described in this report (see Appendix C), and in the BNL Site Environmental Monitoring Plan (Naidu et al., 1997). Comparing analytical data from the surveillance wells to NYS DOH and DOE reference levels provides a way to evaluate the potential impact of radiological and non-radiological levels of contamination. The groundwater resources underlying the BNL site are designated as Class GA fresh groundwater by NYS. Non-radiological data for groundwater samples collected from surveillance wells (which are not used for drinking water supply) are usually compared to NYS DEC Ambient Water Quality Standards (6NYCRR 703.5). Radiological data are compared to NYS DWS for tritium, gross beta, and strontium-90), NYS AWQS for gross alpha and radium-226/228, and DOE DCGs for other beta/gamma-emitting radionuclides.

\subsubsection{Non-Radiological Analyses}

\subsection{Research Facilities}

Alternating Gradient Synchrotron/LINAC and BLIP Areas: In the AGS experimental areas, surface spills and discharges to cesspools and recharge basins have contaminated the soils and groundwater with VOCs. Also, several documented spills have occurred in the AGS Bubble Chamber area, which was used as a storage area for drums and liquid-filled scintillation counters.

The surveillance well network for the AGS/LINAC and BLIP areas consists of 19 shallow to deep Upper Glacial aquifer wells which primarily monitor groundwater near and downgradient of the AGS Bubble Chamber spill areas and the AGS and AGS Booster facilities (Figure 8-4). During 1997, groundwater samples were collected from 14 of the AGS/LINAC and BLIP area surveillance wells, and analyzed for water quality, VOCs, and metals. The $\mathrm{pH}$ of the groundwater samples collected was typically below the lower limit of the NYS AWQS of $6.5-8.5$, with a median pH of 6.1. Other water quality parameters were below the applicable NYS AWQS. Samples from seven wells showed metals concentrations above NYS AWQS. Elevated levels of iron were detected in two wells (up to $1.6 \mathrm{mg} / \mathrm{L}$ ), sodium in five wells (up to $38 \mathrm{mg} / \mathrm{L}$ ), and zinc in one well $(1.7 \mathrm{mg} / \mathrm{L}$ ). Elevated iron and zinc detected in two of the wells, 54-01 and 54-02, is likely due to degradation of the wells' carbon steel casings. VOC analysis of groundwater samples collected from the AGS/ LINAC and BLIP area show TCA, TCE, and DCE at concentrations that exceeded NYS AWQS. Levels of TCA that exceeded standards were detected in wells 54-07 and 64-03 at maximum concentrations of $471 \mu \mathrm{g} / \mathrm{L}$ and $18 \mu \mathrm{g} / \mathrm{L}$, respectively. TCE and DCE were also detected in Well 54-07, at maximum concentrations of $25.9 \mu \mathrm{g} / \mathrm{L}$ and $15.5 \mu \mathrm{g} / \mathrm{L}$, respectively. The VOCs in Well 64-03 may have originated from cesspools associated with Buildings 914 and 919 , whereas the VOCs in 
well 54-07 may have originated from the Bubble Chamber spill areas. The contents of the Building 914/919 cesspools were characterized under the IAG (Cesspools EE/CA); they contained VOCs at levels above NYS Soil Cleanup Guidelines. No VOCs were detected in the LINAC and BLIP area wells. The full extent of groundwater contamination downgradient of the AGS/LINAC and BLIP areas is being examined as part of the BNL CERCLA Program (see section 8.1.2.1.3).

\subsection{Support Facilities}

Sewage Treatment Plant / Peconic River Area: The Sewage Treatment Plant processes sanitary sewage for BNL facilities. The discharge is regulated under a NYSDEC SPDES permit.

The surveillance well network at the STP and Peconic River areas consists of over 50 shallow to deep Upper Glacial aquifer wells (Figures 8-5, 8-6 and 8-13). Twenty-one of the wells are located off-site, and are currently monitored as part of the OU V Pre-ROD monitoring program (see Section 8.1.2). As part of the BNL Facility Surveillance Program for the STP, groundwater samples from 13 of these wells were analyzed for water quality, VOCs, and metals (Tables 8-7, 8-8 and 8-9). In most wells, the $\mathrm{pH}$ of groundwater was typically below the NYS AWQS of $6.5-8.5$, with a median $\mathrm{pH}$ of 5.6. Most other water quality parameters were within the applicable NYS AWQS. Although detectable levels of nitrates $\left(\mathrm{NO}_{3}\right)$ were found in five shallow wells located near the STP filter beds, only one well (38-02) had concentrations that were slightly above the NYS AWQS of $10 \mathrm{mg} / \mathrm{L}$, with a maximum observed concentration of $12 \mathrm{mg} / \mathrm{L}$. Iron exceeded NYS AWQS of $0.3 \mathrm{mg} / \mathrm{L}$ in four wells, with maximum concentrations ranging from $0.39 \mathrm{mg} / \mathrm{L}$ to $1.4 \mathrm{mg} / \mathrm{L}$. Four wells had sodium concentrations above the NYS AWQS of $20 \mathrm{mg} / \mathrm{L}$, with maximum concentrations ranging from $22.9 \mathrm{mg} / \mathrm{L}$ to $32.5 \mathrm{mg} / \mathrm{L}$. Although trace amounts of chloroform were detected (maximum concentration of $2 \mu \mathrm{g} / \mathrm{L}$ ), no VOCs were detected above NYS AWQS in any of the STP area wells. However, TCE at levels exceeding NYS AWQS are observed in wells located to the east of BNL, that are monitored under the OU V Pre-ROD Monitoring Program (see Section 8.1.2.1.5).

BNL Shotgun Range: In the north central portion of the site (north of the new Waste Management Facility), BNL maintains a recreational shotgun range. There is concern that the deposition of lead shot used at the range has, or will, degrade soil and groundwater quality. Furthermore, the shotgun range lies within the zone of contribution for BNL potable supply wells 11 and 12, south of the shotgun range. Routine sampling of them has not revealed elevated lead concentrations (see Section 8.1.1.2). Groundwater quality in the shotgun range area is currently evaluated from four shallow Upper Glacial aquifer wells. During 1997, a composite soil sample was

also collected. It contained lead at a concentration of $96 \mathrm{mg} / \mathrm{kg}$, which is below the SCDHS soil cleanup criteria of $400 \mathrm{mg} / \mathrm{kg}$.

During 1997, two rounds of groundwater samples from four wells located in the shotgun range area were collected and analyzed for metals and water quality. The $\mathrm{pH}$ of groundwater was below the NYS AWQS of $6.5-8.5$, with a median $\mathrm{pH}$ of 5.6. Other water quality parameters were below the applicable NYS AWQS. All metals, including lead, were also below NYS AWQS.

Water Treatment Plant Area: At the direction of the NYSDEC, five groundwater surveillance wells were installed at the WTP in 1993 to assess potential leaching of iron from the plant's recharge basins into the groundwater. Naturally high levels of iron in groundwater are removed at the WTP, and the precipitated iron is discharged to the recharge basins.

During 1997, two rounds of groundwater samples were collected from these five wells, and analyzed for water quality and metals. The $\mathrm{pH}$ of the groundwater from two upgradient wells was typically slightly below the lower limit of the NYS AWQS of $6.5-8.5$, with a median pH of 6.1, whereas it was within limits in three wells directly downgradient of the basins, with a median $\mathrm{pH}$ of 7.0. Other water quality parameters were below the applicable NYS AWQS. Most metals concentrations (including iron) were below the applicable NYS AWQS. However, sodium was detect- 
ed slightly above the NYS AWQS of $20 \mathrm{mg} / \mathrm{L}$ in one well (73-01), with a maximum concentration of $26 \mathrm{mg} / \mathrm{L}$.

Building 423 (Motor Pool) Area: Building 423 serves as the site motor pool, where BNL's fleet vehicles are repaired and refueled. Gasoline is stored in two 8,000 gallon-capacity underground storage tanks (USTs), and waste oil is stored in one 500 gallon-capacity UST. Although the USTs and associated distribution lines meet SC Article 12 requirements for secondary containment, leak detection, and high level alarms, BNL initiated a groundwater monitoring program in 1996 to ensure that potential leakage will be detected if a tank alarm system failed.

During 1997, three rounds of groundwater samples were collected from the two surveillance wells and analyzed for VOCs, and checked for floating petroleum product. TCA was detected at concentrations exceeding NYS AWQS in well 102-06, with a maximum observed concentration of $8 \mu \mathrm{g} / \mathrm{L}$. The fuel additive MTBE was also detected in Well 102-06 at a maximum concentration of $7.4 \mu \mathrm{g} / \mathrm{L}$, which is well below the NYS DWS of $50 \mu \mathrm{g} / \mathrm{L}$. No floating product was observed.

On-Site Service Station: Building 630 is a commercial automobile repair and gasoline station for the BNL site. Gasoline is stored in two 8,000 gallon capacity and one 6,000 gallon capacity underground storage tanks (USTs), and waste oil is stored in one 500 gallon capacity UST. Although the USTs and associated distribution lines meet SC Article 12 requirements for secondary containment, leak detection, and high level alarms, BNL initiated a groundwater monitoring program in 1996 to ensure that potential leakage will be detected if a tank alarm system failed.

During 1997, three rounds of groundwater samples were collected from the two surveillance wells and analyzed for VOCs, and checked for floating petroleum product. PCE and carbon tetrachloride were detected at concentrations exceeding NYS AWQS. PCE was detected in both well 85-16 and well 85-17, at maximum observed concentrations of $12.1 \mu \mathrm{g} / \mathrm{L}$ and $11 \mu \mathrm{g} / \mathrm{L}$, respectively. Carbon tetrachloride was found in one sample from well 85-17 at a concentration of $6.5 \mu \mathrm{g} / \mathrm{L}$. The fuel additive MTBE was also detected in Well 85-17 at a maximum concentration of $18.6 \mu \mathrm{g} / \mathrm{L}$, which is well below the NYSDWS of $50 \mu \mathrm{g} / \mathrm{L}$. No floating product was observed.

Former Chemistry Department Area: The Former Chemistry Department complex was located on Rochester Street and Bell Avenue. In the 1950s, the Chemistry Department conducted a longterm solar neutrino study using a 1,000 gallon-capacity tank installed underground south of Bell Avenue. This tank was filled with 1,000 gallons of carbon tetrachloride. Available records indicate that the carbon tetrachloride was removed from the tank, and that air was blown through it to remove residual traces of the solvent. During CY 1998, BNL will locate and remove the tank, and install additional wells to further evaluate groundwater quality downgradient of the tank.

Groundwater quality downgradient of the Former Chemistry Department complex is presently monitored by a single shallow Upper Glacial aquifer well (Figure 8-7). During 1997, the well (8506) was sampled for VOCs. Carbon tetrachloride and chloroform were detected above NYS AWQS at maximum concentrations of $20 \mu \mathrm{g} / \mathrm{L}$ and $9 \mu \mathrm{g} / \mathrm{L}$, respectively.

Major Petroleum Facility (MPF) Area: The CSF supplies steam for heating to all major facilities of the Laboratory through an underground distribution system. The MPF is the holding area for most fuels used at the CSF. Five shallow wells monitoring the MPF were installed as part of the licensing requirements for this facility, and are screened across the water table so that free products (i.e., oil floating on top of the groundwater) can be detected. The surveillance wells at the CSF were installed primarily to monitor ground-water contamination resulting from a 1977 leak of approximately 23,000 gallons of Alternative Liquid Fuel (a fuel oil/spent solvent mixture). The CSF/MPF area has been the subject of an RI/FS (OU IV), and has been undergoing active soil and groundwater remediation since the winter of 1997 (see Sections 8.1.2.1.4 and 8.1.2.3).

The surveillance well network at the CSF and MPF area consists of 30 shallow to deep Upper Glacial aquifer wells (Figures 8-5 through 8-8). During 1997, 23 wells were monitored for water quality, metals, and VOCs. The five MPF wells were also sampled monthly for floating petroleum

1997 BNL Site Environmental Report $8-63$ 
Table 8-7

BNL Site Environmental Report for Calendar Year 1997

Sawage Treatment Plant/Peconic River Area

Groundwater Surveillance Wells, Water Quality Data

\begin{tabular}{|c|c|c|c|c|c|c|}
\hline Well & $\begin{array}{l}\text { No. of } \\
\text { Samples }\end{array}$ & $\begin{array}{l}\mathrm{pH}(\mathrm{SU}) \\
\text { Range }\end{array}$ & & $\begin{array}{l}\text { Chlorides } \\
\text { (mg/L) }\end{array}$ & $\begin{array}{l}\text { Sulfates (a) } \\
(\mathrm{mg} / \mathrm{L})\end{array}$ & $\begin{array}{l}\text { Nitrate (NO3) (a) } \\
(\mathrm{mg} / \mathrm{L})\end{array}$ \\
\hline $38-01$ & 4 & $4.8-5.4$ & $\begin{array}{l}\text { Max. } \\
\text { Avg. }\end{array}$ & $\begin{array}{r}6.416 \\
5.1\end{array}$ & $\begin{array}{l}<1.0 \\
14.5\end{array}$ & $<1.0$ \\
\hline $38-02$ & 3 & $5.4-5.9$ & $\begin{array}{l}\text { Max. } \\
\text { Avg. }\end{array}$ & $\begin{array}{l}22.1 \\
11.9\end{array}$ & $\begin{array}{l}20.4 \\
14.5\end{array}$ & $\begin{array}{r}12.0 \\
7.1\end{array}$ \\
\hline $38-03$ & 4 & $5.1-5.8$ & $\begin{array}{l}\text { Max. } \\
\text { Avg. }\end{array}$ & $\begin{array}{l}14.7 \\
10.0\end{array}$ & $\begin{array}{l}17.6 \\
14.8\end{array}$ & $\begin{array}{r}3.3 \\
<1.0\end{array}$ \\
\hline $38-05$ & 4 & $5.5-6.3$ & $\begin{array}{l}\text { Max. } \\
\text { Avg. }\end{array}$ & $\begin{array}{l}11.3 \\
10.2\end{array}$ & $\begin{array}{l}14.6 \\
12.3\end{array}$ & $\begin{array}{l}3.5 \\
3.2\end{array}$ \\
\hline $38-06$ & 4 & $5.2-5.7$ & $\begin{array}{l}\text { Max. } \\
\text { Avg. }\end{array}$ & $\begin{array}{l}5.0 \\
4.7\end{array}$ & $\begin{array}{r}10.0 \\
8.6\end{array}$ & $\begin{array}{l}<1.0 \\
<1.0\end{array}$ \\
\hline $39-05$ & 4 & $5.4-5.7$ & $\begin{array}{l}\text { Max. } \\
\text { Avg. }\end{array}$ & $\begin{array}{l}21.3 \\
16.6\end{array}$ & $\begin{array}{l}9.3 \\
6.6\end{array}$ & $\begin{array}{l}<1.0 \\
<1.0\end{array}$ \\
\hline $39-06$ & 4 & $5.8-6.4$ & $\begin{array}{l}\text { Max. } \\
\text { Avg. }\end{array}$ & $\begin{array}{l}47.1 \\
35.1\end{array}$ & $\begin{array}{l}31.3 \\
12.8\end{array}$ & $\begin{array}{r}1.1 \\
<1.0\end{array}$ \\
\hline $39-07$ & 4 & $5.7-6.2$ & $\begin{array}{l}\text { Max. } \\
\text { Avg. }\end{array}$ & $\begin{array}{l}37.9 \\
21.9\end{array}$ & $\begin{array}{l}13.3 \\
11.3\end{array}$ & $\begin{array}{l}6.2 \\
3.7\end{array}$ \\
\hline $39-08$ & 4 & $5.4-6.1$ & $\begin{array}{l}\text { Max. } \\
\text { Avg. }\end{array}$ & $\begin{array}{l}39.3 \\
31.3\end{array}$ & $\begin{array}{l}16.9 \\
14.9\end{array}$ & $\begin{array}{l}5.3 \\
4.2\end{array}$ \\
\hline$\overline{3} \overline{9}-0 \overline{9}$ & 4 & $4 . \overline{9}-5.1$ & $\begin{array}{l}\text { M̄ax. } \\
\text { Avg. }\end{array}$ & $\begin{array}{r}10.2 \\
9.5\end{array}$ & $\begin{array}{l}8.7 \\
7.7\end{array}$ & $\begin{array}{l}<1.0 \\
<1.0\end{array}$ \\
\hline $39-10$ & 4 & $6.4-6.7$ & $\begin{array}{l}\text { Max. } \\
\text { Avg. }\end{array}$ & $\begin{array}{l}8.2 \\
6.3\end{array}$ & $\begin{array}{l}8.6 \\
6.5\end{array}$ & $\begin{array}{l}<1.0 \\
<1.0\end{array}$ \\
\hline $60-01$ & 4 & $4.8-5.5$ & $\begin{array}{l}\text { Max. } \\
\text { Avg. }\end{array}$ & $\begin{array}{r}10.9 \\
8.0\end{array}$ & $\begin{array}{r}13.0 \\
9.6\end{array}$ & $\begin{array}{l}<1.0 \\
<1.0\end{array}$ \\
\hline $61-03$ & 3 & $4.7-5.1$ & $\begin{array}{l}\text { Max. } \\
\text { Avg. }\end{array}$ & $\begin{array}{l}13.2 \\
11.6\end{array}$ & $\begin{array}{l}12.7 \\
12.1\end{array}$ & $\begin{array}{l}<1.0 \\
<1.0\end{array}$ \\
\hline NYS AWQS & & $6.5-8.5$ & & 250 & 250 & 10 \\
\hline Typical MDL & & & & 4 & 4 & 1 \\
\hline
\end{tabular}

a): Holding times for sulfates and nitrates were usually exceeded.

products, and twice per year for polynuclear aromatics and base-neutral extractable compounds (EPA Method 625), in accordance with the NYSDEC license (see Section 2.3.4). The pH was typically below the lower limit of the NYS AWQS of $6.5-8.5$, with a median pH of 6.0. Other water quality parameters were below the applicable NYS AWQS. All metal concentrations were below the applicable NYS AWQS. In the five wells monitoring the MPF, VOCs were above NYS AWQS, in upgradient Well 76-25 with TCA at a maximum concentration of $8.2 \mu \mathrm{g} / \mathrm{L}$, and PCE was detected in well 76-19 at a maximum concentration of $9.9 \mu \mathrm{g} / \mathrm{L}$. The TCA detected in well 76-25 is likely to have originated from releases in the Building 650 area, whereas the PCE in well 76-19 is likely to have originated historical spills at the MPF. No benzene/ethylbenzene/toluene/xylene (BETX) or other hydrocarbon-related compounds were detected in the MPF wells. As in previous years, no floating petroleum products were observed during 1997. 
Table 8-8

BNL Site Environmental Report for Calendar Year 1997

Sewage Treatment Plant/Peconic River Area.

Groundwater Surveillance Wells, Metals Data

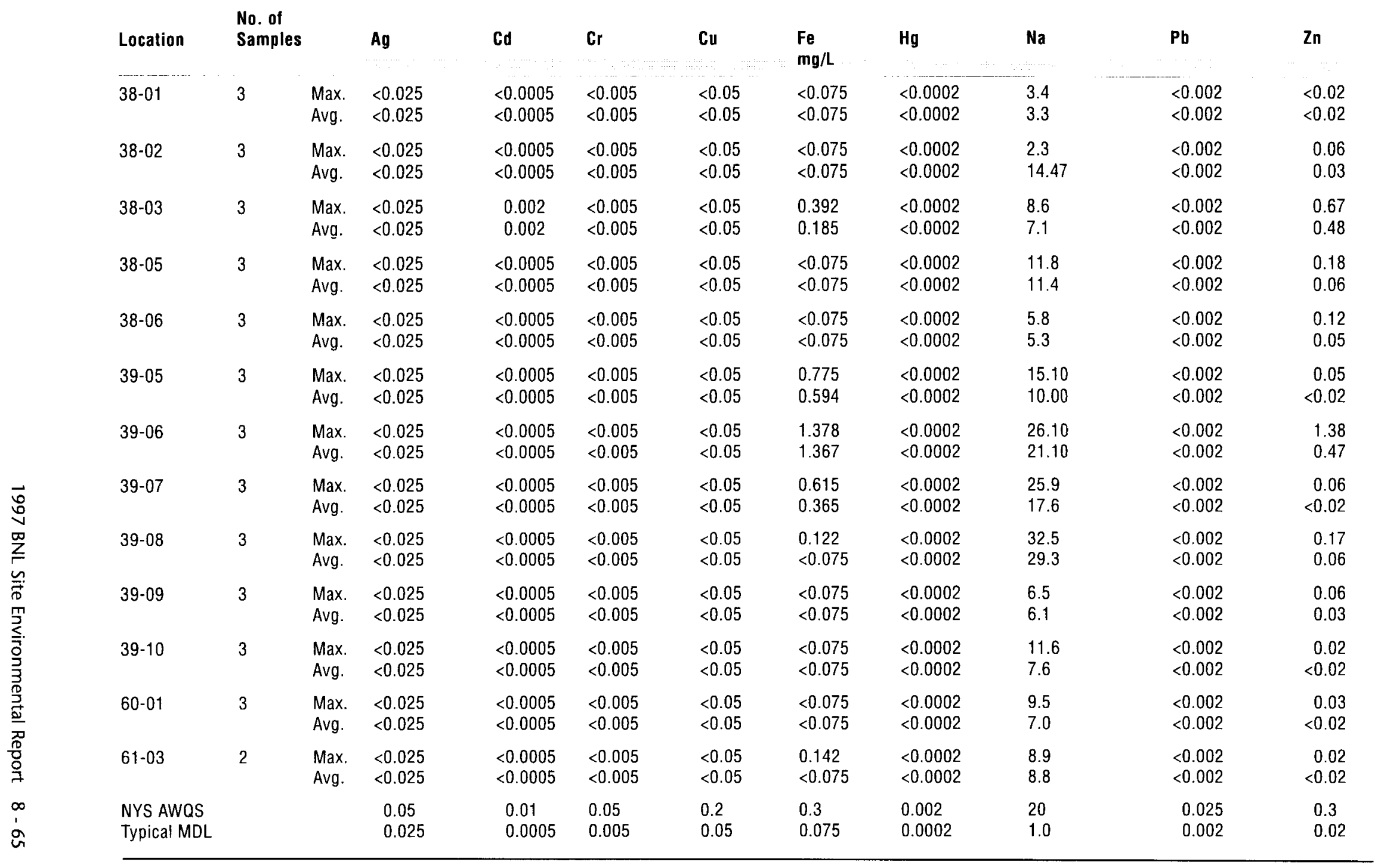


New Waste Management Facility: In CY 1997, BNL began operating a new Waste Management Facility (WMF) located close to the geographic center of the site. The new facility is designed to safely handle, repackage, and temporarily store BNL derived hazardous and radioactive waste prior to shipment to an off-site disposal or treatment facility. The new WMF is designed and operated in a manner that meets all applicable federal, state and local environmental protection requirements; never the less, BNL established a groundwater monitoring program as a secondary means of verifying the effectiveness of the engineering and operational controls.

The new WMF is monitored by eight shallow Upper Glacial aquifer wells. During 1997, three rounds of groundwater samples were collected and analyzed for VOCs, metals and water quality. The $\mathrm{pH}$ of groundwater was slightly below the NYS AWQS of $6.5-8.5$, with a median pH of 6.2. All other water quality parameters were below the applicable NYS AWQS. Except for sodium, metal concentrations were also found to be below NYS AWQS. Sodium routinely exceeded the 20 $\mathrm{mg} / \mathrm{L}$ AWQS in well 55-03, with a maximum observed concentration of $38 \mathrm{mg} / \mathrm{L}$. All VOCs were below applicable NYS AWQS.

\subsubsection{Radiological Analyses}

\subsection{Research Facilities}

Alternating Gradient Synchrotron (AGS) Area: Wells in the vicinity of the AGS are positioned in Grids 54, 64, and 65 (see Figure 8-4). Man-made (or anthropogenic) radionuclides have been detected in groundwater downgradient of the Brookhaven Linac Isotope Producer (BLIP) and AGS facilities. These radionuclides have been produced through activation and/ or spallation processes in soil constituents by secondary radiation generated by beam/target interactions. The radiological data are presented in Table 8-9. Except for well 54-01, which showed two highly divergent gross beta values in 1997, all gross activity concentrations in wells in this part of the site were typical of nominal environmental levels. The high gross beta value of $34 \mathrm{pCi} / \mathrm{L}(1.3 \mathrm{~Bq} / \mathrm{L})$ in the 54-01 well sample may be falsely elevated due to analytical instrument problems (see Chapter 10 for details).

Well 64-02 continued to show low levels of tritium, consistent with values observed since this well's installation in 1994 . The maximum observed concentration was $2,470 \mathrm{pCi} / \mathrm{L}$ ( 91 $\mathrm{Bq} / \mathrm{L}$ ). Samples from this well also continued to show sodium-22 (half-life $=2.6$ years), at a maximum concentration of $21 \mathrm{pCi} / \mathrm{L}(0.8 \mathrm{~Bq} / \mathrm{L})$. A more extensive investigation of possible radionuclides in groundwater downgradient of the BLIP facility is scheduled for CY 1998.

Brookhaven Medical Research Reactor (BMRR): The BMRR's primary cooling water system consists of a recirculating loop containing 2,550 gallons of water. The tritium concentration in the primary water is approximately $465 \mathrm{mCi} / \mathrm{L}(17 \mathrm{MBq} / \mathrm{L})$. However, unlike the High Flux Beam Reactor, the BMRR has neither a spent fuel storage canal nor an imbedded pressurized piping system, which could provide a route of environmental release for radioactive liquids.

Potential environmental vulnerabilities at the BMRR were initially evaluated during the HFBR Tritium Remediation Project, and later as part of the BNL Facility Review Project. Low levels of tritium $(2,450 \mathrm{pCi} / \mathrm{L}[91 \mathrm{~Bq} / \mathrm{L}])$ were detected in a groundwater sample collected in January 1997 from a shallow Upper Glacial aquifer-monitoring well (94-01), located 400 feet south of the BMRR. Therefore, BNL installed two shallow monitoring wells directly downgradient of the BMRR. Subsequent sampling of the new wells revealed tritium concentrations of up to $11,400 \mathrm{pCi} / \mathrm{L}(422$ $\mathrm{Bq} / \mathrm{L}$ ). Twenty-five temporary Geoprobe ${ }^{\mathrm{TM}}$ wells were then installed to identify the source and determine the extent of the tritium contamination (Paquette, 1997). The highest tritium levels were found in temporary wells installed within 50 feet of the BMRR, where a maximum concentration of $11,800 \mathrm{pCi} / \mathrm{L}(437 \mathrm{~Bq} / \mathrm{L})$ was detected. A plume of tritiated groundwater was traced from the BMRR to approximately 400 feet south (downgradient), where a maximum concentration of $3,800 \mathrm{pCi} / \mathrm{L}(141 \mathrm{~Bq} / \mathrm{L})$ was detected. The tritium is believed to have originated from the 
Table 8-9

BNL Site Environmental Report for Calendar Year 1997

Radiological Data tor Groundwater Wells netar AGS, BLIP and LINAC Areas

\begin{tabular}{|c|c|c|c|c|c|c|}
\hline Well ID & $\mathbf{N}$ & & Gross Alpha & Gross Beta & Tritium & $\mathrm{Na-22}$ \\
\hline 044-02 & 3 & $\begin{array}{l}\text { Max. } \\
\text { Avg. }\end{array}$ & $\begin{array}{l}2.4 \pm 1.2 \\
1.2 \pm 3.4\end{array}$ & $\begin{array}{l}6.9 \pm 2.5 \\
3.7 \pm 8.8\end{array}$ & $\begin{array}{l}<372 \\
-134 \pm 376\end{array}$ & ND \\
\hline $053-01$ & 4 & $\begin{array}{l}\text { Max. } \\
\text { Avg. }\end{array}$ & $\begin{array}{l}4.8 \pm 1.3 \\
1.7 \pm 5.5\end{array}$ & $\begin{array}{l}5.2 \pm 2.3 \\
2.3 \pm 5.0\end{array}$ & $\begin{array}{l}402 \pm 212 \\
107 \pm 550\end{array}$ & ND \\
\hline 054-01 & 3 & $\begin{array}{l}\text { Max. } \\
\text { Avg. }\end{array}$ & $\begin{array}{l}<1.4 \\
\quad 0.7 \pm 0.7\end{array}$ & $\begin{array}{l}4.01 .2 \\
3.7 \pm 0.9\end{array}$ & $\begin{aligned}< & 372 \\
& -72 \pm 377\end{aligned}$ & ND \\
\hline 054-02 & 3 & $\begin{array}{l}\text { Max. } \\
\text { Avg. }\end{array}$ & $\begin{array}{l}3.5 \pm 1.2 \\
1.0 \pm 4.3\end{array}$ & $\begin{array}{l}8.1 \pm 2.5 \\
4.6 \pm 6.1\end{array}$ & $\begin{array}{l}673 \pm 233 \\
491 \pm 570\end{array}$ & ND \\
\hline 054-03 & 2 & $\begin{array}{l}\text { Max. } \\
\text { Avg. }\end{array}$ & $\begin{aligned}< & 1.2 \\
& 0.6 \pm 1.4\end{aligned}$ & $\begin{array}{l}<3.8 \\
\quad 0.4 \pm 2.3\end{array}$ & $\begin{array}{r}<324 \\
39 \pm 235\end{array}$ & ND \\
\hline 054-05 & 3 & $\begin{array}{l}\text { Max. } \\
\text { Avg. }\end{array}$ & $\begin{array}{l}5.9 \pm 1.5 \\
2.0 \pm 6.7\end{array}$ & $\begin{array}{l}9.0 \pm 2.5 \\
4.8 \pm 8.0\end{array}$ & $\begin{aligned}< & 372 \\
& -95 \pm 279\end{aligned}$ & ND \\
\hline 054-06 & 3 & $\begin{array}{l}\text { Max. } \\
\text { Avg. }\end{array}$ & $\begin{array}{l}4.0 \pm 1.2 \\
2.0 \pm 4.4\end{array}$ & $\begin{array}{l}6.0 \pm 2.4 \\
4.4 \pm 2.9\end{array}$ & $\begin{array}{r}<372 \\
92 \pm 408\end{array}$ & $\begin{array}{l}0.14 \pm 0.003 \\
\text { (a) }\end{array}$ \\
\hline 054-07 & 3 & $\begin{array}{l}\text { Max. } \\
\text { Avg. }\end{array}$ & $\begin{array}{l}2.3 \pm 1.0 \\
0.3 \pm 3.3\end{array}$ & $\begin{array}{r}15.1 \pm 2.7 \\
8.3 \pm 13.7\end{array}$ & $\begin{array}{l}717 \pm 234 \\
397 \pm 657\end{array}$ & $\begin{array}{l}1.43 \pm 0.03 \\
0.94 \pm 0.85\end{array}$ \\
\hline $054-08$ & 3 & $\begin{array}{l}\text { Max. } \\
\text { Avg. }\end{array}$ & $\begin{array}{l}3.0 \pm 1.1 \\
1.7 \pm 2.6\end{array}$ & $\begin{array}{r}12.0 \pm 2.6 \\
7.7 \pm 11.2\end{array}$ & $\begin{array}{l}993 \pm 215 \\
662 \pm 719\end{array}$ & ND \\
\hline $54-10$ & 2 & $\begin{array}{l}\text { Max. } \\
\text { Avg. }\end{array}$ & $\begin{array}{l}2.4 \pm 1.0 \\
2.1 \pm 0.8\end{array}$ & $\begin{array}{l}33.7 \pm 3.4 \\
20.6 \pm 36.9\end{array}$ & $\begin{array}{l}494 \pm 216 \\
225 \pm 761\end{array}$ & $\begin{array}{l}0.30 \pm 0.01 \\
\text { (a) }\end{array}$ \\
\hline 064-01 & 3 & $\begin{array}{l}\text { Max. } \\
\text { Avg. }\end{array}$ & $\begin{array}{l}3.5 \pm 1.2 \\
1.5 \pm 3.5\end{array}$ & $\begin{array}{ll}4.7 \pm & 2.4 \\
4.4 \pm & 0.4\end{array}$ & $\begin{array}{r}<291 \\
25 \pm 303\end{array}$ & ND \\
\hline $064-02$ & 5 & $\begin{array}{l}\text { Max. } \\
\text { Avg. }\end{array}$ & $\begin{array}{l}1.8 \pm 1.0 \\
0.2 \pm 1.9\end{array}$ & $\begin{array}{l}8.4 \pm 1.4 \\
4.9 \pm 7.0\end{array}$ & $\begin{array}{l}2,470 \pm 379 \\
1,337 \pm 2,131\end{array}$ & $\begin{array}{r}21.0 \pm 0.42 \\
7.80 \pm 0.85\end{array}$ \\
\hline 064-03 & 3 & $\begin{array}{l}\text { Max. } \\
\text { Avg. }\end{array}$ & $\begin{array}{l}2.3 \pm 1.1 \\
0.7 \pm 2.8\end{array}$ & $\begin{array}{l}7.4 \pm 2.4 \\
4.6 \pm 5.1\end{array}$ & $\begin{array}{r}<291 \\
35 \pm 576\end{array}$ & $\begin{array}{l}3.60 \pm 0.07 \\
2.04 \pm 2.75\end{array}$ \\
\hline \multicolumn{7}{|c|}{$\begin{array}{l}\mathbf{N}=\text { No. of samples collected. } \\
\text { ND = Not Detected. } \\
\text { Notes: } \\
\text { (a) This nuclide detected only once. } \\
\text { Maximum values reported with } 2 \sigma(95 \%) \text { conficlence interval. } \\
\text { Average values calculated as arithmetic mean of individual measurements } \pm 2 \text { standard errors of the mean. }\end{array}$} \\
\hline
\end{tabular}

historical discharge of primary cooling water to a basement floor drain and sump system that may have leaked. The last such discharge from this system occurred in 1987, and the floor drains are scheduled to be permanently sealed in CY 1999 to prevent any future releases to the underlying soils. 


\subsection{Support Facilities}

Sewage Treatment Plant / Peconic River Area: For groundwater in the area surrounding the STP, gross alpha activity values were typical of ambient groundwater values while gross beta activities were elevated in Wells 38-03 and 39-08 with a maximum recorded value of $61 \mathrm{pCi} / \mathrm{L}(2.3 \mathrm{~Bq} / \mathrm{L})$ (Table 8-10). These wells showed elevated gross beta concentrations in 1996 also. Tritium was present at up to $3,630 \mathrm{pCi} / \mathrm{L}(134 \mathrm{~Bq} / \mathrm{L}$ )(Figure 8-43). Though cesium-137 has been detected in groundwater in this area in the past, no significant concentrations were observed in samples collected in 1997 . The only well which showed cesium-137 was $39-09$ at $0.21 \pm 0.14 \mathrm{pCi} / \mathrm{L}(8 \pm 5$ $\mathrm{mBq} / \mathrm{L}$ ), a concentration which is at the limit of detection and, therefore, questionable as a valid result. The drinking water standard for cesium-137 is $120 \mathrm{pCi} / \mathrm{L}(4.4 \mathrm{~Bq} / \mathrm{L})$. No other anthropogenic radionuclides were detected in groundwater in this area.

New Waste Management Facility (WMF): The new WMF is monitored by eight shallow Upper Glacial aquifer wells. During 1997, three rounds of groundwater samples were collected for radiological analysis (Table 8-11). With one exception, gross activity levels in these samples were typical of ambient background levels. Well 56-01 showed slightly elevated gross beta activity, with a maximum value of $12.8 \mathrm{pCi} / \mathrm{L}(0.47 \mathrm{~Bq} / \mathrm{L})$, due to cobalt-60 (half-life $=5.2$ years), which was detected in two of the three samples collected from this well in 1997. The maximum concentration of cobalt 60 observed was $4.4 \mathrm{pCi} / \mathrm{L}(0.16 \mathrm{~Bq} / \mathrm{L})$. The drinking water standard for this radionuclide is $200 \mathrm{pCi} / \mathrm{L}(7.4 \mathrm{~Bq} / \mathrm{L})$. This material is not related to the WMF. The likely sources of the cobalt are (1) past leakage from nearby underground sanitary lines (which at one time transported liquid wastes containing this nuclide from Building 811 to the STP) or (2) the underground storage tank leak which occurred at Building 830 in 1988. Though the Building 830 tank is downgradient of well 56-21, contaminants from the 1988 release are within the hydraulic zone of influence/capture created by pumps at Wells No. 11 and 12 .

While results indicated maximum tritium concentrations above the minimum detection limit (MDL) at wells 55-03 and 66-07, these values were extremely close to the MDL of $254 \mathrm{pCi} / \mathrm{L}(9.4$ $\mathrm{Bq} / \mathrm{L}$ ). When the $95 \%$ confidence intervals are considered, these two values are not statistically different from the MDL and do not, therefore, represent clear detections. The annual average value for each well, which includes all three-sample results, was less than the typical MDL for this analysis.

\subsubsection{Surveillance of Private Supply Wells}

\subsubsection{Radiological Analyses}

1995-1996 Surveillance Program: Between September 1995 and May 1996, the SCDHS sampled approximately 550 residential wells from the area shown in Figure 8-44. Approximately 550 samples were collected for tritium analysis, 220 samples were collected for gross alpha and gross beta activity, and 100 wells sampled for strontium-90.

Detectable levels of tritium were found in thirteen of the private wells, all at levels significantly below the Safe Drinking Water Act (SDWA) standard of $20,000 \mathrm{pCi} / \mathrm{L}(740 \mathrm{~Bq} / \mathrm{L})$. The concentrations in those wells ranged from $410 \mathrm{pCi} / \mathrm{L}(15 \mathrm{~Bq} / \mathrm{L})$ to a maximum of $3,930 \mathrm{pCi} / \mathrm{L}(145 \mathrm{~Bq} / \mathrm{L})$, or $2 \%$ to $20 \%$ of the drinking water standard. Figure $8-45$ summarizes these results.

Gross alpha, gross beta, and strontium-90 concentrations above the minimum detection limit were found in several private well samples. Figure 8-46 illustrates the results of these tests. No private well sampled during this period showed gross alpha, gross beta, or strontium-90 concentrations that exceed or approach the drinking water standards of $15 \mathrm{pCi} / \mathrm{L}(0.6 \mathrm{~Bq} / \mathrm{L}), 50 \mathrm{pCi} / \mathrm{L}$ $(1.9 \mathrm{~Bq} / \mathrm{L})$, and $8 \mathrm{pCi} / \mathrm{L}(0.3 \mathrm{~Bq} / \mathrm{L})$, respectively.

1997 Surveillance Program: In 1997 the SCDHS sampled water from approximately 100 residential wells to the east of BNL for tritium, gross alpha and gross beta activity. 
Table 8-10

BNL Site Environmental Report for Calendar Year 1997

Gross Activity and Tritium Results at STP and Peconic River Area

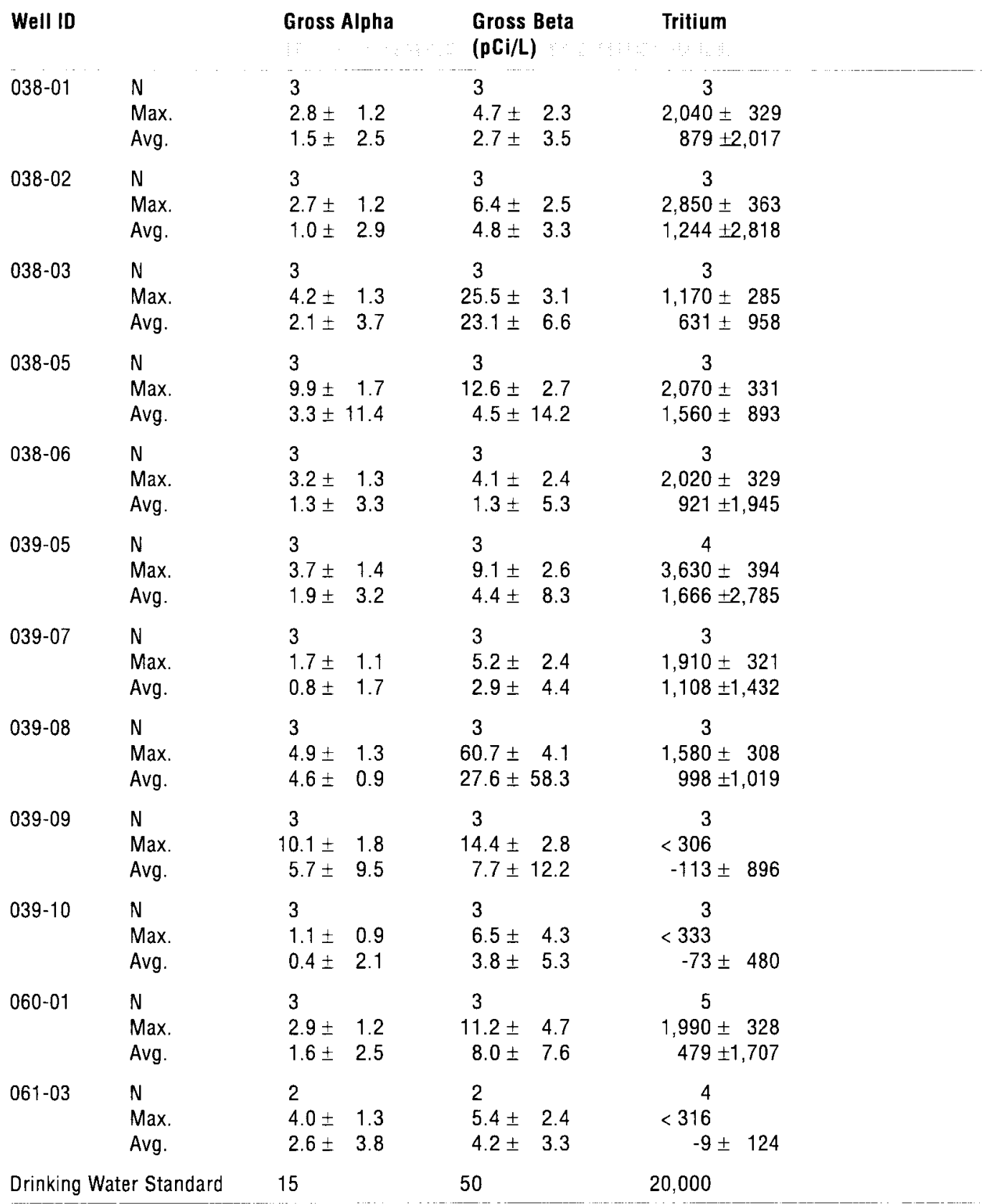

1. Maximum values reported with $2 \sigma(95 \%)$ contidence interval.

2. Average values calculated as arithmetic mean of individual measurements \pm 2 standard errors of the mean. $\mathbf{N}=$ Number of samples collected. 
Well 38-02

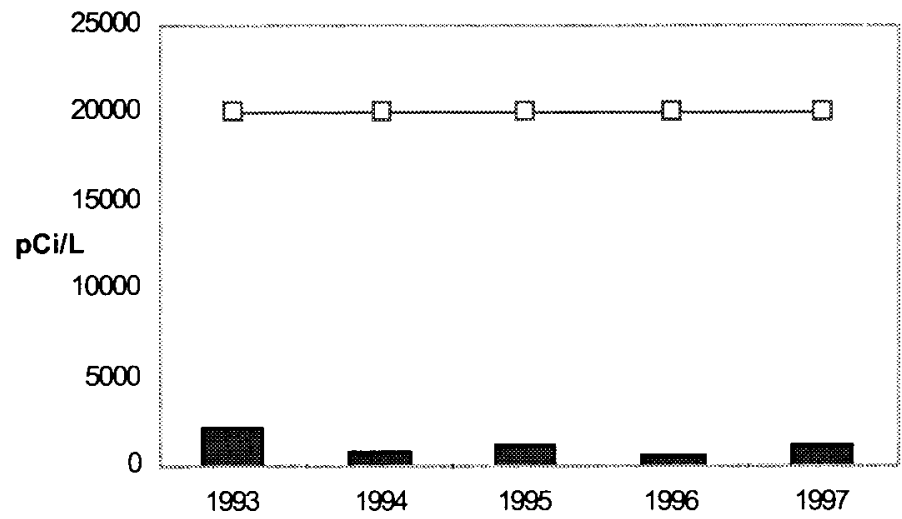

Well 38-03

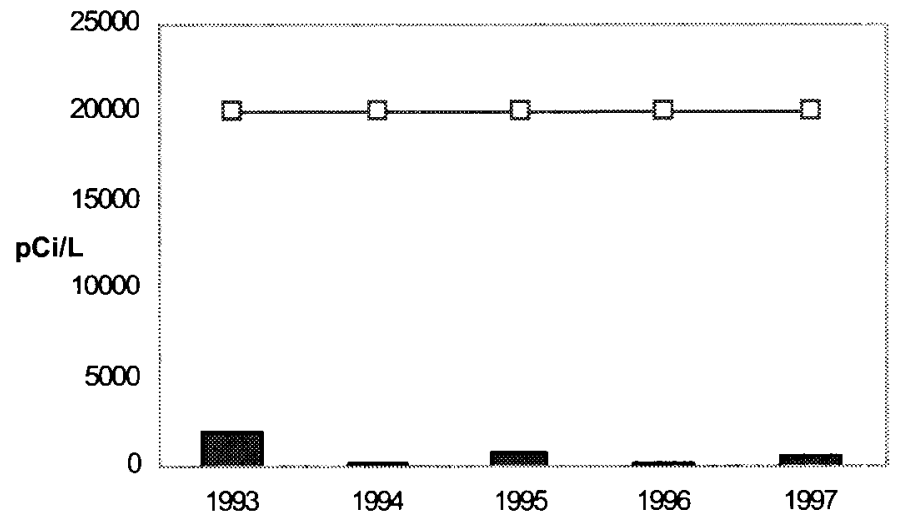

Well 39-07

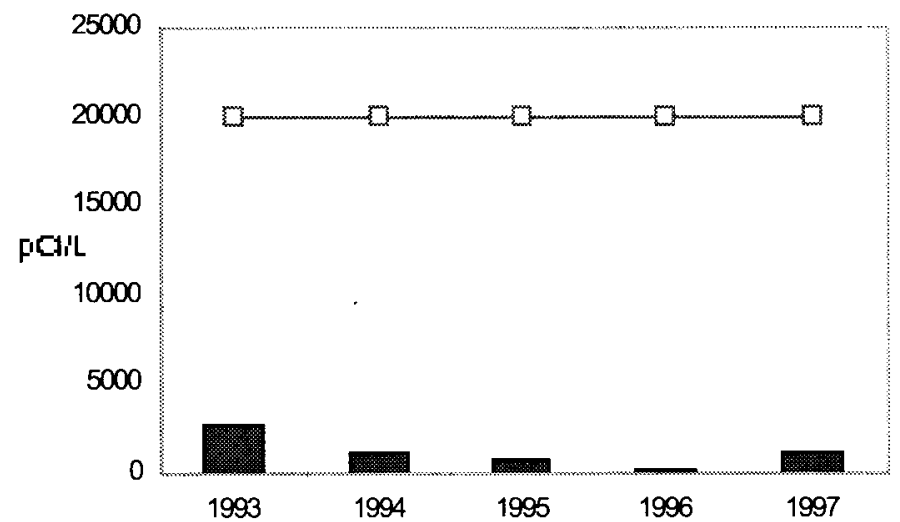

Well 39-08

Tritium $\ldots$ SDWA Limit

Figure 8-43. Annual average tritium concentration trend plots for selected wells located in the STP Filter Bed area.

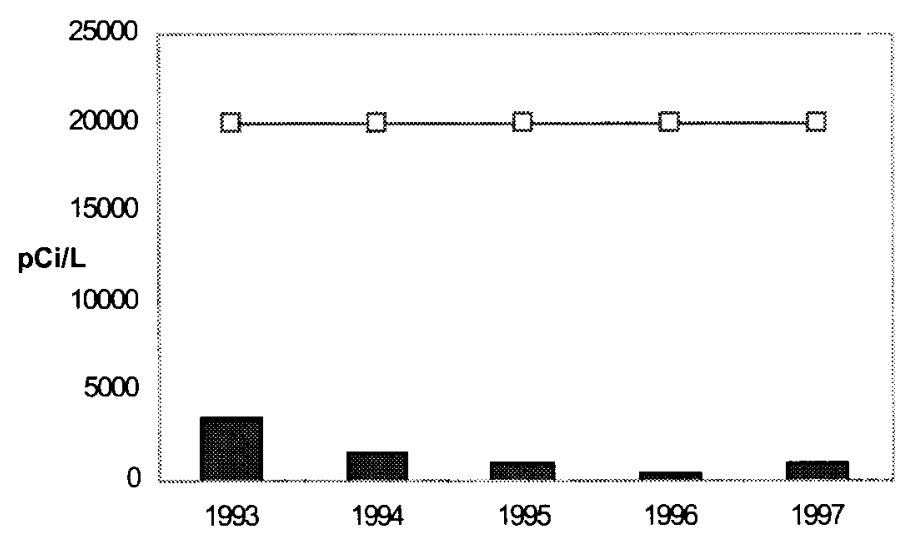


Table 8-11

BNL Site Environmental Report lor Calendal Year 1997

Gross Activity and Tritium Results at New Waste Management Facility

\begin{tabular}{|c|c|c|c|c|c|}
\hline Well ID & $\mathbf{N}$ & & Gross A.lpha & $\begin{array}{l}\text { Gross Beta } \\
\text { (pCi/L) }\end{array}$ & Tritium \\
\hline $055-03$ & 3 & $\begin{array}{l}\text { Max. } \\
\text { Avg. }\end{array}$ & $\begin{array}{l}3.4 \pm 1.2 \\
1.6 \pm 3.6\end{array}$ & $\begin{array}{ll}4.2 \pm & 2.3 \\
3.5 \pm & 1.3\end{array}$ & $\begin{array}{l}384 \pm 179(\mathrm{MDL}: 254) \\
192 \pm 338\end{array}$ \\
\hline 066-07 & 3 & $\begin{array}{l}\text { Max. } \\
\text { Avg. }\end{array}$ & $\begin{array}{l}3.2 \pm 1.2 \\
1.8 \pm 3.0\end{array}$ & $\begin{array}{l}5.4 \pm 2.4 \\
2.9 \pm 4.6\end{array}$ & $\begin{array}{l}294 \pm 174(\mathrm{MDL}: 254) \\
117 \pm 502\end{array}$ \\
\hline $055-10$ & 2 & $\begin{array}{l}\text { Max. } \\
\text { Avg. }\end{array}$ & $\begin{array}{l}3.2 \pm 1.0 \\
1.5 \pm 4.8\end{array}$ & $\begin{array}{l}4.5 \pm 2.2 \\
3.1 \pm 3.9\end{array}$ & $\begin{array}{l}<283 \\
107 \pm 389\end{array}$ \\
\hline $056-21$ (a) & 2 & $\begin{array}{l}\text { Max. } \\
\text { Avg. }\end{array}$ & $\begin{array}{l}4.3 \pm 1.4 \\
2.5 \pm 5.1\end{array}$ & $\begin{array}{r}12.8 \pm 2.7 \\
8.5 \pm 12.0\end{array}$ & $\begin{array}{l}<316 \\
213 \pm 116\end{array}$ \\
\hline $056-22$ & 3 & $\begin{array}{l}\text { Max. } \\
\text { Avg. }\end{array}$ & $\begin{array}{l}0.7 \pm 1.0 \\
0.3 \pm 1.0\end{array}$ & $\begin{array}{l}4.0 \pm 2.4 \\
3.1 \pm 1.8\end{array}$ & $\begin{array}{r}<303 \\
65 \pm 128\end{array}$ \\
\hline $056-23$ & 4 & $\begin{array}{l}\text { Max. } \\
\text { Avg. }\end{array}$ & $\begin{array}{l}2.0 \pm 1.2 \\
0.9 \pm 1.4\end{array}$ & $\begin{array}{l}6.0 \pm 2.2 \\
3.7 \pm 5.0\end{array}$ & $\begin{array}{l}<316 \\
-57 \pm 335\end{array}$ \\
\hline $066-83$ & 3 & $\begin{array}{l}\text { Max. } \\
\text { Avg. }\end{array}$ & $\begin{array}{l}1.8 \pm 0.8 \\
1.3 \pm 1.3\end{array}$ & $\begin{array}{l}7.7 \pm 2.3 \\
5.1 \pm 7.3\end{array}$ & $\begin{array}{l}<316 \\
10 \pm 183\end{array}$ \\
\hline
\end{tabular}

Maximum values reported with $2 \sigma(95 \%)$ conficlence interval.

Average values calculated as arithmetic mean of individual measurements \pm 2 standard errors of the mean. $\mathbf{N}=$ Number of samples collected.

Notes:

(a) Co-60 detected in well 056-21 in May 28 and August 26 samples at 2.5 and $4.4 \mathrm{pCi} / \mathrm{L}$, respectively.

Gross alpha concentrations in the wells ranged from 1 to $3 \mathrm{pCi} / \mathrm{L}(0.04$ to $0.1 \mathrm{~Bq} / \mathrm{L})$; a range typical of ambient environmental levels. Gross beta concentrations were also nominal, ranging from 2 to $6 \mathrm{pCi} / \mathrm{L}(0.07$ to $0.2 \mathrm{~Bq} / \mathrm{L})$. Figure $8-47$ summarizes the results. No private well sampled during this period showed gross alpha or gross beta concentrations that exceeded or approached their respective drinking water standards of $15 \mathrm{pCi} / \mathrm{L}(0.6 \mathrm{~Bq} / \mathrm{L})$ and $50 \mathrm{pCi}(1.9 \mathrm{~Bq} / \mathrm{L})$.

Detectable levels of tritium were found in eight private wells, all at levels significantly below the drinking water standard of $20,000 \mathrm{pCi} / \mathrm{L}(740 \mathrm{~Bq} / \mathrm{L})$. The concentration ranged from 800 to 2,201 $\mathrm{pCi} / \mathrm{L}$ ( 30 to $81 \mathrm{~Bq} / \mathrm{L}$ ), or $4 \%$ to $11 \%$ of the drinking water standard. Figure $8-48$ summarizes these results.

\subsubsection{Non-Radiological Analyses}

1995-1996 Surveillance Program: Approximately 550 residential wells were sampled for VOCs during September 1995 through May 1996. There were detectable levels of TCE, TCA, DCE, and chloroform in several of the wells. The concentrations fell above the Maximum Contaminant Levels (MCLs) of $5 \mu \mathrm{g} / \mathrm{L}$ in two wells for TCE; five wells for TCA; and one well for DCE. Figure 849 summarizes these results.

The solvent TCA was detected in one residential well at $180 \mu \mathrm{g} / \mathrm{L}$. It is likely to have originated from a previously identified source in the Brookhaven Industrial Park as described in Geraghty and Miller (1992) and SCDHS (1990). 
1997 Surveillance Program: Approximately 100 residential wells were sampled for VOCs during September 1997. TCE, TCA, DCE, MTBE, and chloroform were detected in several wells. The observed concentrations fell above the MCL of $5 \mu \mathrm{g} / \mathrm{L}$ in one well for TCE. All other concentrations were below NYS DWS, including wells sampled for MTBE (NYS DW $50 \mu \mathrm{g} / \mathrm{L}$ ). Figure 8-50 summarizes these results.

Low concentrations of tetrachloroethylene, xylene, trimethylbenzene, methylethylbenzene, and napthalene were detected in one residential well, but were significantly below the drinking water standards established for these contaminants.

\subsubsection{Surveillance of SCWA Municipal Supply Wells}

In 1996, the Suffolk County Water Authority (SCWA) began monitoring the supply wells in the vicinity of BNL for radionuclides. Samples were obtained from the William Floyd well field located to the southwest of BNL, the Lambert Avenue well field to the south, and the Country Club Drive well field to the southeast. The locations of these public water supply well fields are illustrated in Figure 8-51. The SCWA used Core Laboratories of Casper, Wyoming to perform these analyses. Core Laboratories is a commercial analytical laboratory that is certified by the NYSDOH to perform these analyses. The SCWA also sent duplicate (or quality assurance) samples to a second analytical laboratory, IEA of Cary, South Carolina.

The samples were analyzed for gross alpha and gross beta activity, tritium, and gamma-emitting radionuclides. Table $8-12$ provides the analytical results for CY 1997 . No elevated gross activity was detected in any sample, nor were any man-made gamma-emitting radionuclides detected. Though tritium was above the minimum detection limit in some cases, all values were below $1,000 \mathrm{pCi} / \mathrm{L}(37 \mathrm{~Bq} / \mathrm{L})$. Regarding these results, the SCWA determined that that public water supply is unaffected by BNL operations, and that it is safe to drink. This finding is further corroborated by the Suffolk County Department of Health Services (SCDHS) who state that:

"Although the results of the test indicates the finding of tritium in the sample, any level which is reported below $1,000 \mathrm{pCi} / \mathrm{L}$ is not considered significant due to the presence of naturally-occurring tritium and the inherent lack of accuracy and precision in analyzing very low levels of tritium" (SCDHS, 1997).

In 1997, the SCWA also monitored these supply wells on a monthly basis for VOCs and the pesticide EDB. None of these contaminants were detected. 


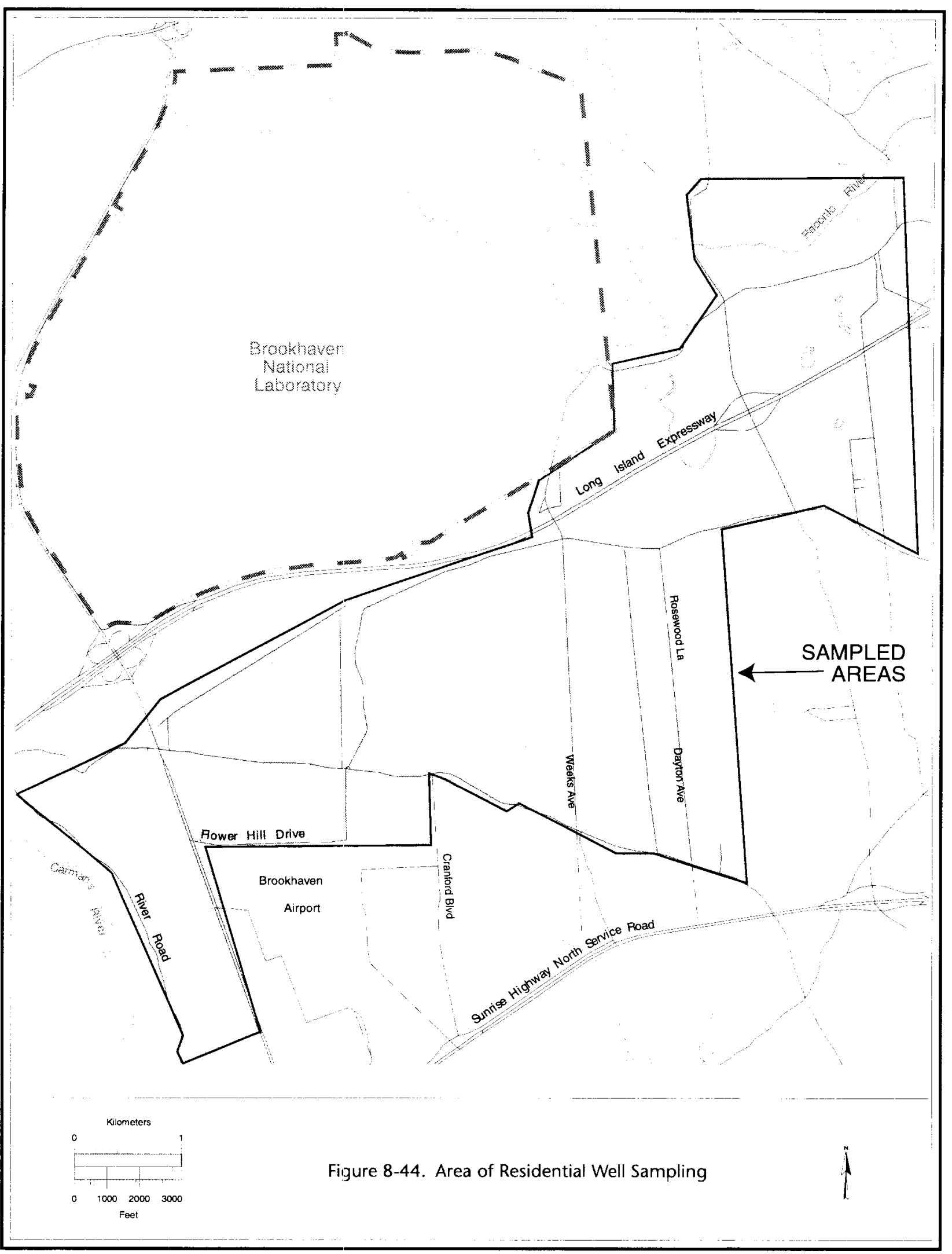


Number of Homes vs. Tritium Concentration

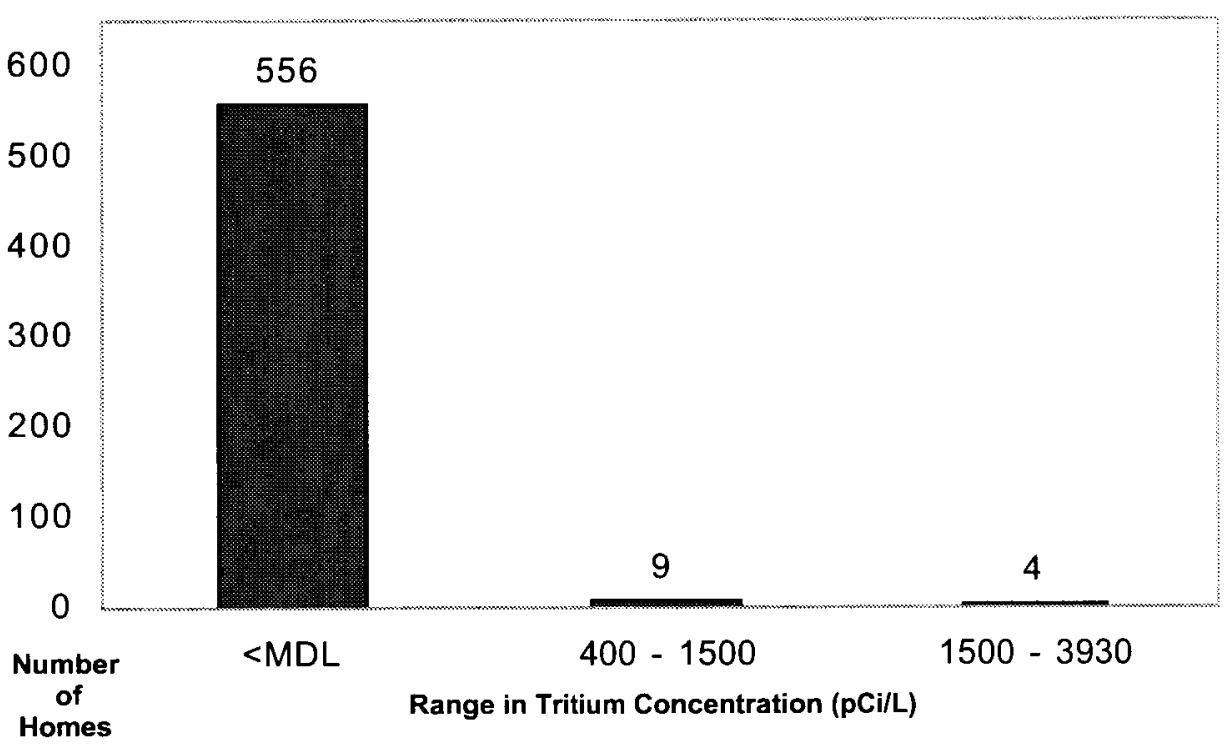

Figure 8-45. Private supply well sampling program for CY 1995 and CY 1996 - Tritium Data

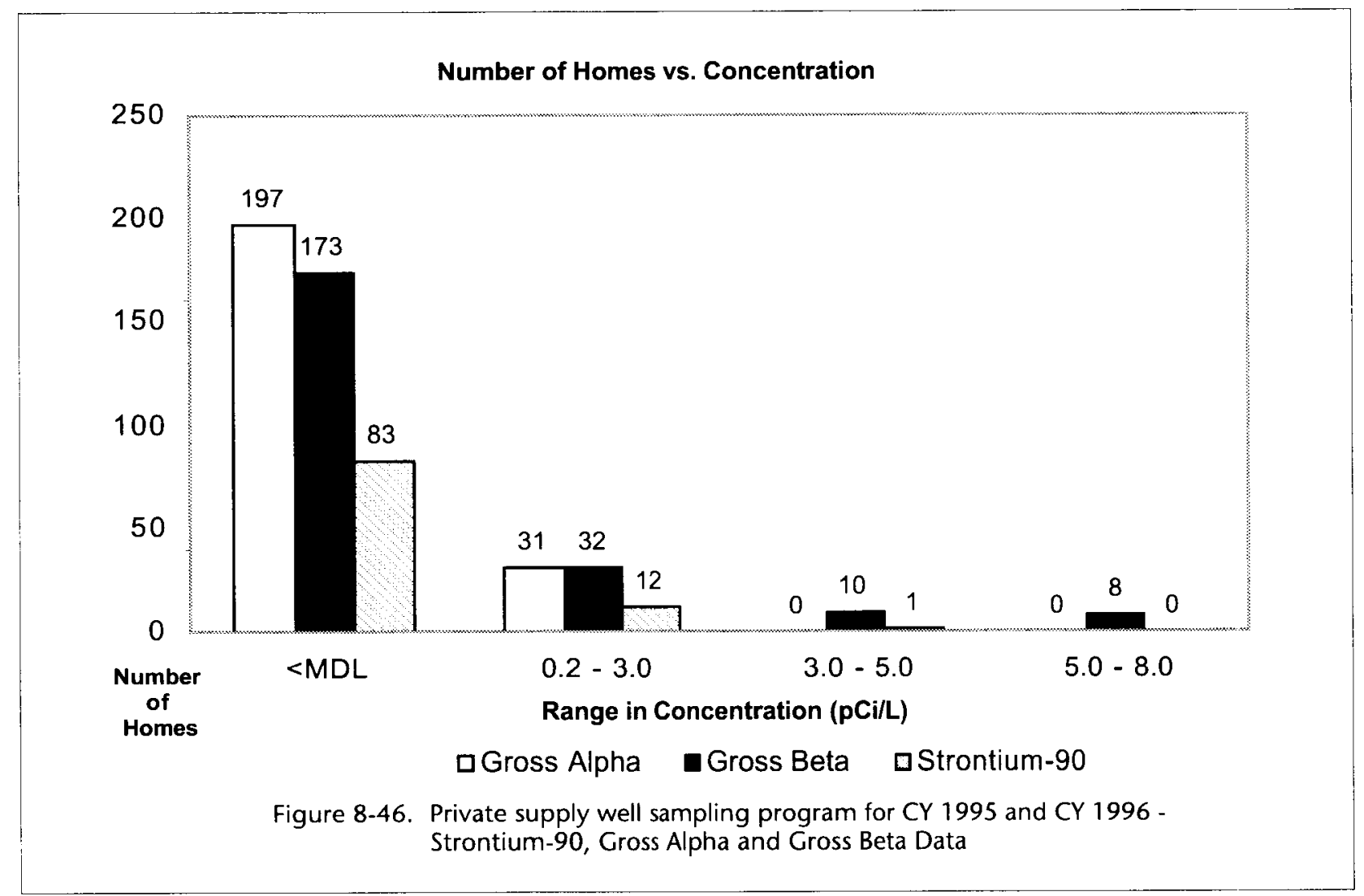




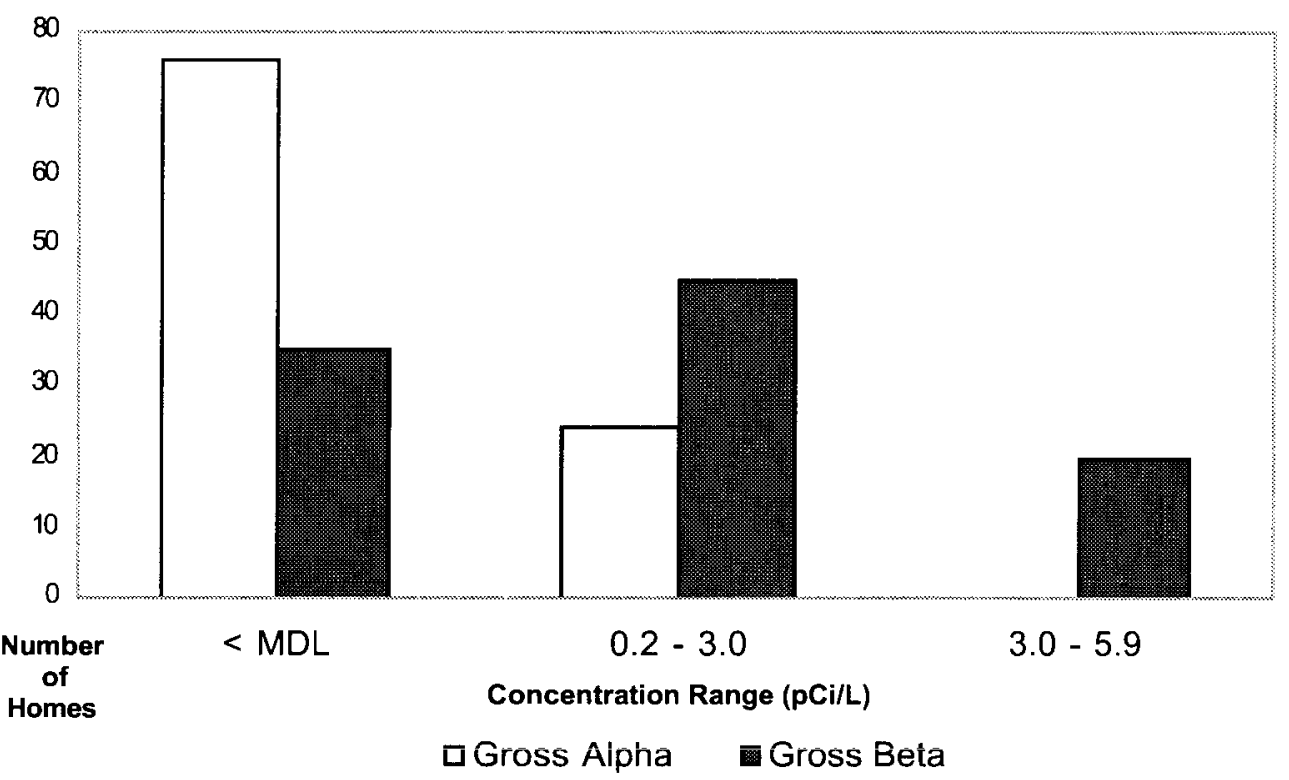

Figure 8-47. Gross activity in private wells sampled in 1997 (number of homes vs. concentration

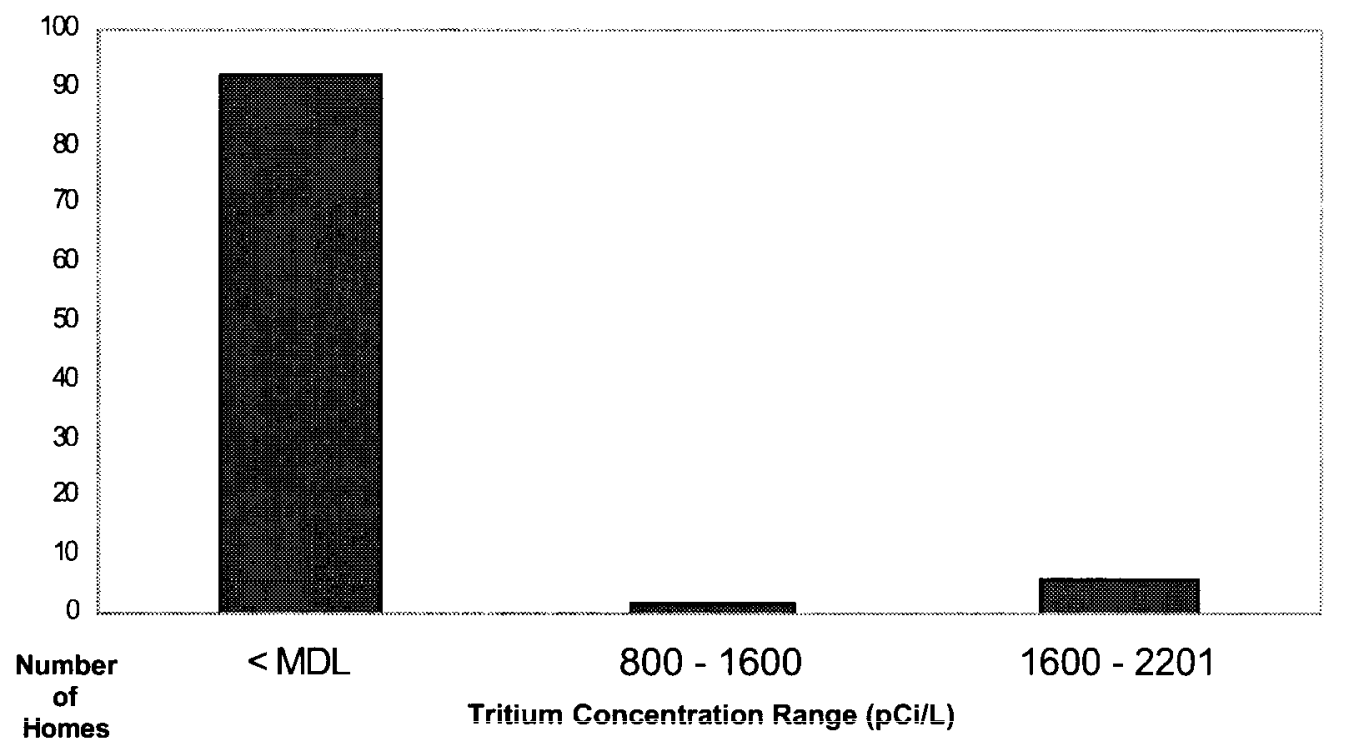

Figure 8-48. Tritium in private wells sampled in 1997 (number of homes vs. concentrations) 


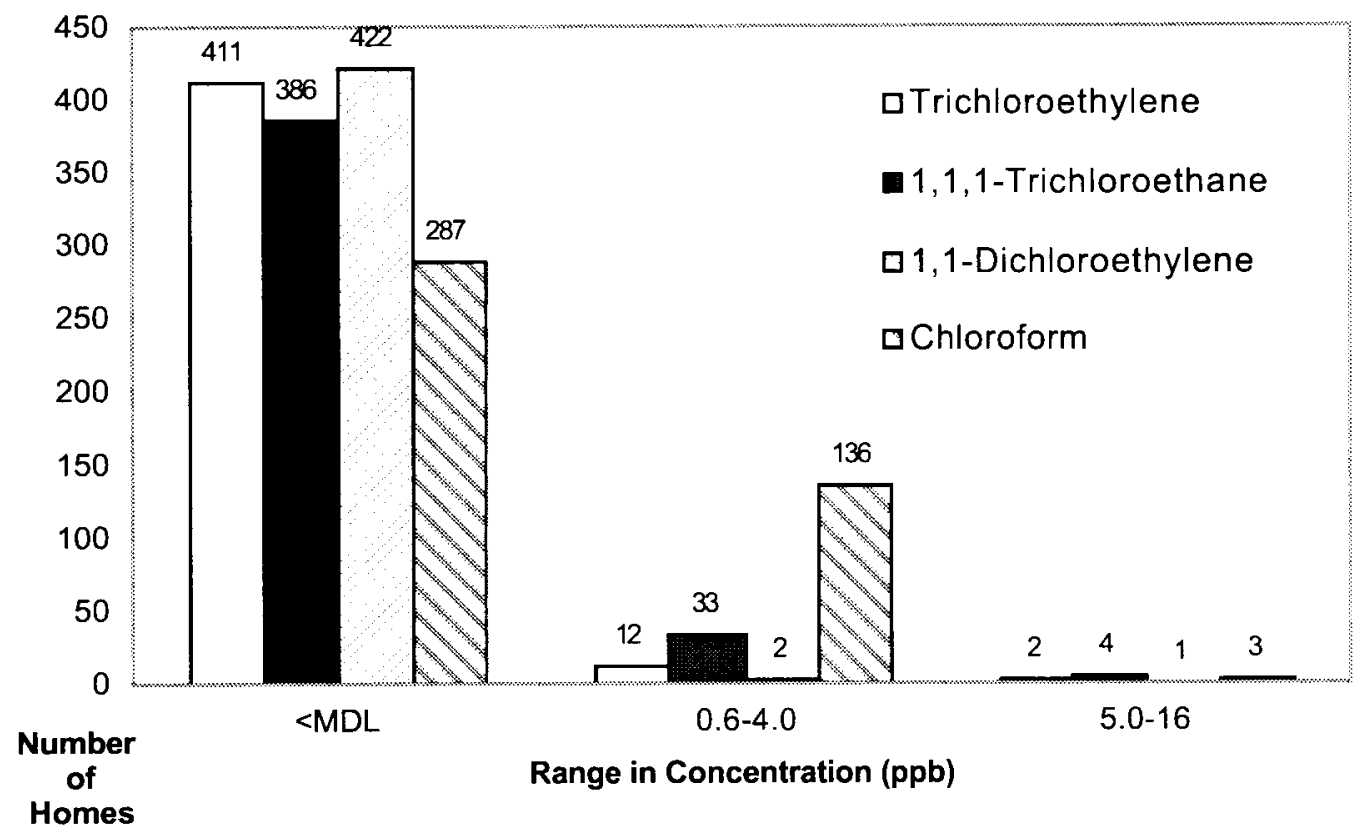

Figure 8-49. Private supply well sampling program for CY 1995 and CY 1996 - VOC Data

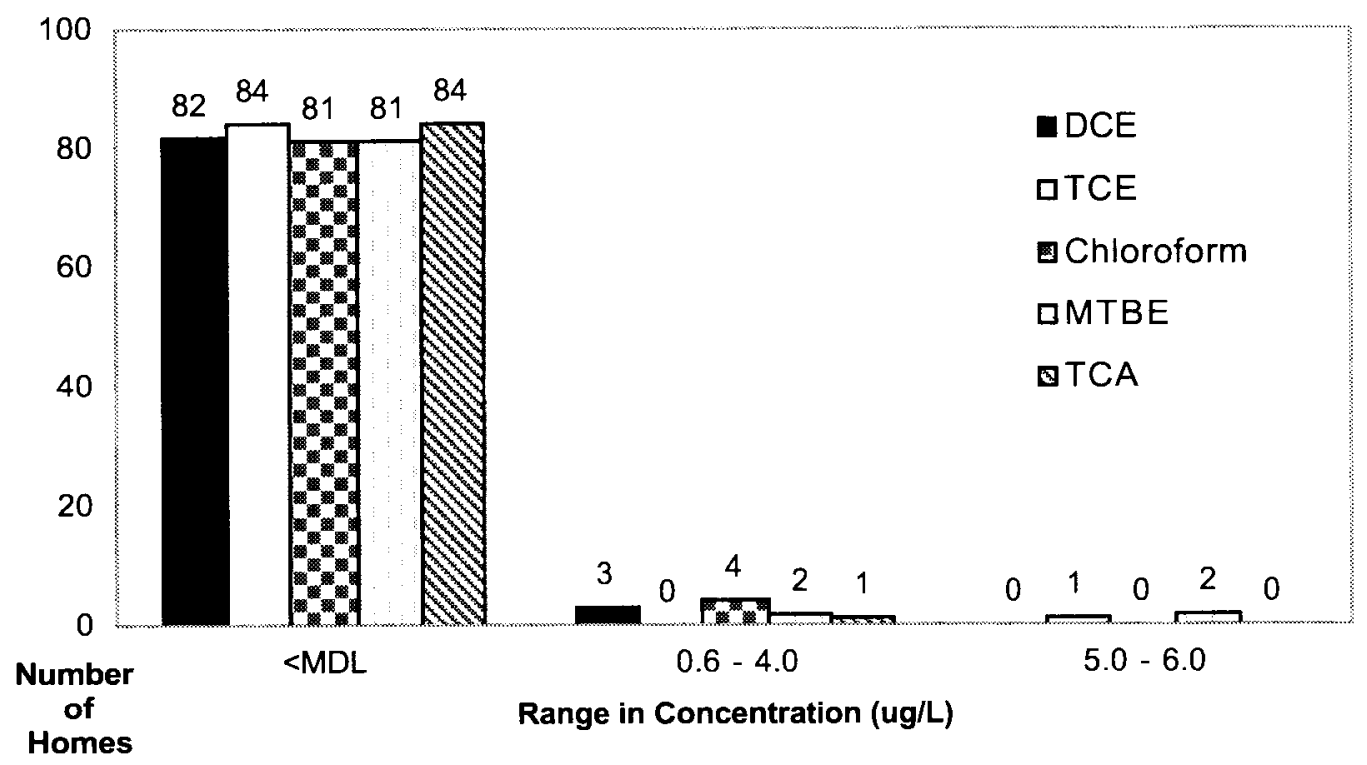

Figure 8-50. Private Supply Well Sampling program for CY 1997- VOC Data 


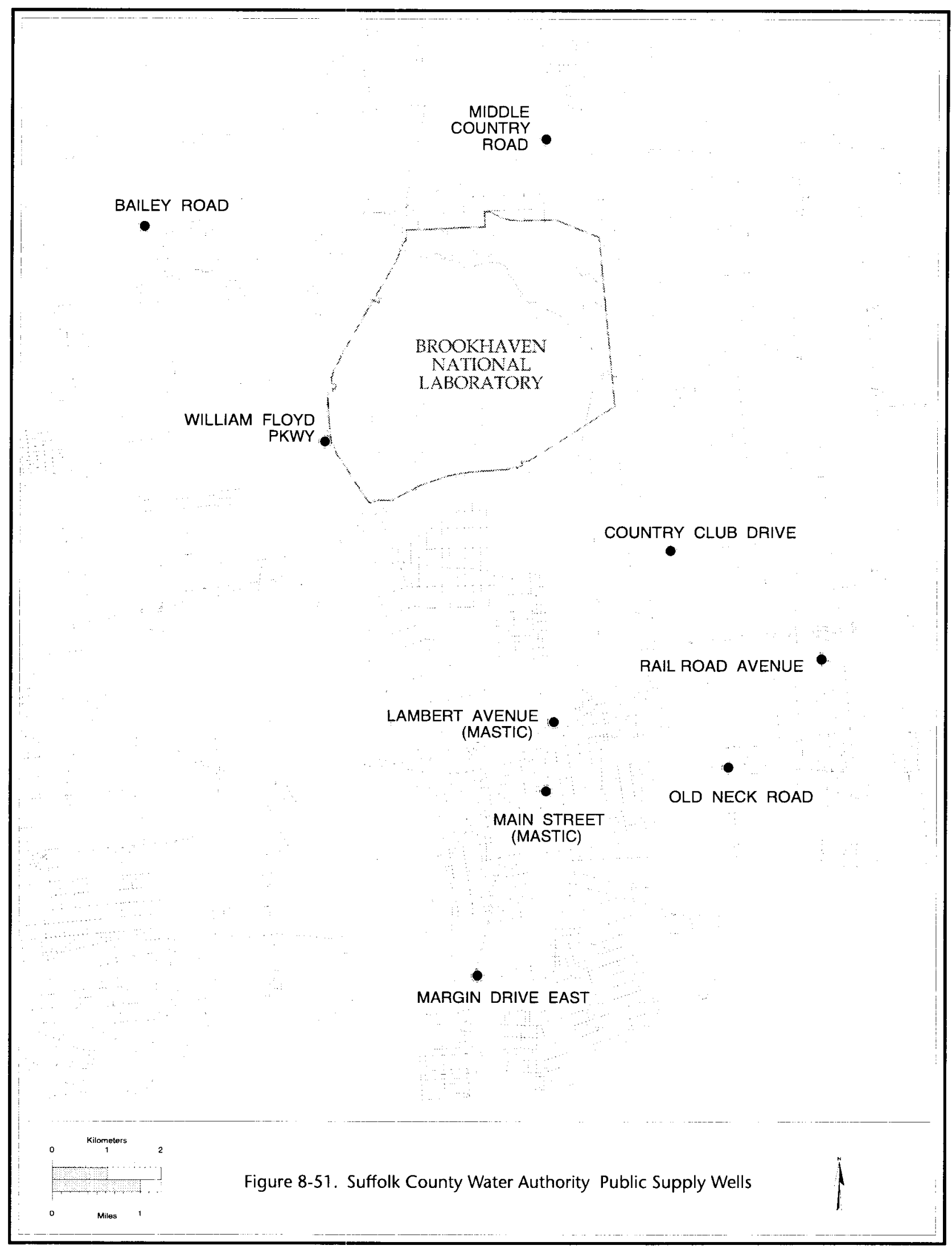


Table 8-12

BNL Site Environmental Report for Calendar Year 1997

SCWA Supply Well Radiological Analysis Data

\begin{tabular}{|c|c|c|c|}
\hline Well & $\begin{array}{l}\text { Depth } \\
\text { (ft.) }\end{array}$ & $\begin{array}{l}\text { Sample } \\
\text { Date }\end{array}$ & Gros: \\
\hline \multicolumn{4}{|c|}{ William Floyd Well Field } \\
\hline 1 & 165 & $\begin{array}{r}\text { 19-Mar-97 } \\
16-\text { Apr-97 } \\
\text { 28-May-97 } \\
\text { 10-Jun-97 } \\
\text { 4-Sep-97 } \\
23-0 \text { ct-97 }\end{array}$ & $\begin{array}{r}<0.8 \\
0.6 \\
<0.5 \\
<0.6 \\
<0.5 \\
<0.6\end{array}$ \\
\hline 2 & 179 & $\begin{array}{r}\text { 19-Mar-97 } \\
\text { 16-Apr-97 } \\
28-\text { May-97 } \\
10-J u n-97 \\
29-J u l-97 \\
4-\text { Sep-97 } \\
\text { 23-Oct-97 }\end{array}$ & $\begin{array}{l}<0.9 \\
1 \\
<0.8 \\
1.1 \\
<0.6 \\
<0.7 \\
<0.9\end{array}$ \\
\hline 3 & 268 & $\begin{array}{r}19-\text { Mar-97 } \\
16-\text { Apr-97 } \\
28-\text { May-97 } \\
10-\text { Jun-97 } \\
4-\text { Sep-97 } \\
23-0 \text { ct-97 }\end{array}$ & $\begin{array}{r}1.0 \\
<1.0 \\
0.9 \\
<0.8 \\
<0.5 \\
<0.8\end{array}$ \\
\hline
\end{tabular}

\section{Gross Beta Tritium \\ (pCi/L)}

$<0.8$

0.6

$<0.6$

$<0.5$

$<0.6$

$<0.9$

0.8

1.1

$<0.6$

$<0.7$

$<0.9$

1.0

$<1.0$

0.9

$<0.8$

$<0.8$

Lambert Ave. Well Field

\begin{tabular}{|c|c|c|}
\hline 1 & 308 & $\begin{array}{r}19-\text { Mar-97 } \\
28-\text { May-97 } \\
5-\text { Sep-97 } \\
23-0 \text { ct-97 }\end{array}$ \\
\hline 2 & 318 & $\begin{array}{r}19-\text { Mar-97 } \\
28-\text { May-97 } \\
5-\text { Sep-97 } \\
23-0 \text { ct-97 }\end{array}$ \\
\hline
\end{tabular}

Country Club Dr. Well Field

\begin{tabular}{|c|c|c|}
\hline 1 & 157 & $\begin{array}{r}\text { 19-Mar-97 } \\
29-\text { MAY-97 } \\
\text { 4-Sep-97 } \\
23-0 \text { ct-97 }\end{array}$ \\
\hline 2 & 163 & $\begin{array}{r}19-\text { Mar-97 } \\
30-\text { May-97 } \\
4-\text { Sep-97 } \\
23-0 c t-97\end{array}$ \\
\hline 3 & 168 & $\begin{array}{r}4-\text { Sep- } 97 \\
23-0 c t-97\end{array}$ \\
\hline
\end{tabular}

Drinking Water Standard

$0.5 \quad 1.3$

$\begin{array}{cc}<200 & \text { ND } \\ <141 & \text { ND } \\ <68.8 & \text { ND } \\ <71.6 & \text { ND } \\ 93.2 & \text { ND } \\ 200^{*} & \text { ND }\end{array}$

$<200 \quad$ ND

$<141 \quad$ ND

$90.1^{*} \quad$ ND

$<71.2 \quad N D$

$129^{*} \quad$ ND

$86.1^{*} \quad$ ND

$211^{*} \quad$ ND

$<200 \quad$ ND

$153^{\star} \quad$ ND

$<68.7 \quad N D$

$<71.3 \quad$ ND

$<56.0 \quad$ ND

$217^{*} \quad$ ND
Gamma-Emitters

$D$
$D$
$D$
$D$
$D$

D

告

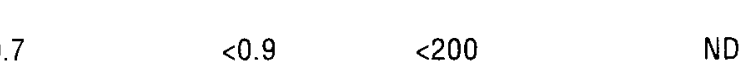

$<200 \quad$ ND

$<56.1 \quad$ ND

$67.6 \quad$ ND

$\begin{array}{lll}<0.8 & 67.6 \quad \text { ND }\end{array}$

$<0.9<200 \quad$ ND

$<0.7 \quad<69.7 \quad$ ND

$1.7 \quad<55.9 \quad$ ND

$<0.7 \quad<67.8 \quad$ ND

$0.8<0.7 \quad<67.8 \quad N$

$\begin{array}{lrcr}<0.7 & 1.4 & <200 & \text { ND } \\ <1.2 & <1.7 & <72.7 & \text { ND } \\ <0.5 & 0.8 & 91.8^{\star} & \text { ND } \\ <0.8 & 1.4 & 255^{\star} & \text { ND } \\ & & & \\ <1.3 & 1.6 & <200 & \text { ND } \\ <3.1 & <2.0 & <72.3 & \text { ND } \\ <0.8 & <2.0 & 80.0^{*} & \text { ND } \\ <1.2 & 1.8 & <67.7 & \text { ND } \\ <0.7 & & & \text { ND } \\ <1.6 & 0.9 & 66.3^{*} & \text { ND } \\ 15 & 3.4 & 78.8^{*} & \text { N/A } \\ & & & \end{array}$

\footnotetext{
* Although the result of the test indicates the finding of tritium in the sample, any level which is reported below $1,000 \mathrm{pCi} / \mathrm{L}$ is not considered significant due to the presence of naturally occurring tritium and the inherent lack of accuracy and precision in analyzing very low levels of tritium. (SCDHS statement) ND $=$ Not Detected.
} 


\section{Chapter 9}

\section{RADIOLOGICAL DOSE ASSESSMENT}

This chapter presents the potential radiological doses to off-site individuals and the surrounding population from BNL airborne effluents, liquid effluents, and special case exposure scenarios, such as the consumption of fish or deer meat. These potential doses are based on calculations using 1997 effluent data and conservative intake and exposure assumptions. All doses are expressed as committed effective dose equivalents (50-year commitled dose), or EDE, from internal deposition of radionuclides. Use of the effective dose equivalent allows doses from different types of radiation to different parts of the body to be expressed on the same relative risk scale. Appendix $B$ describes the calculational methods used.

\subsection{Effective Dose Equivalent Calculations - Airborne Pathway}

Brookhaven National Laboratory is subject to the requirements of Title 40 CFR Part 61, Subpart $\mathrm{H}$, National Emission Standards for Hazardous Air Pollutants (NESHAPs). This EPA Rule establishes national policy on the airborne emission of radionuclides. It specifies the monitoring and reporting requirements for various types of radionuclides and establishes the public dose limit for the airborne pathway as $10 \mathrm{mrem}(0.1 \mathrm{mSv})$ per year.

\subsubsection{Air Dispersion Model}

The NESHAPs regulations require the use of the CAP88-PC (Clean Air Act Assessment Package1988) computer model in demonstrating site compliance. The model uses a Gaussian plume equation to estimate the average dispersion of radionuclides released from elevated stacks or area sources (EPA, 1992). The program computes radionuclide concentrations in air, rates of deposition on ground surfaces and concentrations in food (where applicable) to arrive at a final value for projected dose at the specified distance from the release point to the location of interest. The program supplies both the calculated EDE to the maximally exposed individual, and the collective population dose within an $80-\mathrm{km}$ radius of the emission source(s). This model gives very conservative dose estimates in most cases.

Input parameters used in the model include radionuclide type, emission rate in curies per year, and stack parameters, such as height, diameter and exhaust velocity of the effluent. Site-specific weather data supplied by measurements from BNL's meteorological tower are used, including wind speed, direction, frequency and temperature. A 10-year average data set for these meteorological parameters is used. Population data for the surrounding area is based on customer records of the Long Island Lighting Company.

For modeling the dose to the maximally exposed individual (MEI), all emission points are colocated at the center of the developed portion of the site (approximately, at the location of the HFBR stack). Due to the wind frequency distribution on-site, the maximum dose is consistently projected in the NNE sector. The distance from the HFBR stack to the nearest residences adjacent to the site boundary in the NNE direction is approximately 3,000 meters. Placement of the MEI at 3,000 meters NNE was initiated with the 1995 Site Environmental Report. Earlier, the MEI was assumed to be at the geographically closest boundary (to the west), only 1500 meters away. However, due to the consistent wind patterns in the area, it is more accurate to locate the MEI in the NNE sector, this somewhat reduces the total dose from the airborne pathway compared to years before 1995 .

\subsubsection{Fugitive Sources}

In addition to point sources such as stacks, 'area' or 'diffuse' sources, which do not have dedicated exhaust systems (also known as 'fugitive' sources), must also be evaluated for airborne emissions. 
The only potential fugitive emission sources in CY 1997 were the RA V Recharge Basin and the STP holding ponds.

The RA V Recharge Basin, which receives water pumped from the southern edge of the HFBR tritium plume, was evaluated in 1997 before the start of operations using conservative estimates of what maximum tritium concentrations might be. The tritium concentrations of the groundwater reaching the recharge basin were expected to be about $3,500 \mathrm{pCi} / \mathrm{L}(130 \mathrm{~Bq} / \mathrm{L})$ or less. However, for the assessment, more conservative assumptions were made; it was assumed that the water contains $20,000 \mathrm{pCi} / \mathrm{L}(740 \mathrm{~Bq} / \mathrm{L})$ of tritium, the drinking water standard. The dose to the MEI residing at the site boundary, northeast of the center of the Laboratory was calculated to be 2.5E-6 mrem/yr. In actuality, analysis of the water processed at the Basin showed that tritium was rarely detectable in the pumped water. Out of 37 water samples collected at the Basin in CY1997, from May (the beginning of operations) through December, only two showed tritium above the detection limit, with a maximum concentration of just $1,820 \mathrm{pCi} / \mathrm{L}(67 \mathrm{~Bq} / \mathrm{L})$. Therefore, the RA $\mathrm{V}$ Basin was not realistically a diffuse emissions source due to a lack of significant source activity. Monitoring for airborne tritium in the vicinity of the Basin confirms this (Chapter 7).

Since the STP holding ponds no longer receive distillate from the Waste Concentration Facility, they contained only trace quantities of tritiated water compared to earlier years. However, since these ponds provide the opportunity for airborne radionuclide generation through evaporation, they were evaluated as fugitive sources. The conservative assumption was made that the maximum source inventory measured in the ponds in 1997 represented the inventory throughout the year. The tritium inventory of Pond No. 1 was the greater of the two at approximately $0.03 \mathrm{Ci}$ $(1.1 \mathrm{GBq})$. Assuming a $10 \%$ loss of this inventory due to evaporation, the dose to the MEI is $8 \mathrm{E}-8 \mathrm{mrem}$.

\subsubsection{Total Dose from the Airborne Pathway}

In 1997, the effective dose equivalent to the MEI adjacent to the NNE boundary of the site from all radiological airborne emissions sources combined was $0.07 \mathrm{mrem}(0.7 \mu \mathrm{Sv})$. This is equal to the calculated value for 1996. Argon-41 released from the BMRR contributed $98 \%$ of this dose. By comparison, this is 143 times less than the EPA airborne dose limit of $10 \mathrm{mrem}(0.1 \mathrm{mSv})$ and 4,286 times smaller than the EDE received annually from natural background radiation. This dose is too small to distinguish from background radiation sources using the most sensitive environmental TLDs. Table 9-1 shows the MEI dose projected for effluents from each facility.

\subsection{Effective Dose Equivalent Calculations - Water Pathway}

Since the Peconic River is not used as a drinking water supply, nor for irrigation, its waters do not constitute a direct pathway for the ingestion of radioactive material (NYSDOH, 1993). However, water in the Peconic River does recharge to the underground aquifer, which is used as a drinking water supply for residential homes. Analyses of water samples from several private wells in Manorville, east of the Laboratory, have shown the presence of tritium since analyses began in 1986. For evaluating the potential maximum EDE to an individual from water ingestion, the results from the radiological analysis of these private wells were used. In 1997, all samples were collected and analyzed by the SCDHS.

Tritium was the only BNL-related radionuclide detected in any of these private wells. The maximum tritium concentration in a residential well in 1997 was $2,201 \mathrm{pCi} / \mathrm{L}(81 \mathrm{~Bq} / \mathrm{L})$, nine times less than the $20,000 \mathrm{pCi} / \mathrm{L}(740 \mathrm{~Bq} / \mathrm{L})$ limit established by the EPA National Primary Drinking Water Regulations under the Safe Drinking Water Act. In calculating the potential dose to an individual via the drinking water pathway, it is conservatively assumed that this maximum concentration is consumed at a rate of 2 liters per day for 365 days a year. Under these assumptions, the dose to the maximally exposed individual via this pathway is $0.1 \mathrm{mrem}(1 \mu \mathrm{Sv})$, or $2.5 \%$ of the $4 \mathrm{mrem}(40 \mu \mathrm{Sv})$ dose limit specified for this pathway by the SDWA. 
Table 9-1

BNL Site Environmental Report tor Calendar Year 1997

Radiological Dose due to Airborne Effluents as Calculated by CAP88-PC

\begin{tabular}{|c|c|c|c|c|c|}
\hline Building & Facility or Process & $\begin{array}{l}\text { Construction } \\
\text { Permit No. }\end{array}$ & $\begin{array}{l}\text { MEI Dose } \\
\text { (mrem) }^{\star}\end{array}$ & $\begin{array}{l}\text { Collective Dose } \\
\text { (person-mrem) }\end{array}$ & Notes \\
\hline 491 & BMRR & None & $6.9 \mathrm{E}-02$ & $3.5 \mathrm{E}+03$ & \\
\hline 705 & HFBR & None & $8.0 \mathrm{E}-05$ & $9.8 \mathrm{E}+00$ & \\
\hline 931 & BLIP & None & $7.3 E-05$ & $3.1 E-02$ & \\
\hline 801 & Target Processing Lab & None & $1.8 \mathrm{E}-06$ & $2.3 \mathrm{E}-01$ & \\
\hline 705 & Evaporator Facility & BNL-288-01 & 1.3E-05 & $1.8 \mathrm{E}+00$ & \\
\hline 1005 & RHIC Accelerator & BNL-389-01 & N.D. & N.D. & \\
\hline-- & AGS Booster & BNL-188-01 & 0 & 0 & (a) \\
\hline 490 & Radiation Therapy Facility & BNL-489-01 & $2.2 \mathrm{E}-04$ & $9.3 E-03$ & (b) \\
\hline 820 & Accelerator Test Facility & BNL-589-01 & N.D. & N.D. & (c) \\
\hline 938 & REF/NBTF & BNL-789-01 & N.D. & N.D. & (d) \\
\hline 510 & Calorimeter Enclosure & BNL-689-01 & N.D. & N.D. & (e) \\
\hline- & STP Holding Ponds & None & $8.4 \mathrm{E}-08$ & 8.3E-05 & \\
\hline 463 & Biology Dept. & None & $2.3 E-07$ & $1.3 \mathrm{E}-02$ & $(f)$ \\
\hline 555 & Chemistry Dept. & None & $1.5 \mathrm{E}-09$ & $1.1 E-04$ & (f) \\
\hline 318 & Dept. of Applied Science & None & 4.0E-05 & $2.8 E+00$ & $(f)$ \\
\hline $490 \mathrm{~A}$ & Dept. of Applied Science & None & $2.3 \mathrm{E}-07$ & $1.2 E-02$ & (f) \\
\hline 490 & Medical Research Center & None & $3.1 \mathrm{E}-07$ & $2.2 E-02$ & (f) \\
\hline $703 W$ & Dept. of Advanced Tech. & None & 3.3E-09 & $1.6 \mathrm{E}-04$ & (f) \\
\hline \multicolumn{6}{|c|}{ New Processes Evaluated in 1997} \\
\hline- & OU V Recharge Basin & None & $2.5 E-06$ & $2.5 \mathrm{E}-03$ & (g) \\
\hline 750 & HFBR Canal Dewatering & None & $6.0 \mathrm{E}-05$ & $8.8 E+00$ & (b) \\
\hline 830 & Kinetic Mixer & None & $3.2 E-05$ & $1.4 \mathrm{E}+00$ & (b) \\
\hline \multirow[t]{2}{*}{701} & BGRR Deep Drain Sump & None & $8.0 \mathrm{E}-08$ & $3.9 \mathrm{E}-03$ & (b) \\
\hline & & Total & 7.0E-02 & $3.5 E+03$ & \\
\hline
\end{tabular}

*1 $\mathrm{mrem}=0.01 \mathrm{msv}$

N.D. = "No Dose", facility did not operate in 1997.

MEI = Maximally Exposed Individual.

Notes: (a) Booster ventilation system prevents air release through continuous air recirculation.

(b) Based on conservative engineering calulations.

(c) This has become a zero-release facility since original permit application.

(d) The Radiation Effects Facility is no longer in use. It may be converted into a medical Proton Therapy Facility at a future clate.

(e) The Calorimeter Enclosure is no longer in use

(f) All doses based on emissions calculated using 40 CFR 61, Appendix D methodology.

(g) Based on pre-operational estimates. This value over-estimates actual dose.

\subsection{Effective Dose Equivalent Calculations - Fish Consumption}

Calculations were also made of the potential dose to an individual consuming fish taken exclusively from Donahue's Pond, fed by the Peconic River. Fish from this and other Peconic locations continue to be analyzed for radiological content because of known radionuclide discharges from the BNL Sewage Treatment Plant, primarily in the 1960s. In 1997, samples were analyzed for gamma-emitting radionuclides only; no analyses for strontium were performed. The maximum concentration of cesium-137 found in fish taken from Donahue's Pond was of the chain pickerel species: $0.46 \mathrm{pCi} / \mathrm{g}(17 \mathrm{mBq} / \mathrm{g})$. This result was obtained from the whole fish, without discrimination between flesh, bone, and viscera.

For the dose evaluation, an individual is assumed to eat $7 \mathrm{~kg}(15.4 \mathrm{lbs}$.) of fish during the year. Exclusive consumption of chain pickerel at this rate and concentration would result in an EDE of 0.16 mrem $(1.6 \mu \mathrm{Sv})$ due to cesium-137. By comparison, the average individual EDE caused by 
the ingestion of naturally-occurring radionuclides in the United States is about 40 mrem $(0.40 \mathrm{mSv})$ per year (NCRP, 1987).

\subsection{Effective Dose Equivalent Calculations - Meat Consumption}

As part of the environmental surveillance program, measurements were made of flesh samples collected from deer taken on BNL property (see Section 7.5.1 for details) and from off-site locations. More cesium-137 was detected in meat samples from on-site deer than in comparable deer from off-site. While on-site sport hunting is not permitted, there are no physical barriers preventing deer from migrating beyond the site boundary. Therefore, deer with elevated cesium concentrations may be taken by hunters.

The NYSDEC Wildlife Branch estimates that consumption of deer meat ranges between 2 to $9 \mathrm{~kg}$ ( 4 to 20 lbs.) per person per year. However, the NYSDOH recommended using a maximum upper bound value for consumption of $30 \mathrm{~kg}(67 \mathrm{lbs}$.) for dose calculations. Basing the calculation of the maximum individual committed EDE on this value, and assuming a cesium-137 concentration equal to the highest observed concentration of $6.0 \mathrm{pCi} / \mathrm{g}(0.2 \mathrm{~Bq} / \mathrm{g})$, the committed $\mathrm{EDE}$ would be 9.0 mrem $(0.09 \mathrm{mSv})$.

\subsection{Collective Dose Equivalent}

While the EDE measures the radiation dose to an individual, the collective effective dose equivalent is a value used to estimate potential health risks to an exposed population. For the air exposure pathway, the CAP88-PC model provides collective EDE estimates using population data for the area within an 80-kilometer radius of the BNL site. The population data is broken into the number of people living within each of the 16 compass sectors at 16-km radial intervals. Argon-41 emitted from the BMRR was the largest contributor to the total collective dose at 3,500 person-mrem (35 person-mSv), constituting 99\% of the total collective dose projected for the population within an $80-\mathrm{km}$ radius of the Laboratory.

The collective EDE to the community using the private water source described in Section 8.1.4 (assumed to be not more than 500 persons) would be 50 person-mrem ( 0.5 person-mSv).

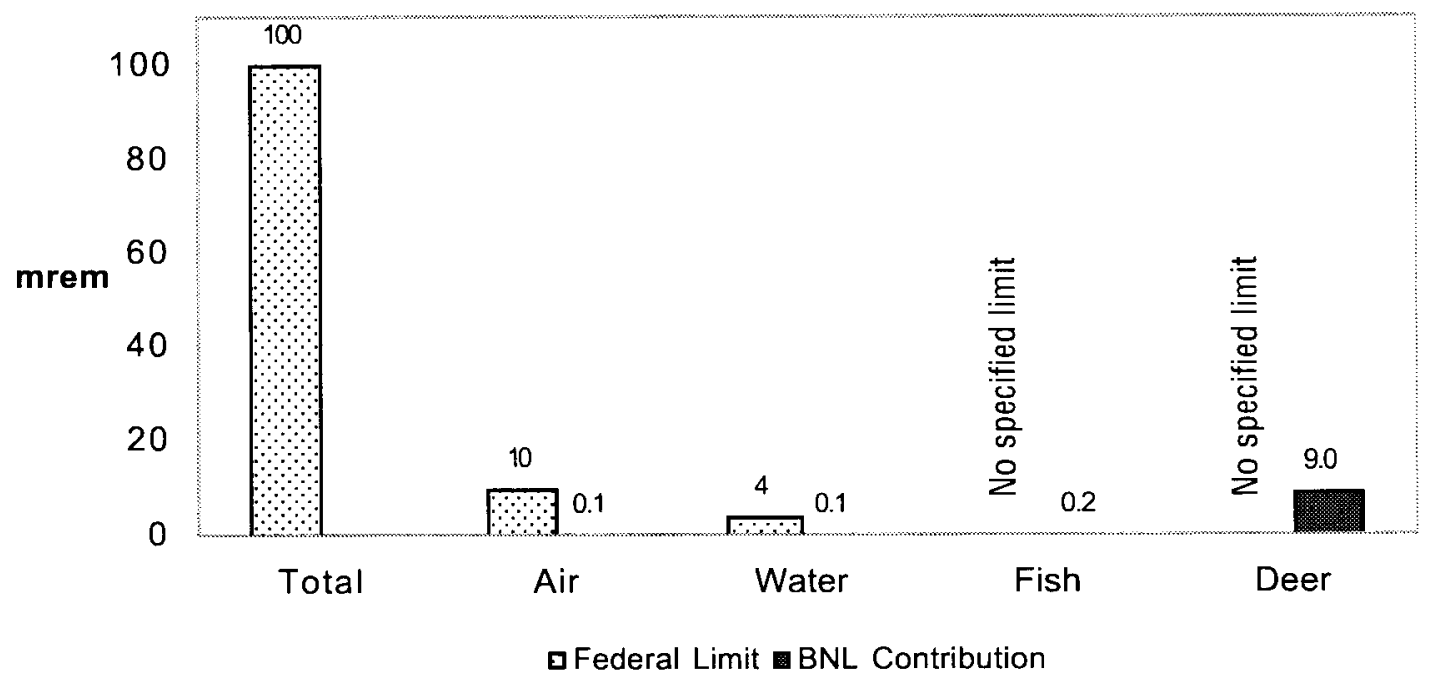

Figure 9-1. Dose summary, maximum BNL contribution and Federal limits 
Table 9-2. Summany of Dose from all Environmental Pathways

\begin{tabular}{|c|c|c|c|c|}
\hline Pathway & $\begin{array}{l}\text { Primary } \\
\text { Contributing } \\
\text { Radionuclide(s) }\end{array}$ & $\begin{array}{l}\text { Maximum } \\
\text { Individual } \\
\text { EDE (mrem) }\end{array}$ & $\begin{array}{l}\text { Regulatory } \\
\text { Pathway } \\
\text { Limit (mrem) }\end{array}$ & $\begin{array}{l}\text { Collective } \\
\text { EDE } \\
\text { (person-mrem) }\end{array}$ \\
\hline Air & $\operatorname{Ar}-41$ & 0.07 & 10 & 3500 \\
\hline Water & $\mathrm{H}-3$ & 0.1 & 4 & 50 \\
\hline Fish & Cs-137 & 0.16 & NS & 100 \\
\hline Deer Meat & Cs-137 & 9.0 & NS & NA \\
\hline $\begin{array}{l}\text { Notes: } \\
\text { 1. } 1 \text { mrem } \\
\text { 2. } E D E=E \\
\text { 3. NS = No } \\
\text { 4. NA = No } \\
\text { 5. Because } \\
\text { than act } \\
\text { 6. The fish } \\
\text { not perf } \\
\text { 7. Deer dos } \\
\text { On-site } \\
\text { 8. Deer dos }\end{array}$ & $\begin{array}{l}\text { Equivalent. } \\
\text { Specified } \\
\text { Table } 9-2 \text { are calcu } \\
\text { d on cesium- } 137 \text { c } \\
\text { n samples collected } \\
\text { n maximum cesium } \\
\text { is not permitted. } \\
\text { onsumption of } 30\end{array}$ & $\begin{array}{l}\text { rather than } m \\
\text { ntrations only. } \\
997 \text {. } \\
7 \text { concentratio } \\
(6.7 \mathrm{lbs} \text { ) of me }\end{array}$ & $\begin{array}{l}\text { d, they are pote } \\
\text { tium- } 90 \text { analyse } \\
\text { erved in deer co } \\
\text { year. }\end{array}$ & $\begin{array}{l}\text { lather } \\
\text { ere } \\
\text { ted on-site. }\end{array}$ \\
\hline
\end{tabular}

This assumes that each of these 500 people consumes water which contains the highest concentration of tritium observed in all of 1997. Finally, the number of individuals who routinely consume fish taken from Donahue's Pond was estimated to be no greater than 625 (LILCO, 1996), giving a collective EDE of 100 person-mrem (1.0 person-mSv) due to cesium137.

By comparison, the collective dose due to external radiation from natural background to the population within an $80 \mathrm{~km}$ radius of the Laboratory amounts to approximately 291,000 person-rem $(2,910$ person-Sv), and about 196,800 person-rem (1,968 person-Sv) from internal radioactivity in the body from natural sources (excluding potential radon contributions).

\subsection{Summary and Conclusion}

Calculations of effective dose equivalents from all BNL facilities which have the potential to release radionuclides to the atmosphere indicate that radiological doses attributable to Laboratory operations were far below the limits established by Federal regulations. Direct measurement of external radiation levels by TLD confirms that exposure rates at the site boundary are consistent with background levels observed throughout New York State (NYS$\mathrm{DOH}, 1993)$.

The EDEs discussed are based on the maximally exposed individual for each scenario using the stated assumptions. It is not plausible that any single person could receive a radiological dose equal to the sum of these individual pathways. For this to occur, an individual would be required to breathe air, consume water, fish and deer at the highest radionuclides concentrations calculated or observed in all samples collected in 1997. However, even if these pathways were to be summed, the total dose from all pathways would equal $10 \%$ of the $100 \mathrm{mrem} / \mathrm{yr}(1 \mathrm{mSv} / \mathrm{yr}) \mathrm{DOE}$ limit established to protect the public. This total represents approximately $3 \%$ of the average individual dose received annually from natural background sources, including radon (NCRP, 1987). These maximum credible doses demonstrate that in 1997, radioactive material associated with BNL operations had no impact on the health of the public or the environment in the surrounding area. 



\section{Chapter 10}

\section{QUALITY ASSURANCE PROGRAM}

Responsibility for quality at BNL starts with the Laboratory Director and permeates down through the entire organization, with individuals at each level assuming their appropriate share. The BNL Quality Management (QM) Office, headed by the QM Manager, coordinates and evaluates QA implementation at the Laboratory, and provides professional assistance and guidance to the Departments and Divisions. The ES\&HS Division appointed a Quality Representative and Quality Management Team (QMT) to assist, assess, advise, and improve implementation of the Divisionwide QA program.

\subsection{Environmental Surveillance Program}

The QA Program developed by BNL to achieve Laboratory objectives provides policies, responsibilities, and guidance procedures for the Divisions and Departments based on DOE Order 5700.6C. The ES\&HS Division has adopted or adapted these program elements into the ES\&HS Division Management System Manual (BNL, 1994) and has established responsibilities, methods, and controls for conducting its operations. The Environmental Protection Office and Analytical Services Laboratory (ASL) integrated both these elements and the additional environmental QA requirements of DOE Order 5400.1 into their sampling, analysis, and data handling activities. The implementing procedures on Environmental Monitoring, Radiation Measurements, Analytical Chemistry, and Regulatory Programs, in conjunction with the ES\&HS Division Management System Manual (BNL, 1994) and the ES\&HS QA Procedures, comprise the QA Program for the environmental surveillance and effluent monitoring programs.

The objectives of the Environmental Protection QA Program are to ensure that management provides planning, organization, direction, control, and support to achieve the objectives of the environmental program; line managers achieve quality in their product or services; and overall performance is reviewed and evaluated using a rigorous assessment process. This program was developed to ensure compliance with QA requirements established by DOE in Orders 5700.6C, Quality Assurance, and 5400.1, General Environmental Protection Program.

The ES\&HS Division is responsible for establishing a program of internal assessments and external audits to verify the effectiveness of the environmental sampling, analysis, and database activities and their adherence to the QA program. Annual self-assessments of activities by the respective managers identify areas needing attention. Furthermore, the ASL participates in inter-laboratory performance evaluation programs organized by DOE, EPA, and NYSDOH. Contract laboratories that augment the capabilities of the in-house Laboratory are required to maintain a comprehensive QA program and are subject to audits by ES\&HS Division personnel to ensure its implementation. In addition, the BNL QM Office, DOE- $\mathrm{CH}$, regulatory agencies, and other independent groups periodically audit the environmental programs.

A major activity for the Environmental Protection Office and the ASL is ensuring that environmental media are sampled and analyzed in a way that provides representative, defensible data. The QA program supports this activity by incorporating QA elements, such as field sampling designs, documented procedures, chain of custody, a calibration/standardization program, acceptance criteria, statistical data analyses, software QA, and data processing systems, in the environmental surveillance and effluent monitoring programs. Standard Operating Procedures are established to calibrate instruments, analyze samples, and check quality control. Depending on the analytical method, quality control checks include analysis of blanks or background concentrations, use of Amersham or National Institute for Standards and Technology (NIST) traceable standards, and analysis of reference standards, spiked samples, and duplicate samples. The Labo- 
ratory supervisors review all analytical and quality control results before the data are reported and incorporated into the database. The ASL is certified by the NYSDOH, Environmental Laboratory Approval Program (ELAP) for specific analytes identified below. The offsite contractor laboratories that perform radiological and chemical analyses to augment the onsite analytical capabilities also are required to incorporate these QA elements into their operation.

\subsubsection{Radiological Analyses}

The ES\&HS Division ASL performs radiological analysis of both environmental and facility samples for gross alpha, gross beta, gamma, tritium, and strontium-90. The Laboratory participates in the DOE Environmental Measurements Laboratory (EML) QA Program and the EPA National Exposure Research Laboratory, Characterization Research Division, Las Vegas (NERL-LV) Performance Evaluation Study. In 1996, NYSDOH ELAP certified the Laboratory for potable and nonpotable analysis of gross alpha and beta and photon emitters (gamma). In addition it was certified to perform potable water analysis for tritium. During 1997, the ASL analyzed samples using an alternative analytical method for determining strontium-90 that was not approved by NYSDOH (see Appendix C). The ASL analyzes proficiency samples as part of the ELAP certification program. The results of these three intercomparison programs are shown in Tables 10-1 through 103 , respectively.

Overall, the ASL performance in the EML intercomparison study was acceptable in $94 \%$ of the analyses performed on 4 matrices. Twenty-five of forty-eight EML analyses were within established acceptance limits, thirteen of forty-eight were within upper and lower limits (warning); ten analyses fell outside the acceptance limits. Many of the March and September air filter test results were reported in the warning and unacceptable range, but a review of the QC data for the unacceptable cobalt-57 and manganese-54 analyses on the air filter matrix showed no problem associated with the sample preparation, analytical process, or data calculations. However, the EML test filter is not the same geometry used to calibrate the gamma spectrometer used in the BNL EM air-monitoring program, which would account for a positive bias. These results imply that the environmental air sampling data presented in this report may be overestimated.

Overall, the ASL performance in the NERL intercomparison study was acceptable in $72 \%$ of the water analyses. The NERL-LV comparisons resulted in excellent agreement for seven of the eighteen analyses (within $1 \sigma$ of the known value), and good agreement for six analyses (within $2 \sigma$ of the known. The five remaining sample analyses were unacceptable because the results were outside the $\pm 3 \sigma$ control limit.

Review of the QC data for the unacceptable results found no problem associated with the sample preparation nor data calculations. The gross alpha and beta results of April and July reported to NERL-LV were unacceptable because the instrument required maintenance that occurred in the latter quarter of 1997. To reduce the number of unacceptable results, a geometry correction factor will be used to account for the slight difference in the way the ASL counts its samples (which is dependent on the instrument) as opposed to the way they are counted at the Labs where the samples are prepared.

Lastly, the radiological results from the ELAP proficiency test for gross alpha and beta showed acceptable agreement for all four analyses performed. BNL did not receive two alpha/beta samples in October 1997 and, therefore, results were not reported. Because of this, the ASL lost alpha/beta certification in potable water analyses for 4 months. Certification was reinstated in calendar year 1998.

Figures 10-1 through 10-3 summarize the internal quality control program for the radiological instruments. Figure 10-1 shows the annual mean and $99 \%$ confidence interval for the efficiency of the alpha, beta, tritium, and strontium-90 analyzers, as determined by a daily calibration standard. All analyzers were stable. Figure 10-2 summarizes the daily variation in background counts from each of these instruments in 1997. An investigation into the wide range of the $99 \%$ confidence interval for $\mathrm{H}-3$ revealed that the liquid scintillator experienced increased variability in 
Table 10-1

BNL Site Environmental Report for Calendar Year 1997

BNL Quality Assessment Program Results

Environmental Measurements Laboratory

\begin{tabular}{|c|c|c|c|c|c|c|c|}
\hline Matrix & Units & Isotope & Date & EML & BNL & Ratio & Comments \\
\hline \multirow[t]{20}{*}{ Air Filter } & \multirow[t]{20}{*}{$\mathrm{Bq} /$ Filter } & \multirow[t]{2}{*}{ Alpha } & Mar-97 & 0.9 & 0.96 & 0.94 & \\
\hline & & & Sep-97 & 1.39 & 1.49 & 0.93 & \\
\hline & & \multirow[t]{2}{*}{ Am241 } & Mar-97 & 0.4 & 0.152 & 2.63 & Not Acceptable \\
\hline & & & Sep-97 & 0.57 & 0.21 & 2.71 & Not Acceptable \\
\hline & & \multirow[t]{2}{*}{ Beta } & Mar-97 & 0.44 & 0.45 & 0.98 & \\
\hline & & & Sep-97 & 2.87 & 3 & 0.96 & \\
\hline & & \multirow[t]{2}{*}{$\mathrm{Ce} 144$} & Mar-97 & 20.4 & 15.7 & 1.30 & Not Acceptable \\
\hline & & & Sep-97 & 22.7 & 19.12 & 1.19 & Warning \\
\hline & & \multirow[t]{2}{*}{ Co57 } & Mar-97 & 14.7 & 10.8 & 1.36 & Not Acceptable \\
\hline & & & Sep-97 & 16.05 & 12.64 & 1.27 & Warning \\
\hline & & \multirow[t]{2}{*}{ Co60 } & Mar-97 & 5.2 & 5.01 & 1.04 & \\
\hline & & & Sep-97 & 9.99 & 10.7 & 0.93 & \\
\hline & & \multirow[t]{2}{*}{ Cs134 } & Mar-97 & 10.8 & 10.88 & 0.99 & \\
\hline & & & Sep-97 & 24.9 & 28.17 & 0.88 & \\
\hline & & \multirow[t]{2}{*}{ Cs137 } & Mar-97 & 11.9 & 8.7 & 1.37 & Not Acceptable \\
\hline & & & Sep-97 & 9.32 & 7.31 & 1.27 & Warning \\
\hline & & \multirow[t]{2}{*}{ Mn54 } & Mar-97 & 10.4 & 7.6 & 1.37 & Not Acceptable \\
\hline & & & Sep-97 & 8.7 & 6.72 & 1.29 & Warning \\
\hline & & \multirow[t]{2}{*}{ Sb125 } & Mar-97 & 17.6 & 12.33 & 1.43 & Not Acceptable \\
\hline & & & Sep-97 & 23.14 & 16.1 & 1.44 & Not Acceptable \\
\hline \multirow[t]{8}{*}{ Soil } & \multirow[t]{8}{*}{$\mathrm{Bq} / \mathrm{g}$} & \multirow[t]{2}{*}{ Am241 } & Mar-97 & 9.1 & 5.68 & 1.60 & Warning \\
\hline & & & Sep-97 & 13.83 & 6.04 & 2.29 & Warning \\
\hline & & \multirow[t]{2}{*}{$\mathrm{C} 060$} & Mar-97 & 1.1 & 1.06 & 1.04 & \\
\hline & & & Sep-97 & 1.51 & 1.5 & 1.01 & \\
\hline & & \multirow[t]{2}{*}{ Cs 137} & Mar-97 & 846.1 & 825.5 & 1.02 & \\
\hline & & & Sep-97 & 775.53 & 810 & 0.96 & \\
\hline & & \multirow[t]{2}{*}{$\mathrm{K} 40$} & Mar-97 & 295.6 & 334.25 & 0.88 & \\
\hline & & & Sep-97 & 261 & 315 & 0.83 & Warning \\
\hline \multirow[t]{6}{*}{ Vegetation } & \multirow[t]{6}{*}{$\mathrm{Bq} / \mathrm{g}$} & \multirow[t]{2}{*}{$\mathrm{Co60}$} & Mar-97 & 13 & 12.5 & 1.04 & \\
\hline & & & Sep-97 & 23.61 & 32.4 & 0.73 & Warning \\
\hline & & Cs137 & Mar-97 & 241.6 & 189.2 & 1.28 & Warning \\
\hline & & & Sep-97 & 595 & 624 & 0.95 & \\
\hline & & $\mathrm{K} 40$ & Mar-97 & 888.1 & 811.5 & 1.09 & \\
\hline & & & Sep-97 & 931.3 & 1130 & 0.82 & Warning \\
\hline Water & $\mathrm{Bq} / \mathrm{L}$ & Alpha & Mar-97 & 1153.3 & 1130.3 & 1.02 & \\
\hline & & & Sep-97 & 492.3 & 557 & 0.88 & \\
\hline & & Beta & Mar-97 & 639.9 & 744 & 0.86 & \\
\hline & & & Sep-97 & 812.5 & 712 & 1.14 & \\
\hline & & Co60 & Mar-97 & 98.4 & 90.85 & 1.08 & \\
\hline & & & Sep-97 & 23.5 & 23.3 & 1.01 & \\
\hline & & Cs 137 & Mar-97 & 91 & 69.7 & 1.31 & Not Acceptable \\
\hline & & & Sep-97 & 41.5 & 34.3 & 1.21 & Warning \\
\hline & & $\mathrm{H3}$ & Mar-97 & 255.7 & 250.3 & 1.02 & \\
\hline & & & Sep-97 & 117.22 & 115 & 1.02 & \\
\hline & & Mn54 & Mar-97 & 26.5 & 20.85 & 1.27 & Not Acceptable \\
\hline & & & Sep-97 & 45.6 & 37.8 & 1.21 & Warning \\
\hline & & Srgo & Mar-97 & 20.3 & 23.2 & 0.88 & Warning \\
\hline & & & Sep-97 & 3 & 2.94 & 1.02 & \\
\hline
\end{tabular}

Note: Comment column provides EML evaluation of analytical performance which is based on conrol limits established from percentiles of historic data disributions. No comment indicates that the performance was still within acceptable limits. A warning means that the results were just within the 2 sigma "window" of acceptable results. 
Table 10-2

BNL Site Environmental Report for Calendar Year 1997

BNL Quality Assessment Program Results

National Exposure Research Laboratory (NERL-LV)

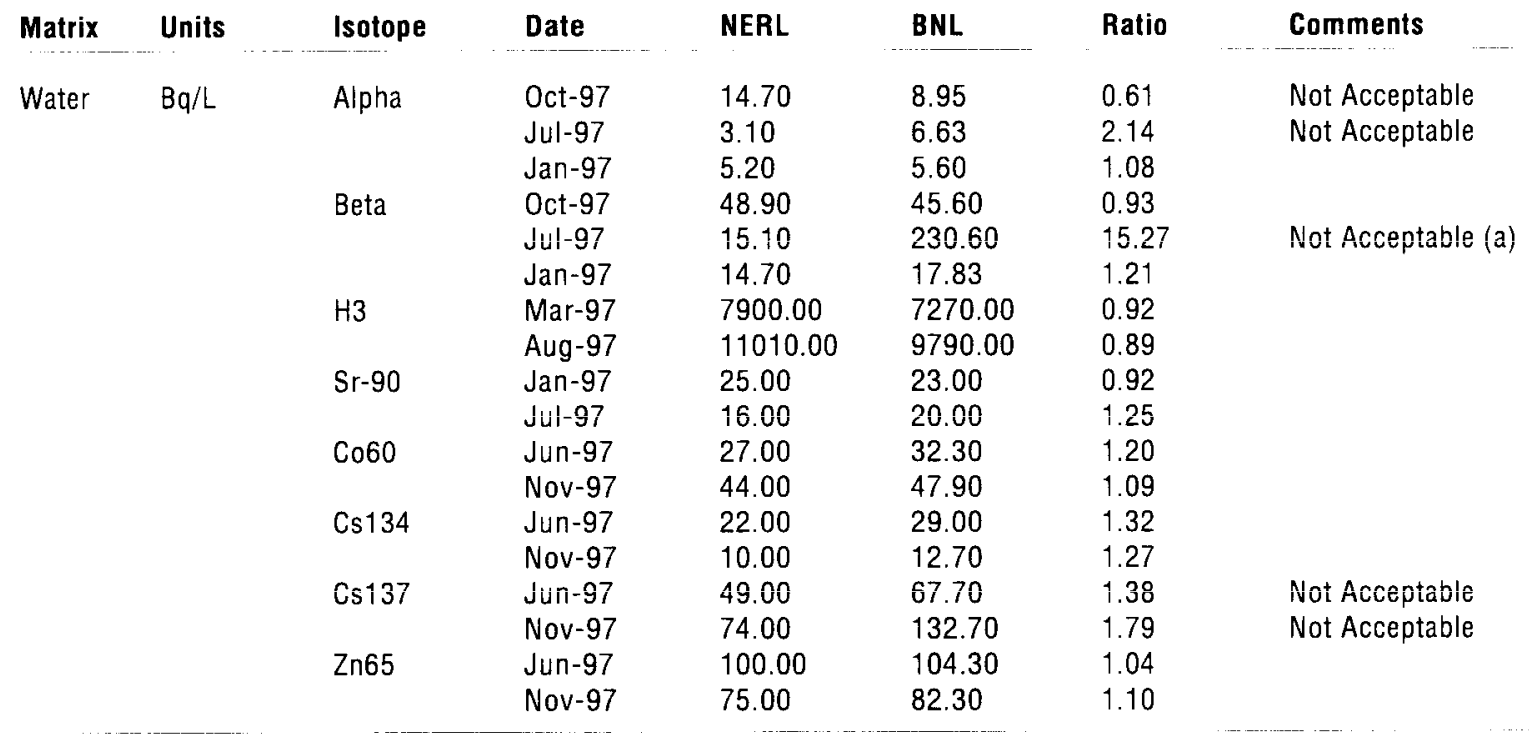

(a) = Result was not acceptable because of transcription error in reporting.

Note: Comment column provides NERL evaluation of analytical performance which is based on 2 and 3 normalized standard deviations about the known value. Results outside these control limits are deemed not acceptable or a statistical outlier. No comment indicates that the performance was within acceptable limits.

Tabie 10-3

BNL Site Environmental Report for Calendar Year 1997

BNL Potable Water Radiochemistry Proticiency Test Results

Environmental Laboratory Approval Program

\begin{tabular}{llllll} 
Analyte & Date & $\begin{array}{l}\text { ELAP } \\
\text { (nCi/L) }\end{array}$ & $\begin{array}{l}\text { BNL } \\
\text { (nCi/L) }\end{array}$ & Ratio & Comment \\
Alpha & Apr-97 & 18 & 12.7 & 0.71 & Warning \\
& Apr-97 & 79 & 84.4 & 1.07 & (a) \\
& Oct-97 & 15.7 & NR & & (a) \\
& Oct-97 & 56.5 & NR & & \\
Beta & & & & \\
& Apr-97 & 13 & 15.7 & 1.21 & (a) \\
& Apr-97 & 76 & 87.6 & 1.15 & (a) \\
\hline
\end{tabular}

(a) = Data was not reported (NR) for Oct 1997 because the sample was not received by BNL.

Note: Comment column provides ELAP evaluation of analytical performance which is based on 95 and $99 \%$ confidence interval about the target value. No comment indicates that the performance was within acceptable limits. 


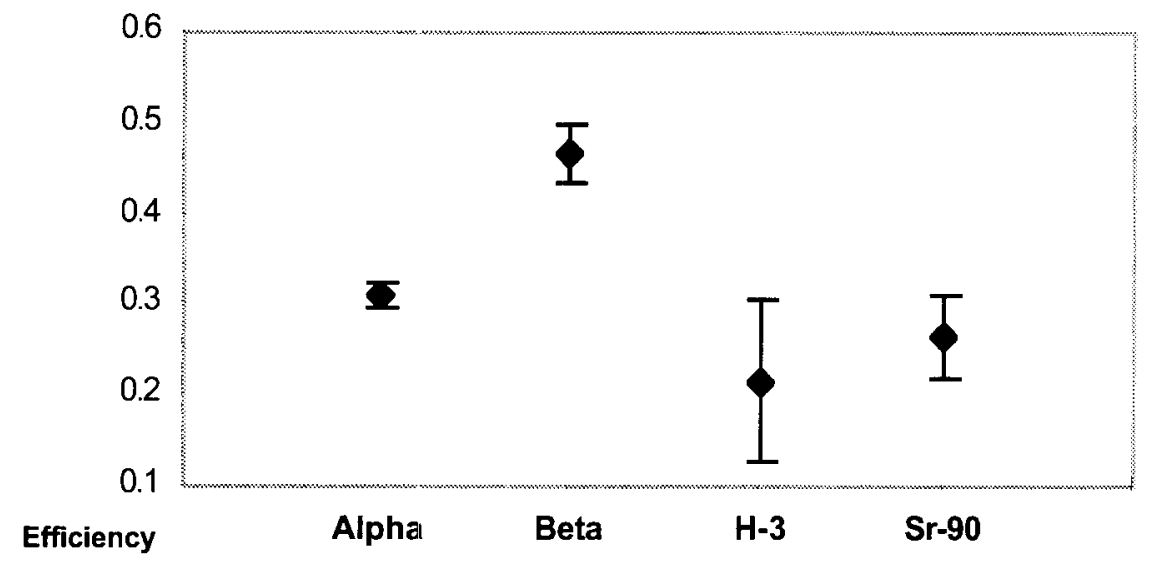

Figure 10-1. Instrument Efficiency Summary for 1997

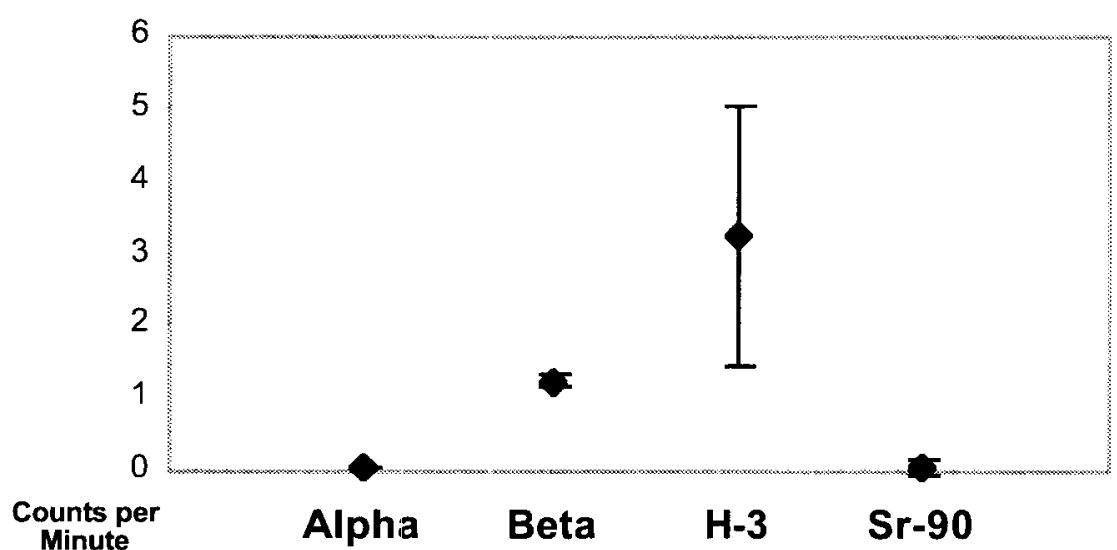

Figure 10-2. Instrument Background Summary for 1997

the first quarter of 1997 during the HFBR Tritium Plume Investigation and required preventative maintenance. Figure 10-3 compares the mean and 99\% confidence intervals of the cesium-137 energy calibration for each gamma detector, as measured by a daily calibration standard. The $661.65 \mathrm{keV}$ cesium-137 gamma energy line is illustrated on the graph as the center dashed line and the acceptance band of $\pm 1 \mathrm{keV}$ is shown as the upper and lower dashed lines. As can be seen, all gamma detectors operated within the acceptance limit during 1997.

The ASL used an alternative strontium-90 method developed at the DOE Argonne National Laboratory (described in Appendix C). Figure 10-4 compares the mean and 99\% confidence interval of the deviation of each detector's response from the calibration value. The plot shows that the mean percent deviation from the calibration standards was within $\pm 2 \%$. Each of the daily efficiency checks performed on all detectors were within the $\pm 5 \%$ acceptance band, except two measurements on detectors 5 and 10. Excess variability in the daily responses of detectors 5 and 10 caused the $99 \%$ confidence interval to exceed the acceptance band even though the daily checks did not. The unit was subsequently sent offsite for repair. Quality control samples spiked with strontium- 90 yielded mean recoveries of $94 \% \pm 8 \%$, which is comparable to results reported the previous year.

Peconic River water samples were processed using the ASL's Sr-90 Water Method (RM-SOP-60). This method is a slight modification of the American Society for Testing and Materials (ASTM) Standard Method for Sr-90 in Water (ASTM-D5811-95) which is intended for environment water samples (i.e., non-process and effluent waters). All of the the Peconic River water samples were found to contain significant amounts of soluble salts that interfered with the strontium yield 


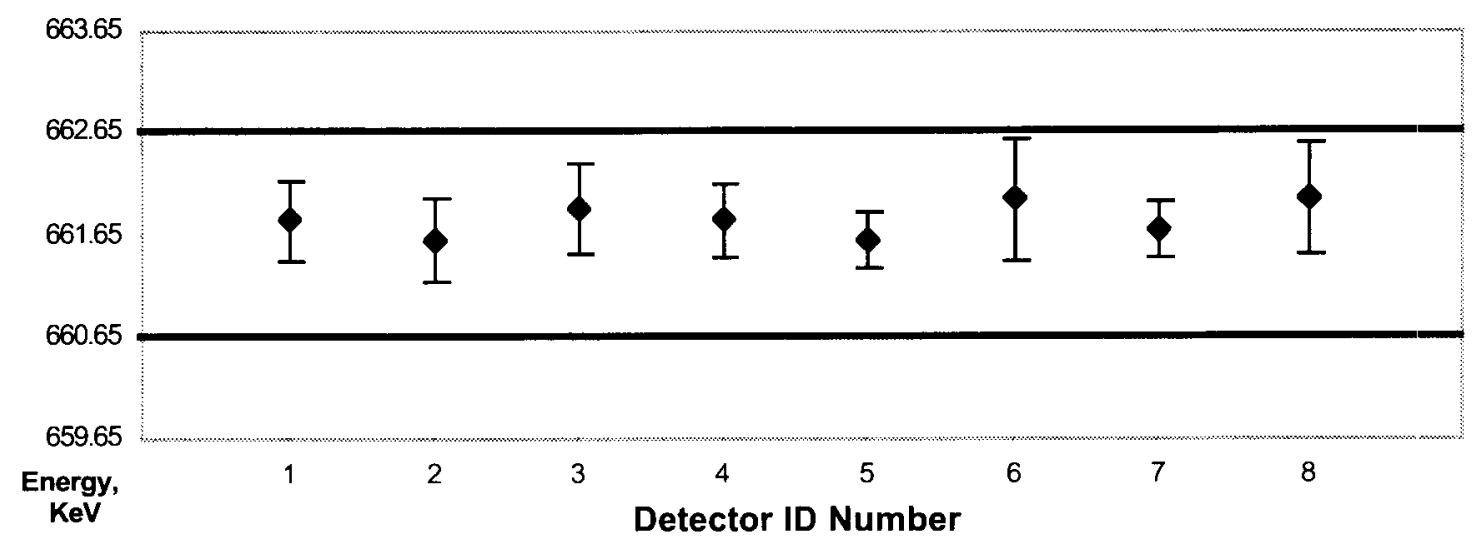

Figure 10-3. Cesium-137 Energy Calibration Summary for 1997

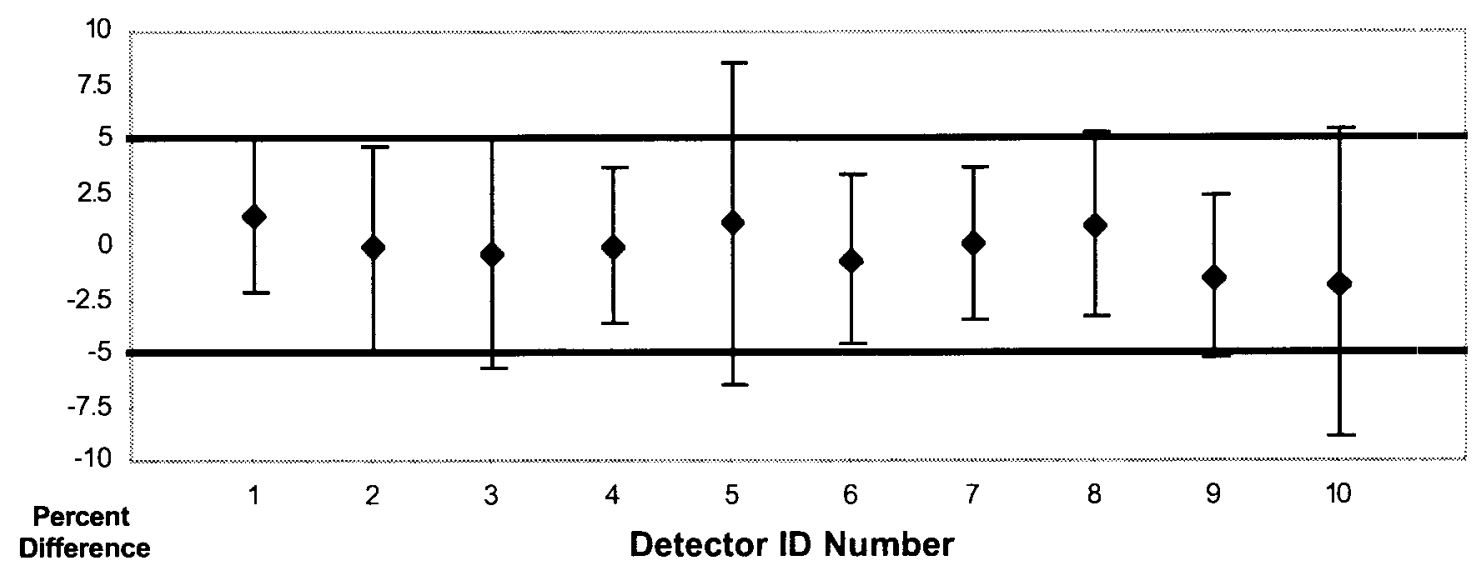

Figure 10-4. Strontium-90 Instrument Efficiency Summary for 1997

determinations. Because the strontium yields in the Peconic samples were below the ASL's acceptance criteria, the data were rejected and footnoted with the statement "sample results invalidated during QA review".

During the first quarter of 1997, there was an onsite audit of the radiological analytical processes conducted by NYSDOH ELAP. In addition, DOE's Office of Environmental Management made two appraisals of the ASL's radiological laboratory. In the April 1997 'Gilbert-Hill' audit of the ASL, corrective action plans for the findings and recommendations were developed and their implementation is virtually complete.

\subsubsection{Analytical Chemistry}

The ES\&HS ASL is certified by NYSDOH ELAP for analyzing metals and anions under the environmental potable water category, and for specific purgeable organic compounds under the environmental analyses of nonpotable water. The analytes for which the ASL holds potable water certification are silver, cadmium, chromium, copper, iron, mercury, manganese, sodium, lead, zinc, chloride, nitrate (as nitrogen), and sulfate. The compounds which it holds certification in nonpotable water are benzene, toluene, xylene, ethylbenzene, chloroform, 1,1-Dichloroethylene (DCE), 1,1-Dichloroethane (DCA), 1,1,1-Trichloroethane (TCA), Trichloroethylene (TCE), and Tetrachloroethylene (PCE).

Table 10-4 shows the results of organic and inorganic proficiency samples analyzed for this certification program. Sixty-seven percent of all organic analyses of proficiency samples performed 
for NYSDOH in January and July of 1997 were within acceptance limits. There was good agreement, within $\pm 20 \%$, in eight of twelve organic analyses. The remaining four tests (in July of 1997 only) were slightly greater than $\pm 20 \%$ of the known value and were not acceptable. These results confirm the accuracy of the data presented in this report.

Similarly, the inorganic NYSDOH proficiency test results were acceptable in $94 \%$ of the analyses as shown in Table 10-5. Results showed excellent agreement, within $\pm 10 \%$, in forty-eight of the fifty-four analyses, with thirty-nine analyses being within $\pm 5 \%$ of the known value, again confirming the accuracy of the data presented in this report. The remaining three were unacceptable; an investigation revealed that a transcription error occurred in reporting mercury. The April 1997 nitrate result just exceeded its acceptance criteria of $\pm 15 \%$. Table $10-5$ gives the corrected results in the case of the mercury data processing error.

The ASL also participated in the EPA Environmental Monitoring Systems Laboratory (EMSL-CI) water pollution and water supply performance evaluation studies. Tables 10-6 and 10-7, respectively, give the results of these studies. Overall, the ASL performance in the EMSL-CI water pollution intercomparison study (WP037, Table 10-6) was acceptable in $89 \%$ of the analyses. The performance was excellent for sixteen of eighteen organic analyses. One of the paired TSS and residual chlorine results was acceptable. An investigation revealed that the analytical data were transcribed incorrectly onto the report form by not applying a factor of 2 dilution. Table 10-7 shows the results from using the WS038/039 EMSL-CI water supply samples for an internal blind QC study. Excellent performance was measured in twenty-one of twenty-three comparisons. The two unacceptable results in September 1997 were due to an error in the total xylene and chloroform algorithms, which has been corrected.

Corrective actions included reprocessing all the xylene and chloroform data, requesting funding to automate data processing, and requesting the manufacturer to adjust the GC/MS settings.

Figures 10-5 and 10-6 summarize the internal quality control program for the ion chromatography and atomic absorption methods used for inorganic analyses. Figure 10-5 presents the annual mean and $99 \%$ confidence interval for reference check and calibration check sample recoveries analyzed in each metal or anion sample batch. Both anions and metals were \pm 15 of the target values, except chromium, which was $\pm 18 \%$. Figure $10-6$ gives the mean and $99 \%$ confidence interval of spike recoveries performed for all analyses. Each daily spike sample measured its recovery within the $\pm 25 \%$ acceptance limit. These data attest to the accuracy of the data presented in this report.

Figures 10-7 through 10-9 show the 1997 results of the internal quality control program of the ASL for the gas chromatography/mass spectroscopy method used for organic analyses. Mean recoveries and $99 \%$ confidence intervals for all ten analytes were within their target ranges; that is, $\pm 30 \%$ for mercury and $\pm 20 \%$ for the remaining nine analytes. These results are a marked improvement from the previous year. In 1996, corrective actions by the manufacturer resulted in instrument upgrades and extension of the warranty period.

Figure 10-7 summarizes the recoveries of the 10 organic reference check samples by presenting the mean and $99 \%$ confidence interval for each of the primary volatile organic compounds. Variability was within the internally established control limit, $\pm 20 \%$ of the known concentration, for each analyte except DCE $( \pm 42 \%)$ and toluene $( \pm 24 \%)$. The acceptance limit established by the EPA National Functional Guideline for this type of QC sample is $\pm 40 \%$. Increased variability of the DCE response was due to poor resolution of this chromatographic peak, which elutes in the region of the chromatogram immediately following the solvent peak. The manufacturer was contacted to make the appropriate adjustments to prevent recurrence of the problem.

Figure $10-8$ shows the $99 \%$ confidence intervals of surrogate and spike recoveries for the organic analyses. The method's performance for each of the two surrogate analyses was $\pm 11 \%$ and $\pm 20 \%$ of the target value (fluorobenzene [Flbenz] and 4-Bromofluorobenzene [BFB], re-

1997 BNL Site Environmental Report $10-7$ 


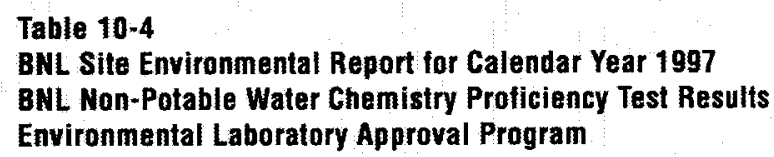

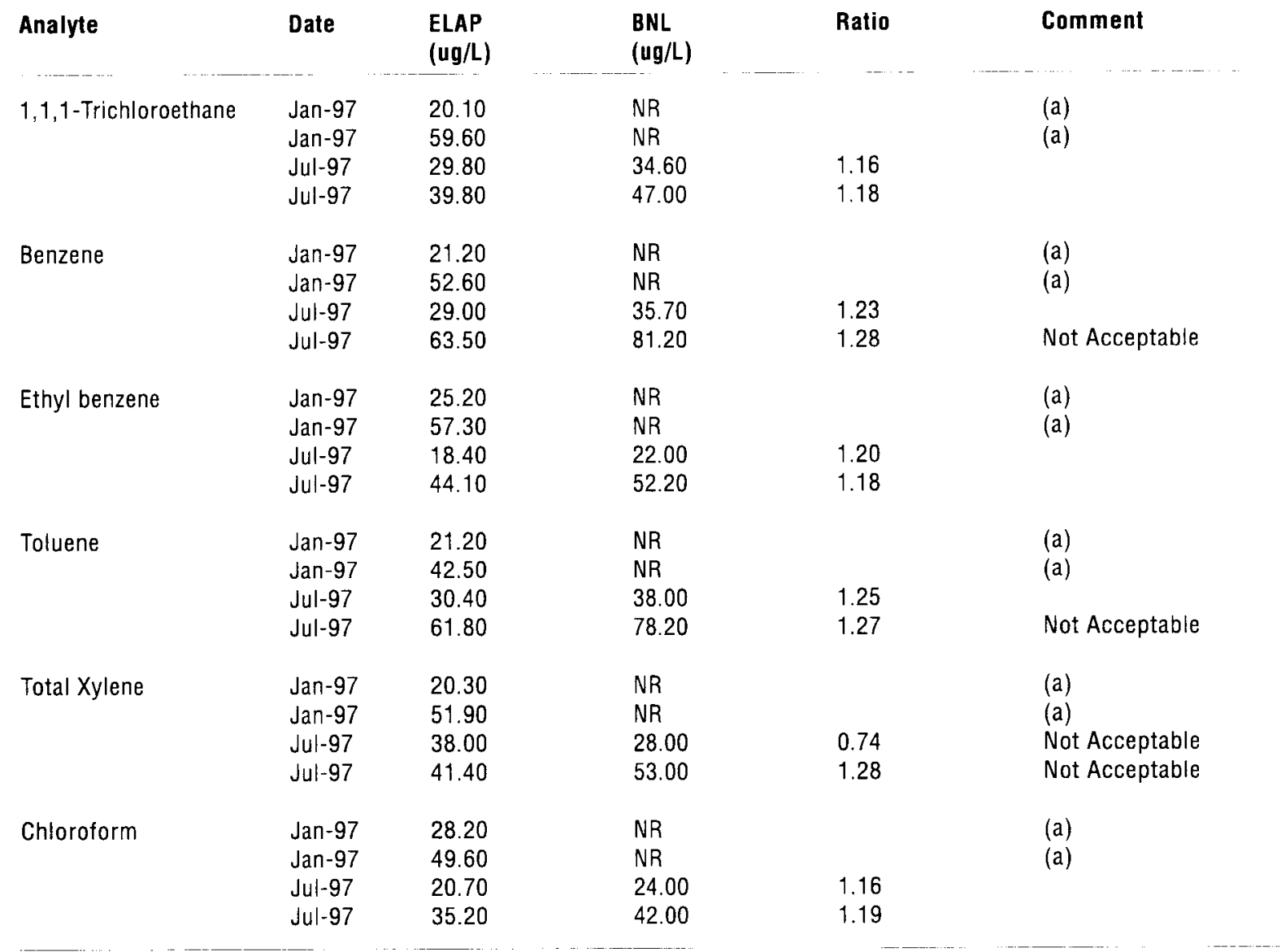

(a) = Data not reported (NR) because samples were not received by BNL.

Note: Comment column provides ELAP evaluation of analytical performance which is based on 95 and $99 \%$ confidence interval about the target value. No comment indicates that the performance was within acceptable limits.

spectively) exceeding the acceptance limit of $\pm 15 \%$ in the BFB case. The matrix spike recoveries ranged between $\pm 20-26 \%$, all within the acceptance band of $\pm 25 \%$ except TCA. This variability was due to instrument problems including malfunctions in the autosampler valve and leaks in the concentrator. Data review and validation resulted in TCA samples being qualified, which means that they were estimates because the surrogate recoveries exceeded EPA limits.

Lastly, the precision of the method was measured by analyzing duplicate samples; Figure 10-9 presents the results as relative percent difference. All duplicate analyses showed agreement within the EPA acceptance limit of $\pm 25 \%$, however they exceeded the internal control limits of $\pm 10 \%$. Irregularities in the injection of internal standards were noted. The percent variation in the internal standards corresponded with the change in spike recoveries, indicating that the variation resulted from inconsistencies in the autosampler mechanical injections.

During 1997, there was an onsite audit of the analytical chemistry processes conducted by NYSDOH ELAP. In addition, an appraisal of the Analytical Services Laboratory was conducted by an independent organization as part of the BNL Tier III Assessment Program. In both cases, correc- 
Table 10-5

BNL. Environmental Report for Calendar Year 1997

BNL Potable Water Chemistry Proficiency Test Results

Environmental Laboratory Approval Program

\begin{tabular}{|c|c|c|c|c|c|}
\hline Analyte & Date & $\begin{array}{l}\text { ELAP } \\
\text { (ug/L) }\end{array}$ & $\begin{array}{l}\text { BNL } \\
\text { (ug/L) }\end{array}$ & Ratio & Comment \\
\hline \multirow[t]{4}{*}{ Cadmium } & Apr-97 & 3.75 & 3.90 & 1.04 & \\
\hline & Apr-97 & 7.50 & 8.00 & 1.07 & \\
\hline & 0ct -97 & 2.50 & 2.46 & 0.98 & \\
\hline & Oct -97 & 6.67 & 6.80 & 1.02 & \\
\hline \multirow[t]{4}{*}{ Chloride } & Apr-97 & 19.10 & 19.50 & 1.02 & \\
\hline & Apr-97 & 156.00 & 153.00 & 0.98 & \\
\hline & Oct-97 & 35.20 & 35.20 & 1.00 & \\
\hline & Oct-97 & 104.00 & 106.00 & 1.02 & \\
\hline \multirow[t]{4}{*}{ Chromium } & Apr-97 & 25.00 & 24.50 & 0.98 & \\
\hline & Apr-97 & 87.50 & 92.00 & 1.05 & \\
\hline & Oct-97 & 33.30 & 36.20 & 1.09 & \\
\hline & Oct-97 & 83.30 & 90.70 & 1.09 & \\
\hline \multirow[t]{4}{*}{ Copper } & Apr-97 & 75.00 & 75.00 & 1.00 & \\
\hline & Apr-97 & 735.00 & 757.00 & 1.03 & \\
\hline & Oct-97 & 100.00 & 104.00 & 1.04 & \\
\hline & Oct-97 & 1000.00 & 1027.00 & 1.03 & \\
\hline \multirow[t]{4}{*}{ Iron } & Apr-97 & 100.00 & 101.00 & 1.01 & \\
\hline & Apr-97 & 308.00 & 314.00 & 1.02 & \\
\hline & Oct-97 & 150.00 & 156.00 & 1.04 & \\
\hline & Oct-97 & 389.00 & 405.00 & 1.04 & \\
\hline \multirow[t]{4}{*}{ Lead } & Apr-97 & 12.50 & 13.20 & 1.06 & \\
\hline & Apr-97 & 50.00 & 57.80 & 1.16 & \\
\hline & Oct-97 & 16.70 & 17.40 & 1.04 & \\
\hline & Oct-97 & 33.30 & 36.00 & 1.08 & \\
\hline \multirow[t]{4}{*}{ Manganese } & Apr-97 & 99.10 & 102.00 & 1.03 & \\
\hline & Apr-97 & 246.00 & 258.00 & 1.05 & \\
\hline & Oct-97 & 83.10 & 86.00 & 1.03 & \\
\hline & 0ct-97 & 213.00 & 223.00 & 1.05 & \\
\hline \multirow[t]{4}{*}{ Mercury } & Apr-97 & 1.69 & 1.25 & 0.74 & (a) \\
\hline & Apr-97 & 6.25 & 5.48 & 0.88 & (a) \\
\hline & Oct-97 & 3.33 & 3.01 & 0.90 & \\
\hline & Oct-97 & 10.00 & 9.97 & 1.00 & \\
\hline \multirow[t]{4}{*}{ Nitrate (as N) } & Apr-97 & 1.29 & 1.49 & 1.16 & Not Acceptable \\
\hline & Apr -97 & 6.92 & 6.91 & 1.00 & \\
\hline & Oct-97 & 0.76 & 0.73 & 0.96 & \\
\hline & Oct-97 & 9.23 & 8.86 & 0.96 & \\
\hline \multirow[t]{4}{*}{ Silver } & Apr-97 & 15.70 & 14.20 & 0.90 & \\
\hline & Apr-97 & 31.90 & 32.80 & 1.03 & \\
\hline & 0ct-97 & 33.70 & 35.00 & 1.04 & \\
\hline & Oct-97 & 41.60 & 44.00 & 1.06 & \\
\hline \multirow[t]{4}{*}{ Sodium } & Apr-97 & 99.10 & 103.00 & 1.04 & \\
\hline & Apr -97 & 234.00 & 239.00 & 1.02 & \\
\hline & Oct-97 & 74.80 & 75.00 & 1.00 & \\
\hline & Oct-97 & 178.00 & 180.00 & 1.01 & \\
\hline \multirow[t]{4}{*}{ Sulfate (as S04) } & Apr-97 & 37.80 & 38.70 & 1.02 & \\
\hline & Apr-97 & 176.00 & 174.00 & 0.99 & \\
\hline & Oct-97 & 79.40 & 80.00 & 1.01 & \\
\hline & Oct-97 & 149.00 & 149.00 & 1.00 & \\
\hline \multirow[t]{4}{*}{ Zinc } & Apr-97 & 88.10 & 98.00 & 1.11 & \\
\hline & Apr-97 & $1540.0 \mathrm{C}$ & 1610.00 & 1.05 & \\
\hline & Oct-97 & 200.00 & 196.00 & 0.98 & \\
\hline & Oct-97 & 987.00 & 995.00 & 1.01 & \\
\hline
\end{tabular}

(a) $=$ B21 BNL values were reversed in data transmissin; corrected BNL results are shown and were acceptable.

Note: Comment column provides ELAP evaluation of analytical performance which is based on 95 and $99 \%$ confidence interval about the target value.

No comment indicates that the performance was within acceptable limits. 
Table 10-6

BNL Site Environmental Report for Calendar Year 1997

BNL. Water Pollution Performance Evaluation Studies - WP037

USEPA Environmental Monitoring Systems Laboratory - Cincinnati

\begin{tabular}{|c|c|c|c|c|c|c|}
\hline Analyte & Units & Date & BNL & EMSL-CI & Ratio & Comments \\
\hline Chloroform & $u g / l$ & May-97 & 57.60 & 59.40 & 0.97 & \\
\hline & $u g / l$ & Nov-97 & 49.90 & 46.40 & 1.08 & \\
\hline $1,1,1$ Trichloroethane & $u g / l$ & May-97 & 57.00 & 54.20 & 1.05 & \\
\hline & $u g / l$ & Nov-97 & 40.60 & 38.70 & 1.05 & \\
\hline Trichloroethene & $\mathrm{ug} / \mathrm{l}$ & May-97 & 61.60 & 64.20 & 0.96 & \\
\hline & $\mathrm{ug} / !$ & Nov-97 & 37.70 & 33.60 & 1.12 & \\
\hline Tetrachloroethene & $u g / l$ & May-97 & 41.70 & 44.30 & 0.94 & \\
\hline & $u g / l$ & Nov-97 & 43.20 & 43.70 & 0.99 & \\
\hline Benzene & $u g / l$ & May-97 & 79.50 & 72.60 & 1.10 & \\
\hline & $\mathrm{ug} / \mathrm{l}$ & Nov-97 & 14.60 & 13.30 & 1.10 & \\
\hline Ethylbenzene & $\operatorname{ug} / /$ & May-97 & 60.80 & 63.30 & 0.96 & \\
\hline & $u g / /$ & Nov -97 & 10.50 & 10.40 & 1.01 & \\
\hline Toluene & $u g / l$ & May-97 & 56.20 & 56.10 & 1.00 & \\
\hline & $u g / l$ & Nov-97 & 13.80 & 12.70 & 1.09 & \\
\hline TSS & $\mathrm{mg} / 1$ & May-97 & 115.00 & 226.00 & 0.51 & Not Acceptable \\
\hline & $\mathrm{mg} / \mathrm{l}$ & Nov-97 & 48.20 & 56.00 & 0.86 & \\
\hline Total Residual $\mathrm{Cl}$ & $\mathrm{mg} / \mathrm{l}$ & May-97 & 59.50 & 118 & 0.50 & Not Acceptable \\
\hline & $\mathrm{mg} / \mathrm{l}$ & Nov-97 & 3.18 & 2.80 & 1.32 & \\
\hline $\begin{aligned} \text { Note: } & \text { Comment colu } \\
& \text { calculated fror } \\
& \text { was within aco }\end{aligned}$ & $\begin{array}{l}\text { des EI } \\
\text { s analy } \\
\text { imits. }\end{array}$ & $\begin{array}{l}\text { valuati } \\
\text { EPA an }\end{array}$ & $\begin{array}{l}\text { nalytica } \\
\text { Labore }\end{array}$ & $\begin{array}{l}\text { Iance } w \\
\text { comm }\end{array}$ & te & $\begin{array}{l}\text { nd } 99 \% \text { predictio } \\
\text { performance }\end{array}$ \\
\hline
\end{tabular}

Table 10-7

BHL Site Environmental Report for Calendar Year 1997

BNL Water Supply Performance Evaluation Studies - WS038 and WS039

USEPÁ Environmental Monitoring Systems Laboratory - Cincinnati

\begin{tabular}{|c|c|c|c|c|c|c|}
\hline Analyte & Units & Date & BNL & EMSL-C! & Ratio & Comments \\
\hline $\mathrm{Cd}$ & $u g / 1$ & Sep-97 & 27.00 & 28.50 & 0.95 & \\
\hline $\mathrm{Cr}$ & $\operatorname{ugg} / !$ & Sep-97 & 23.70 & 23.90 & 0.99 & \\
\hline $\mathrm{Cu}$ & $\mathrm{ug} / \mathrm{l}$ & Sep-97 & 506.00 & 490.00 & 1.03 & \\
\hline $\mathrm{Hg}$ & $\mathrm{ug} / \mathrm{l}$ & Sep-97 & 3.46 & 3.80 & 0.91 & \\
\hline $\mathrm{Mn}$ & $\mathrm{ug} / \mathrm{l}$ & Sep-97 & 86.00 & 82.00 & 1.05 & \\
\hline $\mathrm{Zn}$ & $\mathrm{ug} / \mathrm{l}$ & Sep-97 & 779.00 & 760.00 & 1.03 & \\
\hline$N 03=N$ & $\mathrm{mg} / 1$ & Sep-97 & 9.58 & 9.50 & 1.01 & \\
\hline SO4 & $\mathrm{mg} / \mathrm{l}$ & Sep-97 & 472.00 & 490.00 & 0.96 & \\
\hline \multirow[t]{2}{*}{ Chloroform } & $u g / 1$ & Mar-97 & 34.50 & 36.50 & 0.95 & \\
\hline & & Sep-97 & 25.30 & 16.20 & 1.56 & Not Acceptable \\
\hline \multirow[t]{2}{*}{ TCA } & $u g / l$ & Mar-97 & 17.00 & 17.20 & 0.99 & \\
\hline & & Sep-97 & 12.70 & 11.20 & 1.13 & \\
\hline \multirow[t]{2}{*}{ TCE } & $\mathrm{ug} / \mathrm{l}$ & Mar-97 & 12.80 & 12.40 & 1.03 & \\
\hline & & Sep-97 & 18.80 & 16.40 & 1.15 & \\
\hline \multirow[t]{2}{*}{ Benzene } & $\mathrm{ug} / \mathrm{l}$ & Mar-97 & 13.60 & 12.50 & 1.09 & \\
\hline & & Sep-97 & 11.20 & 9.39 & 1.19 & \\
\hline \multirow[t]{2}{*}{ PCE } & $\mathrm{ug} / 1$ & Mar-97 & 14.70 & 14.10 & 1.04 & \\
\hline & & Sep-97 & 7.85 & 7.60 & 1.03 & \\
\hline \multirow[t]{2}{*}{ Toluene } & $u g / l$ & Mar-97 & 18.70 & 16.20 & 1.15 & \\
\hline & & Sep-97 & 8.09 & 7.31 & 1.11 & \\
\hline \multirow[t]{2}{*}{ Ethylbenzene } & $u g / l$ & Mar-97 & 15.80 & 15.70 & 1.01 & \\
\hline & & Sep-97 & 12.50 & 11.60 & 1.08 & \\
\hline Total Xylenes & $u g / l$ & Mar-97 & 12.20 & 22.90 & 0.53 & Not Acceptable \\
\hline
\end{tabular}

10 - 101997 BNL Site Environmental Report 


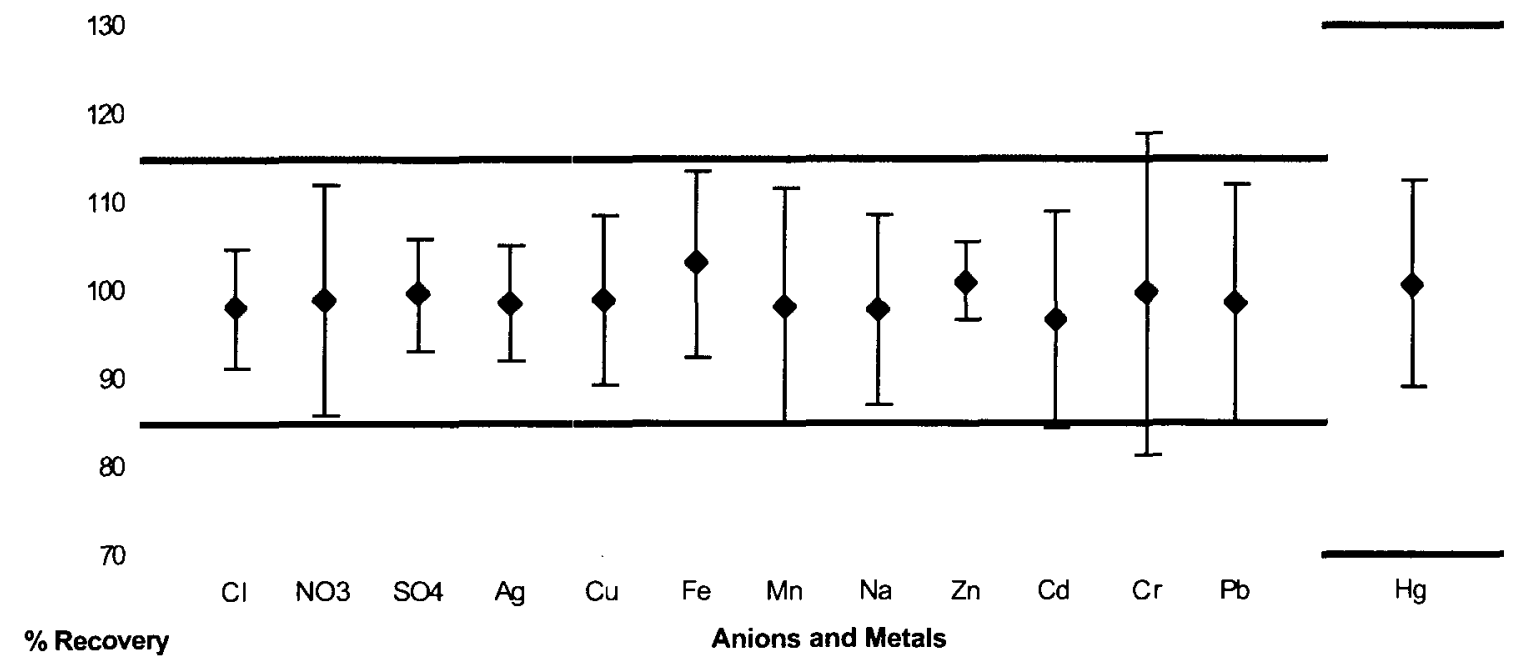

Figure 10-5. Reference Check Summary for 1997 Inorganic Analyses

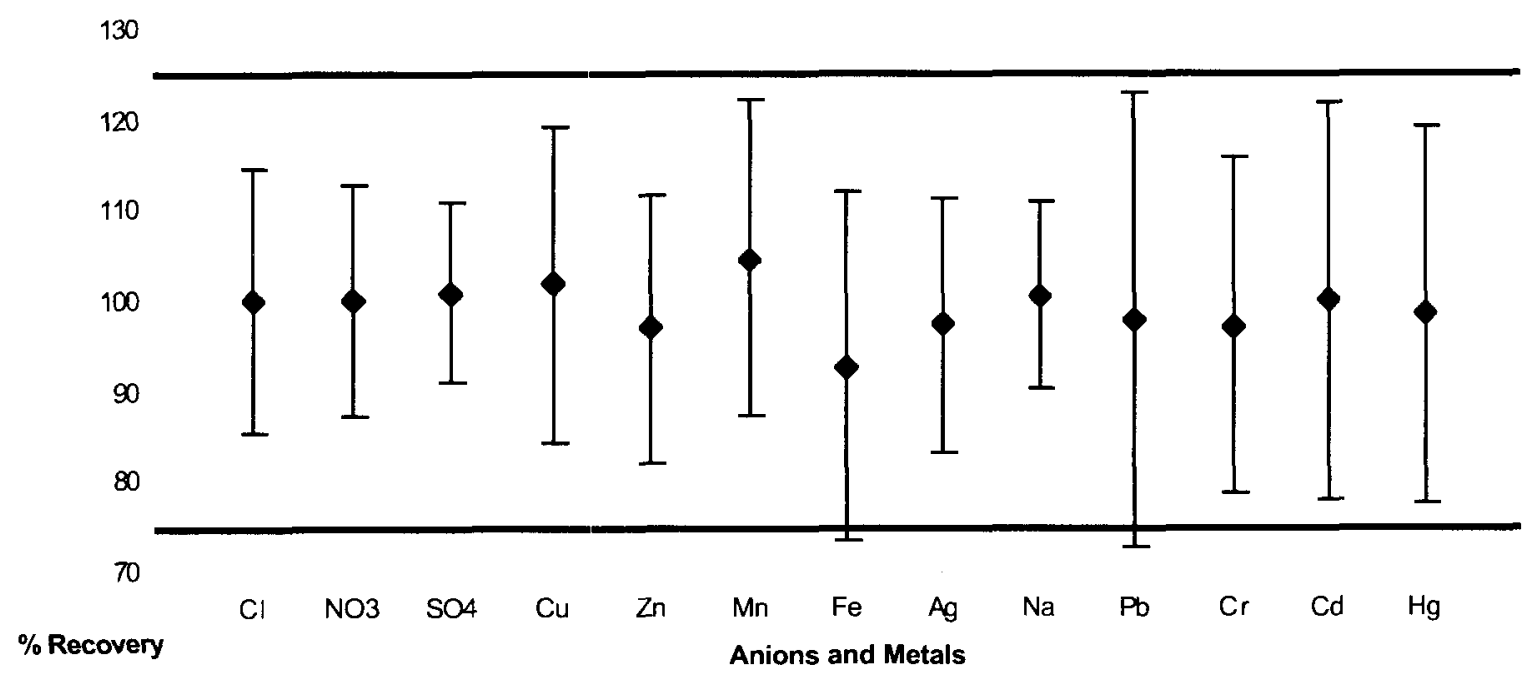

Figure 10-6. Summary of Spike Recoveries for 1997 Inorganic Analyses

tive action plans for the findings and recommendations were developed and implementation is ongoing.

\subsubsection{Contractor Laboratories}

Samples collected for regulatory compliance, such as SPDES discharge monitoring reports, Water Treatment Plant (WTP) monthly reports, and Central Steam Facility (CSF) semiannual reports are analyzed by offsite contractor laboratories. Contractor laboratories were used when the ASL could not perform a specific analysis, such as strontium-90 or Toxicity Characteristic Leachate Procedure (TCLP) by EPA methods. The laboratory has a person dedicated to specifying contract and technical requirements, including applicable certifications for each analytical method, and evaluating the contractor's performance. The incoming data packages are reviewed to ensure that 


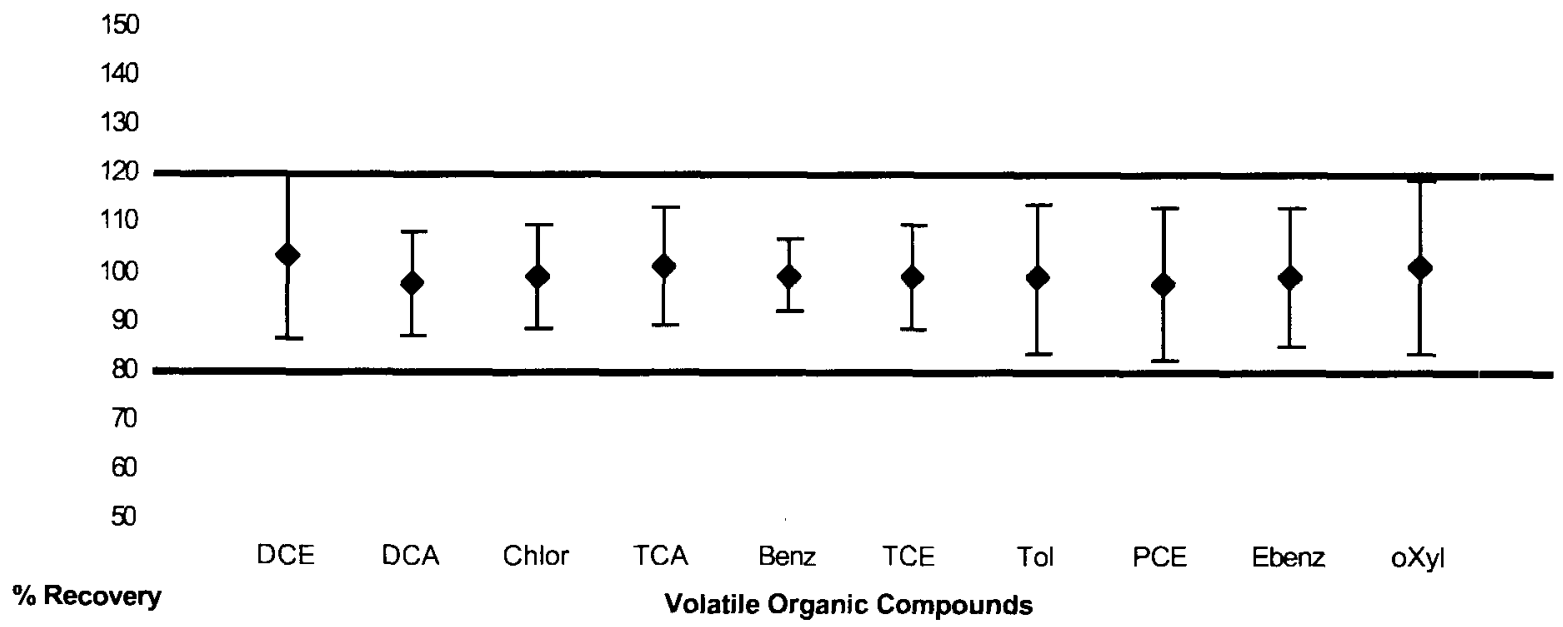

Figure 10-7. Reference Check Summary for Organic Analyses in 1997

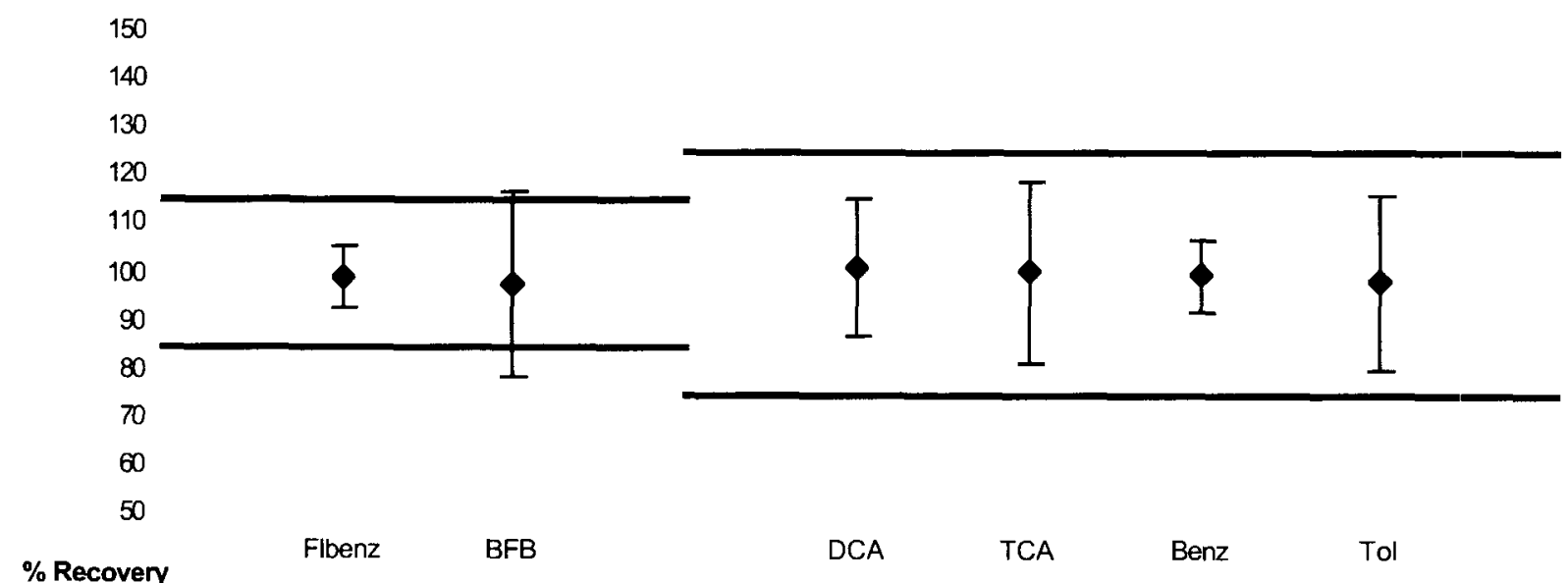

Figure 10-8. Surrogate and Spike Recovery Summaries for Organic Analyses

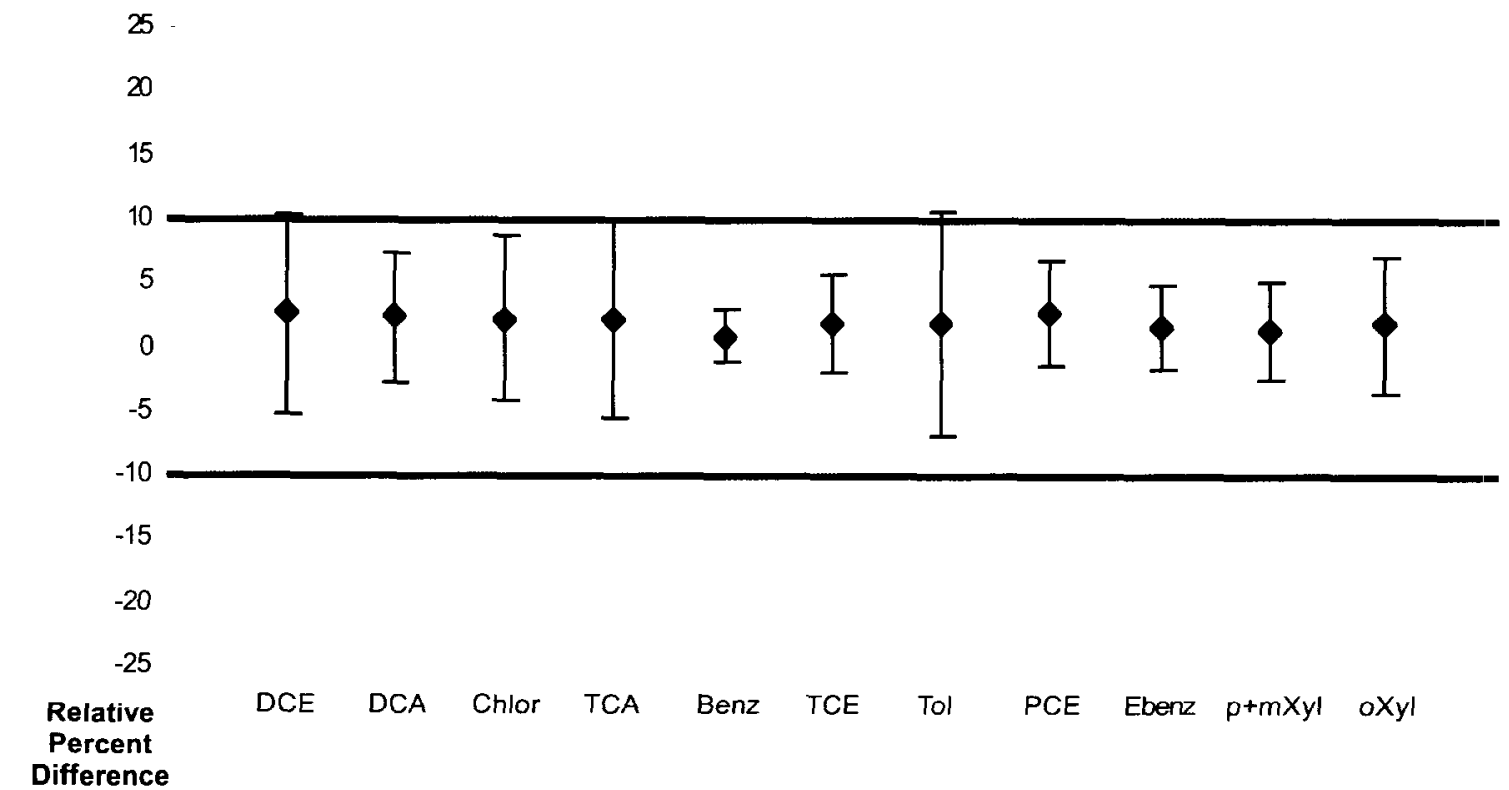

Figure 10-9. Matrix Spike Duplicate Summary for Organic Analyses in 1997 
they comply with the contract specification before the data is reported. The commercial laboratories are audited periodically by the supervisor and QA Officer to verify competence in analytical methodology and implementation of a comprehensive QA program.

The contract laboratories responsible for analyzing the BNL SPDES samples are required to participate in the NPDES Performance Evaluation Study; these results are presented in Table 10-8. Twenty-four of the twenty-four analyses showed acceptable agreement which is an improvement from the performances of the previous years two contractor labs.

A contractor laboratory participated in the EMSL-CI Water Pollution Performance Evaluation Study (WP038 and WP039) in May and November of 1997. The results given in Table 10-9 for the same SPDES parameters show acceptable agreement for twenty-six of twenty-eight analyses. However, one sample in May 1997 for Oil and Grease was outside the acceptance limit. Overall, this contractor laboratory perforned acceptably in $97 \%$ of the comparisons. A dilution error

Table $10-8$

BNL Site Environmental Report for Calendar Year 1997

BNL Contractor Laboratory Performance Evaluation Study

BNL National Pollution Discharge Ellmination System (NPDES) - DMR OA 17

\begin{tabular}{|c|c|c|c|c|c|c|}
\hline Analyte & Units & Date & Reported & NPDES & Ratio & Comments \\
\hline $\mathrm{Cu}$ & $\mathrm{mg} / \mathrm{L}$ & Jan-98 & 289.000 & 277.000 & 1.04 & \\
\hline $\mathrm{Fe}$ & $\mathrm{mg} / \mathrm{L}$ & Jan-98 & 1996.000 & 0.95 & & \\
\hline $\mathrm{Pb}$ & $\mathrm{mg} / \mathrm{L}$ & $\operatorname{Jan}-98$ & 429.000 & 430.000 & 1.00 & \\
\hline $\mathrm{Ni}$ & $\mathrm{mg} / \mathrm{L}$ & Jan-98 & 185.000 & 188.000 & 0.98 & \\
\hline $\mathrm{Zn}$ & $\mathrm{mg} / \mathrm{L}$ & Jan-98 & 1564.000 & 1551.000 & 1.01 & \\
\hline $\mathrm{Cr}$ & $\mathrm{mg} / \mathrm{L}$ & Jan-98 & 418.000 & 420.000 & 1.00 & \\
\hline $\mathrm{Mn}$ & $\mathrm{mg} / \mathrm{L}$ & Jan-98 & 1101.000 & 1100.000 & 1.00 & \\
\hline $\mathrm{Cd}$ & $\mathrm{mg} / \mathrm{L}$ & Jan-98 & 65.800 & 69.000 & 0.95 & \\
\hline $\mathrm{pH}$ & & Jan-98 & 6.530 & 6.580 & 0.99 & \\
\hline TSS & $\mathrm{mg} / \mathrm{L}$ & $\operatorname{Jan}-98$ & 40.200 & 46.000 & 0.87 & \\
\hline Oil and Grease & $\mathrm{mg} / \mathrm{L}$ & Jan-98 & 8.500 & 12.200 & 0.70 & \\
\hline Ammonia - N & $\mathrm{mg} / \mathrm{L}$ & Jan-98 & 2.970 & 2.800 & 1.06 & \\
\hline NO3 - N & $\mathrm{mg} / \mathrm{L}$ & Jan-98 & 31.500 & 31.000 & 1.02 & \\
\hline Kjeldahl - N & $\begin{array}{l}\mathrm{mg} / \mathrm{L} \\
\mathrm{mg} / \mathrm{L}\end{array}$ & $\operatorname{Jan}-98$ & 23.000 & 24.000 & 0.96 & \\
\hline 5 Day BOD & $\mathrm{mg} / \mathrm{L}$ & Jan-98 & 46.000 & 50.300 & 0.91 & \\
\hline Total Cyanide & $\mathrm{mg} / \mathrm{L}$ & $\operatorname{Jan}-98$ & 0.162 & 0.190 & 0.85 & \\
\hline Total Phenolics & $\mathrm{mg} / \mathrm{L}$ & Jan-98 & 0.124 & 0.113 & 1.10 & \\
\hline Total Residual $\mathrm{Cl}$ & $\mathrm{mg} / \mathrm{L}$ & $\operatorname{Jan}-98$ & 1.430 & 1.390 & 1.03 & \\
\hline \multicolumn{7}{|l|}{ Fathead Minnow } \\
\hline Chronic Data - & & & & & & \\
\hline Survival, NOEC & $\%$ & Jan-98 & 25.000 & 25.000 & 1.00 & \\
\hline Growth, IC25 & $\%$ & Jan-98 & 24.200 & 37.700 & 0.64 & \\
\hline Growth, NOEC & $\%$ & Jan-98 & 12.500 & 25.000 & 0.50 & \\
\hline \multicolumn{7}{|l|}{ Cerlodaphnia } \\
\hline Chronic Data & & & & & & \\
\hline Survival, NOEC & $\%$ & Jan-98 & 12.500 & 25.000 & 0.50 & \\
\hline Growth, IC25 & $\%$ & Jan-98 & 12.700 & 15.700 & 0.81 & \\
\hline Growth, NOEC & $\%$ & Jan-98 & 12.500 & 12.500 & 1.00 & \\
\hline
\end{tabular}

Note: Comment column provides evaluation of analytical performance which is based on 95 and $99 \%$ prediction interval calculated from samples analyzed by EPA and State laboratories. No comment indicates that the performance was within acceptable limits. 


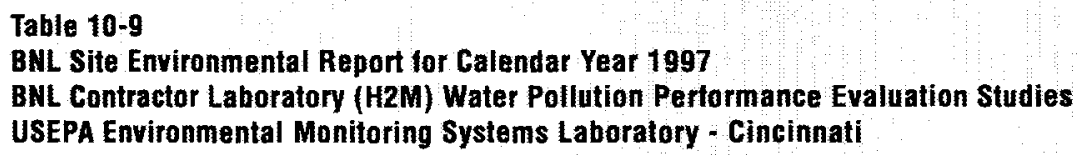

\begin{tabular}{|c|c|c|c|c|c|c|}
\hline Analyte & Units & Date & Contractor & EMSL-CI & Ratio & Comments \\
\hline $\mathrm{Cu}$ & $\mathrm{ug} / \mathrm{l}$ & $\begin{array}{l}\text { Nov-97 } \\
\text { Nay-97 }\end{array}$ & $\begin{array}{l}289.000 \\
118.000\end{array}$ & $\begin{array}{l}277.000 \\
115.000\end{array}$ & $\begin{array}{l}1.04 \\
1.03\end{array}$ & \\
\hline $\mathrm{Fe}$ & $\mathrm{ug} / \mathrm{l}$ & $\begin{array}{l}\text { Nov-97 } \\
\text { May-97 }\end{array}$ & $\begin{array}{r}1996.000 \\
402.000\end{array}$ & $\begin{array}{r}2100.000 \\
393.000\end{array}$ & $\begin{array}{l}0.95 \\
1.02\end{array}$ & \\
\hline $\mathrm{Pb}$ & $\mathrm{ug} / \mathrm{l}$ & $\begin{array}{l}\text { Nov-97 } \\
\text { May-97 }\end{array}$ & $\begin{array}{l}429.000 \\
126.000\end{array}$ & $\begin{array}{l}430.000 \\
130.000\end{array}$ & $\begin{array}{l}1.00 \\
0.97\end{array}$ & \\
\hline $\mathrm{Ni}$ & $u g / l$ & $\begin{array}{l}\text { Nov-97 } \\
\text { May-97 }\end{array}$ & $\begin{array}{l}185.000 \\
426.000\end{array}$ & $\begin{array}{l}188.000 \\
417.000\end{array}$ & $\begin{array}{l}0.98 \\
1.02\end{array}$ & \\
\hline $\mathrm{Zn}$ & $u g / l$ & $\begin{array}{l}\text { Nov-97 } \\
\text { May-97 }\end{array}$ & $\begin{array}{r}1561.000 \\
304.000\end{array}$ & $\begin{array}{r}1551.000 \\
296.000\end{array}$ & $\begin{array}{l}1.01 \\
1.03\end{array}$ & \\
\hline $\mathrm{pH}$ & & $\begin{array}{l}\text { Nov-97 } \\
\text { May-97 }\end{array}$ & $\begin{array}{l}6.680 \\
9.300\end{array}$ & $\begin{array}{l}6.580 \\
9.300\end{array}$ & $\begin{array}{l}1.02 \\
1.00\end{array}$ & \\
\hline TSS & $m g / 1$ & $\begin{array}{l}\text { Nov }-97 \\
\text { May-97 }\end{array}$ & $\begin{array}{l}596.000 \\
710.000\end{array}$ & $\begin{array}{l}512.000 \\
685.000\end{array}$ & $\begin{array}{l}1.16 \\
1.04\end{array}$ & \\
\hline Oil and Grease & $\mathrm{mg} / \mathrm{l}$ & $\begin{array}{l}\text { Nov-97 } \\
\text { May-97 }\end{array}$ & $\begin{array}{r}8.500 \\
15.500\end{array}$ & $\begin{array}{l}12.200 \\
32.000\end{array}$ & $\begin{array}{l}0.70 \\
0.48\end{array}$ & $\begin{array}{l}\text { Warning } \\
\text { Not Acceptable }\end{array}$ \\
\hline Ammonia - $\mathrm{N}$ & $\mathrm{mg} / \mathrm{l}$ & $\begin{array}{l}\text { Nov-97 } \\
\text { May-97 }\end{array}$ & $\begin{array}{l}2.970 \\
0.250\end{array}$ & $\begin{array}{l}2.800 \\
0.261\end{array}$ & $\begin{array}{l}1.06 \\
0.96\end{array}$ & \\
\hline N03 - N & $\mathrm{mg} / \mathrm{l}$ & $\begin{array}{l}\text { Nov }-97 \\
\text { May }-97\end{array}$ & $\begin{array}{r}31.500 \\
0.611\end{array}$ & $\begin{array}{r}31.000 \\
0.620\end{array}$ & $\begin{array}{l}1.02 \\
0.99\end{array}$ & \\
\hline Kjeldahl - N & $\mathrm{mg} / \mathrm{l}$ & $\begin{array}{l}\text { Nov-97 } \\
\text { May-97 }\end{array}$ & $\begin{array}{r}23.000 \\
2.900\end{array}$ & $\begin{array}{r}24.000 \\
2.600\end{array}$ & $\begin{array}{l}0.96 \\
1.12\end{array}$ & \\
\hline 5 Day BOD & $\begin{array}{l}\mathrm{mg} / \mathrm{l} \\
\mathrm{mg} / \mathrm{l}\end{array}$ & $\begin{array}{l}\text { Nov-97 } \\
\text { May-97 }\end{array}$ & $\begin{array}{r}46.000 \\
106.000\end{array}$ & $\begin{array}{l}50.300 \\
93.100\end{array}$ & $\begin{array}{l}0.91 \\
1.14\end{array}$ & \\
\hline Total Phenolics & $\mathrm{mg} / /$ & $\begin{array}{l}\text { Nov-97 } \\
\text { May-97 }\end{array}$ & $\begin{array}{l}0.124 \\
2.110\end{array}$ & $\begin{array}{l}0.113 \\
2.080\end{array}$ & $\begin{array}{l}1.10 \\
1.01\end{array}$ & \\
\hline $\begin{array}{l}\text { Total Residual } \\
\text { Chlorine }\end{array}$ & $\mathrm{mg} / \mathrm{l}$ & $\begin{array}{l}\text { Nov-97 } \\
\text { May-97 }\end{array}$ & $\begin{array}{l}1.630 \\
2.750\end{array}$ & $\begin{array}{l}1.390 \\
2.630\end{array}$ & $\begin{array}{l}1.17 \\
1.05\end{array}$ & \\
\hline
\end{tabular}

Note: Comment column provides evaluation of analytical performance which is based on 95 and $99 \%$ prediction interval calculated from samples analyzed by EPA and State laboratories. No comment indicates that the performance was within acceptable limits.

seems to be the most likely cause of this problem, but no attributable cause for the oil and grease data have been provided by the contractor laboratory.

\subsection{The HFBR Tritium Plume Characterization Project}

In December of 1996, groundwater samples taken from one of two recently installed permanent wells south of the BNL High Flux Beam Reactor (HFBR) had detectable levels of tritium $(2,500$ 
pCi/L). In January 1997, confirmatory samples from well 75-12 showed tritium at a concentration of 44,700 pCi/L, over twice the federal drinking water standard of $20,000 \mathrm{pCi} / \mathrm{L}$. BNL implemented an intensive groundwater investigation to characterize the extent of tritium in groundwater downgradient of the HFBR. Beginning in mid-January of 1997, twenty-five temporary Geoprobe (GP) wells were installed close to the HFBR and groundwater samples taken at 5 different depths for tritium, strontium-90, gamma and gross alpha/beta analyses. The ES\&HS Division's ASL performed all radiological analyses on the GP water samples, the analytical results are listed in the Operable Unit III Tritium Compilation Report (ITC, 1997).

During characterization, split groundwater samples from the 25 GP wells were sent to the USEPA's National Air and Radiation Environmental Laboratory (NAREL) in Montgomery, AL. The NAREL performed distilled tritium measurements on the GP water samples, as well as gamma analyses on select samples. The EPA measurements confirmed BNL's accuracy in performing distilled tritium analyses in groundwater using EPA Method 906.0. Figure 10-10 compares the results of 48 analyses performed at BNL's ASL with those from EPA's NAREL. Only results greater than the ASL's minimum detectable level (MDL) of $700 \mathrm{pCi} / \mathrm{L}$ are shown. Regression of the data show that the BNL tritium results were within $5 \%$ of the USEPA results, as demonstrated by the slope of 1.05. The correlation coefficient (R2) of the paired data was 0.9982 . The ratios of the BNL tritium result to the EPA result were also calculated for each GP sample collected during Phase-I of the Tritium Plume Characterization Project. The mean ratio for the 48 comparisons was $0.97 \pm 0.15$, which demonstrates excellent agreement between the ASL and the U.S. EPA/NAREL. Eighty-three percent of the 48 "positive" BNL results shown in Figure 10-10 were within $+20 \%$ of the U.S. USEPA measured values. This finding was noted in the February 1997 "Interim Report on the Office of Environment, Safety and Health Oversight of Groundwater Tritium Plume Recovery Activities at BNL" published by the U.S. DOE Office of Oversight.

Beginning in early February of 1997, twenty-one additional GP wells were installed at locations north and south of the HFBR to further characterize the tritium plume. In total, 46 temporary GP wells were installed. As the investigation progressed, there was a need to install wells deeper than the 100 foot depth limitation of the Geoprobe. From late February through November 1997, 77 vertical profile (VP) wells were drilled. Groundwater samples were acquired for tritium, strontium-90, gross alpha/beta and gamma measurements at 10 -foot intervals to a depth of 200 feet below grade.

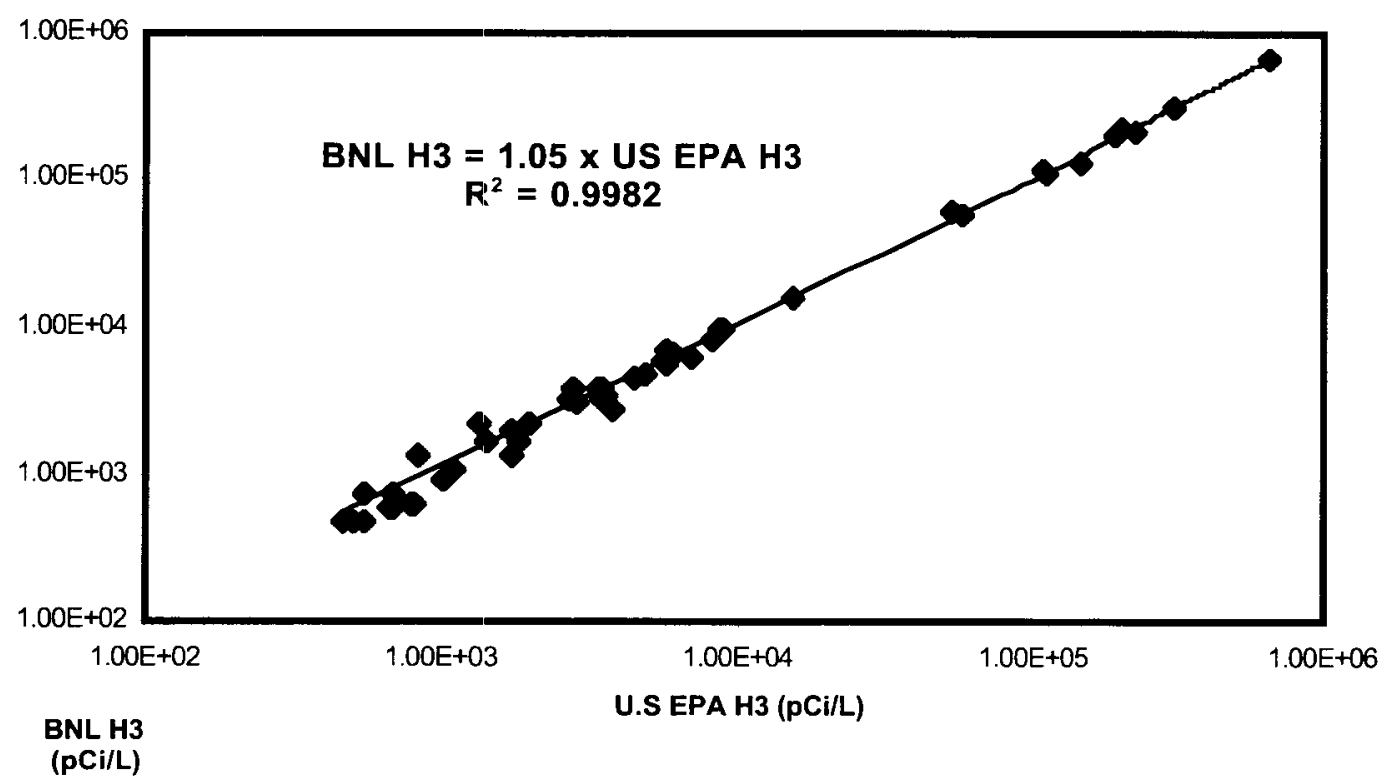

Figure 10-10. Comparison of BNL vs. U.S. EPA Tritium Results on 48 HFBR Geoprobe Water Samples: January 1997 
Due to the large number of samples, ASL services were supplemented by four additional NYS Certified laboratories to perform tritium, strontium-90; gamma and gross alpha/beta analyses on the VP and GP groundwater samples, using approved USEPA methods. The laboratories were selected from their past performance in two national radiological assessment programs: (a) DOE's Environmental Measurements Laboratory (EML) QAP; and (b) the USEPA/NERL-LV Radiological Program:

(1) Data Chem Labs (DCL), Salt Lake City, UT

(2) Environmental Physics Inc. (EPI), Charleston SC

(3) IEA, Inc., Carey, NC

(4) Quanterra Lab, St. Louis, MI.

In May 1997, each of the five participating laboratories received a set of "blind" water samples containing strontium-90, gamma and gross alpha/beta activity. These quality assurance (QA) samples were prepared by the ES\&HS Division's ASL using National Institute of Standards and Technology (NIST) Certified radionuclides added to Long Island tap-water. This approach established each laboratory's accuracy for radiological analyses (other than tritium) that were performed during the HFBR Plume Investigation Project. Table 10-10 shows the results of the five laboratories that performed gross alpha/beta, gamma and strontium-90 analyses on the "blind" QA tap-waters using EPA Methods 900.0,901.0 and 905.0, respectively. With the exception of Quanterra Lab, all 5 laboratories were able to measure strontium-90, Gamma and Gross alpha/ beta activity to within $\pm 25 \%$ of known activity concentrations.

\section{Contractor Lab Tritium Analysis Accuracy}

Each contractor laboratory, including the ASL, received the complete sample set for a given GP or VP location to assure data uniformity. Two QA samples were always included in every BNL shipment to a contractor laboratory: 1) a double steam-distilled deep-well water sample (American Eagle Water Co, East Orange, NJ) that served as a 'Blank'; and 2) a BNL spiked tapwater sample that contained a known amount $(200,000 \mathrm{pCi} / \mathrm{L})$ of NIST traceable tritium.

With every 40-60 samples shipped to each contractor laboratory, a BNL groundwater sample of known tritium activity concentration was also sent. This BNL groundwater was one of the $48 \mathrm{GP}$ samples that had been previously measured by both BNL and the U.S. EPA in January 1997 (Figure 10-10).

Each of the three QA samples (e.g., Blank, H3-spike and BNL/EPA measured GP sample) were used to assess the contractor labs' accuracy for every batch of samples they analyzed for tritium. Batch precision was determined using the reported results of field duplicates submitted to a laboratory in each batch of samples. Table 10-11 shows the mean ratio of reported to known tritium results for each of the 4 contractor laboratories during Phase-II of the HFBR Tritium Plume Investigation Project. These data show that each laboratory was able to measure tritium activity concentrations to within $\pm 15 \%$ of "known" tritium levels. With the exception of Data Chem Lab (DCL), all "blank" samples submitted for tritium analysis were reported as < MDL. The contract with Data Chem Labs was terminated in March 1997 when it was discovered that "blank" results of 1000 $\mathrm{pCi} / \mathrm{L}$ were reported by the laboratory on four consecutive occasions. Tritium results $>1000 \mathrm{pCi} / \mathrm{L}$ were also reported by Data Chem Labs at VP well 094, located at the BNL south-boundary. At the request of $\mathrm{BNL}$, these samples were reanalyzed and subsequently found to be non-detectable (i.e., $<\mathrm{MDL}$ ) for tritium. A letter of retraction, claiming that tritium results for VP-094 was biased high, was received by BNL from Data Chem Labs on March 27, 1997.

\section{Audit of the ASL}

Between April 2-4, 1997, an audit of the ASL was conducted by Charles Miller of Gilbert-Hill Associates and David Baldwin of Pacific Northwest National Laboratory. The audit was requested by DOE Headquarters to assess the tritium analytical data generated during Phases I and II of the HFBR plume characterization. The final report, issued on May 7, 1997, contained 29 corrective 
Table 10-10

Results of BNL Prepared Blind QA Water Samples*

Analyzed by U.S. EPA Methods May 1997

\begin{tabular}{|c|c|c|c|c|c|}
\hline LAB & & $\begin{array}{l}\text { Gross Alpha } \\
\text { (216 pCi/L) }\end{array}$ & $\begin{array}{l}\text { Gross Beta } \\
\text { (304 pCi/L) }\end{array}$ & $\begin{array}{l}\text { Gamma }\left({ }^{137} \mathrm{Cs}\right) \\
(459 \mathrm{pCi} / \mathrm{L})\end{array}$ & $\begin{array}{l}\mathrm{Sr}-90 \\
(297 \mathrm{pCi} / \mathrm{L})\end{array}$ \\
\hline \multicolumn{6}{|l|}{ IEA } \\
\hline & Result & $226.3 \pm 6.0$ & $301.2 \pm 4.1$ & $502.2 \pm 29.7$ & $310.2 \pm 4.3$ \\
\hline & Ratio & 1.05 & 0.99 & 1.09 & 1.04 \\
\hline \multicolumn{6}{|l|}{ EPI } \\
\hline & Result & $264.0 \pm 18.5$ & $2 B 6 \pm 15.0$ & $487.0_{ \pm} 80.0$ & $296.0 \pm 7.5$ \\
\hline & Ratio & 1.22 & 0.99 & 1.06 & 1.00 \\
\hline \multicolumn{6}{|l|}{ DCL } \\
\hline & Result & $220.0 \pm 4.7$ & $340.0 \pm 3.8$ & $470.0 \pm 70$ & NR \\
\hline & Ratio & 1.02 & 1.12 & 1.02 & \\
\hline \multicolumn{6}{|c|}{ Quanterra } \\
\hline & Result & $228.0 \pm 24.7$ & $238.0 \pm 24.2$ & $536.5 \pm 66.9$ & $198.1 \pm 39.0$ \\
\hline & Ratio & 1.06 & 0.78 & 1.17 & 0.67 \\
\hline \multicolumn{6}{|c|}{ BNL/ASL } \\
\hline & Result & $228.0 \pm 30$ & $352.0 \pm 40$ & $579 \pm 60$ & $273.4 \pm 8.4$ \\
\hline & Ratio & 1.06 & 1.16 & 1.25 & 0.92 \\
\hline
\end{tabular}

${ }^{\star}$ NIST Certified radionuclides added to acidified $\left(\mathrm{HNO}_{3}\right)$ DI-Water. NR means not reported by contractor lab.

Table 10-11

Accuracy of Contractor Labs Performing Distilled Tritium Analyses in Water During Phase-11 of HFBR Plume Project

\begin{tabular}{lccc} 
Contractor Laboratory & $\mathbf{N}$ & $\begin{array}{l}\text { Mean Ratio } \\
\mathbf{\pm 1} \text { of Reported Results to Known Values }\end{array}$ & \begin{tabular}{l} 
Blank Results \\
\hline EPI
\end{tabular} \\
IEA & 16 & $1.15 \pm 0.23$ & All Acceptable \\
Quanterra & 24 & $1.10 \pm 0.22$ & All Acceptable \\
Data Chem Lab & 13 & $0.96 \pm 0.15$ & All Acceptable \\
\hdashline $\mathbf{N}=$ \# of "Blind" QA samples analyzed (which include Tritium Spikes and GP samples of known tritium levels) \\
\hline
\end{tabular}

action recommendations to improve the quality of radiological data reported by the ASL. Approximately $90 \%$ of the recommendations were accepted and were subsequently incorporated into all radiological analyses performed by the ASL. Several of the corrective actions that the ASL implemented improved quality assurance by adding spikes and spiked duplicates into each analytical batch to determine precision. Figure 10-10 shows the Relative Percent Difference (RPD) for each of the 198 analytical batches of tritium analyses performed immediately after the GilbertHill Audit of the ASL. The RPD statistic is the measure of batch precision and is defined as the 
difference between two tritium results (performed on spiked tap water samples) divided by the average of the two results. The acceptance criteria for batch precision is an RPD statistic $<20 \%$ for activity concentrations five times greater than the method MDL. The data in Figure 10-11 show that tritium precision was consistent for all 198 analytical batches performed by the ASL after the audit.

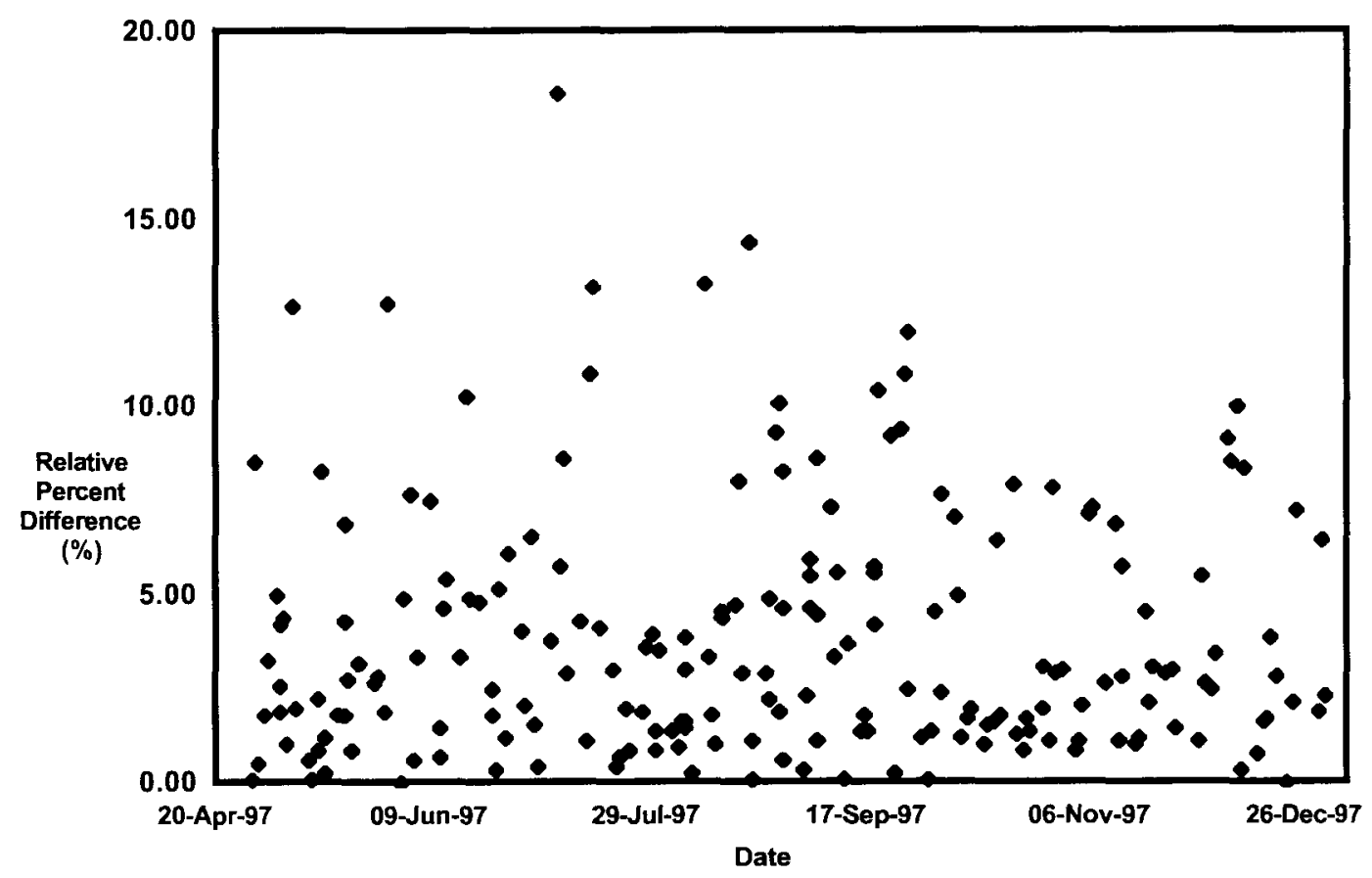

Figure 10-11. ASL Tritium Precision

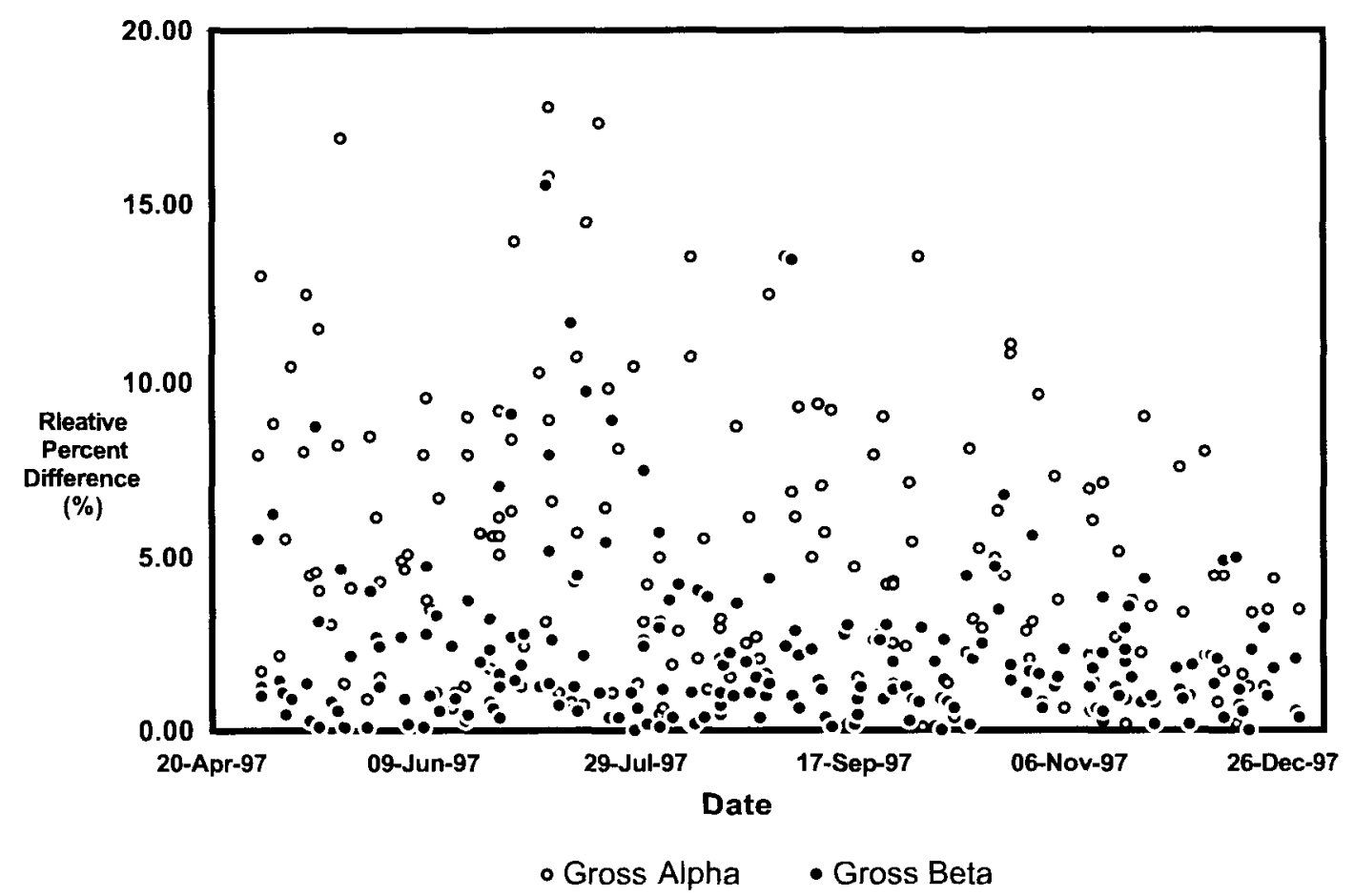

Figure 10-12. ASL Gross Alpha/Beta Precision 


\section{Gross Alpha/Beta Analyses}

Figure 10-12 shows the RPD values for the 126 batches of gross alpha and beta analyses performed by the ASL after the ASL audit in April 1997. Precision was consistently below $20 \%$ during the calendar year for both ASL counting units.

In the first quarter of 1998, the ASL discovered that several carriers that hold the alpha/beta planchets in Unit 2 were slightly contaminated on the external surface. The contamination was removed and the empty carriers are each routinely background counted on a biweekly basis. The low levels of contamination would not have been discernable on the spike and spiked duplicate carrier locations used to determine gross alpha and beta precision shown in Figure 10-12. However, the low-level contamination might have affected certain environmental samples placed in contaminated carrier locations of Unit 2. A detailed review of all daily gross alpha/beta analyses performed on BNL potable water (i.e., FN and ZB) during 1997 showed a slight gradual increase in alpha/beta activity over time. Still, all FN and ZB results were below the EPA drinking water standard. Because no background checks were made on the empty carriers in 1997, some batches counted in Unit 2 might have been biased high by 20 to $25 \%$ by contamination of the planchet carriers.

In October 1997 one of the 2 Tennelec gross alpha/beta counters experienced electronic difficulties that caused a $15 \%$ drop in its efficiency. The instrument was serviced and a new power pack installed, after which the background and alpha/beta efficiencies were restored to their typical levels, as shown in Figures 10-1 and 10-2.

\subsection{Quality Assurance Program for CERCLA Groundwater Monitoring Activities}

This section describes the QA requirements for field activities that were conducted as part of the 1997 Environmental Restoration Division (ERD) Sitewide Groundwater Monitoring Program. The offsite contractor laboratories that perform the radiological and chemical analyses as part of this program are certified by the NYSDOH, Environmental Laboratory Approval Program (ELAP) and are required to perform all analytical work in accordance with the ERD Statement of Work for Hazardous Chemical and Radiochemical Analytical Services. In addition, contractor laboratories are audited periodically to verify their competence in analytical methodology and implementation of a comprehensive QA program.

Details for attaining QA objectives for environmental sampling and analysis programs include field quality control samples. Field blanks are collected for every 20 samples shipped to the laboratory and are used to evaluate potential cross contamination of samples due to sampling equipment. For projects with less than 20 monitoring wells, a minimum of one field blank is collected per project for each sampling event. A trip blank is also sent to the laboratory with each shipment to determine if any cross contamination occurs between aqueous samples during shipment. Blind duplicate samples are analyzed to check reproducibility of analytical data. At least five percent of the total number of samples are duplicated to evaluate the precision of the methods used. Matrix spike/matrix spike duplicates (MS/MSDs) for organic analysis are also performed.

The Draft ERD Calendar Year 1998 Sitewide Groundwater Monitoring Program Quality Assurance Project Plan describes the QA program and the QC requirements followed during the sitewide groundwater-sampling program. The project's organization structure, documentation requirements, sample custody requirements, acceptance criteria, and audit and corrective action provisions, and guidance on collecting of QA/QC samples are also described in this document. 



\section{APPENDIX A LIST OF ACRONYMS}

\begin{tabular}{|c|c|c|c|}
\hline AGS & Alternating Gradient Synchrotron & HWMG & Hazardous Waste Management Group \\
\hline$A O C$ & Area of Concern & IAC & Interagency Agreement \\
\hline ASL & Analytical Services Laboratory & LEPC & Local Emergency Planning Committee \\
\hline AUI & Associated Universities Inc. & LINAC & Linear Accelerator \\
\hline BETX & Benzene Ethylbenzene Toluene Xylene & MDL & Minimum Detection Limit \\
\hline $\mathrm{BHG}$ & Brookhaven Group (DOE) & MLD & Million Liters per Day \\
\hline BLIP & Brookhaven LINAC Isotope Froducer & MPF & Major Petroleum Facility \\
\hline BMRR & Brookhaven Medical Research Reactor & MRC & Medical Research Center \\
\hline BNL & Brookhaven National Laboratory & NA & Not Analyzed \\
\hline BSA & Brookhaven Science Associates & NPDES & National Pollutant Discharge Elimination \\
\hline $\mathrm{BOD}_{5}$ & Biochemical Oxygen Demand & & System \\
\hline CAA & Clean Air Act & ND & Not Detected \\
\hline CBS & Chemical Bulk Storage & NEPA & National Environmental Policy Act \\
\hline CERCLA & $\begin{array}{l}\text { Comprehensive Environmental Response, } \\
\text { Compensation \& Liability Act }\end{array}$ & NESHAPS & $\begin{array}{l}\text { National Emission Standards for Hazard- } \\
\text { ous Air Pollutants }\end{array}$ \\
\hline $\mathrm{CH}$ & $\begin{array}{l}\text { Chicago } \\
\text { Certificate to Onerate }\end{array}$ & NIST & $\begin{array}{l}\text { National Institute for Standards and } \\
\text { Technology }\end{array}$ \\
\hline CSF & Central Steam Facility & NPL & National Priority List \\
\hline $\mathrm{CY}$ & Calendar Year & NR & Not Reported \\
\hline CWA & Clean Water Act & NS & Not Sampled \\
\hline DAS & Department of Applied Scierice & NSLS & National Synchrotron Light Source \\
\hline DAT & Department of Advanced Technology & NYCRR & New York Code of Rules and Regulations \\
\hline DCA & Dichloroethane & NYS & New York State \\
\hline DCE & Dichloroethylene & NYS AWQS & $\begin{array}{l}\text { New York State Ambient Water Quality } \\
\text { Standard }\end{array}$ \\
\hline $\begin{array}{l}\text { DCG } \\
\text { DMR }\end{array}$ & Derived Concentration Guide & NYSDEC & New York State Department of Environ- \\
\hline DMR & Discharge Monitoring Report & & mental Conservation \\
\hline DOE & Department of Energy & NYSDOH & New York State Department of Health \\
\hline $\begin{array}{l}\mathrm{DOT} \\
\mathrm{ECL}\end{array}$ & $\begin{array}{l}\text { Department of Transportation } \\
\text { Environmental Conservation Law }\end{array}$ & NYSDOT & $\begin{array}{l}\text { New York State Department of Transpor- } \\
\text { tation }\end{array}$ \\
\hline EDB & Ethylene Dibromide & NYS DWS & New York State Drinking Water Standard \\
\hline EM & Environmental Monitoring & OER & Office of Environmental Restoration \\
\hline EMG & Environmental Monitoring Group & OU & Operable Unit \\
\hline EML & Environment Measurements Laboratory & PCB & Polychlorinated biphenyls \\
\hline EMS & Environmental Management Section & PCE & Tetrachloroethylene \\
\hline EMSL-LV & $\begin{array}{l}\text { Environmental Measurements Systems } \\
\text { Laboratory - Las Vegas }\end{array}$ & $\begin{array}{l}P C \\
P \& C A\end{array}$ & $\begin{array}{l}\text { Permit to Construct } \\
\text { Photography and Graphic Arts }\end{array}$ \\
\hline EP & Environmental Protection & $\mathrm{PE}$ & Plant Engineering \\
\hline EPA & Environmental Protection Agency & POC & Principal Organic Compound \\
\hline EPO & Environmental Protection Office & PVC & Polyvinyl Chloride \\
\hline ERD & Environmental Restoration Division & QA & Quality Assurance \\
\hline ES\&H & Environmental, Safety, and & RACT & Reasonable Available Control Technology \\
\hline & Health Services & RCRA & Resource Conservation and Recovery Act \\
\hline HFBR & High Flux Beam Reactor & $\mathrm{RI} / \mathrm{FS}$ & Remedial Investigation/Feasibility Study \\
\hline HWMA & Hazardous Waste Management Area & RHIC & Relativistic Heavy Ion Collider \\
\hline HWMF & Hazardous Waste Management Facility & RSD & Response Strategy Document \\
\hline
\end{tabular}




\begin{tabular}{|c|c|c|c|}
\hline SAG & Sampling and Analysis Group & SPDES & State Pollutant Discharge \\
\hline SARA & Superfund Amendments and & & Elimination System \\
\hline & Reauthorization Act & STP & Sewage Treatment Plant \\
\hline SCDHS & Suffolk County Department of Health & TCA & $1,1,1$-Trichloroethane \\
\hline & Services & TCE & Trichloroethylene \\
\hline SCWA & Suffolk County Water Authority & TCLP & Toxic Characteristic Leachate Procedure \\
\hline SDWA & Safe Drinking Water Act & TLD & Thermoluminescent Dosimeters \\
\hline SEAPPM & Safety and Environmental Administrative & TSCA & Toxic Substance Control Act \\
\hline & Policy and Procedures Manual & TSS & Total Suspended Solids \\
\hline S\&EP & Safety and Environmental Protection & TVOCs & Total Volatile Organic Compounds \\
\hline SER & Site Environmental Report & & Wlatilo Oramis rammound \\
\hline SERC & (New York) State Emergency Response & VOC & Volatile Organic Compound \\
\hline & Committee & WCF & Waste Concentration Facility \\
\hline S\&M & Supply and Materiel & WMD & Waste Management Division \\
\hline SOC & Synthetic Organic Compound & WSRRSA & Wild, Scenic, and Recreational River \\
\hline SOP & Standard Operating Procedures & & Systems Act \\
\hline $\mathrm{CC}$ & Spill Prevention Control and Counter & WTP & Water Treatment Plant \\
\hline
\end{tabular}

\section{LIST OF UNITS}

$\begin{array}{llll}\mathrm{Bq} & \text { Becquerel } & \mathrm{mCi} & \text { Millicurie } \\ \mathrm{Bq} / \mathrm{L} & \text { Becquerel per liter } & \mathrm{MeV} & \text { Mega electron volt } \\ \mathrm{Bq} / \mathrm{M}^{3} & \text { Becquerel per cubic meter } & \mathrm{mg} / \mathrm{L} & \text { Milligram per liter } \\ { }^{\circ} \mathrm{C} & \text { Degrees Centigrade } & \mathrm{ml} & \text { Milliliter } \\ \mathrm{cc} & \text { Cubic centimeter } & \mathrm{MLD} & \text { Million liters per day } \\ \mathrm{Ci} & \text { Curie } & \mathrm{mrem} & \text { Millirem } \\ \mathrm{CiMW}-\mathrm{h}^{-1} & \text { Curie per megawatt hour } & \mathrm{mrem} / \mathrm{yr} & \text { Millirem per year } \\ \mathrm{cm} & \text { Centimeter } & \mathrm{mSv} & \text { milliseivert } \\ \mathrm{cm} & \text { Cubic centimeter } & \mathrm{mSv} / \mathrm{yr} & \text { milliseivert/year } \\ \mathrm{cm} / \mathrm{d} & \text { Centimeters per day } & \mathrm{MW} & \text { Megawatts } \\ \mathrm{m}^{3} / \mathrm{min} & \text { cubic meters per minute } & \mathrm{nCi} / \mathrm{L} & \text { Nanocuries per liter } \\ \mathrm{d} & \text { Day } & \mathrm{pCi} / \mathrm{kg} & \text { Picocuries per kilogram } \\ \mathrm{gal} & \text { Gallon } & \mathrm{pCi} / \mathrm{L} & \text { Picocuries per liter } \\ \mathrm{GBq} & \text { Giga Becquerel } & \mathrm{pCi} / \mathrm{m}^{3} & \text { Picocuries per cubic meter } \\ \mathrm{GeV} & \text { Giga electron volt } & \mathrm{pH} & \text { Hydrogen ion concentration } \\ \mathrm{GeV} / \mathrm{amu} & \text { Giga electron volt per atomic mass unit } & \mathrm{rem} & \text { Roentgen equivalent man } \\ \mathrm{gph} & \text { Gallon per hour } & & \text { (Unit of radiation dose equivalent) } \\ \mathrm{ha} & \text { Hectare } & \mathrm{Sv} & \text { Sievert } \\ \mathrm{kg} / \mathrm{yr} & \text { Kilogram per year } & \mathrm{TBq} & \text { Tera Becquerel } \\ \mathrm{km} & \text { Kilometer } & \mu \mathrm{Ci} & \text { Microcuries } \\ \mathrm{L} / \mathrm{d} & \text { Liters per day } & \mu \mathrm{Ci} / \mathrm{L} & \text { Microcuries per liter } \\ \mathrm{m} & \text { Meter } & \mu \mathrm{g} / \mathrm{L} & \text { Micrograms per liter }\end{array}$




\section{APPENDIX B \\ METHODOLOGIES}

\section{Dose Calculation - Atmospheric Release Pathway}

Dispersion of airborne radioactive material was calculated for each of the 16 compass sectors using the CAP88 dose model. CY 1996 site meteorology and 10 year wind averages were used to calculate annual dispersions for the midpoint of a given sector and distance. Facility-specific radionuclide release rates (in $\mathrm{Ci}$ per year) were also used. All annual site boundary and collective dose values were generated using the CAP88 computer code, which calculates the total dose due to contributions from the immersion, inhalation, and ingestion pathways.

\section{Tritium Dose Calculation - Potable Water Pathway}

The method used to calculate the maximum individual committed effective dose equivalent and the collective dose equivalent are shown along with the basic assumptions used in the calculation. For the maximum individual, the highest annual average tritium concentration, measured from a single potable well was used to calculate the total quantity of tritium ingested via the drinkingwater pathway. For calculating the collective dose equivalent, the annual average tritium concentration was obtained by averaging all positive results from potable wells, which were in the demographic region adjacent to the Laboratory. The annual intake of tritium via the drinking water pathway was calculated from the following equation:

$$
\begin{aligned}
\text { AI }=1 \times 10^{-6} \mathrm{C} \cdot \mathrm{IR} \cdot \mathrm{T} \\
\text { Where: } \mathrm{AI}=\text { Activity Intake, } \mu \mathrm{Ci} \\
\mathrm{C}=\text { annual average water concentration, } \mathrm{pCi} / \mathrm{L} \\
\mathrm{IR}=\text { Ingestion Rate }(2) \mathrm{L} / \mathrm{d} \\
\mathrm{T}=\text { Time, } 365 \mathrm{~d}
\end{aligned}
$$

The committed effective-dose equivalent was calculated from the following equation:

$$
\begin{array}{ll}
\mathrm{H}=\mathrm{AI} \times \mathrm{DCF} \times \mathrm{P} \\
\text { where: } & \mathrm{H}=\text { committed effective dose-equivalent, rem } \\
& \mathrm{AI}=\text { Activity Intake, } \mu \mathrm{Ci} \\
& \mathrm{DCF}=\text { Dose Conversion Factor, } \mathrm{rem} / \mu \mathrm{Ci}(6.3 \mathrm{E}-5 \mathrm{rem} / \mu \mathrm{Ci}) \\
& \mathrm{P}=\text { Exposed population }
\end{array}
$$

To determine the maximum individual dose, the population parameter was set to unity. For the collective dose calculation, the exposed population was assumed to be approximately 500 .

\section{Dose Calculation - Fish Ingestion Pathway}

To estimate the collective-dose equivalent from the fish consumption pathway, the following procedure was used:

a. Radionuclide data for fish samples were all converted to $\mathrm{pCi} / \mathrm{g}$ wet weight; this is the form in which the fish is caught and consumed.

b. The average fish consumption for an individual engaged in recreational fishing in the Peconic River was based on a study done by the NYSDEC which suggests that the consumption rate is approximately $7 \mathrm{~kg} / \mathrm{yr}$ (NYSDEC, 1985).

c. DOE Order 5400.5 50-year Committed Dose Equivalent factors (in rem per $\mu \mathrm{Ci}$ intake) based on the ICRP 26 model were applied. They are as follows: 
Tritum: $6.3 \mathrm{E}-05 \mathrm{rem} / \mu \mathrm{Ci}$

Strontium-90: $1.3 \mathrm{E}-01 \mathrm{rem} / \mu \mathrm{Ci}$

Cesium-137: $5.0 \mathrm{E}-02 \mathrm{rem} / \mu \mathrm{Ci}$

d. Calculation: Intake $(7 \mathrm{~kg} / \mathrm{yr}) \times$ Activity in flesh $\mu \mathrm{Ci} / \mathrm{kg} \times$ Factor $\mathrm{rem} / \mu \mathrm{Ci}=\mathrm{rem}$

\section{Dose Calculation - Deer Meat Consumption}

This calculation is performed in exactly the same way as shown in the previous section. The same DOE Order 5400.5 dose conversion factors are used. The only change is the estimate of total kilograms ingested in the course of a year. For deer meat, the consumption rate of $30 \mathrm{~kg} / \mathrm{yr}$ is based on the upper range of venison consumption estimates supplied by the NYSDEC Wildlife Branch.

\section{Radiological Data Processing}

Radiation events occur in a random fashion such that if a radioactive sample is counted multiple times a distribution of results will be obtained. This spread, known as a Poisson distribution, will be centered about a mean value. If counted multiple times, the background activity of the instrument (the number of radiation events observed when no sample is present) will also be seen to have a distribution of values centered about a mean. The goal of a radiological analysis is to determine whether the sample in question contains activity in excess of the instrument or method blank background. Since the activity of the sample and the background are both Poisson distributed, subtraction of background activity from the measured sample activity results in a value which may vary slightly from one analysis to the next. Therefore, the concept of a minimum detection limit (MDL) is established to determine the statistical likelihood that the sample contains activity that is truly greater than the instrument background.

Identifying a sample as containing activity greater than background when it actually is not is known as a Type I error. As with most laboratories, the BNL Analytical Laboratory sets its acceptance of a Type I error at 5\% when calculating the minimum detection limit for a given analysis. That is, for any value which is greater than or equal to the MDL there is $95 \%$ confidence that it represents the detection of true activity. Values, which are less than the MDL may be valid, but they have a reduced confidence associated with them. Therefore, all data is reported regardless of its value.

At very low sample activity levels, close to the instrument background, it is possible to obtain a sample result, which is less than the background. When the background activity is subtracted from the sample activity to obtain a net value, a negative value results. In such a situation, a single radiation event observed during a counting period could have a significant effect on the result. Subsequent analysis may produce a net result that is positive. Therefore, all negative values are retained for reporting as well. This data handling practice is consistent with the guidance provided in NCRP Report No. 58, Handbook of Radioactivity Measurements Procedures and DOE/EH0173T, Environmental Regulatory Guide for Radiological Effluent Monitoring and Environmental Surveillance. 


\section{APPENDIX C INSTRUMENTATION AND ANALYTICAL METHODS}

The analytical laboratory of S\&EP Division is divided into 1) radiological, and 2) nonradiological sections to facilitate analysis of specific parameters in each category. The following analytes are analyzed in each category.

- Radiological: Gross alpha, gross beta, gamma, tritium, and strontium-90.

- Nonradiological: Purgeable aromatics, Purgeable halocarbons, PCBs, anions, and metals.

The methods and instrumentation for each category are briefly described below. Only validated and regulatory referenced methods were used during the analysis. All samples were collected and preserved by trained technicians according to appropriate referenced methods. Well-qualified, and trained analysts performed different analyses. The analytical laboratory is certified by NYS$\mathrm{DOH}$ for the radiological and nonradiological parameters (except for PCBs) performed. The radiological laboratory participates in the following:

\section{Gross Alpha and Gross Beta Analysis - Water Matrix}

Water samples are collected in one-liter polyethylene containers, and preserved at the time of collection by acidification to $\mathrm{pH} 2$ using nitric acid. If the samples are effluent or surface stream samples from locations DA, EA, HM or HQ, or Building 535B daily process samples, then $100 \mathrm{ml}$ are extracted for analysis. Groundwater samples are typically analyzed using a 100 -ml aliquot. The aliquot is evaporated to near-dryness in a glass beaker, which is rinsed to remove the solids and the combined solids and rinsate are transferred to a $5-\mathrm{cm}$ diameter stainless-steel planchet, which is then evaporated to dryness. The planchettes are placed in a drying oven at $105^{\circ} \mathrm{C}$ for a minimum of 2 hours; removed to a desiccator and allowed to cool; weighed and counted in a gas-flow proportional counter for 200 minutes. Samples are normally processed in batch mode. The first sample of each batch is a background, which is subtracted from the raw data before computing net activity concentration. System performance is checked daily with NIST-traceable standards: Americium-241 for alpha, and Strontium-90 for beta. Laboratory duplicates and spiked duplicates are performed within batch of samples to determine precision and accuracy, respectively.

\section{Gross Alpha and Gross Beta Analysis - Air Particulate Matrix}

Air particulate samples are collected on $50-\mathrm{mm}$ glass fiber filters at a nominal flow rate of 15 liters per minute. At the end of the collection, the filters are returned to the analytical laboratory for assay. Filters are counted twice in a gas flow proportional counter for 50 minutes. The first count occurs immediately upon receipt in the analytical laboratory, and is used to screen the samples for unusual levels of air particulate activity. The filters are then recounted approximately one week later. This delay permits the short-lived radon/thoron daughters to decay. The second analysis is used for environmental assessments. The first sample of each batch is a blank filter whose count rate is subtracted from the raw data before calculating net activity concentration. The system's performance is checked daily with NIST-traceable standards: Americium-241 for alpha, and Strontium-90 for beta.

\section{Tritium Analysis - Water Matrix}

Water samples are collected in polyethylene containers. No preservatives are added before collecting the sample. Effluent and surface stream samples from locations DA, EA, HM, or HQ, or Building 535B daily- process samples as well as groundwater samples were analyzed using a 7-ml aliquot. Potable-water samples were distilled following the method outlined in EPA 1980, 906.0 
and a $7 \mathrm{ml}$ aliquot analyzed. Liquid scintillation cocktail then is added to the aliquot so that the final volume in the liquid-scintillation-counting vial is $7 \mathrm{ml}$ of sample plus $10 \mathrm{ml}$ of cocktail. Samples then are counted in a low-background liquid-scintillation counter for 50 minutes. Samples are normally processed in batch mode. The first sample of each batch is a steam distilled water background value that is subtracted from the raw data before calculating the net activity concentration. The second sample in each batch is a NIST-traceable tritium standard, which is used to verify the system's performance and efficiency. Each sample is also monitored for quenching. Corrections for background, quenching, and efficiency for the sample matrix are factored into the final net concentrations for each sample. Laboratory duplicates and spiked duplicates are performed within batch of samples to determine precision and accuracy, respectively.

\section{Tritium Analysis - Air Matrix}

Concentration of tritium in ambient and facility air is measured by drawing the air through a desiccant at a rate of approximately $200 \mathrm{cc} / \mathrm{min}$. At the end of each collection period, typically one week, the desiccant is brought to the analytical laboratory for processing. It is heated in a glass manifold system. Effluent samples have dedicated glassware, as do environmental samples. The off-gas, containing moisture from the sampled air, is collected by a water-cooled glass condenser. A 7-ml aliquot of this water is then assayed for tritium content. Liquid scintillation cocktail is then added to the aliquot so that the final volume in the counting vial is $17 \mathrm{ml}$. Samples are then counted in a low-background liquid scintillation counter for 50 minutes. Samples are normally processed in batch mode. The first sample of each batch is a steam distilled water background valve that is subtracted from the raw data before computing net activity concentration. The second sample in each batch is a NIST-traceable tritium standard, which is used to verify the system's performance and efficiency. Each sample is also monitored for quenching. Corrections for background, water recovery, air sample volume, quenching and efficiency for the sample matrix are factored into the final net concentrations for each sample. Laboratory duplicates and spiked duplicates are performed within batch of samples to determine precision and accuracy, respectively.

\section{Strontium-90 Analysis}

Strontium-90 analyses are currently performed on water, soil and aquatic biota samples. Ground water samples are processed in house using DOE Method RP500, which utilizes a crown ether to selectively separate strontium from the acidified sample matrix. The strontium is then eluted using dilute nitric acid. The resulting eluent is then evaporated on a $2.5 \mathrm{~cm}$ stainless steel planchet and the sample counted in a gas-flow proportional counter. Samples are prepared in batches, including a standard and a method blank in each batch. Chemical recovery is determined for each sample by the recovery of strontium carbonate. NIST-traceable strontium-90 standards are used to calibrate and verify the performance of the counting instrument. Samples are counted twice to verify strontium-90 and yttrium-90 in growth.

Potable water samples as well as samples of solids are shipped to a contractor laboratory, which is certified to perform the EPA 1980, 905.0 method for strontium-90 in drinking water. This method employ's time-consuming and costly wet-chemistry techniques to isolate strontium from the sample. Samples are counted twice to verify strontium-90 and yttrium-90 in growth. Samples are typically processed in a batch. Backgrounds and system performance are verified with each batch. Chemical recoveries are determined by a combination of gravimetric and strontium- 85 standard addition techniques.

\section{Gamma Spectroscopy Analysis}

Surface, potable, and groundwater surveillance samples are typically of 12 liters and are placed in polyethylene bottles without preservatives. Samples are then passed through a mixed-bed ionexchange column at a rate of $20 \mathrm{cc} / \mathrm{min}$. The column is then removed, the resin placed in a Teflon-lined aluminum can and counted on a calibrated gamma spectroscopy detector for 50,000 
seconds. Where effluent is sampled in a flow-proportional manner, a $10-\mathrm{ml}$ aliquot is passed through the mixed bed column on an as needed basis. Typically, the sizes for such samples approach 50 to 100 liters. Air-particulate filters and air-charcoal canisters are counted directly on the calibrated gamma spectroscopy detector for 10,000 seconds. Soil, vegetation, and aquatic biota are all processed following collection. Typically, a 50, 100, or 300-g aliquot is taken, placed in a Teflon-lined aluminum can and directly counted. For gamma spectroscopy analyses, overnight backgrounds are counted once per week, with calibration check and background checked daily. Analytical results reflect net activity that has been corrected for background and efficiency for each counting geometry used.

\section{Purgeable Aromatics and Purgeable Halocarbons}

Water samples are collected in $40 \mathrm{ml}$ glass vials with removable teflon-lined caps without any head space, and preserved with $1: 1 \mathrm{HCl}$ to $\mathrm{pH}<2.0$. Samples are stored at $4^{\circ} \mathrm{C}$ and analyzed within 14 days.

Ten (10) purgeable compounds (benzene, toluene, ethyl benzene, total xylenes, chloroform, 1,1dichloroethane, 1,1-dichloroethylene, tetrachloroethylene, 1,1,1-trichloroethane, and trichloroethylene) are analyzed under this category following EPA Method 624 protocols using GC/MS. These ten compounds were chosen as the target compounds since they are known or suspected to be present in the monitoring wells based on DOE's survey of the site in 1988 (USDOE, 1988) and a comprehensive analysis of 51 new monitoring wells installed in 1989 using EPA's Contract Laboratory Program (CLP) (EPA, 1987, 1988). There are currently two Hewlett-Packard GC/MS instruments. One instrument is exclusively used to analyze of purgeable compounds and the other for screening extractables and other extraneous compounds in non-routine samples. Since the groundwater under BNL is classified as a sole source aquifer under the Safe Drinking Water Act and Class GA groundwater by the NYSDEC, the detection limits reported for the compounds are close to drinking NYS DWS and AWQS. Even though the QC generated for the purgeable analysis meets the EPA drinking water method 524.2 requirements, to facilitate certification from NYSDOH for limited number of analytes required by BNL, EPA method 624 is used under nonpotable water category.

The method involves purging a $25-\mathrm{ml}$-aliquot of the sample with ultra pure helium in a specially designed sparger using the Purge and Trap technique. Each sample is spiked with a known concentration of internal standards and surrogates before purging to facilitate identifying, quantifying, and determining the extraction efficiency of analytes from the matrix. The purged analytes are trapped on to a specially designed trap and thermally desorbed on to the DB-624 megabore capillary-chromatographic column by back flushing the trap with helium. Individual compounds are separated with a temperature program of the $\mathrm{GC}$ and enter the mass spectrometer where they undergo fragmentation to give characteristic mass spectra. The unknown compounds are identified by comparing their mass spectra and retention times with reference compounds, and quantitated by internal standard method. The quantitation data is supported by extensive QA/QC, such as tuning the mass spectrometer to meet bromofluoro-benzene criteria, initial and continuing calibrations verifying daily response factors, method blanks, surrogate recoveries, duplicate analysis, matrix spike and matrix spike duplicate analysis, and reference standard analysis to verify the daily working standard.

\section{PCB Analysis}

Samples are collected in 50-100 ml glass containers with teflon-lined lid and stored at $4^{\circ} \mathrm{C}$ and analyzed within 30 days.

Transformer oil, mineral oil, hydraulic fluid, waste oil, and spill wipe-samples are analyzed for PCBs using gas chromatography-electron capture detector (GC-ECD) method. This method is similar to EPA SW-846 method 8080 and is targeted to identify and quantitate seven different mixtures of PCB congeners in the samples. 
The method consists of diluting a known weight of the sample with isooctane and removing the interfering compounds with one or more aliquots of concentrated sulfuric acid till the acid layer is almost colorless. The entire oil matrix, along with other interfering polar compounds, are selectively removed from the sample, leaving the PCBs in isooctane solvent.

There are two GC-ECD instruments for analyzing PCBs. Each GC-ECD instrument is calibrated with different concentrations of each PCB mixture to establish linearity. The PCBs found in the samples are identified and quantitated by comparing the retention times and chromatographic patterns with the standards. Methods blanks, duplicates, spikes, and reference standards are run as part of QA/QC.

\section{Anions}

Chloride, nitrate-N, and sulfate are analyzed using Dionex Ion-chromatography (IC) with ion suppression and conductivity detection technique.

Samples from monitoring wells are collected in $100-\mathrm{ml}$ polyethylene bottles, cooled to $4^{\circ} \mathrm{C}$, and analyzed within 28 days. For nitrate analysis in drinking water analysis, samples are supposed to be analyzed within $48 \mathrm{hrs}$. However, even though holding times were exceeded for nitrate analysis of some non-potable monitoring well samples, the depletion of nitrate is expected to be negligible.

The anions are passed through an anion-exchange polymer column and eluted with carbonate/ bicarbonate solution. Then the eluent passes through an ion-suppressing column where the background contribution from the eluent is suppressed, leaving the target anions to be detected by conductivity meter.

Initially, the IC system is calibrated with standards to define its working range. The target anions in the samples are identified and quantitated by comparing the retention times and areas with the standards. Method blanks, duplicates, replicates, spikes, and reference standards are routinely analyzed as part of QA/QC.

\section{Metals}

Samples are collected in 500-ml glass bottles and stabilized with ultra-pure nitric acid to a $\mathrm{pH}$ of $<2$. The samples are analyzed within 6 months, except for mercury, which is analyzed within 26 days.

Cadmium, chromium, lead (furnace), copper, iron, manganese, silver, sodium, zinc (flame), and mercury (manual cold vapor) are analyzed with Perkin-Elmer atomic absorption spectrometer. Using the flame technique, the sample containing the target element is nebulized and atomized in an oxy-acetylene flame. At the same time, a beam of light from a element-specific hollow cathode lamp corresponding to the absorption frequency of target element is passed through the flame. The atomized element absorbs the energy specific to that element from the cathode lamp and the intensity of absorption is proportional to the concentration of the element in the sample. Calibration curves establish the linearity of the system and samples are quantitated by comparing with standards.

Using the furnace technique, chemical interference is eliminated in two stages: first, by heating the sample at $105-110^{\circ} \mathrm{C}$ to remove moisture, and second, at $600-900^{\circ} \mathrm{C}$ to burn out any organic matrix. Final atomization is achieved by heating the furnace to $2400-2700^{\circ} \mathrm{C}$. The rest of the technique is similar to the flame method, above. Using this furnace technique, sub-ppb detection limits are possible for water samples.

Using a cold-vapor technique for mercury, a $100-\mathrm{ml}$ aliquot of the sample is digested with potassium permanganate/persulfate oxidizing solution at $95^{\circ} \mathrm{C}$ for 2 hours to oxidize any organically bound and/or monovalent mercury to mercury (II) ion state. Excess oxidizing agent is destroyed with hydroxylamine hydrochloride. The mercuric ion later is reduced to elemental mercury with 
excess stannous chloride, which is purged with helium into the absorption cell. The absorption is directly proportional to the concentration of mercury in the sample.

All these atomic absorption techniques involve initial calibrations to define the calibration range, continuing calibrations, method blanks, duplicates, replicates, matrix spikes, and reference standard analysis as a part of QA/QC. 



\section{APPENDIX D \\ CY 1997 SER- GROUNDWATER MONITORING WELLS LIST \\ Wells Sampled by Envirionment, Safety and Health Services Division (ESH) and Environmental Restoration Division (ERD)}

$\begin{array}{llll}\text { OPERABLE } & \text { UNIT I AREA } & & \\ \text { HWMF/Current Landfill (RA-V) } & 98-63 & \text { ERD } \\ 77-02^{*} & \text { ERD } & 99-04 & \text { ERD } \\ 87-21^{*} & \text { ERD } & 107-10 & \text { ERD } \\ 88-13^{*} & \text { ERD } & 107-23 & \text { ERD } \\ 88-14^{*} & \text { ERD } & 107-24 & \text { ERD } \\ 88-20^{*} & \text { ERD } & 107-25 & \text { ERD } \\ 88-13 & \text { ERD } & 107-26 & \text { ERD } \\ 88-14 & \text { ERD } & 108-08 & \text { ERD } \\ 88-20 & \text { ERD } & 108-12 & \text { ERD } \\ 88-26 & \text { ERD } & 108-13 & \text { ERD } \\ 98-19 & \text { ERD } & 108-14 & \text { ERD } \\ 98-21 & \text { ERD } & 108-17 & \text { ERD } \\ 98-22 & \text { ERD } & 108-18 & \text { ERD } \\ 98-30 & \text { ERD } & 108-30 & \text { ERD } \\ 98-33 & \text { ERD } & 115-03 & \text { ERD } \\ 98-58 & \text { ERD } & 115-13 & \text { ERD } \\ 98-59 & \text { ERD } & 115-14 & \text { ERD } \\ 98-61 & \text { ERD } & 115-15 & \text { ERD } \\ 98-62 & \text { ERD } & & \end{array}$

$115-16$
$115-28$
$115-29$
$115-30$
$115-31$
$115-32$
$115-33$
$115-34$
$115-35$
$115-36$
$115-41$
$115-42$
$116-05$
$116-06$
$000-124$
$000-137$
$000-138$
$800-54$

ERD
ERD
ERD
ERD
ERD
ERD
ERD
ERD
ERD
ERD
ERD
ERD
ERD
ERD
ERD
ERD
ERD
ERD

Current Landfill-Compliance

87-09* ERD

87-11 ERD

87-23 ERD

87-24 ERD

87-26 ERD

87-27 ERD

88-21 ERD

88-22 ERD

88-23 ERD

88-109 ERD

88-110 ERD

Former Landfill

$86-42^{*} \quad$ ERD

86-72 ERD

87-22 ERD

97-17 ERD

97-64 ERD

106-02 ERD

106-30 ERD

\begin{tabular}{|c|c|c|c|c|c|c|c|}
\hline \multicolumn{8}{|c|}{ OPERABLE UNIT III AREA } \\
\hline \multicolumn{2}{|c|}{ Waste Concentration Facility } & \multicolumn{2}{|c|}{$\begin{array}{l}\text { New Waste Management } \\
\text { Facility }\end{array}$} & $\begin{array}{l}75-12 \\
75-39\end{array}$ & $\begin{array}{l}\mathrm{ESH} / \mathrm{ERD} \\
\mathrm{ERD}\end{array}$ & $\begin{array}{l}85-40 \\
85-41\end{array}$ & $\begin{array}{l}\text { ERD } \\
\text { ERD }\end{array}$ \\
\hline $65-06^{\star}$ & ERD/ESH & $55-03$ & ESH & $75-40$ & ERD & $85-65$ & ERD \\
\hline $65-02$ & ERD/ESH & $55-10$ & ESH & $75-41$ & ERD & $85-66$ & ERD \\
\hline $65-03$ & ERD/ESH & $56-21$ & ESH & $75-42$ & ERD & $85-67$ & ERD \\
\hline $65-04$ & ERD/ESH & $56-22$ & ESH & $75-43$ & ERD & $85-68$ & ERD \\
\hline $65-05$ & ERD/ESH & $56-23$ & ESH & $75-44$ & ERD & $85-69$ & ERD \\
\hline $65-18$ & ERD & $66-07$ & ESH & $75-44$ & ERD & $85-70$ & ERD \\
\hline $65-19$ & ERD & $66-83$ & ESH & $75-46$ & ERD & $85-71$ & ERD \\
\hline $65-20$ & ERD & rildin & & $75-47$ & ERD & $85-72$ & ERD \\
\hline $75-09$ & ERD & Building & 830 & $75-48$ & ERD & $85-73$ & ERD \\
\hline $75-10$ & ERD & $\begin{array}{l}66-08 \\
66-09\end{array}$ & $\begin{array}{l}\mathrm{ERD/ESH} \\
\mathrm{ERD/ESH}\end{array}$ & $\begin{array}{r}75-50 \\
75-85\end{array}$ & ERD & $85-74$ & ERD \\
\hline \multicolumn{2}{|c|}{ AGS/LINAC Areas } & BMRR & & $75-86$ & ERD & $85-76$ & ERD \\
\hline $44-02^{*}$ & ESH & $94-01$ & ESH & $75-87$ & ERD & $85-77$ & ERD \\
\hline $53-01^{*}$ & ESH & $84-12$ & ESH & $75-88$ & ERD & $85-78$ & ERD \\
\hline $54-01$ & ESH & $84-13$ & $\mathrm{ESH}$ & $75-89$ & ERD & $86-09$ & ERD \\
\hline $54-02$ & ESH & & & $76-10$ & ERD & $95-42$ & ERD \\
\hline $54-03$ & ESH & HFBR and & Rerned. System & $76-171$ & ERD & $95-43$ & ERD \\
\hline 54-05 & ESH & HW-01 & ESH & $76-172$ & ERD & $95-44$ & ERD \\
\hline $54-06$ & ESH & $\mathrm{HW}-02$ & ESH & $76-173$ & ERD & $95-45$ & ERD \\
\hline $54-07$ & ESH & $65-01^{*}$ & ESH/ERD & $76-174$ & ERD & $95-46$ & ERD \\
\hline $54-08$ & ESH & $65-37$ & $E R[1$ & $76-175$ & ERD & $95-47$ & ERD \\
\hline $54-10$ & ESH & $65-38$ & ER[I & $76-177$ & ERD & $95-48$ & ERD \\
\hline $64-01$ & ESH & $65-39$ & ER[I & $77-10$ & ERD & $95-51$ & ERD \\
\hline $64-02$ & ESH & $65-40$ & ER[I & $77-11$ & ERD & $95-52$ & ERD \\
\hline $64-03$ & ERD/ESH & $65-41$ & ER[ & $85-01$ & ERD & $95-53$ & ERD \\
\hline $85-07$ & ERD & $65-41$ & ER $[$ I & $85-02$ & ERD & $95-54$ & ERD \\
\hline $85-13$ & ERD & $75-11$ & ESF/ERD & $85-39$ & ERD & $95-55$ & ERD \\
\hline
\end{tabular}




$\begin{array}{ll}96-55 & \text { ERD } \\ 104-10 & \text { ERD } \\ 104-11 & \text { ERD } \\ 104-25 & \text { ERD } \\ 105-07 & \text { ERD } \\ 105-22 & \text { ERD } \\ 105-23 & \text { ERD } \\ 105-24 & \text { ERD } \\ 105-29 & \text { ERD } \\ 105-42 & \text { ERD } \\ 105-43 & \text { ERD } \\ 105-44 & \text { ERD } \\ 113-08 & \text { ERD } \\ 113-09 & \text { ERD } \\ 113-11 & \text { ERD }\end{array}$

\begin{tabular}{|c|c|}
\hline $\begin{array}{l}\text { Former } \\
75-01 \\
75-02\end{array}$ & $\begin{array}{l}\text { Area } \\
\text { ERD/ESH } \\
\text { ERD/ESH }\end{array}$ \\
\hline $\begin{array}{l}\text { Former } \\
\text { Depart } \\
85-06\end{array}$ & $\begin{array}{l}\text { stry } \\
\text { rea } \\
\text { ERD/ESH }\end{array}$ \\
\hline $\begin{array}{l}\text { Shotgu } \\
46-01 \\
56-04 \\
56-05 \\
56-06\end{array}$ & $\begin{array}{l}\text { ESH } \\
\text { ESH } \\
\text { ESH } \\
\text { ESH }\end{array}$ \\
\hline $\begin{array}{l}\text { Supply } \\
85-01^{*} \\
85-02^{*} \\
85-03\end{array}$ & $\begin{array}{l}\text { aterial Area } \\
\text { ESH } \\
\text { ESH } \\
\text { ESH }\end{array}$ \\
\hline
\end{tabular}

$\begin{array}{ll}86-01 & \text { ESH } \\ 86-21 & \text { ESH } \\ 96-06 & \text { ESH } \\ 96-07 & \text { ERD/ESH } \\ 105-02 & \text { ESH }\end{array}$

105-02

ESH

Water Treatment Plant Area

63-01 ESH

63-02 ESH

63-03

73-01

73-02

ESH

ESH

$\mathrm{ESH}$

\section{Western Supply Well Area}

83-01

83-02

84-01

ERD/ESH

$\mathrm{ERD} / \mathrm{ESH}$

ESH

\section{Southern Sector - \\ oU III Plumes}

On- and Off-site Areas

$\begin{array}{ll}\text { 95-85 } & \text { ERD } \\ 105-05 & \text { ERD } \\ 105-21 & \text { ERD }\end{array}$

105-21 ERD

106-19 ERD

113-06 ERD

113-07 ERD

113-08 ERD

113-10 ERD

114-06 ERD

114-07 ERD

121-06 ERD

121-07 ERD

121-08 ERD

121-09 ERD

121-10 ERD

$\begin{array}{llll}121-11 & \text { ERD } & 122-20 & \text { ERD } \\ 121-12 & \text { ERD } & 122-21 & \text { ERD } \\ 121-13 & \text { ERD } & 122-22 & \text { ERD } \\ 121-14 & \text { ERD } & 124-02 & \text { ERD } \\ 121-18 & \text { ERD } & 126-01 & \text { ERD } \\ 121-19 & \text { ERD } & 130-02 & \text { ERD } \\ 121-20 & \text { ERD } & 130-03 & \text { ERD } \\ 121-21 & \text { ERD } & 130-04 & \text { ERD } \\ 121-22 & \text { ERD } & 000-97 & \text { ERD } \\ 121-23 & \text { ERD } & 000-98 & \text { ERD } \\ 122-02 & \text { ERD } & 000-99 & \text { ERD } \\ 122-04 & \text { ERD } & 000-101 & \text { ERD } \\ 122-05 & \text { ERD } & 000-102 & \text { ERD } \\ 122-09 & \text { ERD } & 000-104 & \text { ERD } \\ 122-10 & \text { ERD } & 000-105 & \text { ERD } \\ 122-18 & \text { ERD } & 000-107 & \text { ERD } \\ 122-19 & \text { ERD } & 000-112 & \text { ERD } \\ & & 000-114 & \text { ERD }\end{array}$

\section{Operable Unit IV Area}

\begin{tabular}{|c|c|c|c|}
\hline \multicolumn{2}{|c|}{$\begin{array}{l}\text { Centrai Steam Faciiity - 1977 } \\
\text { Spill Site }\end{array}$} & $\begin{array}{l}76-185 \\
76-186\end{array}$ & $\begin{array}{l}\text { ERD } \\
\text { ERD }\end{array}$ \\
\hline $76-02^{\star}$ & ESH/ERD & ou IV - & frn Plume \\
\hline $76-24^{\star}$ & ESH/ERD & $76-29$ & ERD \\
\hline 76-04 & ESH/ERD & $86-04$ & ESH \\
\hline $76-05$ & $\begin{array}{l}\text { EPD } \\
\text { FRD }\end{array}$ & $86-05$ & $\mathrm{ESH}$ \\
\hline $\begin{array}{l}76-06 \\
76-07\end{array}$ & $\begin{array}{l}\text { ERD } \\
\text { ERD }\end{array}$ & $86-06$ & ESH \\
\hline 76-08 & ESH/ERD & $86-07$ & $\mathrm{ESH}$ \\
\hline $76-09$ & ESH/ERD & 86-08 & ESH/ERD \\
\hline $76-19$ & ERD & $86-09$ & ESH \\
\hline $76-21$ & ESH/ERD & $86-43$ & ERD \\
\hline $76-22$ & ESH/ERD & $86-70$ & ERD \\
\hline $76-23$ & ESH & 105-05 & \\
\hline $76-178$ & ERD & $105-06$ & ESH \\
\hline $76-179$ & ERD & $105-07$ & \\
\hline $76-180$ & ERD & $106-04$ & \\
\hline $76-181$ & ERD & 6- & \\
\hline $76-182$ & ERD & $106-14$ & \\
\hline $76-183$ & $D$ & $106-15$ & \\
\hline $76-184$ & בI & 1 & \\
\hline
\end{tabular}

\begin{tabular}{lllr}
$106-17$ & ERD & \multicolumn{2}{c}{ Builuting o5o Outfail } \\
$106-20$ & ERD & $66-17$ & ERD \\
$106-22$ & ERD & $66-18$ & ERD \\
$106-23$ & ERD & $76-07$ & ERD \\
$106-24$ & ERD & $76-09$ & ERD \\
$106-25$ & ERD & $76-10$ & ERD \\
$114-01$ & ERD & $76-13$ & ERD \\
$800-59$ & ERD & $76-20$ & ERD \\
$800-60$ & ERD & $76-22$ & ERD \\
Major Petroleum Facility & $76-24$ & ERD \\
$76-25^{*}$ & ESH & $76-27$ & ERD \\
$76-16$ & ESH & $76-167$ & ERD \\
$76-17$ & ESH & $76-168$ & ERD \\
$76-18$ & ESH & $76-169$ & ERD \\
$76-19$ & ESH & $76-181$ & ERD \\
Building 650 & & $76-182$ & ERD \\
$76-25$ & ERD & $76-183$ & ERD \\
$76-28$ & ERD & $76-184$ & ERD \\
& & $76-262$ & ERD \\
& & $76-263$ & ERD \\
& & $76-264$ & ERD \\
& & $76-265$ & ERD
\end{tabular}

D - 21997 BNL Site Environmental Report 


\section{Operable Unit V Area}

\begin{tabular}{|c|c|c|c|}
\hline & & & \\
\hline Sewage & nent Plant - & $39-06$ & $\mathrm{ESH}$ \\
\hline Peconic & & $39-07$ & $\mathrm{ESH}$ \\
\hline $37-02^{*}$ & ERD & $39-08$ & ESH \\
\hline $37-03^{*}$ & ERD & $39-09$ & ESH \\
\hline $37-04^{\star}$ & ERD & $39-10$ & ESH \\
\hline 38-01 & ESH & $41-01$ & ERD \\
\hline $38-02$ & ESH & $41-02$ & ERD \\
\hline $38-03$ & ESH & $41-03$ & ERD \\
\hline $38-04$ & ESH & $49-05$ & ERD \\
\hline $38-05$ & ESH & $49-06$ & $E R D$ \\
\hline $38-06$ & ESH & $50-01$ & RD \\
\hline $39-05$ & ESH & $50-02$ & RD \\
\hline & & $60-01$ & \\
\hline
\end{tabular}

\section{Operable Unit VI Area}

Biology Agricultural Fields Meadow Marsh

$58-02^{*}$

$58-03^{*}$

$89-13$

89-14

99-05

99-06

99-10

99-11

100-04

100-11

100-12

100-13

100-14

000-110

800-24

800-25

$\begin{array}{ll}\begin{array}{l}\text { North Boundary -Background } \\ \text { Wells } \\ 000-118\end{array} \\ 000-119 & \text { ERD } \\ 000-120 & \text { ERD } \\ 07-04 & \text { ERD } \\ 07-05 & \text { ESH } \\ 17-01 & \text { ESH } \\ 17-02 & \text { ESH/ERD } \\ 17-03 & \text { ESH } \\ 17-04 & \text { ESH/ERD } \\ 18-01 & \text { ESH/ERD } \\ 18-02 & \text { ESH/ERD } \\ 18-04 & \text { ESH/ERD } \\ 18-05 & \text { ERD } \\ 34-02 & \text { ERD } \\ 34-03 & \text { ERD } \\ 63-09 & \text { ERD } \\ 72-03 & \text { ERD } \\ 72-04 & \text { ERD } \\ & \text { ERD }\end{array}$

$\begin{array}{ll}61-03 & \text { ESH/ERD } \\ 61-04 & \text { ERD } \\ 61-05 & \text { ERD } \\ 000-122 & \text { ERD } \\ 000-123 & \text { ERD } \\ 000-141 & \text { ERD } \\ 000-142 & \text { ERD } \\ 000-143 & \text { ERD } \\ 000-144 & \text { ERD } \\ 000-145 & \text { ERD } \\ 000-146 & \text { ERD } \\ 000-147 & \text { ERD } \\ 600-15 & \text { ERD }\end{array}$

$\begin{array}{ll}600-16 & \text { ERD } \\ 600-18 & \text { ERD } \\ 600-19 & \text { ERD } \\ 600-20 & \text { ERD } \\ 600-21 & \text { ERD } \\ 600-22 & \text { ERD } \\ 600-23 & \text { ERD } \\ 600-24 & \text { ERD } \\ 600-25 & \text { ERD } \\ 600-26 & \text { ERD } \\ 600-27 & \text { ERD }\end{array}$

ERD
ERD
ERD
ERD
ERD
ERD
ERD
ERD
ERD
ERD
ERD

600-15 ERD 


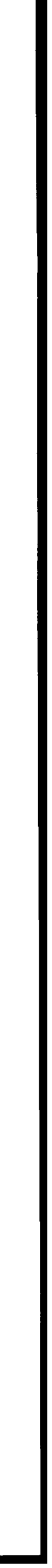




\section{APPENDIX E REFERENCES}

Bari, R.A., Gordon, D., Moran, D., and Volkow, N., 1997. Report of the Ad Hoc Committee on Environmental, Safety, and Health Decision Making at Brookhaven National Laboratory

(April 29, 1997).

Brookhaven National Laboratory, 1997.

Environmental Monitoring Report for the Current Landfill Area.

Brookhaven National Laboratory, 1998. 1997 Environmental Restoration Division Sitewide Groundwater Monitoring Report (June 1998).

CDM Federal Programs/Lawler Matusky and Skelly Engineers, 1995. Sitewide Biological Inventory Report (September 25, 1995).

CDM Federal Programs, 1996. Brookhaven National Laboratory, Draft Final, Remedial Investigation/Risk Assessment Report, Operable Unit I/VI (February 29, 1996).

Corin, L.P., 1990, Review of Federally Threatened or Endangered Species Potentially Impacted by Construction of the RHIC at Brookhaven National Laboratory, Letter to Gerald C. Kinne. (September 25,1990 ).

U.S. Department of Energy, 1988. Environmental Survey Preliminary Report, Brookhaven National Laboratory (June 1988).

U.S. Department of Energy, 1988a, Internal Dose Conversion Factors for Calculation of Dose to the Public (July 1988). DOE/EH-0071.

U.S. Department of Energy, 1997a. Interim Evaluation of Tritium Plume Recovery Activities at Brookhaven National Laboratory (February 1997).

U.S. Department of Energy, 1997b. Integrated Safety Management Evaluation of the Brookhaven National Laboratory (April 1997).

U.S. Department of Energy, 1997c. Draft Department of Energy Action Plan for Improved Management of the Brookhaven National Laboratory (June 1997).

U.S. Department of Energy, 1997d. Status of Groundwater Tritium Plume Recovery Activities at Brookhaven National Laboratory (October 1997).

U.S. Environmental Protection Agency, 1992.

User's Guide for CAP88-PC, Version 1.0,

(March 1992). US EPA 402-B-92-001.

Geraghty and Miller, Inc. 1992. Final Evaluation of Groundwater Flow and Quality at the Southern Boundary, Brookhaven National Laboratory, Upton, New York (August 1992).
Geragthy and Miller, 1996b, Regional Groundwater Model, Brookhaven National Laboratory, Upton, New York (November 1996).

Government Accounting Office, 1997. Department of Energy Information on the Tritium Leak and Contractor Dismissal at Brookhaven National Laboratory (November 4, 1997). RCED-98-26. International Technology Corporation, 1997. Operable Unit III, Tritium Compilation Report (June 24, 1998).

Koppelman, L., 1978, Long Island Waste Treatment Management Plan, Vol. I and II (July 1978).

Long Island Lighting Company, 1996, 1997. Long Island Lighting Company Population Estimates. Miltenberger, R.P., Royce, B.A., Naidu, J.R. (eds.), Brookhaven National Laboratory Site Report for Calendar Year 1988, (June, 1989). BNL-52207.

Nagle, C.M., 1975, Climatology of Brookhaven National Laboratory: 1949-1973, Brookhaven National Laboratory Report No. 50466 (November 1975).

Nagle, C.M., 1975, Climatology of Brookhaven National Laboratory: 1974 and through 1977, Brookhaven National Laboratory Report No. 5857 (May 1978).

Naidu, J.R., Paquette, D.E., Lee, R.J., Schroeder, G., and Lagattolla, R., 1997. Brookhaven National Laboratory. Environmental Monitoring Plan for Calendar Year 1997 and 1998 (March 1997).

National Council on Radiation Protection and Measurements, 1987a, Recommendations on Limits for Exposure to Ionizing Radiation, NCRP Report No. 91.

National Council on Radiation Protection and Measurements, 1987b, Exposure of the Population of the United States and Canada from Natural Background Radiation, Report No. 94.

New York State Department of Health, 1993, Environmental Radiation in New York State 1993, Albany, New York.

New York State Department of Health, 1996, Radioactive Contamination in the Peconic River. NYSDOH Bureau of Environmental Radiation Protection, Albany, New York.

Panek, F., 1985, New York State Department of Environmental Conservation, Personal Communication with J.R. Naidu, 1985. 
Paquette, D.E., 1997. Brookhaven National Laboratory. Brookhaven Medical Research Reactor, Groundwater Contamination Investigation Final Report (December 22 2 1997).

Royce, B.A., 1997. Interim Report of the Brookhaven National Laboratory Facility Review, Review of Potential Environmental Release Points - Priority One Facilities (September 9, 1997).

Royce, B.A., and Collins, J.W., 1997. Interim Report of the Brookhaven National Laboratory Facility Review, Review of Potential Environmental Release Points - Priority Two Facilities (December 3, 1997).

Scheibel, M.S., 1990, Review of New York State Endangered Species Potentially Impacted by Construction of the RHIC at Brookhaven National Laboratory. Letter to Gerald C. Kinne (September 24, 1990).
Suffolk County Department of Health Services, 1990. Suffolk County Groundwater Investigation Report; North Shirley, New York (October 1990). Suffolk County Department of Health Services, 1997. Letter from J.H. Baier (Suffolk County Deparitmentit of Health Services) tó P.D. Bond (Brookhaven National Laboratory) dated September 15, 1997. Title Interpretation of Tritium Results.

Warren, M.A., de Laguna, W., and Lusczynski, N.J., 1968, Hydrology of Brookhaven National Laboratory and Vicinity, U.S. Geological Survey Bulletin 1156-C. 


\section{Internal Distribution:}

Department

AGS

BIOLOGY

BOOSTER

BSA

CHEMISTRY

CS

DAS

DAT

DIRECTOR'S OFFICE

M. Bebon

M. Davis

J. Marburger

G. Ogeka

A. Roberts

T. Sheridan

\section{EM}

ERD

ESD

ES\&H

HUMAN RESOURCES

INSTRUMENTATION

MEDICAL

NSLS

OMC

$\mathrm{PA} / \mathrm{Cl}$

PE

P\&GA

PHY

REACTOR

RHIC

S\&M

WMD

\section{Person}

E.Lessard

D. I. Lowenstein

W. Sims

F. Wm Studier

W. Weng

G. Fess

C. Creutz

R. Spellman

J. Hurst

J. Davenport

R, Bari

K. Brog

T. Kirk

D. MícWhan

P. Paul

M, Schlender

W. Gunther

W. Dorsch

R. Howe

J. Meersman

B. Flores

L. DeBobes

R. Miltenberger

o. White

S. Briggs

R. D'Angio

V. Radeka

D. Grabowski

N. Volkow

W. Casey

M. Hart

B. Breitenstein

M. Lynch

K. Geiger

M. Rowe

W. Chaloupka E. Murphy

J. Laurie

M. Murtagh

W. Reeside

D. Ports

S. Musolino

S. Ozaki

M. Guacci

R. Pierce
DOE Distribution:

Office of Environmental Guidance and Compliance (EH-23) - 5 copies

Office of Environmental Audit (EH-24) - 2 copies

Office of NEPA Project Assistance (EH-25) - 2 copies

Chicago Operations Office - 10 copies

Brookhaven Group - 10 copies

H. McCammon, Office of Health

and Environmental Research - 1 copy

EPA Distribution: ( 2 copies each)

M. Logan, U.S. EPA Region II

P. Giardina, Radiation Safety Program, U.S. EPA Region II

W. Gunther, U.S. EPA, Office of Radiological Programs,

Washington, $D C$

J. Logsdon, U.S. EPA, Office of Radiological Safety Program

\section{New York State:}

R. Aldrich, NYS Department of Health (DOH)

R. Cowen, NYSDEC

R. Schneck, NYSDEC

C. Hamilton, NYSDEC

J. Lister, NYSDEC

M. Chen, NYSDEC

Suffolk County:

J. Baier, Suffolk County Department of Health Services (SCDHS)

C. Bradley, Health Commissioner, SCDHS

D. Moran, SCDHS

J. Pim, SCDHS

P. Ponturo, SCDHS

M. Trent, SCDHS

G. Proios, Suffolk County Executive Office

M. LoGrande Suffolk County Water Authority

R. Corwin, Suffolk County Water Authority

ATSDR:

A. Dudley

A. Block

\section{U.S.Senator}

D. Moynihan

C. Schumer

\section{U.S. Congressman:}

M. Forbes

R. Lazio

\section{General Distribution:}

B. Balke, Lawrence Livermore Laboratory

P.E. Bramson, Batelle Pantex

D. Brekke, Sandia National Laboratory

Hue-Su Hwang, Sandia National Laboratory

D.A. Cirrincione, Rocky Flats Plant

J.D. Cossairt, Fermilab

I.M. Fisenne, Environmental Measurements Laboratory

N.W. Golchert, Argonne National Laboratory

D.W. Grobe, Fermilab 
General Distribution (cont'd.):

W.R. Hansen, Los Alamos Scientific Laboratory

J.D. Heffner, Savannah River Laboratory

D.L. Hoff, Idaho National Engineering Laboratory

J. Hunter, Rutgers University

R. E. Jaquish, Pacific Northwest Laboratory

L. Koppelman, Nassau-Suffolk Regional Planning Board

B. Nemickas, United States Geological Survey

E. O Connell, State University of New York, Stony Brook

P. Rohwer, Oak Ridge National Laboratory

J.D. Sage, Bettis Atomic Power Laboratory

A.R. Seepo, Schnectady Naval Reactors Office

L. Scholt, Los Alamos Scientific Laboratory

J. Soldat, Pacific Northwest Laboratory

R.K. Woodruff, Pacific Northwest Laboratory

J. Stencel, Princeton Plasma Physics Laboratory

L. Willis, Associated Universities, Inc.

Note: Additional reports are distributed to interested parties responding to the BNL press release that announces the issuance of the report. 
